University College

Thesis submitted for the Ph.D. degree, 1999

Translation Technique in the Peshitta to Jeremiah

Gillian Greenberg

B.Sc., M.B., B.S., M.A.

BIBL

LONDON
UNIV. 
Abstract of thesis

\section{Translation technique in the Peshitta to Jeremiah}

This discussion is based on a word by word comparison of the source document and the translation throughout the 1364 verses of the book. The conclusions drawn are:

1. the translator's main aim was to present the sense of his Hebrew Vorlage without change, and to do so in a readily accessible presentational style. The evidence on which this conclusion is based is the presence of two co-existing forms of translation throughout:

(i) almost always literal, in presentation of the sense. The few points at which the sense is modified almost all pertain to the theme of the movement from the Temple- and sacrifice-based pre-exilic religion to a prayer-based religion compatible with exile;

(ii) often non-literal, stylistically, in pursuit of the precise and intelligible presentational style. When the translator wished to add lexical items, breaking the constraints of quantitative literalism so as to increase the precision of expression, he did so.

2. Comparison of earlier with later mss. shows that these characteristics are to be found not only in the work of the translator, but also in the work of later editors: evidently those editing Peshitta mss. valued the presentational style sufficiently to impose it on the text even though they knew that by so doing they were likely to lessen the correspondence between that text and the Hebrew Vorlage.

3. The Vorlage was probably a document almost but not quite at the end of the process of recension which led to the formulation of MT: a group of minuses in which LXX and the Peshitta agree against MT, occurring at points of the Hebrew text where textual criticism suggests some underlying problem, constitute the evidence on which this conclusion is based.

4. The translator's approach to the choice of lexical equivalents is that of one 
who enjoyed exercising literary initiative.

5. There is no evidence that more than one translator was involved.

6. Future work, assessing the literary style of the Peshitta as a whole, is suggested to throw light on the puzzle of the incompatibility of the Peshitta to Isaiah and to Psalms with the classification of the other books of the Peshitta according to the characteristics of the translation technique. 
Table of Contents

Page

Acknowledgments $\quad 6$

$\begin{array}{lll}\text { Chapter } 1 \text { Introduction } & 7\end{array}$

The nature of the Vorlage 9

The nature of the Urtext 15

The work of the editors 23

The choice of $7 \mathrm{a} 1$

Influence from the Targums 25

The character of the translation 27

Maximalist view of translation technique 29

$\begin{array}{ll}\text { Published work } & 30\end{array}$

$\begin{array}{lll}\text { Annex } 1 \text { Aphrahat } & 37\end{array}$

Annex 2 The language of the Vorlage 40

Chapter 2 Translation Technique 44

Preservation of the sense of MT 47

Choice of lexical equivalents $\quad 52$

Literary initiative $\quad 52$

Precision 65

Occasional inattention $\quad 67$

Harmonisation 69

Other biblical books $\quad 72$

Within Jeremiah 73

$\begin{array}{ll}\text { Additions } & 76\end{array}$

Increasing clarity 77

Specifying subject or object $\quad 84$

Additional verb $\quad 87$

tor 91

Epithets 92

New information $\quad 93$

Figurative language $\quad 96$

Anthropomorphism 98

Grammatical consistency 102

Number 102 
Table of Contents

Person 106

Gender 108

Logical cohesion 109

Word order 111

Number of translators $\quad 118$

Annex 3 Translation of שTה 120

Chapter 3 Duplicate Passages 124

Both passages in Jeremiah $\quad 130$

Independent translation $\quad 130$

Dependence 134

One passage in another book $\quad 138$

Isaiah 139

Kings $\quad 143$

Obadiah 150

Wording of the Vorlagen 153

Chapter 4 Minuses 156

Qumran evidence 157

Accidental minuses $\quad 169$

Deliberate minuses 176

Wording of the Vorlagen 182

Chapter 5 The Work of the Editors 197

In common with translation technique 199

Development in the language with time 217

Chapter 6 Difficult Hebrew 221

Taking guidance from LXX 227

Guesswork, based usually on etymology 251

Another part of the Hebrew Bible 274

Mimicking the sound of the Hebrew word 284

Atomistic translation 286

Chapter 7 Conclusion 290

Bibliography 294 


\section{Acknowledgments}

So many people have given me so much help during the time that I have worked on the Peshitta to Jeremiah that it is difficult to know where to start in acknowledging their generosity and support. Selection is always invidious, but there are some in particular to whom I wish to express thanks.

Dr. Donald Walter gave me immediate permission to use his collations of the manuscript variants in advance of the publication of his work by the Leiden Peshitta Institute; this was great generosity, and similar generosity was shown me by Dr. Konrad Jenner, Head of the Peshitta Institute, who gave me equally unstinting permission to use this material before its publication. Professor John Klier was, as always, a supportive Head of Department, particularly at the time of Dr. Michael Weitzman's sudden and premature death. Dr. Robert Murray took over the supervision of this thesis after that sad time, and gave me great support at a time when I much needed it, as well as bringing his learning and intellectual rigor to bear on the work. Of Dr. Michael Weitzman there is so much to say: it was his scholarship, outstanding in depth as well as in range, which first inspired me to work in the field of Peshitta studies; it was his generosity, both with his learning and with his time, which supported me during the work, and it is with enormous sadness that I write these words. Quite simply, no student could ever have had a better teacher. Finally, my husband: without the inspiration of his original thinking, his constant and unbounded enthusiasm, and his unfailing support I would not even have begun this course of study, let alone been able to do the work embodied in this thesis. 
Chapter $1 \quad$ Introduction

Translation Technique in the Peshitta to Jeremiah

Jeremiah is a long book, containing about thirteen hundred verses, onefourteenth of the entire Hebrew Bible; the verse by verse study of a text of this length has given an excellent opportunity for an analysis of the translation technique.

\section{Translation technique}

Translation technique is here taken, following the definition used by Tov, in a discussion of the translation technique in LXX, to incorporate the following three components:

(1) the characteristic approach of the translator to his source text, for instance the choice of lexical equivalents, the degree of adherence to the source text, and the equivalence of source and translated grammatical categories;

(2) cooperation between translators and the use of earlier translations;

(3) the work of later editors of the original translation, that is, revisional activity (Tov, 1987, p.339).

\section{The arrangement of the discussion}

The principal elements of the discussion are divided into chapters according to the following outline:

Chapter 1: in this chapter, the study is introduced, with a broad discussion of: the probable nature of the Vorlage and of the Urtext;

the general characteristics of the translation and of the principal editorial work, in relation to the religious background against which the translator and the later editors worked;

the choice of $7 \mathrm{a} 1$ as the basis for the study;

the general impact of the translation on the reader;

the decision to take a maximalist view of translation technique;

and of some of the important literature on the Peshitta to Jeremiah which has not 
Chapter $1 \quad$ Introduction

al ready been adequately reviewed in published work; fuller discussion of the relevant literature is given in the individual chapters.

Chapter 2: the characteristic approach of the translator to his source text is discussed here. The detailed analysis shows, in essence, that the sense of the Hebrew is almost always accurately translated, but that, particularly in relation to the selection of lexical equivalents, and to the constraints of quantitative literalism, the approach is frequently non-literal.

Chapter 3: there are a number of duplicate passages in Jeremiah; usually, both members of the pair are in Jeremiah, but in some cases one member of the pair is in another biblical book. The translations of these passages, discussed in this chapter, give further information on the translator's approach to his source text, and also throw light on Tov's second component, the extent to which the translator of Jeremiah was influenced by work on the Peshitta which had already been completed.

Chapter 4: the minuses in the Peshitta in comparison with the MT are analysed here; this analysis, taken together with the text of LXX, gives insight into the Vorlage at certain points. Although, in the absence of ms. evidence, the suggestion is not susceptible to proof, the findings amount to strong evidence that some of these minuses, "true" with respect to MT, are only "apparent" with respect to the Vorlage.

Chapter 5: ms. evidence shows that the Peshitta to Jeremiah has been extensively revised, and the work of the later editors is discussed here. It is apparent that the features which characterise "translation technique" also characterise "revisional activity".

Chapter 6: the translator evidently had an excellent knowledge of Hebrew, but there are some passages which he failed to understand, sometimes because the Hebrew was difficult, perhaps using unfamiliar roots, and sometimes because the Hebrew was obscure, perhaps as a result of textual corruption during transmission. These passages are discussed in this chapter, and the influences 
Chapter 1

Introduction

on the translator and the various approaches he employed in working on these areas are analysed. Influence from LXX, although sporadic, is clear in a substantial proportion of these passages. There is also occasional evidence of influence from parts of the Peshitta which had already been translated.

Chapter 7: the general conclusions are that:

the translation technique is homogeneous, and there is no evidence that more than one translator was involved;

this homogeneous translation technique is compatible with that described in the literature for other books of the Peshitta;

this technical homogeneity, and the apparent ease with which translations of the passages which are duplicated in other books of the Hebrew Bible and the Peshitta fit into these other books, raises the question of the number of translators of the Peshitta as a whole. The extensive literature on the Peshitta as a translation concentrates on the translation technique and characteristics distinguishing one book from another; an analysis of literary style, that is the stamp by which an individual writer's work is immediately recognisable, might throw light on that question and would be an interesting field for future research.

\section{The need to define the Vorlage and the Urtext}

Ideally, a discussion of translation technique would progress from a presentation of the findings of a comparison of the translation with the source text to a discussion of the interpretation of those findings. In the present context, there is an element of uncertainty which makes this approach inadequate. The choice of the texts to represent the Vorlage and the Urtext is the problem, a choice which must be defended by reasoned argument based on indirect evidence, since of course direct ms. evidence does not exist.

\section{The nature of the Vorlage}

Evidence concerning the date and place of the translation, assembled from a 
number of lines of investigation, shows that the Vorlage could well have been close to the Massoretic Text (MT) ${ }^{1}$. Gelston's analysis of the Peshitta of the Twelve Prophets shows that the translator knew the Septuagint, and indeed sometimes showed literary dependence on that Version, giving a terminus post quem of the middle of the second century B.C.E. (Gelston, 1987, p.192); Aphrahat's knowledge of the standard text of the Peshitta gives a terminus ante quem of the first half of the fourth century C.E. (ed. Parisot, 1894).

This gives a period of several centuries during which the Peshitta could have originated. Gelston refines this estimate by showing the close but not exclusive agreement of the Hebrew Vorlage presupposed by the Peshitta with the MT, which suggests a date for the Version shortly before the standardisation of the MT, and shows that although the uncertainty concerning the date of that standardisation, and the existence of the proto-Massoretic MSS. in the period leading up to that date, make it impossible to infer a precise date for the Peshitta, the balance of probability suggests a date in the middle or later part of the first century C.E. (Gelston, 1987, pp.192-193). Weitzman, in the most recent published discussion of the date at which the Peshitta was written, brings together evidence derived from literary tradition, references to historical events, citations of the Peshitta and citations in the Peshitta, vocabulary, and grammar, and on the basis of these additional factors reaches a slightly later date, concluding that a date close to $150 \mathrm{C}$.E. is probable for the translation of the earlier books of the Hebrew Bible (Weitzman, in press ${ }^{2}$, p.248).

There is a great deal of published work on the question of the date of the standardisation of the MT, and although it would be outside the present writer's remit to review this literature, some discussion of the points of principal relevance here is desirable.

1. Since MT is almost always uniquely defined, despite some ms. variation outlined for instance by Tov (Tov, 1992, pp.25-39) the term will be used in this discussion without further qualification. 
Chapter $1 \quad$ Introduction

In the earlier literature, Talmon assembles evidence in the rabbinic writings, Hebrew fragments from after C.E. 70 such as those from Wadi Murabba'at and Massada, and some subsidiary details from the ancient Versions, and concludes that proto-MT texts ${ }^{3}$ were indeed established during the first century C.E.; he supports this conclusion by showing that, at the period following the destruction of the Second Temple, the renewed dispersion of the Jews, and the cultural and religious disruption of the time, a standardised text would have been of great value (Talmon, 1975, pp.8-11).

Cross brings evidence from the biblical documents of Genesis, Exodus, Numbers, Isaiah, and the Minor Prophets from Murabba'at to show that the archetype of the MT had been promulgated at least by 100 C.E. (Cross, 1975(i), pp.183-184). Goshen-Gottstein describes the first century C.E. as the time of stabilisation and growing preponderance of the "Massoretic type" of ms.

(Goshen-Gottstein, 1975, p.46).

Albrektson questions the theory that the emergence of the standard text resulted from deliberate text-critical activity intended to create a normative recension (Albrektson, 1978, p.59). He says of Jeremiah "Could the traditional text of the Book of Jeremiah, notoriously marked by expansion, conflation and harmonising, really have been deliberately preferred on text-critical grounds to the type of text found in the Septuagint and in 4QJer ${ }^{\mathrm{b}}$, far superior to the MT?";

Footnote from p. 10 contd.

which was fortunately completed shortly before his sudden and sadly premature death earlier this year. The present writer had the privilege of discussing the book in detail with Dr. Weitzman, and as publication was expected in 1998 , it seemed reasonable to refer to it whenever material in the book gave the best presentation of his work on any particular point. There have unfortunately been some delays, inevitable in the circumstances, and one regrettable result is that readers are unable to refer to the book for themselves. Whenever possible, therefore, references to published papers have been substituted. Publication is now expected in 1999.

3. "Proto-MT" is taken to mean a text containing the consonantal base of the MT (Tov, 1992 , p.23). 
Chapter 1

Introduction

his suggestion is, rather, that the victorious text supplanted other texts because it had been used by the Pharisaic scribes who supplanted other groups. He ascribes little or no importance to the motives other than textual criticism which might cause a text to have been deliberately preferred; nonetheless, he reaches a conclusion compatible with those reached by the authors mentioned above, arguing that the process of standardisation of the MT was well advanced by the early part of the second century C.E. (Albrektson, 1978, pp.62-63). The later reviews by Mulder (Mulder, 1985, pp.44-45) ${ }^{4}$ and by Dirksen (Dirksen, 1988, pp.258-259) present similar conclusions, and GoshenGottstein's later paper confirms his earlier assessment that the first century C.E. was a time of stabilisation and growing preponderance of the "Massoretic type" of ms., with unification at about 100 C.E (Goshen-Gottstein, 1992, pp.208, 212).

Against the background of the evidence for the date of standardisation of the MT, it is historically possible that a ms. which was close to even if not identical with MT would have been in existence at the time of writing of the Peshitta, and could have formed the Vorlage.

This consensus, that a proto-MT ms. would have been available to the writers of the Peshitta, does not of course prove that such a ms. was offered and accepted. It does however seem likely that the translators would have sought out a "model" text as the basis of work of such importance, and that the model they would have been offered would have been in the line of transmission of MT. Here, the obvious analogy is with the selection of the ms. from which those writing the Septuagint would work, described in Josephus (Antiquities of the Jews, Book XII, Ch. 2, paras. $6,11,14,15)$ :

4. Mulder (Mulder, 1985, p.45) discussing the importance of the Peshitta in establishing, together with the Septuagint, which of a number of text-forms is "the better" emphasises that both these Versions witness not to "the Hebrew text, but to a tradition", that is to one of the several "pre-massoretic text-forms". 


\section{Chapter $1 \quad$ Introduction}

para. 6: Eleazar in his reply to King Ptolemy's letter telling him of his desire to have "the Law" translated says "Be assured that we shall submit to anything that is of benefit to you... for we ought to make a return for the kindness which you have shown our fellow-citizens...And it will the part of your piety and uprightness to send back the Law when it has been translated, together with those who are bringing it, in safety". para. 11: describing the books which the elders chosen by Eleazar brought to the king: "with the leather skins on which the laws were written in letters of gold" at which the king "marvelled at the fineness of the membranes and the impossibility of telling where they were joined, so well were they fitted together"

para. 14: "And so the king rejoiced ... and he was amazed at the depth of mind and wisdom of the lawgiver; and he began to discuss with Demetrius how it was that though this legislation was so admirable none of the historians or poets had made mention of it." Demetrius explained "that no one had ventured to undertake a description of these laws because of their divine and awful nature, and that some who had already attempted this had been afflicted by God." para. 15: "The king, then, having received these books from the hands of Demetrius, did obeisance to them ... he also invited the translators to come to him frequently from Judaea"

Whether or not this idealised account given by Josephus is accurate, it is entirely plausible that the best possible ms. would have been desired by those undertaking this biblical translation, and that those offering the ms. would have felt their own prestige to be reflected in the excellence of that text. It seems probable that those who were planning the preparation of the Syriac translation would, similarly, have done all they could to obtain the best possible Hebrew ms. as the basis for their work. It is unlikely that a ms. from a tradition outside that of the Second Temple, or a great deal older than the recensions current at that time, would have been acceptable to those planning the translation into Syriac, or would have been offered by those whom they approached.

On the basis of Weitzman's opinion that the Peshitta was written in the second 
Chapter $1 \quad$ Introduction

century C.E. rather than in the first, and indeed probably in the second half of the second century, in conjunction with the evidence that the MT was likely to have been standardised by that date, it seems that the text provided could have been, rather than a "proto-MT" ms., a ms. so close in time to the MT as to be virtually indistinguishable from the MT. However, evidence to be presented in Chapter 4 "Minuses in the Peshitta to Jeremiah" suggests that the ms. provided was indeed a proto-MT ms.: the practicalities of the circulation of proto-MT mss. may explain this apparent contradiction. It is perfectly plausible that the Vorlage available in the East, to the Syriac school, may have been in a form which had already been superseded in the West at the time when the Peshitta was being written. Even if those in the East, requesting the loan of a ms., would have liked to receive the latest possible edition, it is possible that those in the West in possession of the mss. would have judged that they should not provide the most up-to-date text; given the difficulties of travel at the time, and the danger that a ms. might be lost or damaged in transit, this would have been a perfectly defensible decision: it would have been hardly reasonable to expect the authorities in the West to offer a ms. which had perhaps barely reached final form.

This conclusion is compatible with the evidence from Qumran, although those deposits show that a substantial number of biblical documents other than protoMT texts were in existence in the Holy Land at the relevant period. Tov concludes that proto-MT mss. accounted only for some $60 \%$ of the biblical texts stored at Qumran (Tov, 1992, p.115). Kutscher describes some of the biblical scrolls found at Qumran as "vernacular" copies, deliberately simplified and otherwise adapted for Hebrew-speaking readers, and circulating in the Holy Land up to the second century C.E. (Kutscher, 1974, pp.8, 78-79) (see also Weitzman, in press, p.55). These non-proto-MT mss., which made up such a large proportion of the total, may have been of great importance during the earlier life of the Qumran community: but their number may give a misleading idea of their importance during the later stages, the time at which the Peshitta was written, when as Tov suggests a central stream in Judaism may have been responsible for the copying and circulation of these texts (Tov, 1992, pp.194 195).

It seems reasonable, therefore, to regard the MT as a close enough approximation to the Vorlage to justify its use in the present discussion. 
Chapter $1 \quad$ Introduction

The nature of the Urtext

The parallel problem is the nature of the original translation into Syriac.

Weitzman has established that few if any of the variants seen in the extant

Peshitta mss. cannot be explained through inner-Syriac development, and that these variants do not amount to evidence of more than one point of contact with the Hebrew: one translation, the Urtext, was apparently made at that point (Weitzman, in press, pp.263ff and Appendix 1, pp.308-9).

The precise character of that Urtext, however, is uncertain. Comparison of the ancient mss. with later texts shows that, at some points where the Peshitta differs from MT, the differences entered early enough to be present in 9a1; other differences were incorporated in later variants, with a trend towards the inclusion of more of the stylistic features which distinguish the Peshitta from MT as time passed. In the absence of complete texts of the ancient mss. it is impossible to reach a quantitative estimate of the extent to which these later readings may have changed the character of the Peshitta from a more to a less literal translation ${ }^{5,6}$. The consensus opinion is that the Urtext was not a precisely literal translation: but the possibility must at least be recognised that it was literal to a considerable extent and that differences between the MT and the Peshitta result not from

5. The term "literal" is used simply as a description, not as a term of praise or of adverse criticism. Barr (Barr, 1979, pp.279-280) notes the pejorative ring that both "word for word" and "paraphrase", describing markedly literal and markedly free translations respectively, carry to modern ears. He demonstrates the need to analyse and define the "various kinds of literalism" (p.281); he shows both that literalism should not automatically be regarded as unintelligent (pp.282-283), and that faithfulness and accuracy are not automatically lacking from a non-literal translation (pp.288-289).

6. Gelston (Gelston, 1987, p. 156) notes that although the fact that the Peshitta is not a slavish translation reduces its direct value as a witness to the Hebrew text, this "by no means makes it an unfaithful or a poor translation". 
Chapter 1

Introduction

"translation technique" but from "revision technique", the differences having entered the text as a result of editorial activity at a point in the history of the Peshitta antedating that time for which ms. evidence exists. In the absence of complete texts of the ancient mss. it is impossible to quantify the extent to which the later variants may have changed the character of the Peshitta from a more to a less literal translation. "Translation technique" is therefore an imprecise term, for it encompasses an indefinable proportion of "revision technique"; nonetheless, since this proportion is indeed indefinable, the term will continue to be used in this analysis.

De Boer (de Boer, 1981, p.348) in his review of surveys of Peshitta studies, cites Haefeli's opinion that there is never likely to be ms. evidence earlier than the sixth century Codex Ambrosianus, and that the major variants, both eastern and western, should be added to this text and that any attempt to reconstruct the Urtext should be abandoned .

Burkitt (Burkitt, 1904, p.42) noted that "The range of variation found in the extant MSS. is very small...The variations themselves are for the most part of the most trifling description".

The arguments put forward by Gelston give a further refinement, a landmark at the fifth century: his analysis shows that it is "hardly conceivable that there was an official revision of the Peshitta as late as even the sixth century which could have won almost universal diffusion throughout the Syriac-speaking churches", and that the standard text, or something very like it, was in existence at the time when the oldest extant mss. were written (Gelston, 1987, p.88). There remains, however, a complete lack of ms. evidence from the probable time of writing of the Urtext in the mid-second century C.E. until mid-fourth century C.E., and scanty evidence only from that time until the writing of $5 \mathrm{~b} 1$.

This scanty evidence of the text of the Peshitta before the fifth century is indirect, largely in the writings of Aphrahat (ed. Parisot, 1894) and to a lesser extent in those of Ephrem (ed. Romana, 1740).

Goshen-Gottstein argues for the importance of these patristic citations as evidence of variants: "short of a find of manuscripts of the second to fifth centuries C.E. there is no escape from a vicious circle, because we cannot take it as mere coincidence that it is in quotations that those deviating readings turn up piecemeal" (Goshen-Gottstein, 1961, p.269); similarly, de Boer quotes Nöldeke 
who wrote that evidence from Aphrahat and from Ephrem suggests that the ancient texts have been seriously corrupted (de Boer, 1981, p.347).

Nonetheless, these patristic citations cannot be used as proof of the existence of mss. containing these variants. It would be circular to argue that because these citations presuppose a Peshitta text which differs from MT they must therefore be inaccurate, but arguments advanced by de Boer encapsulate the caution necessary in accepting such citations as evidence (de Boer, 1981, p.355). De Boer discusses the difficulty of making use of patristic quotations in an attempt to reconstruct a text, and says of such quotations "satisfactory answers are still awaited to the questions whether the quotations were cited from memory, whether they were applied to devotional or theological purposes, and whether, particularly in the commentaries, Syriac, Greek and possibly other texts were consulted". In note 22 he emphasises his view that a variant reading in a commentary or homiletic text which turns up in one or more later manuscripts of the Bible "is not ... a cogent argument for assuming an original Bible text. Such readings need support from elsewhere ..."

Detailed analysis such as that put forward by Owens (Owens, 1988, pp.16-41) supports this argument: Owens concludes that Aphrahat knew a Leviticus text which was close to the dominant P-text, but that he sometimes quoted loosely and partially (pp.16-17), conflated passages (pp.26-27), used paraphrase (p.33), and quoted from memory (p.41). (Owens gives numerous examples to substantiate each of his points; the page references given here are for representative examples.) Koster points out that the problem may not be restricted to conclusions based on the work of Aphrahat: other Syrian authors may similarly have given inaccurate quotations (Koster, 1988, p.119). There are however some citations of passages of Jeremiah where there is no reason to suppose that the kinds of failing instanced by Owens or Koster are present: these are passages, shown in detail in Annex 1, where Aphrahat's citation is very close to or identical with 7a1, but 9a1 agrees with MT against 7a1: at first sight, evidence that the new readings were known by the time of writing of the Demonstrations, dated to between 337 and 345 C. E $_{i}$ However, even in ms. BM. add.17182, part of which dates from 474 C.E., it is possible that the scribe might have substituted a new reading for an old, and these citations therefore do not give certain evidence of the existence of the new readings earlier 
Chapter 1 Introduction

who wrote that evidence from Aphrahat and from Ephrem suggests that the ancient texts have been seriously corrupted (de Boer, 1981, p.347).

Nonetheless, these patristic citations cannot be used as proof of the existence of mss. containing these variants. It would be circular to argue that because these citations presuppose a Peshitta text which differs from MT they must therefore be inaccurate, but arguments advanced by de Boer encapsulate the caution necessary in accepting such citations as evidence (de Boer, 1981, p.355). De Boer discusses the difficulty of making use of patristic quotations in an attempt to reconstruct a text, and says of such quotations "satisfactory answers are still awaited to the questions whether the quotations were cited from memory, whether they were applied to devotional or theological purposes, and whether, particularly in the commentaries, Syriac, Greek and possibly other texts were consulted". In note 22 he emphasises his view that a variant reading in a commentary or homiletic text which turns up in one or more later manuscripts of the Bible "is not ... a cogent argument for assuming an original Bible text. Such readings need support from elsewhere ..."

Detailed analysis such as that put forward by Owens (Owens, 1988, pp.16-41) supports this argument: Owens concludes that Aphrahat knew a Leviticus text which was close to the dominant P-text, but that he sometimes quoted loosely and partially (pp.16-17), conflated passages (pp.26-27), used paraphrase (p.33), and quoted from memory (p.41). (Owens gives numerous examples to substantiate each of his points; the page references given here are for representative examples.) Koster points out that the problem may not be restricted to conclusions based on the work of Aphrahat: other Syrian authors may similarly have given inaccurate quotations (Koster, 1988, p.119). There are however some citations of passages of Jeremiah where there is no reason to suppose that the kinds of failing instanced by Owens or Koster are present: these are passages, shown in detail in Annex 1, where Aphrahat's citation is very close to or identical with 7a1, but $9 \mathrm{a} 1$ agrees with MT against 7a1: at first sight, evidence that the new readings were known by the time of writing of the Demonstrations, dated to between 337 and 345 C. Ea $_{i}$ However, even in ms. BM. add.17182, part of which dates from 474 C.E., it is possible that the scribe might have substituted a new reading for an old, and these citations therefore do not give certain evidence of the existence of the new readings earlier 6a. Ms 9a1 shows agreements with MT not shared by any other ms, apart from those wholly or partly copicd from it (Weitzman, 1988, pp.225-226). Weitzman discusses in this paper how this position could have been reached either by revision after the MT, or by preservation of the original text, and shows that the latter is the more probable explanation in this case. 
Chapter 1

Introduction

than the late fifth century. Further, unfortunately, there are no citations in Aphrahat in which 7a1 and 9a1 agree against MT, a position which would give a pre-fifth century date of entry, for the new reading concerned, into an ancestor of both these lines of transmission. It is therefore impossible to arrive at the date of entry of these variants, dominant in Aphrahat though not in Ephrem ${ }^{7}$ : the centuries between the writing of the Peshitta and the earliest ms. of the Demonstrations remain blank, and the proportion of the non-literal features of $7 \mathrm{a} 1$ which was present in the Urtext and that which results from the work of the editors is impossible to determine.

Papers read at the Peshitta Symposium in 1985 consistently give evidence suggesting that the Urtext was not a precisely literal translation. Brock concludes that P-Isaiah was not, "even in its original form, a very literal translation from the Hebrew" (Brock, 1988, p.78); van der Kooij argues that the Urtext of P-Genesis was not literal in the sense of being Hebraistic (van der Kooij, 1988, pp.193-194); and, developing this theme, Gelston discusses the difficulty of being sure that a variant which represents "the kind of expansion often found in $\mathrm{P}^{\prime \prime}$ is in fact an expansion rather than the original P-text (Gelston, 1988, pp.90-91).

Taylor argues in his monograph on the Peshitta to Daniel that this text is "fairly literal", but includes such interpretation as is necessary to make it more readable or easier to understand, and shows departures from the literal when needed at particular phrases or expressions (Taylor, 1994, p.319). Lane comes to similar conclusions in his monograph on the Peshitta to Leviticus, showing that the translators aimed more at conveying the inner meaning of the text than at a translation based on formal equivalents (Lane, 1994, p.99).

Koster concludes that "at every stage and in every single ms, including those representing the earliest stage, the same process took place that characterises the development of $\mathrm{P}$ as a whole: the gradually ( $\mathrm{sic}$ ) change and expansion of the text further away from the MT" (Koster, 1993, p.242).

7. This seems paradoxical, since spread would have been expected to be from the West to the East, and Ephrem would thus have known of revised mss. earlier than would Aphrahat. Weitzman discusses this point, arguing that the new readings themselves originated at some prestigious centre in the East and spread westwards only gradually (Weitzman, in press, p.3()2). 
The analysis to be presented in detail in Chapter 5 will show that there were some points at which even 9a1, shown by Weitzman to contain unique agreements with MT (Weitzman, 1988, pp.225-226) differed from that text. Although Weitzman does not suggest that the Urtext was absolutely literal, he does emphasise that the original translation was sometimes constrained by quantitative literalism, and he assesses the later readings as of such importance that the stylistic adjustments and clarifying additions of which they consist effectively constitute a second edition of the Peshitta (Weitzman, in press, p.301): this decision is based on judgment, not on absolute certainty.

Dirksen summarises the position: although the texts which are reflected in the most ancient mss. take us back to the sixth, sometimes even the fifth century C.E., this is at least three centuries (Dirksen, presumably taking the sixth century as the landmark, says four centuries) after the Peshitta was written, and as to variants entering the mss. during this period "we can do little more than guess" (Dirksen, 1992, pp.376-377).

There is, thus, general agreement that these later readings may be seen as nonliteral variants entering a non-literal translation, with the exact proportion of nonliteralness which had entered the translation at the time of the Urtext unknown: this leads to the conclusion that both the translators, working in the second century C.E., and the editors, working in later centuries and against a different religious background, introduced non-literal elements into the translation. In the case of the editors these elements were probably introduced without reference to the Hebrew, and show that this group was ready to rewrite the Syriac mss. in certain ways which they must have realised might divert the renderings away from the original Hebrew.

Whether or not this suggestion, that both translators and editors introduced nonliteral elements, is plausible, depends on the attitude at the times concerned, within the circles in which the translators and editors worked, to a non-literal translation of a biblical text. Here again, as in the discussion of the proportion of non-literal elements which entered the Peshitta at the Urtext stage or later is concerned, balance is important, for the description of a translation as "free" or "literal" is not absolute but relative. Barr emphasises that a mixture of such literal and non-literal elements is frequently found within a single ancient ms. (Barr, 1979, p.281). Brock describes a continuum in translation between these 
Chapter 1

Introduction

two poles "free" and "literal" (Brock, 1992, pp.4-6), outlining three types of translation, the referential, in which the translator seeks to produce a mirror translation; a type in which the work is reader- rather than source text- oriented, in which the aim is the transfer of information with some exposition, employing appropriate cultural equivalents where needed to involve the reader emotionally; and a third in which the translator seeks to impose his own views on the text. Lane defines two kinds of translation, first the "formal", in which extensive use is made of cognate words, transliterations, and homophones, with the emphasis on the external resemblance between the text and the translation. The second kind is the "dynamic", in which more than the single word is taken into account, and the emphasis is on the inner meaning of the text, so that its sense is conveyed in the translation (Lane, 1994, p.99).

In principle, then, there is no reason why the Peshitta should not include both elements, the proportion depending on the translator's exact aims, and this seems to be a fair description of the text in Jeremiah: some aspects, such as sense, are almost always literally translated, while others, such as word order and consistent one-for-one lexical correspondence at least for the more important elements in the vocabulary (Brock, 1984, pp.85-86), are treated with some freedom.

The point of outstanding interest is that a non-literal translation was evidently acceptable to the two completely different religious groups who were responsible for the Peshitta, the translators originally and the editors who succeeded them. Weitzman, writing on the Pentateuch, the Psalter, and on the Peshitta as a whole, suggests that the presence of some features which are inconsistent with rabbinic Judaism, more prevalent in the Psalter than in the Pentateuch, may be explained by a gradual change in the religion of the translators: " The Judaism of the Peshitta Pentateuch...is predominantly rabbinic but embodies some non-rabbinic elements. The religion of the Peshitta Psalter is emphatically different from rabbinic Judaism...The hypothesis may be ventured that the Pentateuch was translated while that community was yet Jewish, and the Psalter when its evangelisation was well under way if not complete" (Weitzman, 1982, p.298). Weitzman points out that the presence of some Jewish exegesis in the Peshitta is compatible with an origin in a Christian community if that community had Jewish roots or Jewish contacts (Weitzman, in press, p.207).

Overall, 
Chapter 1

Introduction

Weitzman concludes that the Peshitta was the work of non-rabbinic Jews, conscious, at least during the time of translation of all but the last books, of isolation from Jews elsewhere in the world (Weitzman, 1996, pp.597-601).

While there would have been no place for non-literal translation in the work of a Jewish group centred in the Second Temple tradition working on a text which was in their view "letter-perfect", for such translators there is no apparent reason why a combination of literal and non-literal renderings would have been unacceptable.

The differences in sense which the translators introduced fit well with Weitzman's conception: he notes that they are rare, because for the most part the translation is literal, though "theologically significant passages are more numerous than previous discussions have allowed" (Weitzman, in press, p. 203). Within Jeremiah there are few such changes, but these include a group emphasising the horror of exile, the importance of prayer, and diminishing the value of sacrifice. For such a community, the production of a biblical text which was readily accessible in a community where the knowledge of Hebrew was decreasing may have been more important than literalness.

Barr notes that where religions compete to interpret the same authoritative scripture, quantitative literalism is favoured (Barr, 1979, pp.305, 324): the element of competition may not yet have been strong enough for such literalism to be necessary. If Christianity reached northern Mesopotamia some time during the second century (Drijvers, 1992, p.127), at the time of the translation there would not yet have been real need to prove the authority of Judaism against the developing Christian church: some degree of non-literalness would not be perceived as likely to lead to the discrediting of the Version as a whole. By the later dates, when the editors were working, the religious climate had changed; but it had changed in such a way that a non-literal translation was still acceptable. Drijvers' discussion implies a purpose for the introduction into the Peshitta of differences from the MT: he suggests that though those Christians who wanted to keep the Hebrew Bible needed a translation, they nonetheless wanted "to define themselves as different from the Jews", as the orthodox Christian minority needed to be able to deal with Jewish material without identifying itself with Judaism (Drijvers, 1992, pp.140, 141). Drijvers points out that the Jews of Edessa, as adherents of an old and traditional religion 
Chapter $1 \quad$ Introduction

"served as a real magnet to many Christians and gave rise to very ambivalent feelings, especially among church leaders and theologians, who warned their coreligionists against the Jewish danger with all the exuberance of traditional rhetoric" (Drijvers, 1994, p.102).

Murray points out that in the Roman Empire the Jews were regarded as "satisfactory citizens" but that in contrast the Christians had only just gained toleration, and that in consequence Aphrahat and Ephrem were concerned lest Christians should revert to Judaism (Murray, 1975, p.19). So to this group too, working at a time when the adoption of the Peshitta by the Syriac-speaking Church and its circulation within that Church was in progress, a non-literal translation would have been acceptable and might even have had certain advantages, emphasising the distance between the Church and the Jews. Millar describes a background against which a community of Christians would have gained security and prestige by emphasising their distance from Judaism (Millar, 1992, pp.115-118), benefits which may have increased as time passed. Millar refers to the sermons of John Chrysostom in 386-387 C.E. in which hostility was directed not against the Jews of Antioch but against those Christians who allowed themselves to be drawn into participation in Jewish festivals. Discussing the change in the imperial attitude towards the Jews in the fourth and fifth centuries C.E., Millar shows that this resulted in a position in which although Judaism was not, if practised by Jews, illegal and in which synagogues had the protection of the law, that protection might be limited and retrospective. Indeed, in the fifth and sixth centuries, although the period should not be seen as one of systematic persecution, and the right to practise Judaism was preserved, there is convincing evidence of a profound change of mood enabling marked antagonism to local Jewish communities (Millar, 1992, p.120): the evidence of editorial revisions increasing the non-literal elements of the translation, showing as it does that the Christians felt no need to support their faith by demonstrating the originality of their text, and that against such a background a non-literal translation would have been perfectly acceptable, may be an added demonstration of the self-confidence of the Christianity of the time. 


\section{Chapter 1 Introduction}

The work of the editors

Whenever the translation did in fact depart from the literal, whether both at the outset and in the later stages of copying and revising, or only during this later period, three elements are clear: first, that it did depart, and to a considerable extent; second, that the great majority of the differences between the MT and the Peshitta to Jeremiah are small, matters of style rather than of sense; and third, that many of these small differences were the work of the editors, not of the translator. This latter point will be established in the detailed discussion of the work of the editors which will be given in Chapter 5, a discussion which has been made possible by the generosity of Dr. Donald Walter and Dr. Konrad Jenner who have allowed me to make use of Dr. Walter's work on ms. variants in P-Jeremiah in advance of its publication in the Leiden Edition of the Peshitta. These variants are of great interest, both in what they do include, and in what they do not. First, they are numerous, and they are almost always consistent with the overall presentational style of the text: in the work of the translator, we see "translation technique", and in the work of the editors, we see the same aims pursued in revision technique. These editors, working without access to or understanding of the Hebrew, were willing to strengthen the style even though they must have realised that in doing so they were likely to diverge from the source text: presentational style was more important to them than was literalness. Second, although they were willing to make numerous changes when they judged these to be desirable, they made only few changes in sense: both translator and editors apparently found in Jeremiah a text which suited their own views well. These severely critical oracles, both those to the Israelites and those to the nations, and the narrative passages with their account of the vacillating king and the brutal treatment meted out to the prophet, may have been in accord with their own opinion and may have conformed well with their own religious agendas: the particularly high prevalence of revised readings in the majority of mss., with unique readings preserved in 9a1 for Jeremiah and Kings, suggests that these books may have formed a pair in the eyes of Syriac scholars, who studied them together, learning from Kings about the sins and downfall of the Jews, and (Kraft and Purintun, 1972, pp.45-49) seeing in Jeremiah the life of a type of Christ ${ }^{8}$. 
Chapter $1 \quad$ Introduction

\section{The choice of $7 a 1$ as the basis for the study}

The extant Peshitta mss. show an impressive degree of uniformity: Koster concludes that "the fundamental uniformity of the text is beyond doubt" (Koster, 1993, p.251). The following discussion has been based on 7a1, which was read in the photolithographic reproduction published by A.M.Ceriani ${ }^{9}$ ( Ceriani, 1876-1883): the availability of this edition was one reason for the choice; also, this is the oldest almost complete ms. of the Peshitta, was in a good state of preservation when the Ceriani edition was made, and the text is usually easily legible. The value of $7 \mathrm{a} 1$, and the problems associated with its use, were discussed by de Boer who noted that in the preparation of the Leiden Edition Codex Ambrosianus was chosen as the basic text for practical reasons but not "because we regard the manuscript as the most important witness for reconstructing the Peshitta version - which Codex Ambrosianus certainly is not" (de Boer, 1981, p.356) and by Dirksen who notes that this ms. contains errors and readings peculiar to itself which have no claim to textual priority (Dirksen,

Foolnote from p.23

8. The traditional position of Jeremiah as the first of the major prophets may possibly also have influenced the amount of attention given to this book, partly as an effect of precedence itself, and partly because of the stated reason for that precedence. The well-known baraita on this (Bava Bathra, 14b) reads:

$$
\begin{aligned}
& \text { סדרן של נביאים יהושע ושפטים שמואל ומלכים ירמיה ויחזקאל ישעיה } \\
& \text {... ישעיה קדים מירמיה ויחזקאל ליקדמיה לישיה ברישא כיון דמלכים סופיה } \\
& \text { חורבנא וירמיה כוליה חורבנא ויחזקאל רישיה חורבנא וסיפיה נחמתא } \\
& \text { וישעיה כוליה נחמתא סמכינן חורבנא לחורבנא ונחמתא לנחמתא }
\end{aligned}
$$

9. To save the reader possible confusion, some of the more important points at which the readily available printed editions such as Lee differ from $7 \mathrm{a} 1$ have been noted in the discussions which follow. There are so many such points, however, that it would have been tedious to comment on them all, and the numerous trivial examples such as the numbering of verses, the presence or absence of seyame, and the presence or absence of waw, have not been noted. 


\section{Chapter $1 \quad$ Introduction}

1988, p.257). Lane agrees that the text is not free of problems but argues convincingly for its value as a "median" text ${ }^{10}$ and its usefulness so long as debate on its role in transmission is not considered foreclosed (Lane 1994, pp.112 , particularly pp.7-9). With this discussion in mind, and with the great help of Dr. Walter's collations available, 7a1 was taken as the basis for the analysis which is presented here.

In summary, the evidence does strongly suggest that the Vorlage was sufficiently close to the MT, and 7al was sufficiently close to the Urtext, for a comparison of the MT and 7a1 to form the basis of a useful discussion, with reference to other documentary evidence where appropriate.

\section{Influence from the Targums}

Weitzman in 1994 analysed the many parallels between the Targums and the Peshitta. Reviewing the literature, he showed that two main theories may be distinguished to explain putative dependence of the Peshitta on the Targums: first, that the writer of the Peshitta "had a copy of Onkelos at his elbow"; second, that the Peshitta is merely a transposition into Syriac of a targum, not a translation at all (Weitzman, 1994, p.60). Weitzman shows that although there are many parallels, not merely in content but in wording too, between the Targums and the Peshitta these agreements are sufficiently explained by

(i) polygenesis: since Syriac is a dialect of Aramaic, the demands of idiom, the pursuit of intelligibility, a wish to resolve logical discrepancies in the Hebrew, and guesswork will often have led to the same rendering in both (pp.62-65);

10. That is, it has "elements in common with the manuscripts older and younger than itself, and a resemblance to its near contemporaries" (Lane, 1994, pp.4-5). 
(ii) common exegetical tradition (pp.65-69) $)^{11,12}$.

There are no convincing cases proving dependence of the Peshitta on theTargums, though many have been so presented in published work; Weitzman discusses these and shows that none stands up to examination: in particular, none shows either of the characteristics which prove dependence, that is either a combination of elements from the Hebrew and the Aramaic, or a text which could only have been reached by misreading or misunderstanding the Aramaic (pp.7173).

The suggestion that the Peshitta is merely a transposition into Syriac of a lost Aramaic version is refuted on the grounds of

(i) the points in the Peshitta which imply direct contact with the Hebrew and yet are so alien to the interpretations found in the extant Targums that "they cannot ever have stood in the Jewish Targum tradition" (pp.73-75);

(ii) the evidence that the Peshitta is written in "pure Syriac" (p.76).

Weitzman's later assessment of the relationship between the Targums and the Peshitta is unchanged (Weitzman, in press, p.129), and the possibility that any Targumic passage has directly influenced the Peshitta is therefore not considered further here.

11. To give one simple and clear example from Jeremiah, in 13:23 the MT כושי is translated similarly in the Peshitta and in the Targum, הידואה and e cosectively, "Indian"; Weitzman ascribes this agreement to common tradition, noting that $\mathrm{R}$. Samuel believed that the Hebrew כוש bordered on India (Weitzman, 1994, p.80).

12. Frankl (Frankl, 1872, p.546) notes that there are fewer points in the Prophets than in the Pentateuch at which traditional interpretations with halachic reference are evoked by difficult passages. There would therefore be fewer points at which traditions held in common by the writers of Targum and of the Peshitta would be important. 
Chapter $1 \quad$ Introduction

\section{The general character of the translation}

The over-riding impression on first reading is the closeness of the Peshitta to Jeremiah to the Hebrew of the Massoretic Text, and it is only on careful study that the extent to which the translation is non-literal becomes apparent. There are nonetheless numerous non-literal elements, as the discussion in Chapter 2 will show; perhaps because the sense of the Hebrew, and its structure, are almost always preserved by the translator, these elements make little initial impact on the reader.

This initial impression of closeness raises the question of the literary quality of the translation: a translation so close to the source text might of course be stilted and awkward to read. So little is known of written Syriac of the time that there is no sound evidence on which to assess this: possibly, the translator was in fact laying the foundations of literary Syriac, and Nöldeke says in the Preface to the first edition of his Compendious Syriac Grammar "Looking to the great influence of the Peshitta on the style of all subsequent writings, I might perhaps have gone somewhat farther in quoting from it" (Nöldeke, 1880, p.ix). Yet in the Preface to the second edition Nöldeke wrote "The Syriac Old Testament frequently approximates the original Hebrew too closely; and, precisely because of the intimate relationship of the languages, we sometimes find ourselves at a loss as to whether the verbal reproduction is still in conformity with the Syriac idiom, or is really a Hebraism" (Nöldeke, 1904, pp.xiii-xiv). The basis for Nöldeke's "too closely" is however uncertain; possibly, the relationship between the two languages, biblical Hebrew and literary Syriac of the second century CE, was so close that it was often natural to preserve the structure and word order of the first when writing in the second ${ }^{13}$.

It seems likely that this translator, whose presentational style as will be shown laid such emphasis on precision, would have wished to write a clear text which

13. Here, the language of the Vorlage is important: this point is applicable only if the translation was made from Hebrew, and the evidence given below in Annex 2 suggests strongly that this was the case. 
Chapter $1 \quad$ Introduction

put no barrier between his readers and his work. He would not have been aiming at the ideal discussed by Brock "In the case of the biblical translator ... reproduction of the word order of the source language is essential" (Brock, 1984, p.81); rather, he would have sought a style which was readily acceptable and reasonably familiar, and which read aloud well; he would not have written in a foreign idiom; and he would not have used a word order which would grate on his readers.

The non-literal features probably fall into two groups: first, there are those which enter the text as the result of the translator's decision to modify the sense, to increase the precision of the text, to vary lexical equivalents, and to differ from MT with respect to the use of synonym or repetition. These cannot have been forced on the translator by the requirements of the target language.

Modifications in word order may be attributed to the desire to improve the flow of the sentence, in which case they too would fall into this first group. Second, there are those which seem to result from differences in the syntactical structure and idiomatic usages of Hebrew and Syriac (Gelston, 1987, p.131; Lane, 1994, pp.99-109); but the difficulty of interpreting such differences is clear from Gelston's comment (p.138) that "while there is often a prevailing tendency to make a particular modification, there is often also the occasional instance of its opposite!".

Although the work of contemporary grammarians, for instance that of Avinery on the translation of the Hebrew construct (Avinery, 1981, pp.36-38) has clarified many problems, considerable areas of ignorance remain. Taylor comments that the high standard of literary achievement of the Peshitta "no doubt profoundly contributed to definitions of norms for literary standards for Syriac literature in general in the following centuries" (Taylor, 1994, p.320); yet in the absence of an adequate body of contemporary texts for comparison this point cannot be pursued, and one hundred years later there is still no definitive indication as to which of Nöldeke's opposing views was correct. 


\section{The approach to differences between MT and 7al}

Having decided that the MT and 7a1 would form the basis of the study, the most important decision was how to assess differences between these two texts: such differences could be attributed to translation technique (for the moment, the term is taken to include the work of the editors in developing the presentational style), or to differences between the Vorlage and the MT or between the Urtext and 7a1. Weitzman points out that, in theory, all discrepancies between the two texts could be attributed to any one of three possibilities (Weitzman, in press, p. 15):

(i) the result of a retroversion of the Peshitta could be treated as the Vorlage, with all discrepancies between that result and MT ascribed to inner-Hebrew corruption;

(ii) the MT could be taken to correspond exactly to the Vorlage, and the existing Peshitta mss. to the Urtext, and a free translation technique taken to explain all discrepancies;

(iii) the MT could be translated into Syriac, the result taken to be the Urtext, and all discrepancies attributed to inner-Syriac corruption.

Where the classification of any given discrepancy is uncertain the objective of the present analysis has been to establish, whenever possible, a credible route by which that discrepancy may be classified in group (ii), thus taking Weitzman's "maximalist" view of translation technique. This viewpoint seems appropriate in the present discussion, as it enlarges the proportion of examples which can be included in this assessment of translation or revision technique. Discrepancies due to textual corruption during transmission are by definition accidental and therefore illustrate neither translation nor revision technique, which both imply the deliberate putting into practice of a policy: although some interesting discrepancies between the two texts almost certainly do belong in groups (i) and (iii) they cannot be considered further here. One exception has, however, been made for certain "minuses", which will be discussed in Chapter 4: these apparently throw light on the wording of the Vorlage, being "true" with respect to the MT but "apparent" with respect to the Vorlage; and they are therefore so 
Chapter $1 \quad$ Introduction

interesting that they had to be included ${ }^{14}$.

\section{Published work on the Peshitta}

Weitzman notes that the admirable quality of the published work on research into the Peshitta is such that nothing would be added to the literature by a further summary (Weitzman, in press, Introduction p.8). Accordingly, and with constraints of space in mind, the present discussion will concentrate on the literature on the Peshitta which has not yet been so comprehensively reviewed. Frankl's discussion of the LXX and the Peshitta to Jeremiah is the outstanding work in the older literature. Frankl explains that his choice of Jeremiah was made in part, because in his opinion, the Hebrew was usually clear without the assistance of the Versions (p.444), making it easier to assess the translation technique in general and therefore to understand variations in that technique forced on the translator in passages where the Hebrew was obscure. His emphasis is on LXX as a translation, but in one section he concentrates on

14. Comparison of the conclusions drawn in two recent articles on the Peshitta and the Septuagint (Dirksen, 1992, pp.381-389) and on the Septuagint (Marquis, 1998, pp.257-258) is interesting. In a discussion of the evaluation of the Peshitta's deviations from the Hebrew when the Peshitta and LXX agree, Dirksen examines the 47 such cases in Genesis chapters 125. In six, he argues that the variant is forced by the demands of syntax. In thirty-two, the Peshitta and LXX share a reading of a type which also occurs in the Peshitta alone, and which, in Dirksen's view, should therefore be considered to result from translation technique (these include examples of the making explicit points which are implicit only in the Hebrew). A further two cases are explained by stylistic differences, and one more by a theological difference. Dirksen thus arrives (p.389) at a total of six differences which he argues may reflect Hebrew variants. Marquis, on the other hand, writes "In-depth and detailed examinations ... with a clear methodology, of the translation technique of Aquila, Theodotion, and Symmachus are sorely lacking"; in his study of the relevance of these writers to text-critical work on Jeremiah he takes the overall view that the technique is in general literal and supports the existence of variant readings. 
Chapter $1 \quad$ Introduction

the Peshitta (Frankl, 1872, pp.545-557).

There are two principal points in Frankl's work which are relevant to the present discussion: first, the links between LXX and the Peshitta; second, his analysis of the subconscious effect on the translator of the sound of words.

Frankl gives numerous examples showing the influence of LXX on the Peshitta, and that there was such influence is not in doubt: several of the passages on which he commented are discussed in Chapter 6 "Difficult Hebrew". However, whereas it is not difficult to establish that there were points at which the translator may have been influenced by LXX, it is less easy to evaluate the importance of this influence in the book as a whole, and a tendency to over-estimate it must be avoided: isolated examples may make a disproportionate impact on the consciousness of the reader. Frankl does not explicitly make this latter point, but evidently appreciated it, for it is clear from his discussion overall that he does not regard the Peshitta as a primarily derivative work. Frankl gives twenty-five examples of passages at which LXX and the Peshitta agree in such a way as, in his view, to suggest influence of the former on the latter (pp.547-550). Even assuming that his perception is accepted in each case, and the discussion in Chapter 6 will show that there is often more than one way in which agreement between the two translations could have been reached, this total is not large, averaging approximately one passage in every two chapters: and these are presumably the instances which Frankl found the most convincing. As the discussion in Chapter 6 will show, polygenesis is a possible explanation of numerous passages in which LXX and the Peshitta agree against the MT. Discussing LXX, Barr notes that "Where it is a matter ... of obscure words in normal contexts and of strange meanings for common words, there was a strong tendency towards the levelling of the vocabulary and the interpretation of that which was rare as if it was that which was more normal" and emphasises that the setting in the Egyptian community throws doubt on claims for knowledge of rare lexical items on the part of the LXX (Barr, 1988, pp.268-269). Barr's analysis here shows clearly why polygenesis might so often occur: in comparing $L X X$ and the Peshitta, we are not comparing the work of two translators of widely different ability, in which case the less skilled might well be assumed to have sought guidance from the more expert, but of two translators with a similar level 
Chapter 1 Introduction

of expert knowledge, a position in which both might well take the same approach to any given problem ${ }^{15,16}$.

The discussion in Chapter 6 will argue that the proportion of passages in Jeremiah in which dependence of the Syriac on the Greek is the only plausible way to explain such closeness is extremely small. There is occasional clear evidence of influence from LXX, but there are few examples of this in Jeremiah, and they should not cloud the reader's perception of the Peshitta as a largely independent translation.

Frankl's second point, the analysis of the subconscious effect on the translator of the sound of words, is interesting in itself as an indicator of occasional inattention. Frankl seems to have been the originator of the term "Syromanie" (p.501) to describe this process of translation of a Hebrew word by a Syriac word of similar sound but different meaning; later writers, for instance Albrektson (Albrektson, 1963, pp.60-61) and Weitzman (Weitzman, 1996, p.593) have given further examples of the phenomenon.

In some passages, Frankl seems too ready to see this process: for instance, he

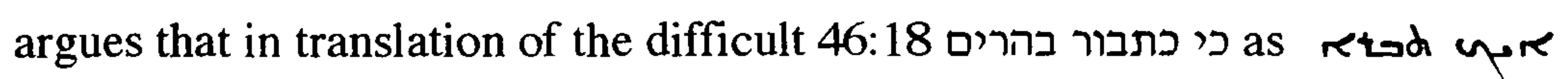
rtafi, (the singular form of retab, although surprising, is that in 7a1)

15. McKane may have tended towards a different view in one of his earlier papers on Jeremiah (McKane, 1972, p.76) in which, discussing the translations of בכרה קלה in 2:23, he says "Pesh. has less right to be regarded as a translation of the Hebrew than LXX". In his overall view (p.80) McKane assesses the Peshitta as, usually, faithful to MT and accurate; in his later commentary on Jeremiah (McKane, 1986, p.xxviii) a similar underlying assessment is evident: "Where there is a difficult Hebrew text ....agreements of Sept. and Pesh. ... are probably explicable as a dependence of Pesh. on Sept."

16. In an early work on the Peshitta Barnes (Barnes, 1901, p. 197) describes LXX influence on the Peshitta as sporadic, affecting occasional words only, rather than a general influence introducing a characteristic, except in Psalms; and even in Psalms, Weitzman considers that the picture may have been distorted because the characteristic apparently introduced by LXX, namely a dread of anthropomorphism, happened to be especially frequent in the Psalter simply because anthropomorphic expressions are especially frequent there (Weitzman, 1994, p.59). 
identifying תבור not as a proper name but as a form of root Łod, the translator clearly erred, led astray by the similarity of the sounds of the Hebrew and Syriac terms concerned. Certainly where תבור occurs elsewhere in MT (Judges 4:6, 12, and 14; 8:18; 1 Sam 10:3; Hosea 5:1; Ps. 89:12; and (Weitzman, in press, Chapter 3, pp.00) 1 Chron 6:62 which is imprecisely translated the translation is with a proper name; but the straightforward contexts make the sense clear, and the apparently mistaken translation in Jeremiah may be a misinterpretation arrived at by careful thought rather than resulting from a lapse of attention.

There is a further example in 48:2, where Frankl suggests that, in translating the difficult גם מדמן תדמי in , LXX was influenced by Syromanie, seeing an Aramaic infinitive in this word (Frankl, 1872, p.501). It seems more probable, however, that the translators into Greek and Syriac both saw in this term an

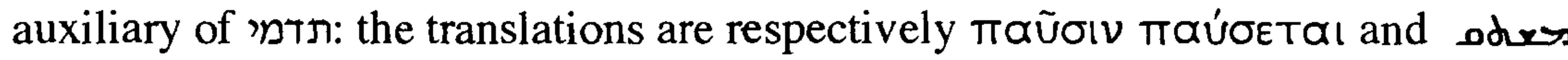
rodurd, (see McKane, 1996, pp.1157-1158); Weitzman (in some notes on this passage which he did not publish but which he gave to the present writer) comments that it seems unlikely that a translator into Greek would be influenced by Syromanie, and indeed Frankl himself in a brief discussion of the place of translation of LXX (Frankl, 1872, p.505) argues that this was unlikely to be Egypt because a Jew living in that country and totally familiar with Greek would hardly make such a mistake: though making a diferent point, he nonetheless reaches the same conclusion as do the other authors.

Frankl gives some better examples, though, and there is no doubt that the phenomenon of Syromanie exists: examples are discussed in Chapter 6. The concept of "Syromanie" is one aspect of a wider area of interest which is almost exclusively relevant only in analyses such as the present one, where the two languages concerned are cognate. The cognate relationship raises two points of particular interest in this context, first that a root may have different meanings in the two languages: obvious examples are root שכח, in Hebrew "to forget" but in Syriac, as root ع 2 , the virtually opposed sense of "to find"; and root שרירות in biblical Hebrew always means stubbornness (B.D.B. p.1057) whereas redat tx means firmness or steadfastness, truth. Differences of this kind are usually well recognised, and do not therefore cause problems in translation. 
More interesting in the context of difficulties arising in the translation of cognate roots is the differing ranges of meaning which may attach to the same root in the languages concerned, and, perhaps the most interesting of all the problems which arises from this, the ignorance of the modern student as to exactly how comprehensive was the ancient translators' understanding of these instances. Given the restricted range of literature extant, it may never be possible to solve this latter problem. Today's student has recourse to help which was not available to the translator: knowledge accrued during the intervening period of almost two thousand years is available, and much of this learning is easily accessed in lexicons and concordances. The translator's knowledge of biblical Hebrew would certainly have been excellent; he would have been able to discuss problems with his colleagues; and he might, if a Jew, have heard the Pentateuch read and perhaps expounded in Aramaic ${ }^{17}$ : nonetheless there are points where his understanding of nuance is in doubt. The two particularly interesting examples are the derived forms of root שבב and שוב. In both these pairs, there is a "core" meaning common to both, and a further development of meaning has occurred in one of the two cognate languages only. For root analysis presented in detail below in Chapter 6 "Difficult Hebrew", suggests that the Hebrew root had developed a meaning which may not have been embodied by the Syriac cognate. Root illustrates the reverse position, having evidently developed in Syriac a meaning not found in the Hebrew cognate; this too is discussed in Chapter 6. Weitzman, in the Introduction to his book on the Peshitta to the Old Testament, points out that outside the Pentateuch the only books of the Hebrew Bible on

17. Familiarity with a complete reading tradition is not certain, even for the Pentateuch: Weitzman (Weitzman, 1996, p.589; and Weitzman, in press, pp.2()-21), $\quad$ shows that some of the translations in the Peshitta contradict the vocalisation of MT, giving examples from Deuteronomy, Judges, and Samuel, and concludes that the translators may have had "a patchy knowledge of a reading tradition, which might or might not cover parts of the book which he happened to be translating". Analysis of Ktib/Qere variants is less helpful here than might have been hoped, for most of the differences in Jeremiah are so subtle that, given that the 
Chapter $1 \quad$ Introduction

which no running commentary exists are Judges and Jeremiah (Weitzman, in Press, p. 10).

The constraints of space preclude an attempt at a running commentary here; but it is hoped that the analysis of the translation technique which follows may fill some part of the gap.

Footnote from p.34 contd.

translation is not an exact reproduction of MT, they are not a sound basis for argument. The analyses published by Gordis (Gordis, 1937, p.65) relating to Jeremiah, and by Englert (Englert, 1949, pp.65-66) on 2 Samuel, suggest respectively that the LXX and the Peshitta follow the Qere more often than the Kethib: this could be due to the translator following a reading tradition but could of course also follow from his having critically assessed the variants and decided that the Qere was, for whatever reason, preferable.

There are 135 passages at which there is a Kethib/Qere difference in Jeremiah (editions of MT vary in this respect to a surprising extent; this count was made from the Snaith edition (Snaith, 1958), in which these points are particularly clearly noted). These have been analysed individually, but the constraints of space make it impossible to give the full results here. At first sight, analysis of the Peshitta to Jeremiah confirms Englert's conclusion: there is, apparently, a marked tendency for the Peshitta to follow the Qere rather than the Kethib: in 65 passages, the Qere has been translated; in 16, the Kethib; in the remaining 54, it is impossible to be sure. However, the differences between the Kethib and the Qere forms are, so often, so subtle that, given that the Peshitta is not a consistently literal translation, it would be unwise to place much faith in this apparent preference.

The translator may not even have weighed up these alternative readings: Barr (Barr, 1967, particularly pp.1-3) points out that although it may seem to the modern reader that the translator "vocalised" the Hebrew it is possible, for instance, that he may have worked from the written form of the Hebrew without fully vocalising this, selecting the meaning according to context; Weitzman (Weitzman, 1997, pp.383-384) points out that, if he found it necessary, the translator could "set aside any tradition of vocalisation".

The difficulty of being sure of the translator's motive is illustrated by the translation of 32:23 ולא שמעו בקולך ובתרותך לא הלכו, where the Qere is ובתורתך. The Peshitta follows the Qere: yoosso, a singular noun. The translator may have been influenced by a reading tradition in deciding to follow the Qere; but he may have been guided by his familiarity with the MT in 


\section{Chapter $1 \quad$ Introduction}

which the singular is far more common: the plural of תורה is found at only 13 other passages in the Hebrew Bible. It is true that in all but two of these the Peshitta has a plural (the two exceptions are Isaiah 24:5, and Ps 105:45), but even so the translator of Jeremiah may simply have preferred the more usual form; also, there are some mss. which have the singular (Kennicott, p.138, 1776).

On the other hand, translations of verbs in the second person feminine singular written in the archaic form (Gesenius, 1903, p.115, n.4, rem.2) with a final yodh, which form another good illustration of the difficulty of determining which of a number of possible reasons prompted the translator's decision, do on balance suggest adherence to the Qere. There are examples in 2:20 . Tתקתי מוסרתיך and שברתי עלך. There are no Kethib/Qere variants in either phrase, and each is translated as if the verb were in the first person, dtod and doong respectively. In each, either a first or a second person translation would make reasonable sense, so it cannot be assumed that the translator failed to understand the archaic grammatical forms: he may simply have judged that the first person fitted the context better. However, in such passages as 3:5, shown below, the form in the Kethib is similar to those in 2:20 but there is also a Qere requiring that a second person form be understood. In these, the Peshitta gives a second person form: so it seems that the translator was influenced by the Qere; but he may have ${ }_{\lambda}$ iudged that only a second person form

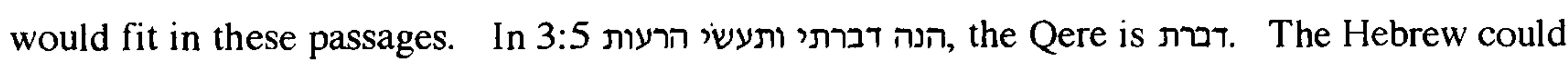
be understood as including a deliberate contrast: "I spoke, but you did evil"; but it could also be taken to mean "you spoke and you did evil": the sense does not dictate the translator's decision to use disarills. 
The familiarity of Aphrahat with the new readings

The passages in which two conditions are met:

(i) Aphrahat's citation agrees closely enough with MT not to be considered as an error;

(ii) the readings in $7 \mathrm{a} 1$ and $9 \mathrm{a} 1$ differ from one another

are set out below ${ }^{1}$.

In each of these passages, examination shows that 9a1 agrees with MT against $7 \mathrm{a} 1$, and Aphrahat's citation is very close to or identical with 7a1, suggesting that either Aphrahat, or the scribe, or both, were familiar with the new readings of 7a1. It is well appreciated that these examples are far too few, and individually not always convincing, to prove this point; nonetheless, taken together, they amount to an interesting group of passages which should not be ignored simply because they constitute only imperfect proof.

In canonical order, the passages are:

$6: 16$ אי-זה דרך הטוב ולכו-בה

$7 \mathrm{a} 1$

9a1 fam

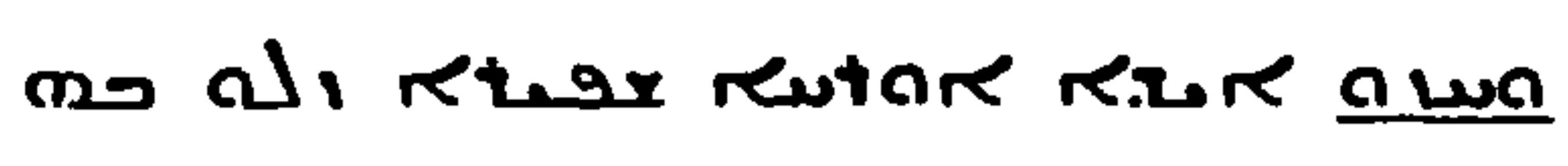
ma al Rtax rewtak R.ter

Demonstratio 12, De Paschate

Aphrahat vol.I, col.513

m D. Rt.ax Rutar Kick awa

The addition of a verb, a a , is in conformity with the translation technique; numerous other examples are discussed in Chapter 2. היכל יהוה היכל יהוה היכל יהוה המה

$7 \mathrm{a} 1$

9a1 fam

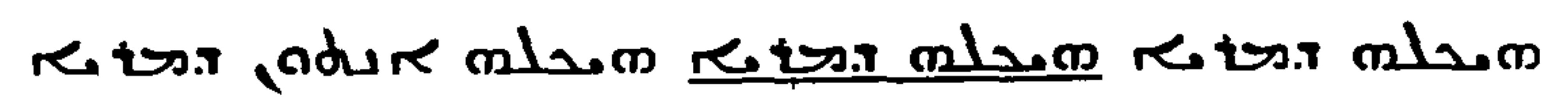

Demonstratio 14, Exhortatoria

Aphrahat vol.I, col.9

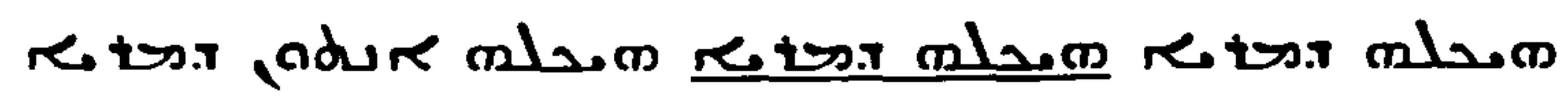

There may be haplography in 9a1, not represented by Aphrahat's citation. 
MT 18:7 רגע אדבר על-גוי ועל-ממלכה לנתוש ולנתוץ ולהאביד

$7 a 1$ a a.soslo

9a1 fam

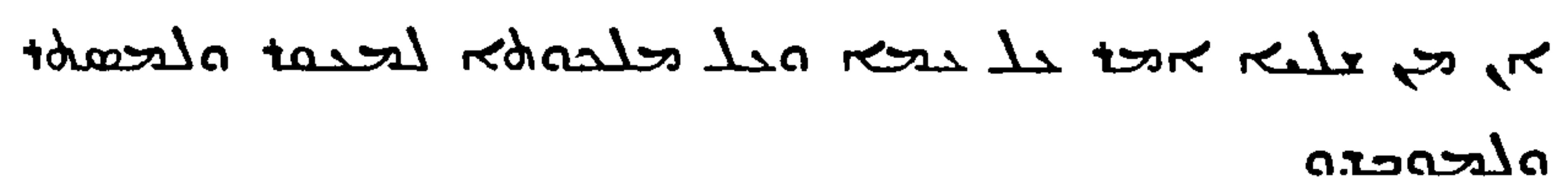

Demonstratio 2, De Caritate

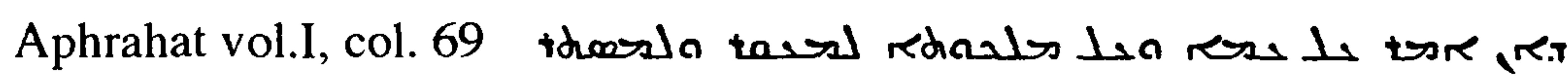
a.sorsla gavosta

The addition of a term, areasla, is in conformity with the tendency to harmonise one passage to another discussed in Chapter 2. Aphrahat's omission of relx $\rightarrow$ does not invalidate this example.

MT 18:9 ורגע אדבר על-גוי ועל-ממלכה

$7 \mathrm{a} 1$

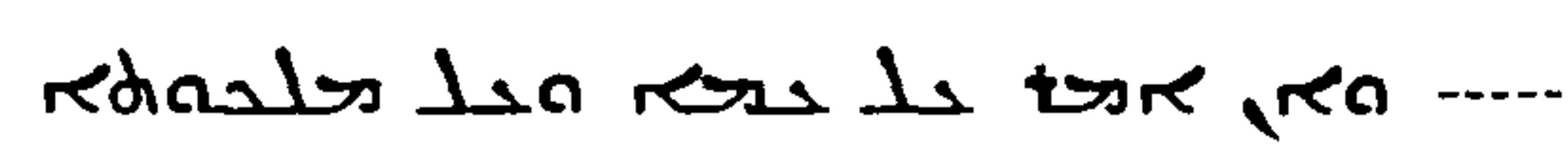

9a1 fam

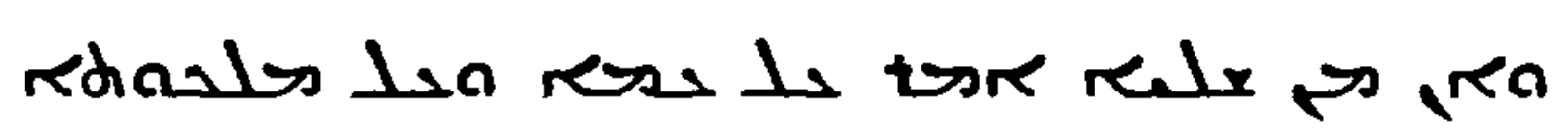

Demonstratio 2, De Caritate; Demonstratio 7, De Paenitentibus; Demonstratio 19, Adversus Iudaeos, Aphrahat I, cols.72, 329, 852 respectively

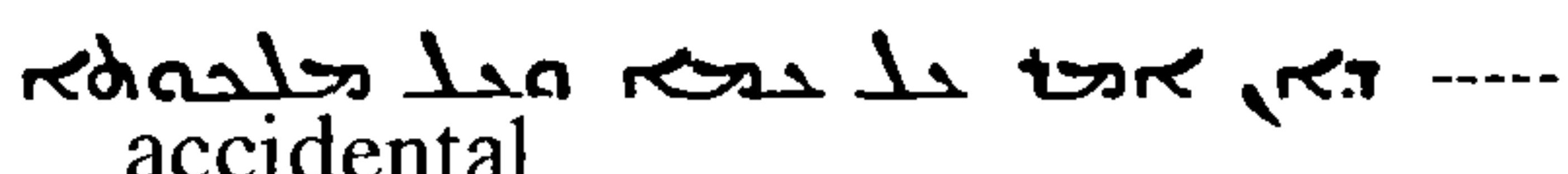

The minus at $\mathrm{rel} \times \mathrm{s}$ in $7 \mathrm{a} 1$ is probably due to haplography with $18: 7$ which also begins רגע אדבר על-גוי

MT 28:14

$7 \mathrm{a} 1$

9a1

Demonstratio 5, De Bellis

Aphrahat vol.I, col.216

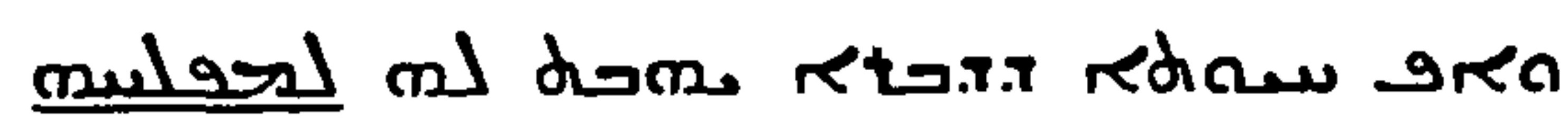

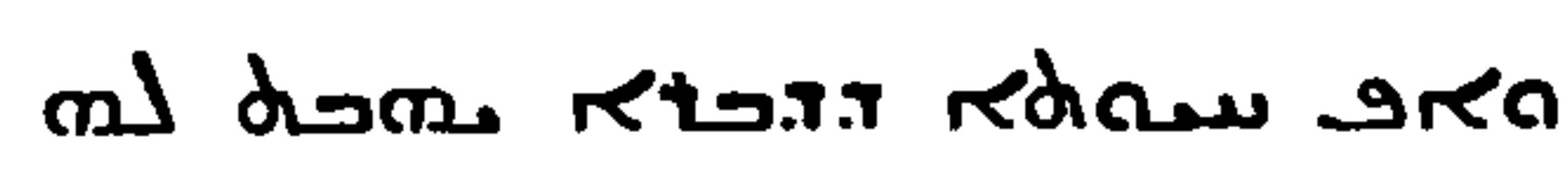

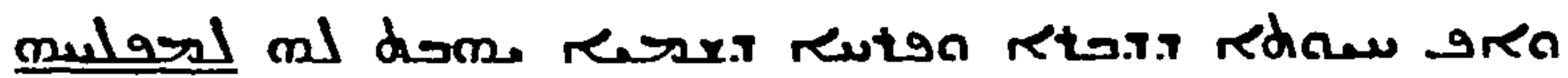

Aphrahat's citation agrees with 7a1 in the addition of the verb, conforming with the drive for precision to be discussed in Chapter 2, at mulas. Aphrahat's other addition at rese.r ruton has no equivalent in 7a1, but does not invalidate this example. 
Annex $1 \quad$ New Readings in Aphrahat

1. Three more are probably simply matters of small changes in idiom with the passage of time: for instance, the Hebrew construct is rendered differently in 9a1 and 7a1 to 35:13, a point discussed in more detail in Chapter 5. It would be unjustifiable to take these as illustrations of Aphrahat's familiarity with the new readings rather than the old, and they are given below only for the sake of completeness:

$5: 14$

$7 \mathrm{a} 1$

9a1 fam
הנני נתן דברי בפיך לאש

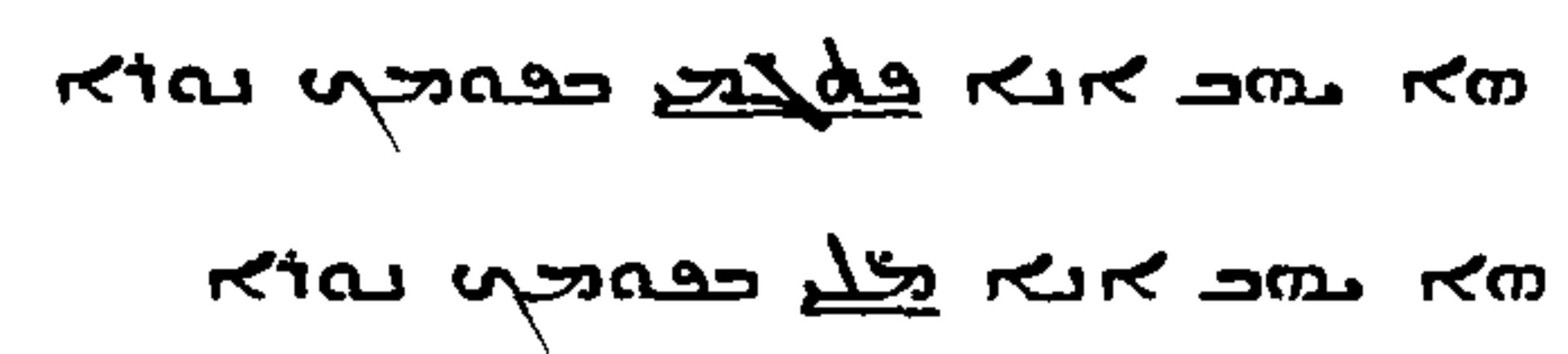

Demonstratio 5, De Bellis

Aphrahat vol. 1, col.200

The variation in the term used for the word of God may simply represent a change in idiom between the time of writing of the ancestor of 9a1 and of Aphrahat.

$9: 25$

$7 \mathrm{a} 1$

9al fam

Demonstratio 11, De Circumcisione

Aphrahat vol.I, col.480

The new reading replaces "Judah" by the more familiar "Jews": the representation in Aphrahat's citation may simply reflect a change in idiom.

MT 35:13

$7 \mathrm{a} 1$

9al fam

Demonstratio 14, Exhortatoria

Aphrahat vol.I, col.576
לאיש יהודה ולישבי ירושלם

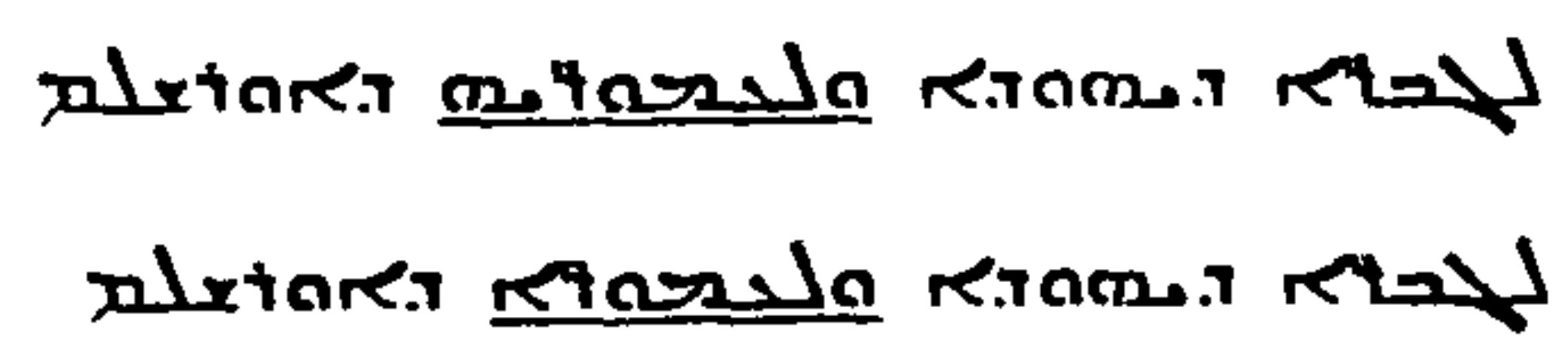

pletarki m.4azela riamo.t raty

The variant here probably represents a change in idiom with the passage of time. 


\section{A Hebrew Vorlage}

The various relationships which have been suggested between the Peshitta and the Targums, or between the Peshitta and a lost Aramaic Vorlage which was closer to MT than are the extant Targums, are discussed in full by Weitzman (Weitzman, in press, pp.87ff) who concludes that there is no evidence for an Aramaic Vorlage. Similarly, Weitzman argues against a Greek Vorlage (Weitzman, in press, pp.69ff).

From within Jeremiah, there is a substantial body of evidence supporting these arguments and suggesting that the Vorlage was written in Hebrew. This evidence falls into five principal categories:

(i) translations which seem to be based on errors or misunderstandings;

(ii) the inconsistent use of LXX for guidance at difficult passages;

(iii) atomistic translations;

(iv) translations in which the Syriac terms chosen mimic the sounds of the Hebrew words;

(v) the spelling of some names.

(i) translations which seem to be based on errors or misunderstandings There are some errors or misunderstandings in the translation which are hard to explain if the Vorlage was written in a language other than Hebrew.

There is an example in 20:3 of a translator's error which must result from his failure to appreciate an imperfect correspondence of the meanings of cognate roots in the two languages. Pashhur's new name is given: לא פשחור קרא יהוה r but in translation we have: שמך כי אם-מגור מסביב

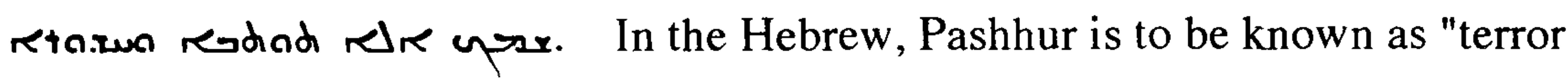
on every side"; in the Peshitta, his new name is "a sojourner and a beggar". The translator has taken סביב, which is often translated by the preposition , משיב, and transformed this to the related noun reta.w, "one who goes about", which in Syriac had developed to "vagrant, beggar". This meaning had not developed in the Hebrew, which has effectively been mistranslated because the translator did not appreciate the difference in range of meaning of the two cognates; the error could not reasonably have occurred without the interplay of the cognate 
Annex 2 The Language of the Vorlage

languages (there is a fuller discussion of the approach to מגור מסביב in other contexts in Chapter 6).

Similarly, at 7:29 דור עברתו, "the generation of his wrath", that is "the generation on whom his wrath will fall", becomes rataressing generation". The translation does not recognise the MT sense of root עבר here, the development of "passing over" to "overflowing", "excessive rage".

There is a further example at 23:40 where there is an error which seems likely to result from the change in meaning between root שכח, in Hebrew "to forget" and in Aramaic and Syriac "to find": כלמות עולם אשר לא תשכח becomes rodma r.efds s. reversing the sense of the MT "shall not be forgotten". This is a mistake which strongly suggests a Hebrew Vorlage.

(ii) the inconsistent use of LXX for guidance at difficult passages Further evidence against a Greek Vorlage is given by the inconsistency of the translators' use of LXX for guidance when working on an obscure passage: the extent to which they apparently went to LXX for help varies between books. Weitzman discusses this variation in his analysis of the features which distinguish a progressive from a conservative translation (Weitzman, in press, p.181). Not only does the influence of LXX vary between books, however: it varies within one book, and even within one verse: examples from Jeremiah are discussed in Chapter 6 "Difficult Hebrew". Were the Vorlage written in Greek, a psychological barrier between the translator and LXX would be removed, and it seems reasonable to suggest that his use of the latter might well have been more frequent and consistent.

(iii) atomistic translations

There are also a small number of passages at which the translator seems to abdicate his function and to give an atomistic translation, resulting in an obscure Syriac text which so closely mirrors the Hebrew of MT that it seems virtually certain to be a direct translation of that Hebrew. For instance, 6:11 ואת חמת יהוה

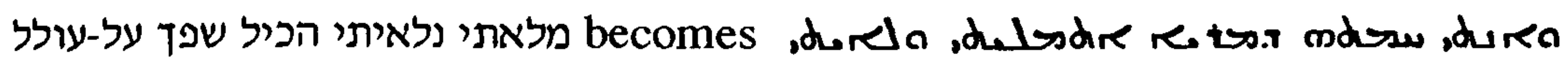

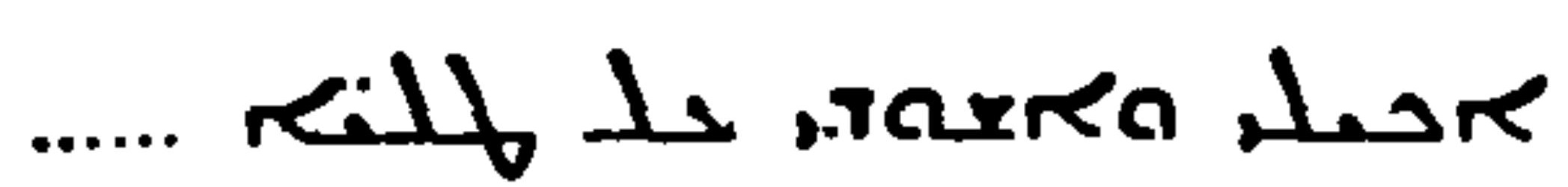


Annex 2 The Language of the Vorlage

(iv) translations in which the Syriac terms chosen mimic the sounds of the Hebrew words

There are other passages at which the Hebrew presents a familiar root in an unfamiliar context, and the translator's solution is to mimic the sound of the Hebrew term in a Syriac term with a different but appropriate meaning: "Syromanie". There is an example in 2:6, where בארץ ערבה ושוחה becomes redomea redatw שוח , "to sink down", was recognised where it occurs in a passage where although the language is figurative the meaning is plain, for instance in 18:20 כי-כרו שוחה לנפשי where it is precisely translated with root 5 . In 2:6, however, the sense "pitted" is less clear, and the similarity in sound between שוח and root $\mathrm{rax}_{\mathrm{n}}$, "to be void, waste" seems likely to have influenced the translator.

There is a further example in 2:20 where תחת כל-עץ רענן את צעה זנה "under every green tree you sprawl in fornication (to fornicate)" becomes

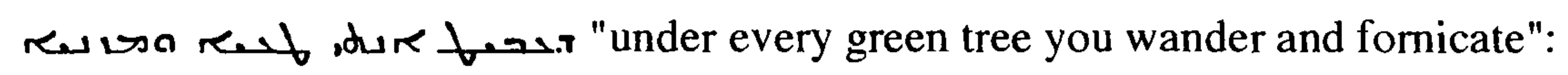
it seems possible that the translator was influenced subconsciously by the similar

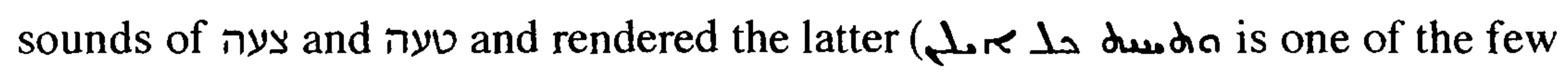
points at which $7 \mathrm{a} 1$ is illegible).

" נפחה נפשה " ,אמללה ילדת השבעה נפחה נפשה באה שמשה בעד יומם 15:9 is admittedly obscure, even though its component roots are not ${ }^{2}$. Its

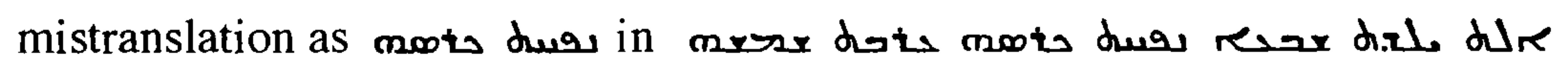
masa da a is however due not to any obscurity but to a failure of צבתה 5uch that the translator wrote the translation of Num such

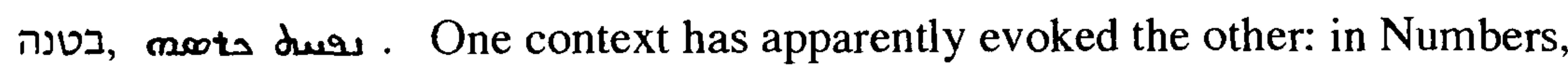
the humiliating treatment of the woman accused of unfaithfulness is described, and the verse in Jeremiah continues בושה וחפרה , expressing the idea of shame; and at the Numbers passage the MT continues ונפלה ירכה, so that not only similar ideas but similar sounds too are present in the subconscious mind. For the similar sounds to influence the translator, it seems most unlikely that he could have been working from a Vorlage in Greek. 
Annex 2 The Language of the Vorlage

(v) the spelling of some names

Greek transliterations of Hebrew names, in which the sibilants $\delta$ and $\checkmark$ are indistinguishable from one another, provide further supplementary evidence that

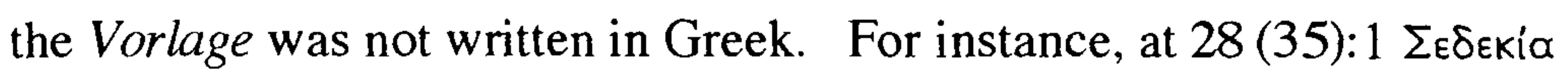

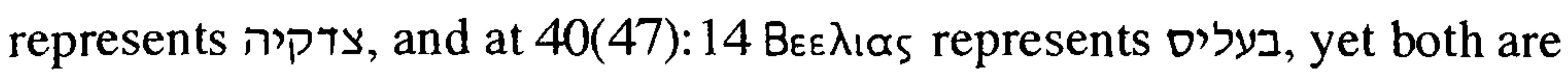

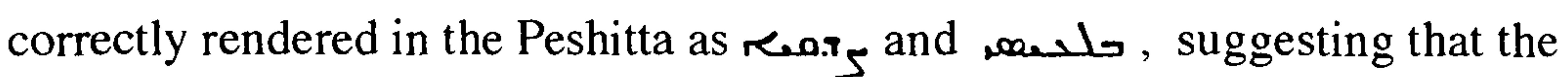
translation was made from a ms. in which each of these letters was identifiable; there are many similar examples outside Jeremiah too. For this to be conclusive evidence, we would have to know that the translators' access to the Hebrew Bible was exclusively through a Greek Version, that they had no familiarity with these names outside such a document, that there was no reading tradition, and that the names were not part of the common cultural background; nonetheless the Syriac spelling of these names adds to the body of evidence suggesting translation from a Hebrew original. 
In this chapter, the characteristic approach of the translator of Jeremiah to his source text will be discussed. This study has shown points of particular interest concerning the following elements of the translation technique:

(i) the preservation of the sense of the source document;

(ii) the selection of lexical equivalents;

(iii) the harmonisation of one verse with another, either within the same book or in another book;

(iv) a. additions; b. minuses ${ }^{1}$;

(v) the representation of figurative language;

(vi) the attitude to anthropomorphism;

(vii) the attitude to grammatical inconsistency in the source document;

(viii) the attitude to logical imprecision in the source document;

(ix) the preservation of the word order of the source document.

The analysis to be presented below will show that while the Peshitta of Jeremiah almost always preserves the sense of the Hebrew, it differs from the MT in style; the Syriac is characterised by accessibility and by precision, with additional terms where desired, giving a text so exact that it may occasionally verge on pedantry. Lexical equivalents are characteristically selected with some degree of freedom. Verses are often harmonised with others, either from within Jeremiah or from other biblical books. Metaphor is sometimes decoded, and simile is often given in its place. Anthropomorphism present in the Hebrew is often preserved. Grammatical inconsistency and logical imprecision in the source document are frequently eliminated, and word order may be changed.

These findings agree well with those in the literature: Gelston writing on the Peshitta of the Twelve Prophets comments (Gelston, 1987, p.111) that the 
primary purpose of the translators was usually "to produce a readable and intelligible rendering in their own language of the Hebrew scriptures still used by their own community in public worship. Intelligibility was often a more important objective than minute and literal accuracy". Later in his book, (pp.156-159) discussing the extent to which the Peshitta of the Dodekapropheton may be used in reconstruction of the Hebrew Vorlage, Gelston notes that the translators took liberties in respect to syntax and vocabulary, were inconsistent in their choice of lexical equivalents, and would make minor adjustments to explicate the meaning of the text or occasionally for theological reasons. Weitzman too describes the striving for clarity and for logical precision (Weitzman, 1996, pp.590-591) and concludes that the translators aimed primarily to convey the plain sense (p.609).

\section{The results of the analysis}

The discussion of translation technique presented here is based on a word by word comparison of the source document and the translation throughout the book; Jeremiah is a long text, 1364 verses in total, and this analysis has yielded a considerable quantity of data from which it has been possible to characterise the features of the translation technique.

In the presentation of the findings of analysis of a text of this length it is essential to find a balance between two approaches: excessive amounts of detail and numerous examples to illustrate each point have the drawback that they take up so much space that there is not enough room for adequate discussion; on the other hand, limiting the quantity of detail too stringently results in a text which does not allow the reader to judge whether or not the conclusions drawn are well-founded. The best solution seems to be to use a structured sample: in this way it is possible to give an approximate quantitative assessment of the frequency of the characteristic features of the translation technique which forms a background to the full discussions in this and later chapters. A quantitative basis to the comparison of these literal and non-literal elements is needed if a balanced assessment of their relative importance in the translation technique is to be 
reached: analysis of the non-literal features readily assumes disproportionate importance in a discussion, because so much more detail is needed to establish the exact nature of the differences between two texts, and the routes by which these have been reached, than to show that two texts are close to one another. The structured sample used is made up of the tenth verses of every chapter (except that in the short chapters 45 and 47 the fifth and the seventh verses respectively were used) so that oracles to the Israelites, narrative sections, and the oracles to the nations are all represented. Tenth, rather than earlier verses, were used because by that stage of a chapter all introductory features have been completed and the writer has usually settled into his main theme, so that the verse is likely to be reasonably representative of the chapter as a whole. The construction of the sample was established at a preliminary stage in the detailed analysis of translation technique, and the sample is therefore unbiased; it was not selected in the light of any prior knowledge that it would demonstrate any particular feature.

Taking the MT punctuation (within individual verses, rather than between groups of verses as indicated by petuhot and setumot ) as indicating divisions between sense units, there are 186 such units in these 52 verses, and the count of the elements of the translation technique can be seen in proportion to this number. Due to constraints of space, and because it is purely a working tool and in itself adds nothing of interest to the discussion, the sample is not reproduced here. Analysis showed that it included seventeen examples of additions; five examples of greater grammatical precision in the translation than in MT; and twelve passages in which the word order had been changed in translation: clearly, these are all features which the translator felt free to introduce when he judged it necessary. Other features of the translation technique, for instance change in the sense, and the characteristic decoding of figurative language, were found but less frequently, and it is important to note that no estimate of overall prevalence can be made on the basis of such small numbers, for the effects of chance on the calculation may be so great as to invalidate any such assessment. 


\section{The results of the comparison of the MT and 7al}

\section{(i) The preservation of the sense of the source document}

The changes in sense which the translator introduced are taken first because, although few in comparison with other points of translation technique which have resulted in differences between the MT and the Peshitta, they are of great interest. These passages have enough in common to be seen as a group: their theme overall seems to reflect the movement away from a Temple-based religion to one which had to be practised in exile and in which, perhaps because of the exile, sacrifice was of diminishing importance, its place being taken by prayer, and faith and (eschatological) hope, rather than external observance, are emphasised: the theological attitudes of the translators are discussed by Weitzman (Weitzman, 1996, pp.597-598) ${ }^{2}$. There are also a small number which suggest actual antagonism to the Israelites.

Twelve examples are used here to illustrate this aspect of technique: in canonical order, they are $7: 4-5,10 ; 8: 10 ; 13: 14 ; 16: 18 ; 17: 26 ; 18: 18 ; 23: 33,39 ; 32: 16-17 ; 33: 6,18$.

\section{$7: 4,5$}

היכל יהוה היכל יהוה היכל יהוה המה

becomes

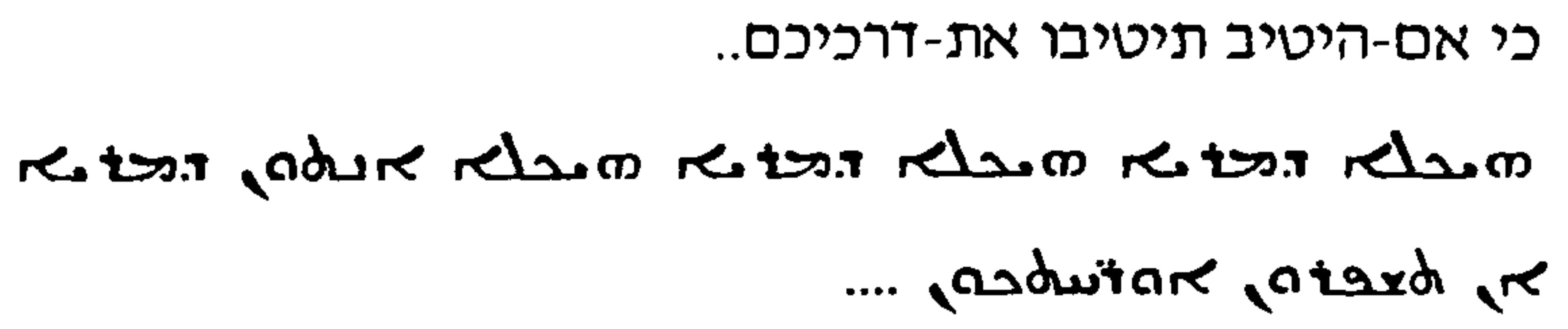

The Syriac may refer to the Christian doctrine that a man should aim to improve

2. Dirksen (Dirksen, 1995, pp. 19-20) discusses the religious stance of the translator of Chronicles, and argues that this is shown even more clearly than Weitzman (Weitzman, 1996, pp.597-598, and in press, pp.208-216) has found. Dirksen cites some deviations from the MT which he argues show the translator's sense of "moral responsibility, together with a strong sense of community". 
himself so that he becomes a temple for the Messiah to dwell in (1 Cor 3:16, 17). The Syriac changes the pronoun from "they" to "you" and implies, perhaps with actual underlying hostility, in a change which was noted by Aphrahat (ed. Parisot , 1894-1897, Dem.I, cols.8-9) and discussed by Burkitt (Burkitt, 1904, p.83) that there is no need for the temple if social justice is pursued ${ }^{3}$. Weitzman notes that the Peshitta "You are the temple of the Lord, if you improve your ways..." implies that the physical Temple is obsolete (Weitzman, in press, p.218).

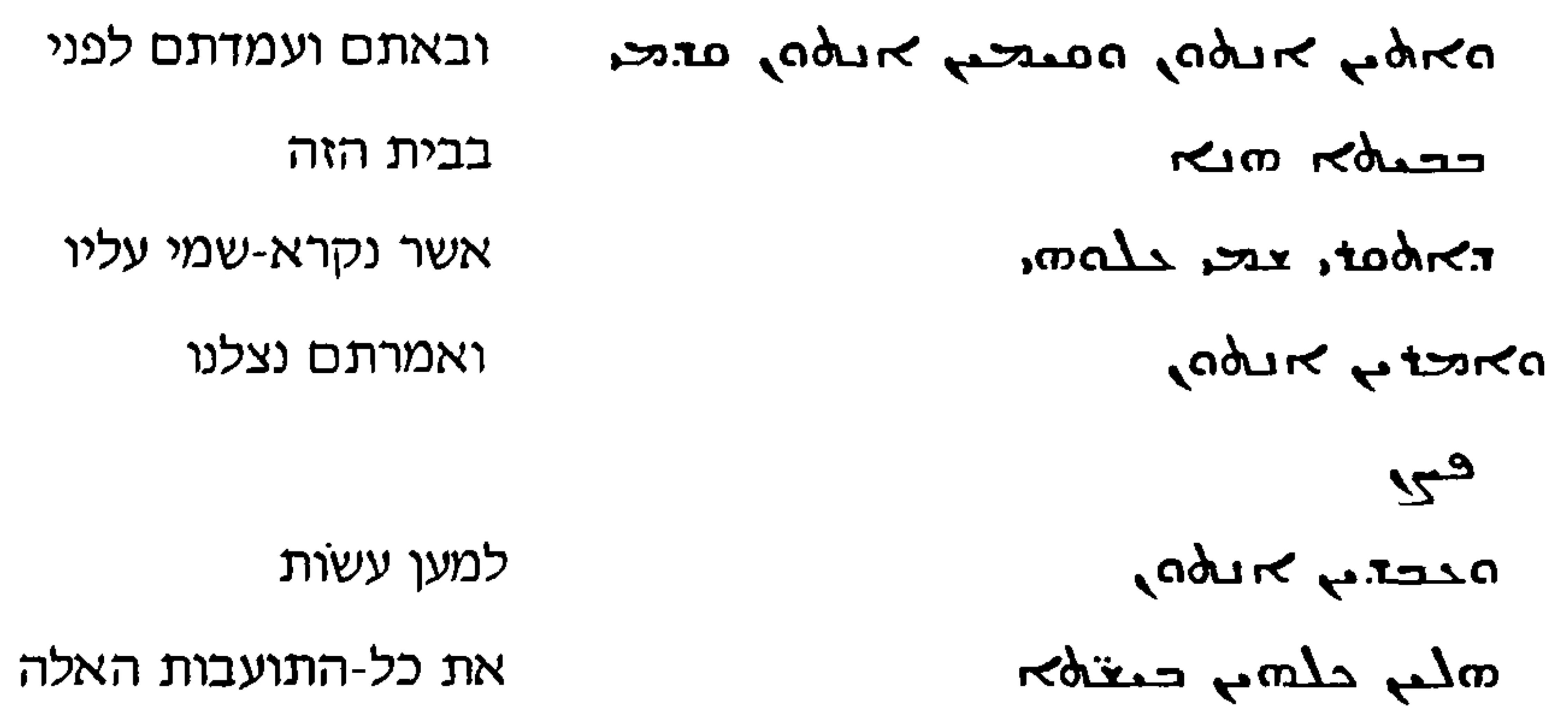

The change from perfect to imperative in the translation of נצלנו, to show a people not merely self-satisfied and over-confident, but imperious and irreverent, may well have been deliberate: the antagonism which the change would have expressed would tally well with the example above in vv.4, 5 .

3. Aphrahat bases his commentary on the difficult המה. In translating this term with adure, he evokes Lev. 26:11, 12, and New Testament passages including 1Cor 3:16, 17; 2Cor 6:16. He says:

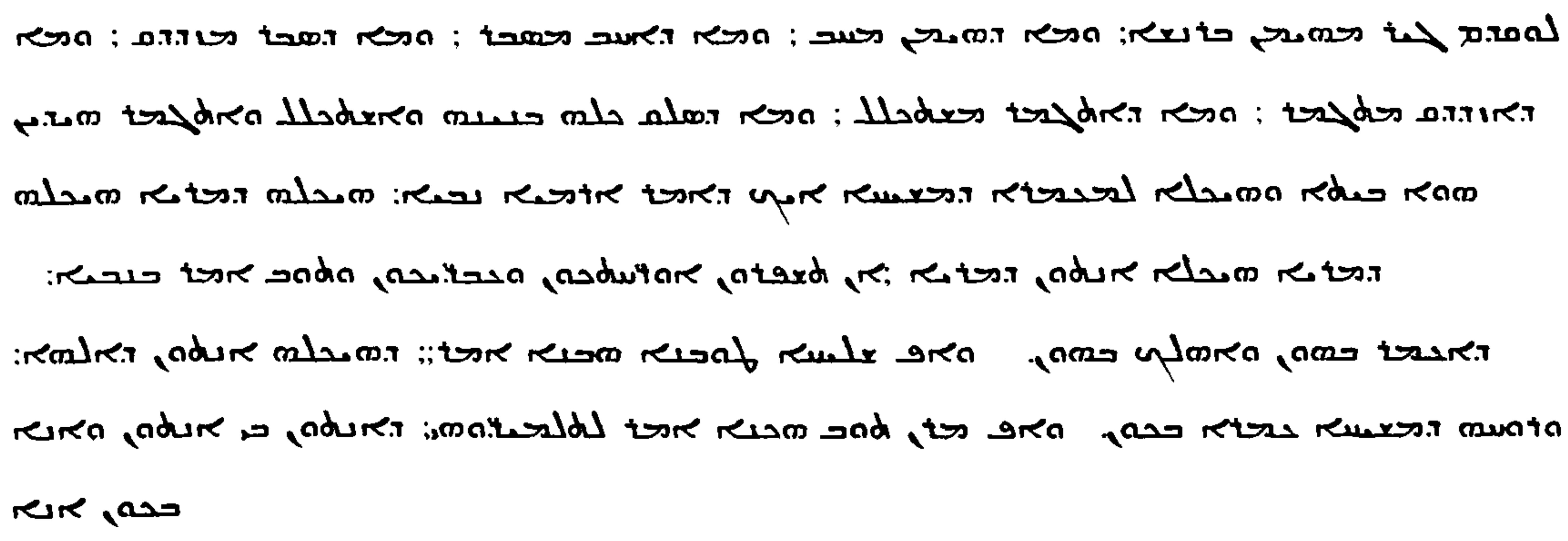


There is an alternative possibility, that the change was not deliberate but due to the translator understanding not נצבְלנו , a Niphal perfect of root נצל as in MT, but as נְְַּלנו , presumably a Piel imperative with an objective suffix (Holladay, 1986, p.246); the Piel of this root occurs for instance at Ezekiel 14:14 נצלו נפשם in the sense "to deliver".

$8: 10$

$$
\text { לכן אתן את-נשיהם לאחרים }
$$
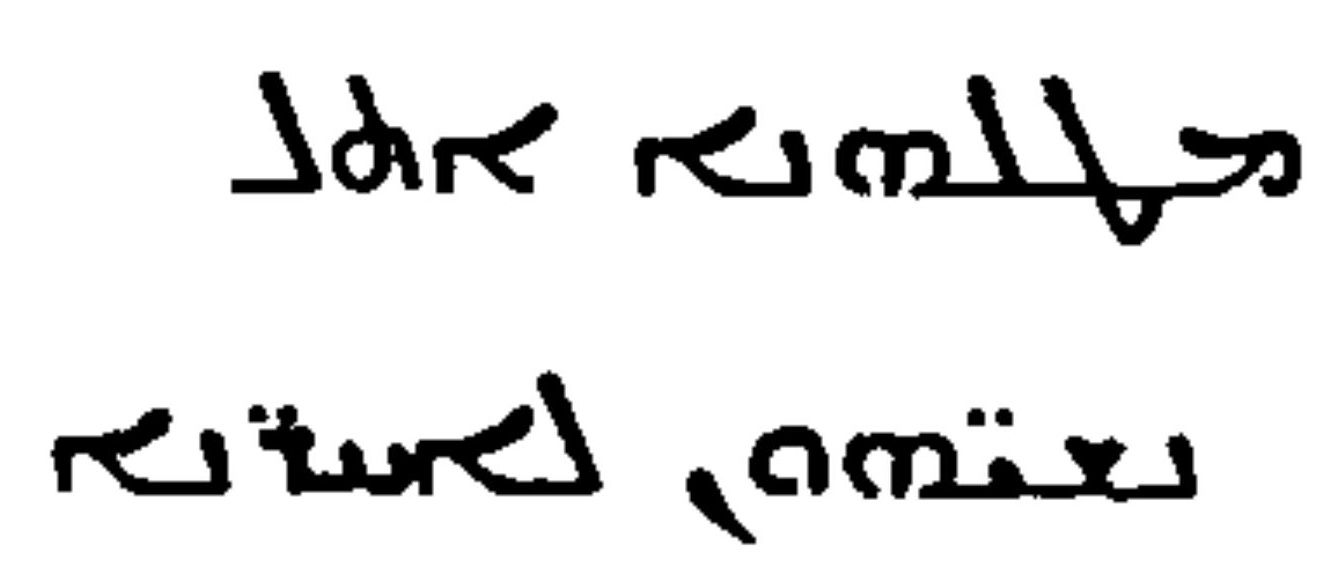

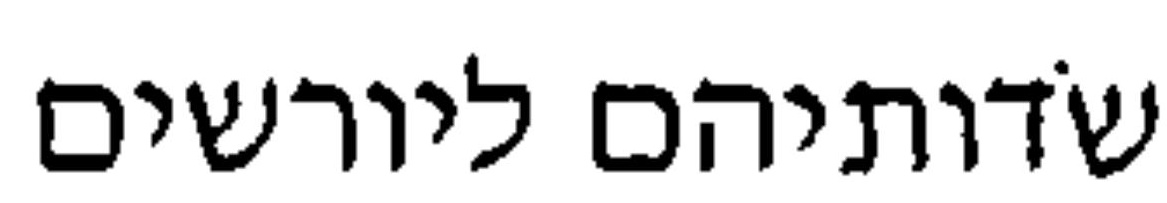

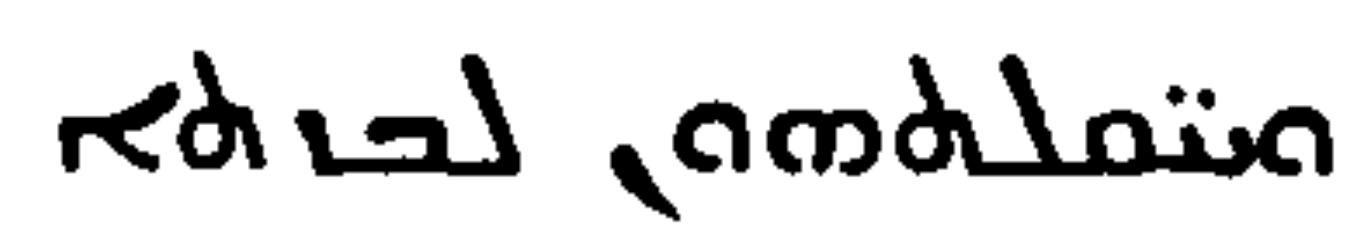
כי מקטן ועד-גדול כלה בצע בצע

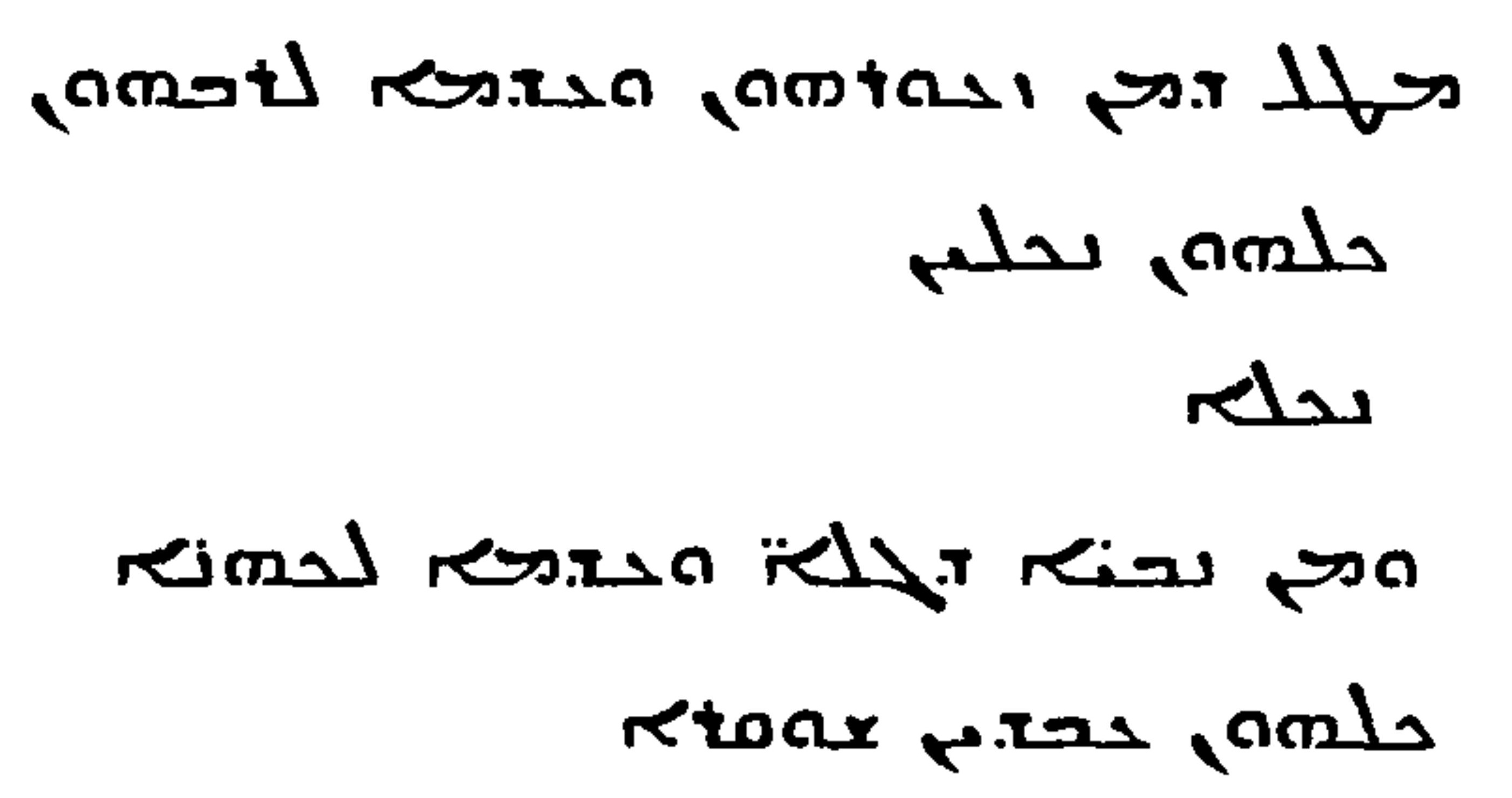

Root מורשים מים, used here to render, is used in Jeremiah as a drudge-word, translating seven Hebrew roots in its thirty-nine occurrences 4.

4. שT: 4:13, 20 x 2, 30;6:7, 26; 9:18(19);10:20;12:12;15:8;20:8;25:36;47:4; 48:1, 8, 15, 18,$32 ; 49: 28 ; 51: 48,53,55,56 ;$ ב : $2: 14 ; 15: 13 ; 17: 3 ; 20: 5$ (crossed equivalent, a feature to

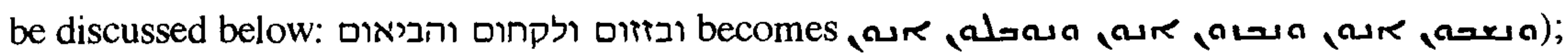

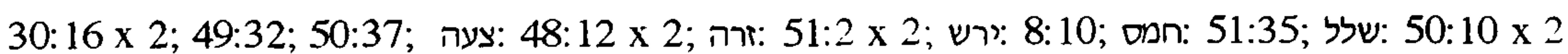

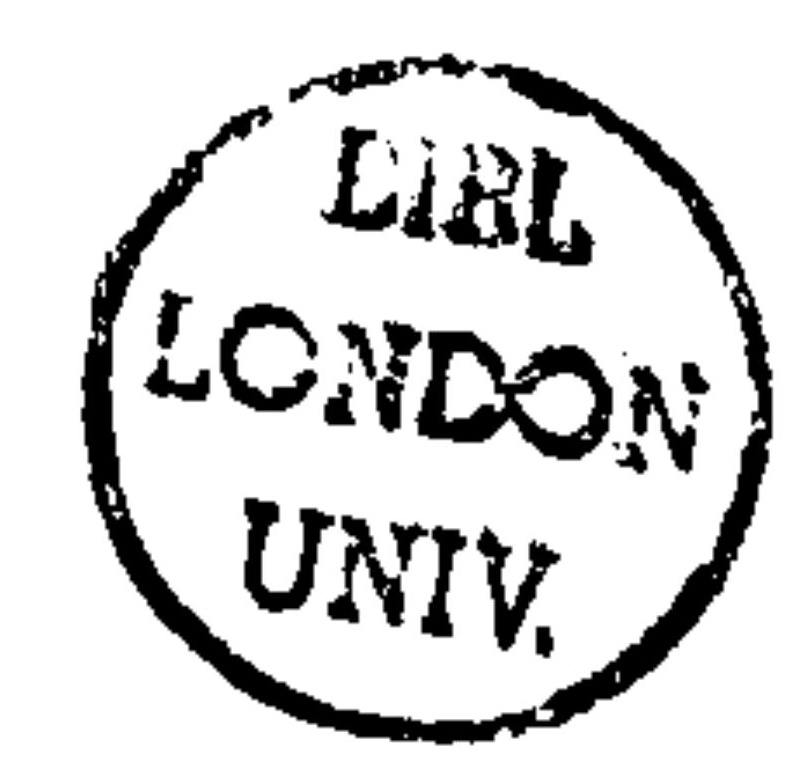


Despite its widespread use, however, its use here rather than the cognate root dit is unexpected, for at all other occurrences of root ירש in Jeremiah, at 30:3;32:8,

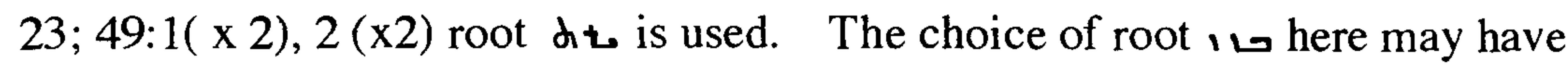
been deliberate, to emphasise the punitive nature of the transfer of ownership which God threatens.

\section{3:14 becomes ונפצתים איש אל-אחיו} root נפץ has been understood to mean "disperse" rather than "shatter", even though the latter meaning seems far more appropriate to the metaphor of the container of wine, and the preposition in "אל-אחיו" fits awkwardly with the sense of "disperse". The sense of the diminished importance of the Temple as a focal point for religious practice, leading to a general preoccupation with exile, may explain the translator's preference for this interpretation.

16:18 gives a striking example of the changed attitude to sacrifice: על חללם את

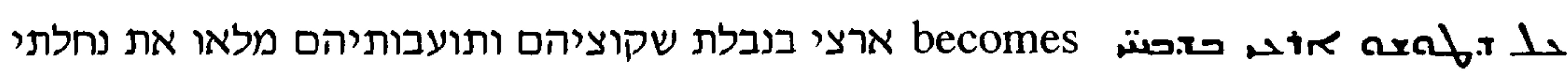

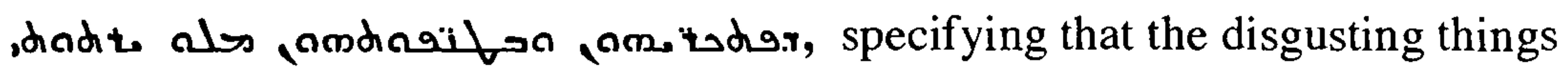
with which God's land has been defiled are items of sacrifice, a point implicit but not explicit in the Hebrew.

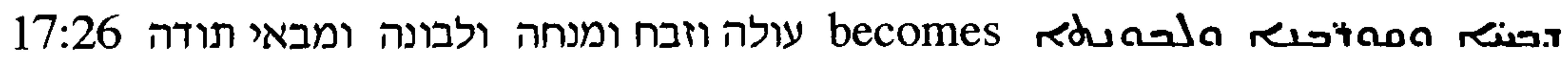
red.rad rdasa, giving a further example of the agenda expressed in the example in 16:18, expressing a casual attitude to sacrifice by the imprecise translation of the relevant terms: the three Hebrew terms זבח, עולה, and מנחה have become only two, مصن and مatr.

18: 18 כי לא תובד תורה מכהן ועצה מחכם ודבר מנביא לכו ונכהו בלשון becomes

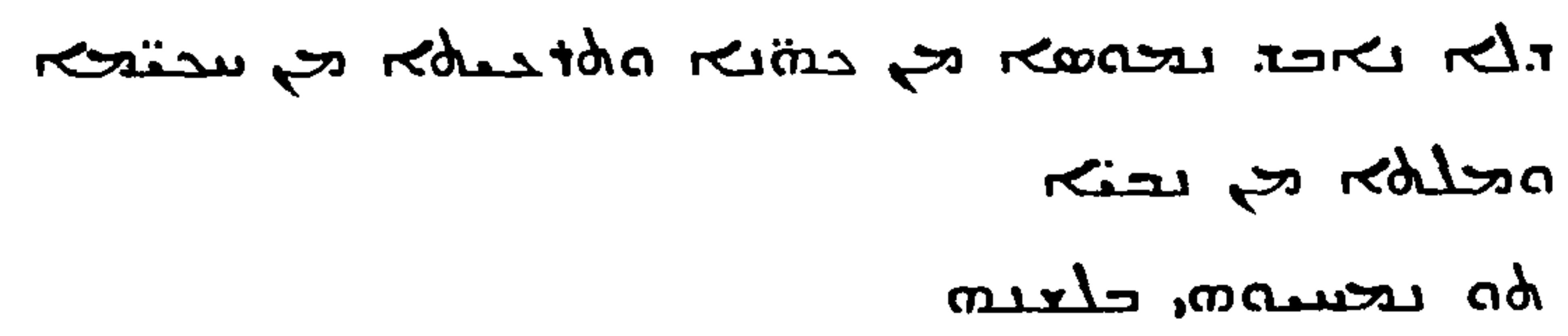

The underhand nature of this opposition is emphasised in the translation by the subtle change from לשem to לשון: Jeremiah's own words are to be turned against 
him.

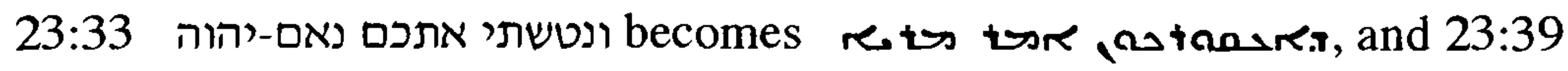
becomes ונטשתי אתכם changes from MT; in both verses it is the translation of root w which is affected. The root occurs in five other verses in Jeremiah, 5:10; 7:29; 12:7; 15:6; and 48:32. In three, root is used: in 7:29 כי מאס יהוה ויטש את-דור עברתו

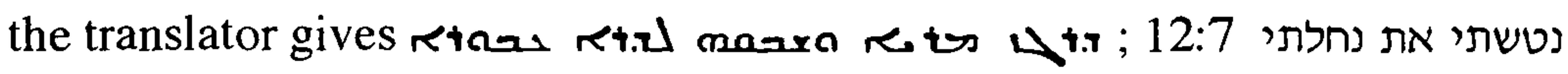

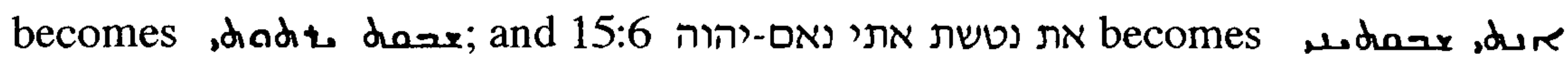
rets tsr. (The occurrences in 5:10 and 48:32 are not relevant, as the sense of the root is different here.) The more forceful roots tos "to uproot" and rix "to expel, reject" used at 23:33 and 39 respectively suggest thoughts of exile.

becomes

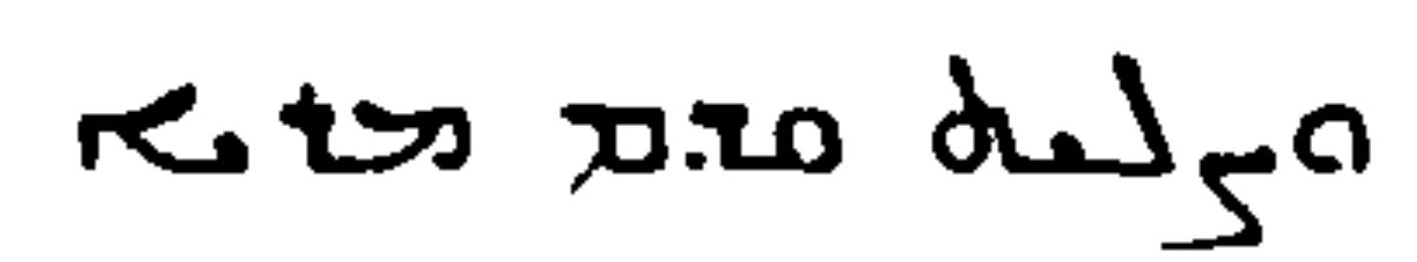

distea rets dow dala ........notad roderaix

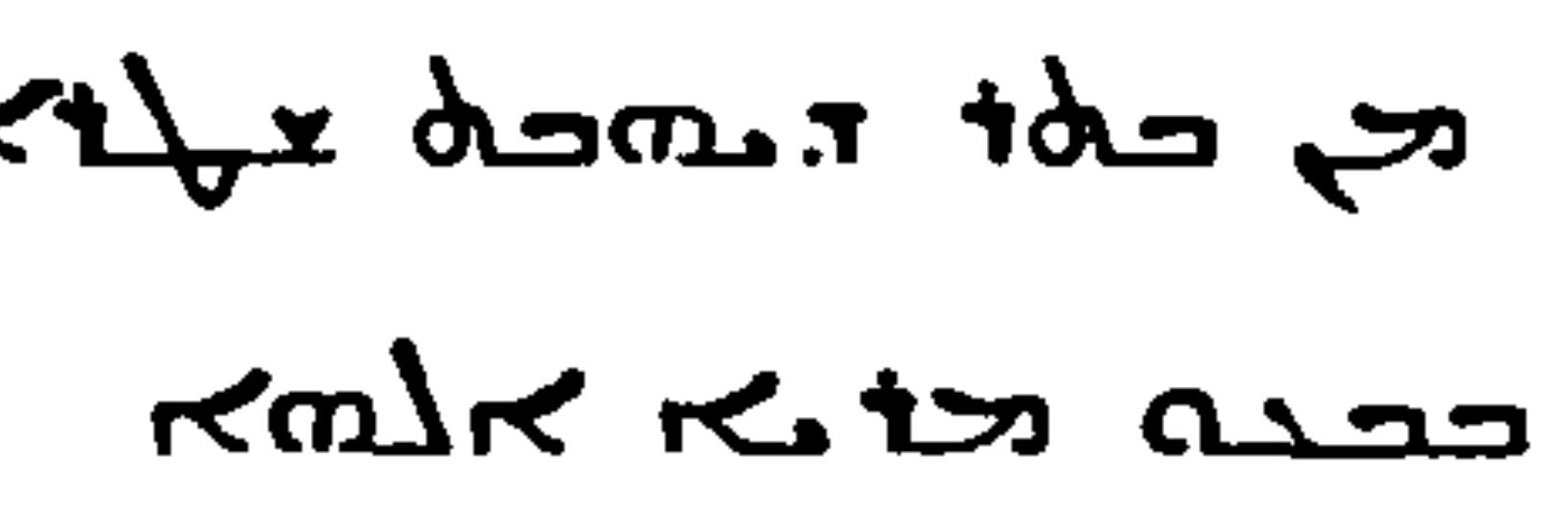
the repetition of the theme of prayer possibly indicating its greater importance.

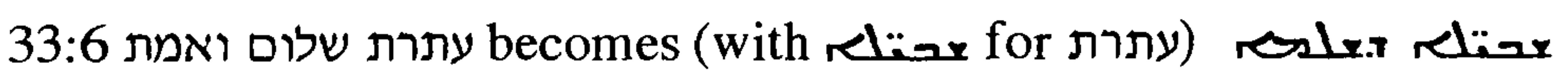
Khossm.ro, with "faith" replacing the faithfulness shown by God to man (this is one of the examples instanced in Weitzman's discussion referred to above (Weitzman, 1996, p.598)).

33:18 shows a changed view of sacrifice: מעלה עולה ומקטיר מנחה ועשה זבח כל

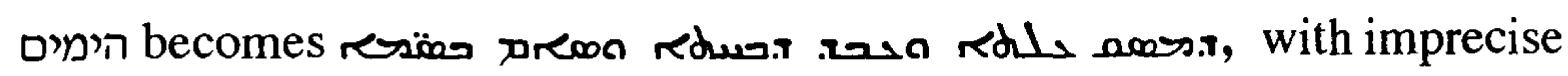
equivalents in translation. 


\section{(ii) The selection of lexical equivalents}

The choice of lexical equivalents is particularly interesting, showing a number of different features of the work of this translator.

I. The exercise of literary initiative, shown in four principal ways:

a. even for important words, there is no clear one-for-one correspondence such as that discussed by Brock (Brock, 1984, p.85).

For some important words, there is a consistent choice of equivalent, but this is by no means invariable ${ }^{5}$, and the selection of one of a number of synonyms is not always determined by the context.

The equivalents selected for two groups of important words:

; רשע ;עון ;פשע ;חטא ;

קצף ;אף ;זעמה ;חרון ;חמתה מעת

are discussed below; the first of these two analyses shows that the translator felt free to achieve his effect in whatever way seemed to him to be best, making a consistent choice of equivalent or varying his selection according to his own taste. This seems to be a positive use of literary freedom, perhaps revealing the translator's feel for rhetorical effect; clearly it is not the work of a man who felt bound to follow a rule which enforced the use of consistent equivalents. The second, however, seems to show a choice of equivalent governed by the Syriac idiom.

Barr (Barr, 1979, pp.310-311) discusses the various possible positions on the scale between free and literal in respect of constancy in the use of equivalents in LXX. Factors which would encourage constancy include the use of a "wordlist"; using books already translated as guidance; an increasing desire for 
accuracy leading to "stereotyping"; and Barr's "imitative" style of translation of which he instances the work of Aquila as the example par excellence. A simple preference for variety would lead to inconsistency in the choice of lexical equivalents, and Barr cites this as "a classic aspect of freer translation". Though in some of the particular examples which Barr cites (Barr, 1979, p.313) ${ }^{6}$ the Peshitta differs markedly from LXX, being literal where the latter is free, there seems no doubt that the translator in the Peshitta to Jeremiah is allowing his personal liking for variety to influence his decisions.

רשע ;עון;פשע ;חטא

עט in invariably translated by the cognate ${ }^{7}$, oner hand, is translated

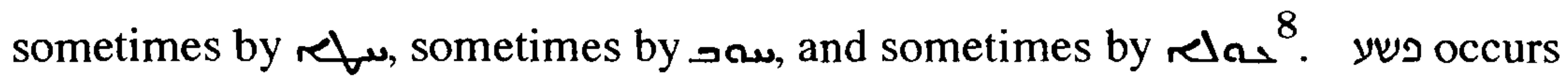
only five times, and is translated in four different ways ${ }^{9}$; and occurs six times and is translated in four of these by the cognate but in two by 10 .

6. Barr cites (i) Prov 30:19 with its four "ways", of the eagle, of a serpent, of a ship, and of a man with a maid: all are דר in Hebrew, but LXX uses three different terms; and in the Peshitta all are translated with restore; (ii) with a difference of the opposite kind, also in Prov. there are seven verses $(2: 8,13,20 ; 3: 6 ; 4: 14,18-19 ; 12: 28)$ in which the Hebrew uses two terms in parallel for "road, path" but in all but one, 3:6, the Peshitta uses rewior in translating both.

7. in $2: 35 ; 3: 25 ; 5: 25 ; 8: 14 ; 14: 7 ; 14: 10 ; 14: 20 ; 15: 13 ; 16: 10 \times 2 ; 16: 18 ; 17: 1 ; 17: 3 ; 18: 23$; $30: 14 ; 30: 15 ; 31: 33(34) ; 32: 35 ; 33: 8 \times 2 ; 36: 3 ; 37: 18 ; 40: 3 ; 44: 23 ; 50: 7 ; 50: 14 ; 50: 20$ (total 27)

8. By ref in $2: 22 ; 3: 13 ; 11: 10 ; 14: 7 ; 14: 20 ; 31: 29(30) ; 32: 18 ; 51: 6$ (total 8$)$; by 3 w in $5: 25 ; 13: 22 ; 16: 10 ; 16: 18 ; 25: 12 ; 30: 14 ; 30: 15 ; 31: 33(34) ; 33: 8 ; 36: 3$ (total 10); by el in $14: 10 ; 16: 17 ; 18: 23 ; 33: 8 ; 36: 31 ; 50: 20$ (total 6$)$

9. By 1 . in 2:8; 2:29; by w in 3:13; by in 5:6; and by 3 in 33:8.

10. By $2 x+$ in $12: 1 ; 23: 19 ; 25: 31 ; 30: 23$, and by refo in $5: 26 ; 14: 20$ 
These different choices do not simply indicate that the Syriac translator had a particularly wide range of synonyms at his disposal, for just as one of these Hebrew roots is translated by more than one Syriac root, so one Syriac root is used to translate more than one of these Hebrew roots. Expressing the data shown above in a different way, w is used to translate not only its cognate but also עון, in $2: 22 ; 3: 13 ; 11: 10 ; 14: 7,14: 20 ; 31: 29(30), 32: 18 ; 51: 6$. In $3: 13$ it translates פשע; and in 5:26; $14: 20$ it translates רמן translates. Similarly, in $5: 25 ; 13: 22 ; 16: 10,16: 18 ; 25: 12 ; 30: 14,30: 15 ; 31: 33(34) ; 33: 8 ; 36: 3$; and in 5:6 it translates פשע; and anslates in 14:10;16:17; 18:23; 33:8; 36:31; 50:20, and פשע 33:8.

Nor does the context seem to explain the different choices: for instance, where פשע is used of sinning against God as for example in 2:8 והרעים פשעו בי and 3:13 אך דעי עונך כי ביהוה אלהיך פשעת, the roots selected differ: 2:8 is translated

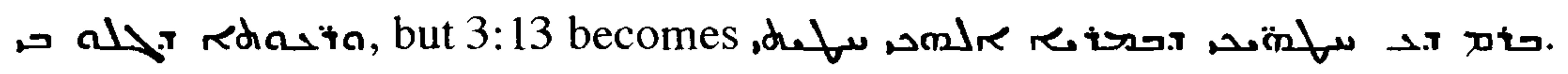
Similarly, where the Hebrew includes עט מון in similar contexts, עמון is differently translated: in 14:7 עונינו , אם עונינו ענו בנו .... לך חטאנו is translated with

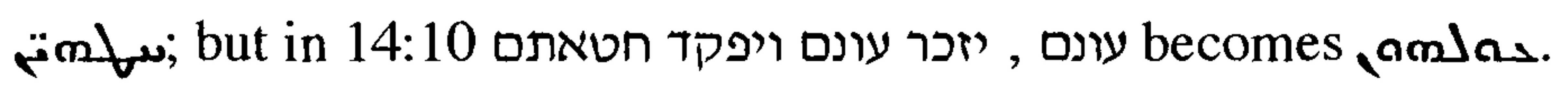
Nor is the identity of the speaker responsible: for instance, in contrast to the use of root wa 16:18 when God speaks, root wh is used when he speaks in $2: 22$.

Analysis by chapter gives no explanation either: there is, for instance, no evidence that the selection of lexical equivalent varies between different parts of the book, which might suggest either that one translator changed his apprach as he gained confidence, or grew tired, or that more than one translator was involved $^{11}$.

11. Holladay (Holladay, 1958, pp.38-39) suggests that translations of root indicate that two translators were involved in the Peshitta, for he finds a clear difference in the choice of levical cquivalents in the first 30 chapters compared with chapters 31-52: in covenantal contcxts, حad is used in the first part of the book but nam later.

Sce also the discussion of root שוב, pp.252-258. 
Possibly, some decisions are explained by the translator's feel for rhetoric: for instance, in 3:13 the Syriac repeats root wer the two Hebrew roots עון and פשע: the translator seems to have deliberately chosen repetition of the one root to achieve his rhetorical effect, rather than varying the root as in the Hebrew, and has avoided root $\Perp$, which he used only a short time earlier, in 2:8. Similarly, in 14:20 רשענו עון אבותינו כי חטאנו לך is translated using root של three times:

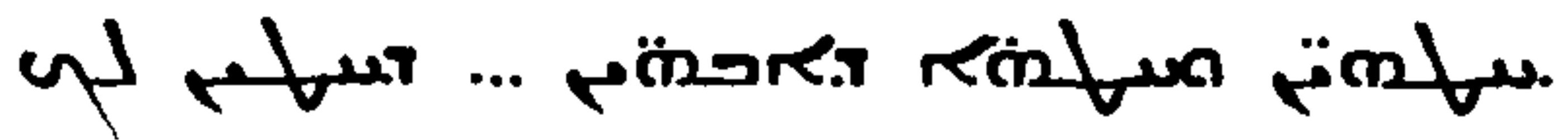

קצף ;זעמה ;חרון ;אף ;חמתה

The translation of these terms within Jeremiah forms an interesting contrast with the above analysis: in translating words for "anger" it seems that the translator is guided by a feel for idiom rather than for rhetoric.

חמה: occurs seventeen times in Jeremiah ${ }^{12}$, and in fifteen of these passages it is translated with the cognate ${ }^{13}$. This suggests a consistent one-for-one equivalence; but the two exceptions are interesting.

In the first exception, 23:19, the first member of a pair of duplicate passages, Runt is used, and this unusual choice seems to be deliberate, for it is associated with the surprising choice of

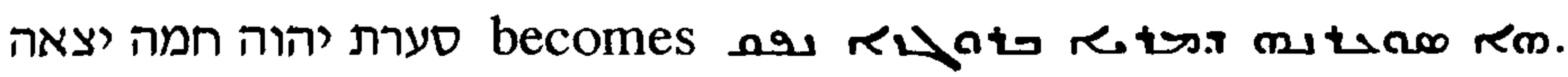

The second exception, in 44:6, is particularly interesting: here, the Hebrew

12. Driver suggests that the use of root ניצא ת ובא כאש חמתי ובערה ואין 21:12 for instance מכבה shows that the meaning "to shine forth" could attach to this root, and brings in support of his suggestion the parallel in this verse with בער (Driver, 1951, p.244). There is no evidence in this translation that this meaning of the Hebrew was recognised: root used.

13. In $4: 4 ; 6: 11 ; 7: 20 ; 10: 25 ; 18: 20 ; 21: 5,12 ; 25: 15 ; 30: 23 ; 32: 31,37 ; 33: 5 ; 36: 7 ; 42: 18 \times 2$ (total 15) 
phrase is unusual: ותתך חמתי ואפי, rather than the idiomatic association of חרון מפני חרון אף יהוה 25:37, and the translation as in, for example, אף-יהוה down inat may reflect this ${ }^{14}$.

אר too is consistently translated ${ }^{15}$, by Кㅇ․

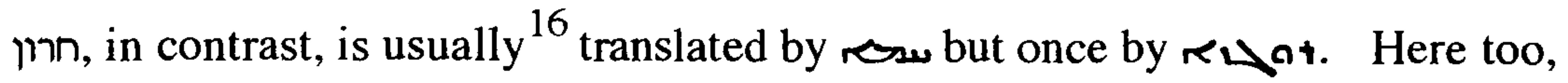
there is a tendency to translate freely, using idiom: 23:20 MT לא ישוב אף-יהוה

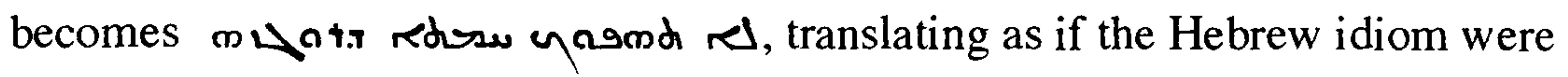
present.

This association of אף אר in an idiom affects the translation. It occurs in

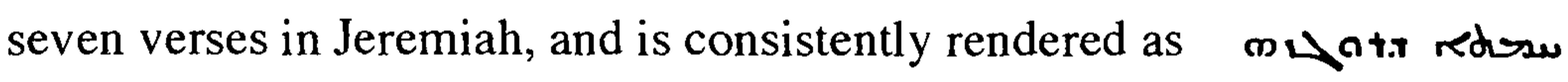

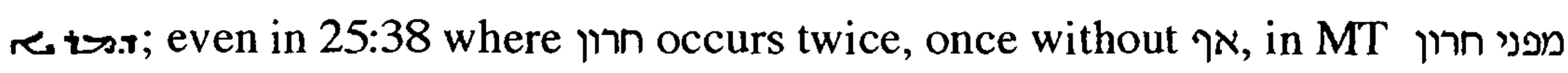

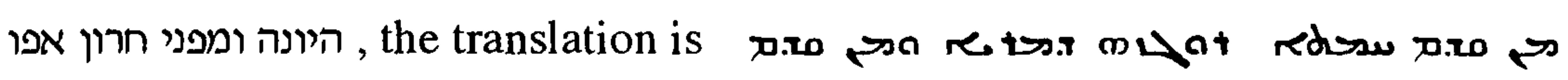

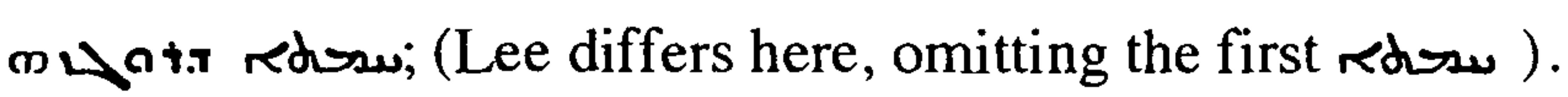

קצח occur three and five times respectively ${ }^{17}$, and are always translated by Rムم+.

This overall pattern suggests first, that for the five Hebrew terms the translator judged that only two, reds and Rவat, were suitable, so that his work was in this respect constrained by a limited vocabulary; second, that despite that limitation, he felt free to use his initiative. Gelston (Gelston, 1987, pp.141,142)

14. This may, however, be an example of the phenomenon of "crossed equivalents", discussed below.

15. אר: by ratat: $4: 8 ; 4: 26 ; 7: 20 ; 12: 13 ; 21: 5 ; 25: 37 ; 25: 38 ; 30: 24 ; 32: 31 ; 32: 37 ; 33: 5$; $36: 7 ; 42: 18 ; 49: 37 ; 51: 45\left(\right.$ total $\left.15^{*}\right)$

*in 23:20, אף-יהוה is translated as m4air redsw, so the intended equivalence is uncertain.

16. חרון: by 4:8; 4:26; 12:13; 25:37; $25: 38$ (see above); 30:24; 49:37; 51:45. 
shows that, in the Twelve Prophets, the same two nouns were almost always used, though redare was available and was used at Micah 7:18; Gelston comments too on the curious fact that it is nat not the cognate which is consistently translated by reds.

b. The use of synonyms or repetition to achieve an effect, independently of the Hebrew usage

A limited vocabulary would of course enforce the use of repetition rather than of synonym, and doubtless did so in some passages. Albrektson (Albrektson, 1963, p.211) discussing the Peshitta to Lamentations, judged that this restricted the translator; Weitzman (Weitzman, 1996, p.592) refers to the problem caused by parallelism where the Syriac did not always have equivalents for the Hebrew synonyms; Gelston, however, points out that "The alleged paucity of Syriac vocabulary is ... relative" (Gelston, 1987, p.139), an assessment to be confirmed by some of the examples given below.

There is an excellent example of the use of repetition to achieve a rhetorical effect in the Hebrew in $4: 23-26^{18}$. Here, each of the four successive verses opens with ראית:

ראיתי את-הארץ ....

ראיתי ההרים ....

ראיתי והנה אין האדם ....

ראיתי והנה הכרמל המדבר ....

The translator chose to make his effect differently, using two roots, wח המז alternately:

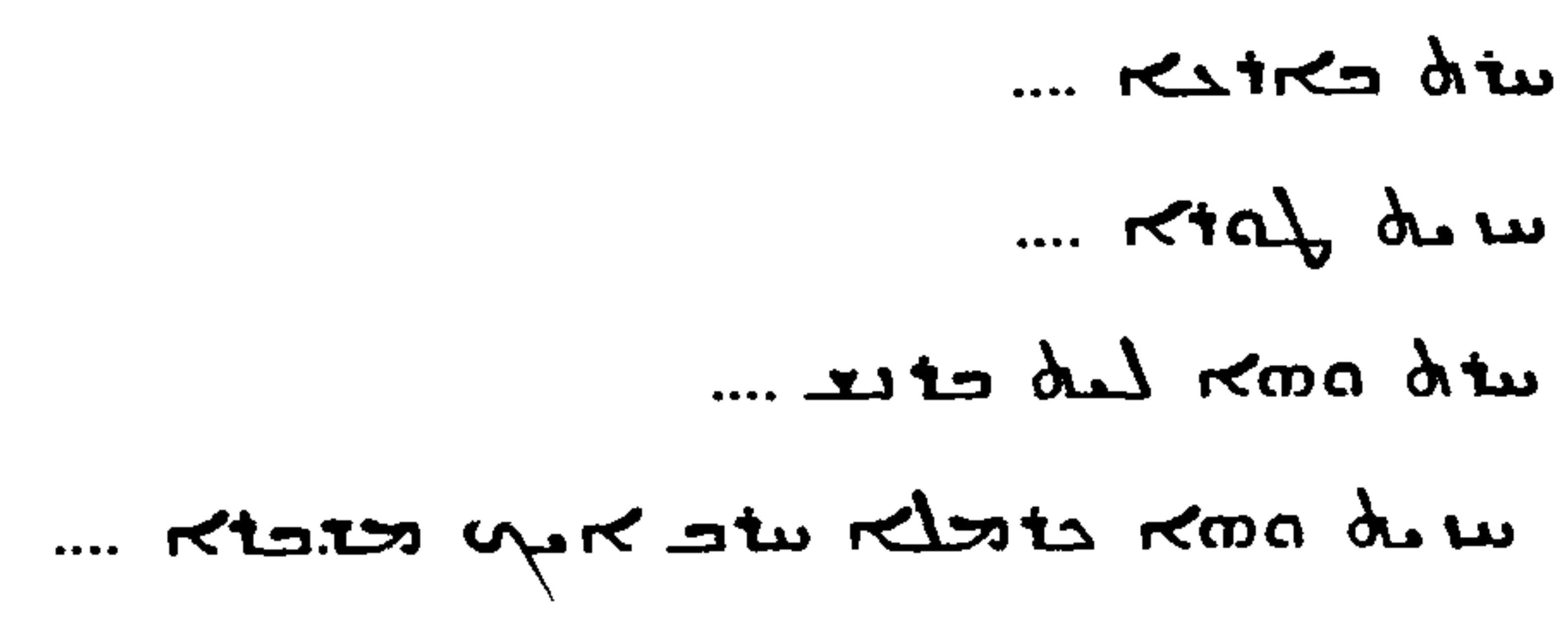

In nearby verses the approach to repetition differs, showing that the translator was not bound by a rule but was exercising his initiative. In 4:22, immediately 
preceding the ראיתי sequence in which one Hebrew root is translated by two Syriac roots, the two Hebrew roots are translated by one, wan are for ולא נבונים המה חכמים המה להרע the Peshitta has

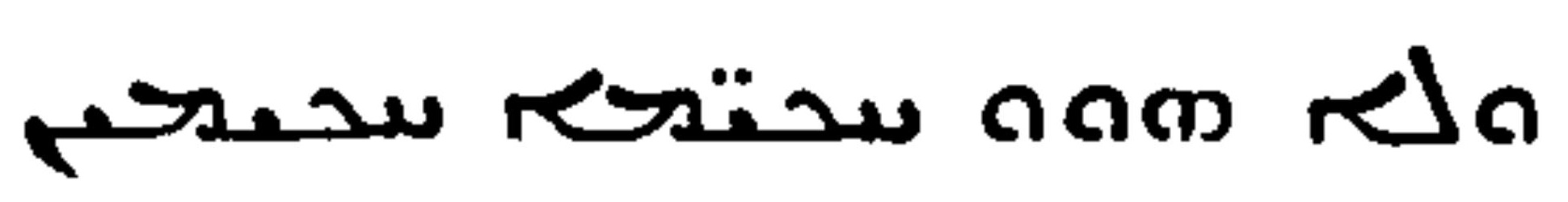
dreal are.

Elsewhere, however, the same two Hebrew roots are translated by three equivalents, משת , מי-האיש החכם ויבן את-זאת 9:11 :حת, and translated as

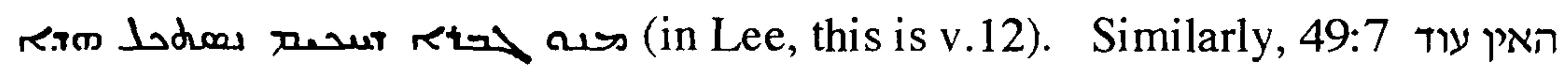

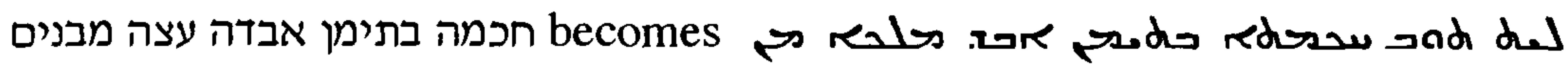

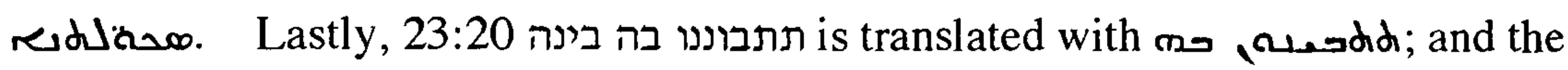
closely similar phrase in 30:24 is also translated with root 2 : there was indeed no paucity of vocabulary enforcing the repetition in 4:22.

In 1:17 there is an example similar to 4:23-26; here the repetition of root $n$ in God's threat אל-תחת מפניהם פן-אחתך לפניהם is surely intentional, but is not represented in the translation ${ }^{19}$ : The single Hebrew root חתת is translated by the two Syriac roots ral and . Further, the translator has not only decided to make his point by using

Footnote from p.57

18. LXX is similar, with

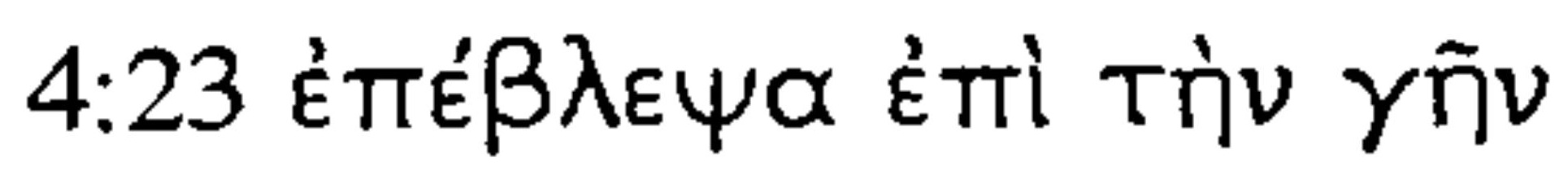

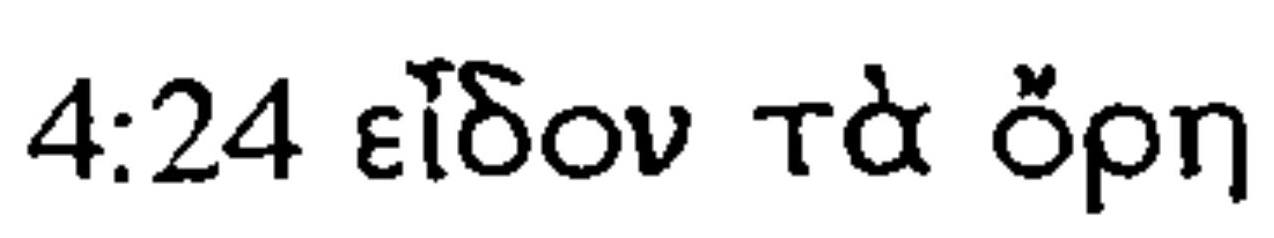

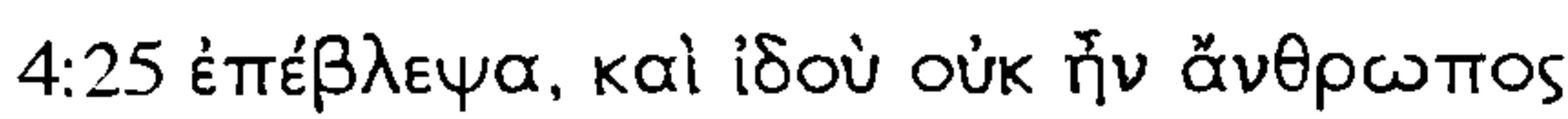

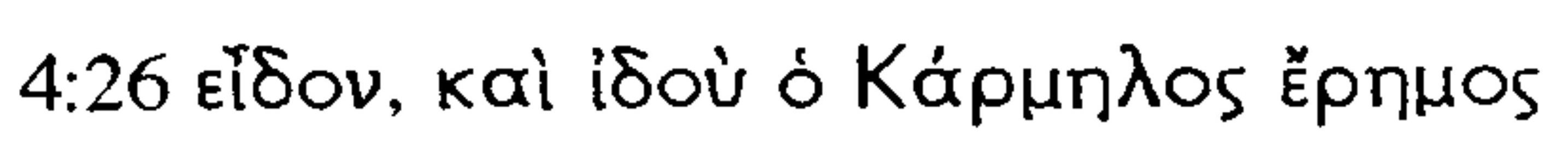

As at 1:17 below, both translators prefer the use of synonyms to achieve their effect, rather than repetition as in MT.

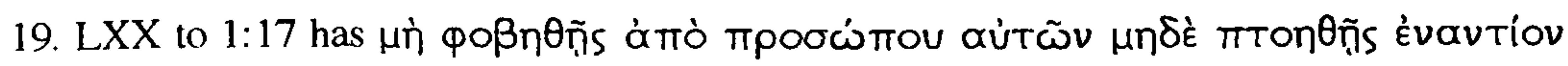

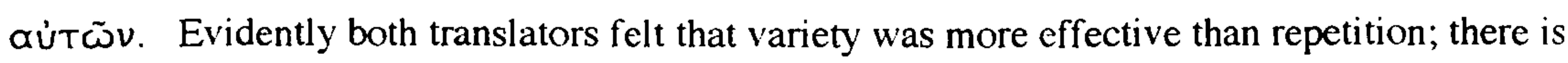
no reason to attribute the form in the Peshitta to influence from LXX, for polygenesis is perfectly possible. 
synonyms; the order in which he uses the synonyms in the translation of this passage is surprising. Root as a verb in Jeremiah ${ }^{20} ;$ re used, outside $1: 17$, only in 10:2; so a less frequently chosen equivalent is used first in Jer $1: 17$, followed by the most often chosen.

Here too, a contrasting approach is found elsewhere:

in 10:2 the Hebrew repetition in ומאתות השמים אל-תחתו כי יחתו הגוים מהמה

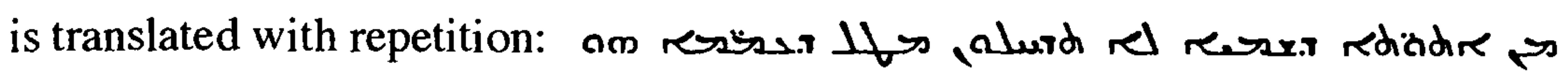

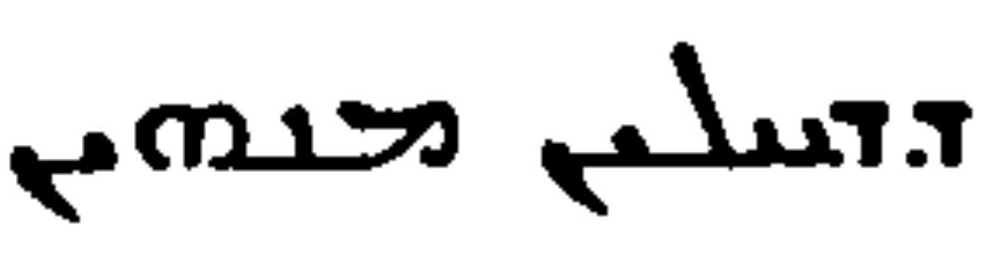

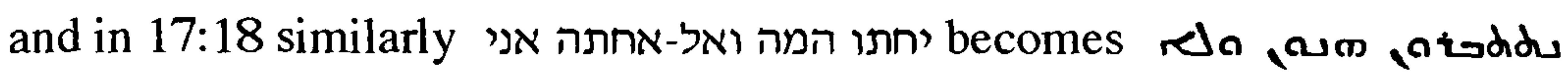
rer todidr.

There are numerous other examples both of the use of synonyms in the Hebrew translated by repetition of a root, and of the opposite, for instance:

11:18 where the deliberate repetition in the Hebrew ויהוה הודיעני ואדעה becomes ההלכים בשררות לבם וילכו אחרי , and 13:10 where the Hebrew, .

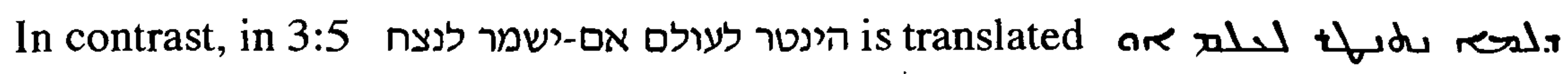

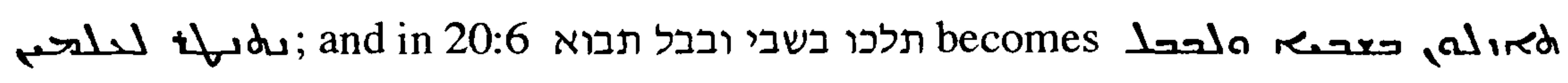
Jired.

c. A variation of the familiar A/B-word approach, described for instance by Weitzman (Weitzman, 1996, p.592)

The essence of this approach is that, where two synonyms are available in Syriac, one, the "A-word" may be used if any of the Hebrew synonyms occurs alone, but if two Hebrew synonyms occur in one verse, the translator tends to use the "A-word" for the first, and the "B-word" for the second. The duplicate passages in Jeremiah, discussed in detail in Chapter 3, provide a comparable 
opportunity for the selective use of Syriac synonyms: in some of these passages, the A-word is used in translating the first and the B-word when working on the second. There are, however, other duplicate passages at which the choice is reversed, so that either the B-word or a word which is not sufficiently established as a lexical equivalent for it to be classified even as a B-word is used in the first passage, with the standard "A-word" equivalent reserved for the second occurrence.

The A-word is used in the first and the B-word in the second:

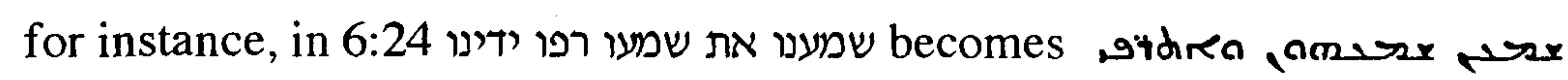

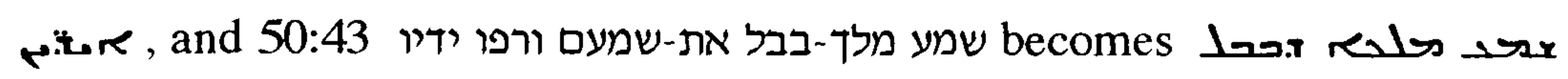

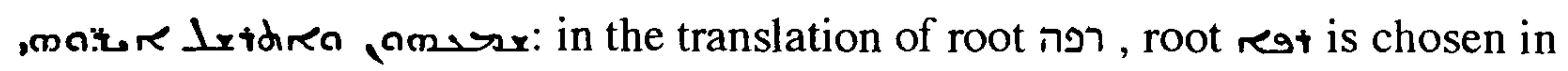
the first of the two duplicate passages and root $1 x t$ in the second, in accordance with the preference elsewhere in Jeremiah $(38: 4 ; 47: 3 ; 49: 24)$ where the cognate is consistently used.

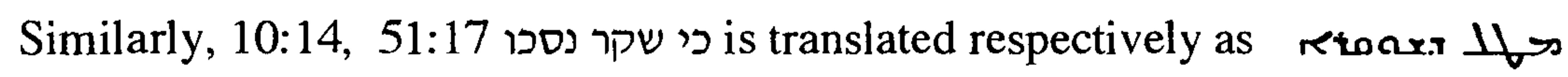
שקר occurs in 36 other passages in Jeremiah, and is translated with the cognate at 21 of these, and with root $\mathrm{x}$ at $16^{21}$; so here too the most frequently selected term is used first, and the less preferred equivalent given at the second passage ${ }^{22}$.

There are, however, other particularly interesting passages in which the choice of synonyms is apparently reversed, the standard equivalent reserved for the second occurrence of the text:

for instance, Jer 10:12 and 51:15 where MT ובתבונתו נטה שמים becomes

21. שקר translated by tax: $5: 31 ; 6: 13 ; 7: 4,8,9 ; 8: 10 ; 9: 2(3), 4(5) ; 10: 14 ; 13: 25 ; 20: 6$;

$23: 14 ; 27: 10,14,15,16 ; 28: 15 ; 29: 9,21,23,31 ;$ and by $17: 3: 10,23 ; 5: 2 ; 8: 8$ x $2 ; 14: 14 \times$

$2 ; 16: 19$ (the translation is imprecise here but this seems the most likely equivalence); $23: 25$,

$26,32 \times 2 ; 37: 14 ; 40: 16 ; 43: 2 ; 51: 17$

22. The choice is not determined by whether or not prophetic words are referred to: for instance, in 5:31 הנבאים נבאו בשקר is translated with שקר הנבאים נבאים 14:14, but in trated with redaly. 


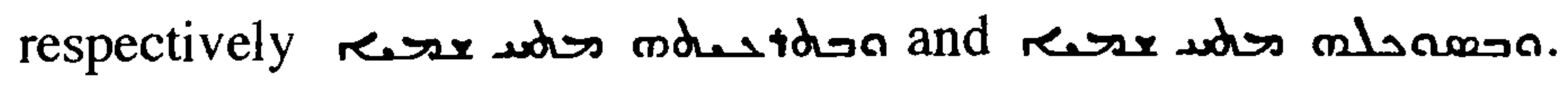

Two roots are used in the Syriac for תבונה, and one of them, root reason, to purpose" is an unusual choice. תבונה occurs nowhere else in Jer, but is found in thirty-nine other passages in the Hebrew Bible ${ }^{23}$ : in twenty-two it is translated by root ow ovate in four by the cognate $\Omega$, , with other roots including rat occurring only once or twice each. Root rat, not even an established B-word, is used in the first of the duplicate passages, not the second: this suggests that the translator anticipated the second passage, and enjoyed exercising some initiative in a surprising choice, planning to use a more usual equivalent at the second opportunity.

There is a similar example in $16: 15$ and 23:8, concerning root נד:

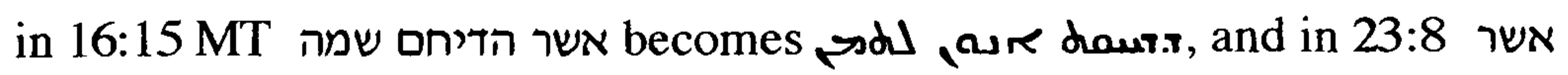

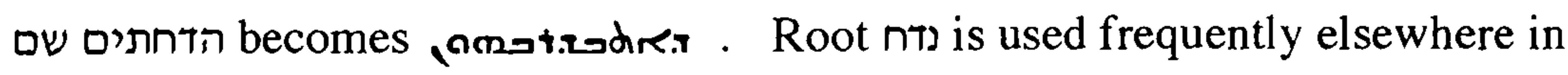
Jeremiah $^{24,25}$, and is usually translated with root 2 , less often with root wat.

23. حم Ex 31:3; 1K 7:14; Job 12:12, 13;

Lox 35:31; 36:1; Dt 32:28; $1 \mathrm{~K}$ 5:9(29); Isa 40:28; Ezek 28:4 (the translation is rather imprecise but this seems the most probable underestanding); Ob 7, 8; Ps 49:4; 78:72; 147(146):5; Prov 2:2, 3, 6; 3:13, 19; 8:1; 10:23; 11:12; 15:21; 21:30; 24:3;

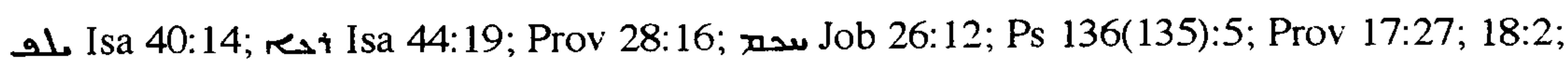
20:5; pre Prov 19:8(9). Hos 13:2, Prov 2:11; 5:1 and Job 32:11 are too freely translated to be helpful here.

24. Gelston (Gelston, 1987, pp.142, 149) discusses the translations of $n$ נIn the Twelve Prophets, and the possible relationship between this and the translation of צלה; no such effect of context is evident in Jeremiah.

25. נדח: translated by ז.t: $8: 3 ; 23: 3,8 ; 24: 9 ; 29: 14,18 ; 32: 37 ; 40: 12 ; 49: 5 ; 49: 36$; by

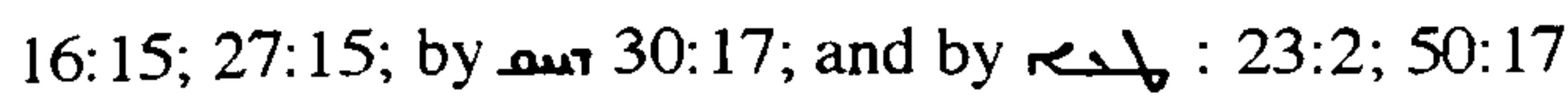

(Root נד also occurs in 27:10 and 43:5, but these are probably not translated.) 
There is a further example in 23:19 and 30:23;

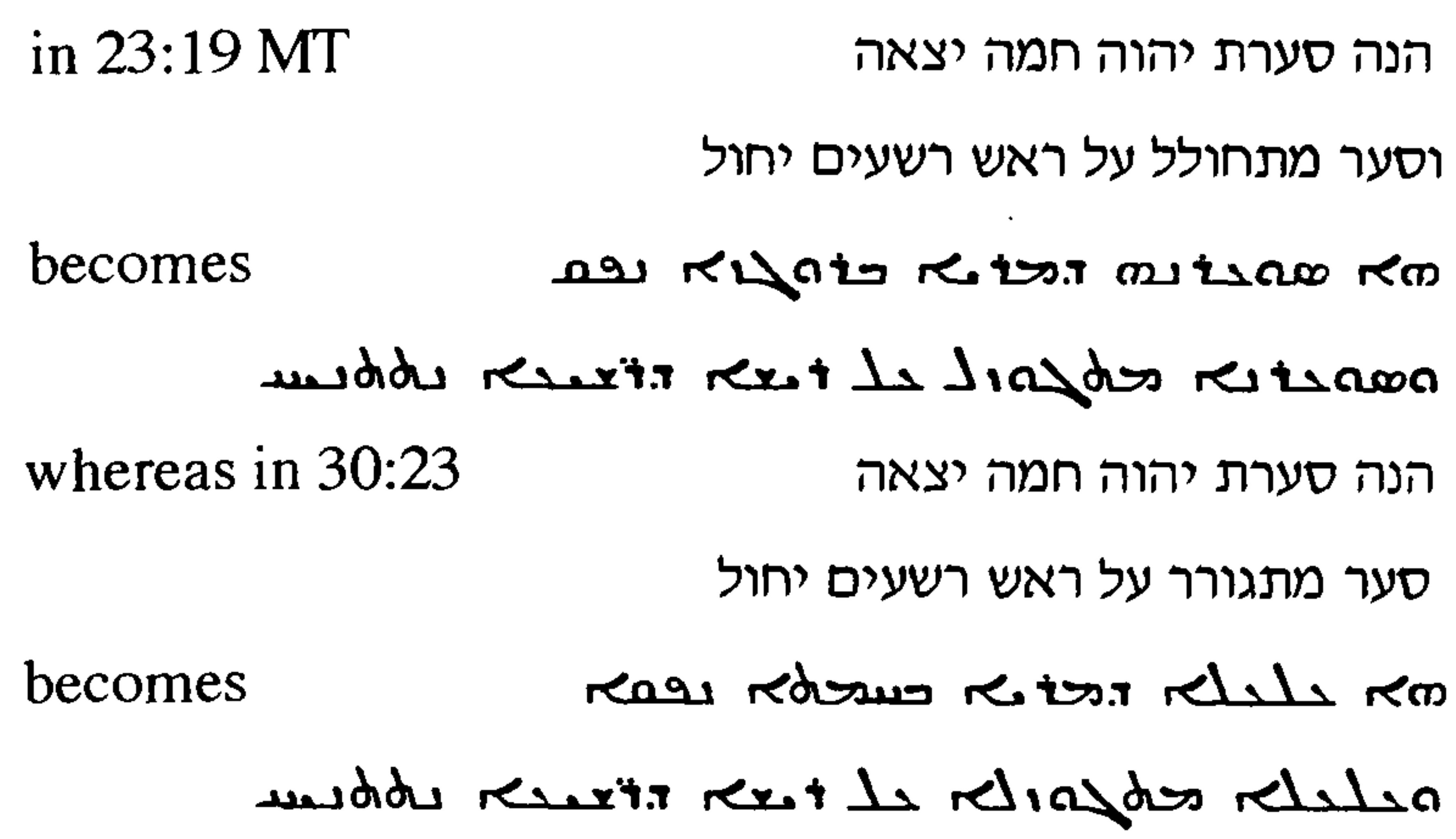

Here, סערת is translated with respectively; the first term is not even a close equivalent, meaning "an action, a visitation" rather than the "rage, tempest" of the Hebrew, perhaps an example of the "Syromanie" discussed above in Chapter $1^{26}$. The Hebrew noun occurs in one other verse in Jeremiah, 25:32; outside Jeremiah it is found quite frequently, and there is no doubt that $\mathrm{r} / \mathrm{N}$ is the standard equivalent ${ }^{27}$.

This duplicate, then, gives another example of an unusual lexical equivalent at the first of the pair, with the standard choice reserved for the second.

26. The suggestion that Syromanie might be the cause of the choice of res $九$ o here was made by Dr. Michael Weitzman in some early unpublished notes to which he generously gave me access.

27. Syriac equivalents used for סערה are in 2Kings 2:1, 11; Isa 29:6; 40:24; 41:16; Jer 25:32; 30:23 x 2; Ezek 1:4; 13:11, 13; Amos 1:14; Zech 9:14; Ps 55:9(8); 83:16(15); 107:25, 29; 148:8; Job 38:1; 40:6; rtsao: Jer 23:19 x 2;

Jonah 1:4, 12 
Finally, both MT and the translation repeat a root in 39:6 וישחט מלך בבל.....

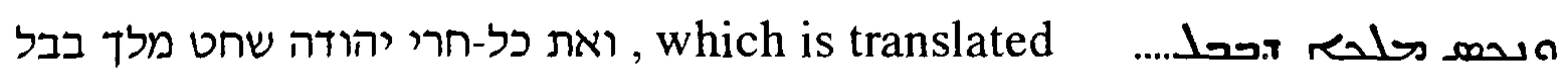

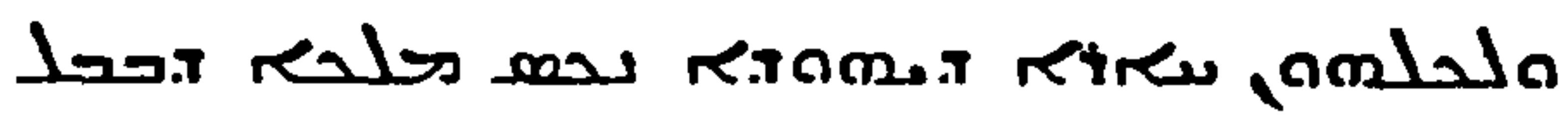

but in 52:10 the repetition is avoided in translation: וישחט מלך בבל את בני צדקיהו........וגם את כל-שרי יהודה שחט ברבלתה

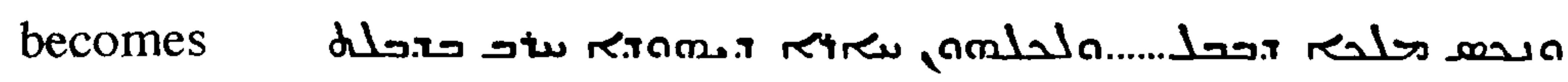
using root w at the second point ${ }^{28}$.

d. The use of "crossed equivalents" In this kind of variation in lexical equivalent the order of a pair of Hebrew words is reversed in the translation. Gelston (Gelston, 1987, pp.135-136) discusses this phenomenon of "crossed equivalents" in the Twelve Prophets, and Taylor (Taylor, 1994, p.320) describes its occurrence in a number of passages in Daniel. The number of such changes is such that a deliberate stylistic modification rather than textual corruption seems likely ${ }^{29}$.

28. Translations of root $n$ give an excellent example of freedom in the choice of lexical equivalent. The term חורים occurs only thirteen times (Jer 39:6 is noted above) in the Hebrew Bible, and is translated by five different equivalents; of the thirteen, six are in Nehemiah where five different Syriac roots are used:

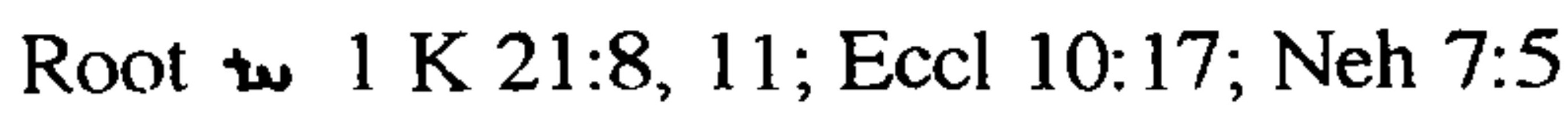

Root $\downarrow_{x}$ Neh 2:16

Root $\rightarrow+$ Jer 27:20; Neh 4:8, 13(14, 19); 6:17

Root Neh 5:7

Root $\_+$Neh 13:17; Isa 34:12 imprecisely translated.

29. This is such an idiosyncratic technique that its presence in more than one book of the Peshitta is perhaps an indicator that these books were all translated by the same person. 
Chapter 2 Translation Technique

There are examples in, for instance,

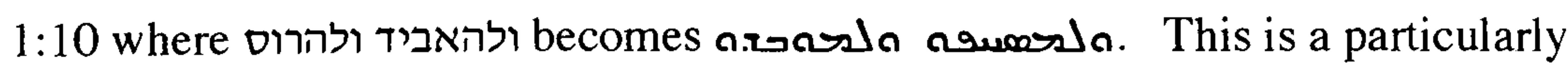
interesting example, for at other occurrences of some or all of this sequence in Jeremiah $^{30}$ the translation is precise.

Further examples of "crossed equivalents" are to be found in:

לא-אחמול ולא-אחוס ולא ארחם

which becomes

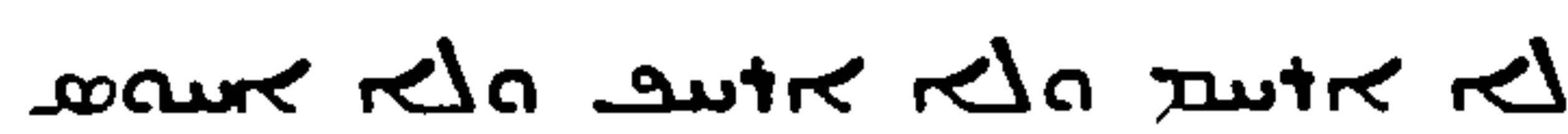

29:18 לאלה ולשמה ולשרקה ולחרפה

becomes

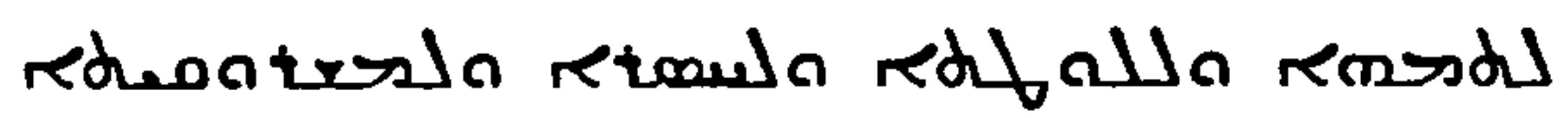

30. לנתוש ולנתוץ ולהאביד ולהרוס לנבות ולנטוע becomes

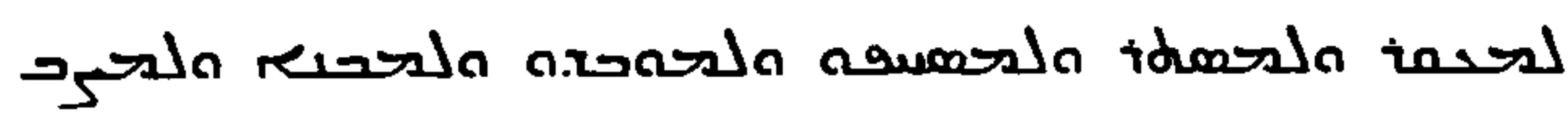
ונתשתי את הגוי ההוא נתוש ואבד becomes

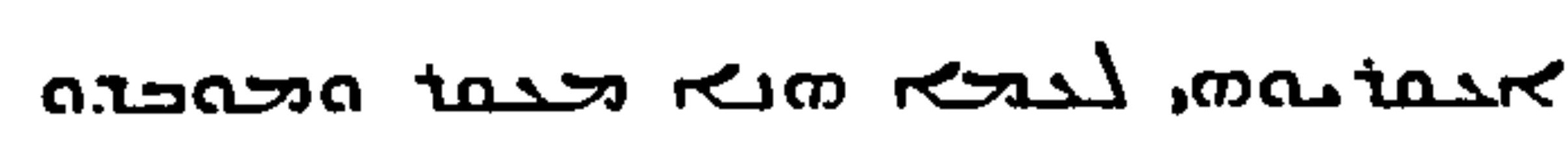
$18: 7$ לנתוש ולנתוץ ולהאביד becomes o.rosta ramesta idossla tars (with an additional term in 7a1 but not in 9a1: see Chapter 5, "The Work of the Revisers") לנבת ולנטע becomes 3 solo reast ובניתים ולא אהרס ונטעתים ולא אתוש becomes

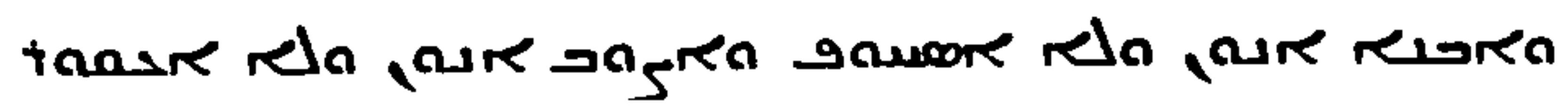
$31: 28$ לנתוש ולנתוץ ולהרס ולהאביד ... לנבות ולנטוע becomes

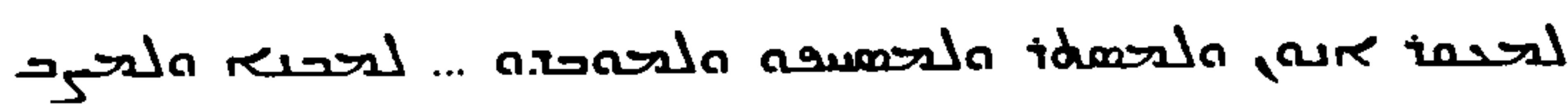
42: 10 ובניתי אתכם ולא אהרס ונטעתי אתכם ולא אתוש becomes 45:4

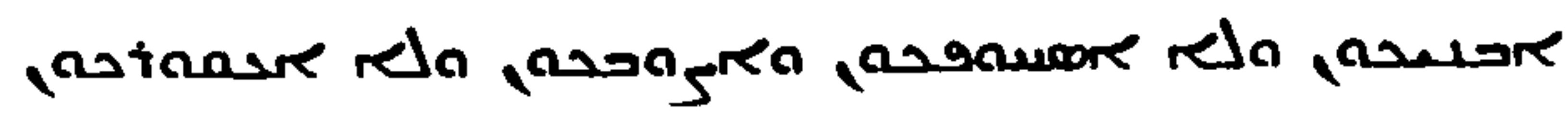
אשר בניתי אני הרס ואת אשר נטעתי אני נתש becomes

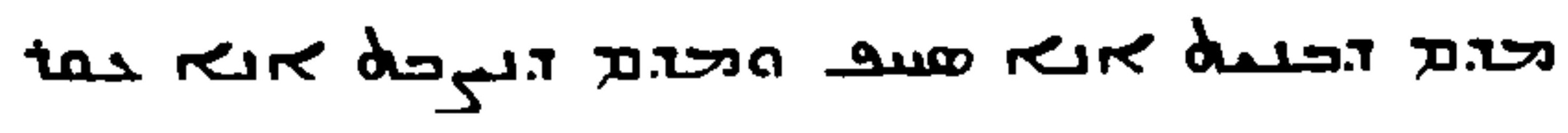




\section{The drive for precision}

Gelston (Gelston, 1987, pp.139-140) discusses examples in the Twelve Prophets where the Peshitta uses two different words to render the same Hebrew word, or Hebrew cognates, and suggests that Syriac idiom, or the subtlety of the sense, may sometimes have determined the translator's choice; he concludes that "the Peshitta translators were not always embarrassed by a paucity of lexical resources". There is in the translation of the Hebrew word a particularly interesting example of apparent freedom in the choice of lexical equivalent which is really an example of such a subtlety: the analysis presented below suggests that the translator worked according to the precise meaning of the Hebrew word, rather than by selecting more or less at random from a number of equally appropriate Syriac equivalents.

The two most frequently used equivalents of שיא and are study of the translations of שin Jeremiah suggested that wased for land in private or public ownership, and rtor for other areas. The suggestion was sufficiently interesting to merit extension of the analysis to include uses of in other biblical books. The extended study was designed both to cover a reasonable canonical range, and to give adequate coverage of the categories in the implicational scale presented by Weitzman (Weitzman, in press, p.179)which shows that certain terms serve as "discriminators" which indicate the degree of conservatism of the translator of the Hebrew book in question. Genesis, Exodus, Leviticus, Numbers, Deuteronomy, Judges, Samuel, Kings, Isaiah, Jeremiah, Ezekiel, and the Twelve were included in the present analysis, giving a total of 249 occurrences of שדה.

It was recognised that, in Weitzman's terms, שיה is not an ideal discriminator, as it has more than one meaning in Hebrew; nonetheless this study gave interesting results. The meanings listed in B.D.B. include "cultivated field", "home of wild beasts", possibly, "plain", as the opposite of mountain; "land", as the opposite of sea; and a wide variety of specific meanings within two broad categories, either "open field, country" or "a definite portion of ground". These include, for instance, "pasture land", "unfrequented land", "home of wild 
beasts", "home of beasts in general", "hunting ground", "an area with plants and trees", "a stony area", "the area outside a walled city", "the site of a small town" and "the personal estate of the king".

As well as this diversity of meanings, there is the additional problem that it is sometimes impossible to be sure which sense is intended by the MT. For instance, within Jeremiah, the field which is bought in chapter 32 may be a cultivated area, pasture land, land on which grew valuable trees, or simply an area of untended land in private ownership. There are similar ambiguities concerning the nature of the field in which is situated the cave of Machpelah in Genesis chapters 23 and 25, that of the field in which David took refuge in 1 Samuel ch. 20, and many other examples ${ }^{31}$.

Nonetheless, some classification according to the intended sense was possible, using three categories:

(i) land which was in neither private nor local community ownership, and which would therefore have been wild;

(ii) land which was in private or local community ownership, whether cultivated or not;

(iii) uncertain.

The results are given in full in Annex 3. In summary, there is a clear distinction: where שידה seems to mean wild land, זמדז is in general the term of choice; where שنדה means privately owned land, the preferred lexical equivalent is Further, there was a development in the translation of ש meaning "wild land": in the group of books where the Peshitta translation is more conservative, that is Genesis, Judges, Samuel and Kings, there is equal use of war, but in the less conservative group, that is Ezekiel and the Twelve Prophets, there is a strong preference for rot

31. Lane (Lane, 1994, p.110) notes the clarification of ושדה מגרש עריהם in Leviticus 25:34 by translating as, nmorno 


\section{Occasional inattention to detail}

Some inconsistency in the selection of lexical equivalents seems virtually certain to have occurred, however, unless in all cases there are subtleties of meaning similar to those in the case of שT of which today's reader is unaware. Gelston (Gelston, 1987, pp.142-143) notes that sometimes the Peshitta translators were "sometimes content with an approximate equivalent even when a more precise one was available". There are numerous examples in Jeremiah of translations which apparently involve the use sometimes of a precise and sometimes of an imprecise equivalent: for instance, root גאה is translated by root re in 13:9, and by roots $\boldsymbol{7}$, Rra and pat in 48:29.

On the other hand, as well as these instances of the use of more than one Syriac word to translate a given Hebrew root, the opposite case is found: in such examples, two explanations are possible. Sometimes, the translator may be constrained by paucity of vocabulary, or may be struggling to give a noncontroversial rendering of a Hebrew term which he does not understand, and so is forced to use one root to translate several Hebrew roots. For instance, Albrektson (Albrektson, 1963, pp.80-81) discusses the translation in Lamentations 1:20 of the precise Hebrew שכל, "to be bereaved" by root with the more general meaning "to destroy"; possibly, this choice indicates that the translator did not really understand the Hebrew here. Weitzman (Weitzman, in press, p.41) notes that in Deuteronomy, Jeremiah, and Psalms " naret and $9+4 d r<$ provide two basic alternative guesses for difficult words, the first being suitable when things look good for the subject and the second when they look bad" 32,33 . many Hebrew roots, provides a good illustration of the difficulty of being sure of

גאה ; 32. Root

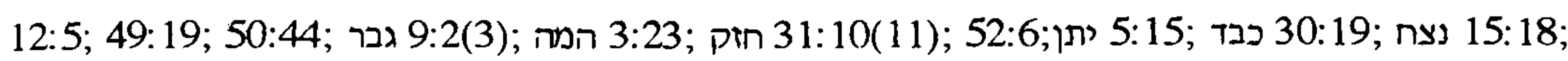

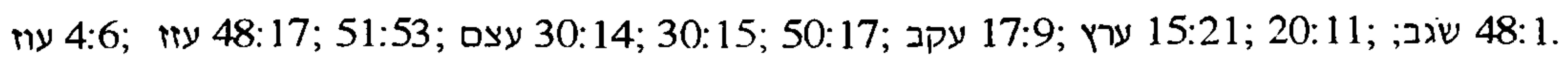
Root is also used in 11:15 to translate עלז, but this is a passage of difficult Hebrew which is discussed in Chapter 6 and is outside the scope of the present chapter. 
the translator's reason for his choice, for detailed examination of the passages suggests that in a number the choice was determined by difficulty or subtlety in the Hebrew. For instance, the usual root to translate כבז is, but in 30:19 is used instead, a reasonable choice in the context.

In other instances, however, the use of "general purpose" or "drudge" words strongly suggests a lack of precision, although, given the limitations of the modern reader's knowledge of the range of vocabulary and perception of nuance, it is not always possible to be sure which is the true explanation.

On balance, it is evident that the translator was not constrained to give a consistent choice of equivalent: it is not always possible to be sure of the reason for the choice seen, which may be, for instance, the exercise of literary initiative; perception of nuance; paucity of vocabulary; or temporary inattention; but whatever the reason, the result is far from the use of consistent equivalents which would characterise a literal translation.

Footnote from p.67

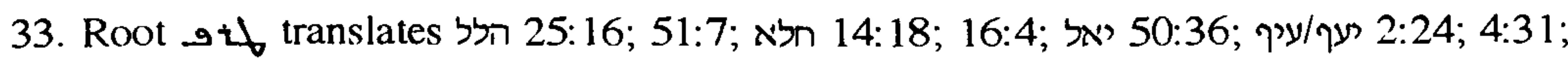

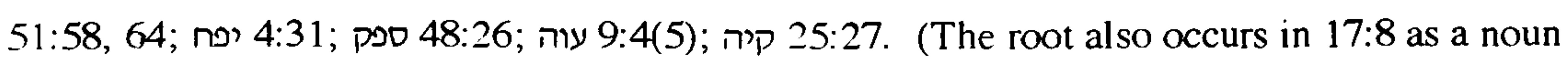
"lear".) 
(iii) the harmonisation of one verse with another, either within Jeremiah or in another book

The wording of one verse may be adapted to conform to that of a similar passage, sometimes from a biblical book other than Jeremiah, but sometimes from within Jeremiah; examples which are given below show possible assimilations of translations of passages from Jeremiah to verses of Deuteronomy, Isaiah, Ezekiel, Nahum, Zechariah, and Psalms. Within the Peshitta to Jeremiah, the technique is fairly common, as the examples below will show, but not of sufficiently high prevalence to occur in the sample of tenth verses.

This technique in biblical transmission is described for instance by Tov (Tov, 1985 (ii) p.3) who concentrates on harmonisations "on the textual level ...(which) belong to the scribal transmission of compositions after their literary shape had been finalised" but who also notes the importance of distinguishing, in some cases, whether a harmonisation in a translation derives from the translator or from his Vorlage (Tov, 1985 (ii) p.19). Gelston (Gelston, 1987 p.150 with reference to the Hebrew Bible and pp.153-156 with reference to possible assimilation to passages in the New Testament) discusses harmonisation as a feature of the translation technique in the Peshitta to the Twelve Prophets. Some of the most interesting examples of harmonisation of passages within Jeremiah, and with passages in other biblical books, are given below; however, before discussing individual verses, it is interesting to note the flexibility with which the approach was applied.

For instance, harmonisation of the many occurrences of the sequence in Jeremiah is found sometimes, but by no means consistently. As in his use of lexical equivalents, the translator evidently felt free to use some discretion. This sequence occurs frequently, in whole or in part, but in the Hebrew the terms are not always in the usual sequence, and sometimes one of the three terms is absent. 
Chapter 2 Translation Technique

In translation:

(i) where the Hebrew terms are given in the usual sequence, and all three are present, the translation is always exact ${ }^{34}$;

(ii) where the sequence is unusual in the Hebrew, as for instance in 21:7 , דבר...חרב...רעב , the order is changed to the usual form in translation;

(iii) an incomplete sequence, in an unusual order, may be changed to make both

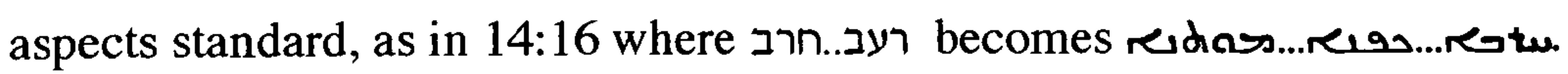
Differing approaches may be seen within the space of only a few verses: for חרב ...רעב 44:27 ח חרב...רעב 44:18 is accurately translated, but in ח

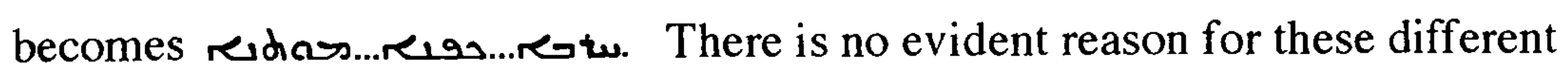
approaches other than the exercise of initiative.

34. The Sequence

14:12

$16: 4$

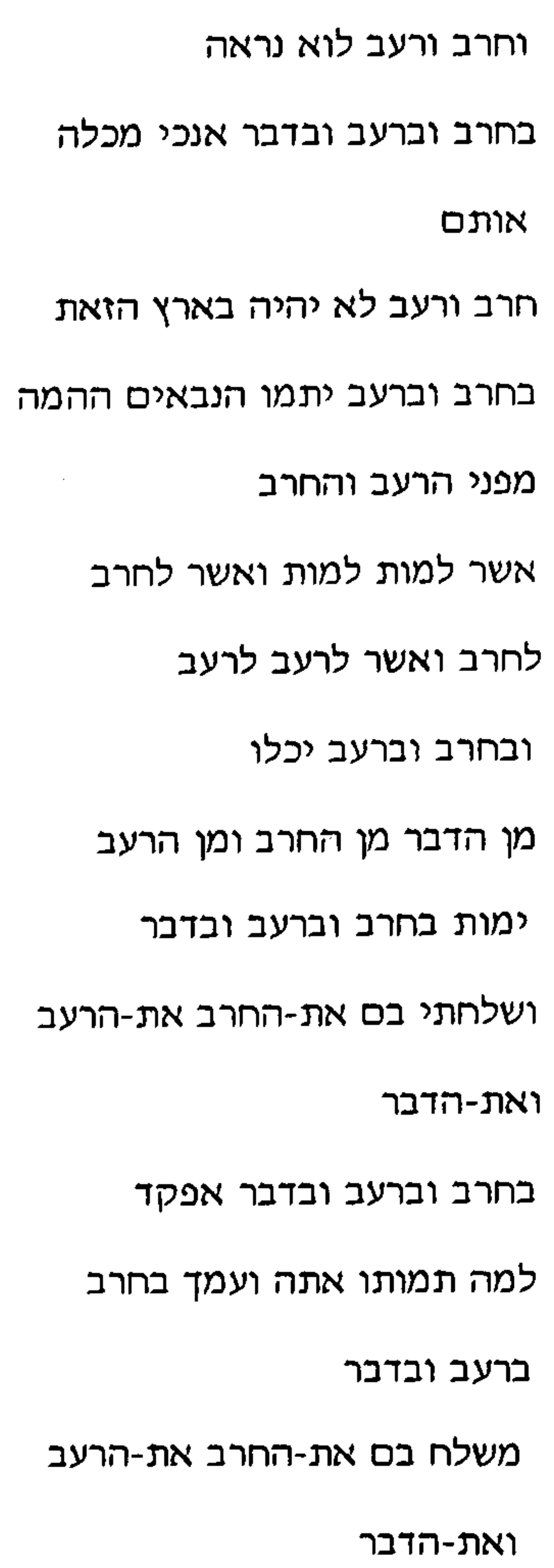

וחרב ורעב לוא נראה בחרב וברעב ובדבר אנכי מכלה

אותם חרב ורעב לא יהיה בארץ הזאת בחרב וברעב יתמו הנבאים ההמה מפני הרעב והחרב אשר למות למות ואשר לחרב לחרב ואשר לרעב לרעב ובחרב וברעב יכלו מן הדבר מן החרב ומן הרעב ימות בחרב וברעב ובדבר ושלחתי בם את-החרב את-הרעב ואת-הדבר וסר בחרב וברעב ובדבר אפקד למה תמותו אתה ועמך בחרב

ברעב ובדבר משלח בם את-החרב את-הרעב ואת-הדבר נסונו

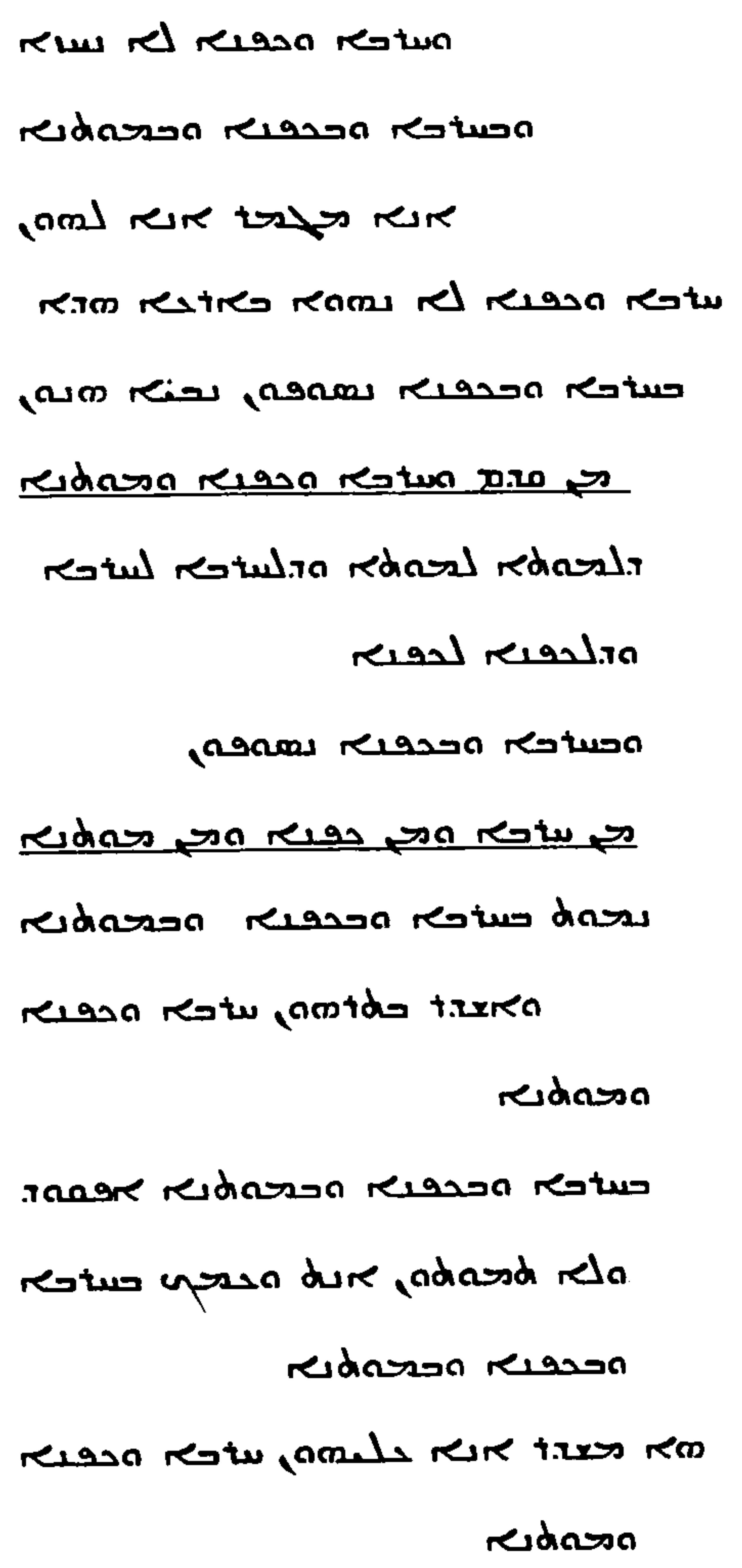


It is not always possible to be sure whether an apparent assimilation represents an intent to bring two verses into line with one another, as in true harmonisation, or a decision to translate with a phrase which may have been "common intellectual property", familiar to the translators of the Peshitta as it had been earlier to those who produced the MT. 7:6 and 22:3, and 9:13(14), shown below, illustrate this problem well.

Some individual examples follow, given in canonical order, in two groups: first those passages where the possible influence is from a biblical book other than Jeremiah, and second those where the assimilation is to another verse of Jeremiah.

Footnole from p.70 contd.

29: 18

43:11

44:12

$44: 13$

$44: 18$

44:27
ורדפתי אחריהם בחרב ברעב

ובדבר

מפני החרב והרעב והדבר

נתנה ביד מלך-בבל בחרב וברעב

ובדבר

קרא לכם דרור ... אל-החרב

אל-הדבר ואל-הרעב

הישב בעיר הזאת ימות בחרב

ברעב ובדבר

ימותו בחרב ברעב ובדבר

בחרב ברעב ובדבר תמותו

אשר למות למות...ואשר לחרב לחרב

יפלו בחרב ברעב יתמו...

בחרב וברעב ימתו

כאשר פקדתי על ירושלם

בחרב ברעב ובדבר

ובחרב וברעב תמנו נונו

ותמו ... בחרב וברעב

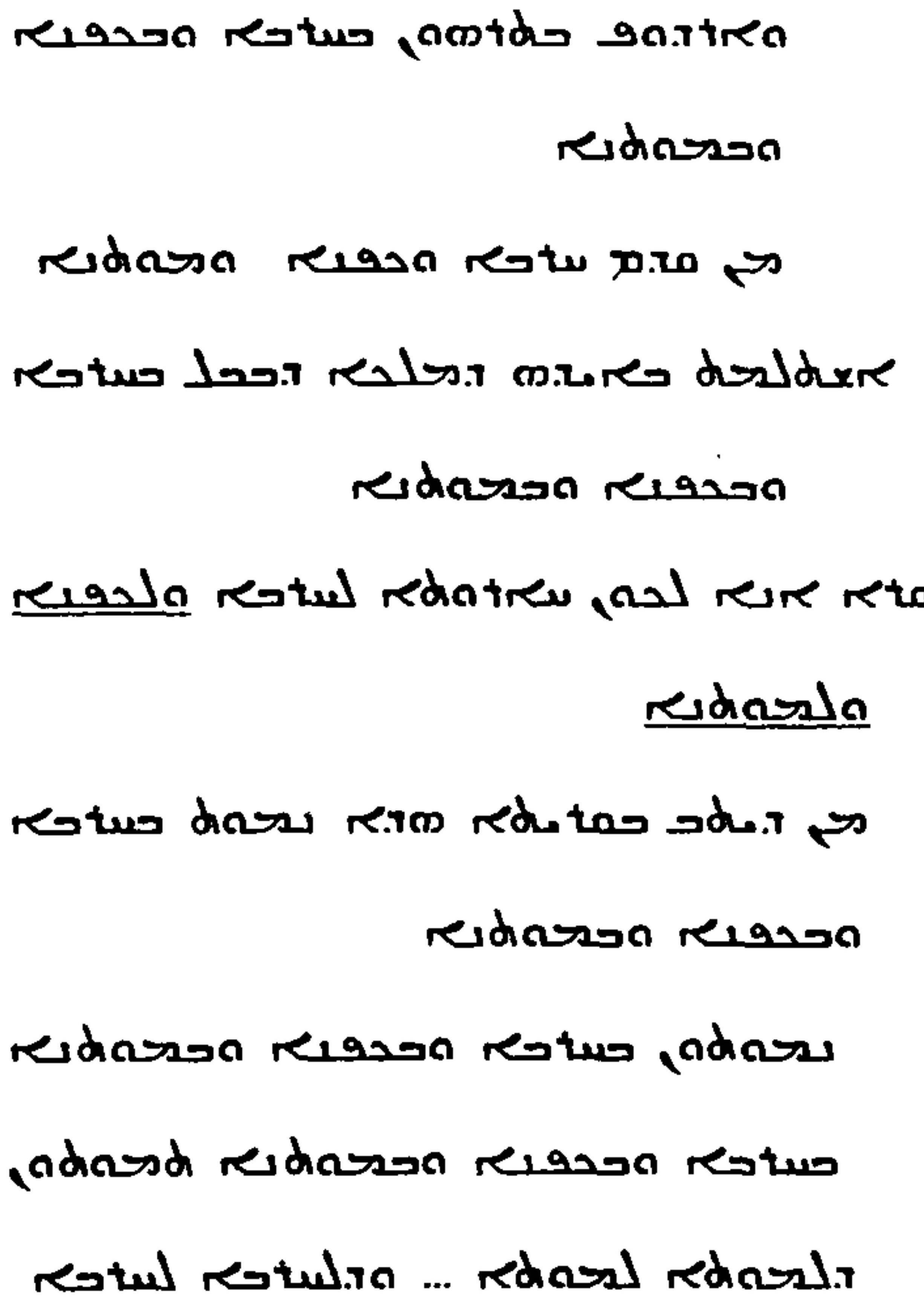

ridason rigsan rowa adosua

Dletar lo d.wagr upe

Rdarson Rerason Rotw

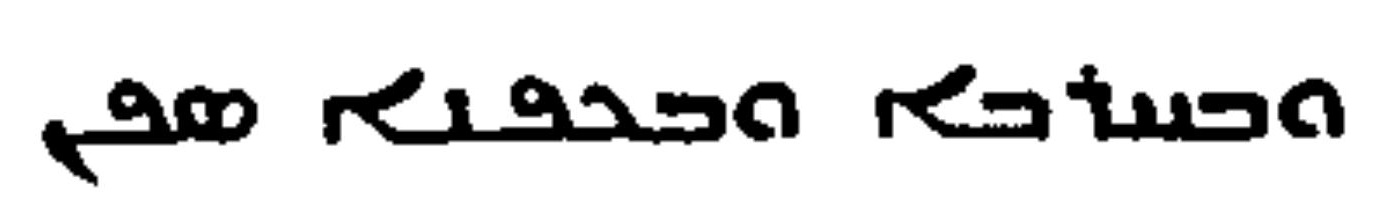

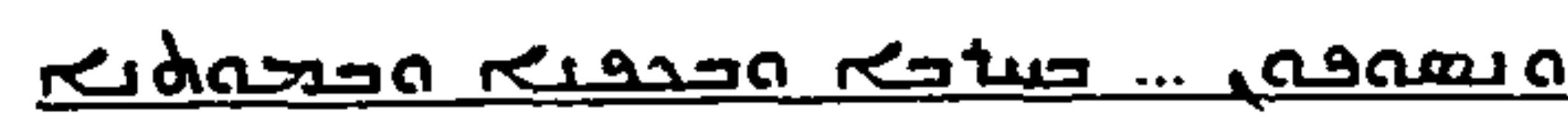




\section{Chapter 2 Translation Technique}

In 7:6 and $22: 3$ the possible influence is from Zechariah. There are two points of particular interest here, first that at first sight it seems that the translation of the earlier verse may have been adapted to that of the later. There is no clear reason why this should not have happened, given that the translator must have been one whose knowledge of the book was excellent: indeed, the approach to the use of lexical equivalents within the duplicate passages discussed below in Chapter 3 strongly suggests that, while working on one chapter, the text of others was clear in his mind; nonetheless, it does seem that the usual pattern is for later passages to be adapted to earlier verses.

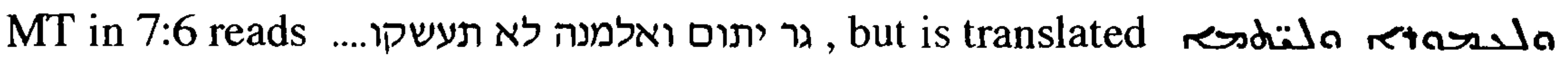

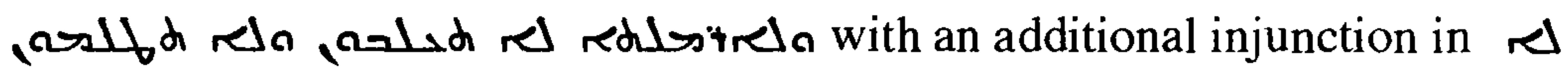
sal.d.

This evokes the MT in 22:3 וגר יתום ואלמנה אל-תנו אל-תחמסו.... which is translated as in 7:6.

Zech 7:10 may provide the explanation: here, the similar MT ואלמנה ויתום גר ועני אל-תעשקו....

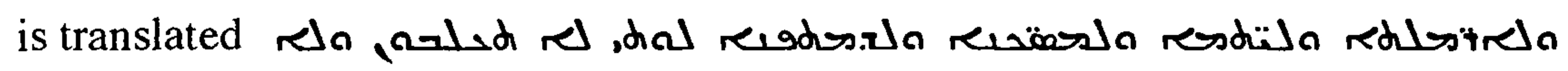
...... $\Omega(1 /$ d: this raises the second point of particular interest, namely that rather than the verse in Jeremiah having been harmonised to that in Zechariah, the verbs $\mathrm{L}$ and alf may have constituted an idiomatic pair which the writers of the Peshitta used in these appropriate contexts.

In 15:5 there may be influence from Isaiah, Nahum, or Psalms. כי מי-יחמל עליך

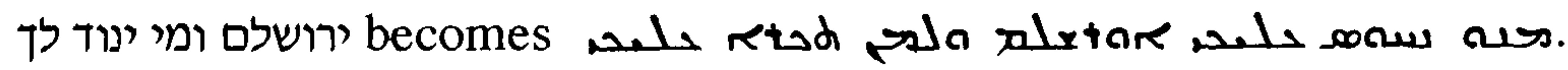
Root TU occurs in ten other passages in Jeremiah, and is appropriately translated with roots 20, , $ه$; (with the exceptions of the difficult 48:27 where root $\rightarrow$ is used, the translator having perhaps understood root 77 , and 50:8 where root $\mathrm{t} \mathrm{i}$ is used, perhaps because root J was understood). Nowhere else in Jeremiah is it translated with root $t\lrcorner d$, and this may be due to the influence of one of three other passages in the Hebrew Bible in which it is paralleled with root נח : these are Isa 51:19; Nah 3:7; Ps 69:21; in each of these the translation is with root tod: 
Isa 51:19 מי ינוד לך ...מי אנחמך is translated as

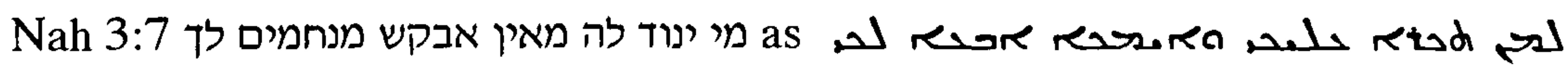

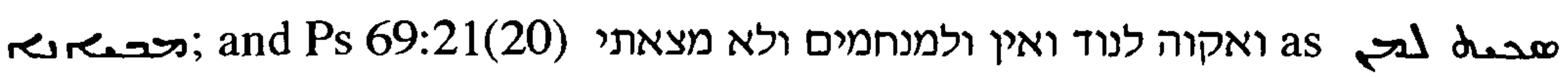
dware rla Rreasla dela ol redis. Here again, as in the example above, the cause of the apparent harmonisation may be the translator's tendency to use an idiomatic phrase.

In 32:20 the possible influence is from Deuteronomy. In the translation of MT אשר שמת אתות ומפתים that of Deut 29:2 האתת והמפתים הגדלים.

In 33:7 the possible influence is from Ezekiel. MT ובנתים כבראשנה is expanded,

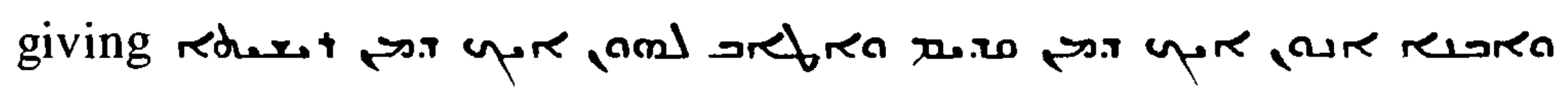
to harmonise the passage with Ezek 36:11 והושבתי אתכם כקדמותיכם והטבתי

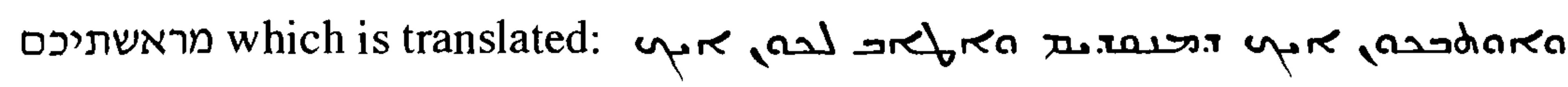
rederet por

In 33:11 the possible influence is from Ps 147(146):1. There is an unexpected

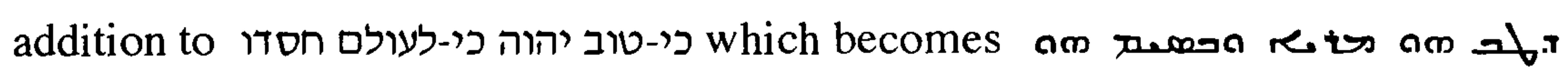

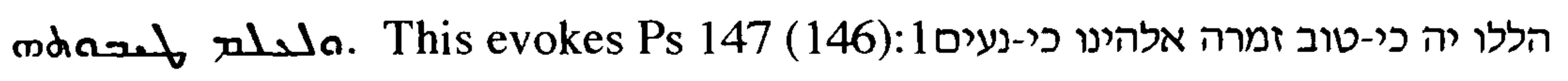

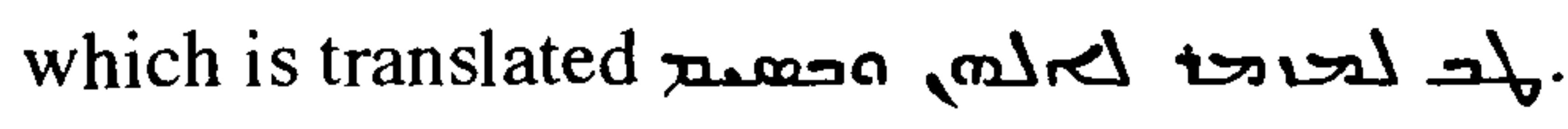

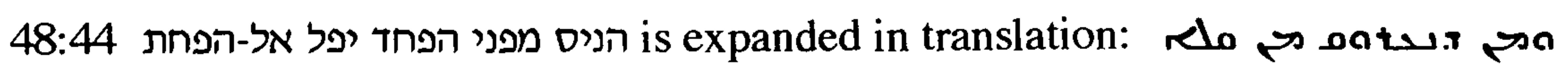

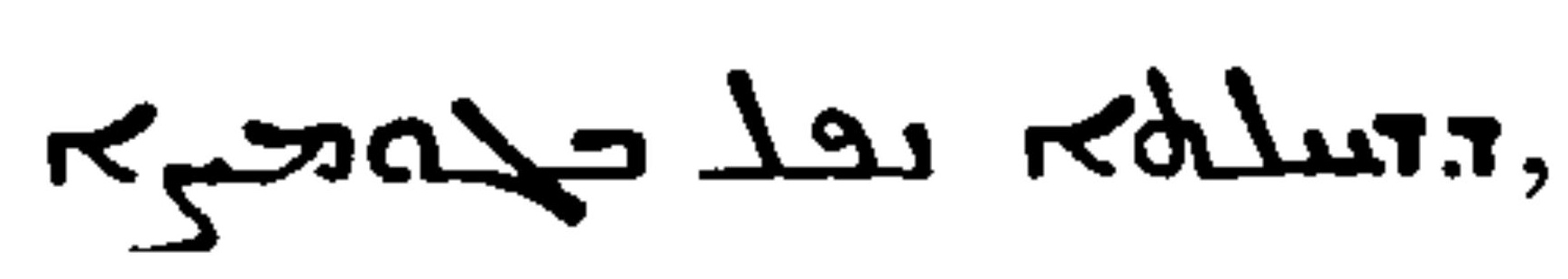
and resembles Isa 24:18 והיה הנס מקול הפחד יפל אל הפחת, which is translated similarly.

Second, passages assimilated to other verses of Jeremiah.

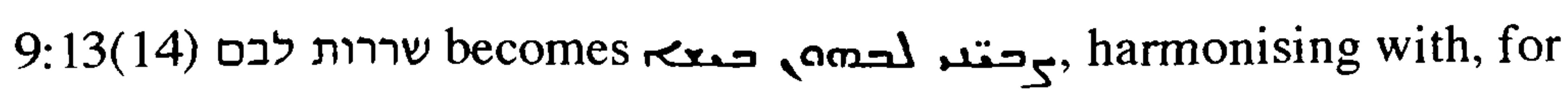
שררות לבם הרע instance, 3:17 


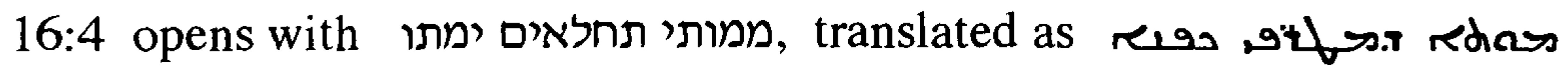
, ואם באתי העיר והנה תחלואי רעב 14:18 by harmonisation to translated as

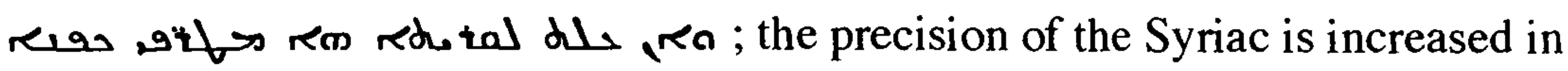
comparison with the Hebrew, a result which may also have motivated the translator.

25:18 לתת אתם לחרבה לשמה לשרקה ולקללה is contracted in translation, with three terms only: Rdeantrsla rmsdla ratal האבת. אRת, which is translated as ושמתים לשמה ולשרקה ולחרבות עולם ratada redentrasla.

30:18 Here, the addition of a phrase harmonises a verse to one which comes later in the book: הנני-שב שבות אהלי יעקוב ומשכנתיו ארחם becomes

Kos

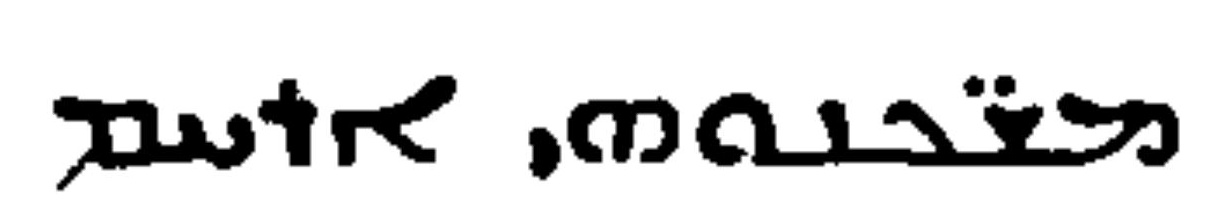

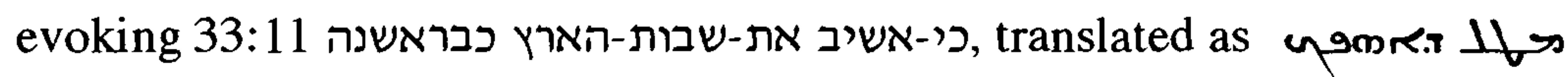

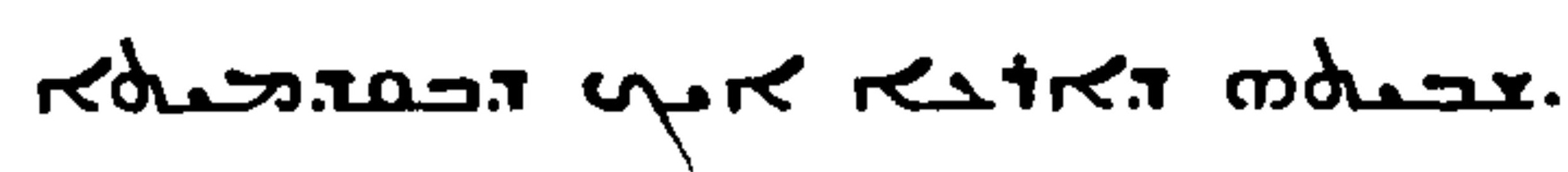

36:7 וישבו איש מדרכו הרעה becomes

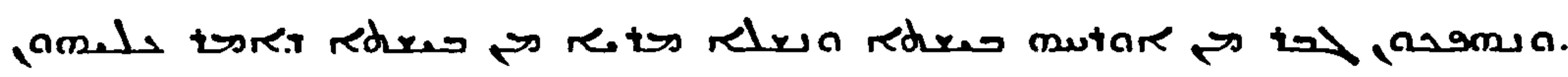
The addition evokes, for instance, $26: 3$ וישבו איש מדרכו הרעה ונחמתי אל-הרעה אשר אנכי חשב לעשות להם

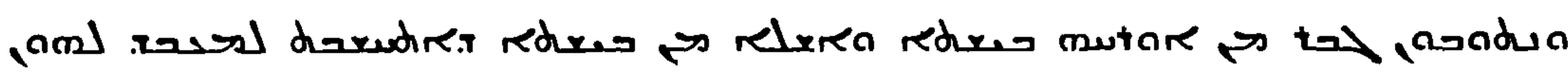
(This is one of the many verses where Lee's text differs markedly from that of 7a1.)

46:26 ונתתים ביד מבקשי נפשם.... has an additional clause in translation, to

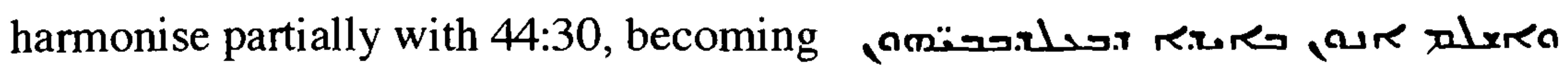

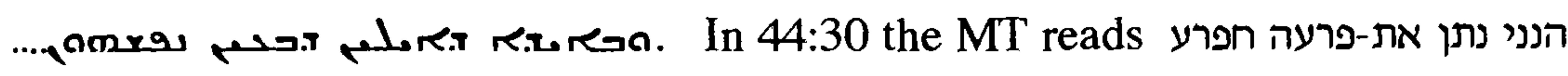
מלך-מצרים ביד איביו וביד מבקשי נפשו, which is translated

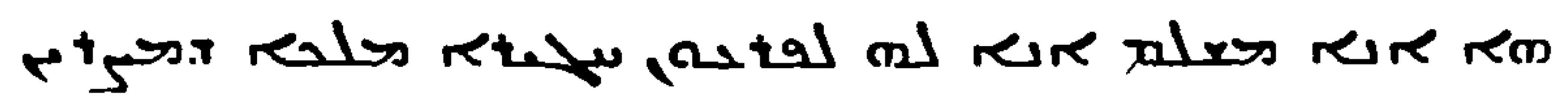

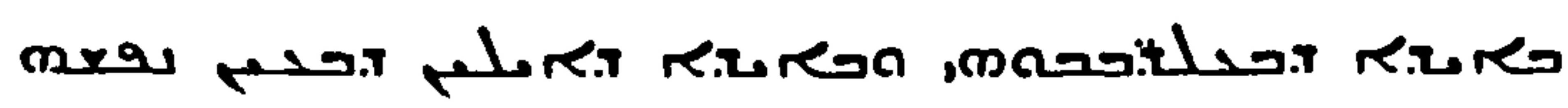




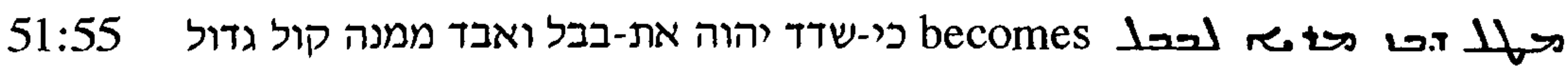

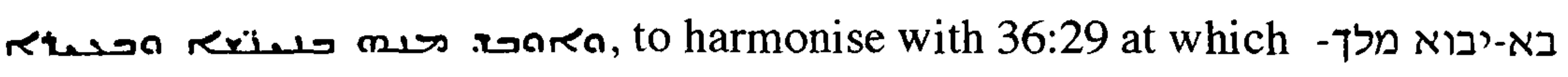
is appropriately translated:

. 
Chapter 2 Translation Technique

(iv) a. additions

This section concerns those additions which were made deliberately, as manifestations of translation technique. However, as Gelston (Gelston, 1987, pp.131-135) notes, it is not always possible to distinguish with certainty between those additions which result from differences in the syntax and idiom of the two languages and those which were intended to change the meaning of the text. So far as subjective assessment makes possible, the former have not been included here: "enforced" changes, where the translator was constrained by writing in a different language, give no insight into his translation technique since he had no choice but to make them. As an obvious example, the independent third person plural pronouns idiomatic in Syriac add to the word count in comparison with Hebrew where objective suffixes are acceptable, but their use would be automatic rather than a matter of judgment.

Any deliberate addition, whatever the reason for making it, by definition breaks the rule of quantitative literalism, and implies that the translator gives greater priority to the motive for the change than to keeping that rule. Such changes are made frequently: there are seventeen examples of additions ${ }^{35}$ within the 186 sense units of the sample of tenth verses, giving a figure of $9 \%$ of sense units affected. This figure excludes the two "enforced" additions, made in recognition of the differences in idiom or syntax between the two languages, and an addition which forms part of an attempt to translate difficult or obscure Hebrew. The high prevalence, together with the trivial nature of many of the examples, suggests that the translator was perfectly ready to move from quantitative literalism: had he been at all reluctant to do this, he could easily have avoided making many of these changes.

35. additions:

epithet 8:10, 28:10; enforced by idiom 13:10, 22:10; for clarity or precision 15:10; 22:10; $26: 10 ; 31: 10 ; 36: 10 ; 40: 10 ; 45: 5 ; 48: 10 \times 2 ; 50: 10 ; \quad$ additional verbs $38: 10 \times 2 ; 44: 10 ; 46: 10$ x 2; difficult or obscure Hebrew 20:10 
Chapter 2 Translation Technique

\section{a. The classification of additions}

Almost all these additions seem to have been made in pursuance of the presentational style; they include:

(i) additions which increase clarity or precision.

Some particularly revealing examples in this group are found at points where the Hebrew is enigmatic: the change in style suggests that the translator put a high value on clarity and immediate accessibility. The analysis presented above has already shown that the translator did not consistently aim at a literal rendering, as he would have done had he felt himself to be translating "letter-perfect" text, so additions breaching the constraints of quantitative literalism for the sake of greater clarity were permissible. Further, such clarity was evidently valued above the preservation of the mood of the Hebrew, where an enigmatic passage would, at passages where the difficulty was not the result of inner-Hebrew corruption, have been deliberately so. The readers of the Peshitta would have been no less educated than those who read the original text, and would have been equally able to extract a hidden sense: so additions which make the text more readily accessible may at the same time eliminate a device deliberately used in order to check the reader's train of thought and allow a pause in which imaginative interpretation was allowed.

Other examples in this group may seem to the modern reader to verge on pedantry, as noted for instance by Albrektson (Albrektson, 1963, pp.210-211): at many the subject or object is stated, or the identity of speaker or addressee specified, and at others an additional verb is given which adds nothing to the sense of the Hebrew, so that these additions serve only to make explicit in the Syriac that which is implicit in the Hebrew, and sometimes even diminish the impact of the text by labouring a point or flattening an image.

(ii) additional epithets

(iii) additions which give new information: this group, supplying facts which cannot be deduced from MT, is very small. 
Selected examples from these three categories will be given below, in canonical order.

(i) additions which increase clarity or precision

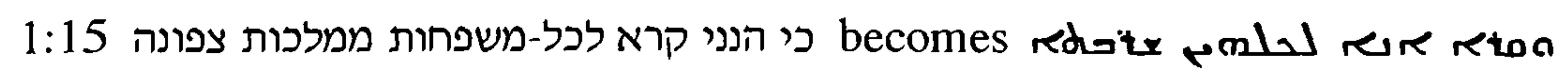

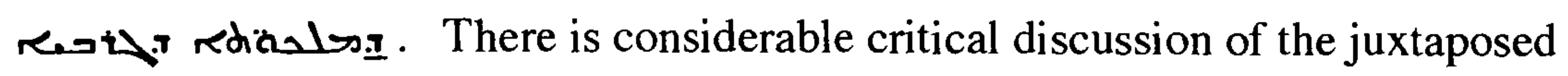
ממלכות and they may be variant readings, or משפחות may be a secondary addition from 25:9 כל משפחות צפון (Janzen, 1967, p.435); whatever the underlying problem, the translator makes sense here by translating as if משפחות is a construct, and adding dalath.

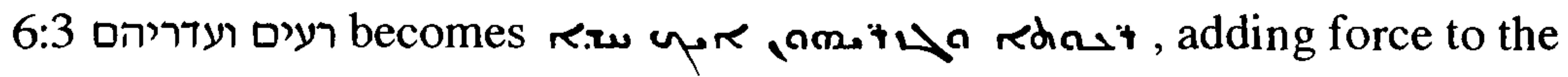
phrase in translation.

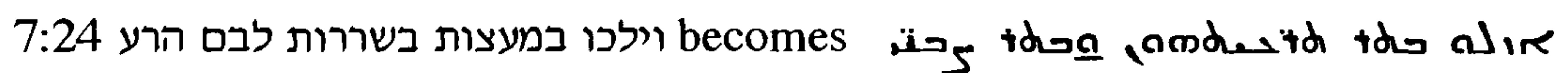
and may indicate that these terms are variants which have been conflated; the verse evokes the parallelism of Ps 81:13 ואשלחהו בשרירות לבם ילכו במועצותיהם, and is discussed by Janzen (Janzen, 1967, pp.435-436). The additional waw in idan gives a clear sense.

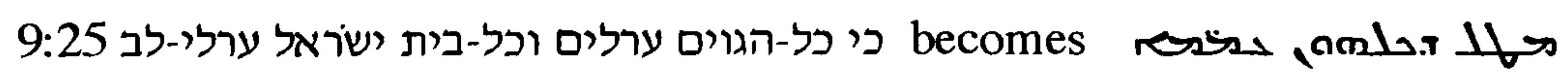

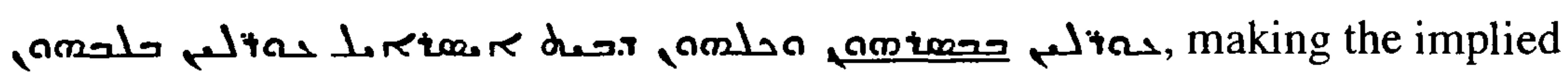
comparison explicit.

$10: 16$ לא-כאלה חלק יעקב כי -יוצר הכל הוא וישואראל שבט נחלתו

becomes:

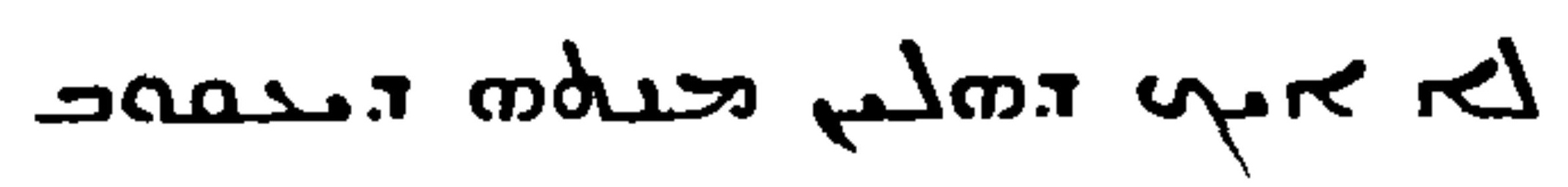

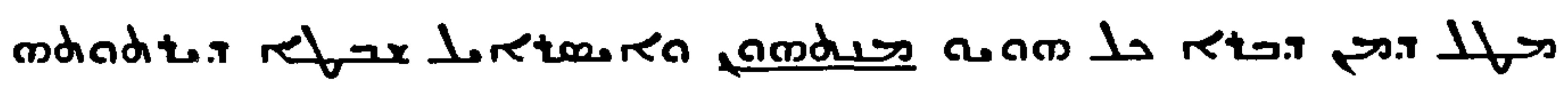
conforming the second clause to the first. 51:19 has a similar expansion, perhaps to harmonise this verse with the earlier one: MT לא-כאלה חלק יעקוב כי-

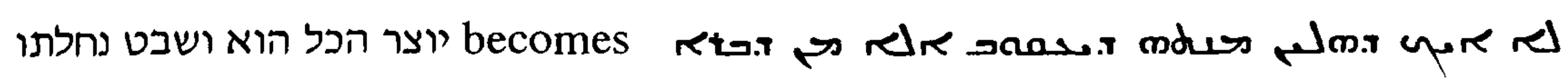

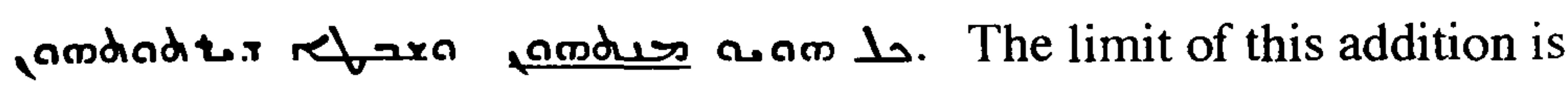
particularly interesting. Restrained as it is, it serves the purpose of increased precision, and also harmonises this verse with 10:16. It does not meet the clear 
need for "Israel" to be supplied in the later verse, and so gives a good example of human inconsistency in the application of the translation technique, virtually inevitable in work on a text of this length.

$$
\begin{aligned}
& \text { ונתתים לזועה לכל ממלכות הארץ } \\
& \text { בגלל מנשה בן יחזקיהו מלך יהודה } \\
& \text { על אשר-עשה בירושלם }
\end{aligned}
$$

has an added term:

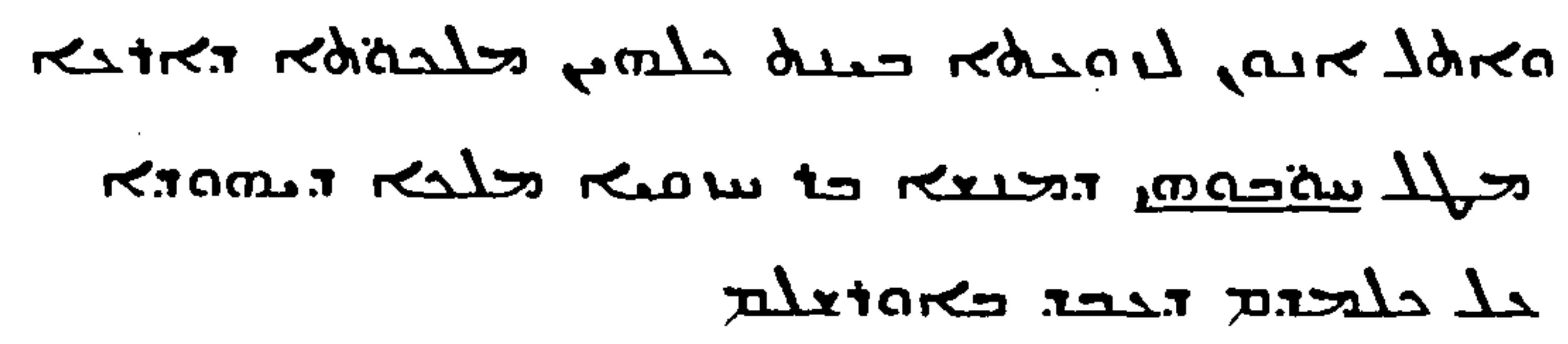

The nature of Manasseh's reign is implicit in MT but explicit in translation.

In 15:10, there is an additional waw. This feature is not always important: for instance, Albrektson (Albrektson, 1963, p.210, n.1) refers to the "very frequent and usually unimportant" additions of waw in the Peshitta to Lamentations, and Brock (Brock, 1988, pp.61-62), noting the limited value of the representation or failure to represent waw in adjudicating Syriac variants where this is the only factor, points out that the translator was evidently not always interested in this feature. The additional waw in 15:10, however, may be an exception. MT seems to lack an adversative particle preceding

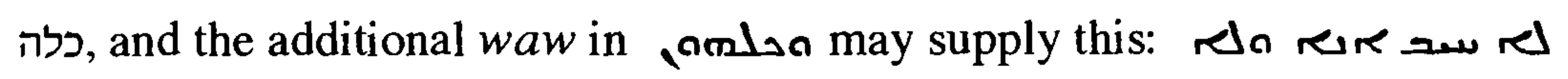

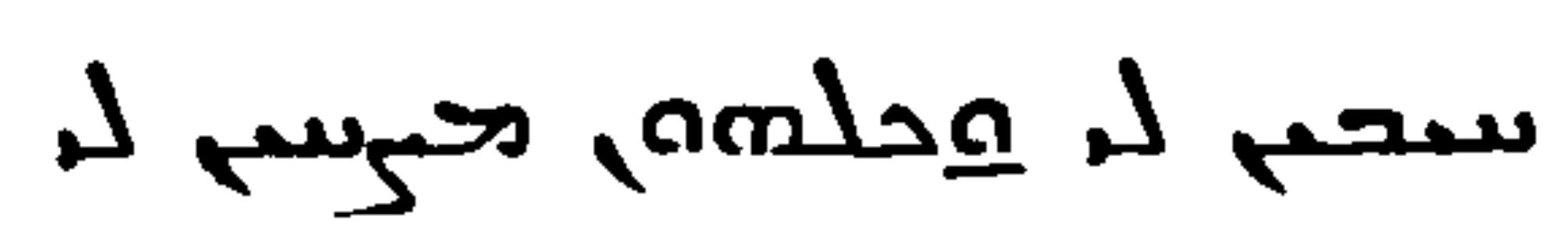

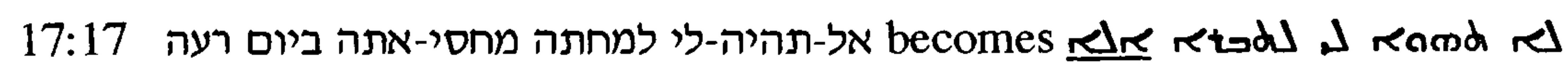
rese the additional

22:7 איש וכליו becomes the translation is more precise than MT, though pedantic to the point at which it diminishes the impact of the imagery. 
22:8 עיר is described as large once only in MT, but twice in the translation:

ועברו גוים רבים על העיר הזאת

....... על-מה עשה יהוה ככה לעיר הגדולה הזאת ועם

becomes

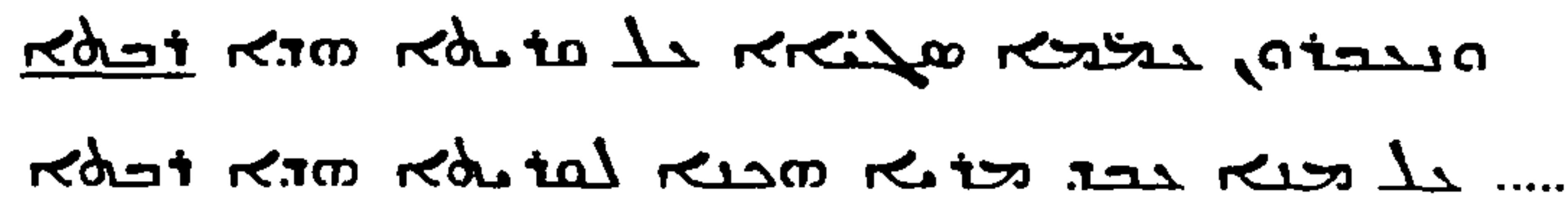

22:10 בحבא כحם מע דק becomes בכו בכו להלך כי לא ישוב עוד וראה את-ארץ מולדתו

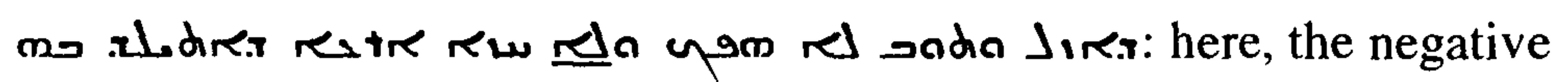
understood in וראה את-ארץ מולדתו is supplied in translation. (The additional in this line is not relevant in the present discussion of additions, since its presence is probably determined more by the grammar of the target language than by translation policy.)

24:5 Making the sense explicit, the translator adds a preposition: MT אשר שלחתי

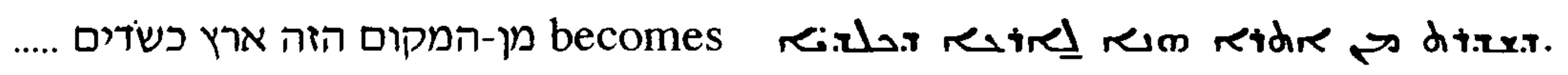

In 26:10 שער-יהוה החדש there is an additional term in translation:

retsis moles redicu reth makes explicit the location of the new gate in the Temple area, although in the context of the complete verse:

וישמעו שרי יהודה את הדברים האלה ויעלו מבית-המלך בית יהוה וישבו בפתח שער-יהוה החדש

there could have been no difficulty in understanding exactly what was meant.

27:14 The opening pronoun adds emphasis: ואל-תשמעו אל-דברי הנבאים becomes

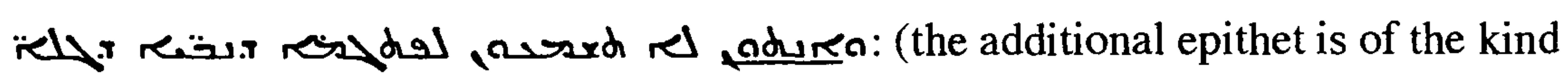
noted below, seen in for instance 6:13).

\section{ואלה דברי הספר אשר שלח ירמיה הנביא מירושלם אל-יתר זקני הגולה ..... מירושלם 29:1}

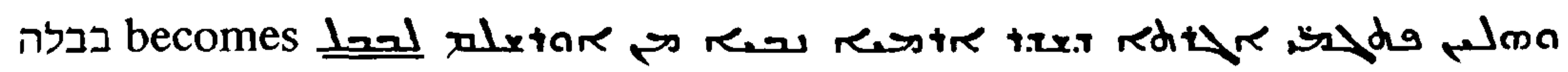
Ialutare the place of exile is stated only once in MT, at the end of the verse; in translation, it is given twice, at the beginning of the list of recipients of the letter too. 


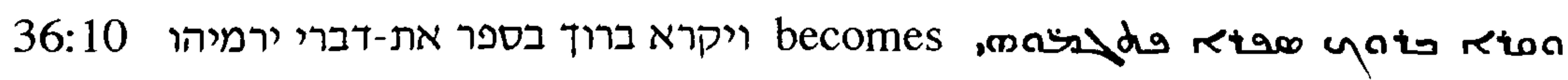

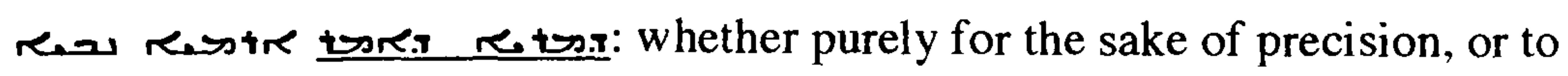
emphasise Jeremiah's prophetic role, the translation specifies that the words which Jeremiah spoke came from God.

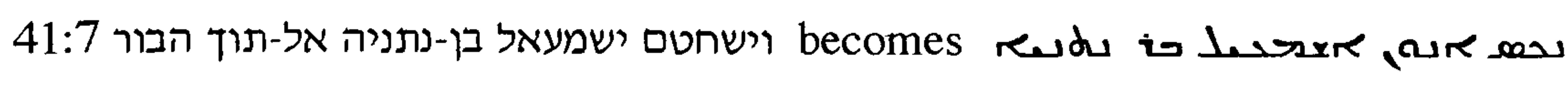

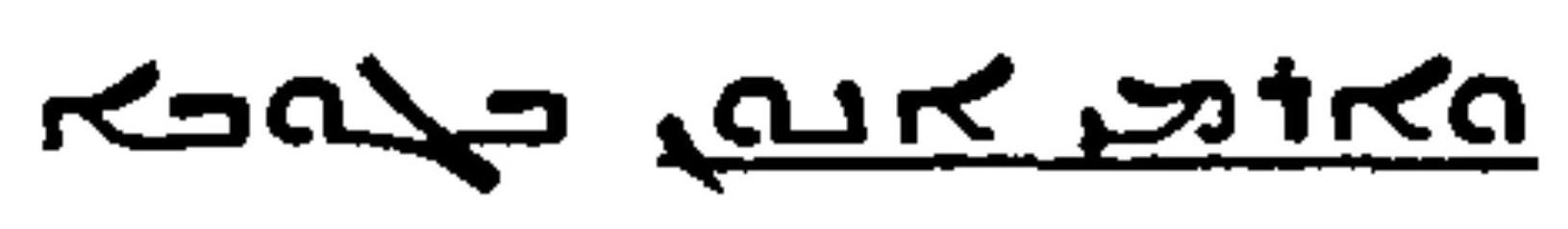

The translator supplies a second verb and its object in , STR to complete the sense.

והבור אשר השליך שם ישמעאל את כל-פגרי האנשים אשר הכה ביד-גדליהו 41:9 הוא אשר עשה המלך אסא מפני בעשא מלך-ישראל אתו מלא ישמעאל בן-נתניהו חללים

becomes

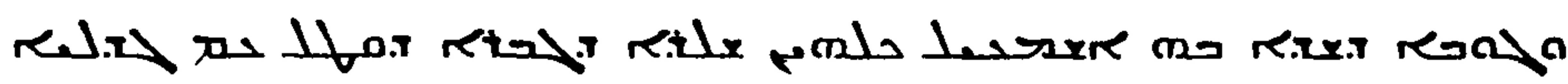

$$
\begin{aligned}
& \text { riam.x reals reore }
\end{aligned}
$$

s. o. The Hebrew is reasonably clear in the context, but is made explicit in translation

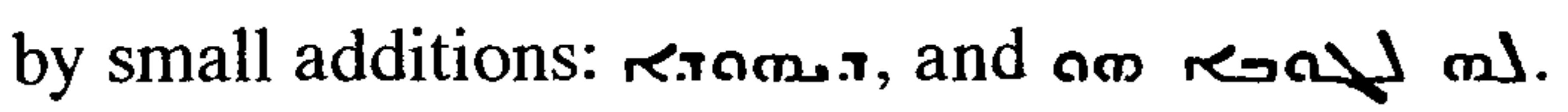

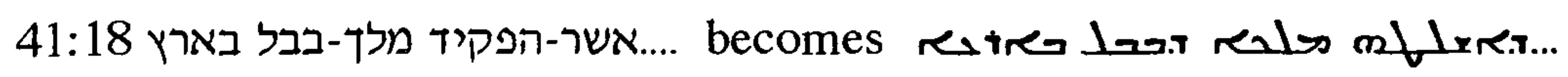
Kramer: there is no doubt that the land over which Gedalya has been appointed governor is Judah; nonetheless, in a pedantic addition, the Syriac specifies this.

44:2 Making explicit the sense of MT על כל-ערי יהודה...... ואין בהם יושב becomes

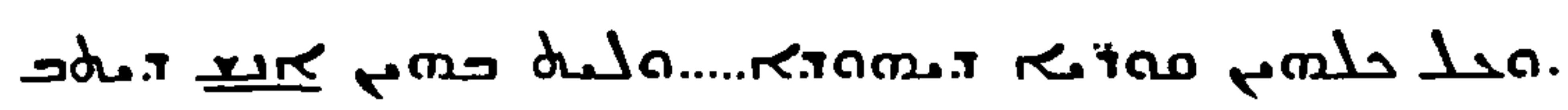

44:24 אל-כל-העם על-הגברים 44:20 is an incomplete echo of ועל הנשים . The translation adds a term, filling an obvious gap, and in the

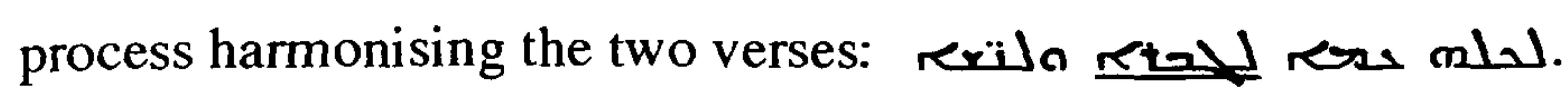

45:4 where God threatens that he will bring disaster upon those whom he once helped: אשר-בניתי אני הרס ואת אשר נטעתי אני נתש ואת-כל-הארץ היא 
Chapter 2 Translation Technique

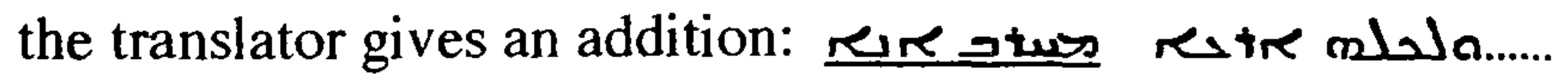

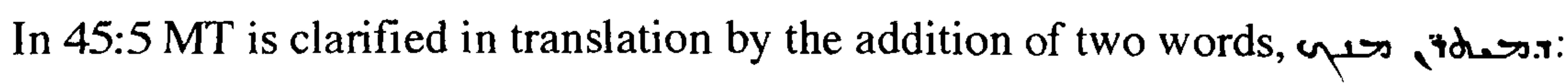
ואתה תבקש-לך גדלות אל-תבקש

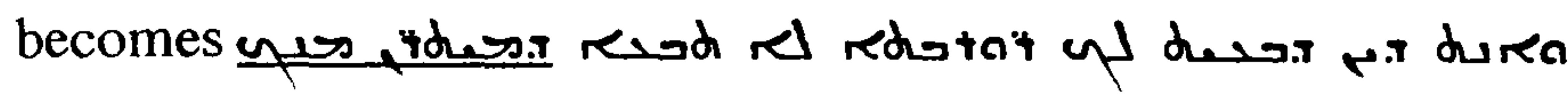

46:6 MT tells of complete defeat: אל-ינוס הקל ואל-ימלט הגבור צפונה על-יד נהר פרת

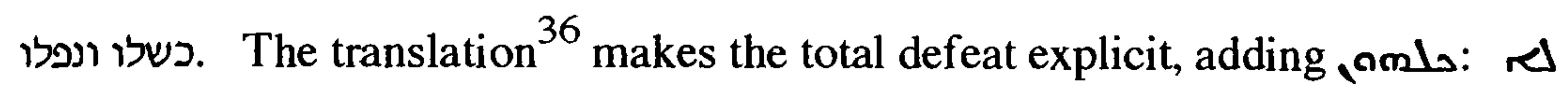

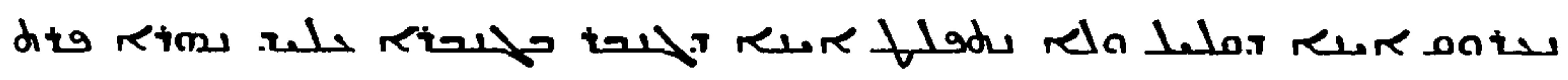
amba alaso alodidre

46:25 To the MT sequence הנני פוקד אל-אמון מנא ועל-פרעה ועל-מצרים ועל-אלהיה ועל מלכיה

the translator adds Pharaoh's forces:

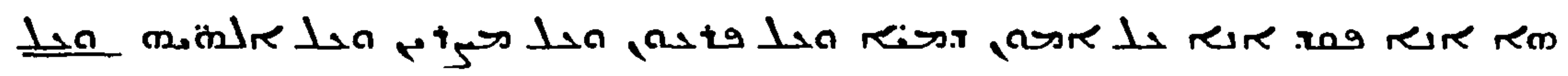

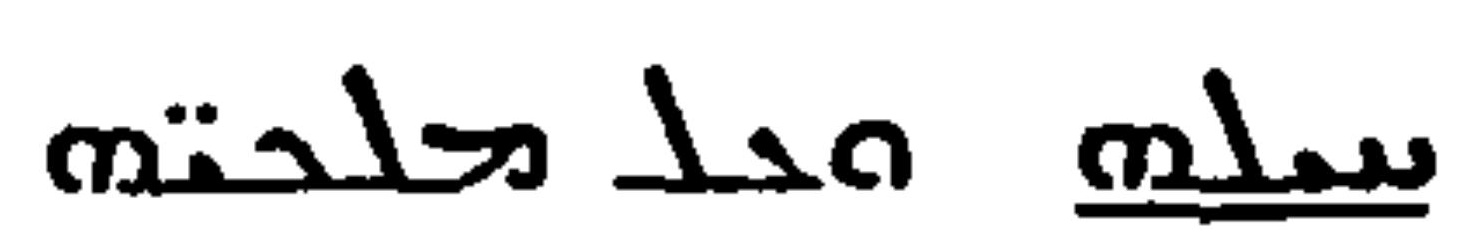

47:6 MT עד-אנה לא תשקטי has an additional phrase in translation:

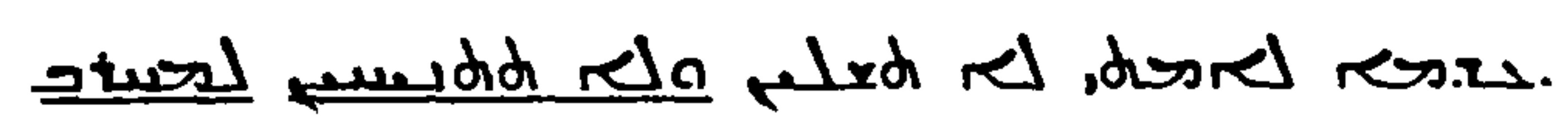

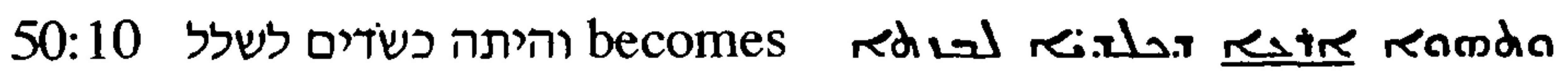

50:20 The sense of MT is made explicit: כי אסלח לאשר אשאיר becomes ames atudxris ratel oarra lfos

51:36 The sense of MT is made explicit in translation: והחרבתי את-ימה becomes

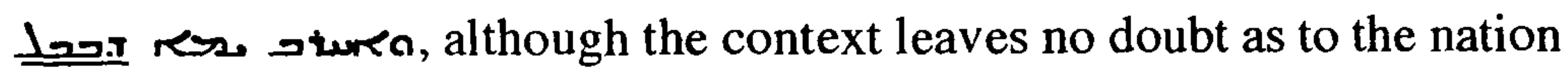

36. There is an interesting example of inner-Syriac comuption here: MT צפונה is translated, in all extant mss., not as restat as but 
Chapter 2 Translation Technique

concerned.

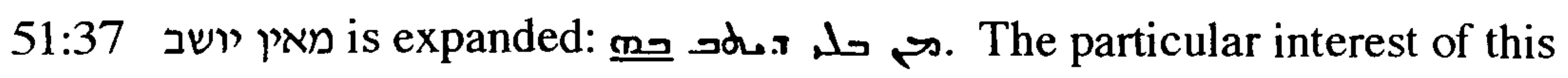
small addition is that in the similar verse at 9:10 מבלי יושב is translated sh.x, without the final term. The two verses are so close:

9:10

ונתתי את-ירושלם לגלים מעון תנים

ואת-ערי יהודה אתן שממה מבלי יושב

$51: 37$

והיתה בבל לגלים מעון תנים

שמה ושרקה מאין יושב

that this seems to be another example of the translator's human inconsistency.

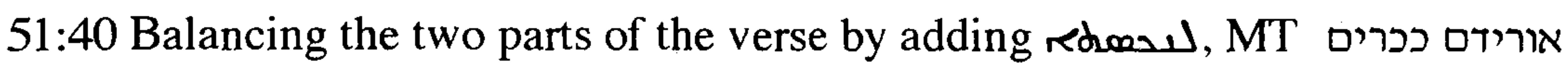
aleres becomes in translation לטבוח כאילים עם-עתודים

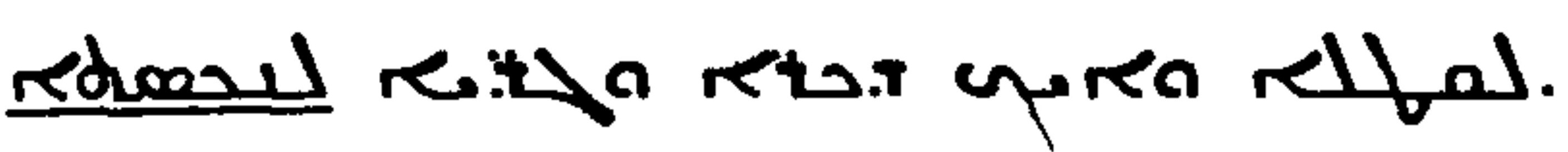

51:46 There are two simple additions here, ruter and clarifying the difficult MT:

$$
\begin{aligned}
& \text { ופן-ירך לבבכם ותיראו } \\
& \text { בשמועה הנשמעת בארץ } \\
& \text { ובא בשנה השמועה } \\
& \text { ואחריו בשנה השמועה }
\end{aligned}
$$

becomes
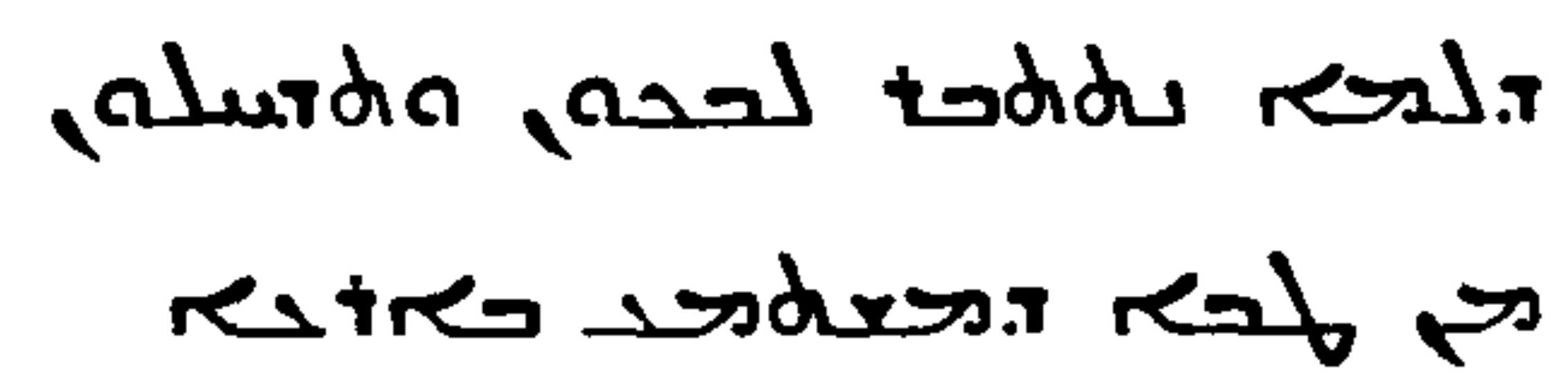

refor redura adren

rerter raf redex midan

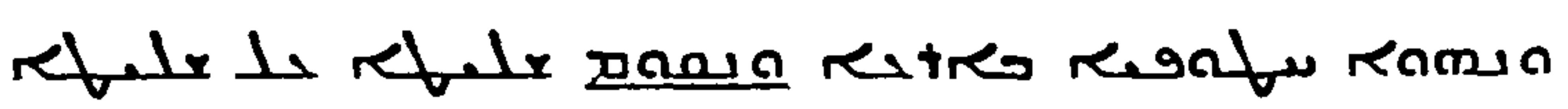

51:51 There are two additions: MT בשנו כי שמענו חרפה becomes in translation

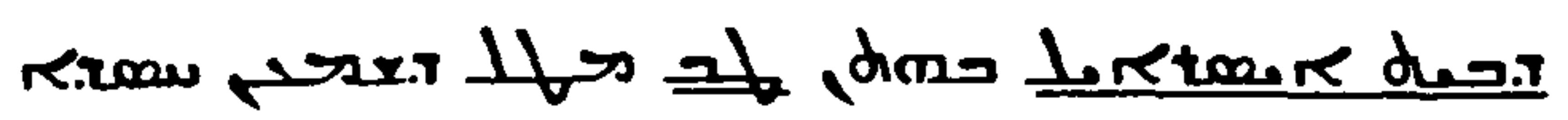


Chapter 2 Translation Technique

Within the group of additions which increase precision are those which specify a subject or an object:

10:7 יאתה lacks a subject for though the general sense is implicit both in the preceding phrase and in the immediately following expansion כי בכל-חכמי הגוים ובכל-מלכותם מאין כמוך. The translation supplies a subject, though changing the sense from "awe", as implied in the Hebrew, to "majesty" :

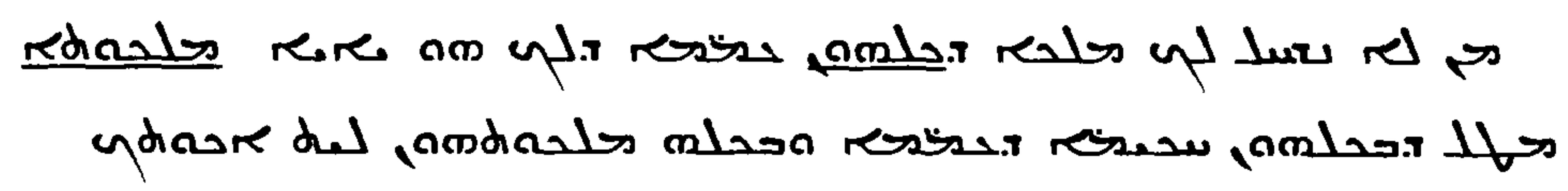

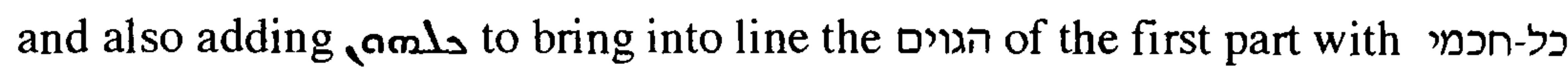
כל-מלכותם and the second.

10:11, 12 The implicit comparison between the gods of 10:11 and the God of 10:12 is explicit in the translation: whereas MT has

(אלהיא די-שמיא וארקא לא עבדו......

יאבדו מארעא ומן-תחות שמיא אלח;

עשה ארץ בכחו ......

the Peshitta has the additional re ts:

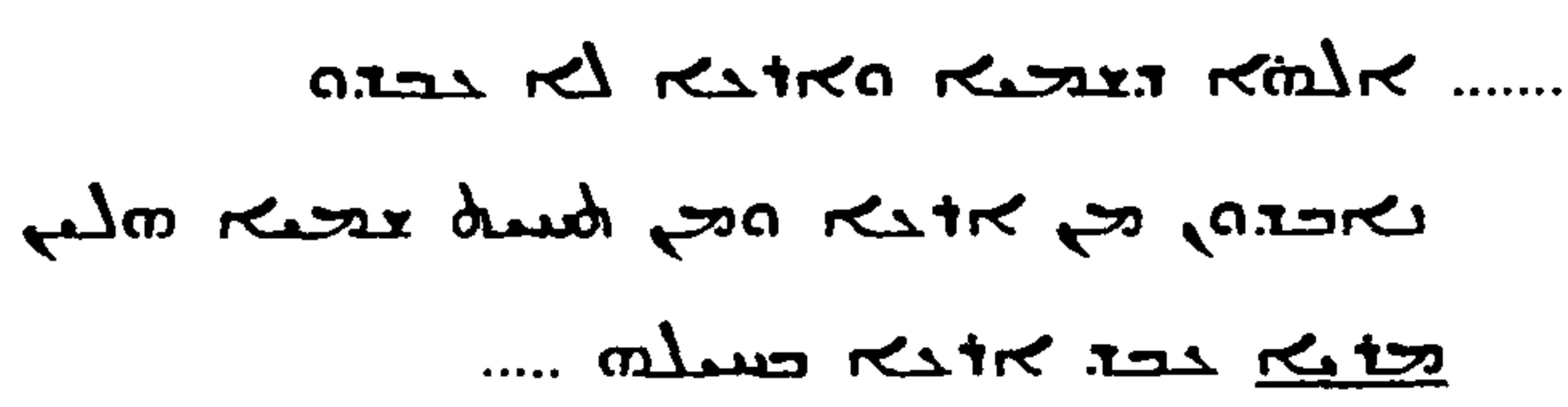

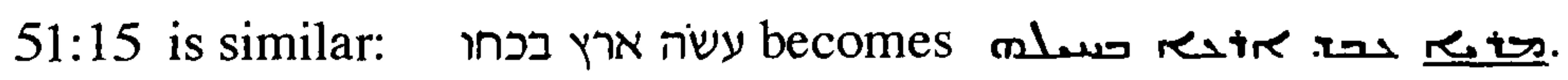

$14: 5$

כי גם אילת בשדה ילדה ועזוב

becomes

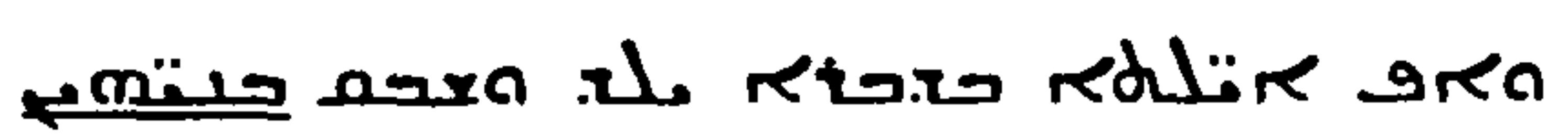

36:18 In the Syriac, but not in the MT, it is explicit that Jeremiah is the grammatical subject: מפיו יקרא אלי את כל-הדברים האלה becomes

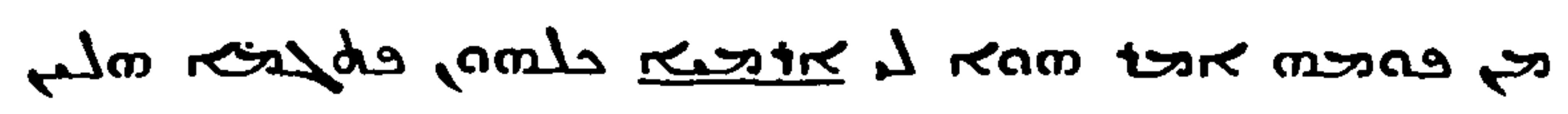

36:30 The sense of the MT לא-יהיה-לו יושב על-כסא דוד is clear only because the 
Chapter 2 Translation Technique

concept is familiar. The translator adds riz in this context meaning successor, giving a subject for sh.r: .นกร.

36:31 MT כל-הרעה אשר-דברתי אליהם ולא שמעו becomes, specifying an object, and

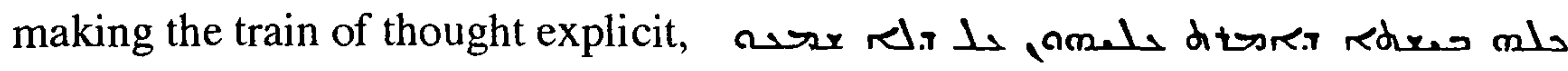
حمل

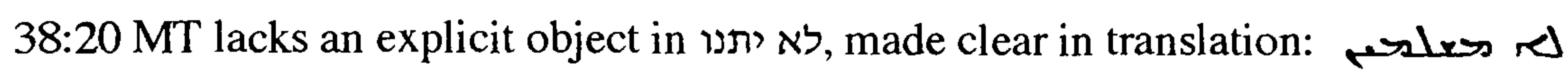
$\underline{1}$

39:12 there can be no doubt, given $v 11$ :

ויצו נבוכדראצר מלך-בבל על-ירמיהו ביד נבוזראדן

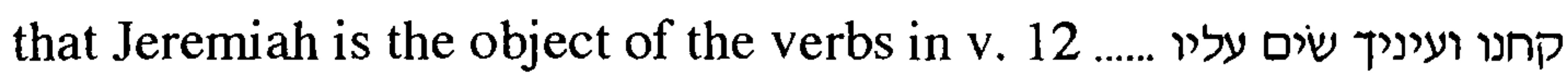

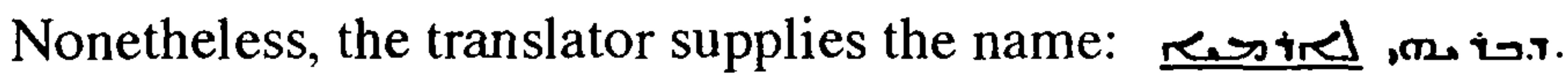

41:16 MT אחר הכה את-גדליה becomes, specifying the subject,

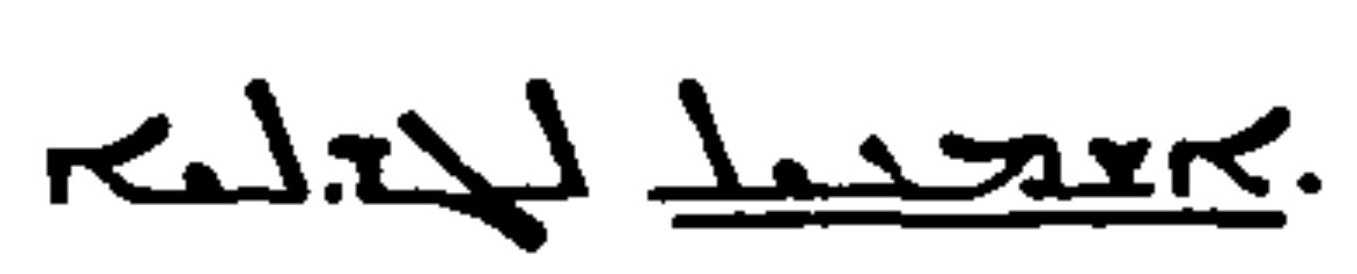

Other additions make explicit the identity of speaker or addressee:

$19: 1$ becomes

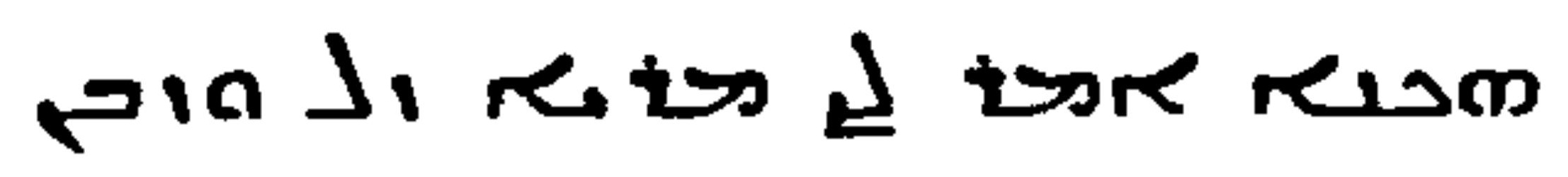

26:1 MT היה הדבר הזה מאת יהוה לאמר is expanded:עr rom tska rets

27:17 MT does not specify the speaker in אל-תשמעו אליהם עבדו את-מלך בבל וחיו

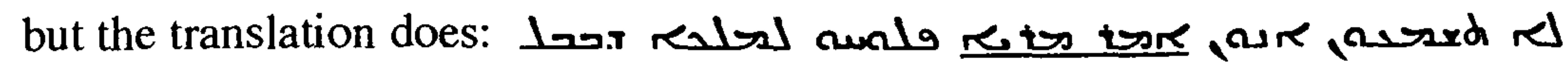
ana

31:21 Specifying the speaker, the translator adds to MT: שובי בתולת ישראל שבי

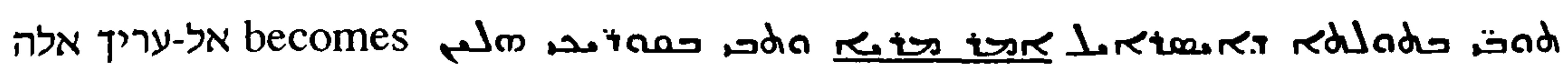


Chapter 2 Translation Technique

(The translator has understood root שוב at the first imperative, and root ישב at the second: see also Chapter 6.)

36:15 The speakers are specified: ויאמרו אליו שב נא becomes otsen aton sh retat

42:11 MT

אל-תיראו מפני מלך בבל אשר-אתם יראים מפניו

אל-תיראו ממנו נאם-יהוה כי-אתכם אני להושיע אתכם

leaves no reasonable doubt that God speaks. Nevertheless, the translation

makes this explicit: aratas

46:3 It is made explicit in the translation though not in MT that it is God who gives the soldiers their orders: MT opens with instructions ...... ערכו מגן וצנה but the translation opens by specifying the speaker ${ }^{37}$ :

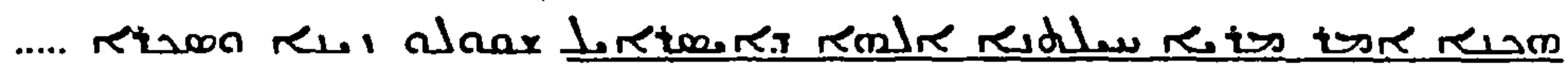

51:34 The speaker is specified: MT אכלנו הממנו נבוכדראצר מלך בבל is introduced in translation: As well as adding to the precision of the rendering, the translator may have decided on this addition for the sake of the inclusion it forms with the end of 51:35. Dittography is possible, but seems less likely.

37. The position of this long sequence is difficult to explain: presumably it is intended to strengthen the beginning of the oracles against the Nations, and would therefore be expected at the beginning of verse 2 . 
Chapter 2 Translation Technique

Sometimes an additional verb is given:

1:15 כי הנני קרא לכל-משפחות ממלכות צפונה is a phrase which the translator felt needed an additional verb to represent the full force of the MT קרא

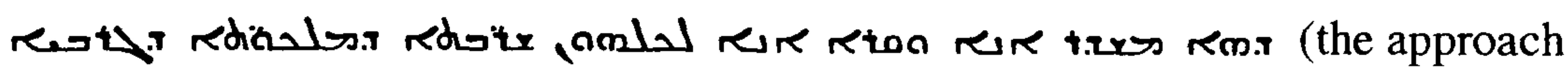
to לכל-משפחות ממלכות is discussed above). Interestingly, the added verb precedes the translated verb ${ }^{38}$.

2:13 God's account of Israel's idolatry is more scathing in translation, with an additional verb emphasising the picture of purposeless activity: לחצב להם בארות becomes riat am otglireo.

4:26 והנה הכרמל המדבר becomes, with an additional verb and a clarification of the figurative language of the MT, rtors serso.

6:16 עמדו על-דרכים וראו ושאלו לנתבות עולם אי-זה דרך הטוב becomes, with an

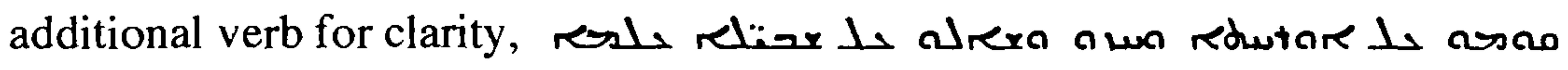
Rtear rewtare rick awa

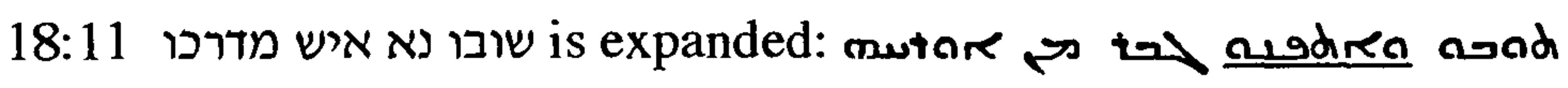

38. Mrs. Weitzman most kindly gave me access to Dr. Weitzman's papers after his death, and in the text of a paper to be presented at a conference, which I have been unable to find in any Proceedings or published in any other form, Weitzman commented on the similar approach in other Versions here: LXX adds ou $\gamma k \alpha \lambda \tilde{\omega}$, the Vulgate has "convocabo", and the Targum gives מכלי "a word entirely distinct from the Hebrew. It is as if all the translators were aware of some special nuance in the Hebrew pר and set about rendering it in their own ways." 
Chapter 2 Translation Technique

19:1 הלוך וקנית בקבק יוצר חרש ומזקני העם becomes in translation:

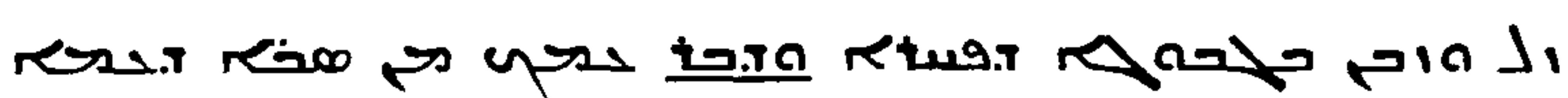

The additional verb at

20:1 MT, clear enough as it stands: וישמע.....את-ירמיהו נבא את-הדברים האלה

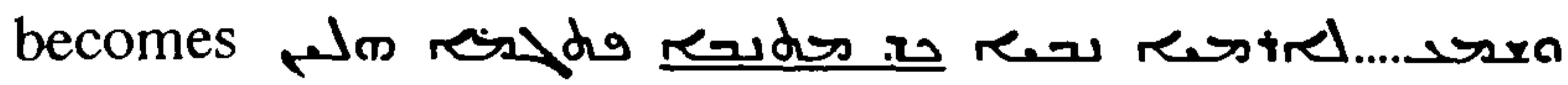

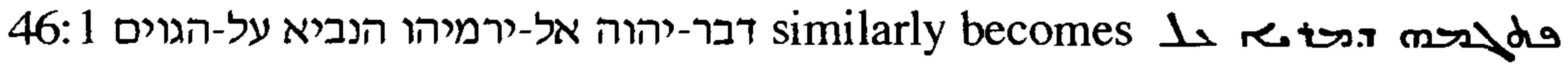
אשר היה דבר-יהוה אל ירמיהו הנביא 47:1, and at there is the same addition: אל-פלשתים ridelg 1 resdur

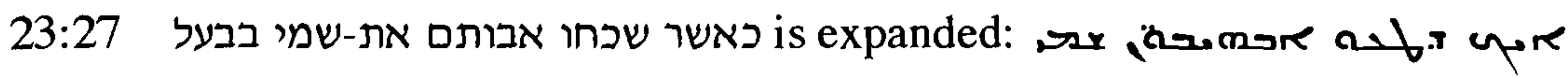
rilan

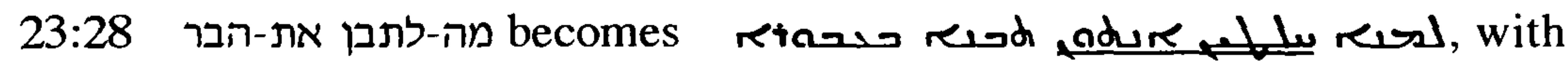
additional terms to clarify the figure in MT.

23:29 Flattening the imagery, MT הלוא כה דברי כאש נאם-יהוה is expanded with an

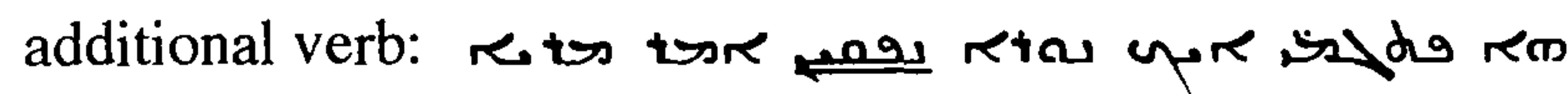

26:19 The sense of the rhetorical question in the Hebrew is expressed, and a note of irony added: ואנחנו עשים רעה גדולה על-נפשותינו

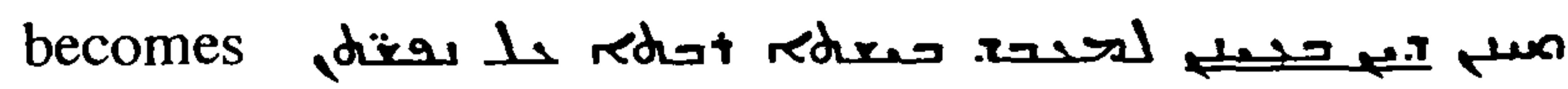

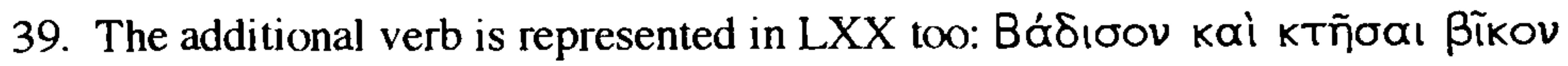

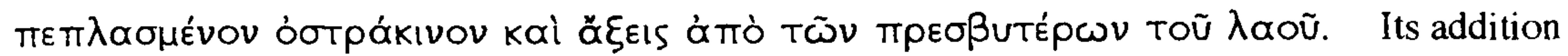
is so clearly necessary that there is no need to postulate influence of the Greek on the Syriac: polygenesis is perfectly plausible.

The use of root זיז for animate objects, and of root for inanimate objects, is mentioned by van der Kooij (van der Kooij, 1988, p.192; also by Weitzman (Weitzman, in press, p.92). 
27:6 There are two processes here: first, MT אנכי נתתי את-כל-הארצות האלה ביד becomes נבוכדנאצר of מל in is then echoed in an additional verb: the line continues MT, but in translation we have susulanging the first part of the verse into line with the second which, in both MT and Peshitta, ends:

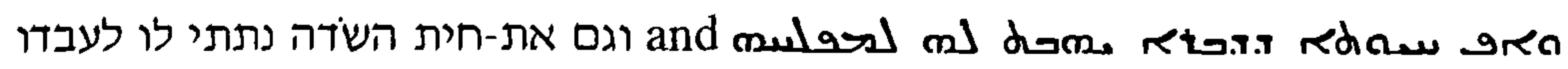

31:40 MT וכל-העמק הפגרים והדשן is expanded by the addition of a participle ${ }^{40}$ :

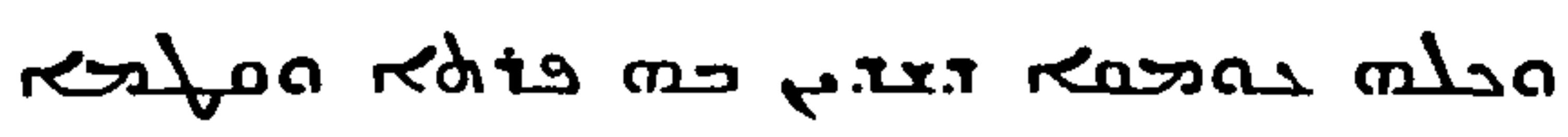

36:12 והנה-שם כל-השרים יושבים is a passage with considerable dramatic impact, perhaps flattened by the addition of another verb to give the rather pedestrian

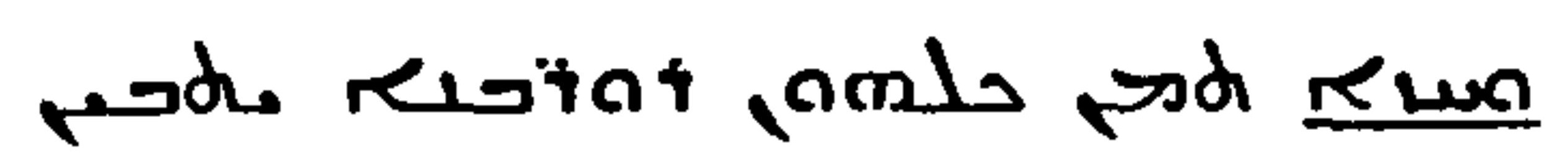

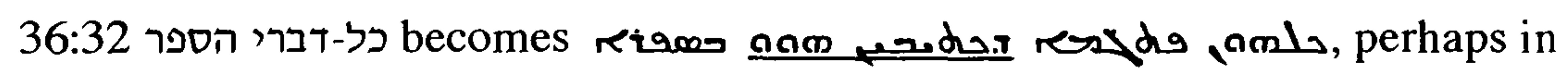
order to emphasise that the book in question is that which Baruch had written to Jeremiah's dictation.

38:10 Zedekiah's order to Eved-Melech: - קח בידך מזה שלשים אנשים והעלית את

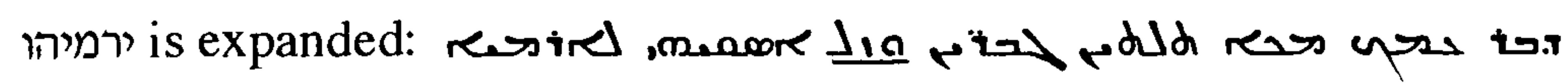

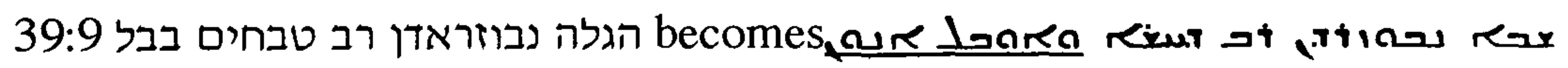
لa

40. The use of redte rather than the expected 2 g is common to all extant mss. It could be deliberate, to give the sense of mutilated bodies rather than simply of corpses, but might simply be due to a scribal error. 
41:16 In the MT, one verb is used for Yohanan's actions:

ויקח יוחנן בן-קרח וכל-שרי החילים אשר-אתו את כל-שארית העם.....

גברים אנשי המלחמה ונשים וטף וסרסים....

In the Syriac, the verb - $-x$ - is repeated at the beginning of $16 \mathrm{~b}$, giving

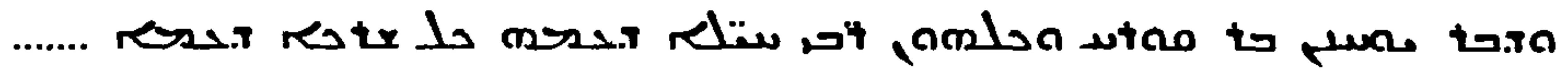

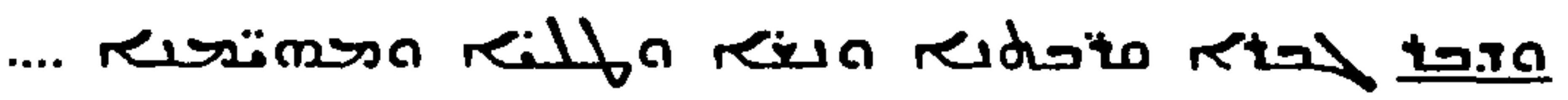

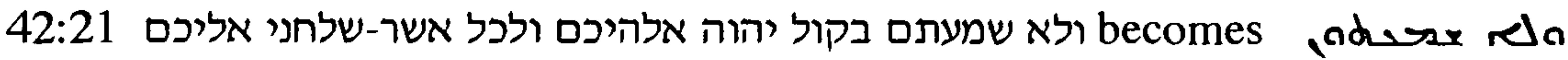

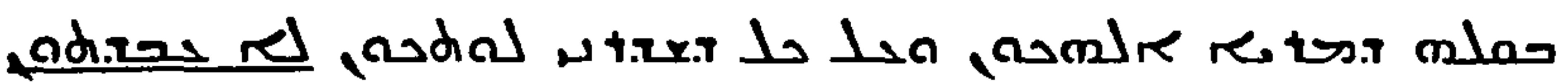

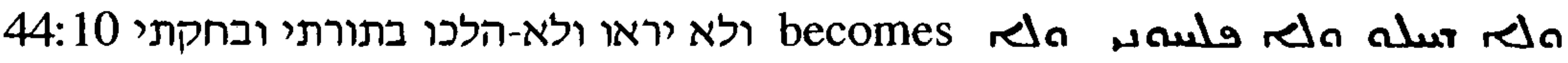

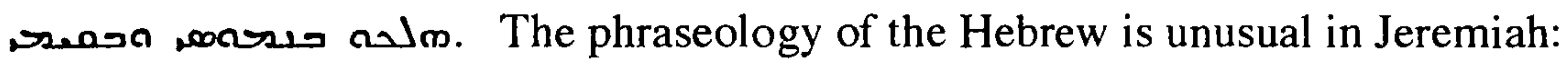
the sequence, with roots ירא מלך possibly relating to the Torah, occurs nowhere else in the book. Either God or his Torah could be the object of root ירא here, and since the fear of God is a recurring theme, using root 1 , as for instance at $5: 22,24 ; 26: 19$; and $32: 39$, it seems more probable that God rather than Torah is the implicit object. The translation is interesting on two counts: first, the translator evidently judged that increased precision was needed, and gave not only a verb, but a verb with an objective pronominal suffix implying that God himself is the object of roots זسג and a similar suffix on root. A would have given increased clarity and would be consistent with the overall style: perhaps this is an example of a human momentary lapse of attention.

46:2 פרעה נכו מלך מצרים אשר-היה על-נהר-פרת becomes, with as an addition:

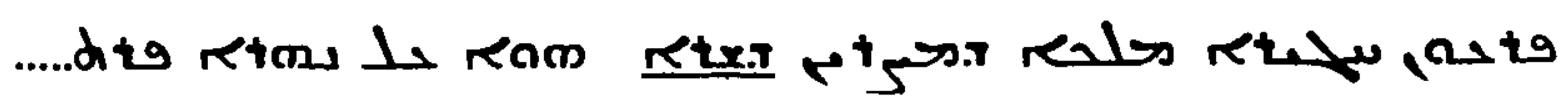

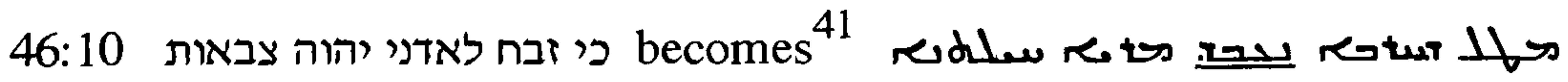
41. Possibly, w w is a scribal error for which entered the text early enough to be present in all extant mss. 
Chapter 2 Translation Technique

48:17 MT נדו לו כל-סביביו has an additional verb in an imprecise translation:

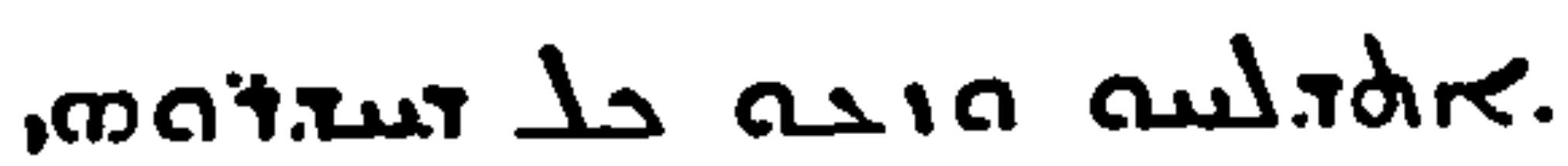

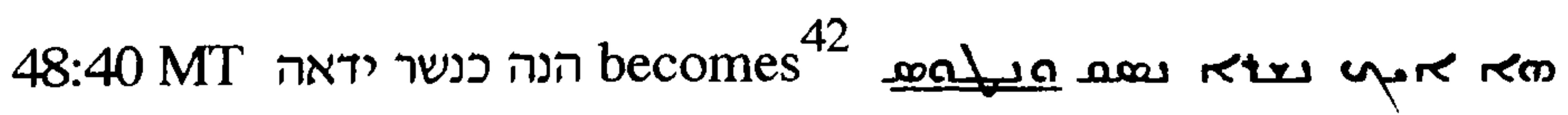

49:18

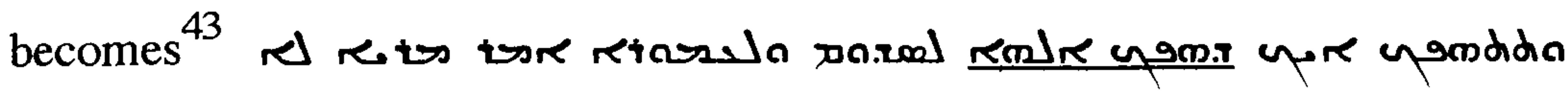

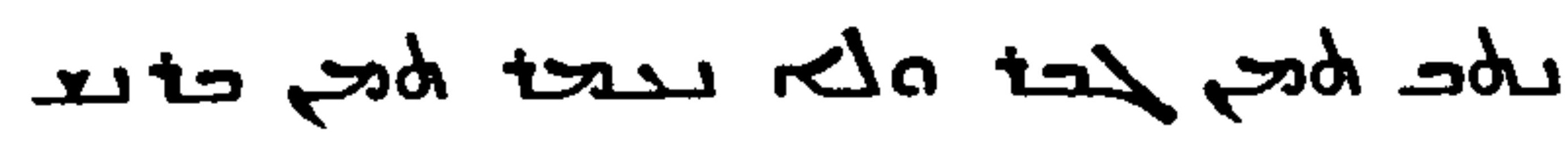

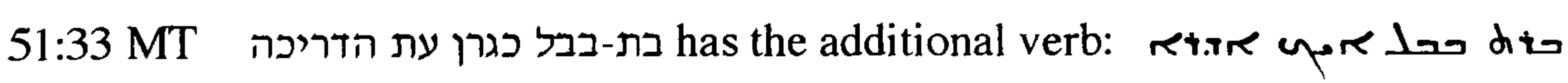

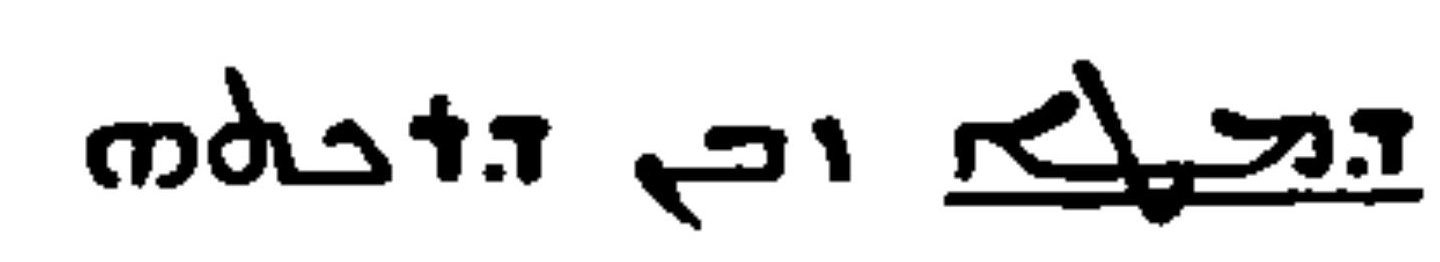

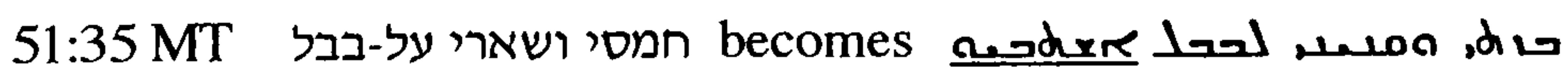

Additions of root tor , making explicit the implicit sense of the MT, account for a large proportion of the total in this group.

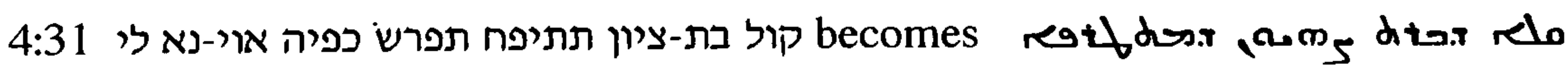
i a retsren motor reotason

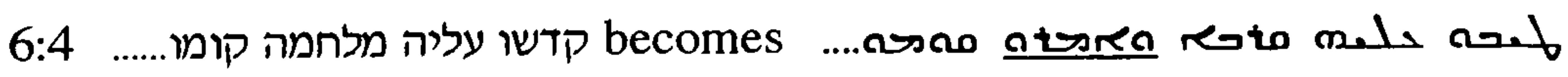

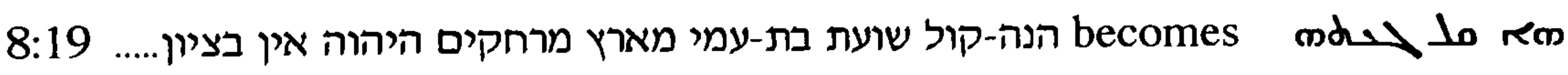
.......

42. There is a possibility that the additional verb here is intended to harmonise this verse with 49:22 הנה כנשר יעלה וידאה, but this is unlikely, because the sense of root sof is more precise than root עלה.

43. For discussion of the accidental minus of ושכניה due to haplography of rtand m ras, see Chapter 5. 
Chapter 2 Translation Technique

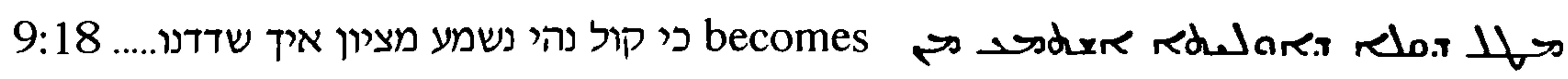

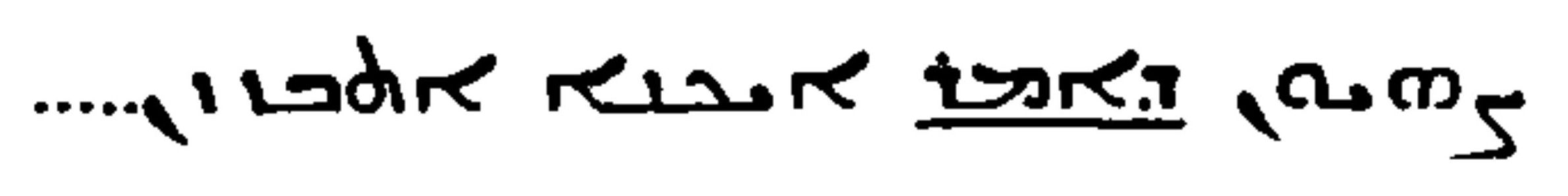

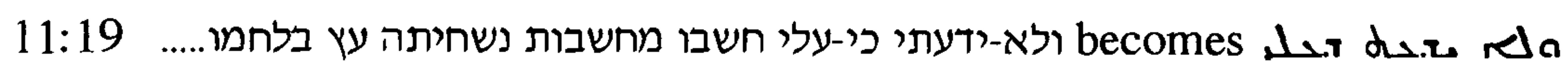

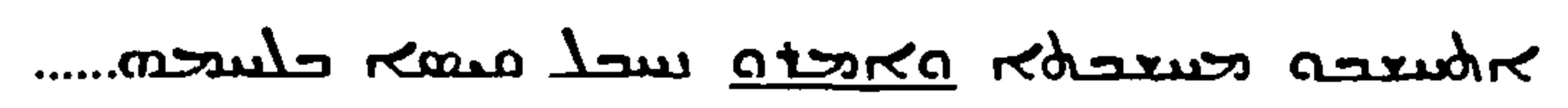

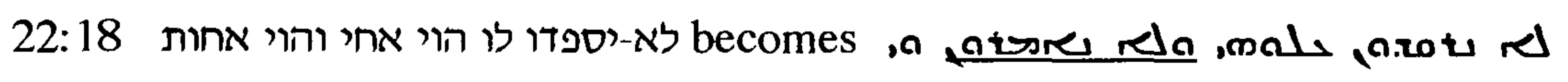
wore in sere

23:31 Both adding a verb and specifying the speaker, MT - הנני על-הנבאים נאם-

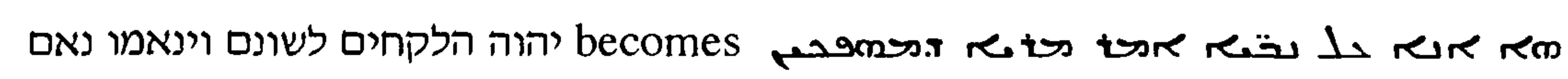
rem tore resptoskn amiel

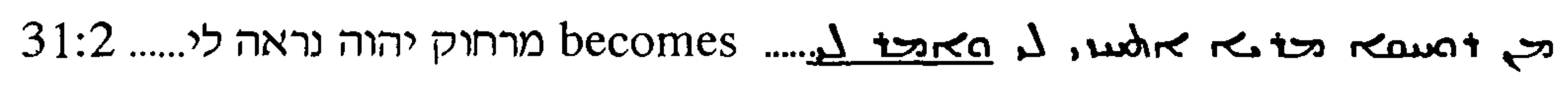

43:1 The translation makes explicit a text which is not, in its context, unclear, though the sequence is awkward: אשר שלחו יהוה אלהיהם אליהם את כל-הדברים האלה

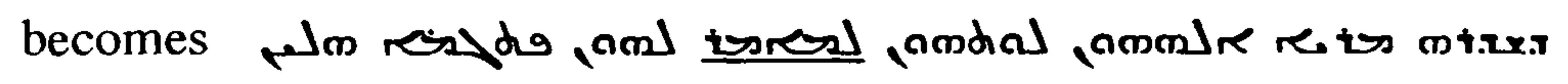

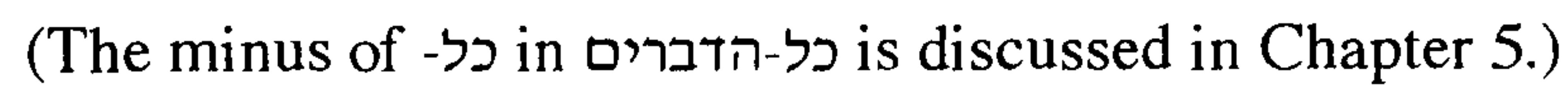

44:15 MT ויענו את-ירמיהו becomes restre atska

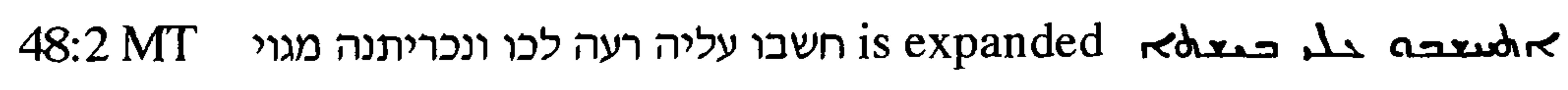
os at atson

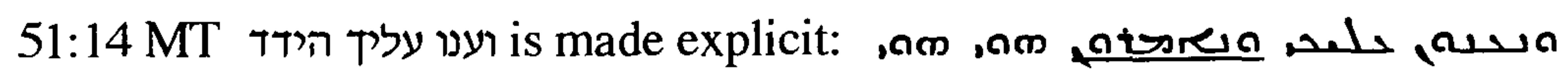

(ii) additional epithets

Expansion of the titles of God is frequent: for instance,

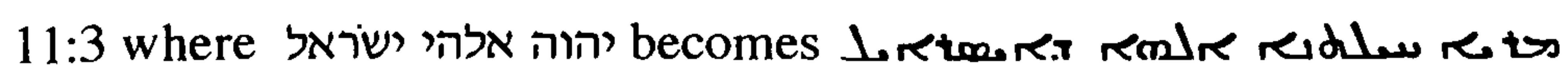

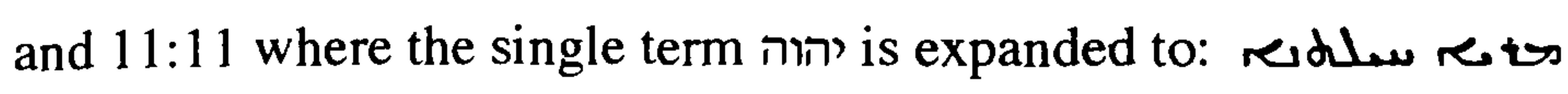


Chapter 2 Translation Technique

In the next example, both LXX and the Peshitta translators clarify the difference between Jeremiah and the false prophets ${ }^{44}$ :

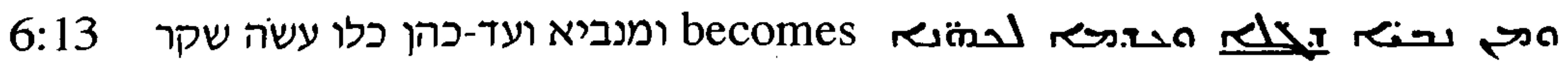

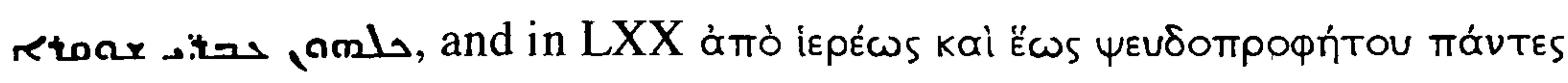

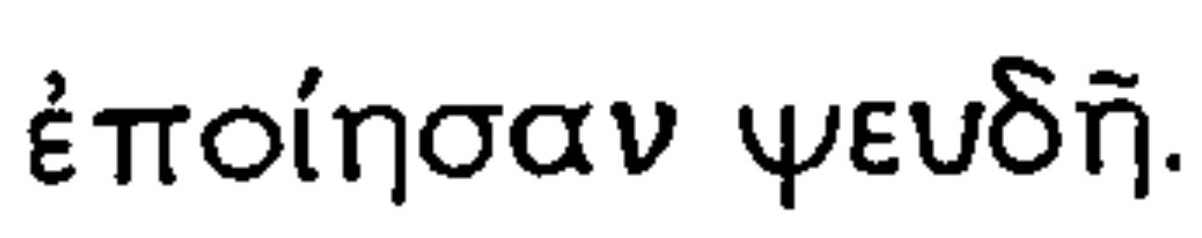

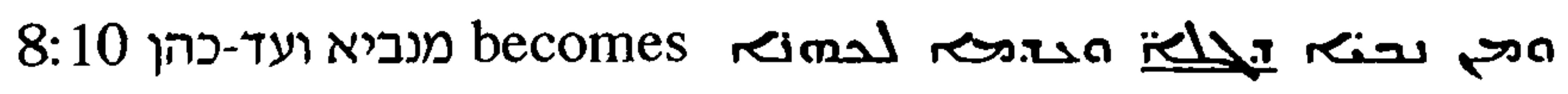

28:10 ויקח חנניה הנביא את-המוטה

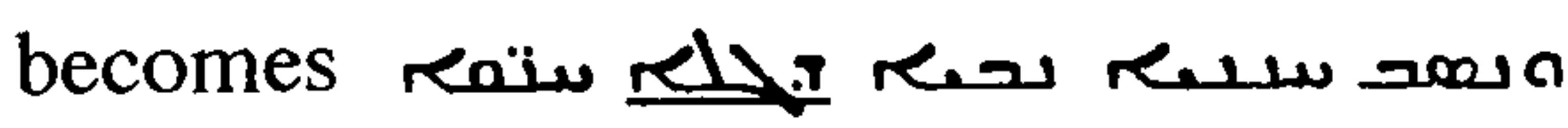

Jeremiah is frequently identified as "the prophet", for instance at

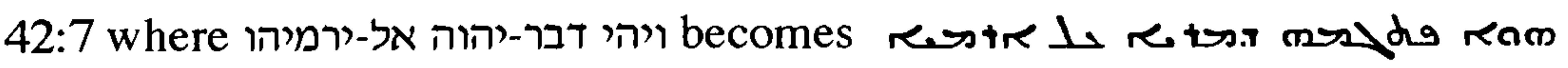
$\underline{\text { Un }}$

41:9 Readers might have been expected to know that אסא was king of Judah; but the Syriac specifies this: riam.i rals ror

(iii) additions which give new information, supplying facts which cannot be deduced from $M T$.

36:9 Baruch's role is emphasised in the translation: קראו צום לפני יהוה כל-העם

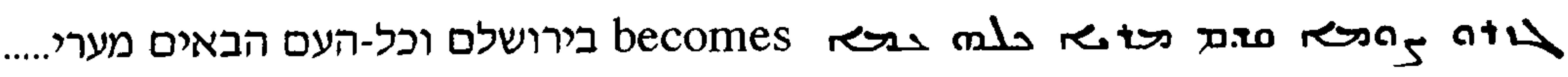

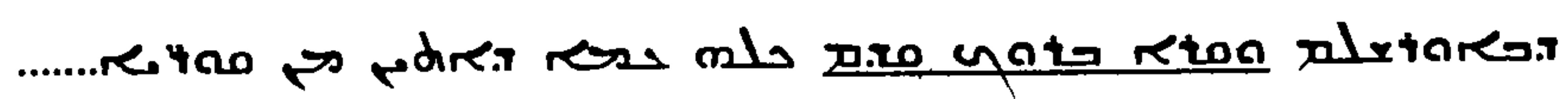

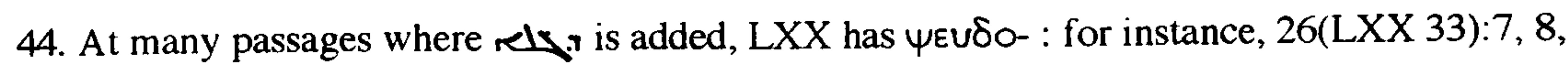
11,16 , where the falseness of the prophets concerned is not explicitly stated in the MT but is to be assumed from their opposition to Jeremiah; and at 27(LXX 34:7):9 where it is clearly appropriate in the context: ....... ואתם אל-תשמעו אל-נביאיכם ואל-קסמיכם. There is no reason to assume influence of the Greek on the Syriac here, for polygenesis is so plausible. 
38:7-11, and 38:14-16, present a particularly interesting problem to which no convincing solution is apparent. There seems to be an underlying problem with the setting of the action, and MT and Peshitta differ as to the whereabouts of the king at this point in the story.

וישמע עבד-מלך הכושי איש סריס והוא בבית המלך כי נתנו את-ירמיהו אל-הבור והמלך 38:7 leaves no doubt that the king was not in his palace at this moment.

38:8 ויצאעבד-מלך מבית המלך וידבר אל-המלך

confirms that though Ebed-Melech was at the palace, the king was not.

ויצוה המלך את עבד-מלך... קח בידך מזה שלשים אנשים והעלית את-ירמיהו הנביא מן 38:10 is nonspecific, since מזה could refer either to the gate of Benjamin or to the palace.

ויקח עבד-מלך את-האנשים בידו ויבא בית-המלך אל-תחת האוצר ויקח משם....38:11 is not sufficiently precise to be helpful, since it introduces a further problem, the nature of this בית-המלך and the room beneath which it is to be found ${ }^{45}$.

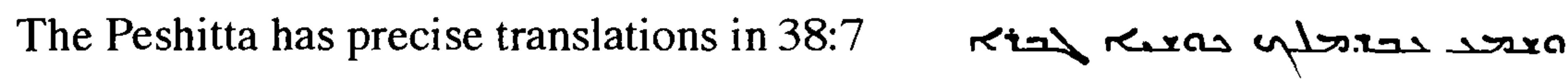

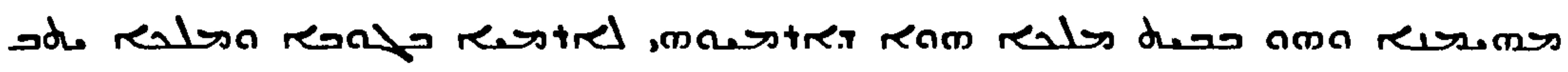
Fis. Reitdo rom

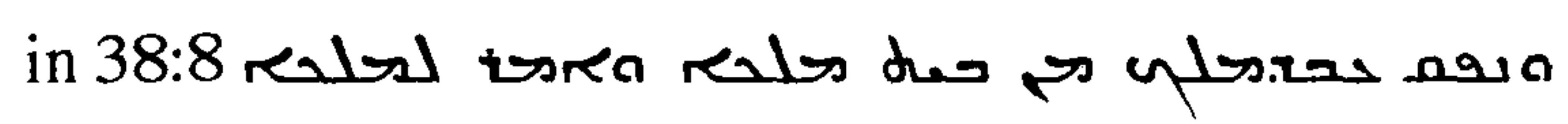

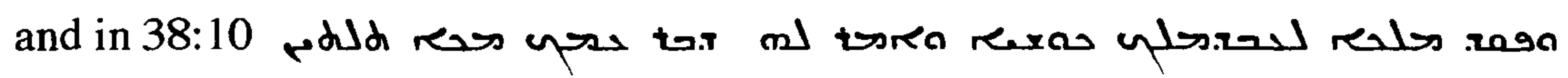
dos

(the additional verb at $J_{1} \mathrm{o}$ is noted above)

but in 38:11 there is an addition which makes it clear that the men whom EbedMelech was to take to help him were in attendance not at the gate of Benjamin, but at the palace:

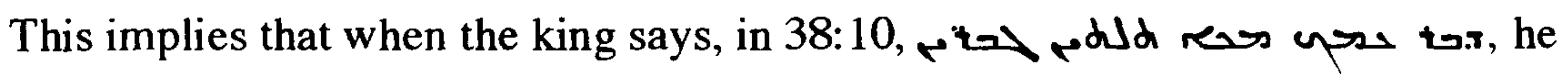
is speaking while in his palace or at any rate from its curtilage, and so contradicts והמלך יושב בשער בנימן 38:7

The same difficulty is evident in 38:16 where וישבע המלך....בסתר

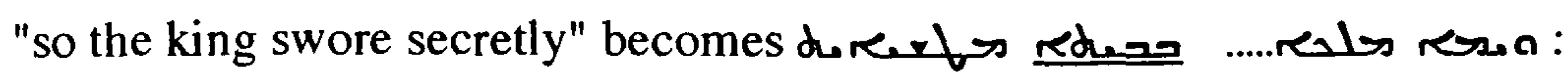

"so the king swore secretly in the palace". The addition provides a location for the king to swear in secret, but here too there is a contradiction, for in $38: 14$ we 45. See next page 
Chapter 2 Translation Technique

וישלח המלך צדקיהו ויקח את-ירמיהו הנביא אליו אל-מבוא השלישי אשר בבית:were told

יהוה..... יה and there is no clue in MT suggesting that the meeting-place has changed.

As will be shown in the discussion of precision in internal logic below, the translator is far more likely to eliminate such problems than to create them. A Vorlage differing from MT at these points seems unlikely to be the complete explanation, firstly because it too would be contradictory, and secondly because there is only partial support in LXX for such a suggestion. Such support as there is is discused by McKane (McKane, 1996, p.952): in verse 8 (LXX 45:8), at מבית המלך, LXX has זpòs aưtòv, representing אליו; as McKane comments this is a difference which does not conform with the normal patterns of the shorter Greek text. McKane argues that the difference between MT and LXX is best explained by there having been two Hebrew texts with the variants מבית המלך and אליו

Nor is there is any evidence from comparison of the different Hebrew and Syriac mss. that these additions reflect corruption at any stage of transmission. Perhaps the translator judged that the conflict between the Babylonians and the Israelites needed to be portrayed as a struggle between might on the one hand and symbolic strength, even if not physical strength, on the other; to make this contrast he needed Zedekiah to be at least a symbolic king, and since the details of the story showed clearly that he was a weak character, vacillating under pressure from his officials, he had at least to have the trappings of monarchy. His actions, therefore, had to be centred on his palace, and the inconsistencies so created, which could have been eliminated only by tampering further with the text, were seen to be justified by the importance of the symbolism; but the analysis of the treatment of figurative language which will be given below shows that the translator is more likely to eliminate than to introduce symbolism, and this would in any case be a most unenlightening use of that form of writing. It seems more probable that the discrepancies between the MT and the Peshitta are to be explained by corruption during transmission, but the exact sequence is not detectable from the present forms.

45. are perhaps to be understood as parts of a storeroom within the palace complex (McKane, 1996, pp.954-955). 
(v) The representation of figurative language

Figurative language may be clarified, sometimes by decoding, or abandoning personification, and sometimes by using simile in place of metaphor. There is one example in the structured sample, in 12:10; this is too small a number to be used as a basis for a calculation of overall prevalence, but does suggest that this is not likely to be high. Some examples follow, given in canonical order.

(i) decoding:

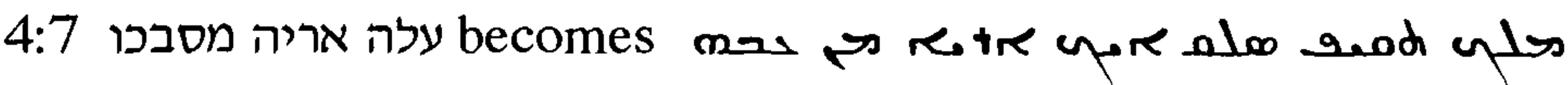

14:2 ושעריה אמללו קדרו לארץ becomes reatrat at 4:28 root ושr, so there is evidence that the term was understood; perhaps the imagery of 14:2 seemed to be obscure and the decoded but pedestrian equivalent appeared preferable.

25:38

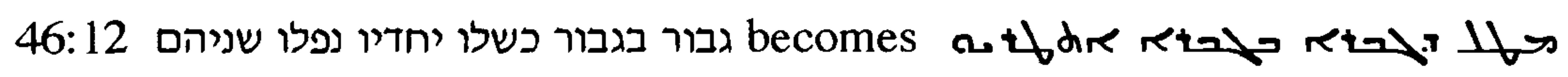
مatato: the MT image of confusion among the nations is decoded in the more prosaic translation.

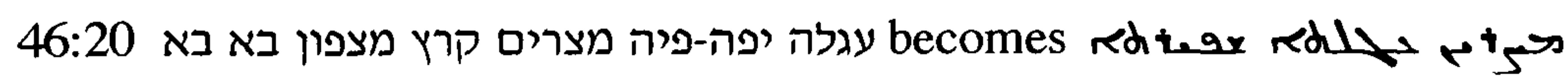

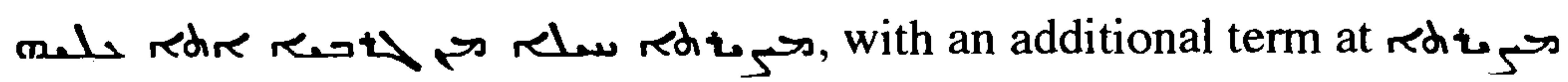
clarifying the imagery of יפה-פיה, and decoding 46 root קרץ in translation

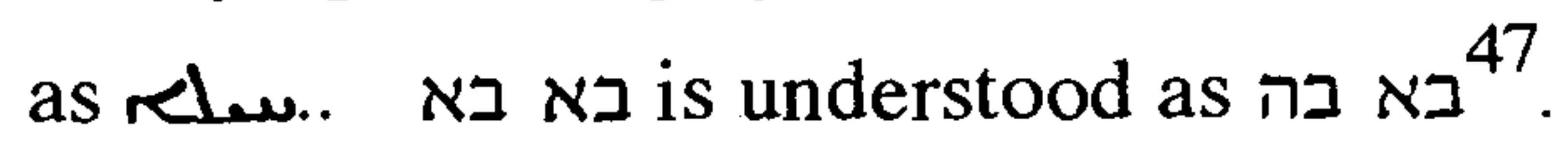

46. The rendering of root קרy may be guessing rather than decoding: the root occurs elsewhere in the Hebrew Bible only at $\operatorname{Ps} 35: 19 ; \operatorname{Pr} 6: 13 ; 10: 10 ; 16: 30$; and Job 33:6; at each there is a clue in the context, and an approximate translation is given, root wit in Psalms and Proverbs, and root 1 in Job. In Jer. 46:20, however, the context gives no good clue to the meaning.

47. There is a good deal of support for this in Hebrew mss. (Kennicott, 1776, pp.156-157). 


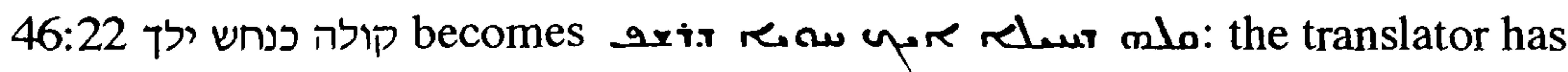
added a term to explain m. which evokes the use of w in the translation of קרץ in 46:20.

47:5 מרח is apparently understood at, for instance, 16:6 where it is translated with root (not, as Lee has, with the cognate), so the flattening of imagery here is not due to failure to understand the Hebrew.

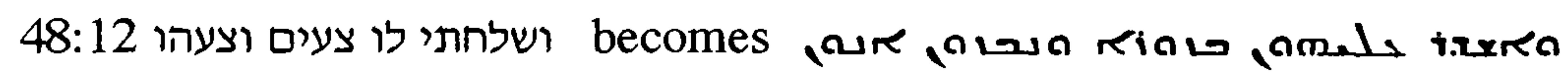
The imagery is flattened by the use of a drudge-word for root צעה which may not have been understood.

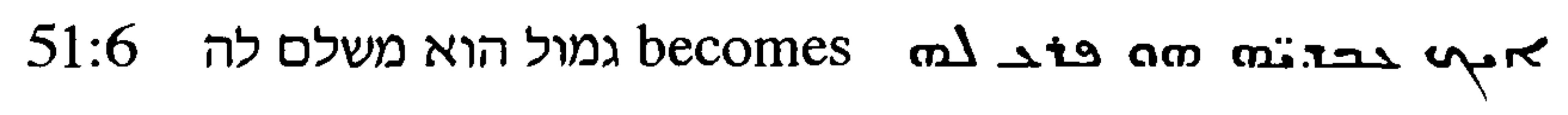

(ii) abandoning personification:

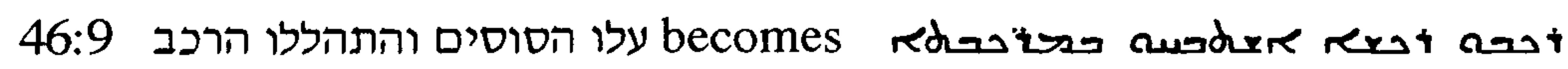
The Hebrew addresses the horses and chariots directly; in translation, the personification is abandoned.

(iii) the frequent use of simile in place of metaphor:

הנה נתתיך היום לעיר מבצר ולעמוד ברזל ולחמות נחשת על-כל-הארץ ..... 1:18

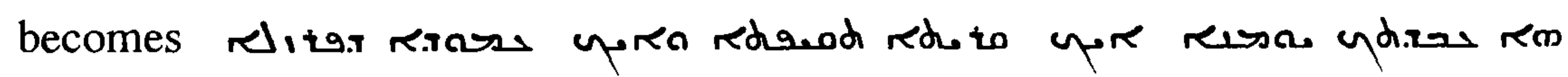

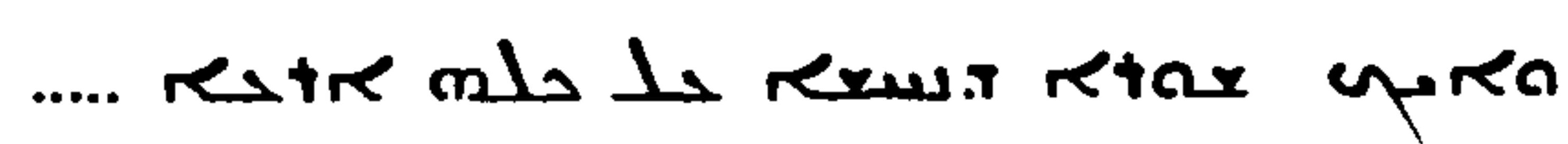

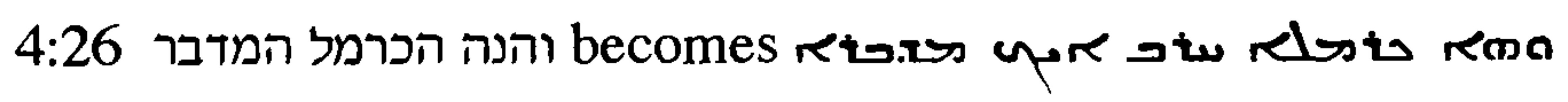

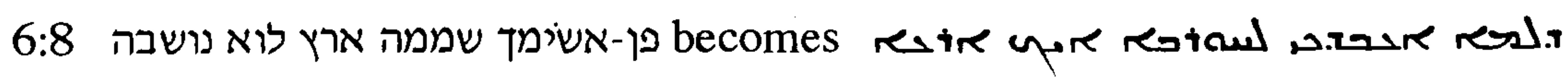
dadedire rels

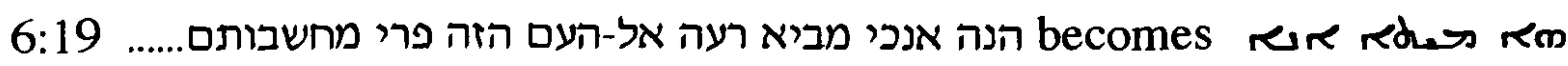

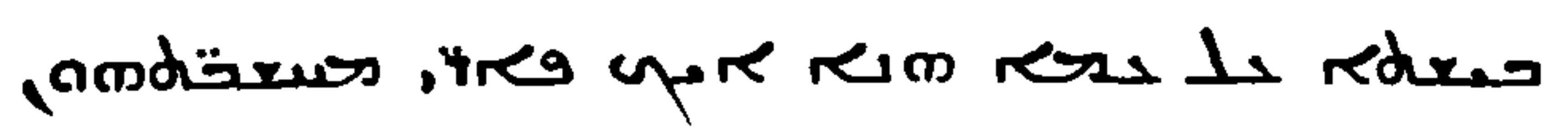


כי מספר עריך היו אלהיך יהודה ומספר חצות ירושלם 11:13

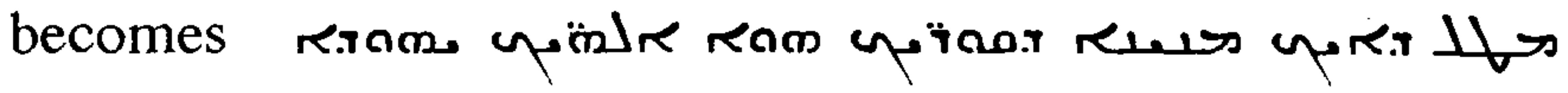

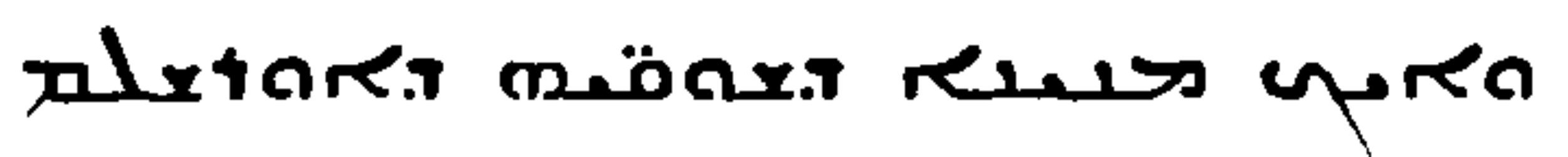

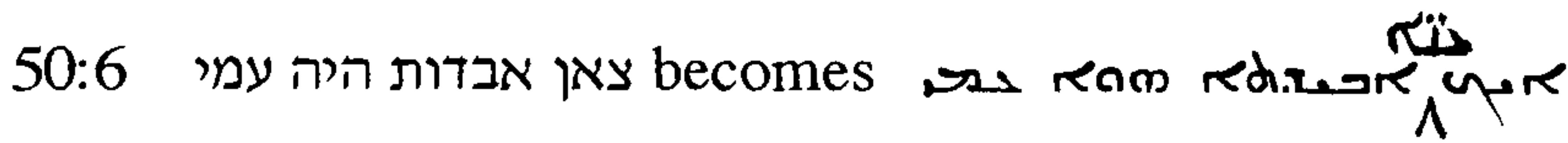

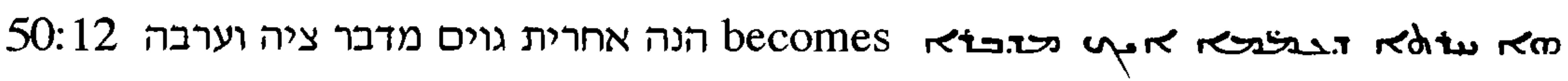
ט.s.

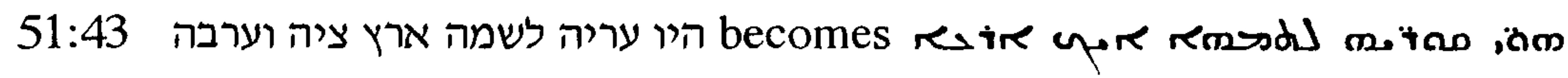
redo.s a redatu

(vi) The attitude to anthropomorphism

Anthropomorphism present in the Hebrew is often preserved. Gelston (Gelston, 1987, pp.151-153) discusses the need for caution in attributing modifications to a dislike of anthropomorphism, and notes that in the Twelve Prophets changes of this kind are rare in comparison with their frequency in the Targums. Gelston also discusses the anthropopathisms in the concepts of God relenting and being angry (p.152), and suggests that where, in both Joel 2:13 and Jon 3:10, root ngm is used to translate root $\square$ נ, this may be a response to the use in biblical Hebrew of נח in the sense of "comfort" as well as of "relent" 48.

48. Loewe (Loewe, 1952, pp.262ff.) discusses repentance rather than relenting, notes the surprisingly large number of words used in the Peshitta to render on, and points out that the translator's apparent reluctance to speak of God as repenting indicates that he was not following LXX in this respect. 
In Jeremiah, God's anger may cease in any of a number of ways, and it is clear from the passages in which God says that he will not relent, as well as from those in which he contemplates doing so, that the concept of God relenting is not unthinkable. Roots used to translate נחס where God is the subject include rad, usm, ret, dx, and examples are shown below.

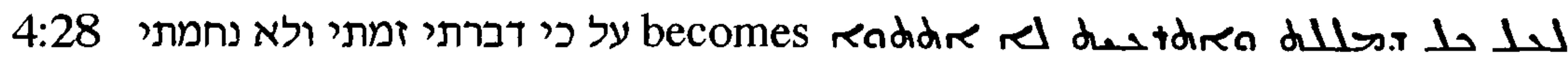

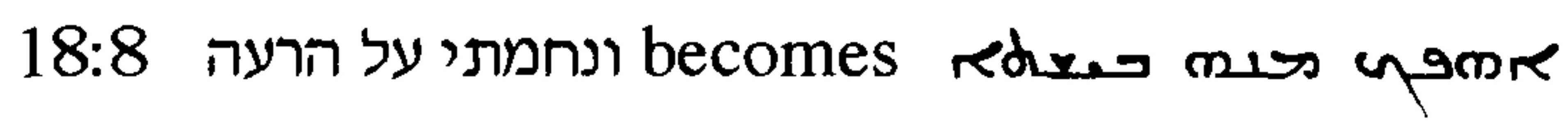

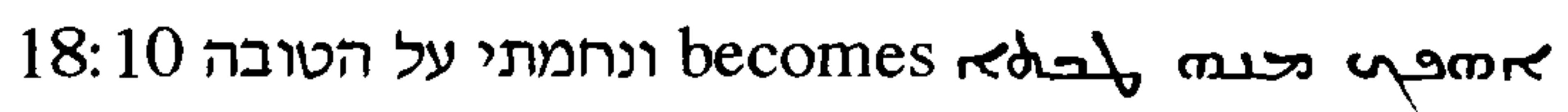

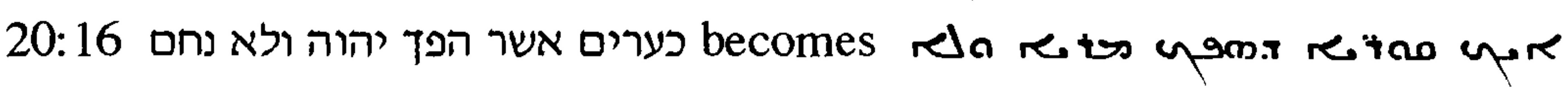
م)

26:3 נחמתי אל הרעה becomes redrea

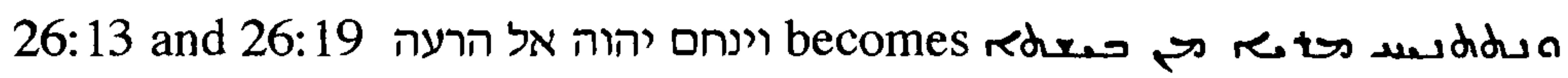
42:10 נחמתי אל הרעה becomes redrea

9:9 God does not weep, though he may tell others to do so: there is some uncertainty as to whether God or Jeremiah speaks in על-ההרים אשיאבכ, though as God is the speaker in vv. 8 and 10 it is likely that he speaks too in v.9. The

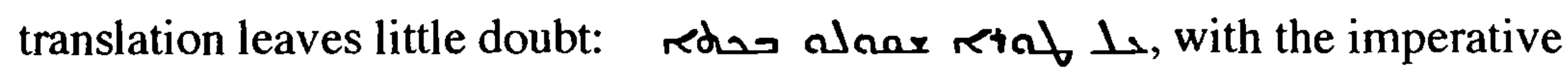
אט:א for the imperfect.

This example well illustrates the mixture of motives which may operate at any point in a translation: as well as eliminating anthropomorphism here, the change increases the precision of the text.

Nor does God plead: at 44:4 MT אל-נא is translated simply with

Other anthropomorphisms at which the translator sometimes appears to balk include physical features other than the heart: for instance, references to God's eyes may be paraphrased:

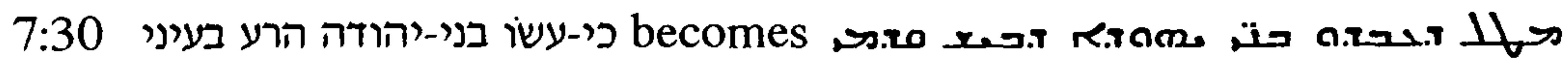
In other passages, however, such as 5:3 יהוה עיניך הלוא לאמונה the translation may

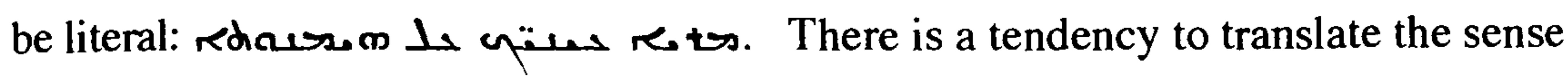
"in my sight" with م.> , and the physical sense. "eyes" literally; thus for instance in 18:10 and 32:30, contexts similar to 7:30, בעיני , w. w is translated , 


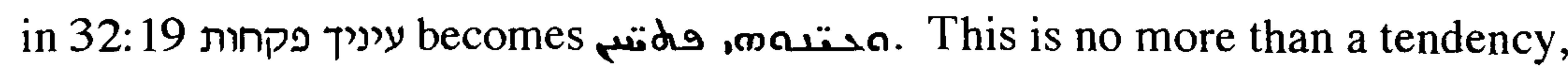

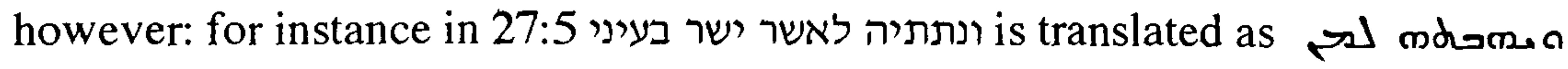

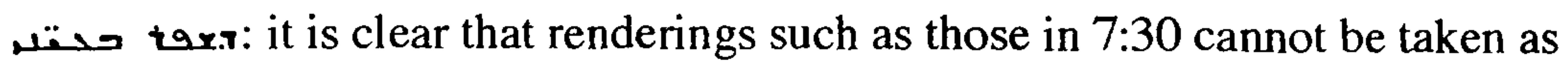
examples of a consistent feature, but possibly as examples of the translator's freedom to use his initiative even in important matters such as this. Gelston (Gelston, 1987, pp.151-152) notes the regular use of 0 as a reverential device in the Targum and its occasional use in the Peshitta to the Twelve Prophets.

A physical reference to God may be avoided, even if it includes no implication that God himself has a physical presence:

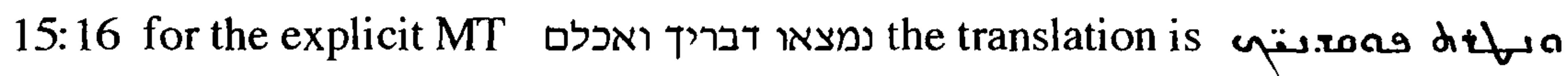
gre disano: the words of God are not found and eaten, they are kept and done. The obvious comparison with Ezekiel 3:1-3 is interesting: here, the explicit Hebrew is accurately translated:

בן-אדם את אשר-תמצא אכול אכול את-המגלה הזאת.... ויאכלני את המגלה הזאת..... בטנך תאכל ומעיך תמלא את המגלה... ותהי בפי כדבש למתוק

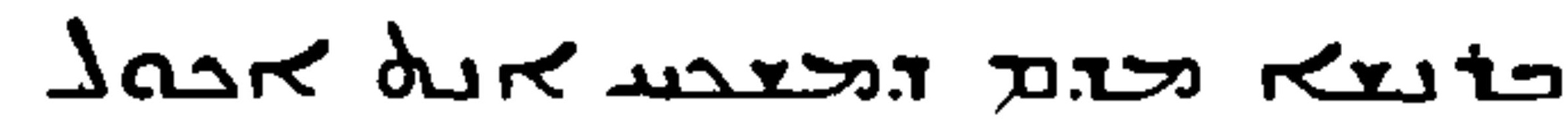

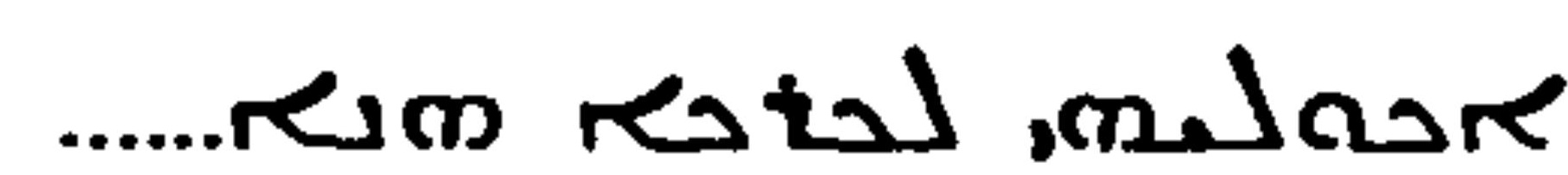

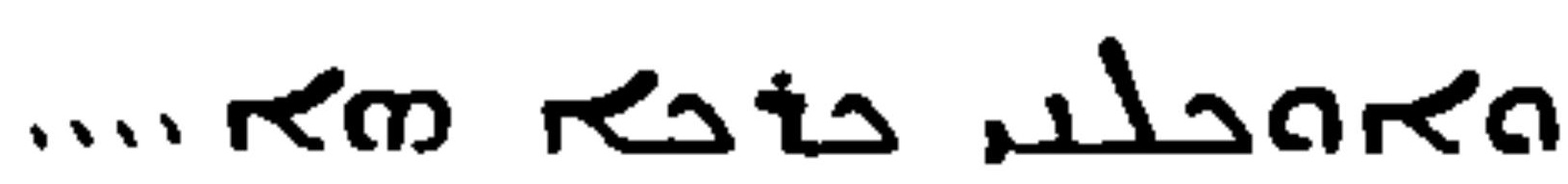

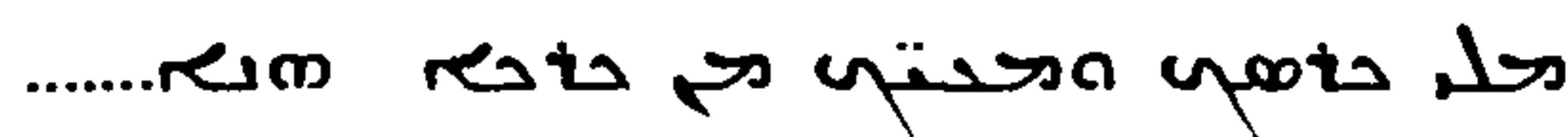

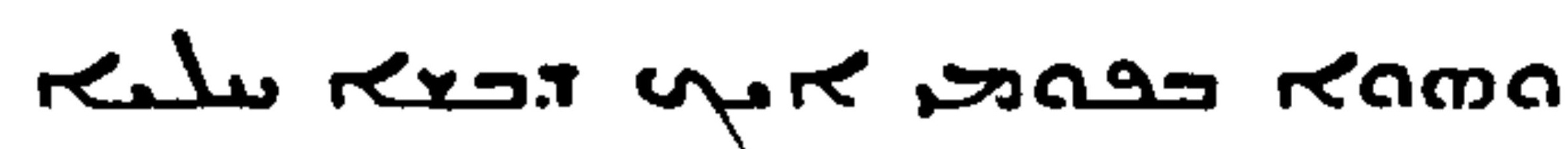

The difference may be that in the Ezekiel passage the detail of the imagery is essential to the sense, whereas in the verse from Jeremiah a small emendation sufficed. It is also possible, however, that in an unpointed text the improbable meaning "eat" at ואכלם was not identified; perhaps the translator understood root כלה "to complete".

On the other hand, God's emotional reactions and intellectual processes are usually acceptable: in 6:21 God is vengeful: הנני נתן אל-העם הזה מכשלים ,

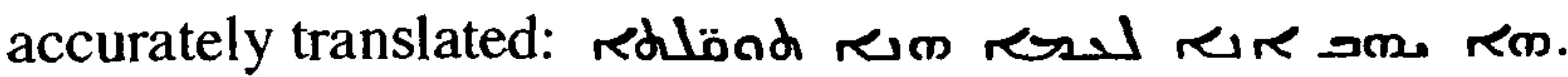

God's soul presents no difficulty:

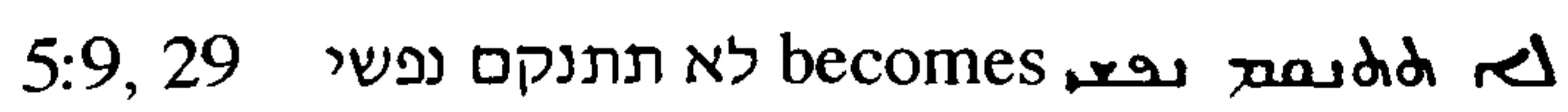

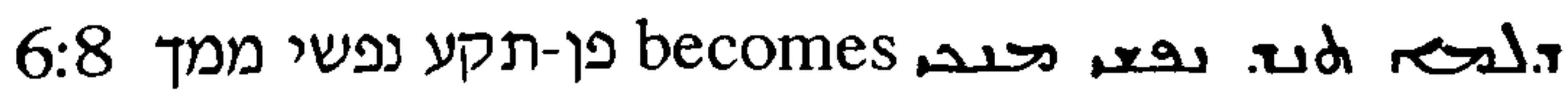

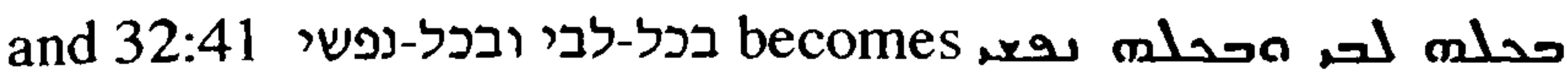


Chapter 2

Translation Technique

all precisely rendered, including the reference to God's heart in the last passage.

God swears an oath both in Hebrew and in Syriac: for instance,

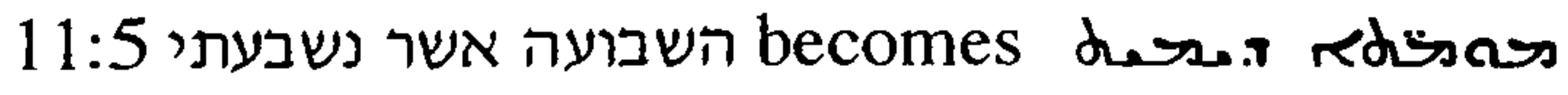

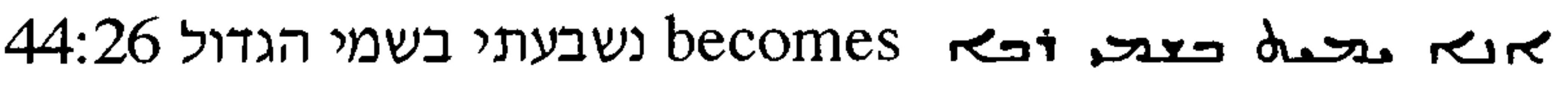

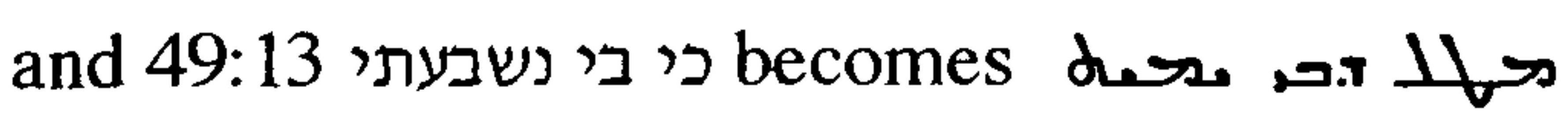

all exactly translated.

These images may be violent, as at

23:29 where God's word, though not God himself, is described:

הלוא כה דברי כאש נאם-יהוה וכפטיש יפצץ סלע

and is essentially unchanged in translation to

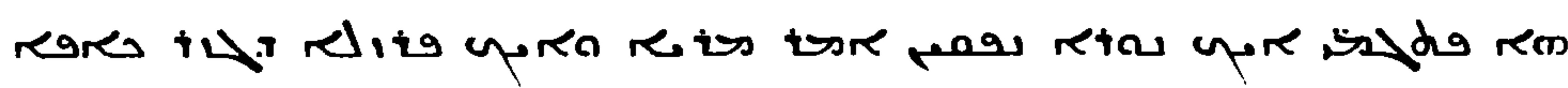


(vii) Increased grammatical precision of the text in comparison with MT

There are numerous examples in this group, for the inconsistencies in grammar which are readily tolerated in MT are frequently eliminated in translation. Five examples are found in the structured sample ${ }^{49}$, suggesting an approximate rate of $3 \%$ of sense units affected. Some examples are given below in canonical order, dealing first with number, then with person, and then with other variables.

(i) Inconsistencies in number tolerated in $M T$ but corrected in the Peshitta ודברתי משפטי אותם על כל-רעתם אשר עזבוני ויקטרו לאלהים אחרים וישתחוו למעשי ידיהם

becomes

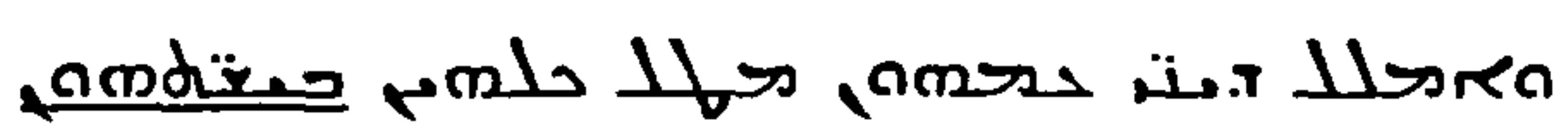

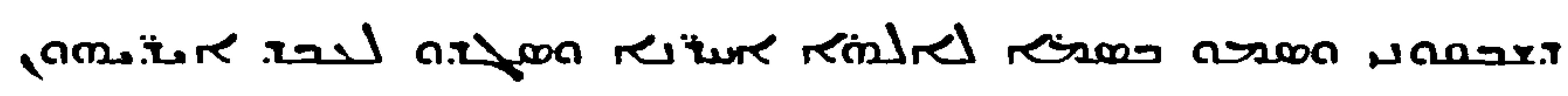
MT has a singular term at רעתם, but then goes on to list several ways in which the Israelites have sinned; the translator corrects this inconsistency, giving a plural at nomdir.

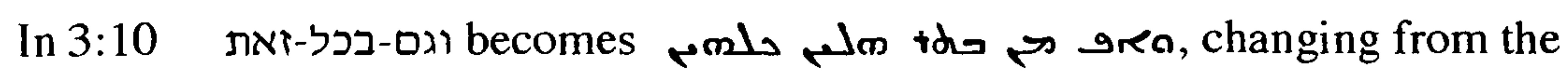

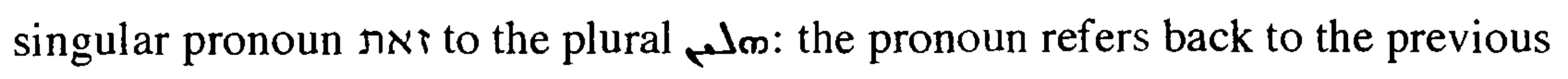
verse ותחנב את-הארץ ותנאב את-האבן ואת-העץ, two processes which in the Peshitta require a plural pronoun though in MT a singular pronoun is acceptable. (This is one of the few parts of $7 \mathrm{a} 1$ which are difficult to read.)

49. The five examples in the sample are

$3: 10 ; 8: 10 ; 15: 10$ in which inconsistency in number is corrected in translation;

42: 10 in which objective suffixes are made consistent;

44:10 in which inconsistency in person is corrected in translation . 
In 4:14 the discrepancy between the singular verb and its plural subject in the MT

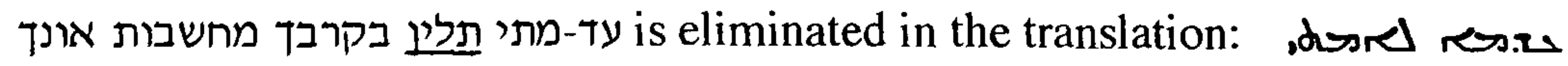
Sadice

11:2 God apparently addresses Jeremiah in the plural: שמען את-דברי הברית הזאת ודברתם אל-איש יהודה..... in translation, the first verb is given in the plural, but the

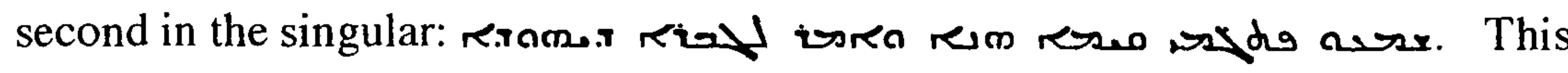
inconsistency within the Syriac is particularly interesting, perhaps resulting from a temporary lapse of attention on the part of the translator (Lee gives both verbs in the singular).

$16: 6,7$

ומתו גדלים וקטנים בארץ הזאת לא יקברו ולא יספדו להם ולא יתגדד ולא יקרח להם ולא יפרסו להם על-אבל לנחמו על-מת ולא-ישקו אותם כוס תנחומים על-אביו ועל-אמו translated as:

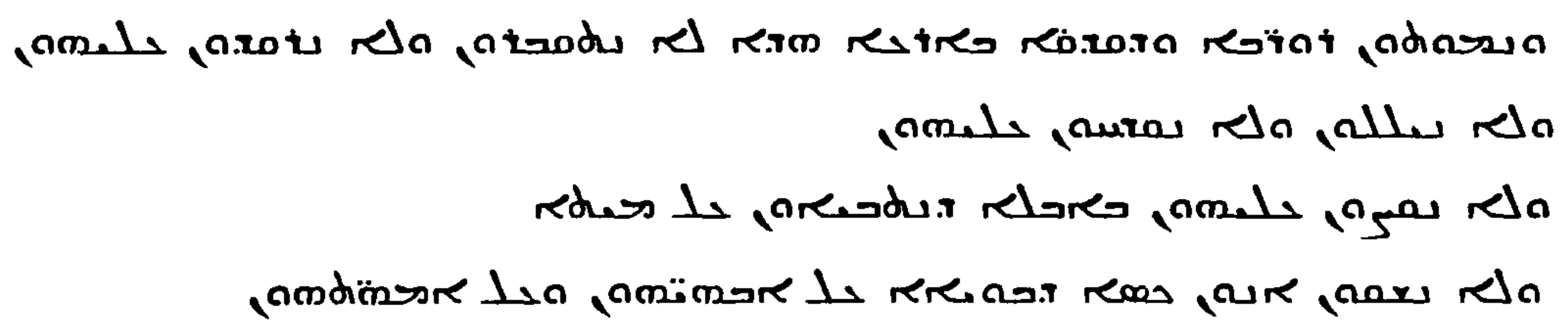

There are several problems here relevant to the present discussion:

להם לח לחם and has been so understood in the

Peshitta;

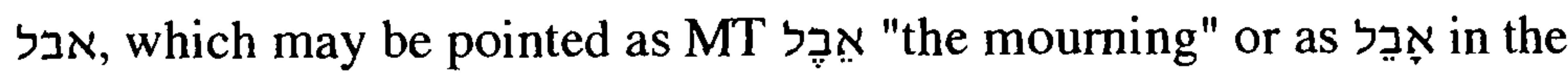
alternative "the mourner";

לנחמו, where the singular objective suffix does not agree with אותם.

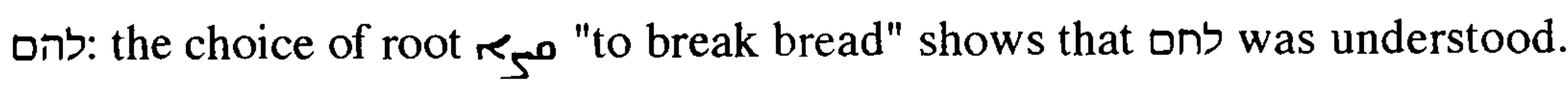

The use of אבל מore, with the preposition, suggests that been understood

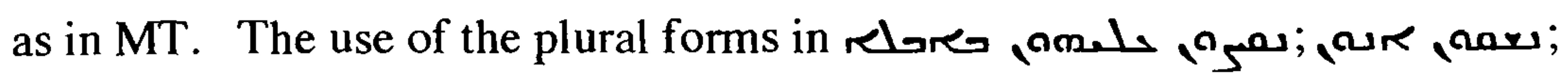

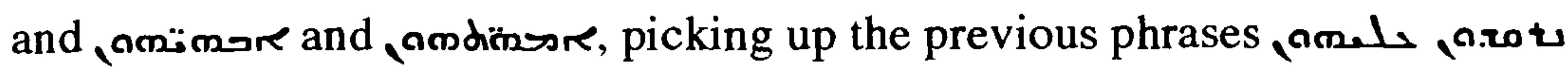

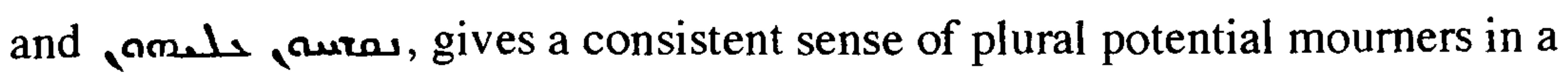
state of potential mourning and eliminates the disagreement in MT of the singular suffix on לנחמו and the plural אותם. 
32:10 ואכתב בספר ואחתם becomes dadudere is an underlying problem concerning the deeds, first evident at this point where the Syriac has the plural $r 4 x$, but the MT has a singular ספ. In MT, two forms of the deeds are mentioned for the first time in $v .11$

$$
\text { ואת-החת את-ספר המקנה המצוה והחקים }
$$

as well as in $\mathrm{v} .14$

(-.... - לקוח את-הספרים האלה

$$
\text { את ספר המקנה הזה ואת החתום ואת ספר הגלוי הזה }
$$

The Peshitta has consistently understood two distinct documents: v. 11 reads

and v. 14 has

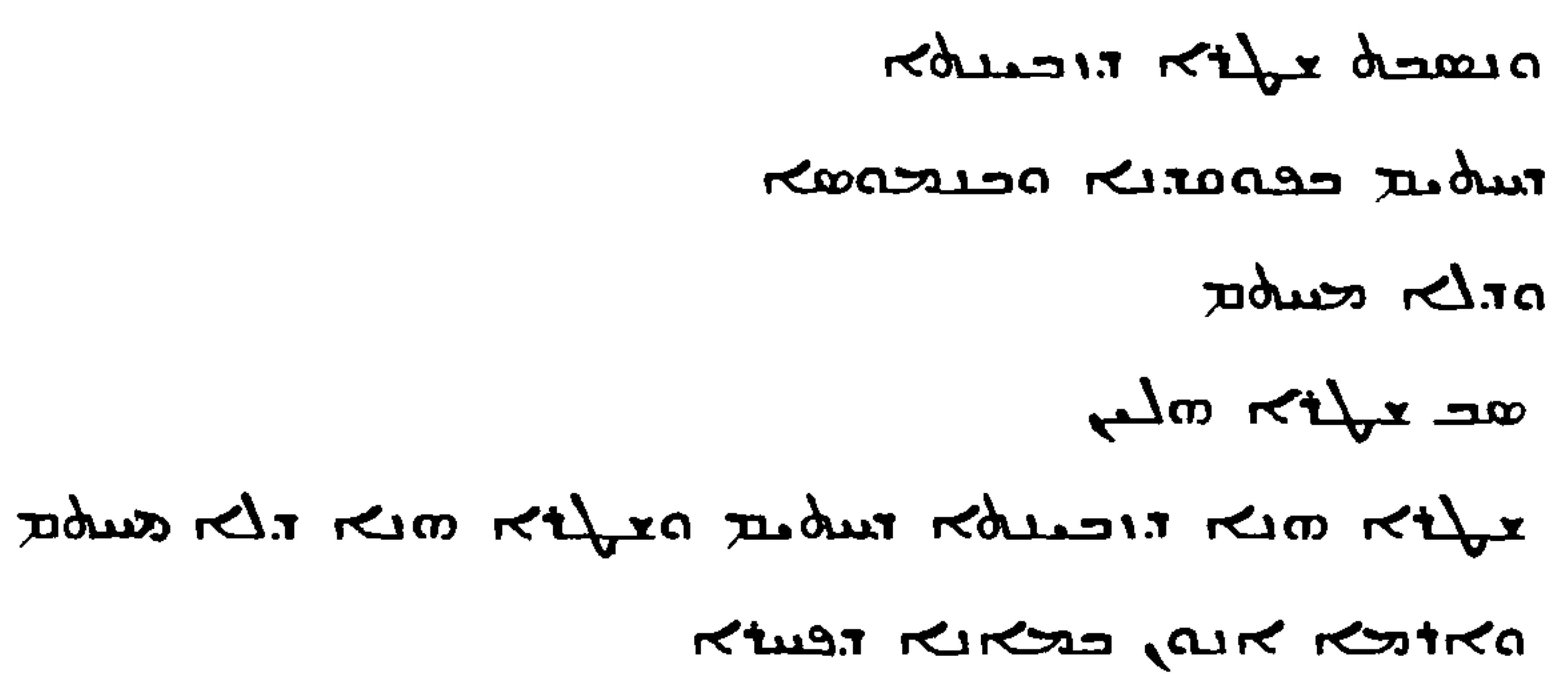

so the plural form at v. 10 is probably a manifestation of the preference for grammatical consistency.

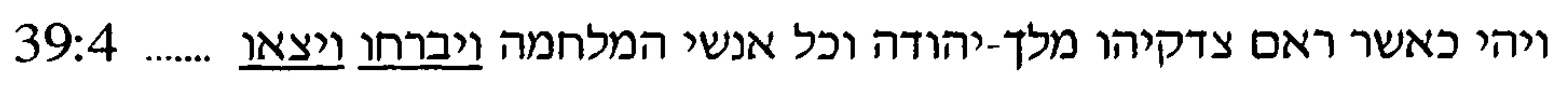
בשער בין החמתים ויצא דרך הערבה

The inconsistency in the number of the verbs is eliminated in translation:

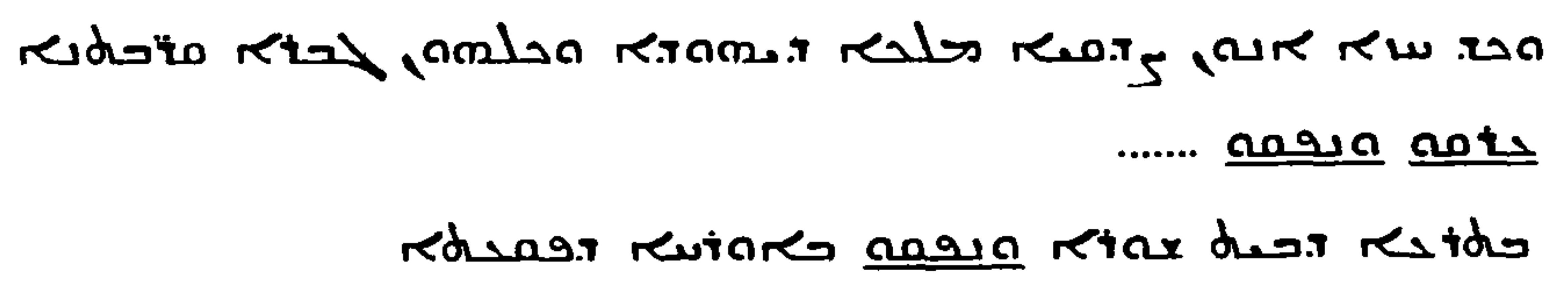

There is an additional point of interest here, the near-duplication of this passage at 52:7 where plural verbs are used consistently in MT and in translation. There is also the interesting comparison with 2 Kings 25:4, where there is yet another slightly different text: the verbs equivalent to the plural forms in the Jeremiah version of this story are absent, and the singular verb at ויצא has a singular 
equivalent here too, though using a different root: ויתבקע העיר וכל-אנשי המלחמה הלילה דרך שער בין החמתים אשר על-גן המלך וכשדים על-העיר סביב וילב דרך הערבה In translation, plural verbs are supplied according to the required sense: a هara, and followed by another plural at $ه$ ira.

46:15 In the MT אביריך , מדוע נסחף אביריך לא עמד כי יהוה הדפו does not agree with the singular נסחף, nor with לא עמד; in translation plurals are used, eliminating the discrepancy ${ }^{50}$ :

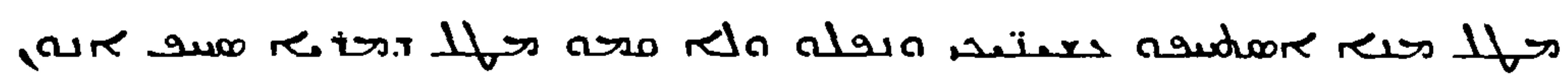

48:12 MT moves from third person singular to third person plural: ושלחתי-לו צעים וצעהו וכליו וריקו ונבליהם ינפצו, with an inconsistency between וכליו "its vessels" and 

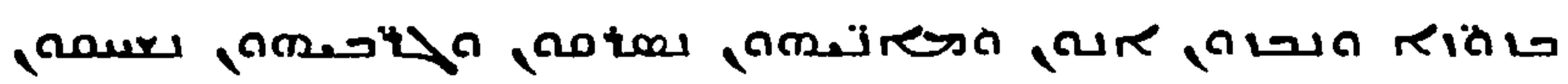

קדשו עליה גוים את-מלכי מדי את-פחותיה ואת-כל-סגניה ואת כל-ארץ ממשלתו becomes, in conformity with the first emendation, a change from the plural "kings" of MT to one in translation, the feminine possessive suffixes of MT are changed to masculine forms so that they agree with that king, rather than with ארץ ממשלתו as in MT. (For discussion of ואת כל-ארץ ממשלתו, see Ch 5, "Minuses".)

Yet in this aspect of technique the translator was not rigid in his approach: for instance, at 8:10 where the MT has the sequence

$$
\text { נשיהם..... שדותיהם..... קטן...... גדול..... נביא...... כהן }
$$

and the translation has

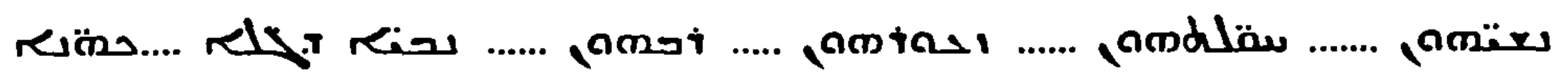


Possessive suffixes have been added to the third and fourth terms to bring them into line with the first and second, but the final two terms have not been emended. This could be because of the awkwardness of adding suffixes to

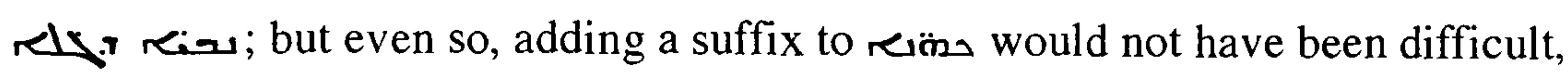
and its absence suggests a flexible attitude on the part of the translator.

(ii) Inconsistencies in person tolerated in MT but corrected in the Peshitta

בימים ההמה ילכו בית-יהודה על-בית ישראל ויבאו יחדו מארץ צפון על-הארץ אשר הנחלתי את-אבותיכם

becomes

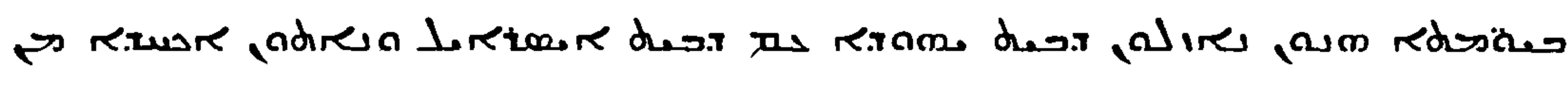
amimar didiori Ritel reaty Rir

The MT makes good sense, but the translator prefers the consistency of third person terms throughout to the impact made in the Hebrew by the change from third person to direct address, and therefore gives אבותיכם for for forn.

\section{$6: 16,17$}

עמדו על-דרכים וראו ושאלו לנתבות עולם אי-זה דרך הטוב ולכו-בה ומצאו מרגוע לנפשכם

ויאמרו לא נלך

והקמתי עליכם צפים הקשיבו לקול שופר

ויאמרו לא נקשיב

The closing phrases ויאמרו לא נקשיב incorporate a change from third person to first person; they become respectively

and

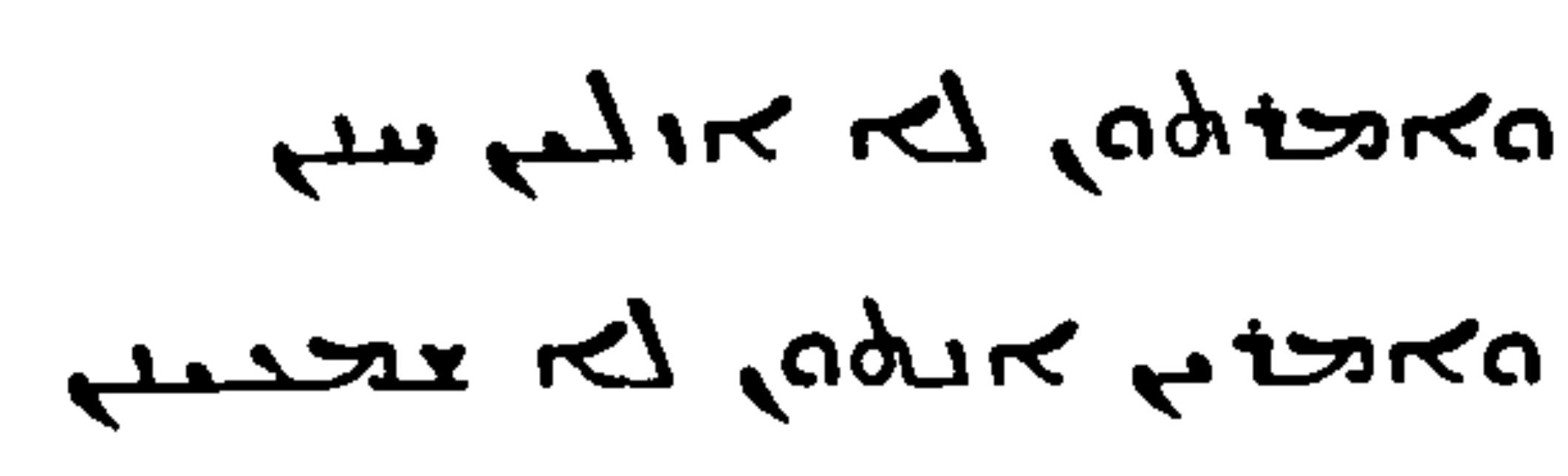

still with a change of person, but now from second person to first. Both verses open with God's address to the people, and in translation, the closing phrases conform more closely with the opening injunctions. 


\section{$6: 23-26$}

MT varies from the word of God addressed to the Israelites in 6:23

$$
\text { ....... ערוך כאיש למלחמה עליך בת-ציון.... }
$$

to the people's reply in $6: 24$ שמענו את-שמעו רפו ידינו צרה החזיקתנו ...

reverting to address in 6:25

and then in 6:26 to continue with address in

but to end with
אל-תצאי השדה ובדרך אל-תלכי טגוניו

בת עמי חגרי שק...

as if this phrase too were spoken by the people. In the Hebrew, the change from the second person of v.23 to the first of v.24 reads well and is represented in the

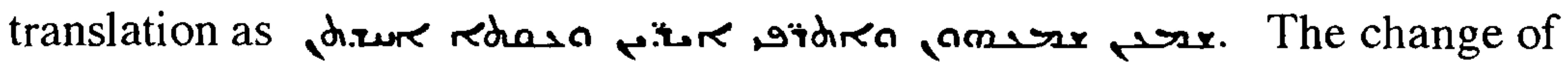
person within v.26 is awkward, however, and the preference in the Peshitta at this point is for grammar which is precise in the smaller scale, within the one

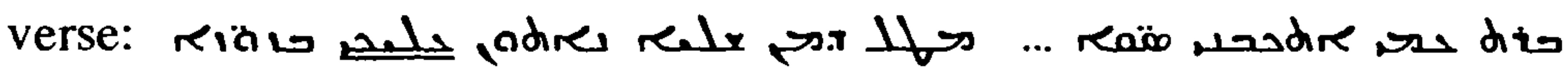

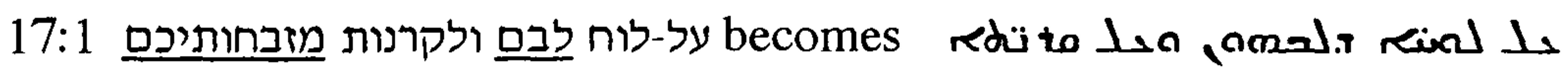

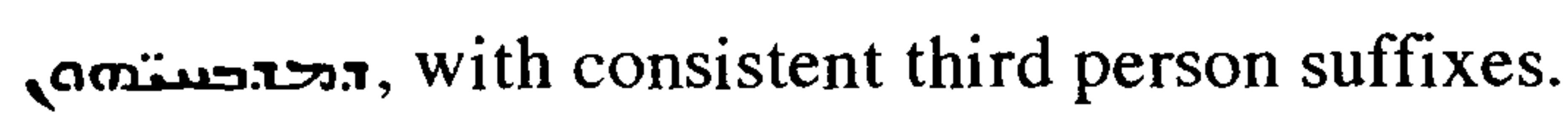

becomes

$$
\text { achasd poha..... }
$$

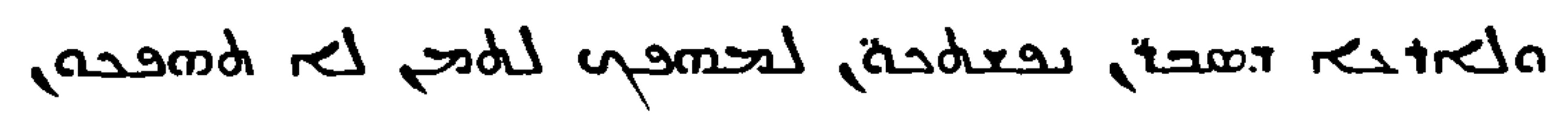

changing from the third person terms of the Hebrew of v.27 to accord with the second person of v. 26. מפני רעתם אשר עשו להכעסני ללכת לקטר לעבד לאלהים אחרים אשר לא ידעום המה אתם ואבתיכם becomes

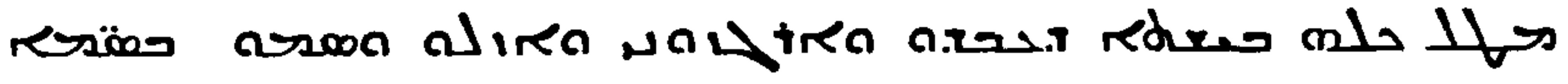

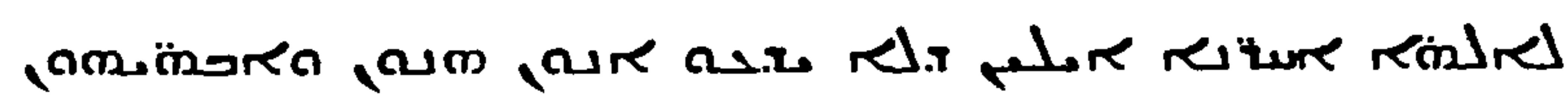

The change from third to second person at אתם ואבתיכם makes reasonable sense, but is surprising, and is eliminated in translation. 
$44: 4,5$

ואשלח עליכספ את-כל-עבדי הנביאים ....

becomes

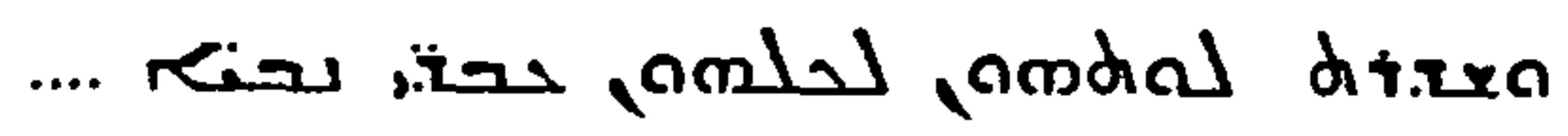

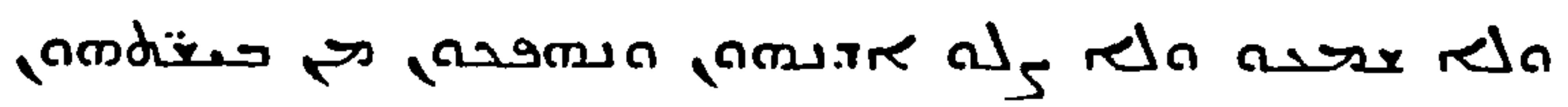
The discrepancy between the opening of v.4 in which God addresses the people and v. 5 in which he reflects on the behaviour of earlier generations is eliminated in the translation. לא דכאו עד היום הזה ולא יראו ולא הלכו בתורתי ובחקתי אשר-נתתי לפניכם ולפני אבותיכס becomes

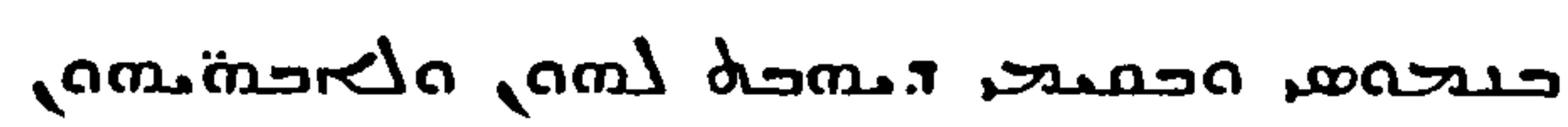

The second person in the Hebrew at the end of the verse makes good sense but is nonetheless changed to third person in translation, smoothing out the text, perhaps at the expense of some of the impact.

(iii) Inconsistencies in gender tolerated in MT but corrected in the Peshitta 51:33 בת-בבל כגרן עת הדריכה עוד מעט ובאה עת-קציר לה: the suffixes are

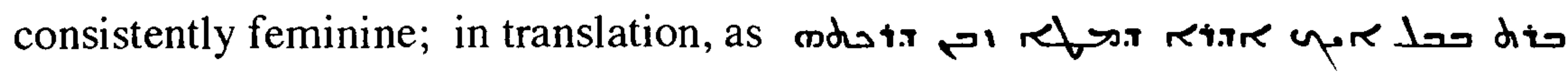

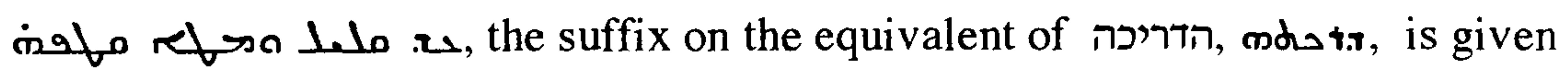
in masculine form to agree with ri.re, perhaps because this is closer in the

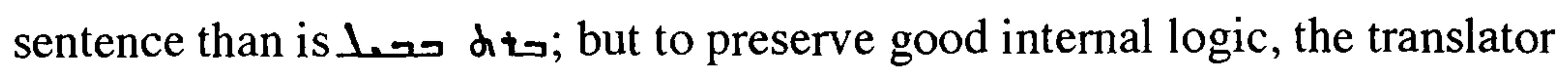

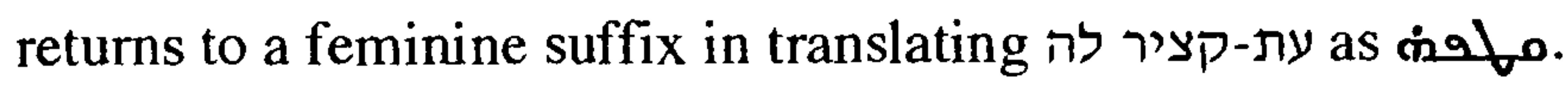


(viii) Improvements in the logical cohesion of the text in comparison with MT:

There are comparatively few examples of this characteristic, and none from within the sample.

$11: 7,8$ ..... לאמר שמעו בקולי ולא שמעו ולא-הטו את-אזנם ... ואביא עליהם את-כל-דברי הברית-הזאת אשר צויתי לעשוֹת

becomes ולא עשi

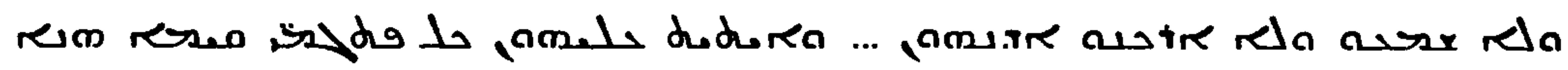

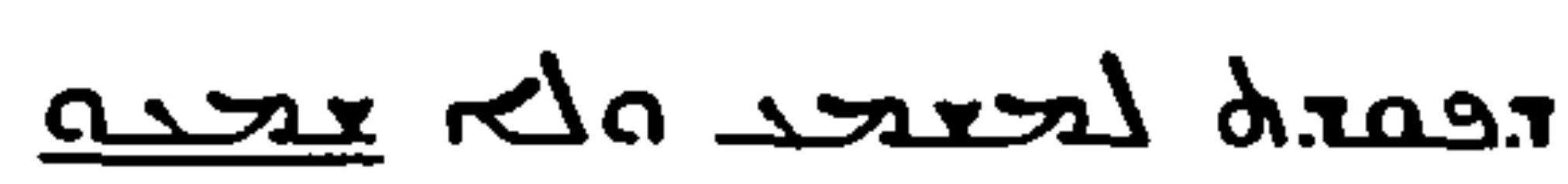

In a change which seems simply pedantic, the Hebrew sequence שמלא .... . ולא עשו....... שמעו

16:13 the sequence of thought at the second אשר is awkward:

והטלתי אתכם מעל הארץ הזאת על-הארץ אשר לא ידעתם ... ועבדתם-שם את-אלהים אחרים יומם ולילה אשב לא-אתן לכם חנינה

A change to waw, perhaps primarily stylistic, also improves the sense:

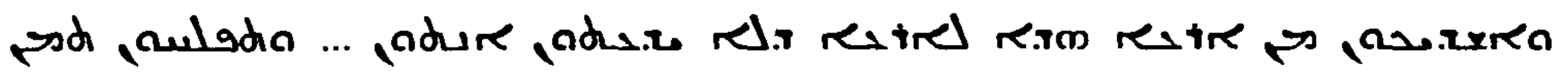

$$
\begin{aligned}
& \text { resut }
\end{aligned}
$$

36:21 The MT כל-השרים העמדים מעל המלך becomes, with a more appropriate preposition, sلals

39:8 The unsatisfactory sense of the second singular "house" in MT ואת-בית

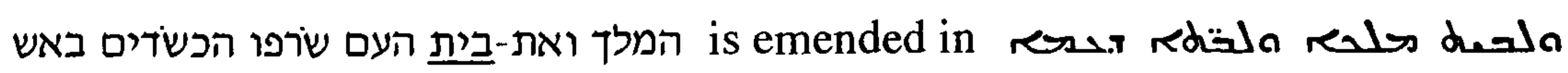

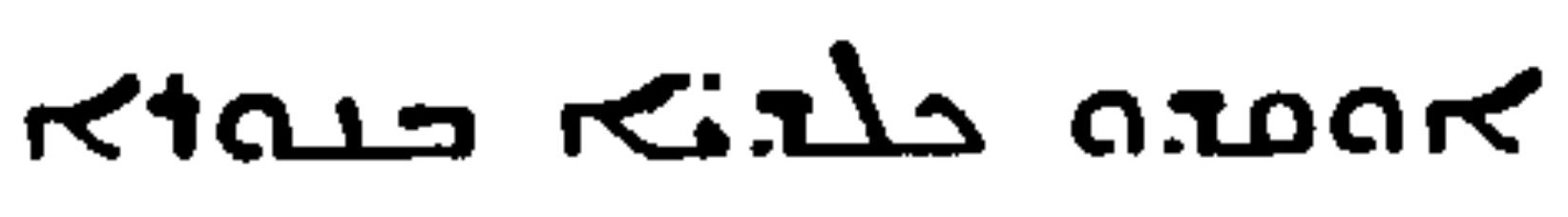

50:37 The singular "chariot" in MT makes poor sense, and is given in the plural

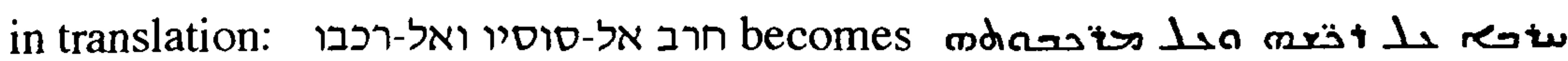


51:21-23 MT has a series of singular nouns: סוס ורכבו ..... רכב ורכבו ..... איש ואשה אכר וצמדו ................. פחור ובתולה וסגני...... רעה ועדרו ....... As expected, the translator works according to strict logic, and puts most into the plural:

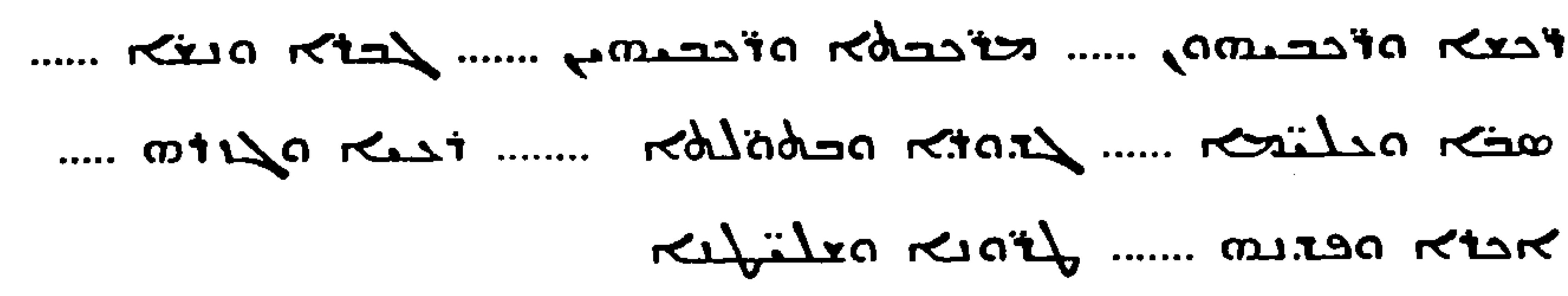

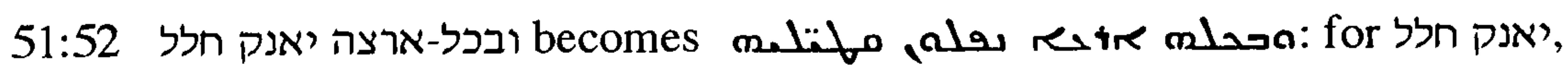

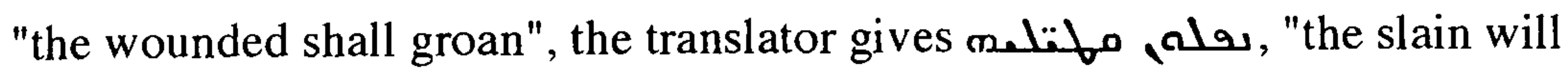
fall". The reason for the change seems to lie in the context: at vv. 47 and 49 root חל, "to pierce", means "to wound fatally". The dead cannot groan, so in a radical improvement אנק has to be translated as "fall". 
Chapter 2 Translation Technique

(ix) the preservation of the word order of the source document

The quantitative assessment based on the structured sample shows that although the total number of such changes in this long text is considerable, the prevalence is low: there are thirteen changes in word order in the sample ${ }^{51}$ (one, in 20:10, is irrelevant here because it is related to the translation of difficult or obscure Hebrew, and is considered in detail in Chapter 6).

The twelve which remain give an approximate rate of $6 \%$ of sense units affected. In a text of this length, such occasional examples mount up to a substantial total; nonetheless, in general, word order is far more likely to be preserved than to be changed. The importance of such changes as there are is difficult to assess: many may have been determined by the translator's sense of how his text would sound when read aloud; others may have been enforced by the differences in idiom and syntax between the two languages ${ }^{52}$; but our appreciation of the idiom and syntax of the written Syriac of that time is incomplete. For instance, Joosten (Joosten, 1988, pp.175-176) writing on the use of particles in the Old Testament Peshitta notes that research on the syntax of the text is still "in an embryonic stage". Nonetheless, and although emphasising that far-reaching conclusions cannot be based on a few examples, he believes that the use of the particles he studies is idiomatic, reflecting "the Syriac style of the oldest period known to us".

Goldenberg (Goldenberg, 1995, pp.25-26) emphasises the difficulty of knowing

52. There are also some particularly interesting differences between the order in 9al and 7al, discussed in Chapter 5, which suggest that Syriac idiom may have changed with the passage of time. Note, however, Nöldeke's footnote to para.226 (Nöldeke, 1904) in which he points out differences in the positioning of the demonstrative pronoun in the custom of two almost contemporary Syriac writers. 
"what kind of Syriac we learn from the Peshitta", a point taken up by Muraoka (Muraoka, 1995, p.41) who notes specifically the difficulty of determining the extent of influence from Hebrew or Greek on the Syriac of the Peshitta.

The work of modern students of Syriac is beginning to reveal rules of syntax which may explain some of these differences: the flexible syntax described by earlier grammarians may in reality have been less flexible than it seemed to them. For instance, Nöldeke discussing the syntax of demonstrative pronouns says of these when used as adjectives that "they stand sometimes before, sometimes after, the substantive .... The majority of the ancient authors (like Aphr.) usually put the demonstrative first; others, however, prefer to place it after the substantive; but there is no consistent practice." (Nöldeke, 1904, para. 226). This point, however, is argued by Avinery (Avinery, 1975, pp.123-124) who, in an analysis of the Peshitta to the Pentateuch, shows a considerable preponderance of passages in which the demonstrative pronoun follows the substantive, and classifies those constructions in which it precedes the substantive.

Similarly, the work of Avinery (Avinery, 1977, pp.48-49) on the nominal clause in the Peshitta to the Pentateuch gives a detailed discussion of the role of contrast or emphasis on the construction of the nominal clause, and Muraoka (Muraoka, 1975, p.28) writing with the different forms of the nominal clause specifically in mind, but not restricting the problem to that construction, finds Nöldeke's treatment inadequate ${ }^{53}$.

53. This study is on the Old Syriac Gospels; here too Muraoka notes the difficulty resulting from inadequate understanding of the language of the time (these texts are judged by Burkitt (Burkitt, 1904, pp.69, 78) to represent, where they differ from the Diatessaron, "the Greek text as read in Antioch about 200 A.D."). Muraoka writes "Despite the abundance of literature... preserved in this language, the right sort of text is hard to come by": that is "early text reasonably free of heterogeneous, i.e. Greek, influence". 
So it may be that, given that the word order of the Hebrew is preserved far more often than not, there were syntactical reasons to change the order at the passages where this was done $\mathrm{S}^{54}$, and the apparent inconsistencies may have good cause of which today's reader is unaware.

Nevertheless some of these differences may in fact represent the translator's free choice in the writing of a flexible language. Gelston notes that the cumulative significance of the stylistic and syntactical modifications is "a clear demonstration that the Peshitta is in no sense a slavish translation", suggesting in addition that the many inconsistencies in this respect may indicate that more than one translator may have been at work (Gelston, 1987, pp.138-139); this point will be taken up below. Lane too notes that Syriac is more "flexible" than Hebrew, with a syntax which is more "biddable" (Lane, 1989, p.473).

The discussion which follows gives some examples of changed word order. It was clearly necessary to make some attempt to analyse these in the present discussion, but the number of examples has been restricted because the underlying themes are more suitable for study by a grammarian than in the present context.

(i) Some, motivated by the drive for precision and accessibility, conform well to the character of the translation overall: in canonical order,

54. In support of this is the observation made by Taylor that the word order in the Peshitta to Daniel is closer to that of MT in the Aramaic portions than in the Hebrew parts (Taylor, 1994, p.308): presumably the Syriac grammar was closer to that of the Aramaic. In this connection, however, I remember a remark made to me orally by Dr. Michael Weitzman, and so far as I know not put in print by him, to the effect that the differences between the Peshitta to the Aramaic portions of the Hebrew Bible and the MT were no less than those between the Peshitta and the Hebrew portions of the Hebrew Bible. 
2:5 The sequence is unusual in MT: מה-מצאו אבותיכם בי עול, and is made simpler in translation: :

38:25 The MT word order, though perfectly intelligible, is awkward: הגידה-נא לנו מה-דברת אל-המלך אל-תכחד ממנו ולא נמיתך ומה-דבר אליך המלך, and becomes in

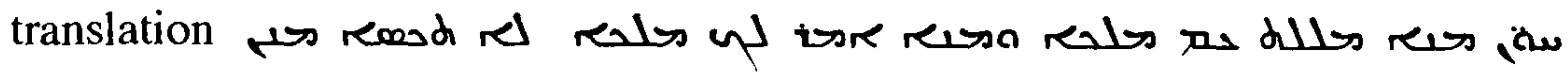
ntor

changing the word order to a clearer and more natural form.

41:3, 4, 5 The MT is clear but awkward, giving ואיש לא ידע as the closing phrase of v. 4, referring to the assassination of Gedalya by Ishmael:

ואת כל-היהודים אשר-היו אתו את-גדליהו במצפה ואת-הכשדים אשר נמצאו-שם את אנשי המלחמה הכה ישמעאל נוסל ויהי ביום השני להמית את-גדליהו ואיש לא ידע

The translator makes a comparatively major change, displacing ואיש לא ידע from v. 4 to v. 3 so as to simplify the flow of sense, and for the sake of precision also changes "and no man knew" to "and no man had heard":

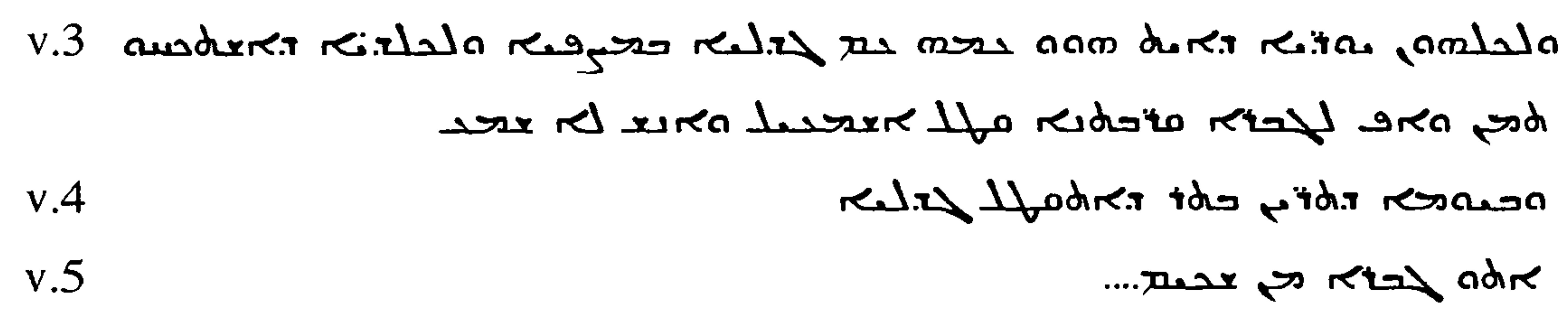

Word order is not always changed, however, even when this would achieve clarity. In this respect too, the translator exercised discretion: there are numerous examples of passages at which a complex word order in the Hebrew is exactly preserved in translation. Possibly, the translator judged that at such passages the order contributed to the emphasis, and therefore wished to preserve it as exactly as he could. There are good examples in, for instance, 12:17 where in translating ונתשתי את-הגוי ההוא נתוש the unexpected word order of the MT is precisely replicated: 
In 25:14 the awkward word order in כי עבדו-בם גם-המה גוים רבים is replicated in

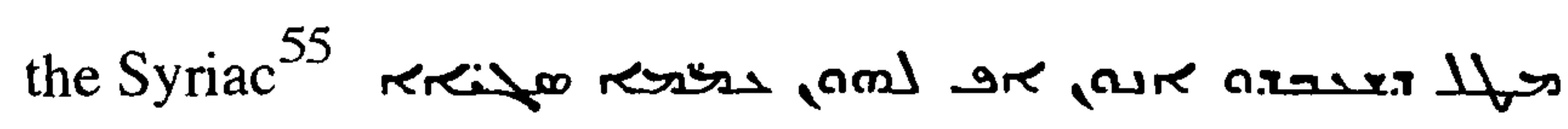

As a final example of the preservation of a complex Hebrew word order, in 44:14 comparison of the component parts shows the preservation of the sequence as in MT:

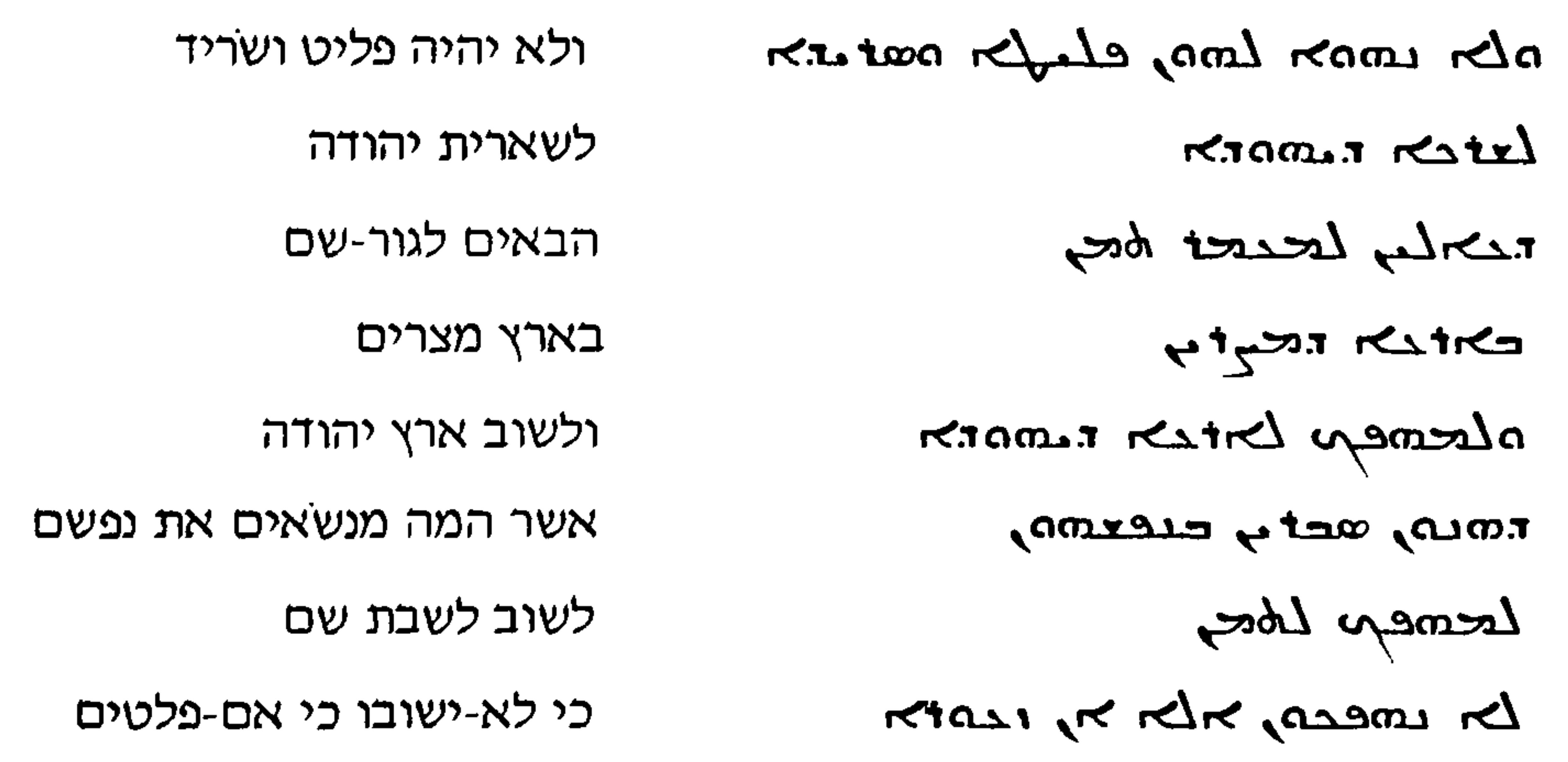

The translator adds $n$ and for explicitness in the first line, and does not reproduce לשבת; otherwise he does not deviate from the word order of MT.

In the majority of other examples, in the absence of a consistent system, it seems probable that the translator's decision may have depended on the sound of the phrase when read aloud ${ }^{56}$.

55. At this example, the sense of עבדו ב"to enslave, to work by means of others" (B.D.B. p.713 gives "to work with, i.e. to use as subjects; McKane, 1986, p.623 suggests "reduce them to slavery) is simplified in translation as raking the sense clear even though preserving the word order.

56. I owe this suggestion to Dr. Robert Murray, who made it in the course of a recent discussion. 
(ii) The position of pronouns

The position of personal pronouns is frequently changed: for example, in

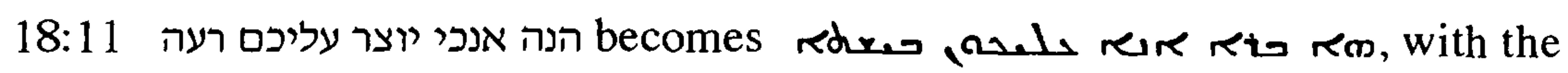
order of participle and enclitic personal pronoun reversed.

Similarly, 33:10 אתם אמרים becomes adur etr.

There is a frequent change in word order in which a suffixed pronoun is moved to a position immediately after the verb; there are many examples, for instance 1:7,9,14;3:6,11;11:6,9;13:6;14:11; and 15:1 where ויאמר יהוה אלי becomes

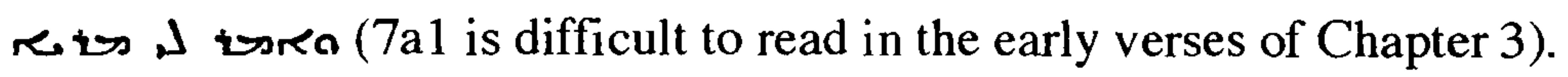

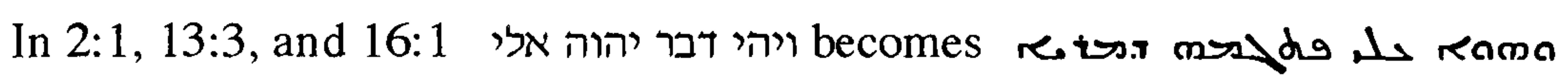

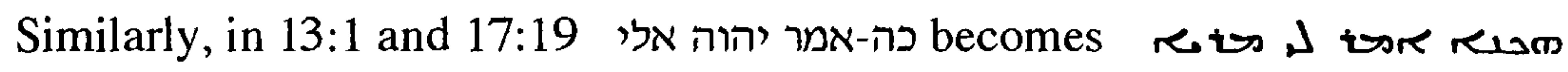

(iii) The position of adverbs

The MT order in which the verb precedes its adverb may be reversed: Nöldeke notes (Nöldeke, 1904, para. 326) that there is apparent flexibility "adverbial qualifications most frequently follow that leading member of the sentence, to which they specially belong ... but often too they precede it" and indeed there are variations:

in 2:10 is translated as alodore

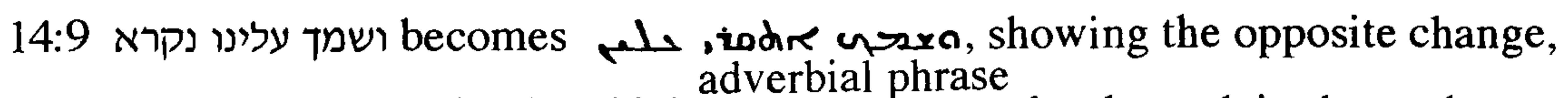

so that an MT construction in which the precedes the verb is changed to give one in which the verb precedes the adverbial phrase.

Yet in 2:12 ושערו חרבו מאד becomes of a ora, preserving the MT order. 
Chapter 2 Translation Technique

(iv) Sequences including כל

These too are treated differently at different passages:

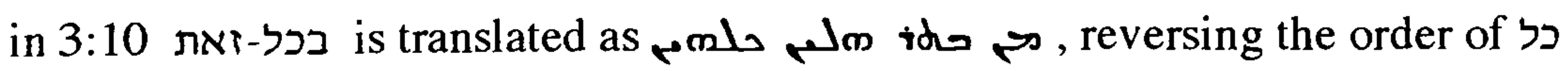
and זיז;

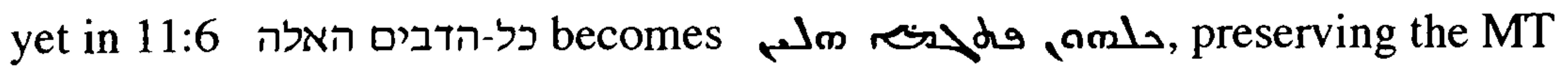
order.

(v) The word order within parallelism

The approach to parallelism would give a useful insight into the translator's handling of word order, if the MT included sufficient numbers of examples both using, and not using, chiasmus. Unfortunately for this discussion, parallelism is not a prominent feature of Jeremiah, and where it is used chiasmus is uncommon. Where chiasmus is found, it may be reproduced in translation, for instance in

6:25 אל-תצאי השדה ובדרך אל-תלכי 6:25ich is translated alired ro rewtorean, and 9:5(6), where the MT שבתך בתוך מרמה במרמה מאנו דעת-אותי is translated as

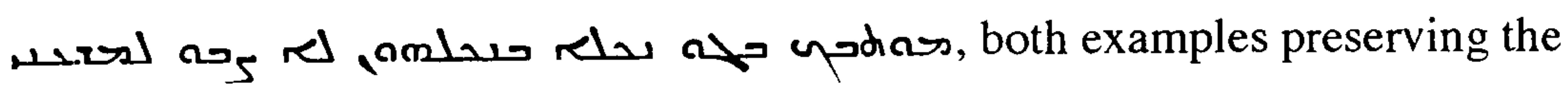
structure of the Hebrew.

In this respect too, there was no rigid rule:

in 12:13, for instance, זרעו חטים וקצים קצרו the chiasmus is eliminated in translation: 


\section{(x) The number of translators}

One important aspect of translation technique which has not yet been discussed is the question of the number of translators: there is so little relevant evidence that there has been nothing of substance to say. It has been shown that the technique varies from passage to passage: this could be seen either as evidence of flexibility, or of inconsistency, in the work of one translator, or could be due to the differences between the techniques of different translators; however, as Gelston (Gelston, 1987, p.157) points out, since a single translator may be inconsistent, caution is needed before assuming that the translation is the work of more than one man. Had more than one man been responsible, the most probable division of labour would presumably have been by parts of the scroll, and it might be possible to find differences between the technique in earlier compared with later chapters: the variations in the choice of lexical equivalents for important words which occur frequently, such as the חטv group discussed above, should then have been a fruitful area for study, but no clear distinction between the approach in different parts of the book is discernible; this contrasts with Holladay's observation refered to above (Holladay, 1976, pp.38-39) that the choice of root to translate root שוב in covenantal contexts "tempts one to think of a double source for the translation of Jeremiah": until chapter 31, root בad is used, but from that point onwards root nom is almost always preferred. There is one factor which suggests that there is little difference between the translation technique in the first half of the book compared with the second: given that additional words are a prominent feature of the translation technique, it is possible that, if more than one translator were involved, there might be a difference in this respect. However, the two texts are closely similar: in the MT, the midpoint of the book occurs at $28: 11$; in the Peshitta, $28: 11$ is a little before the midpoint, but the difference is too small to constitute evidence that more than one hand was at work.

Discussion of the literary quality of the different chapters would be out of place in the present study, but no careful reader could fail to notice this, and possibly to react to it: so the translator's work might have been different in the oracles to the nations from that in the oracles to the Israelites. Nor is literary quality the only factor which varies in different parts of the book: the extensive literature on the 
Chapter 2 Translation Technique

source and genuineness of the different parts is outside the scope of the present discussion, but representative comments include those of, for instance, Nicholson (Nicholson, 1970, p.26) who considers that there are some prose passages which cannot be attributed to Jeremiah, and Carroll (Carroll, 1986, p.38) who describes the book as "a miscellaneous collection of discrete and disparate writings".

Whatever may be the truth of the construction of the book, there is agreement that the style differs markedly in the different parts, and so a difference in translation technique might reflect one translator's varying reaction to the character of the text on which he was working. The fact that there is nonetheless so little evidence suggesting that the translation is the work of more than one man seems to support, rather convincingly, the opinion that it is indeed the work of one translator only. 
Annex 3 The translation of

\section{The translation of שT as a discriminator between conservative and progressive approaches}

The translation was examined to see if שTה would form a discriminator between the conservative and progressive approaches to the Peshitta described by Weitzman (Weitzman, in press, pp.167ff).

Nine Syriac terms are used, in the Peshitta of the Hebrew Bible, in the translation of שT:

\begin{tabular}{|c|c|c|c|c|}
\hline سمlN & 164 & restre & 9 & redurag \\
\hline זיד & 54 & reto & 2 & Rext \\
\hline דת. & 9 & אחמד R & 2 & to \\
\hline
\end{tabular}

not translated 6

total: $\quad 249$

The two terms rare, clearly, the only lexical equivalents used sufficiently frequently for further analysis to be productive; together, these two account for 218 of the total occurrences, 22 of which are in Jeremiah.

The relevant passages were classified into three groups according to the kind of land apparently meant by שT:

(i) wild land, in neither private nor community ownership (total 48);

(ii) land which was in private or local community ownership (total 103);

(iii) uncertain (total 67).

Analysis of groups (i) and (ii) shows a clear distinction (group (iii) was not included, as it seemed more likely to confuse results than to be helpful): in group (i), where שTד apparently means wild land, הכ is the term of choice, used in $30(63 \%)$ ) of the 48 passages; in group (ii), where שT means owned land, the preferred lexical equivalent is wased in 100 of the 103 passages. A difference in translation policy for שTה meaning wild land is evident between Weitzman's "conservative" group, that is Genesis, Judges, Samuel and Kings, where there is equal use of wa and ${ }^{1}$, and his most "progressive" group, that is Ezekiel and the Twelve Prophets, where there is a strong preference for <to: ${ }^{2}$.

1. 20 occurrences, of which half are translated with and half with and and.

2. 12 occurrences, of which eleven are translated with retar. 
Jeremiah comes next to the most conservative group in Weitzman's classification. Unfortunately, there are only four passages in this book in which שنהה means "wild land", all translated with rę.

Equivalents of שT meaning "owned land"on the other hand, show no real variation. With the exception of the three usages of rax in Judges, Raw is the invariable choice.

These results suggest that שידה, although not ideal for the reasons given in the discussion in Chapter 2, is a useful discriminator additional to those which Weitzman uses.

The 27 relevant passages in Jeremiah are:

$4: 17 ; 6: 12,25 ; 7: 20 ; 8: 10 ; 9: 21 ; 12: 4,9 ; 13: 27 ; 14: 5,18 ; 17: 3 ; 18: 14 ; 26: 18$;

$27: 6 ; 28: 14 ; 32: 7,8,9,15,25,43,44 ; 35: 9 ; 40: 7,13 ; 41: 8$.

Twenty-two of these are translated by either was or in canonical order, these are כשמרי שׁדי היו עליה מסביב

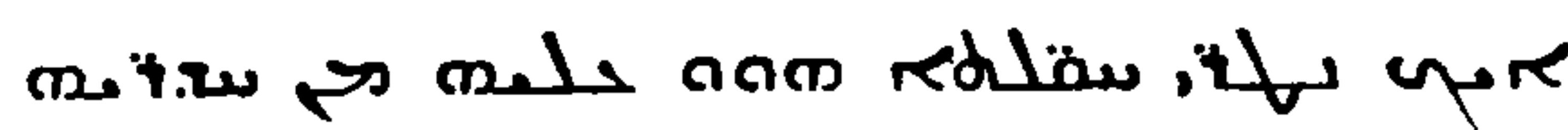
שדות ונשים יחדו יושי אל-תצאי השדה ובדרך אל-תלכי ועל-עץ השדה ועל-פרי האדמה

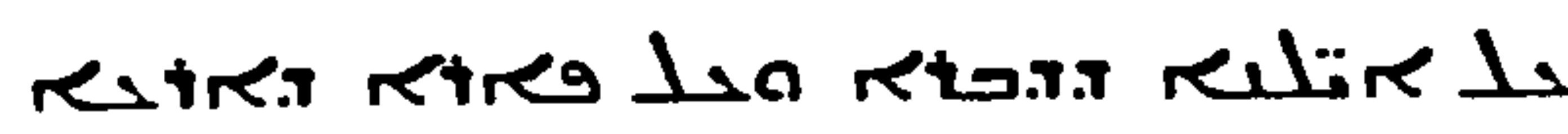

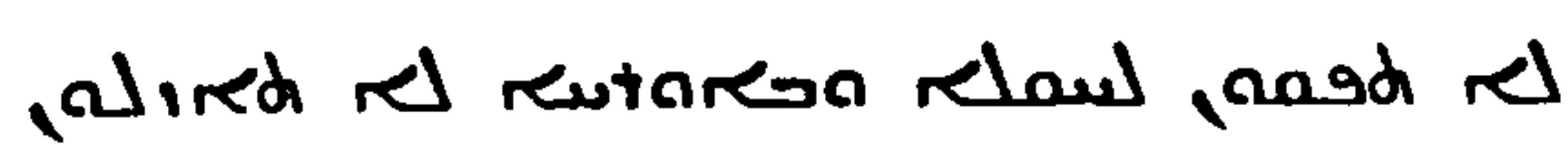
שטדותיהם ליורשים

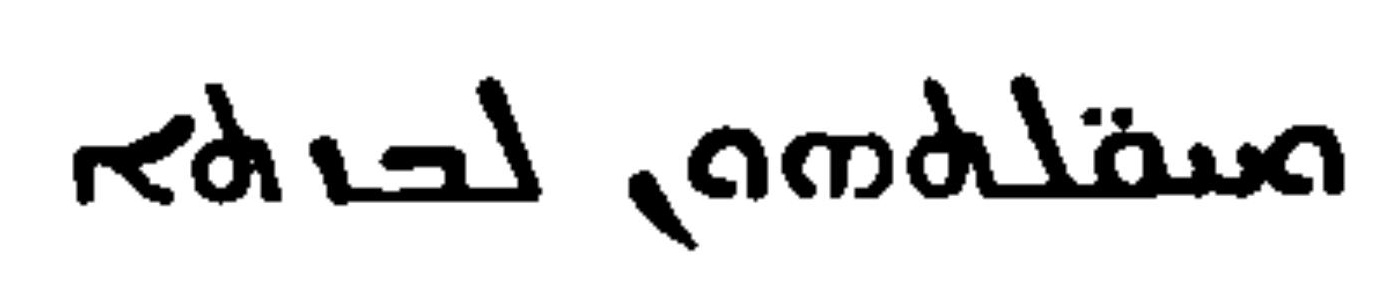
$12: 4$ כדמן על-פני השדה

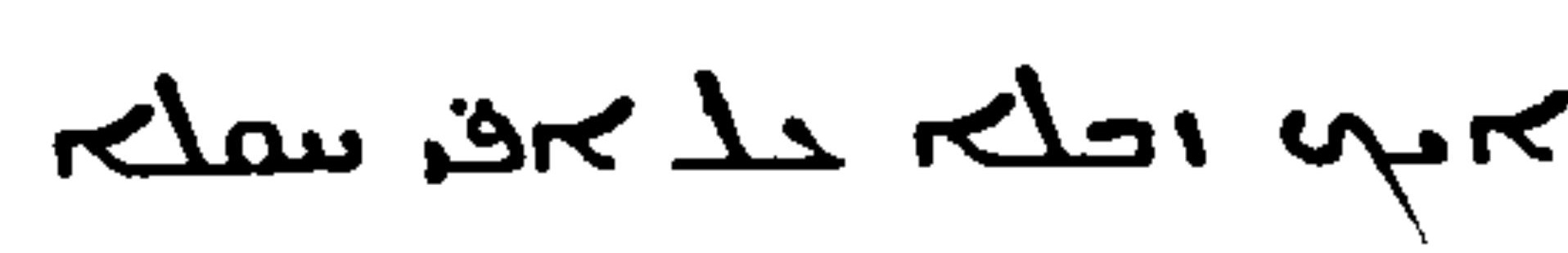
ועשב כל-השדב ייבש

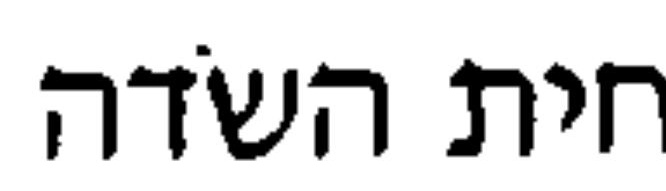




\section{$35: 9$}

$41: 8$ כרם ושדה וזרע

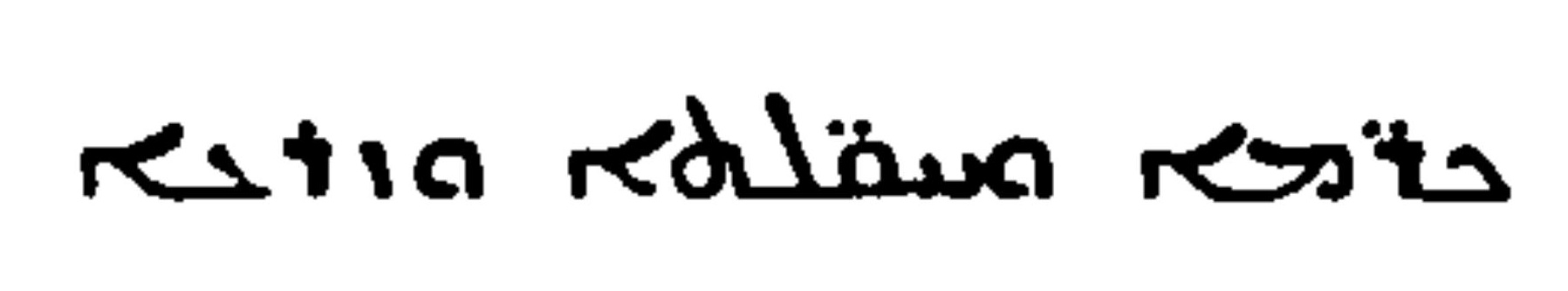
יש-לנו מטמנים בשדה

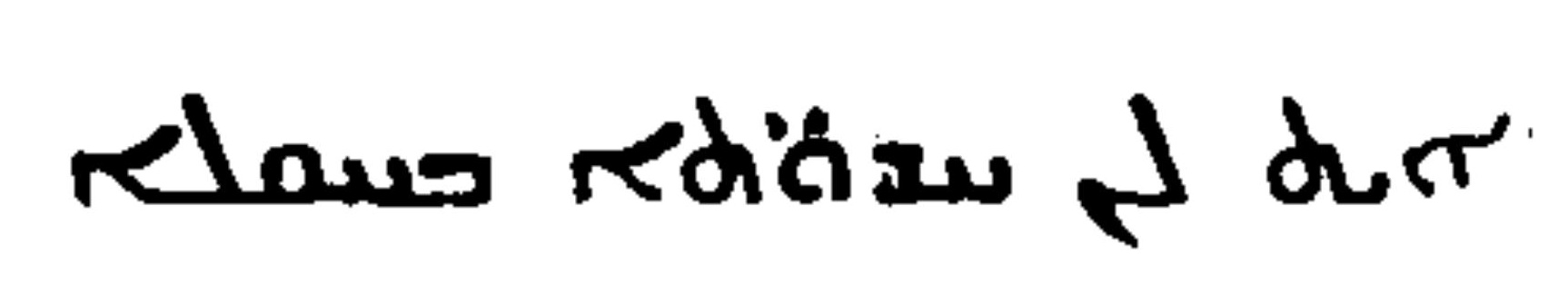

Of these 22 passages,

four refer to land in group (i): $12: 9 ; 14: 5 ; 27: 6 ; 28: 14$. All are translated with rto.r.

fifteen refer to land in group (ii): 4:17; 6:12=8:10; 7:20;9:21; 12:4; 26:18;32:7, $8,9,15,25,43,44 ; 35: 9$. Fourteen are translated with rew, and one with retor.

In three passages, it is impossible to be sure of the writer's intention; these are 6:25, 17:3 and 41:8. 
Annex 3 The translation of שTה

(All the references in Chapter 32 to the field which Jeremiah buys are translated with wald and this increases the number in this group; but this does not invalidate the conclusion of this analysis, for the translator, as has been shown, did not feel bound by any need to maintain an equivalence once chosen.) 
The book of Jeremiah contains a number of passages of which there are duplicates either within that book or in other biblical books. Here, as in this analysis as a whole, the constraints of space have made it impossible to give every example which would illustrate the points made in the discussion which follows; those which have been selected were chosen with care to ensure that they are representative of the technique as a whole. The most important duplicates where both members of the pair are in Jeremiah are
1. $6: 12-15 ; 8: 10-12$
9. $19: 8 ; 49: 17$
2. $6: 22-24 ; 50: 41-43$
10. $21: 9 ; 38: 2$
3. $7: 31-33 ; 19: 5-7$
11. $23: 5,6 ; 33: 15,16$
4. 10:12-16; 51:15-19
12. $23: 19-20 ; 30: 24-25$
5. $11: 20 ; 20: 12$
13. $30: 10,11 ; 46: 27,28$
6. $15: 13,14 ; 17: 3,4$
14. $39: 1-2 ; 52: 4-7$
7. $16: 14,15 ; 23: 7,8$
15. $49: 18 ; 50: 40$
8. $17: 10 b ; 32: 19 b$
16. $49: 19-21 ; 50: 44-46$

\section{Examples involving other books include}

1. Jeremiah 10:25; Ps 79:6

2. Jeremiah chapters 39 and $52 ; 2$ Kings chapters 24 and 25

3. Jeremiah chapter 48; Numbers chapter 21

4. Jeremiah chapter 48 ; Isaiah chapters 15 and 16

5. Jeremiah chapter 49; Obadiah

Analysis of the translation technique in these passages is complicated by the variability of the precision of duplication: in almost all these pairs of passages, there are some phrases in which the Hebrew of the two members of the pair differs slightly, and these are intimately mixed with others in which the Hebrew is identical. Where the Hebrew is identical the translation of the second occurrence of the passage is usually a copy of the first; but the translator maintained his usual meticulous approach in his work on these duplicates so that 
where the Hebrew is not quite identical the small differences are usually precisely represented in the translations. Sometimes, however, the application of the standard presentational style, for instance the customary striving for clarity or for grammatical agreement between all phrases in a passage, may result in identical translations of non-identical Hebrew phrases, and this may give a false impression that the translation of one has been influenced by that of the other. There are certain other positions which lead to a false impression that one translation has influenced the other: for instance, where the Hebrew of one passage is clearer than that of the other, the translator may decide to render, at both sites, the clearer Hebrew; this is not an example of the influence of one translation on the other, but of the translator's assessment of the different clarity of the two Vorlagen. Similarly, where both the Hebrew and the Syriac are identical the translator of the second has probably copied the translation of the first: this is of course evidence not of influence of one translation on the other, but simply of economy of effort.

Although these passages constitute an obvious area in which to look for evidence of influence of one translation on another, both within Jeremiah and involving other biblical books too, little such evidence is found: there is indeed little to distinguish the relationship between the translations of the duplicate passages from that between any other passages of the Peshitta to Jeremiah.

Such is the strength of the accumulated evidence that these passages were largely translated independently of one another that it forms the basis of suggestions concerning the wording of the Vorlagen in some instances to be discussed below. There is no doubt that a translation in one book of the Peshitta occasionally sometimes influenced the translator of another. Weitzman (Weitzman, 1997, pp.393-396; and in press, p.187) has given examples of passages where the translator of one book found in the Hebrew text of a given passage an association which led him to a passage in a different book, which the translation shows he consulted in the Peshitta and not simply in the Hebrew ${ }^{1}$;

1. Weitzman shows for instance that Genesis, Samuel, Psalms, Job, and Lamentations are linked by their understanding of עני "affliction" as "enslavement" in agreement with the 
Chapter $3 \quad$ Duplicate Passages

the latter point is of fundamental importance, for it distinguishes between those translations which may have been influenced by the Hebrew of other passages, of which examples will be given below, and those of even greater interest in the present discussion where the influence is from the translation itself.

There are even some passages (Weitzman, in press, p.193) where the translator "faced with a given Hebrew word found a verse in another book where that same word occurred but adopted instead the Syriac rendering of a different word in that verse".

Weitzman gives one unequivocal example from the translations of the long passage duplicated in Jeremiah and in 2 Kings, relating to the translations of two items in the temple, מכונה in Jer 52:17, and כתרת in Jer 52:22. The Hebrew term מכונה properly denotes a wheeled stand, of which the temple had ten, one for each of the ten lavers. The Hebrew term כתרת properly indicates each of the capitals above the temple pillars. Each term is however understood in the Peshitta as "basin": מכונה is translated by (2Kings 25:13, 16, and by rear Jer 52:17 (though not in Jer 52:20, a difference which Weitzman explains); כתרת is translated in both books by reve. Both equivalences can be traced to the Peshitta of the detailed account of the temple in 1 Kings 7 . Here the translator thought that the מכונה in 1 Kings 7:27-37 was not a wheeled stand but a basin; and as to כתרת which until 7:31 had been translated as redst denoting a "crowning slab", this understanding was unsuitable here and the כתרת too had to become an resin". The sense "basin" continues to be used for

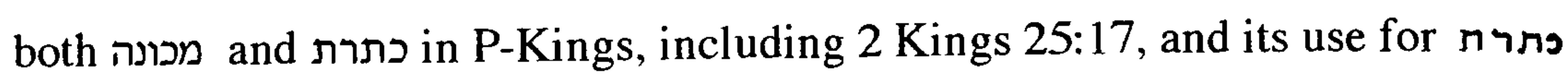
in the corresponding verse in Jeremiah, 52:22, cannot be convincingly explained except as a borrowing from Kings. This demonstration of dependence of $\mathrm{P}$ -

Footnote from previous page contd.

first occurrence of the verb ענה (Piel) in Gen 15:13 in the context of prediction of the Egyptian bondage where 1 is appropriate. In another example, Exodus, other later sites in the Pentateuch, Ezekiel, Psalms, Ezra, and Chronicles are linked by their translation of נדבה "a freewill gift" by Rextos "(gift) separated off"; Weitzman explains the development of sense here from the first occurrence of נדבה, in Exod 35:29. 
Jeremiah suggests, though it does not prove, that the understanding of Jer 52:17 as ris likely also to be dependent on P-2 Kings 25:13. Walter (Walter, 1995, pp. 187-204) has suggested that there is evidence in the duplicate passages recounting the attack on Jerusalem in 2 Kings 25 and Jeremiah 52 of influence from the translation of Jeremiah on P-Kings ${ }^{2}$; a representative selection of examples from this paper is given below as a basis for discussion. Walter's examples show well the interdependence of the two books; they do not, however, establish beyond doubt the influence of one translation on the other, as distinct from the influence of the Hebrew of one book on the translation of the other.

For 2 Kings 25:4 וכל אנשי המלחלמה הלילה דרך שער בין החמתים the translation reads

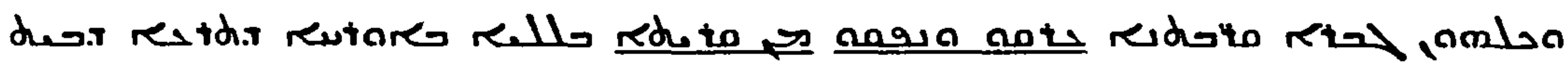
Rtar, and Walter suggests that the presence of the additional terms

2. Weitzman's example instanced above shows influence from the translation of a book earlier in the canon on a later one, agreeing well with Beckwith's suggestion (Beckwith, 1985, p.309) that the books were translated substantially in the order traditional among the Jews. Others of Weitzman's examples (Weitzman, in press, pp.187-188) , for instance the understanding of "siegeworks" which links Samuel, Kings, Isaiah, Jeremiah, Ezekiel, and Daniel are less easy to accommodate, for the passage on which the interpretation depends is in Jer 32:34, canonically later than either Samuel or Isaiah. Similarly, the Pentateuch, Judges, Isaiah, and Proverbs are linked by the translation of root חק with forms derived from root o.2 "examine"; the key occurrence of the root, on which this understanding depends, is in Judges, later than the Pentateuch. Walter's suggestions of influence from P-Jeremiah on P-Kings would at first sight run contrary to Beckwith's suggestion; Beckwith notes, however, (p.309) that "books which contained important testimony to Jesus and to Christianity... would naturally tend to jump the queue", so in view of the importance of Kings and Jeremiah to Christianity discussed above, it is possible that work on these two books would have been given priority and treated more or less simultaneously, and influence of Jeremiah on Kings is plausible. 
Chapter $3 \quad$ Duplicate Passages

(and, presumably, red to too) in the translation indicates influence from Jer 39:4 וכל אנשי המלחלמה ויברחו ויצאו לילה מן העיר דרך גן המלך בשער בין החמתים

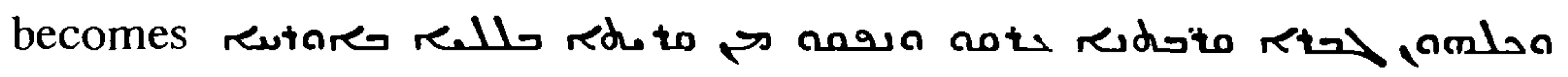

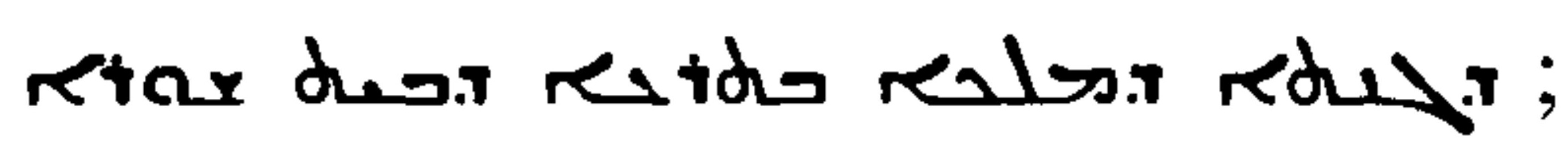

or Jer 52:7 וכל אנשי המלחלמה יברחו ויצאו מהעירלילה דרך שער בין החמתים אשר על גן

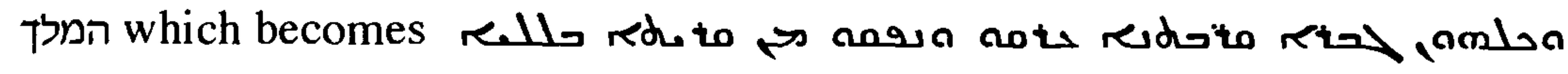

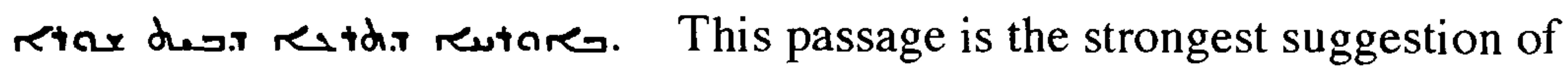
influence from Jeremiah on Kings, and even here the gap in sense is so clear that it is possible that the translator simply went to the Hebrew of the appropriate verses in Jeremiah to improve the clarity of his text: this is not a conclusive example of influence of one translation on the other.

Walter gives further examples which he himself regards as less conclusive. In

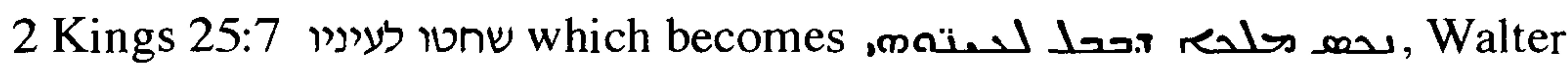
suggests that the additional terms s in this translation result from influence from the Jeremiah passages:

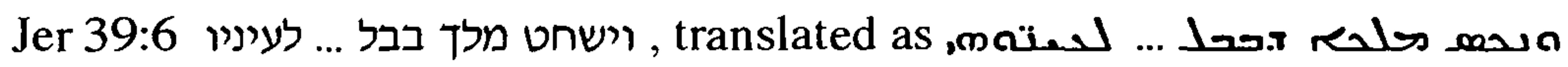
and Jer 52:10 וישח דבר מלך בבל ... לעיניו where the translation reads

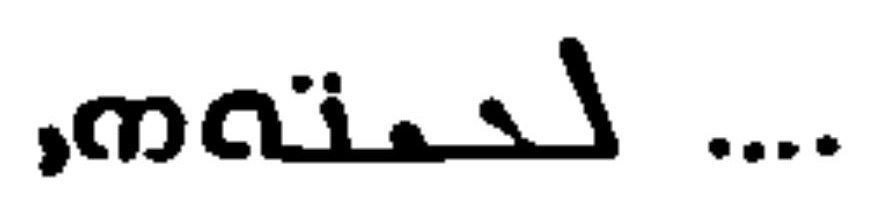

It is also possible, however, that the additions are in line with the general presentational style and have been made simply to increase the precision of the Kings text; in Chapter 2 a number of examples were given showing additions of just this kind, specifying the identity of the subject even though there could have been no reasonable doubt on the point.

There is a similar example in 2 Kings 25:11 הגלה נבוזראדן רב טבחים, which becomes لحר : Walter suggests that the mention of Babylon in P-2 Kings 25:11 may come from Jer 39:9: הגלה נבוזראדן

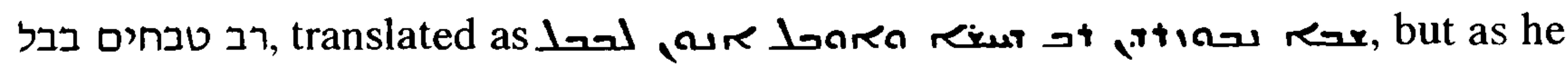
himself notes it could also have been copied from 2 Kings 25:13, malar ... 1al. This addition too would also, of course, fit well with the standard presentational style, achieving precision of expression. 
There is a further example in 2 Kings 25:3; Jer 39:2, 52:6. Walter suggests that the near identity of 2 Kings $25: 3$ to Jer 39:2 is surely significant, though he himself points out that the additional details of the year and the month could both have been supplied from Kings ( 2 Kings $25: 2 \mathrm{~b}, 3,8$ respectively). In MT, 2 Kings 25:3 reads בתשעה לחדש ויחזק הרעב בעיר ולא היה לחם לעם הארץ, and is

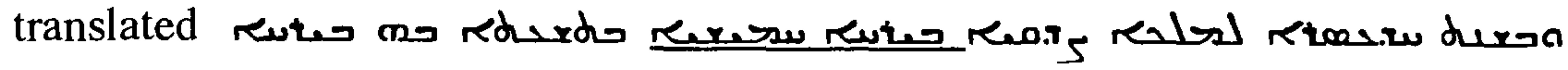

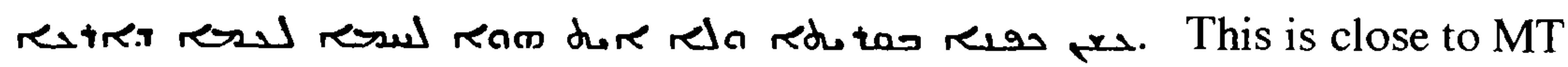
for Jer 39:2 בעשתי עשרה שנה לצדקיהו בחדש הרביעי בתשעה לחדש, for which the translation is virtually identical to that of 2 Kings 25:3 (except that it has not (S) but (2) the extent of giving, as in the translation of the Kings

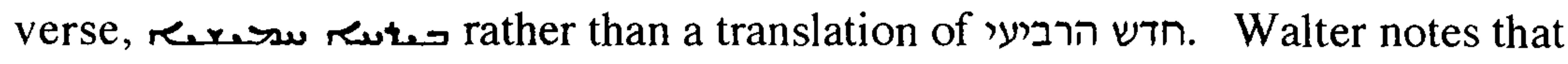
there is some mss. support for החמישי (Walter, 1995, p.199) though this is found only in three Hebrew mss. of Jeremiah; החמישי could also have been understood from 2 Kings ובחדש החמישי 25:8.

In summary, the additional details in P-Kings might have been the result of influence from P-Jeremiah, but could equally have been supplied from other verses in Kings; and rever. influence of P-Kings, but might possibly have been the date given in the Vorlage. This passage is not strong evidence of influence of one translation on the other, in either direction, for the translators may be responding not to their colleagues' renderings but to the Hebrew of the Vorlagen.

Overall, Weitzman's and Walter's examples constitute some evidence, albeit limited, of influence of the translation of one duplicate passage on that of another; but they should be weighed against the considerable body of evidence to be presented below showing that the translations of the duplicate passages are largely independent of one another. 
Chapter 3 Duplicate Passages

\section{Duplicate passages in which both members of the pair are in Jeremiah}

Independent translation of each passage

There is abundant evidence that the translator usually approached each member of a pair of duplicate passages independently of his work on the other. This evidence of independence falls into three principal categories:

(i) precise rendering of passages of non-identical Hebrew;

(ii) independent choice of lexical equivalents;

(iii) differing degrees of literalness.

Constraints of space are such that the number of examples given has had to be restricted, but each duplicate was studied in detail in the preparation of this chapter, and great care has been taken to ensure that the examples selected are representative and do not give a biased picture.

(i) precise rendering of passages of non-identical Hebrew

This is well illustrated by the pair of passages $6: 12-15 ; 8: 10-13$. In 6:12, 13 ונסבו בתיהם 6:12 8:10 the precise translation technique is seen: in translating לכן אתן את-נשיהם לאחרים שזותיהם ליורשים לאחרים שדות ונשים יחדו 8:10, meticulous translation has preserved in the Syriac the difference between, for

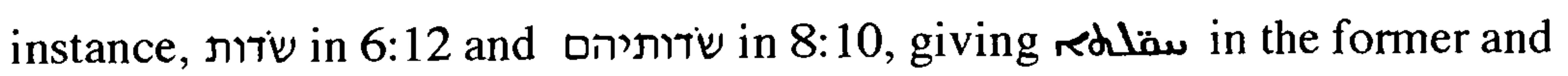
مقandin the latter.

The next few lines, however, at first sight suggest that this approach has been abandoned so as to make the two texts similar: 8:10 כי מקטן ועד-גדול becomes

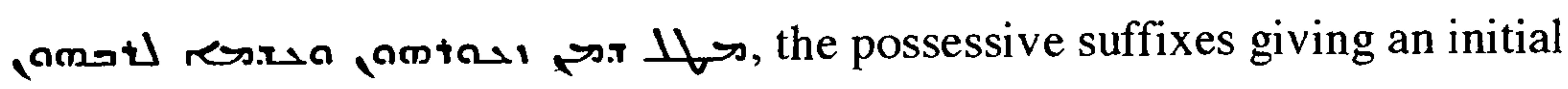
impression that the translation was intended to bring this verse into line with 6:13 in which the Hebrew has כי מקטנם ועד גדולם and which becomes, naturally,

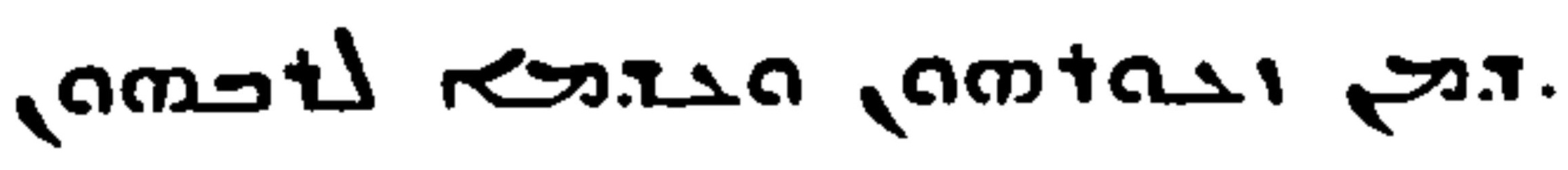

This is not, however, definite evidence of influence of one translation on the other: a simpler explanation lies in the application of the standard presentational style which seeks grammatical consistency. Here, the terms in 8:10 are being made consistent with those earlier in that verse: amta, and amot) do not 
Chapter 3 Duplicate Passages

precisely translate קטול משיהם and but they do conform with שטותיהם. Similarly, in translating כלו עשה שקר and in both verses, the singular

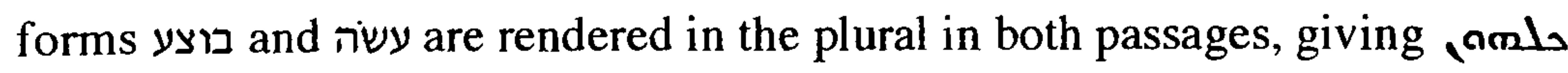
to agree with the more logically exact كلה دصل

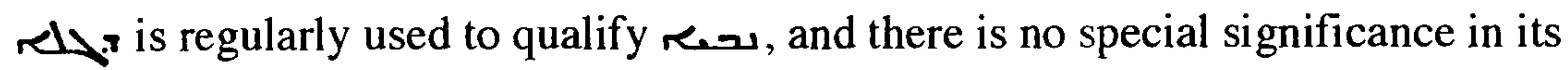
addition to both passages in the translation of ומנביא ועד כהן.

Further examples of the precise translation technique applied to each member of a pair include, for instance, in the pair of passages 6:22-24; 50:41-43, the

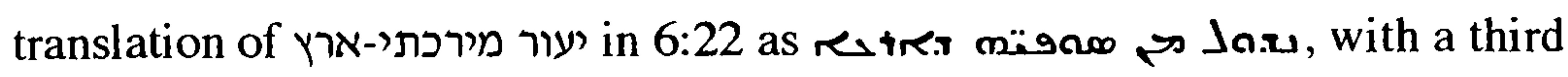
person singular verb, in comparison with 50:41 יערו מירכתי-ארץ which is

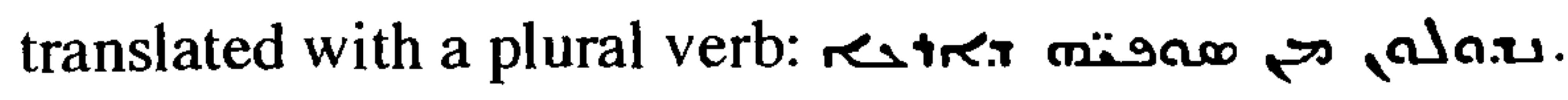

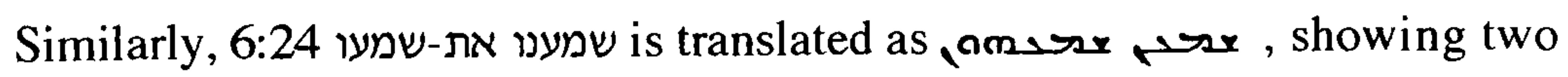
points of interest: first, שמענו is appropriately translated with a first person plural verb, in comparison with 50:43 שמע מלך-בבל את-שמעם which is rendered meticulously as צבר sلver. Second, the application of the standard presentational style which seeks grammatical consistency is evident: in 6:24 has been translated as , שמעו in 50:43 but to make it agree with the plural subject of 6:23

קשת וכידון יחזיקו אכזרי הוא ולא ירחמו

קולם כים יהמה ועל סוסים ירכבו ערוך כאיש למלחמה עליך בת ציון

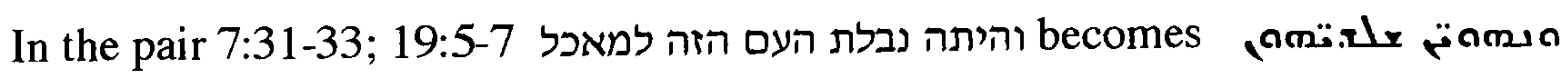

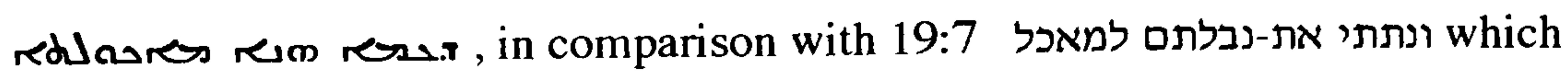
is translated rdlasoss, am a.r. Jdrea, preserving the differences in root and in grammatical form between the two verbs used in the Hebrew in ונתתי and והיתה.

11:20 in comparison with 20:12 provides a similar example: ויהוה צבאות שפט צדק מל becomes בחן כליות ולב

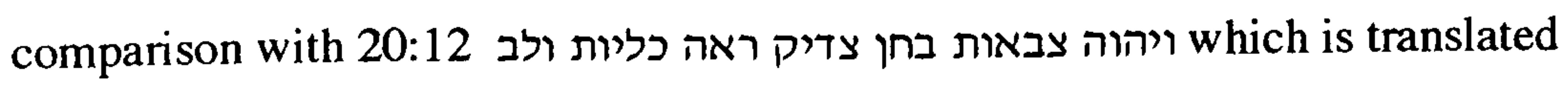
 


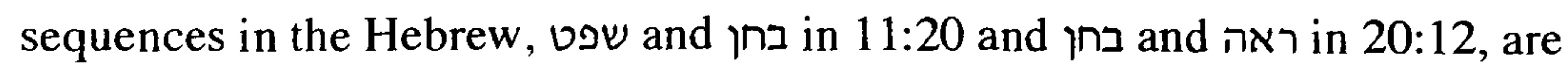
preserved in the Syriac.

15:14 כי-אש קדחה באפי עליכם תוקד and the near duplicate in 17:4 are of great interest. Textual criticism has focussed on 15:13-14 as a possible fragment of $17: 1-4$; the argument is outside the scope of the present discussion, but the translator's approach to these two verses is relevant and striking: it must have been as clear to him as to later readers that one passage was likely to be a corruption of the other, but nonetheless he translated each precisely: 15:14 is כי-אש קדחתם 17:4 andered as

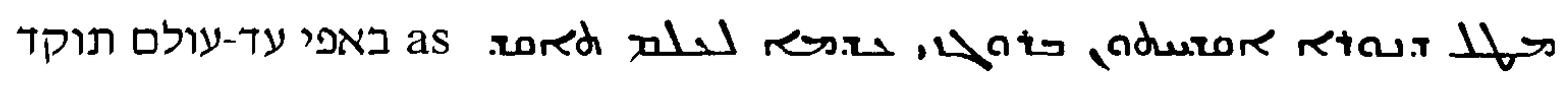

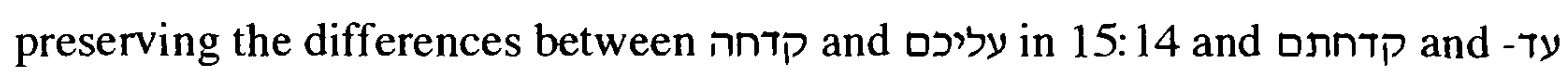
עולם 17:4.

The pair 17:10 and 32:19 provide a particularly clear example: in the first, MT is ולתת לאיש כדרכו; in the second, the MT is לתת לאיש כדרכיו. The translations as

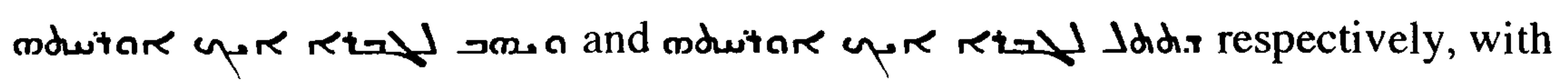
the unusual use of root $\lrcorner d u$ in the second, are so different that the variation must be intentional.

In the translations of the difficult Hebrew of 49:19 and 50:44 there is a further example in which the application of the presentational style results in an unfounded impression of influence. ארגיעה אריצנו in 49:19, and ארגה ארוצם in 50:44, are both translated ב בעل with the precise style in that it agrees with the (understood) sheep in the "sheepfold of Eitan", and in 49:19 is presumably given for that purpose although it is not an accurate translation of the Hebrew.

There are several points within the duplicate passages where phrases present in one member of the pair are absent from the other, and where the translation represents the difference. For instance, in 6:22 and 50:41, the latter includes the

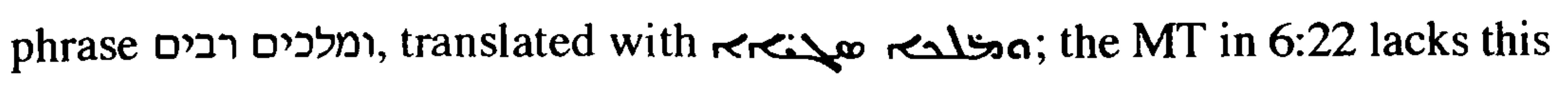


phrase, and so does the translation.

There is a similar example in 7:31 and its duplicate 19:5, where the MT אשר בגיא

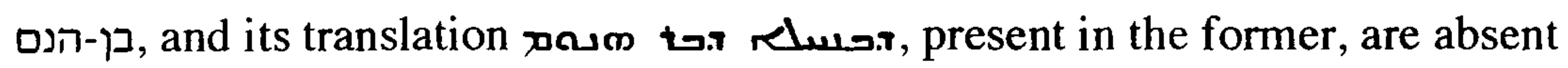
from the latter.

One further example of this particular point will be all that space allows: in the pair 16:15 and 23:8, אשר נתתי לאבותם occurs in the first but not the second, and

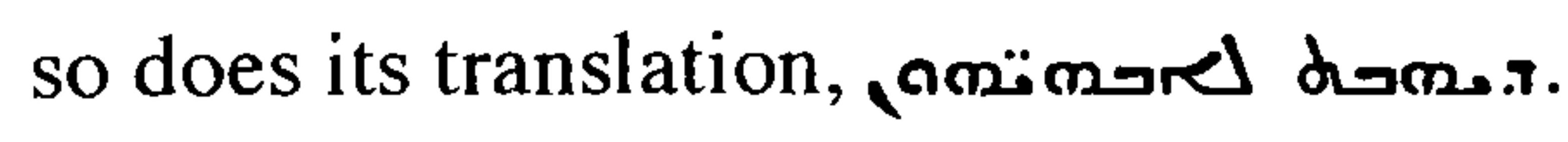

(ii) independent choice of lexical equivalents

The selection of lexical equivalents in some of these passages was discussed in detail in Chapter 2; a little repetition may be helpful here. The familiar "Aword" and "B-word" approach is seen in some pairs, for instance in 6:24 and 50:43 where root רפה is translated in the first passage by the cognate, which is the A-word, and in the second by root $\perp x t$, the B-word. There is another example in the pair 10:14 and 51:17 where root שקר is translated in the first passage by the cognate, which is the A-word here too, and in the second by root 1 r, the Bword.

Other passages were discussed in which this approach is varied, using in the first passage a synonym which may be so approximate, and so seldom selected, as hardly even to qualify as a B-word, amd reserving the A-word for the second passage of the pair. Examples given in Chapter 2 included תבונה 10:12 and 51:15; נדח 16:15 and 23:8; and 23:19 and 31:23: in each instance, the accepted equivalent is used in the second passage, and an unusual term given in the first.

There is a further example in 49:19 and 50:44: in the translation of

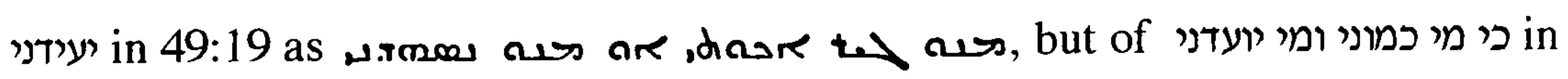

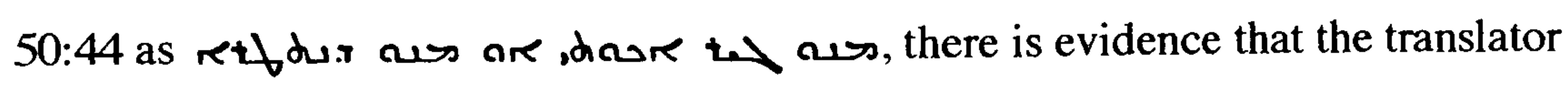
reconsidered: in the first, he selects root tmo "to witness", appropriate as an equivalent of root 7 ; by the time he reached the second, however, he has decided to make a change and selects root rt女 "to assail". Clearly, these renderings show the translator treating each passage as an 
independent exercise. Yet the picture is complex: in 23:19 and 30:23 the final

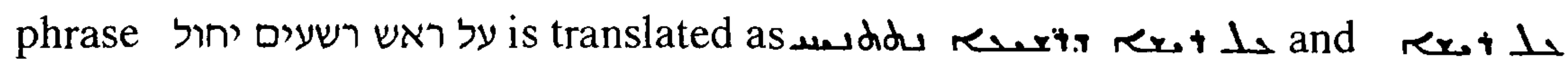
Sespectively: the choice of root resth in both is surely not coincidental but must indicate that the translator wished to repeat his first decision.

(iii) differing degrees of literalness

In some duplicate passages, there is a difference in the degree of literalness in the

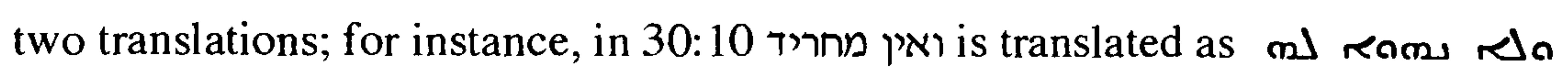
r. translation as $m$ lass $\rightarrow$ h. $\mathrm{h}$ a is more literal.

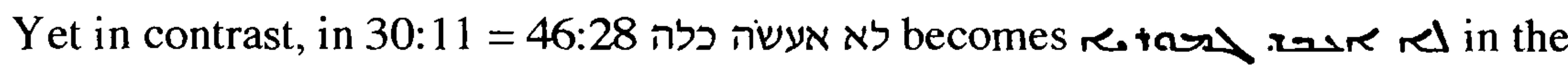
first, but acore $\mathrm{J}$ in the second: the second translation is neater than the first though less literal.

Influence of the translation of one passage on the other The examples presented above illustrate the independence of the translation of one member of a pair of that of the other member. There follow some examples of the opposite, of passages where some influence of one translation on the other seems probable. On balance, these are far fewer than those showing independence.

This evidence falls into two principal categories:

(i) the use by both translators of an unusual lexical equivalent;

(ii) a similar understanding in both passages of an area of difficult Hebrew.

(i) The use by both translators of an unusual lexical equivalent seems likely to be the result of influence of one translation on the other. One example was noted above, the rendering of root חול 23:19 and 30:23 by rooth 6:14 and 8:11 provide another example: 6:14 וירפאו את שבר עמי על נקלה and the 
almost identical 8:11 וירפו את שבר עמי על נקלה are both translated as poraso

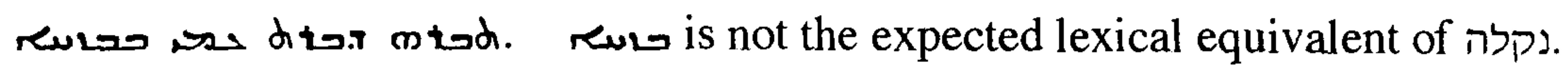

The sense is close, for to pay only superficial attention to a wound may be akin to despising the wounded, but 2 has a strong sense of active mockery. Taking all other comparable occurrences of root קלל in the Niphal, there are four passages in which root 2 is used (1Sam 18:23; 2Sam 6:22; 2K 3:18, 20:10); one in which root 1 is used (1K 16:31); two in which root 1 is used (Isa 49:6 $\mathrm{\iota}_{1}$; Ezek 8:17(18)); and one, in $\operatorname{Pr} 14: 6$, where there is no precise translation. There is one other comparable occurrence of the root in Jeremiah, in 15:10 where root $2 w_{y}$ is used. So root a choice unique to these verses, and it seems that the second translation may be in this respect a copy of the first, as in 6:23 and 50:42 below.

In this latter pair, notwithstanding the mechanical difficulty of working with such widely separated parts of a long scroll, one translation does seem to have קשת וכידן יחזיקו אכזרי הוא Influenced the other. In each, the verse opens with

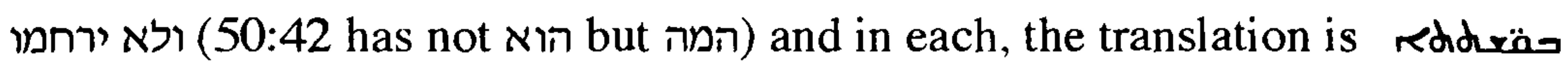

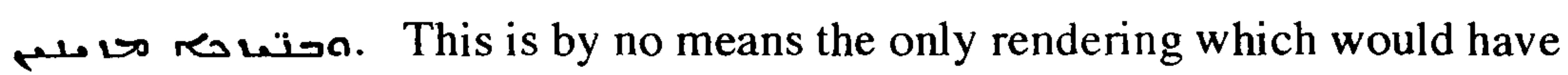
been acceptable, and is perhaps not even the most likely translation: roots w or wure would have been more probable choices for root pin.

Yet here too, despite having copied where he felt justified in doing so, the translator continues to refer to the Hebrew afresh in his work on the second passage: in translating ערוך כאיש למלחמה later in these verses he gives רברז in in 6:23, but res in 50:42 (this is one of the numerous points at which Lee differs from 7a1); the probable underlying thought process is discussed in more detail in Chapter 6, but two conclusions are clear: first, he thought about each passage individually; second, despite changing his mind, he did not return to $6: 23$ to change his translation.

A similar understanding at both translations of an area of difficult Hebrew is another manifestation of probable influence of one translation on the other. The pair 10:13 and 51:16 include the difficult phrase לקול תתו המון מים בשמים.

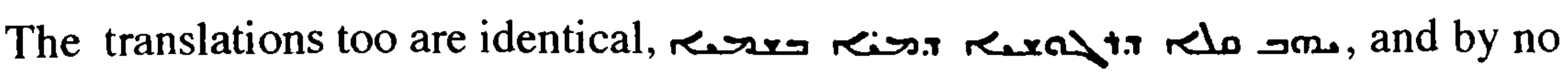


Chapter $3 \quad$ Duplicate Passages

means the only way in which the problem could have been approached: it seems certain that in rendering the second the translator decided to repeat his work on the first. In the same verses, ויעל נשאים 10:13 and ויעלה נשאים מקצי ארץ ומים

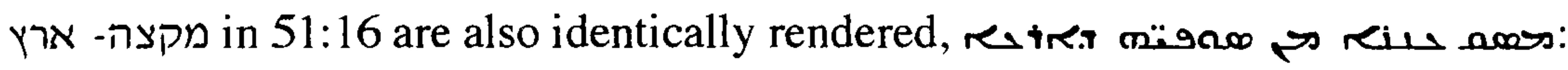
a simple decision to repeat the translation of the first occurrence of the phrase seems to have been made here too.

Yet within the same passages, הביש כל-צורף מפסל in 10:14 and הברף מפסל

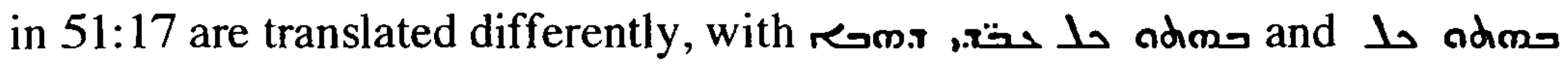

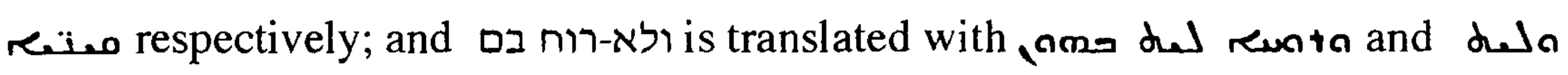
rent respectively; careful reading shows repeatedly that the translator's approach is complex and variable.

There is a further example at the difficult passage in 15:13 which is duplicated in 17:3, of particular interest when compared with the evidence of independent חילך ואוצרותיך לבי אתן 15:13 17:4 discussed above. In

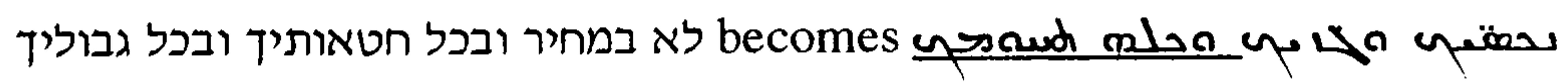

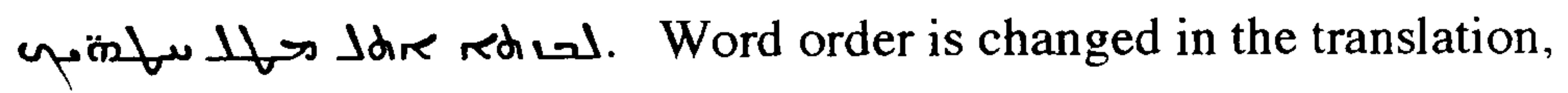
representing ובכל גבוליך not in its position in the Hebrew but as the completion of the sequence לא במחיר . חילך ואוצרותיך is not represented.

In הררי בשדה חילך כל אוצרותיך לבז אתן במתיך בחטאת בכל גבוליך becomes is included in the translation of the previous verse). As in 15:13, גבוליך is בכל in is not represented.

The similarities between these translations of passages of difficult Hebrew are so strong that some element of influence seems certain. לא במחיר in is:13 difficult, possibly a corruption of במחיר arising from the wish to connect this term with the preceding לבז אתן and to show that "Judah's treasures would be looted and no price paid for them" (McKane, 1986, p.386). In 17:3, though, בכל-גבוליך, would not have been difficult to translate. It reads awkwardly in the word sequence in the MT, but the translator has already decided to change the order of other terms and could have coped with this too had 
he not been influenced by his work on the earlier verse.

There is another example in 49:19 and 50:44; here, the Hebrew is particularly difficult and the translation by no means obvious, so the close similarity of the Syriac in the two passages strongly suggests that the translation of one influenced that of the other, and given the closeness of the two texts in the scroll refernce from one to the other would have been fairly easy.

49:19 מגאון הירדן אל-עה איתן כי-ארגיעה אריצנו מעליה is almost identical to 50:44(43) מגאון הירדן אל-נוה איתן כי-ארגעה ארוצם מעליה מותו- and the translations too are almost identical:

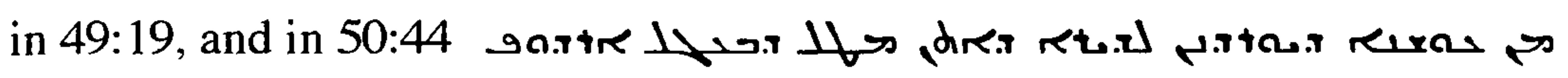
mos , NR.

In both, the figurative גאון is understood and translated in the same way, probably correct but by no means the only translation which would have been acceptable. In the Hebrew, there is a grammatical incongruence of עה (masculine) and מעליה (a traditional understanding that the suffix on sem is feminine is suggested by the vocalisation in the Trinitarian Bible Society edition of the Peshitta (1954)). This persists in the masculine ${ }^{3}$ <t.x in the translation; this is an incongruence which would not usually be tolerated in the Peshitta, strongly supports the suggestion that there was some copying, and may be a point which the translator missed on both occasions when he worked on this passage. Alternatively, he may simply have abdicated his function at this point in this particularly difficult verse and decided to give a literal translation of the Hebrew איתן . מעליה too is similarly understood in both passages, and translated in both as if it were a nomen proprium rather than "an abode of permanency" (B.D.B.).

Yet here again influence is not consistent: $\mathrm{D}$ is represented in 49:19 only by waw, a reasonable decision as its sense is unclear; however by the time he came to work on 50:44 the translator had evidently changed his mind, and gives . 1 .

3. T. Th is almost always masculine, though it is usually feminine when used in the term Кะ. T "an archimandrite, abbot" (J.Payne Smith, 1903, p.91). 
Chapter $3 \quad$ Duplicate Passages

2. Duplicate passages in which one member is in Jeremiah, and the other in another biblical book

Independent translation of each passage

As in the rendering of the duplicate passages within Jeremiah, study of those pairs of which one member is in a different biblical book gives abundant evidence that the translator usually approached each member of any given pair of passages independently of his work on the other. As in the discussion above concerning the duplicates within Jeremiah, the evidence falls into the three principal categories:

(i) precise rendering of passages of non-identical Hebrew;

(ii) independent choice of lexical equivalents;

(iii) difference in the degree of influence from LXX;

not all categories of evidence, however, are represented by analysis of every pair of passages.

Contrary evidence, suggesting the influence of one translation on the other member of the pair, also falls into the two categories seen above:

(i) the use by both translators of an unusual lexical equivalent;

(ii) a similar understanding in both passages of an area of difficult Hebrew.

As in the above discussion, examples in these categories are far fewer than those showing independence.

For ease of reference, rather than presenting first evidence showing independent translation drawn from study of each pair, and then giving such evidence as there is suggesting the contrary position of dependence, each pair of passages has been presented separately.

Here too, constraints of space are such that the number of examples given has had to be restricted, but as before great care has been taken to ensure that those which are given are representative. 
Chapter 3 Duplicate Passages

a. Jeremiah and Isaiah

Independent translation of each passage

(i) precise rendering of passages of non-identical Hebrew

There is strong evidence in the translations of the oracles against Moab in chapter 48 of Jeremiah 48 and chapter 15 of Isaiah that the translators worked independently of one another.

Jeremiah 48:5

כי מעלה הלחות בבכי יעלה בכי

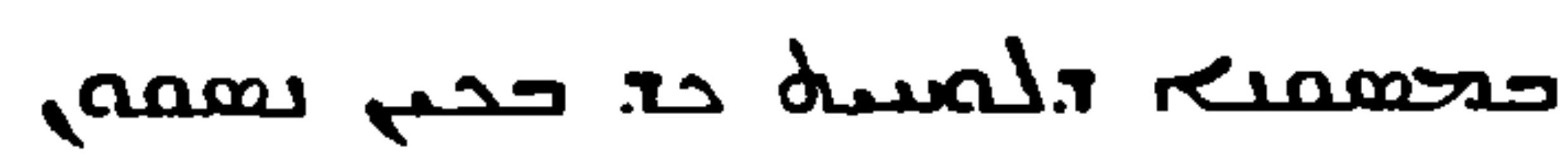

כי במורד חורנים צרי צעקת שבר שמעו

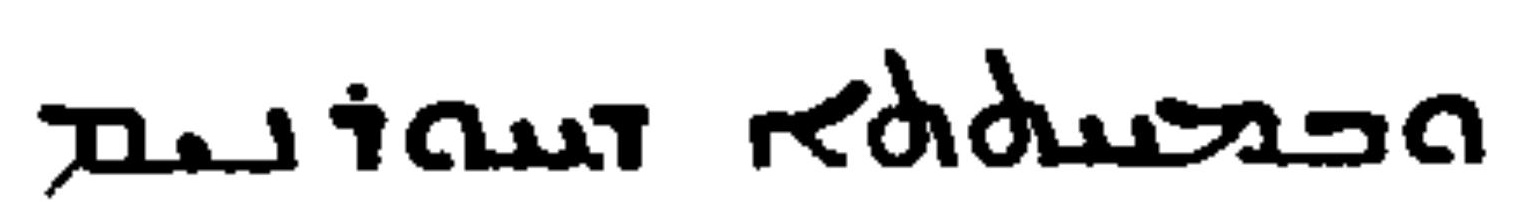

a.ren retodis redila rastor
Isaiah $15: 5 b$

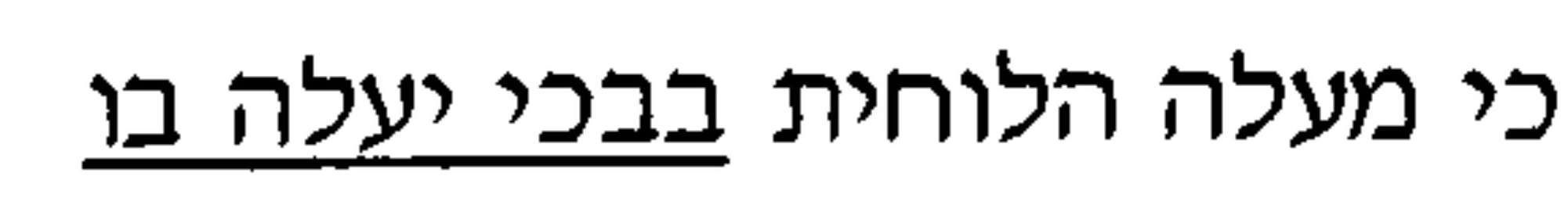

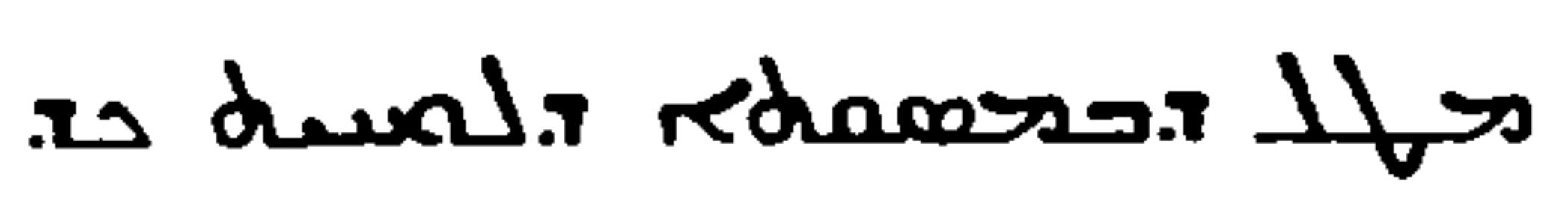

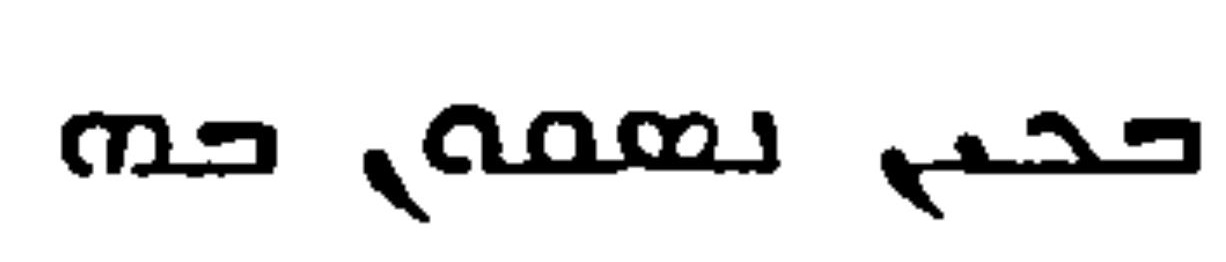

כי דרך חורנים זעקת שבר יעערו

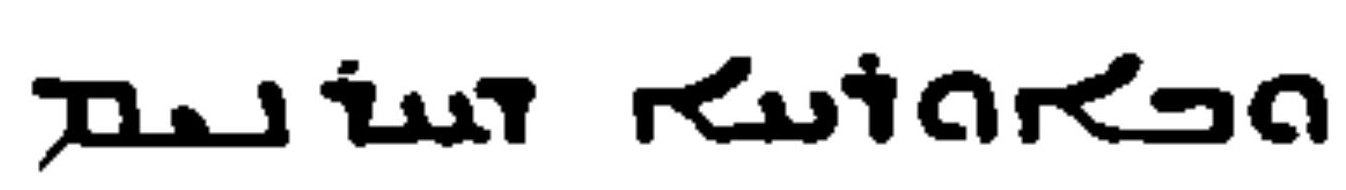

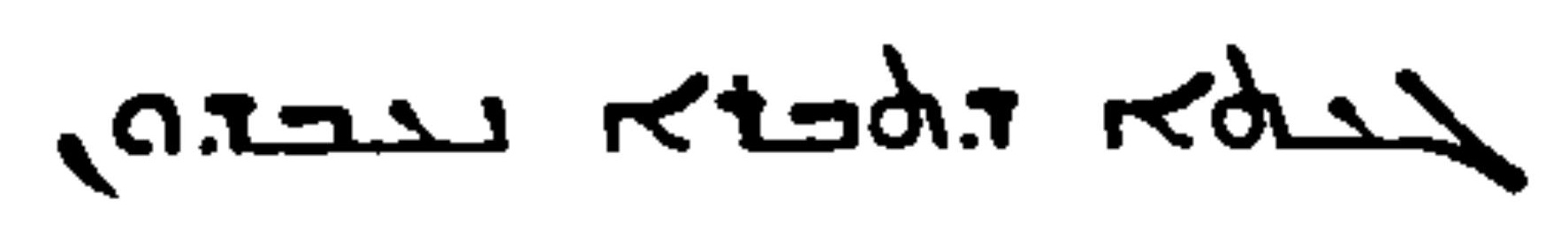

in Isaiah are translated to show the

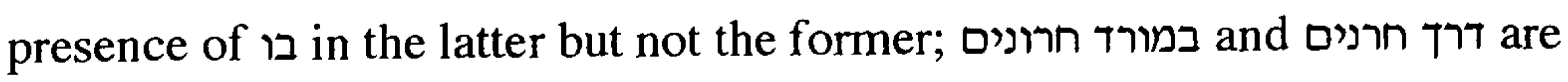
translated appropriately as respectively.

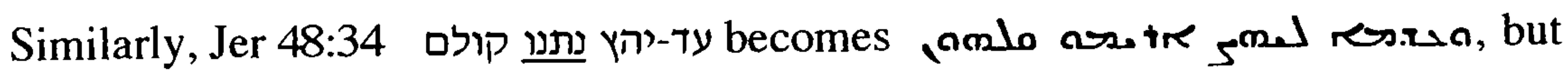
Isa 15:4 עד-יהץ נשמע קולם is translated

(ii) independent choice of lexical equivalents

The choice of lexical equivalents suggests that the translations of Jer 48:29 and Isaiah 16:6 שמענו גאון מואב :becomes in Jeremiah the imprecise

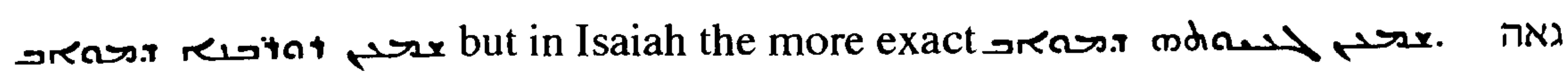
מאז in the next phrase in Jeremiah, and גא מאד in Isaiah, are translated 
$\neg$ and, $\sim 2$ dre $=6$ respectively, so that P-Jeremiah uses two roots, $\rightarrow$ and , r where P-Isaiah uses one only.

In the difficult next lines, Jer 48:30 אני ידעתי נאם יהוה עברתו ולא כן בדיי is

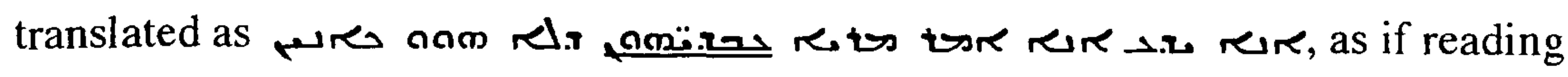

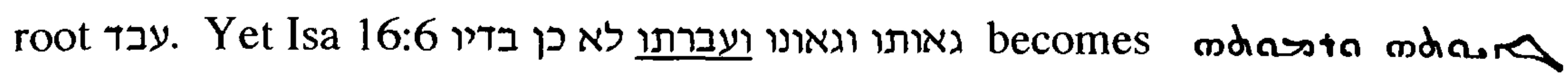
revm rom \& modra, closer to the sense of MT.

In Jer 48:37 and Isa 15:2 there is further strong evidence of independence:

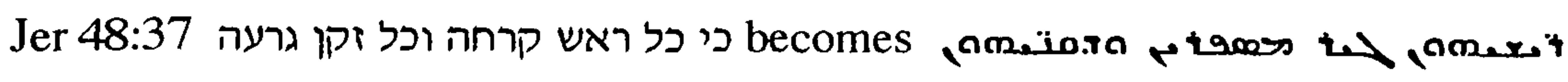

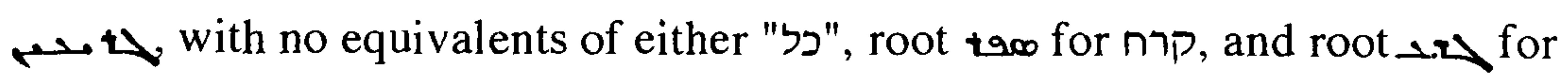

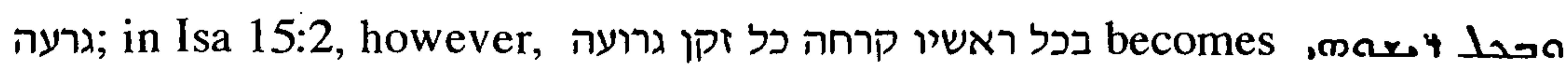

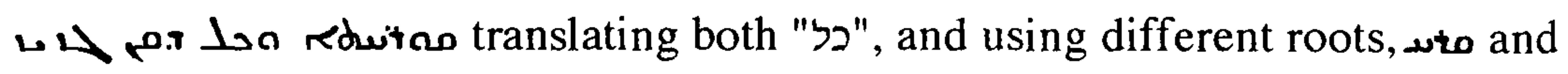
4 respectively.

As a final example of independent translations, consider Jer 48:31 and Isa 16:7:

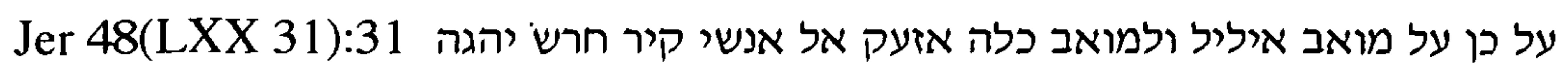

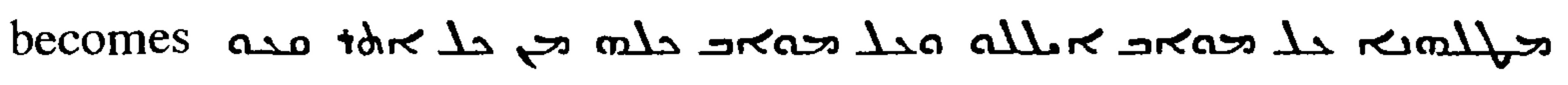

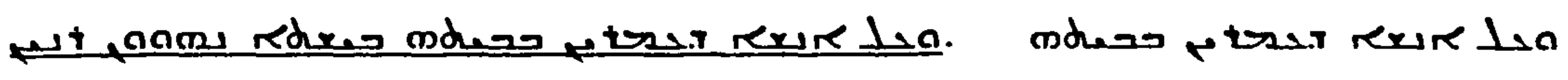
م evil" seems to have entered the translation as an understanding of root חרש meaning "magic art" (B.D.B p.361) in the phrase "against the men of his walls they will meditate on evil". ד stre "from every place" has no equivalent in

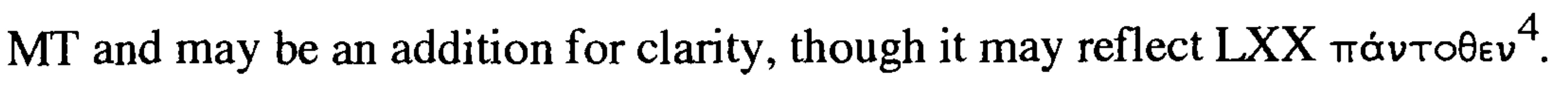
In contrast, Isa 16:7 למן ייליל מואב למואב כלה ייליל לאשישי קיר חרשה תהגו אך נכאים becomes raxis rëre ل1

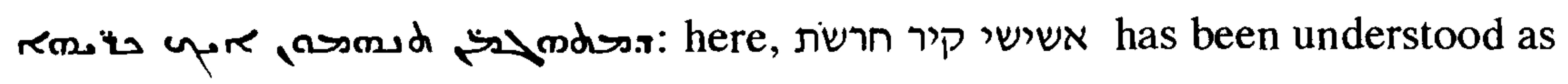

4. LXX is apparently based either on a different understanding of the word division, or on a " $\cap$ "

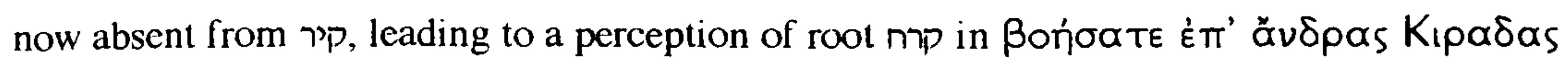

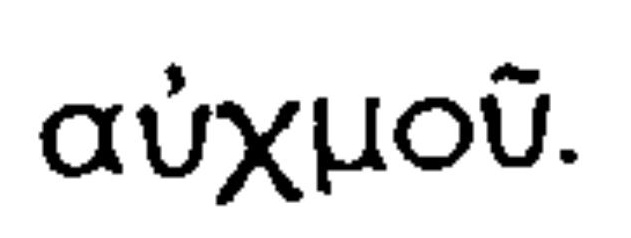


Chapter 3 Duplicate Passages

"the foundations of the walls which are ruined", presumably based on an understanding of root חרש in its sense "to plough", giving "ploughed" walls, that is a ploughed field where once there were houses: this evokes Jeremiah 26:18 ציון שדה תחרש

(iii) evidence of difference in the degree of influence from LXX There is one passage suggesting that the translator of Jeremiah was more influenced by the LXX than was the translator of Isaiah: in Jer 48:34 and Isa 15:5:

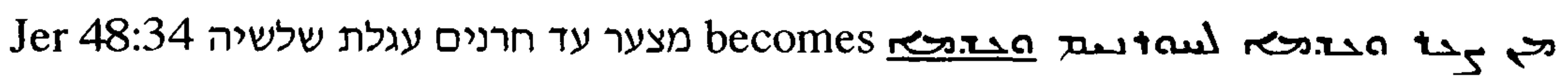

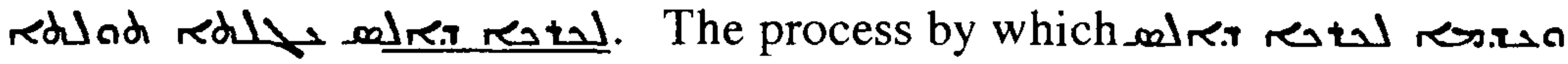
seems to have entered the text is discussed more fully in Chapter 6; for the present, the point to note is that it is absent from the translation of Isaiah 15:5 in which

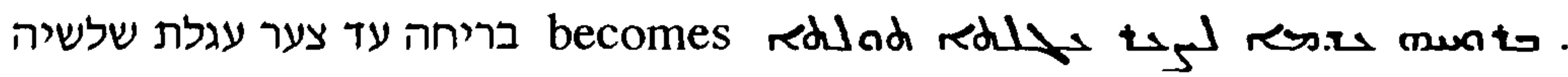

Influence of the translation of one passage on the other

(i) the use by both translators of an unusual lexical equivalent: although Jer 48:5 and Isaiah 15:5 illustrate the independence of the two translations, the complex nature of the approach is shown in these examples too, for there is also one point in these lines which may illustrate influence. This inconsistency, which could equally well be described as flexibility, is hardly surprising in a work of this length.

Jer 48:5

כי במורד חורנים צרי צעקת-שבר שמען

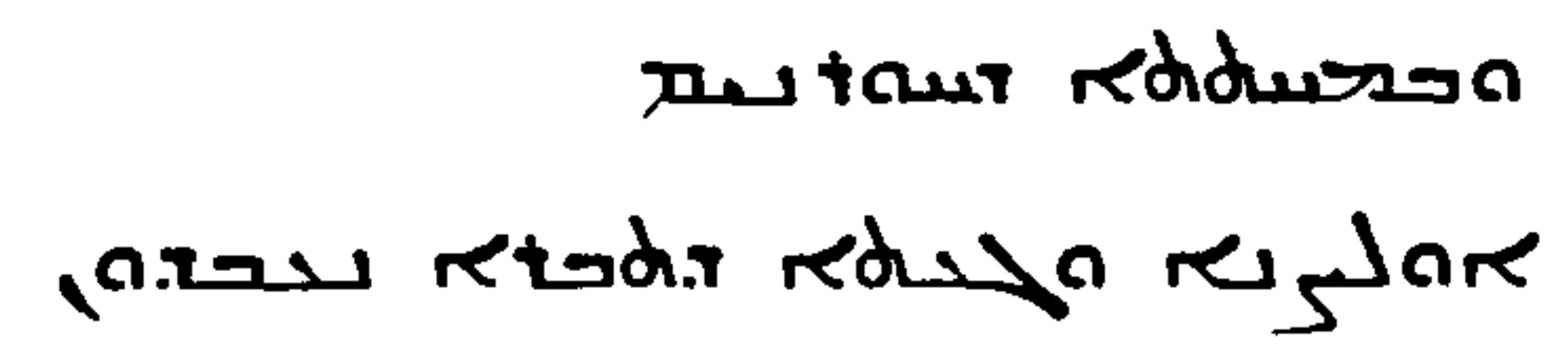

Isaiah 15:5

כי דרך חורנים זעקת-שבר יעערו

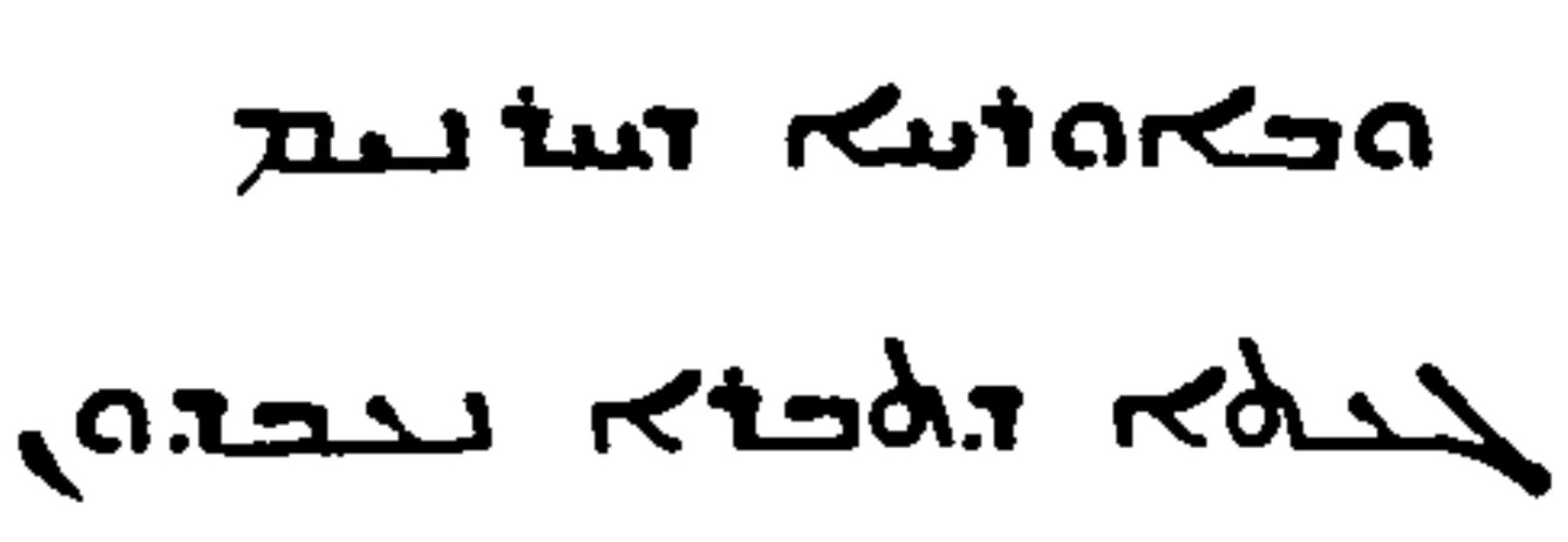

The presence of שמעו in Jeremiah as a translation of in Isaiah as a translation of the difficult יעער is interesting, since it translates neither Hebrew word accurately. There are no exactly comparable passages elsewhere in the 


\section{Chapter $3 \quad$ Duplicate Passages}

Hebrew Bible. McKane (McKane, 1996, p.1160) suggests that "שמעו is perhaps tolerable if it is to be regarded as the equivalent of a passive", and this seems to be the understanding in the Peshitta; on this basis, the translations fit the standard translation technique well: examples of the tendency to render figurative language with a clear, if pedestrian, equivalent, were shown in Chapter 2 and this could be one such. " שרת.ה " makes plain sense of the figurative Hebrew and כי מעלה הלחות בבכי in the previous line where

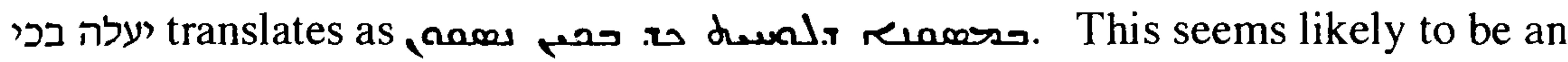
example of influence, but it is not possible to determine the direction of that influence.

One other similar example of possible influence is to be found in Jer 48:30 and

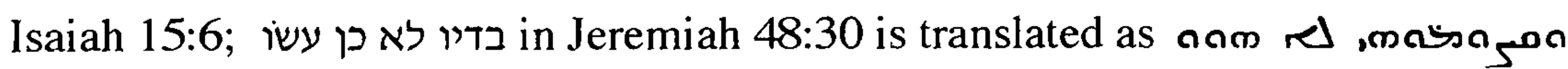
, and and the translation of Isaiah 16:6, where the Hebrew has no בתم רلתm, strongly resembles P-Jeremiah, with לא כן עשו equivalent of . Tha implication of this example is that the influence was not from PIsaiah on P-Jeremiah, but vice versa:: this suggestion would not fit with Beckwith's overall hypothesis concerning the order of translation, but would be compatible with the special circumstances noted in footnote (2) above.

There is a possible example of influence in the choice of lexical equivalence in

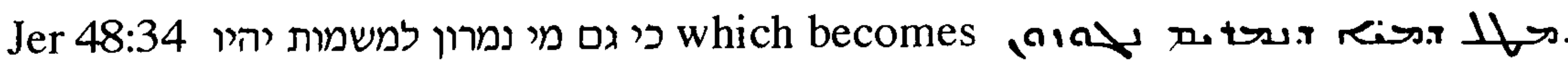
Isa כי מי נמרון משמות יהיו is identically translated.

This example must be considered for completeness, for the translation of root by root a "to be lacking" is unusual and used nowhere else in Jeremiah ${ }^{5}$ or in 
Chapter $3 \quad$ Duplicate Passages

Isaiah $^{6}$; but it is so likely that both translators independently selected this equivalence as particularly appropriate in the context of a failing water course that it is an unconvincing example.

\section{b. Jeremiah and Kings}

These duplicate passages are very long, and at some points, where the early verses of Jer 39 also tell the story, there are not two but three texts to consider. Some of the most interesting and informative points have been selected for detailed discussion below; because of the constraints of space, it has been necessary to select certain points as illustrations of general features, rather than noting each one individually.

In summary, there are many points which give evidence that one translation was not influenced by the other, and a small number which show the reverse. Where there is such influence, it seems usually to be from the Peshitta to Kings on the Peshitta to Jeremiah.

The approach to this long duplication is, outstandingly, not rigid: where he wished to incorporate an element from the work on Kings, the translator of Jeremiah did so, but far more often he preserved the differences between the Hebrew of these passages. Where the Hebrew is identical in both, the translations are so close that one or other must be a copy: this, however, as was noted earlier, is economy of effort rather than influence of one translation on another.

6. $1: 7 ; 5: 9 ; 6: 11 ; 13: 9 ; 17: 9 ; 24: 12 ; 33: 8 ; 49: 8,19 ; 42: 14 ; 52: 14 ; 54: 1,3 ; 59: 16 ; 61: 4 ; 62: 4$;

$63: 5 ; 64: 9$ 


\section{Chapter $3 \quad$ Duplicate Passages}

Independent translation of each passage is shown by

(i) precise rendering of passages of non-identical Hebrew

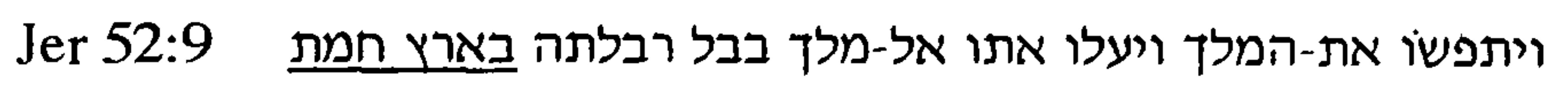

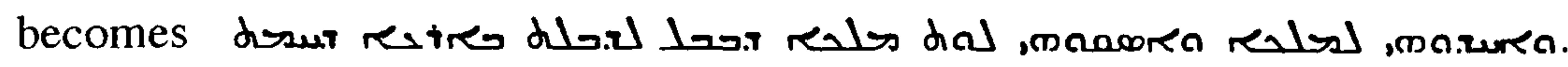

2 Kings 25:6 is identical except that it has no equivalent of בארץ חמת, and the difference is preserved in the translation: ויתפשו את-המלך ויעלו אתו אל-מלך בבל . becomes רבלתה

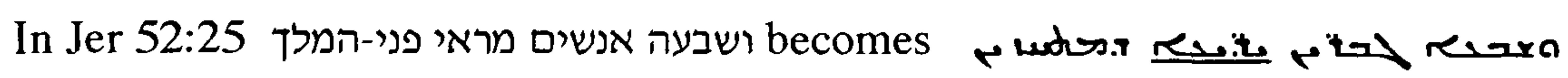

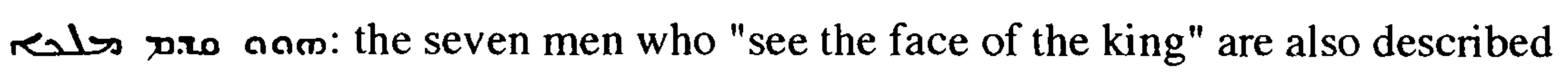
in the translation as "well-known". In 2 Kings 25:19, there are five men rather than seven, and no additional term enters in the course of translation: וחמשה אנשים مسבצer.

(ii) independent choice of lexical equivalents

There is a suggestion in this analysis that the translator of Kings is more likely to select a cognate than is the translator of Jeremiah: this is evident in three of the examples which follow.

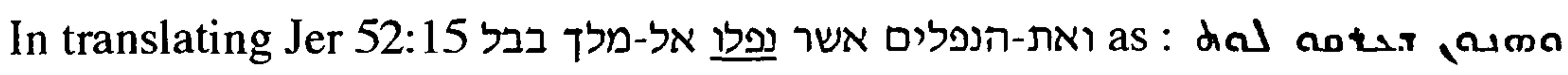
נפל in its sense "to desert" (B.D.B. p.657). In the virtually identical corresponding passage in 2 Kings $25: 11$ the translation is

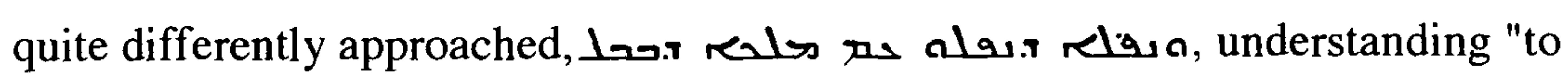
fall in violent death" (B.D.B. p.657) and relying on imitation of the form of the Hebrew.

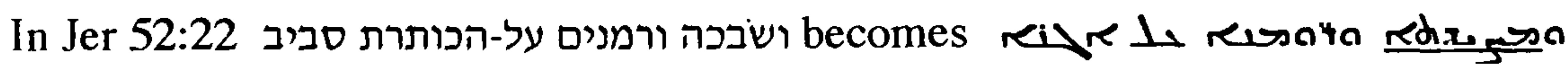

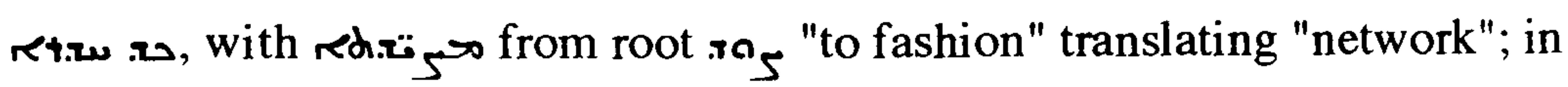

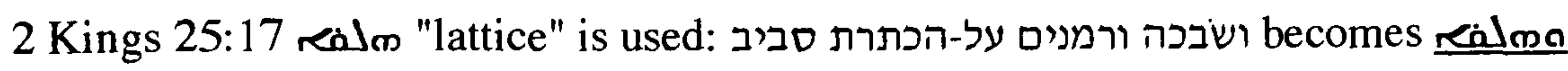

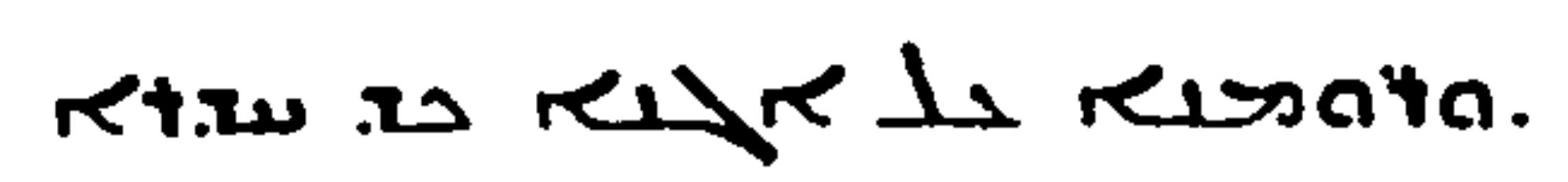


Chapter 3 Duplicate Passages

In Jer 52:25 פקד root s translated with root

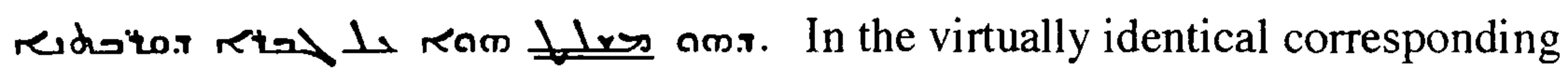

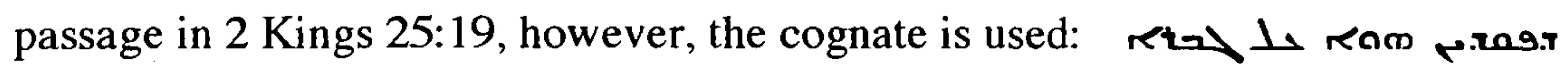
ridoto.

In Jer 52:32 and 2 Kings 25:28 וידבר אתו טבות is translated in Jeremiah as redzear mos, but in Kings with the cognate: rdit ars 11 so.

(iii) differing degrees of literalness

In some passages, the translation in Kings is more literal than that in Jeremiah. There is an addition intended to increase precision, in Jer 52:13 ואת בית המלך which is translated reram.r reals dealo; the identical Hebrew in 2 Kings 25:9 is simply translated: reals dealo.

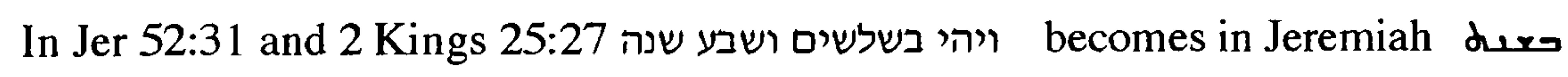

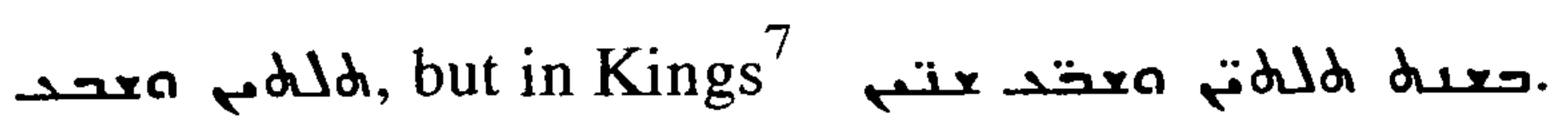

7. Jer 52:4 and 2 Kings 25:1 too have no representation of ויהי in the opening line:

$$
\text { ויהי בשנה התשעית למלכו }
$$

becomes mdarls sedis reduran, and is translated similarly in Kings, except that an ordinal is used there instead of the cardinal in Jeremiah. This omission is compatible with the translation policy in both books, so it does not constitute evidence of influence of either translation on the other: although in the oracular sections of Jeremiah the term is almost always translated, it is usually omitted in the narrative chapters. The term occurs 43 times within Jeremiah: in predominantly oracular chapters translated: $1: 3,4,11,13 ; 2: 1 ; 13: 3,8 ; 15: 16 ; 16: 1 ; 18: 5 ; 20: 3 ; 24: 4 ; 28: 1,12 ; 29: 30 ; 32: 26$; $33: 1,19,23 ; 34: 12 ; 35: 12 ; 43: 8$ (total 22$)$; not translated: $13: 6 ; 26: 8 ; 35: 11 ; 43: 1$ (total 4$)$; 
Chapter $3 \quad$ Duplicate Passages

Strikingly, in Jer 52:34 and 2 Kings 25:30 וארחתו ארחת תמיד נתנה לו becomes in Jeremiah, in a radical change perhaps indicating a guess, rom; in Kings the more literal translation is given: doresere rate mohatran m) dan ramads.

In contrast, there are other passages in which the translation in Jeremiah is the more literal:

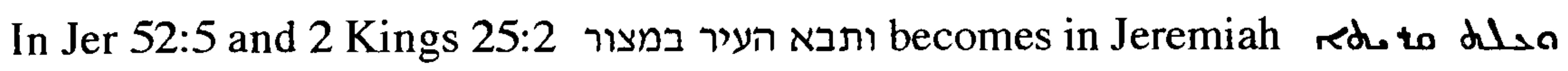
rsare, with a more idiomatic rendering in Kings: redo to dractron rstares.

Similarly, in Jer 52:22 and 2 Kings 25:17, Kings is more idiomatically translated: is rendered in Jeremiah וכאלה לעמוד השני Kings rewtre riass do gre resa.

Footnote from previous page contd.

in predominantly narrative chapters

translated: $36: 1,9,27 ; 37: 6 ; 42: 7$ (total 5); not translated: $36: 16,23 ; 37: 13 ; 39: 4 ; 41: 1,4,6,7,13 ; 42: 7 ; 52: 4,31$ (total 12)

Thus, it is translated in 22 of its 26 occurrences in predominantly oracular chapters, but in only 5 of its 17 occurrences in predominantly narrative areas. Showing a similar approach, in the primarily narrative text of 2 Kings, taking the last 43 occurrences in the book to match the 43 in Jeremiah, it is translated in only 12 :

not translated: $5: 7,8 ; 6: 5,20,24,26,30 ; 7: 16 ; 8: 3,5,15,21 ; 9: 22 ; 10: 7,9,25 ; 12: 7,11(10)$; $13: 21 ; 14: 5 ; 17: 25 ; 18: 1,9 ; 19: 1,37 ; 20: 4 ; 22: 3,11 ; 25: 1,25,27$ (total 31);

translated: $6: 25 ; 7: 18,20 ; 11: 3 ; 15: 5,12 ; 17: 3,7,28,32 ; 19: 35 ; 24: 1$ (total 12) . 
In Jer 52:31 נשא אויל מרדך מלך בבל בשנת מלכתו את-ראש יהויכין מלך-יהודה the

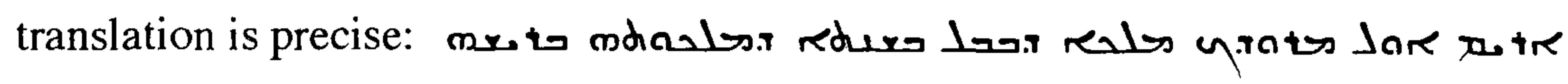

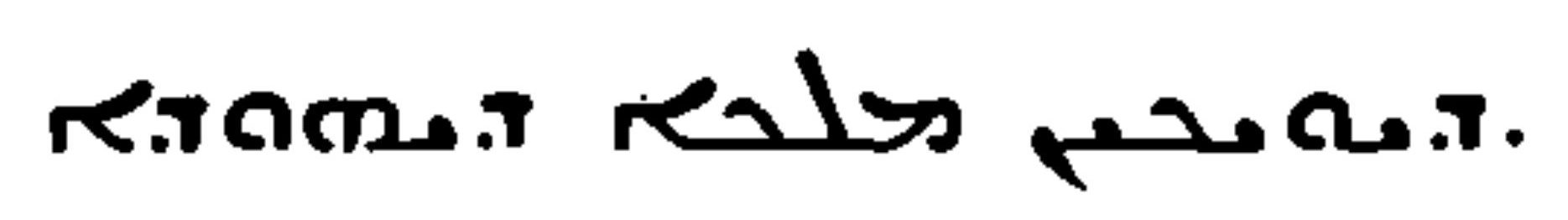

In contrast there is a helping addition in 2 Kings 25:27: Yants Jare potre

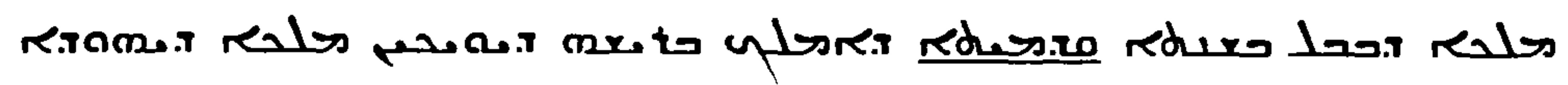

Influence of the translation of one passage on the other

(i) the use of an unusual lexical equivalent:

in Jer 39:1 there is a choice of lexical equivalent which at first sight strongly suggests influence from 2 Kings 25:1. The point is the translation of root in as mater root reted is the usual equivalent in Kings, selected at but one of the comparable passages ${ }^{8}$, but is used nowhere else in Jeremiah to translate this root used in this sense; so the possibility of influence of the translation of the Kings passage on that of Jeremiah at this point seems clear. On the other hand, however, it is possible that the translator of Jeremiah, knowing his text so well, was influenced by the phrase ויחנו עליה 52:4, and worked on 39:1 so as to assimilate it to that later account of the same episode.

There is another translation which strongly suggests influence from the Peshitta to Kings on P-Jeremiah, or vice versa, that of the difficult יגבים: in Jer 39:10 ומן העם הדלים אשר אין להם מאומה השאיר נבוזראדן רב טבחים בארץ יהודה

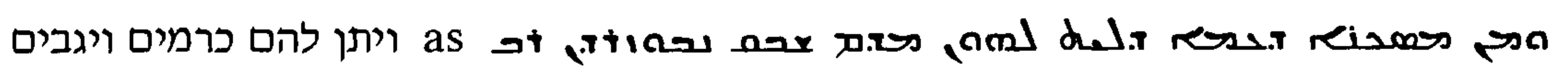
rit;

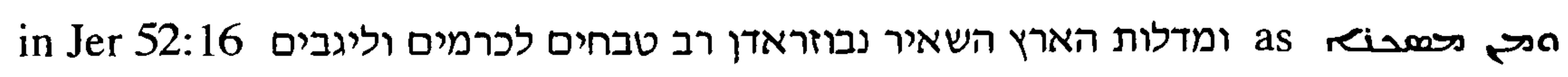

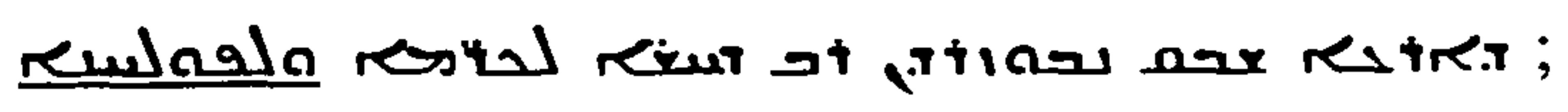
15:27 root 0 is used; in 2 Kings 16:5 the translation is imprecise. In Jeremiah, root $q$ is is used in $21: 4,9 ; 32: 2$; and 37:5. 


\section{Chapter $3 \quad$ Duplicate Passages}

and in 2 Kings 25:12 ומדלת הארץ השאיר רב-טבחים לכרמים וליגבים as משת 9. These translations are of great interest: not so much for the choice of the same root in both Kings and Jeremiah, for clearly the term must mean something similar to כרמים, so that a word for "work" of some kind is likely to be appropriate, and the frequently used root ald would be likely to fit the context well. The point which strongly suggests that one translation influenced the other is the use of the same form of the root, حصنr, in both books. depending on the pointing, could be either "vineyards" or "vine-dressers"; the Nestorian text of the Trinitarian Bible Society (Trinitarian Bible Society, 1852) vocalises as șị in 2 Kings 25:12 and Jer 39:10 (the pointing in Jer 52:16 is illegible), suggesting that the traditional reading was "vineyards". פماسك , then, could have meant either a parallel term, which here would have been "fields", i.e. that which was to be tilled, or "work, labour". Both meanings are attested, though only infrequently; the former is found at, for

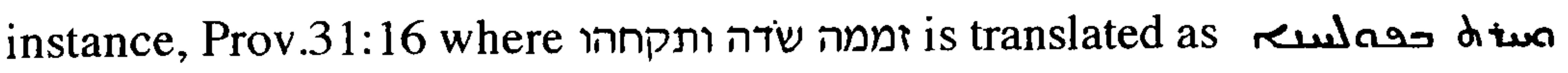
mdiain, and the latter at, for instance, Neh 3:5 where עבדת אדניהם is translated as

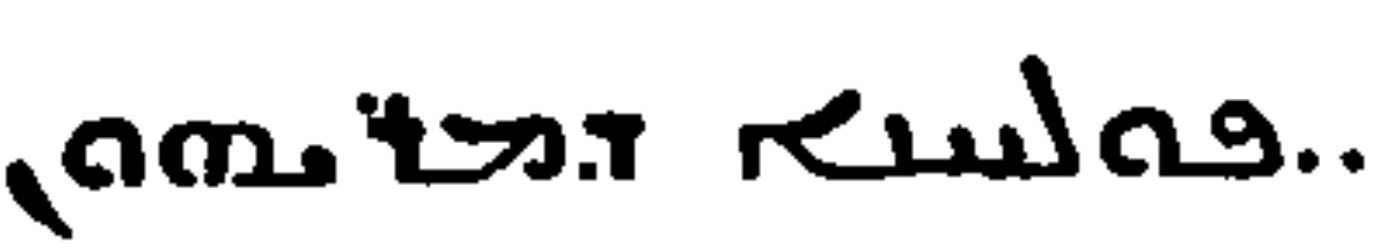

McKane (McKane, 1996, p.979) says that the Peshitta here agrees with Targum in attaching the sense "fields" 10 , though Targum מפלחין בחקלין ובכרמין is a little free and it is difficult to be sure exactly what was the translator's understanding of each individual word $^{11}$. The Targum does seem to agree well with McKane's

9. The Leiden edition of Kings (Peshitta Institute, 1976) gives rilala, not remala, in 2 Kings 25:12, noting that 6ph2 has rillo.

10. Costaz (Costaz, 1963) gives "fields" as a possible translation of rewa; Payne Smith does not give "fields".

11. Hayward (Hayward, 1987, p. 155) comments that the Targum here "makes what sense it can of a difficult word". 
suggestion (McKane, 1996, pp. 979-980) for the translation of MT here as "allocating vineyards and fields for them to cultivate", taking ויתן להם to mean "gave them the responsibility to cultivate" rather than "gave them ownership". In Qohelet 5:8 ויתרון ארץ בכל היא מלך לשידה נעבד which is translated in the Peshitta as

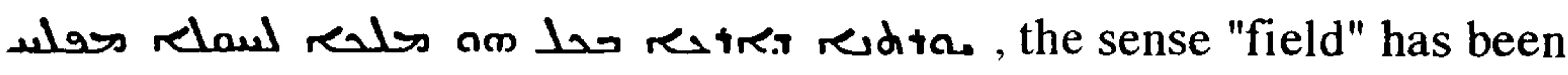
understood; Jastrow, however (Jastrow, 1992), cites this passage: ויתרון ומותר as support for his translation of פולחנות as "work, tilling".

In summary, there is clearly a strong possibility that one translation influenced the other in the choice of rewlion a the direction of influence is impossible to determine, but in view of the dependence of P-Jeremiah on P-Kings discussed above it is reasonable to suppose that this is also the case in this example ${ }^{12}$.

There is another inconclusive example of influence in the translation of Jer 52:4 and 2 Kings 25:1 where in rendering ויבנו עליה דיק סביב both passages have

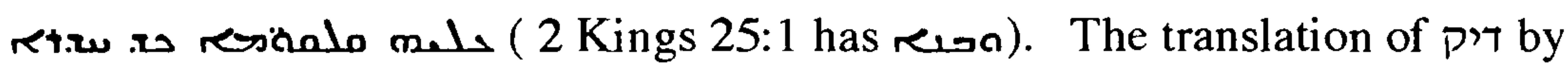
rsân مी is not consistent elsewhere in the Hebrew Bible: the term occurs only at four other passages, all in Ezekiel: 4:2;17:17; 21:27 (22); 26:8. ملمهم is given in Ezek 4:2, but roo.r at the other passages, suggesting that it would be the more usual equivalent.

(ii) Similar understanding in both passages of an area of difficult Hebrew There is one passage, Jer 39:4 and 52:7, 2 Kings 25:4, which seems at first sight to show that the translator of 2 Kings was influenced by P-Jeremiah; this is one of Walter's examples and was noted above in the discussion of the literature concerning duplicate passages. In translation the obvious gap has been filled, but not necessarily by recourse to the translation: the translator could easily have referred to the Hebrew Vorlage to find out what was missing. 
Chapter $3 \quad$ Duplicate Passages

There is a related example in the following verses:

Jer 39:5 וירדפו חיל-כשידים אחריהם וישגו את-צדקיהו בערבות ירחו ויקחו אתו

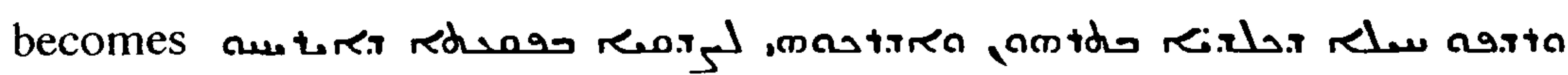

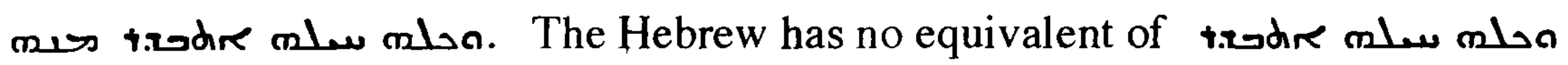

וכל-חילו נפצו 25:5; but the phrase does appear in both Jer 52:8 and 2 Kings

מעליו. Influence from the one of the other two translations is possible, but here

too the translator may have been influenced by the Hebrew Vorlage of those

passages rather than by the Syriac translation, and even in the absence of Jer 52:8

the example would not constitute strong evidence of influence of the translation of

2 Kings on that of Jeremiah.

In Jer 52:17 and 2 Kings 25:13 the almost identical Hebrew, respectively

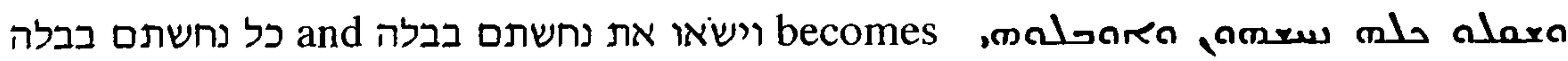

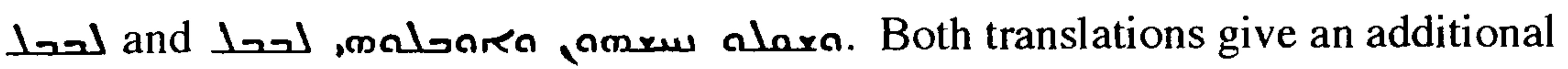
verb in, malanan. This is not conclusive evidence that one translation influenced the other, for the use of an additional verb to increase the precision of the translation has been seen in a number of examples shown in Chapter 2 and could well result from polygenesis.

There is strong evidence of copying in, for instance, Jer 52:8-10 and 2 Kings 25:5-7, and several other verses where both the Hebrew and the translations are identical. Identical Hebrew and identical Syriac does not constitute evidence of influence of one translation on the other, however, merely of reasonable economy of effort on the part of one or other translator.

\section{c. Jeremiah and Obadiah}

Independent translation of each passage

(i) precise rendering of passages of non-identical Hebrew

There is ample demonstration that the translations were independent of one another: differences between the content and order of the lines in the two MT 
Chapter $3 \quad$ Duplicate Passages

passages are preserved in the translations ${ }^{13}$ :

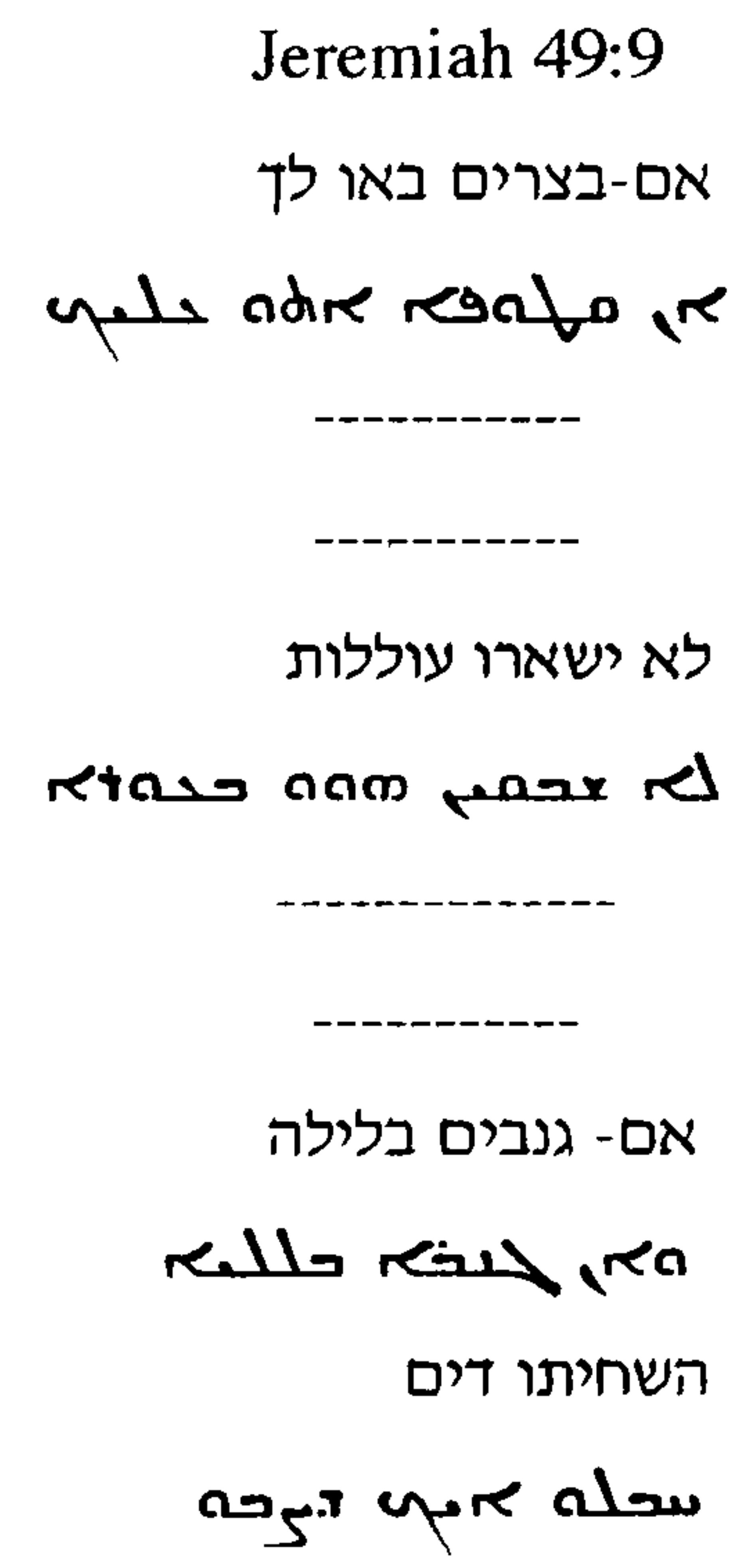

Obadiah 5

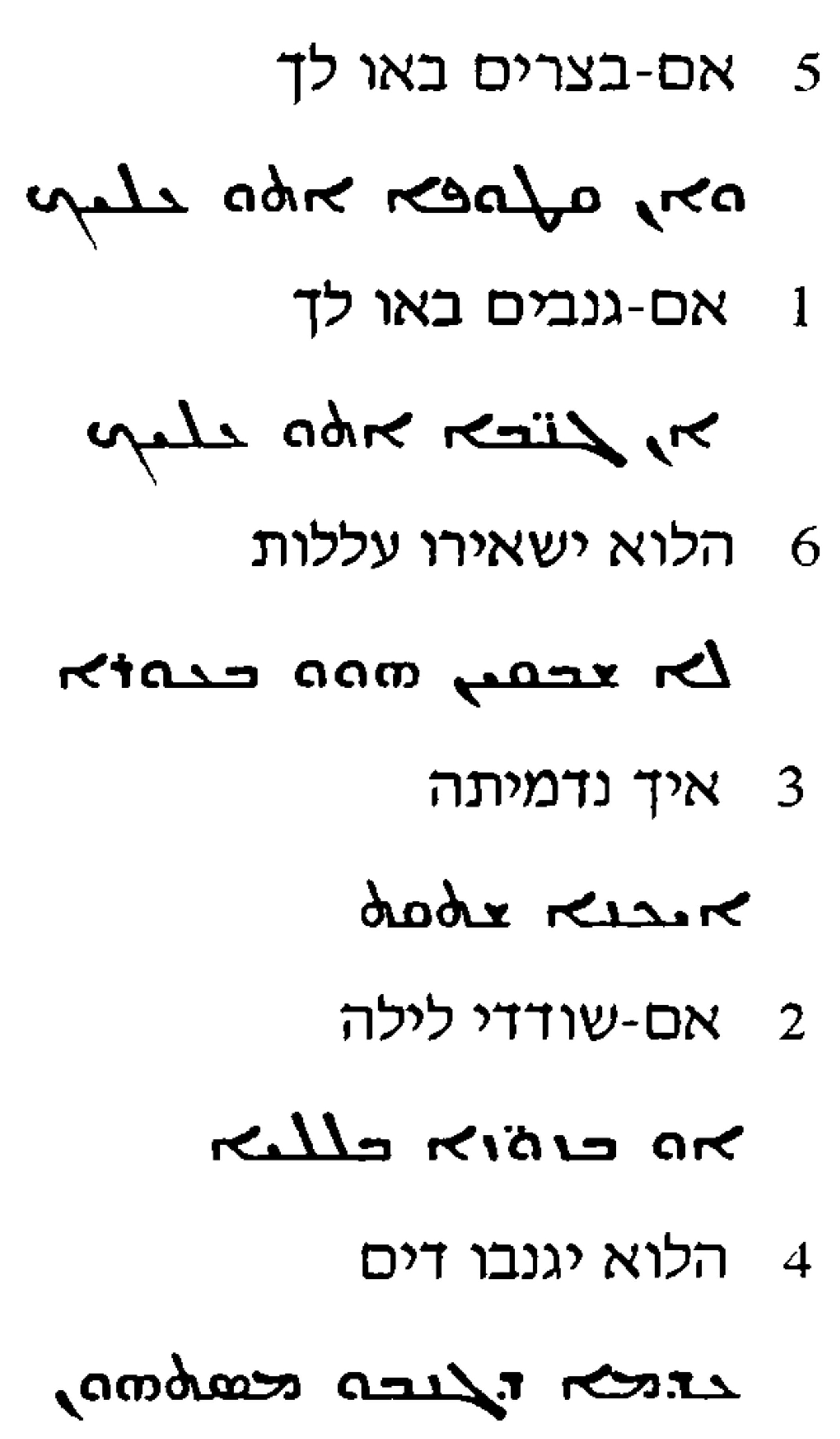

There is additional evidence of independence in the translations of other verses: in

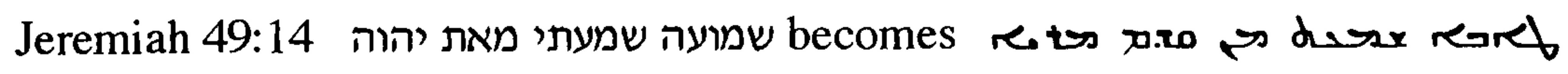

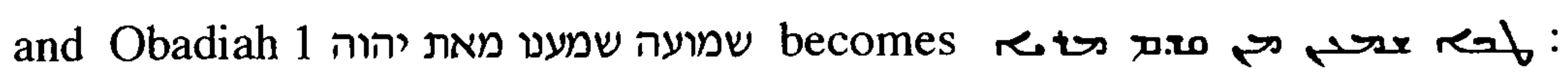

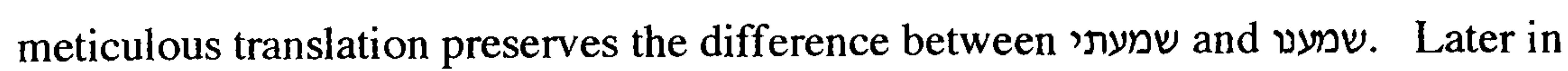

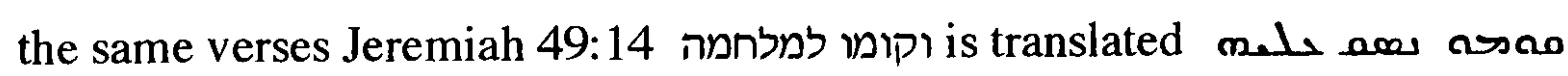
קומו ונקומו עליה למלחמה 1 ; the difference from Obadiahslated as

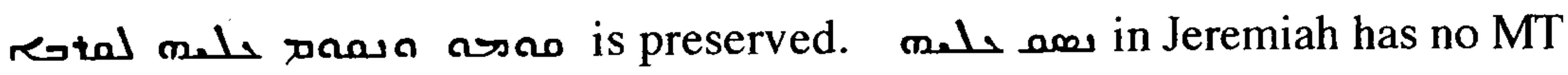
equivalent, and is probably simply an example of an addition similar to those discussed in Chapter 2.

In Jeremiah 49:15 and Obadiah בזוי אתה מאד and respectively are 2 בזוי באדם appropriately translated with Rere $\rightarrow$ dure in Obadiah.

13. The numbers against the lines of Obadiah show the MT order. 
Chapter 3 Duplicate Passages

תפלצתך השיא אתך occurs and is translated in Jeremiah 49:16, but does not occur in Obadiah and is not represented in the translation of Obadiah.

Jeremiah 49:14 includes התקבצו ובאו עליה, but there is no equivalent in Obadiah 1; nor is there a translation in either book. On the other hand, מרו

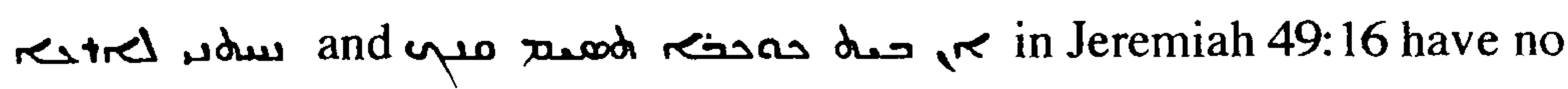
equivalents in the Hebrew. It could be argued that both these discrepancies result from the influence of the Obadiah text on that in Jeremiah, if there were sufficient evidence of influence of one translation on the other to support the suggestion. In that argument, התקבצו ובאו עליה is not translated in Jeremiah simply because it is absent from Obadiah; and אמר בלבו מי יורידני ארץ is represented in Jeremiah because it is present in Obadiah. This is possible, and it is also possible that the translator worked on Jeremiah from his slightly imperfect memory of Obadiah; but it is also possible that the independence of these two translations is the true picture and that these apparent discrepancies really represent the Vorlagen, a point to be developed below and in the next chapter which deals with minuses in the Peshitta.

(ii) independent choice of lexical equivalents

Jeremiah 49:16 and Obadiah 3 זדון לבך השיאך שכני בחגוי הסלע almost identical in

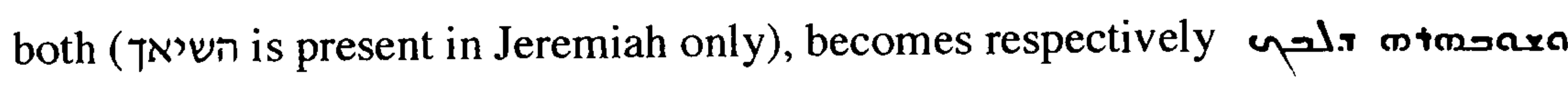

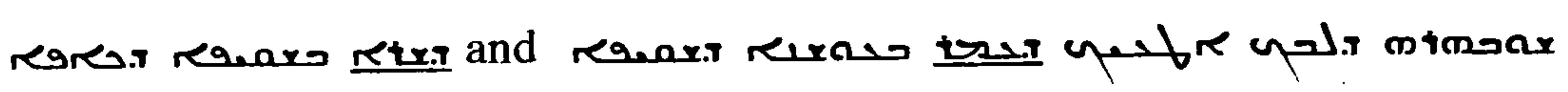
using root retr in Jeremiah and ts in Obadiah, and translating with the precise regax in Jeremiah and the figurative reras in Obadiah.

Influence of the translation of one passage on the other

(i) The choice of lexical equivalent:

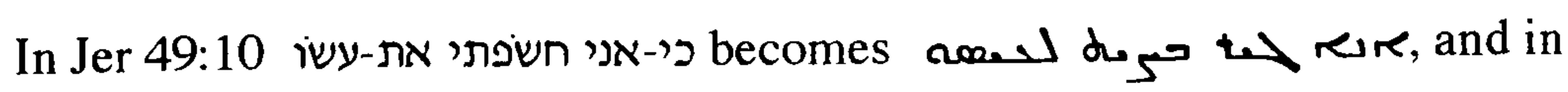

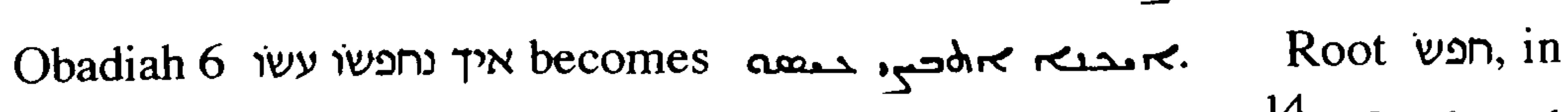
comparable senses, is consistently translated with root $r_{5}{ }^{14}$. On the other hand, 
three different roots in its four occurrences in Isaiah: Is 20:4 and 52:10 ris; 30:14 9 47:2 ad. The choice of the same root, $r_{5}$ "search into, inquire" to translate both חשש "strip off, strip, make bare" and "search" suggests though it does not prove influence of Obadiah on Jeremiah: the translator of Jeremiah was uncertain as to the best rendering of root qun, and went to Obadiah for help, a somewhat similar process to that referred to by Weitzman in which the translator, puzzled by a given Hebrew word, found a verse in another book where that same word occurred, but adopted instead the Syriac rendering of not that word but of another in the same verse.

\section{Possible differences between the Vorlage and MT}

In view of the body of evidence suggesting that the translations of duplicate passages are largely independent of one another, it is possible to make some suggestions concerning the wording of the Vorlagen:: the degree of consistency of the translation technique is such that major differences between MT and the Peshitta may well indicate differences between the Vorlage and MT.

Some passages at which there are terms present in the Hebrew of one member of the pair but not in the other, but where the translations are identical, so that there is apparently an addition to the translation of one of the passages, have been discussed above. Such additions may show the use of the Hebrew of one passage to allow the translator to fill a gap in the sense of the other; they may also result from deliberate harmonisation: Chapter 2 included a number of examples showing how the translation of a given verse may have been adapted to bring it into line with that of another.

14. There is one exception, in Psalm 64:7, where the search for a synonym to render יחפשו עולת led to the use of wמנו חפש מחפש in one occurrence. There is another less relevant exception in Prov. 28:12 (11) where the translation is imprecise. 
Chapter 3 Duplicate Passages

Harmonisation cannot, however, explain the opposite picture, points at which the Hebrew has a phrase in both members of the pair but the phrase appears in only one of the passages in translation.

For instance, take the oracle against Moab in Numbers 21 and Jer 48: the closest verses are Numbers 21:28 and Jer 48:45

Jer 48:45

בצל חשבון עמדו מכח נסים

כי-אש יצא מחשבון

s

ולהבה מבין סיחון

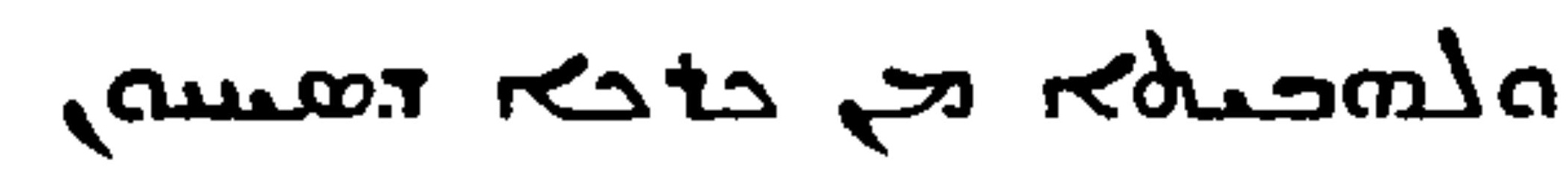

ותאכל פאת מואב

sress mdireg Jadira
Num 21: 28

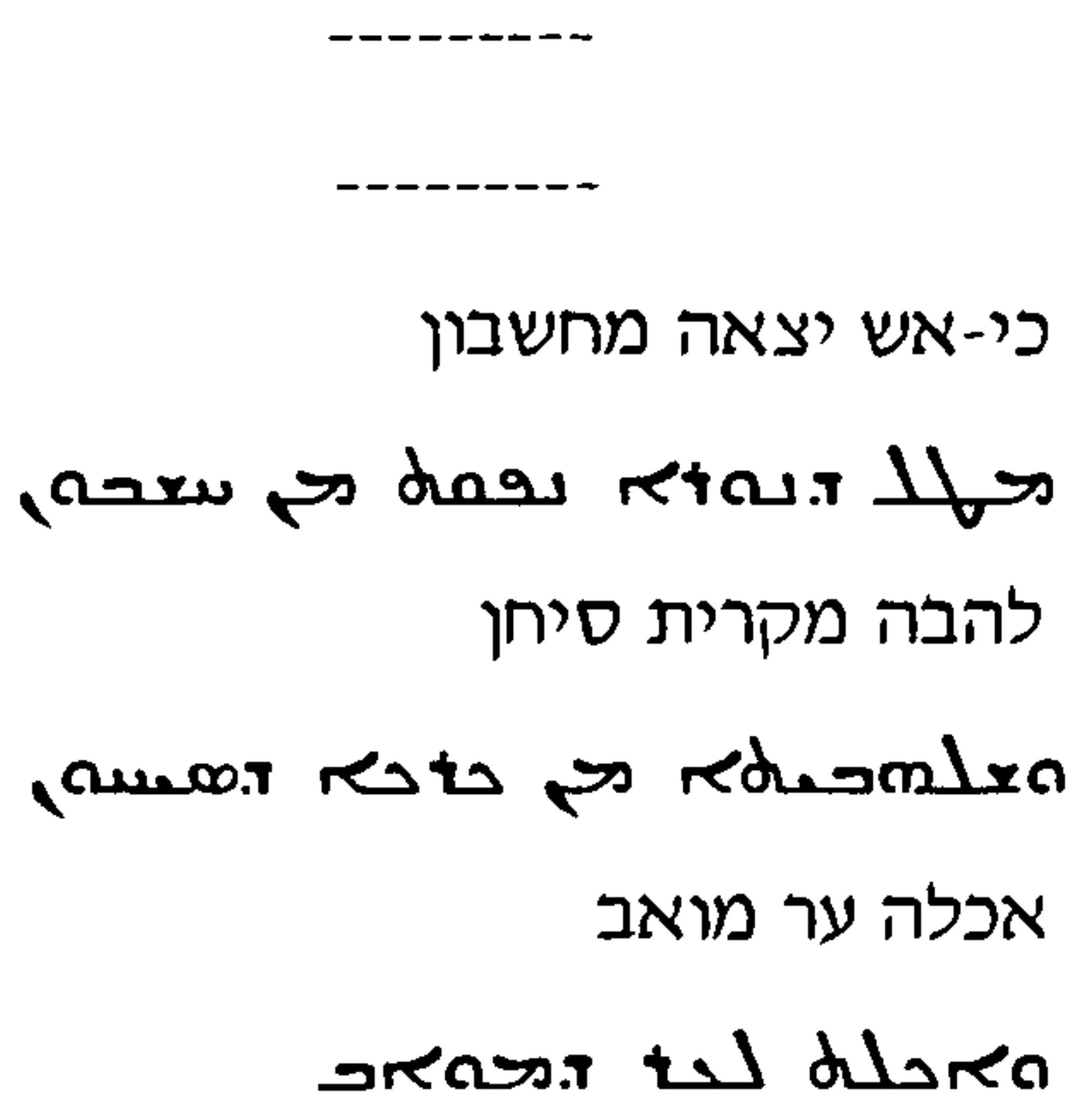

There is no equivalent in the Hebrew of Numbers of Jer 48:45a בצל חשבון עמדו , מכח נסים, nor is the phrase translated into Syriac in Jeremiah. This is a complex problem: McKane (McKane, 1996, pp.1196, 1197) suggests that the omission of this line from the Peshitta is simply a solution to the difficulty of translating it, and of course this is a possibility, though as will be shown in Chapter 6 that would be an unusual approach to the translation of a difficult passage. Another possible explanation for the lack of a Syriac translation of בצל חשבון עמדו מכח נסים in Jeremiah might be that the translator reached this part of Jeremiah, recognised the verse which he knew well from the Pentateuch, and reproduced the Syriac rendering from there, carelessly failing to check that the Hebrew of the two verses was exactly the same rather than approximately the same ${ }^{15}$.

15. This would be a somewhat similar process to that described by Greenberg for the translation of 2 Samuel 22 and the duplicate in Psalm 18. Here, the Peshitta in Samuel appears to have been translated from the Psalm, a sequence which could not be accommodated in 
Chapter 3 Duplicate Passages

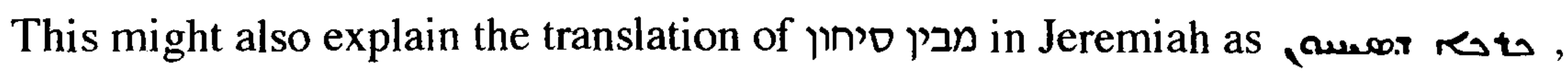
less appropriate than in Numbers where it translates קרית סיחן. Clearly S cannot be coincidental; this is the only occurrence in the Pentateuch of rev to translate any word for city. McKane (McKane, 1996, pp.1197-1198) argues that מבין, מבית wT as a corruption of which was itself a variant of קרית, citing evidence from 2QJer and three Hebrew mss., and that the translator has assimilated $v .45 \mathrm{~b}$ to Num 21:28.

The translation in Jeremiah is not simply a copy of that in Numbers: for instance, the differences between ותאכל פאת מואב in Jeremiah and אכלה ער מואב in Numbers are preserved; so it is reasonable to suggest that these are independent translations and that, at the stage when P-Jeremiah was written, בצל חשבון עמדו מכח נסים was absent from the Vorlage and that this rather than influence from Numbers explains its absence from the Peshitta.

Footnote from previous page contd.

Beckwith's hypothesis (Beckwith, 1985, p.309). The reconstruction suggested by Greenberg, and accepted by Weitzman, is that the translator working on 2 Samuel came to Chapter 22, recognised in it the psalm which he knew and loved, and preferred on the whole to work from the text of the psalm. When the translator of Psalms reached Psalm 18 he simply took, almost without emendment, the work of his colleague in 2 Samuel. Thus the translation of the psalm was used twice, and there never was a translation written for 2 Samuel 22. 
Chapter $4 \quad$ Minuses

The Causes of Minuses in the Peshitta to Jeremiah

There is so much of interest to be learnt from an analysis of the minuses in the Peshitta of Jeremiah that the subject merits a chapter to itself, and was therefore not included in the analysis of translation technique which was presented in Chapter 2.

In total, minuses in this text are fairly common: there are thirteen in the 186 sense units of the sample of tenth verses, an overall prevalence of approximately $7 \%$. Minuses will be considered in the present chapter in three principal groups.

\section{(i) Minuses which are apparently accidental}

The least interesting, since they throw no light on the translator's motives and attitudes, are those apparently due to error. Nonetheless, these will be discussed first because their prevalence gives useful background information against which to assess the other two groups. There are three minuses in this category in the sample, in $27: 10 ; 35: 10 ; 38: 10$.

\section{(ii) Minuses apparently made deliberately}

Minuses apparently made deliberately by the translator are themselves divisible into two classes:

a. those which conform to aspects of the translation technique presented in Chapter 2, for instance the drive for precision and clarity, or simply to conform to the translator's personal preference. There are four minuses in this category in the sample, in 2:10, 14:10;16:10, 29:10.

b. those which were made deliberately in the translation of passages of particularly difficult Hebrew. There are two minuses in this category in the sample, in 5:10 and 20:10.

(iii) Minuses which throw light on the wording of the Vorlage

Minuses which throw light on the wording of the Vorlage are the most interesting of the three groups. These examples in this group do not prove that the Peshitta 
gives a unique insight into the history of MT, an insight not obtainable from study of any other witness, for the strongest evidence to be presented below is based on a combination of data from both the Peshitta and LXX. Nonetheless, they do show clearly the contribution which Peshitta study may make to this area of textual criticism. There are four minuses in this category in the sample, in $27: 10 ; 34: 10 ; 41: 10 ; 52: 10$.

\section{The value of the Qumran evidence}

There are few firm points on which to base discussion of the causes of minuses, and the fragments found at Qumran, in Caves 2 and 4, form one such point: the evidence they provide is indirect rather than direct, but nonetheless strong. The Qumran material affords "a vertical cross-section view of the transmission of the Bible text" (Talmon, 1964, pp.98-99) and the insight into the textual history of the book of Jeremiah gained from study of these fragments makes not only a quantitative but a qualitative contribution to the strength of the present argument concerning the insight given by minuses into the wording of the Vorlage.

The importance of these fragments in this context lies in their demonstration that, at the time when the documents were deposited, at least two forms of the book of Jeremiah were extant. The literature is extensive; publications by Cross, Tov, Janzen, Bogaert, and Soderlund (references are set out below at appropriate points) cover the points which are relevant for present purposes, namely the dating of the manuscripts, their relation to one another in terms of transmission, and the aims of their editors.

There are four manuscripts or collections of fragments which are relevant here, three from Cave 4 and one from Cave 2. These are $4 \mathrm{QJer}^{\mathrm{a}}, 4 \mathrm{QJer}{ }^{\mathrm{b}}, 4 \mathrm{QJer}{ }^{\mathrm{c}}$, and 2QJer. These have been dated, on the basis of comparison of variants. palaeographic evidence, and in some instances carbon dating, as follows: $4 \mathrm{QJer}^{\mathrm{a}}$ to the third century B.C.E. (Cross, 1975 (ii), pp.156-157); 4 QJer ${ }^{b}$ (Cross, 1975 (iii), p.308) to the Hasmonean period; 
$4 \mathrm{QJer}^{\mathrm{c}}$ (Cross, 1975 (iii), p.308), to a date no earlier than the end of the first century B.C.E.;

2QJer (M.Baillet et al.,1962, p. 62) to the first century C.E.

The documents represent:

4 JJer $^{\mathrm{a}}$ (Ulrich et al., 1997, p.145 ${ }^{1}$ ): 7:1-2, 15-19, 28-9:2; 9:7-15; 10:9-14², 23; $11: 3-6,19-20 ; 12: 3-7,13-16,17-13: 7 ; 13: 22$ ? $27 ; 14: 4-7 ; 15: 1-2 ; 17: 8-26$;

$18: 15-19: 1 ; 20: 14-18 ; 21: 1$ ?; 22:3-16; 26:10?.

4QJer ${ }^{\mathrm{b}}$ (Ulrich et al., 1997, p.171 ${ }^{3}$ ) : 9:22-10:21, which has minuses at some points discussed below.

$4 \operatorname{QJer}^{\mathrm{c}}$ (Ulrich et al., 1997, p.177) : 4:5, 13-16; 8:1-3, 21-9:5; 10:12-13; 19:8$9 ; 20: 2-5,7-9,13-15 ; 21: 7-10 ; 22: 4-6,10-17,17 ?-28^{5} ; 25: 7-8,15-17,24-26$; $26: 10-13 ; 27: 1-3,13-15 ; 30: 6-9,17-31: 4 ; 31: 4 ?-14,19-26 ; 33: ? ; 33: 16-20$

4QJer ${ }^{\mathrm{d}}$ (Ulrich et al., 1997, p.203): 43:2-10

4QJer ${ }^{\mathrm{e}}$ (Ulrich et al., 1997, p.206): 50:4-6

1. Janzen (Janzen, 1973, pp.173-181) gives a slightly different list: 7:29-9:2 (most of this section is missing); $9: 7-14 ; 10: 9-14 ; 11: 3-6 ; 12: 3-6 ; 12: 13-16 ; 12: 17-13: 7 ; 14: 4-7 ; 15: 1-2$; $17: 8-26 ; 18: 15-19: 1 ; 22: 4-16$.

2. this is of particular interest because it relates to the difference between this text and that of $4 \mathrm{QJer}^{\mathrm{b}}$.

3. Janzen (Janzen, 1973, p. 173), gives a slightly different list: 9:22-10:18; 43:3-9; 50:4-6; the difference here is due to the controversy concerning the attribution of $4 \mathrm{QJer}$, d, and $\mathrm{e}$ to the same or different hands. Tov (Tov, 1989, p.191) has argued on the basis of the handwriting and other scribal habits that three different hands are represented and that the siglum $4 \mathrm{QJer}^{\mathrm{b}}$ 
2QJer (Baillet, 1962, pp. 63ff): mainly fragments only of passages from chapters $42-44$; 46-49, i.e. 42:7-11; 43:8-11; 44:1-3, 12-14; 46:27-47:7; 48:7, 25-39.

$4 \mathrm{QJer}^{\mathrm{a}}$ and 4 QJer ${ }^{\mathrm{c}}$, and 2 QJer, correspond to the the book of Jeremiah as it appears in MT; $4 \mathrm{QJer}^{\mathrm{b}}$ is closer to the form of the book in LXX; the two principal differences between these forms of Jeremiah, that is length and structure, are both detectable on study of the Qumran fragments. The most striking feature of $4 \mathrm{QJer}^{\mathrm{b}}$ is the absence from the fragment of any equivalent of MT-Jeremiah 10:6-8, 10, verses which are also absent from LXX-Jeremiah, and in the order of these verses which is $1-5 a, 9,5 b, 11-12$, resembling that in LXX rather than that in MT. In chapter 43 too, the shorter text of LXX is reflected: for instance, in verses 4,5 , and 6 attributes of proper nouns and other phrases which are given in MT are lacking from the fragment : minuses from MT which the Qumran fragments share with LXX are: 43(LXX 50):4, 5 בו קרח; 43(LXX 50):5 מכל הגוים אשר נדחו שם (Tov, 43(LXX 50):6 (i), 1985 (i), p.213 nn.9, 10).

In contrast, accepting published reconstructions, other fragments closely resemble MT. For instance, using the reconstruction of Baillet et al.of material from Cave 2 (Baillet et al., 1962, p.63), in 42(LXX 49):9 the fragment reads: כוה אמר יהוה אלוהי ישראל אשר שלחתמה אותי אליו להפיל תחנותיכמה לפניו : : the terms from are present in MT but are absent from LXX. There is also evidence here that the MT order of chapters is that of 2QJer: chapter 47 follows chapter 46 in 2 QJer (here p.65), though in LXX the sequence is different, representing

Footnotes from previous page contd.

should be reserved for one only, the others being called $4 \mathrm{QJer}{ }^{\mathrm{d}}$ and $4 \mathrm{QJer}{ }^{\mathrm{e}}$; similarly, Ulrich et al. belicve that $4 \mathrm{QJer}{ }^{\mathrm{d} \text { and } \mathrm{e}}$ are distinguishable from $4 \mathrm{QJer}^{\mathrm{b}}$ (pp.203, 206). There is some persisting disagreement on this point, not relevant here.

4. Tov (Tov, 1981, p146) lists only: fragments only of chapters $8 ; 19-22 ; 25-27 ; 30-33$

5. The apparent repetition of $v .17$ is due to there being different parts of the verse in different parts of the mss. 
chapter 47 following immediately after chapter $51^{6}$.

These differences between LXX-Jeremiah and MT-Jeremiah have of course long been known. In 1862 Graf (Graf, 1862, p.xliii) published a detailed analysis of the differences between the LXX and MT texts of Jeremiah which combine to produce the difference in length: he found that LXX-Jeremiah is shorter than MTJeremiah by one-eighth, approximately 2700 words, this considerable difference being made up mostly of individual words and phrases ${ }^{7}$, though there are some slightly longer passages.

The difference in order of the chapters in LXX-Jeremiah and MT-Jeremiah has been much discussed, and it is generally agreed that the order in LXX is likely to be the original. Tov (Tov, 1985 (i), p.217 n.23) notes two verses in support of this argument: first, 25:13 והבאותי על הארץ ההיא את כל דברי אשר דברתי עליה את כל , and argues that this makes sense only if the oracles against the nations follow immediately. This is a fair point, though perhaps not quite so unarguable as Tov implies, for there is reasonable sense in the MT sequence in which this verse is immediately followed by כי עבדז בם גם המה גוים רבים ומלכים נוס גדולים ושלמתי להם כפעלם וכמעשה ידיהם, and then by the verses concerning the היין.

6. Careful comparison of $2 \mathrm{QJer}$ and MT and LXX, however, shows that the relationship is complex. For instance, in 47(LXX 29):4 (see Chiesa, here pp.267,268) MT reads להכרית, represented also in the Peshitta והכרתי 2QJer, in contrast, reads LXX kai áqavic̃. It is not impossible that the first person form in $2 \mathrm{QJer}$ and LXX is the original, such is the tolerance of MT for grammatical inconsistency between various parts of the one verse, but in this context: על היקם הבא לשדוד את כל פלשתים להכרית לצר ולצידון כל שריד עזר כי it is more probable that the MT form is the original. The implication is that the first person form was present in the Vorlage used for LXX, and represents a variant in common with $2 \mathrm{QJer}$.

7. For instance, Graf notes (pp.xliii, xliv) that the phrase נאם-להוה occurs in 64 more passages in MT than in LXX, that the divine titles include צבאות 56 more times in MT than in LXX, and that Nebuchadrezzar is named 36 times in MT but is referred to by title only in LXX in 23 of these passages. 
Tov also points out that 25:15 כה אמר יהוה אלהי ישראל אלי קח את כוס היין החמה הזאת מידי והשקיתה אתו את כל הגוים אשר אנכי שלח אותך אליהם, which follows these oracles in LXX, forms a suitable conclusion to that collection; this too is a reasonable suggestion, though it could well be argued that the whole of 25:8-38 would form a good introduction to the foreign oracles, rather than a conclusion. Much of the literature on these two forms of Jeremiah is concerned with their relationship, that is whether the short form represents an abbreviation of a longer Vorlage by the writer of LXX, or the longer form represents an expansion of a short Vorlage in the process of development of MT. There is a good deal of evidence suggesting that the translator of LXX was in general unlikely to abbreviate to any significant extent ${ }^{8}$, but in the light of the Qumran findings the focus must in any case be moved earlier in history, to the stage of development of the two families of the Hebrew book rather than the time of the first translation

8. For instance, there is close agreement between the short text of LXX, particularly with respect to proper nouns, and MT of 2 Kings 24- 25, in contrast to the differences between LXX and MT for Jeremiah 52, the parallel chapter. MT-2 Kings 25:18 provides an example: שריה

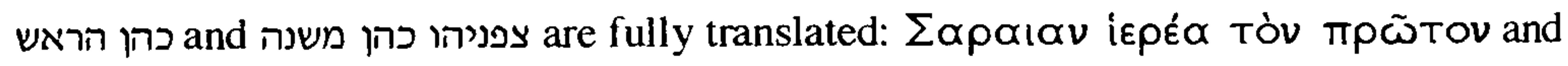

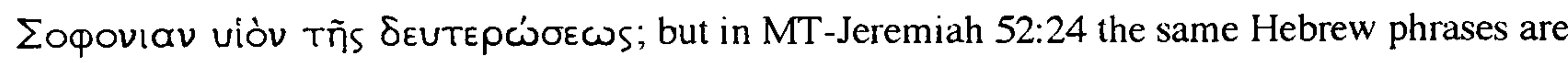

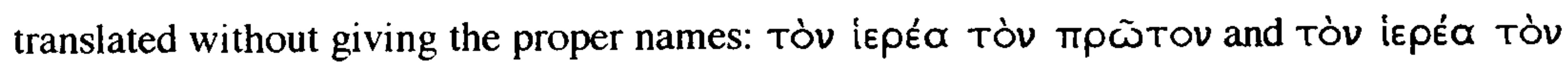

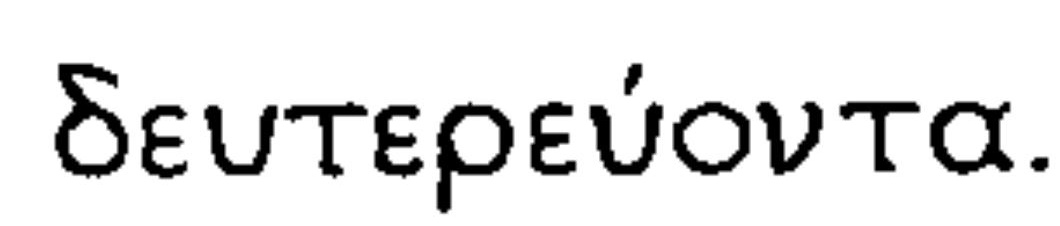

The impression is strengthened by comparison of LXX with the Qumran fragments, where the clear impression is that the translator was unlikely to have made many omissions. For instance, in 43(LXX 50):6, 7 reproduced in Tov (E.Tov, ibid., here p.326) את הגברים ואת הנשים ואת הטף ואת בנות [המלך ואת כל הנפש אשר הני]ח נבוזרדן את גדליהו בן אחיקם ואת ירמיהו הנביא [ואת ברוך בן נריהו ויבאו א]רץ מצרים כי לא שמעו בקול יהוה [ו]יבאו תחפُאחס

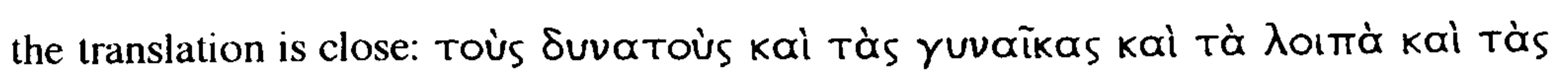

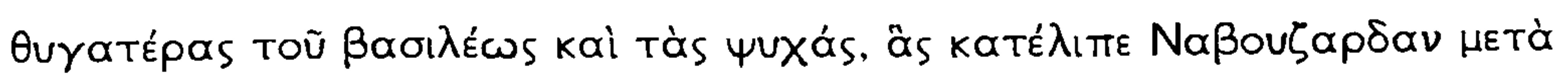

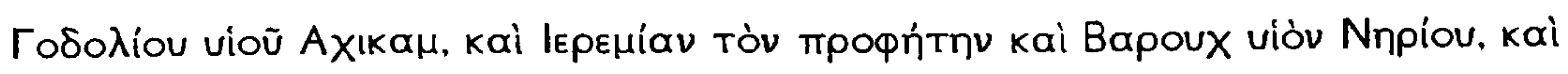

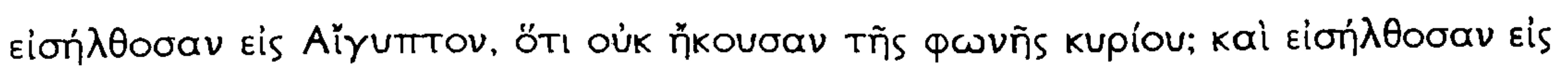
Taquas. 
into Greek. The evidence that there were the two Hebrew forms of Jeremiah together in the Qumran collection at the very least strongly suggests that LXX was made from a short Vorlage, and not by a translator abbreviating a longer Vorlage such as that represented by MT. McKane (McKane, 1986, p.217) says "There can be no doubt that in Sept. we encounter the Hebrew text at an earlier point in its history than we do in MT, and that MT has been reached by a process of piecemeal aggregation".

However, the general principles raised in discussion of the probability that a scholar working with a biblical ms. would abbreviate or expand his Vorlage remain relevant, even though the scholarly activity concerned is likely to be that of a scribe or editor working in the line of transmission of the Hebrew before the time of the translation, for there are still three possibilities:

(i) there was an original short form of the book which was translated into Greek; also, one or more mss. of this form were expanded to form a longer document which was the basis of MT;

(ii) there was an original long form which was the basis of MT, one ms. of which was abbreviated by editors to form the Vorlage of LXX;

(iii) there were two unrelated documents, one longer and one shorter, from the first.

The third possibility seems unlikely, for the reader of LXX and MT is in no doubt that these are different forms of the same book; the differences are many,

Footnote from previous page contd.

Here, the names of the fathers of Gedaliah and Baruch are given in the Qumran document and translated into Greek, with no omissions. Comparison of MT with LXX at first sight suggests that LXX has omitted details elsewhere: LXX represents simply נבוזרדן, leaving the office unstated, whereas MT at this point has נבוזראדן רב-טבחים; and LXX represents simply גדליהו בן אחיקם גדליהו בן אחיקם בן שפן. In both respects, however, LXX exactly represents the Qumran fragment. There is thus no good evidence, in those few points at which comparison is possible, suggesting that the translator into Greek readily omitted terms from his Vorlage. 
but in essence unimportant and of detail only. The expansion is literary rather than thematic, largely rhetorical elaboration, though Bogaert (Bogaert, 1994, p.403) suggests that whereas the original form of the book may have been "La Vie et les Paroles de Jérémie selon Baruch", in the development of the longer text the emphasis was shifted away from the role of Baruch towards the MT presentation of Jeremiah as the author of the book as a whole rather than of the oracles alone.

Decision as to which of the other two possibilities is the more likely depends on comparison of the acceptability of expansion or of abbreviation as components of translation technique of a biblical text. A decision to omit any part of a text from a translation would be expected to be more difficult than a decision to add to the text: there is a psychological gulf between attempting to improve a translation, particularly a biblical translation, by making restricted additions, and deciding that any word of the original is superfluous and should be excised. Majority opinion indeed agrees with the first possibility, that there was an original short form of the book which was translated into Greek and of which one or more mss. were also expanded to form a longer document which was the basis of MT. This school of thought is well represented by Janzen (Janzen, 1973); a major proponent of the second possibility is Soderlund (Soderlund, 1985). These discussions focus on the work of the translator, rather than on the earlier stage which the Qumran evidence shows to be the important time, but the principles are nonetheless relevant to the present discussion. Janzen believes that LXX represents a translation which was largely accurate, argues (p.9) that texts are more likely to grow than to contract in transmission despite the frequency of haplography, and shows that LXX does not usually condense (n.32, pp.190,191). He gives in support of his general argument (n.35, pp.191-192) examples of secondary expansion from textual criticism of, for instance, the Iliad, the Gilgamesh Epic, and Egyptian mortuary texts.

Soderlund, on the other hand, argues that it is unwise to generalise from the "three small fragments" (p.196) which make up 4QJer ${ }^{\mathrm{b}}$, that each point must be 
taken on its merits, and gives in support of his belief that LXX represents a contracted ms. some instances of "condensation" from the Gilgamesh Epic, classical texts, and possibly from the Ras Shamra literature (pp.200-202). The balance of the evidence, showing that the short Hebrew form of the book, with the components arranged as in LXX, was present in the Qumran collection, strongly suggests that the Janzen school of thought is correct: MT developed by gradual expansion of a shorter ms. with a different emphasis. The importance of this conclusion in the context of minuses in the Peshitta of Jeremiah is the light it throws on the value of retroversion in the attempt to establish the Vorlage. In general, it is impossible to rely on retroversion as a method of reconstructing a Vorlage with certainty, for all the factors on which conclusions are based are interdependent: textual criticism of the MT may be supported by study of the Versions; use of the Versions in textual criticism must be founded on an appreciation of the techniques favoured by their translators; and understanding of these translation techniques must be based on comparison of the Versions with MT. The translator's technique and corruption during transmission may both operate, the first deliberately and the second accidentally, to result in a Version which differs not only from MT but from the Vorlage.

There are of course numerous published discussions of the difficulty of using retroversion in this way; for example, Driver (Driver, 1913; p. xxxviii) and Aejmelaeus (Aejmelaeus, 1987, p. 60) combine textual criticism of MT with analysis of the translation technique and proceed to an assessment of the probable integrity of the translation. Goshen-Gottstein (Goshen-Gottstein, 1963, pp.130-158, particularly pp.133-134) discusses some of the dangers of retroversion, pointing out (p.133) the hazards of subjectivity and the difficulty of avoiding this trap.

The arguments in the literature concerning the use of retroversion from LXX in establishing the form of the Vorlage are of course largely applicable to retroversion from the Peshitta. Weitzman (Weitzman, 1994, pp.52-54) shows that even where the agreement of two Versions on any individual point seems at first sight to give substantial evidence as to the wording of the Vorlage, such correspondence may also result from influence of one translation on the other, or 
the independent reflection of common exegetical tradition, showing polygenesis rather than textual connection. Polygenesis may also operate to give two similar but independent Versions if, faced with a passage of particularly difficult Hebrew, translators into Greek and Syriac both decided to omit the same word or even phrase, deciding that by doing so they could reach reasonable sense without moving too far away from the Hebrew. Similarly, both translators, dealing with a passage of repetitive Hebrew, might have decided to abridge their translation, for the sake of clarity or of literary impact.

Despite these inevitable difficulties in interpretation, since the evidence suggests that MT developed gradually by expansion of an earlier shorter form, retroversion at passages where both the Peshitta and LXX have minuses, particularly where textual criticism suggests some complexity in the Hebrew, may plausibly indicate areas where the gradual expansion of the original short form had not reached the MT stage at the time when the Peshitta was written. Three principal types of mss. are postulated here: LXX represents a development of the original short form of the book; the Peshitta shows a longer, still proto-MT stage; and MT has been further expanded from the stage represented by the Peshitta. The suggestion is supported by the nature of MT at the points where some, though not all, of the minuses common to LXX and the Peshitta occur. A substantial proportion are found at areas of MT where the Hebrew is complex, and where the complexity is of a nature which could be due to processes liable to occur during transmission, for instance secondary textual expansion, the incorporation of doublets, or dittography. Albrektson (Albrektson, 1978, pp. 59ff) points out that, rather than representing the result of deliberate unification of a text, and including those variants which were judged to be superior, the MT may simply represent one text which, as a result of extraneous events, happened to be the sole survivor of a number of editions: accepting this argument, it is one of those editions which the Peshitta seems to represent ${ }^{9}$.

9. The principal argument against this suggestion, based on the accepted understanding of the relative dates of the establishment of MT and the translation into Syriac, was discussed in Chapter 1. 
There are of course other possible explanations of minuses at which the Peshitta and LXX agree against MT: one is polygenesis at passages where the term in question is unclear or apparently superfluous, to be discussed below. The possible influence of LXX on the translator, or on the revisers, of the Peshitta presents a more difficult problem: it could be argued that in passages at which the Peshitta and LXX agree against MT they do so not because these two Versions were made from Vorlagen which were similar at those points but because the Peshitta was sometimes written, and sometimes revised, so as to correspond with LXX. Those working on the Peshitta might well have found the style of the Lucianic revision, in particular, one which they wished to emulate; for instance, the Peshitta and the Lucianic revision have in common the tendency to explicate detail, and the latter was made early enough to have influenced the early editors, even if not the translators (Barthélemy, 1963, pp.126-127).

This is a possibility which cannot be disproved, but against it is the preponderance of passages at which the Peshitta differs from LXX and agrees with MT, showing clearly that there was no systematic attempt to bring the Syriac Version into line with the Greek.

Janzen's work is valuable here, although his interest was in LXX only and he hardly refers to the Peshitta, for study of the Peshitta translation of the double readings which Janzen identifies shows clearly that this is the work of a translator who did not lightly omit terms present in his Vorlage. Janzen (Janzen, 1967; 1973) has identified more than forty double readings. The term "double reading" is taken here as in Janzen's definition (Janzen 1967, p.434): readings which combine variants from two or more manuscripts" arising from "more or less systematic collation of divergent text traditions", or from "ad hoc comparison of manuscripts, or scribal memory of an alternative reading", or through misreading (Janzen, 1967, e.g. p.437 n.12); Janzen suggests that where double readings do not occur purely accidentally, the motive behind their development is often the concern to ensure that the correct reading of the passages is not lost to the text tradition. Talmon too discusses the development of variants (Talmon, 
1964, p.100) either from the incorporation into the main text of marginal or intralinear corrections or annotations, or from the scribe's deliberate effort to preserve each of two textual traditions.

Janzen's examples include for instance 1:15 כי הנני קרא לכל משפחות ממלכות צפונה which has apparently arisen through the deliberate conflation of two variants; 2:17, 18 בעת מוליכד בדרך ועתה מה לך לדרך מצרים, which seems to result from a corrupt dittography;

and graphic difficulties such as that in 23:27 החשבים להשכיח את עמי שמי where and $v$ seem to have been confused.

In most of Janzen's examples, LXX represents one component of the doublet only, but the Peshitta represents both, giving a valuable insight into the attitude of the translator. A translator anxious to defend the originality of his Vorlage, and having in mind the critical reader who might find grounds for suspicion in apparently purposeless repetitions suggesting the possibility of underlying deliberate conflations or scribal error, might make omissions to avoid such controversy, particularly if he did not regard himself as bound by the constraints of working with a letter-perfect text. Nevertheless, when translating double readings the translator into Syriac gave both components ${ }^{10}$, although his careful

10. One further point of great interest raised by comparison of LXX and Peshitta at these points is a possible difference between the representation of doublets occurring in the oracles against the nations and that in other parts of the book: in the foreign oracles, there are some instances where LXX represents one component of a doublet and the Peshitta represents the other, rather than giving both components as is usual. The comparative scarcity of such examples in the book as a whole, together with the presence of three in chapters $41-44$, suggests a difference between the transmission history of the oracles against the nations and the other parts of the book: possibly, whereas the expansion of the oracles against the Israelites and the narrative chapters had progressed to a stage at which both components were included by the time the Peshitta was written, the expansion of the oracles against the nations was at an earlier stage. Those writing the Peshitta had a pre-amalgamation ms. to work from. This suggestion would be compatible with the theory that the oracles against the nations circulated separately from the rest of the book at some stage (see for instance Janzen 1973 p.115), but is made only tentatively since the supporting evidence is scant. 
reading of the Hebrew must often have led him to suspect the presence of secondary expansion of the text, and a glance at LXX would in many cases have strengthened his suspicion that the Vorlage showed signs of corruption. This translator, however, evidently valued literalness above such concerns, a particularly interesting finding in the light of the discussion in Chapter 2 which showed that when he judged it was appropriate to break the constraints of quantitative literalism he was ready to do so: indeed, in the Peshitta to Qohelet the translator not only breaks these constraints but does so sometimes by including more than one way of rendering an underlying Hebrew phrase (Lane, 1979, pp.487-489) ${ }^{11}$.

Against such a background, any minuses are of great interest. As in the earlier chapters, the most interesting examples are discussed in detail here, but because of the restrictions on space, some of the less informative minuses could not be considered individually.

The analysis depends heavily on comparison with LXX, although of course the many factors involved produce a complex picture and the evidence is rarely conclusive. Such is the importance here of comparison with LXX that examples will be subdivided according to their relation with that text:

those where LXX, in those passages where the texts are sufficiently close for comparison to be possible, agrees with MT against the Peshitta: it does not have a minus but represents all the relevant terms of MT;

those where LXX agrees with the Peshitta against MT, but the improvement in clarity resulting from the minus is so obvious that the two translators could well have made the same decision independently of one another, through polygenesis;

11. Lane notes the alternative possibility, that these doublets resulted from later attempts to assimilate the text to other Hebrew interpretations, but argues in favour of the suggestion above (Lane, 1979, 487-489). 
Chapter $4 \quad$ Minuses

those where LXX agrees with the Peshitta against MT, and the minus is of a kind compatible with its having occurred during the transmission of the text; and those where the texts of LXX and MT differ so much that comparison with LXX to determine whether the latter agrees with MT or with the Peshitta is impossible.

\section{(i) Minuses which are apparently accidental}

Minuses have been considered accidental if:

a. they do not seem to have been introduced in conformity with the translation technique, that is they do not improve the clarity or precision of the text, or the grammatical cohesion, nor do they seem to have been intended to harmonise one verse with another;

b. in those passages where comparison is possible, the lacking term is present in LXX;

c. there is no textual difficulty in MT suggesting that there may have been textual corruption.

There is a particular problem raised by minuses which seem to be due to haplography: although haplography may occur simply when the eye is distracted by two words which look similar, it also occurs where the text includes a major repetitive component. Some of the latter passages may have resulted from scribal error in the transmission of the Hebrew. In these cases, where there has been dittography in the Hebrew text at a stage later than the translation of the Peshitta, the minus is "apparent" with reference to the Vorlage, but "true" with reference to MT. There is an unavoidable subjective element in classification here: so far as possible, examples of simple haplography have been attributed to error and are discussed in the present section, but those occurring at points where there is reason to postulate that there was textual corruption during transmission of the Hebrew are discussed in (iii) Minuses which throw light on the wording of the Vorlage. 
In a section dealing with accidental omissions trivial examples only would be expected, and most of those which follow are indeed minor.

ואתה אל-תתפלל בעד-העם הזה ואל-תשא בעדם רנה ותפלה ואל-תפגע-בי 7:16

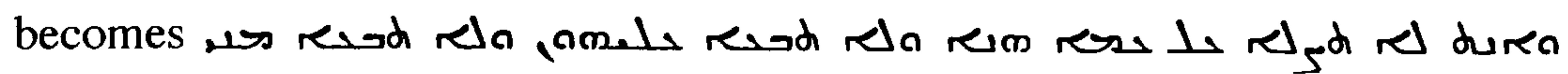

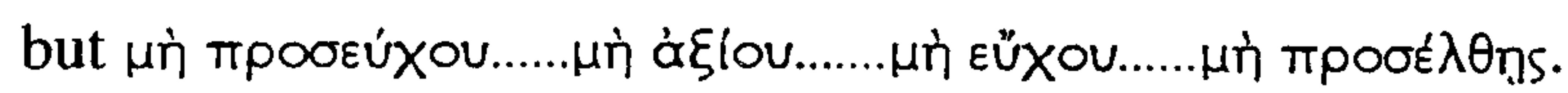

In the Hebrew, and LXX, four terms are used to proscribe three activities: Jeremiah is not to pray for this people, nor to cry to God on their behalf, nor to pray for them, and not to intercede with God for their sake. In translation, however,neither רנפלה nor no representedwith one reference only to prayer. Not only is this an important and striking verse, but it is closely similar to 11:14 where there are also two references to prayer: ואתה אל-תתפלל בעד-העם הזה ואלתשים, and all terms are translated: תשא בעדם רנה ותפלה

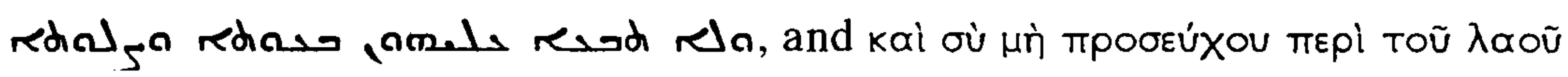

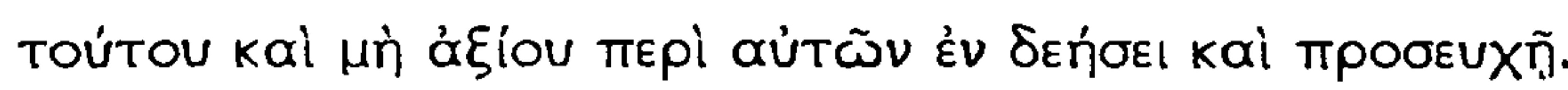

The minus seems particularly likely to be due to error when considered in the light of the increased emphasis on prayer which seems to be a feature of the Peshitta to Jeremiah, discussed in earlier chapters; a deliberate omission here would be inconsistent with that policy.

18:7, רגע אדבר על גוי ועל ממלכה לנתוש

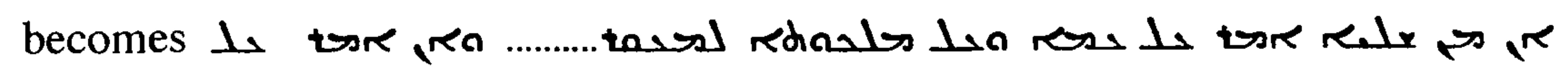

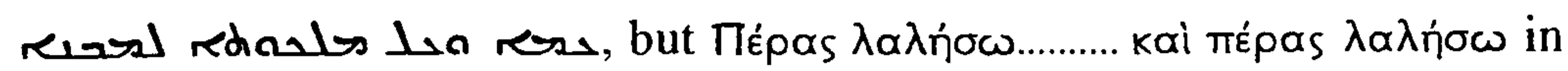
LXX. The first "רגע", in v.7, is translated in the Peshitta, but not the second in $v .9^{12}$. 
Chapter $4 \quad$ Minuses

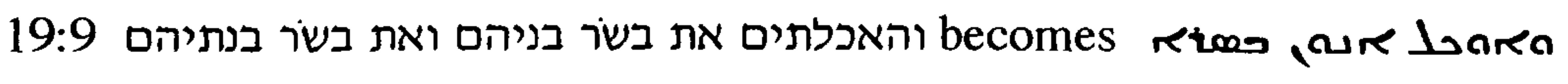

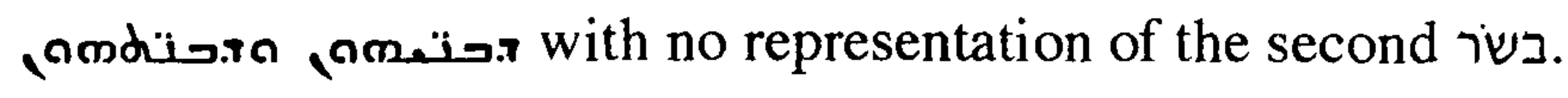

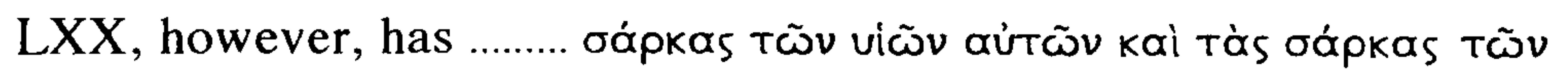

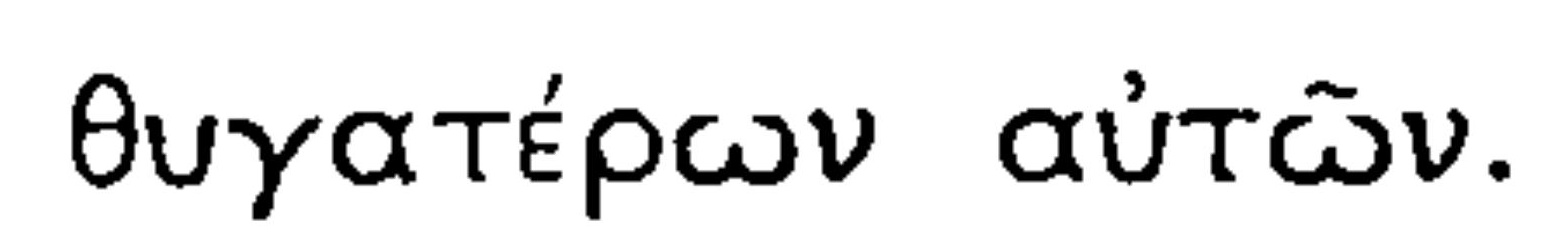

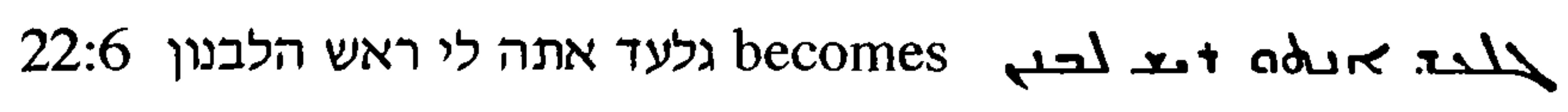

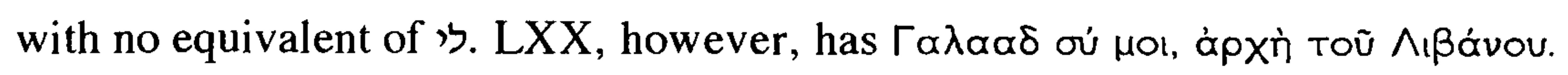

את יכניהו בן-יהויקים מלך-יהודה ואת-שרי יהודה ואת-החרש ואת-המסגר מירושלם 24:1

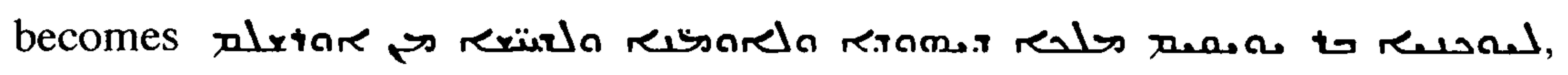
with no representation of שרי יהודה, possibly having been lost by haplography with מלך-יהודה. LXX, however, has .......... kaì toùs å̃pxovtas.....

ושלח יהוה אליכם את כל עבדיו ...... ולא שמעתם ולא הטיתם את אזנכם לשמע becomes ולא שמעתם with no representation of

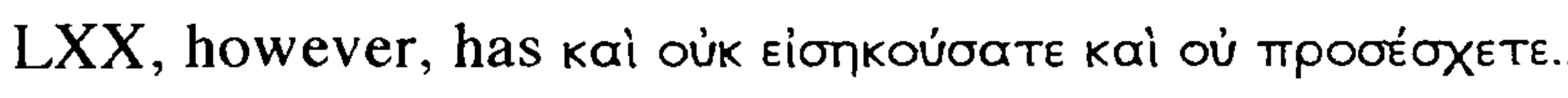

27(LXX 34:13):16 ואל הכהנים ואל כל העם הזה דברתי לאמר כה אמר יהוה becomes resthesentation of דברתי לאמר. LXX has a slightly different form, but does not have this minus:

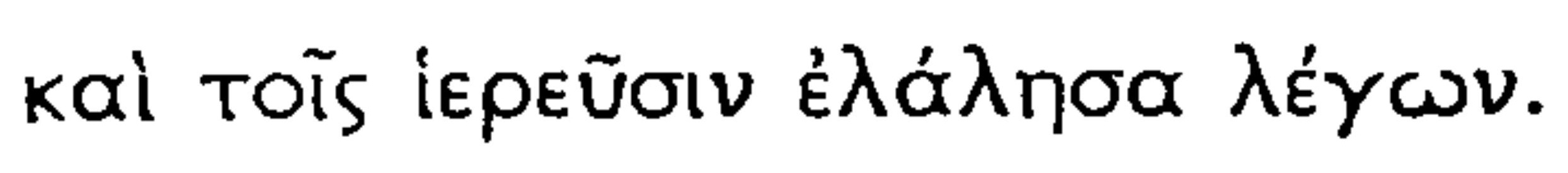

34(LXX 41):2

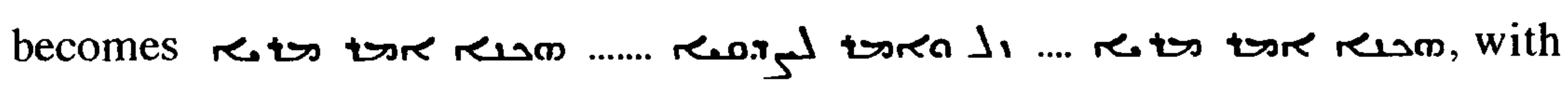
no representation of ואמרת אליו. LXX, however, has ......... kai épeĩs đưtū........

12. The "crossed equivalent" here is noted in Chapter 2. 
Chapter $4 \quad$ Minuses

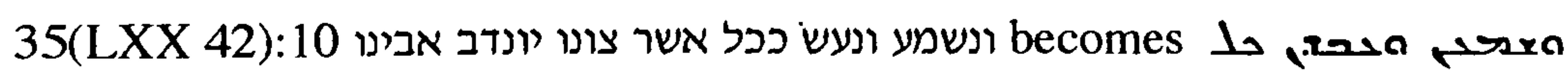

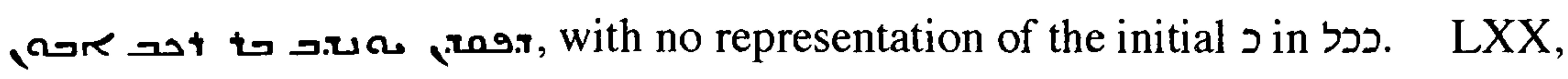
however, has

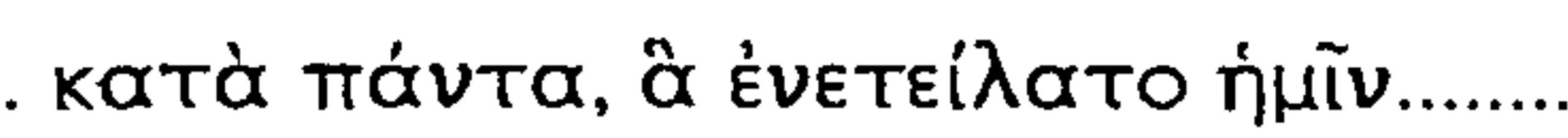

38(LXX 45):22 והנה כל-הנשים אשר נשארו בבית מלך-יהודה מוצאות אל-שרי מלך בבל ית becomes restat dal

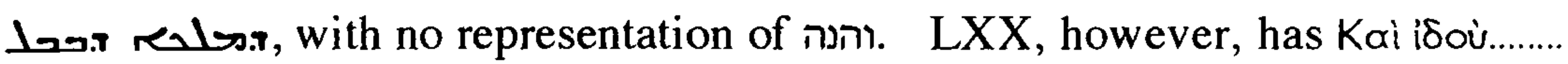

42(LXX 49):2 The epithet in רמיהו הנביא is not represented in the Peshitta

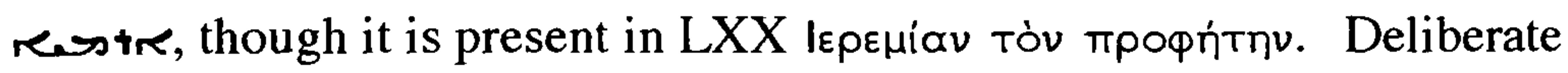
omission of an epithet is inconsistent with the translation technique seen in Chapter 2.

42(LXX 49):2 והתפלל בעדנו אל יהוה אלהיך בעד כל השארית הזאת כי נשארנו מעט מהרבה

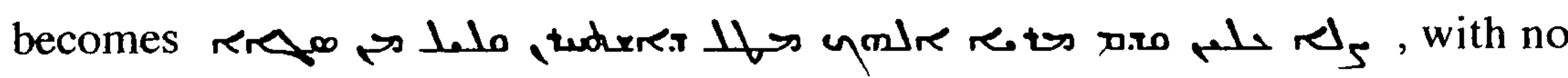

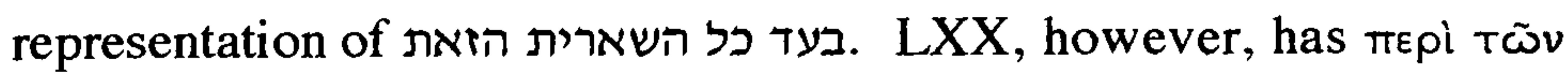

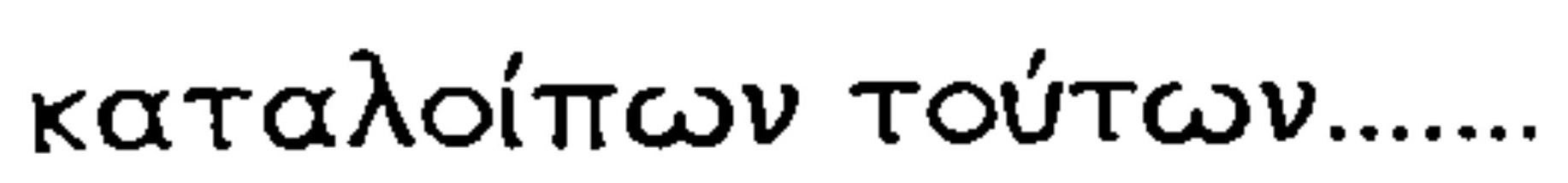

42(LXX 49):5 יהי יהוה בנו לעד אמת ונאמן אם לא ככל הדבר אשר ישלחך יהוה אלהיך

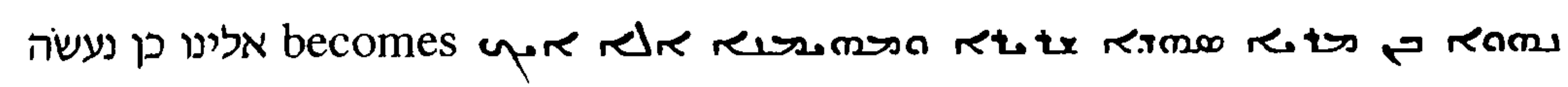

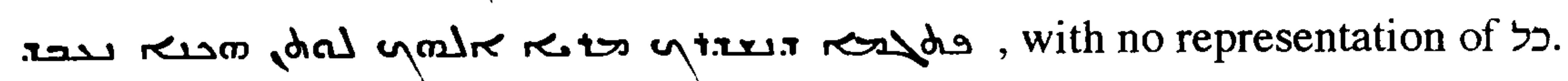
LXX, however, has

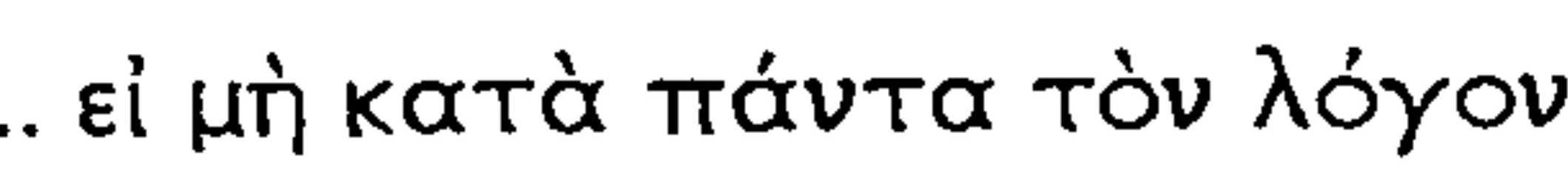

48(LXX 31):20 הילילי וזעקי הגידו בארנון כי שדד מואב becomes

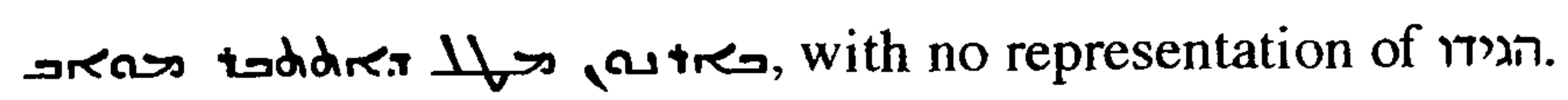

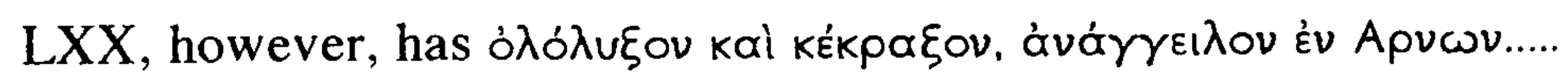

48(LXX 31):36 על כן לבי למואב כחללים יהמה ולבי אל-אנשי קיר-חרש כחלילים יהמה

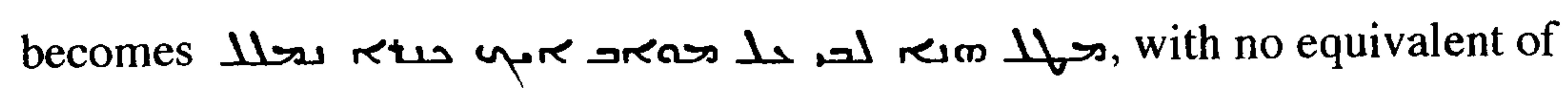
to כחללים יהמה probably as a result of eyeskip from יהמה ולבי אל-אנשי קיר-חרש

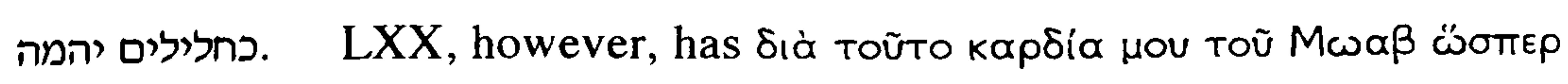

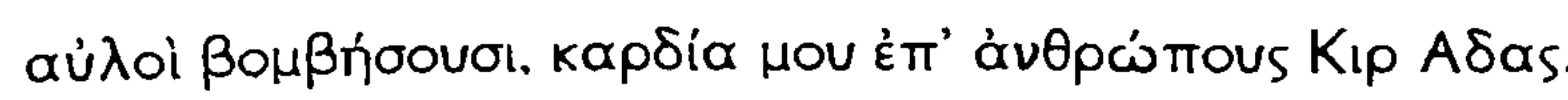


Chapter $4 \quad$ Minuses

48(LXX 31):37 כי כל ראש קרחה וכל זקן גרעה על כל ידים גדדת ועל מתנים שن

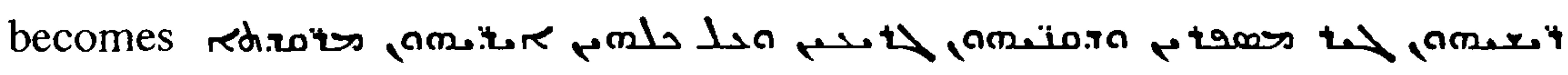
"כל" This seems unlikely to be error, but is classified here because there is no apparent reason why the difference would have been introduced deliberately, and it is not

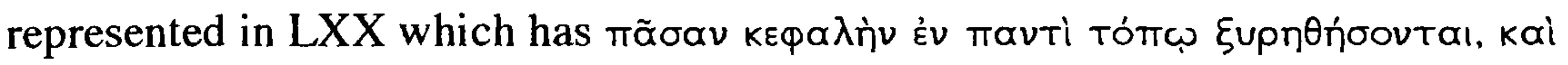

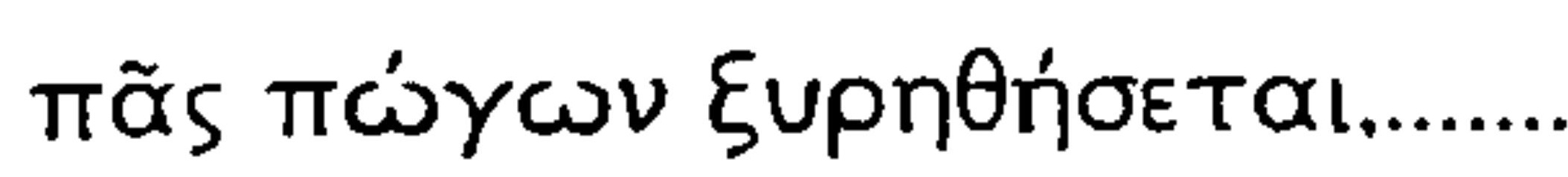

48:25-39 is discussed by Baillet et al. (Baillet et al., 1962, p.66) who give the following reconstruction of verse 37: כיא כול רואש] קורחה וככו]ל [ז]קן תגר[ע] [על כול

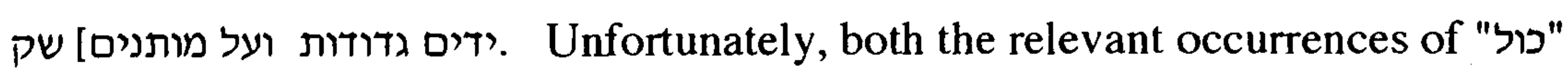
are largely in the reconstructed sections, though of course the presence of the lamedh of the second implies that the remaining letters were also there in the original text.

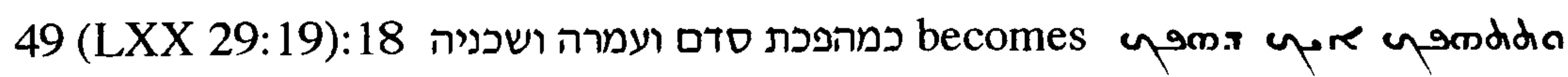

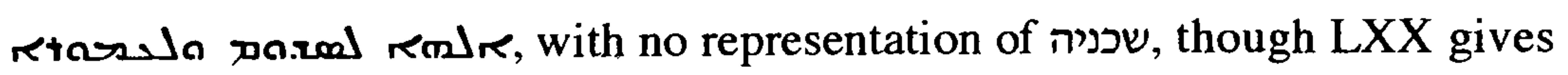

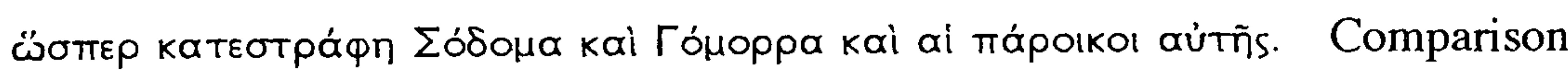
with the duplicate at 50:40 is helpful: כמהפכת אלהים את סדם ואת עמרה ואת שכניה

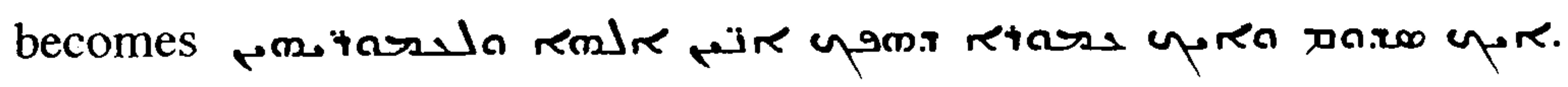

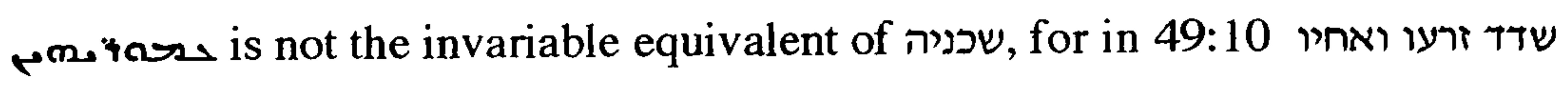

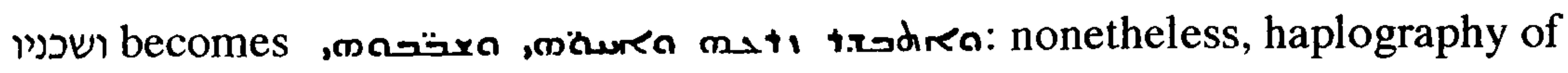
"Gomorrah" with a putative 1 in 49:18 seems likely: this would of course be a scribal error, not attributable to the translator, and must have occurred at an early stage in transmission since all extant mss. are identical in this respect.

49 (LXX 30:6):28(27) לקדר ולממלכות חצור אשר הבה נבוכדראצור מלך בבל becomes rals with no

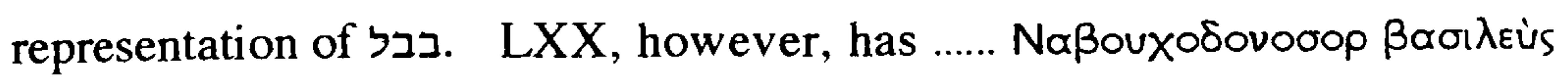

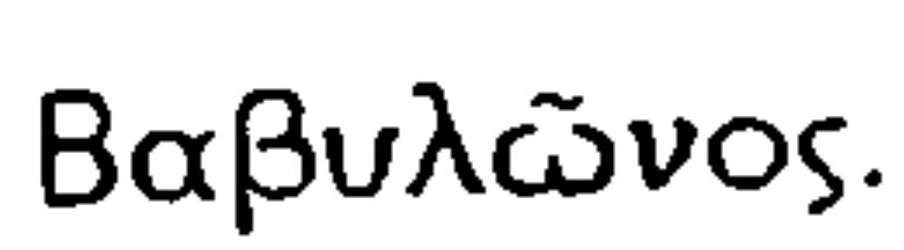


Chapter $4 \quad$ Minuses

49 (LXX 30:8):30 נסו נדו מאד, becomes a.uמה at, with no representation of

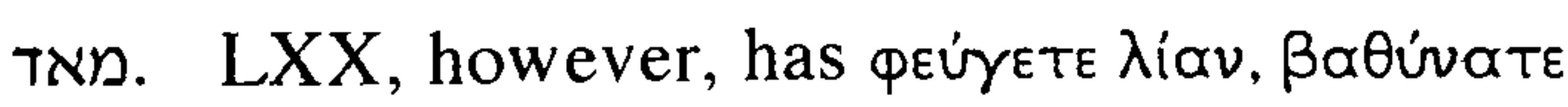

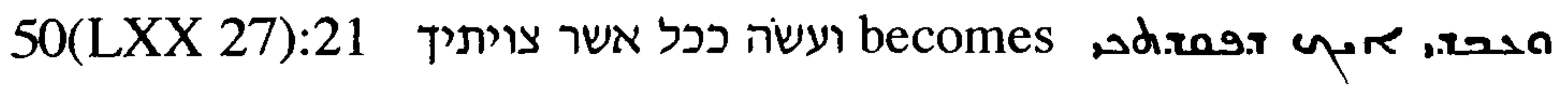

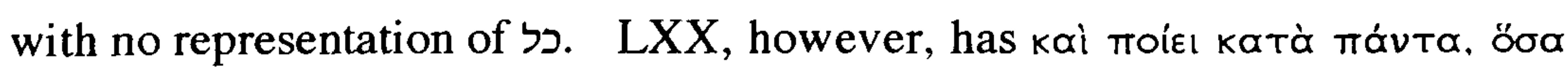

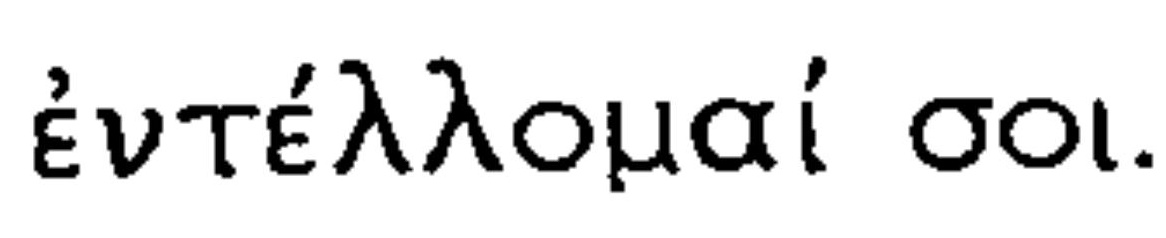

50(LXX 27):24 יקשתי לך וגם נלכדת בבל ואת לא ידעת נמצאת וגם נתפשית כי ביהוה

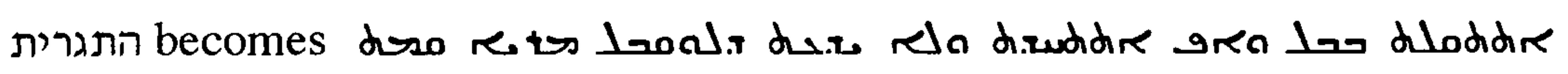

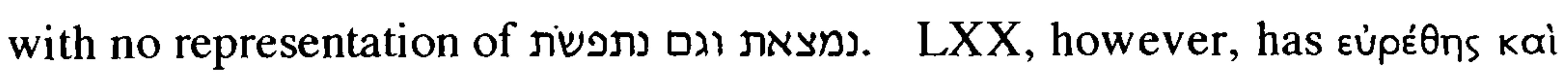
$\dot{\varepsilon} \lambda \hat{n} \mu \phi \theta n s$.

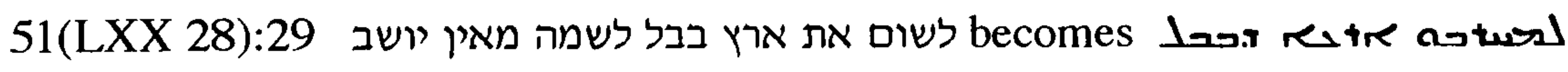
לשמה LXX, hith no representation of

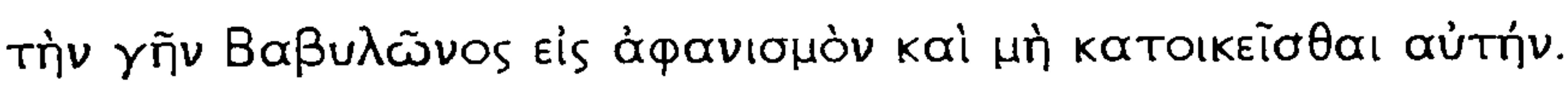

51(LXX 28):35 חמסי ושארי על בבל תאמר ישבת ציון ודמי על ישבי כשדים תאמר ירושלם

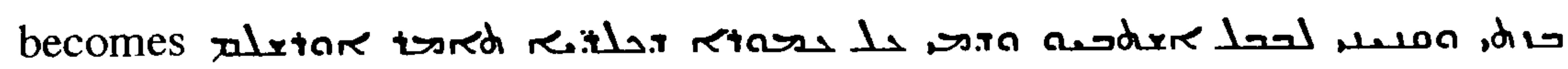
with no representation of תאמר ישבת ציון. LXX, however, has épeĩ katookoũod $\Sigma i \omega v$.

51(LXX 28):38 יחדו ככפרים ישאגו becomes

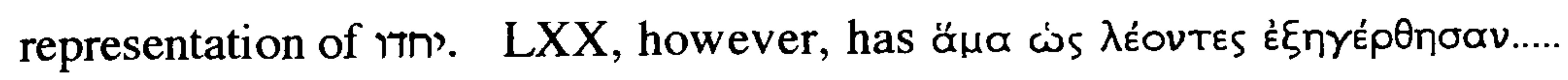

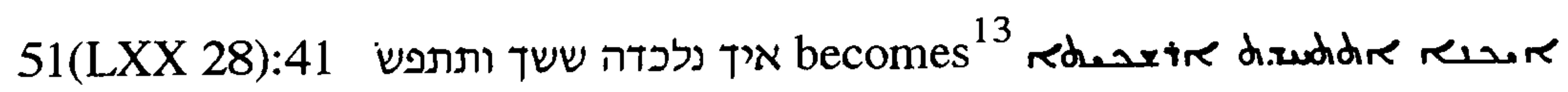
with no representation of ותתפש. LXX, however, has $\pi \tilde{\omega} s \dot{\varepsilon} \dot{\alpha} \lambda \omega$ kai

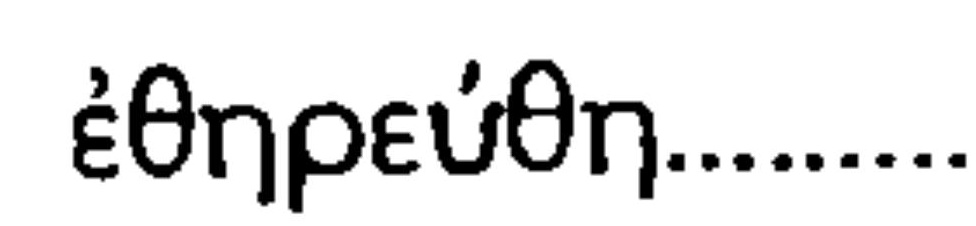

13. The Athbash code for Babylon in ששT was recognised, as at 25:26, and the biblical antecedents of Parthia identified with the Babylonians (Weitzman, 1996, p.607). 
Chapter $4 \quad$ Minuses

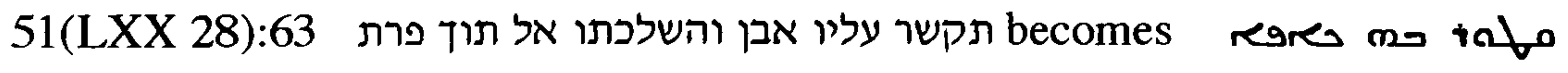

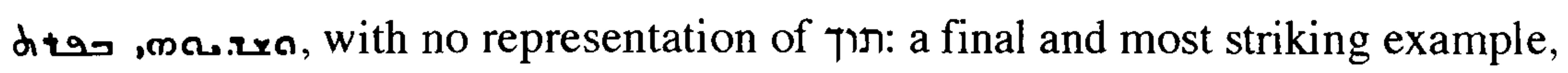
for omission of any part of this instruction, so short and so full of impact, is

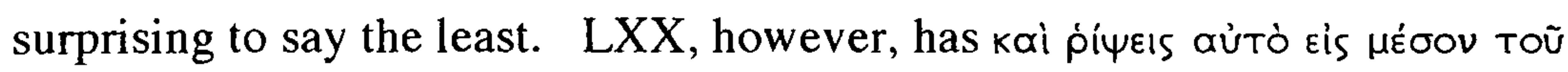
Eưppátou.

In the following examples, the texts of LXX and MT differ so much that comparison with LXX to determine whether the latter agrees with MT or with the Peshitta is impossible.

10:9 describes the manufacture of idols:

כסף מרקע מתרשיש יובא וזהב מאופז מעשה חרש וידי צורף תכלת וארגמן לבושם מעשה חכמים כלם

Whether כלם refers to the idols themselves, or to their clothing, is unclear; the term has no equivalent in the translation:

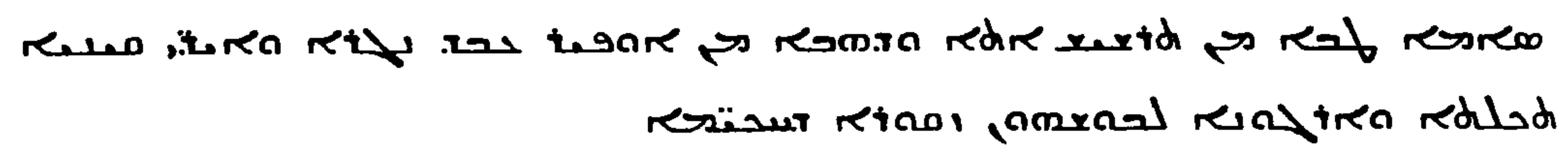

27(LXX 34):7 ועבדו אתו כל הגוים becomes mith no representation of כל.

38:10 והecomes : as in 42(LXX 49):2 noted above, the epithet is not represented in the Peshitta rastre; deliberate omission of an epithet would be inconsistent with the translation technique described in Chapter 2. 
Chapter $4 \quad$ Minuses

ויבאו כל שֹרי מלך-בבל וישבו בשער התוך

נרגל שוֹ אצר סמגר-נבו שר סכים רב-סריס נרגל שך אצר רב-מג

וכל שארית שרי מלך-בבל

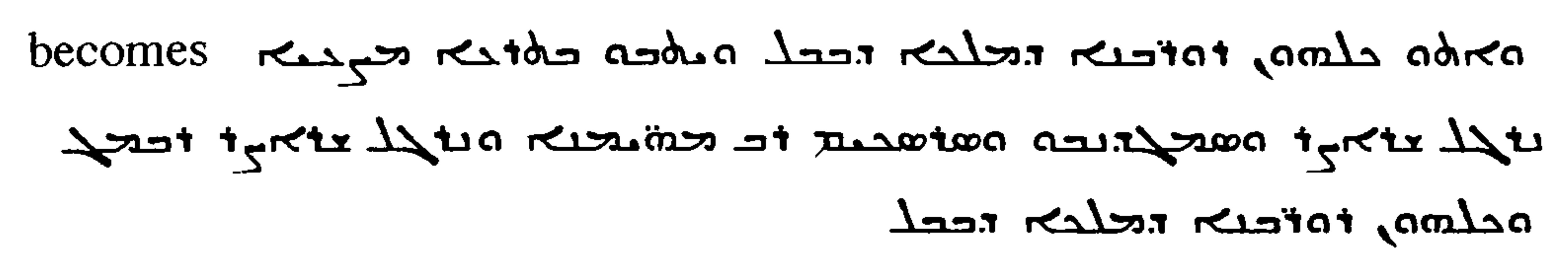

There is no equivalent in the translation of שארית in the last phrase of the verse, so that וכל-שארית שרי מלך-בבל, all the remainder of the princes of the king of Babylon, becomestall, all the princes of the king of Babylon. The effect is that the end of the verse is virtually a repetition of the beginning. The sense of the Hebrew is partially lost, and the list of names seems pointless.

(ii) Minuses which were apparently made deliberately

Minuses apparently made deliberately by the translator are themselves divisible into two classes:

a. minuses which conform to aspects of the translation technique presented in Chapter 2;

b. those which were made deliberately in the translation of passages of particularly difficult Hebrew: discussion of these passages will be reserved for Chapter 6.

a. minuses which conform to aspects of the translation technique presented in Chapter 2

In most examples in this group, the term not represented in the Peshitta has an uncertain meaning in MT, and seems to have been omitted in the interests of clarity. In a smaller number, the minus may have been made so as to harmonise two verses with one another; there are also some where the minus probably results from the difference in idiom between Hebrew and Syriac. Some of these terms may have entered the text as a result of textual corruption during 
Chapter $4 \quad$ Minuses

transmission, but the evidence for this is not strong and there is no convincing reason to argue that any of these minuses is attributable to a difference between MT and the Vorlage:

First, examples where LXX, in those passages where the texts are sufficiently close for comparison to be possible, agrees with MT against the Peshitta: it does not have a minus but represents all the relevant terms of MT.

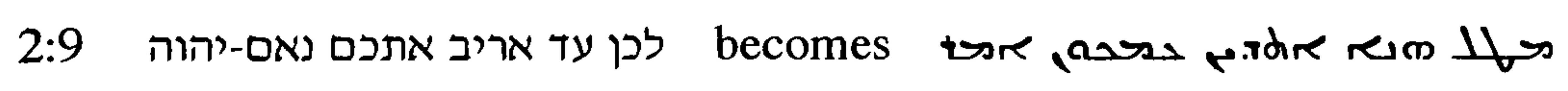

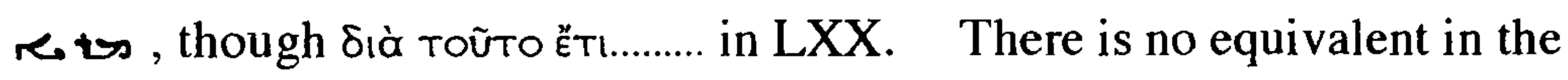
Peshitta of עד, possibly because its sense is unclear; it appears to refer back to some earlier discussion, but as this is unidentifiable in the context the translator may have decided that the translation would be clearer without it.

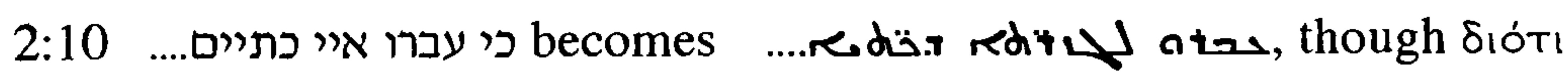
$\delta$ IÉ $\lambda \theta_{\varepsilon} T \varepsilon \ldots . . . . . .$. in LXX. כ seems to have no real meaning in this context, since what follows in the MT is in no sense a reason for what has preceded; in an otherwise exact Syriac translation, there is no equivalent of this term ${ }^{14}$.

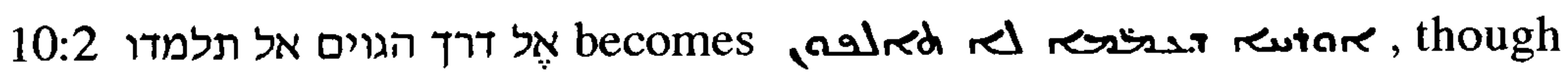

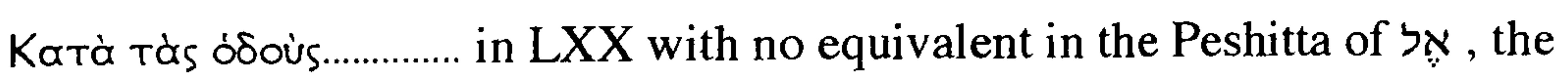
meaning of which is uncertain ${ }^{15}$.

14. However, it has been pointed out to me by Dr. Robert Murray, in discussion, that is so essentially idiomatic that the translator could well decide not to render it.

15. The understanding of the second אל תלמדו אל, is the unusual construction iscussed by Driver (Driver, (1937/8), p. 106. 
Chapter $4 \quad$ Minuses

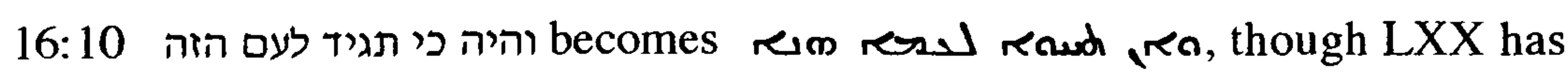

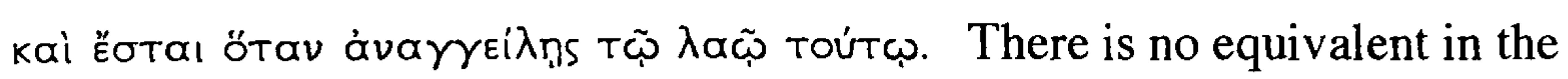
Peshitta of והיה, a recurring feature of this translator's technique discussed in greater detail in Chapter 3.

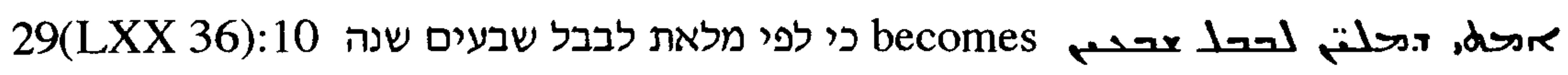

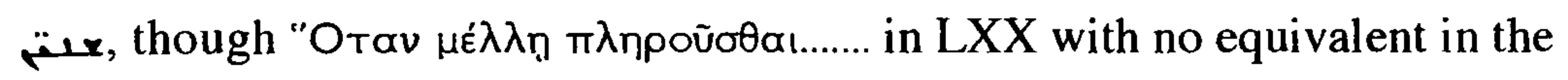
Peshitta of 3 , which has no clear function in MT; but see footnote (14) above.

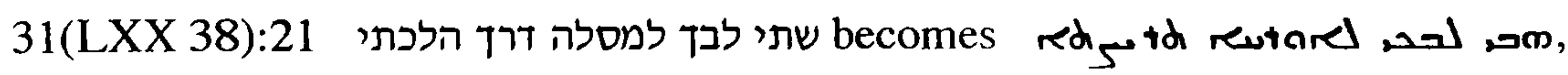

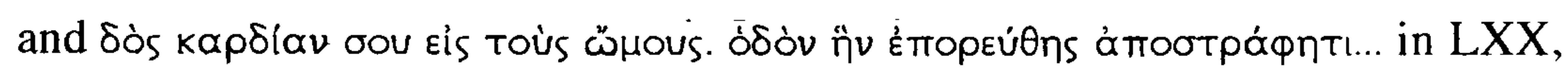

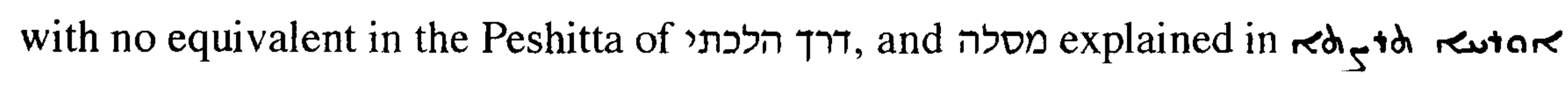
"the straight way". (LXX differs from MT in other details at this point.)

31(LXX 38):40 וכל העמק הפגרים והדשן וכל השרמות עד נחל קדרון, becomes (1) though kail mávtes $\alpha \sigma \alpha p \eta \mu \omega \theta$ in LXX, with no equivalent in the Peshitta of וכל השרמות; apparently the translator preferred to omit this difficult term rather than to attempt to translate it either in its Ktib form or in the Qere השדמות (LXX differs from MT in other details at this point.)

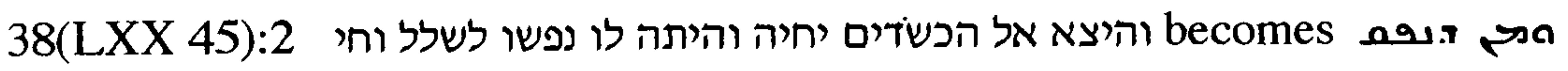

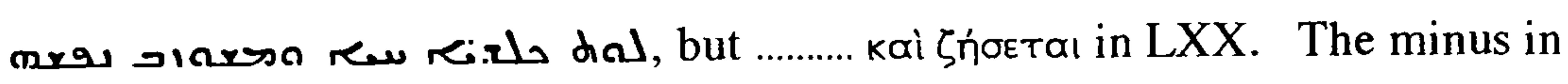
the Peshitta may have been intended to harmonise this verse with 21:9 which is closely similar: והיוצא ונפל על הכשידים הצרים עליכם יחיה והיתה לו נפשו לשלל, but

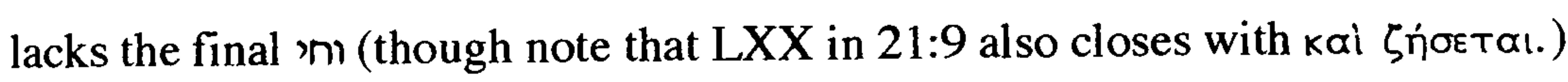

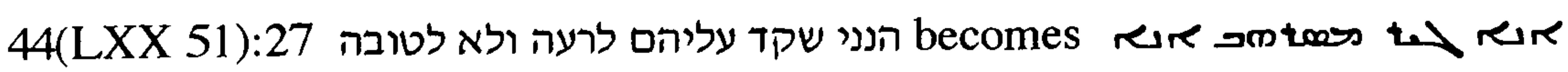

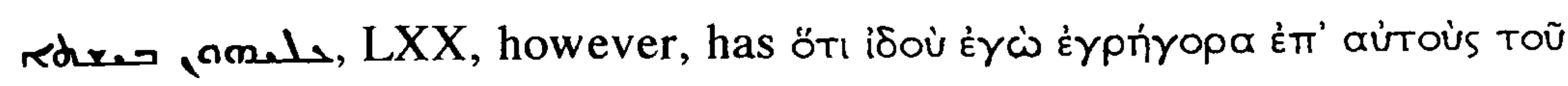

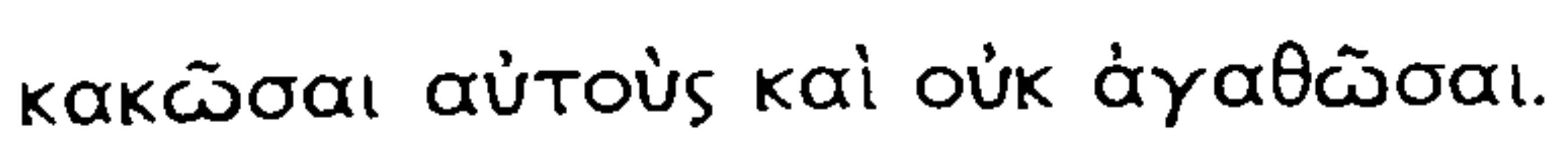

is not represented in the Peshitta, so that "Behold, I am watching over them for evil and not for good" becomes "for I bring evil speedily upon them". 
Chapter $4 \quad$ Minuses

Possibly, there is an underlying evocation of the words of the first vision, in 1:12, where Jeremiah sees the מקל שקד: and God says שקד אני על-דברי לעשיתו: in this verse, the Syriac translation of the Hebrew pun on root moasd sada 14 rer, seen again in 44:27.

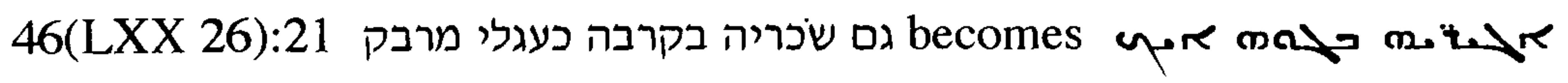

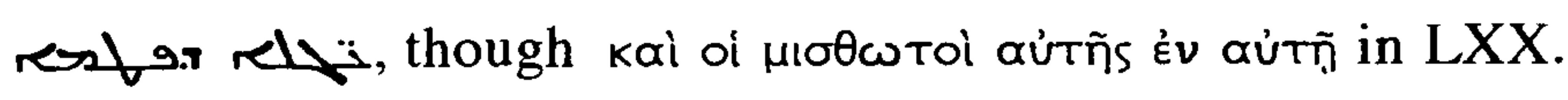

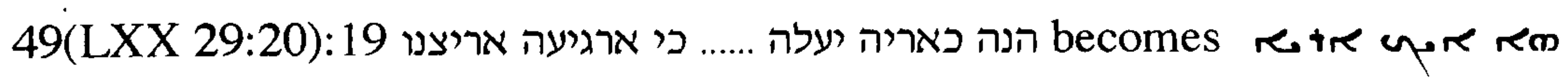

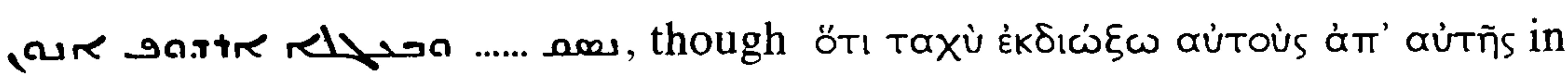
LXX. There is no equivalent of $\supset$, which does not naturally fit at this point in the MT where in any case $p$ would be expected (McKane, 1996, p.1226); and see footnote (14) above.

This verse is also discussed in Chapter 6.

Second, LXX agrees with the Peshitta against MT, and the agreement between the two Versions may well be the result of polygenesis

\section{2:30}

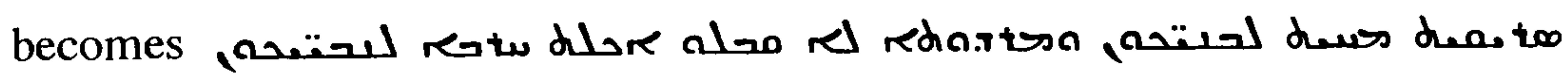
rellows retre que, with no equivalent in the translation of the possessive suffix on חרבכם. LXX here is similar to the Peshitta, giving $\mu$ áxaıpa, but since the sense of the suffix is unclear the similarity of the two Versions here may well be due to polygenesis.

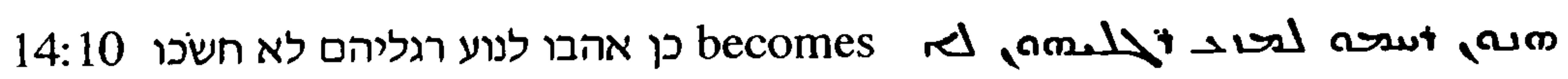

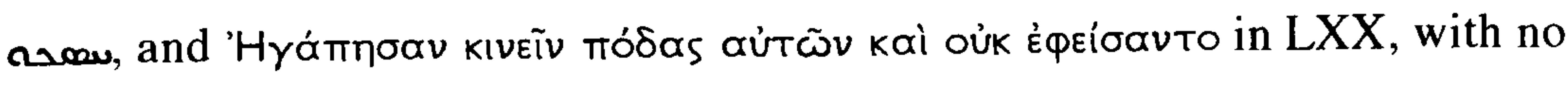
equivalent of $p$. As in 2:10 above, the term not represented in the translation has 
Chapter $4 \quad$ Minuses

no clear sense in its context: $p$ here implies a comparison, but there is no comparison in the text ${ }^{16}$.

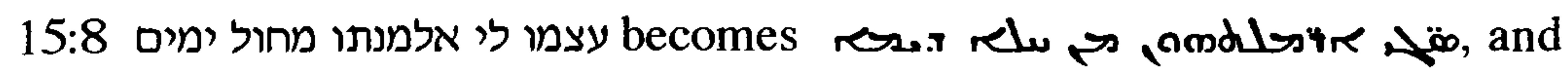

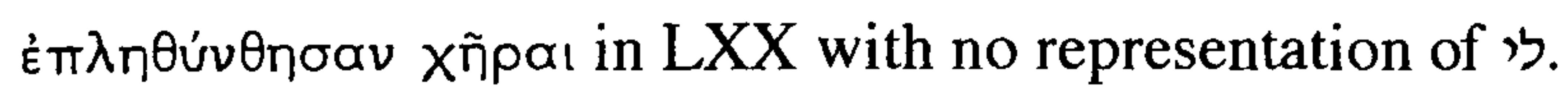

Comparison with the similar construction in 4:12 רוח מלא מאלה יבוא לי

is interesting; here, the similar sense "comes at my bidding" (McKane, 1986, p.340) is translated $S$ redred $\eta ̋ \xi \varepsilon 1 \mu O เ$ in LXX in a precise rendering in which it is not clear whether or not the translator understood the sense of the Hebrew. The absence of a translation of in 15:8 suggests that neither translator understood the exact significance of the term and that both avoided word-for-word translations here because the sense would have been obscure.

51(LXX 28):43 היו עריה לשמה ארץ ציה וערבה ארץ לא-ישב בהן כל-איש

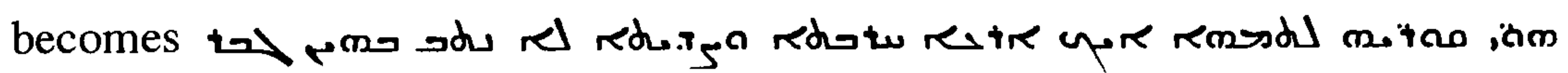
with no equivalent of the second ארץ agree with מת a making and

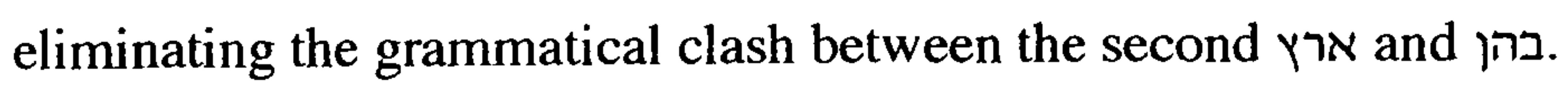

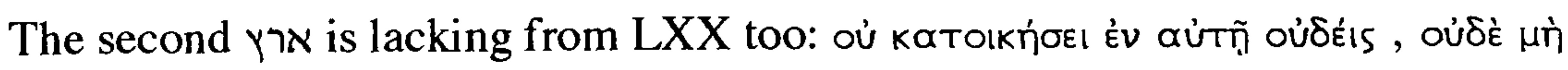

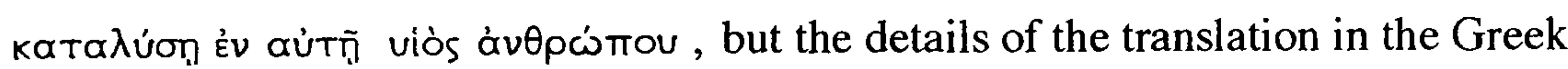
also suggest that the term was present in the Vorlage and that the translation was adapted to correct the grammar (see McKane, 1996, p.1332).

16. Here too, Dr. Robert Murray has pointed out to me in the course of discussion that the function of $p$ here may be essentially idiomatic, and that in consequence the translator saw no need to render it. 
Chapter $4 \quad$ Minuses

Third, examples at which the texts of LXX and MT differ so much that comparison with LXX to determine whether the latter agrees with MT or with the Peshitta is impossible.

ז. 23:8 becomes אשר העלה ואשר הביא את זרע בית ישראל מארץ צפונה reaty reatre ז זרע : is omitted from P, possibly, for consistency with the many other uses of בית ישראל which do not include this term in, for instance, $3: 20 ; 10: 1 ; 11: 17$. ואשלח אליכם לאמר לא תאמרו משא יהוה

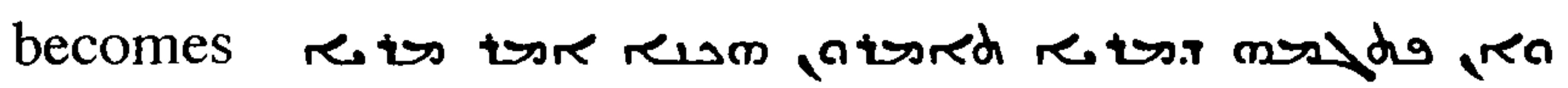
rem resda aditor th

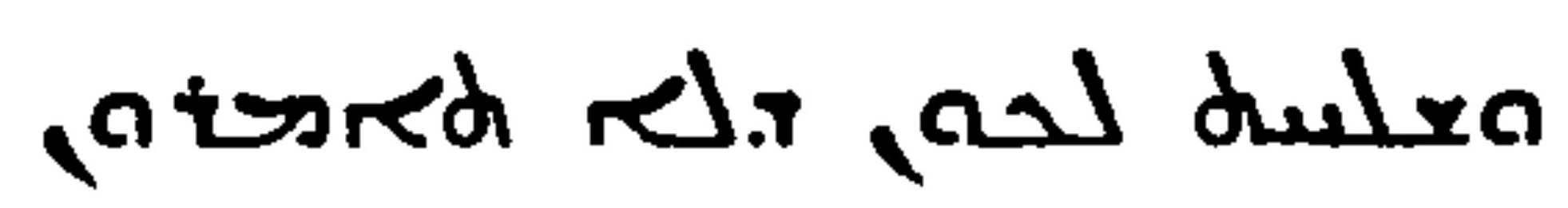

with no equivalents in the Peshitta of לכן, of either the second or third משטא יהוה, or of לאמר. The translation gives a clearer sense than that of the complex repetitive Hebrew.

29(LXX 36):24, 25

ואל שמעיהו הנחלמי תאמר לאמר כה אמר יהוה צבאות אלהי ישראל לאמר יען אשר אתה שלחת בשמכה ספרים אל כל העם אשר בירושלם ואל צפניה בן מעשיה הכהן ואל כל הכהנים לאמר

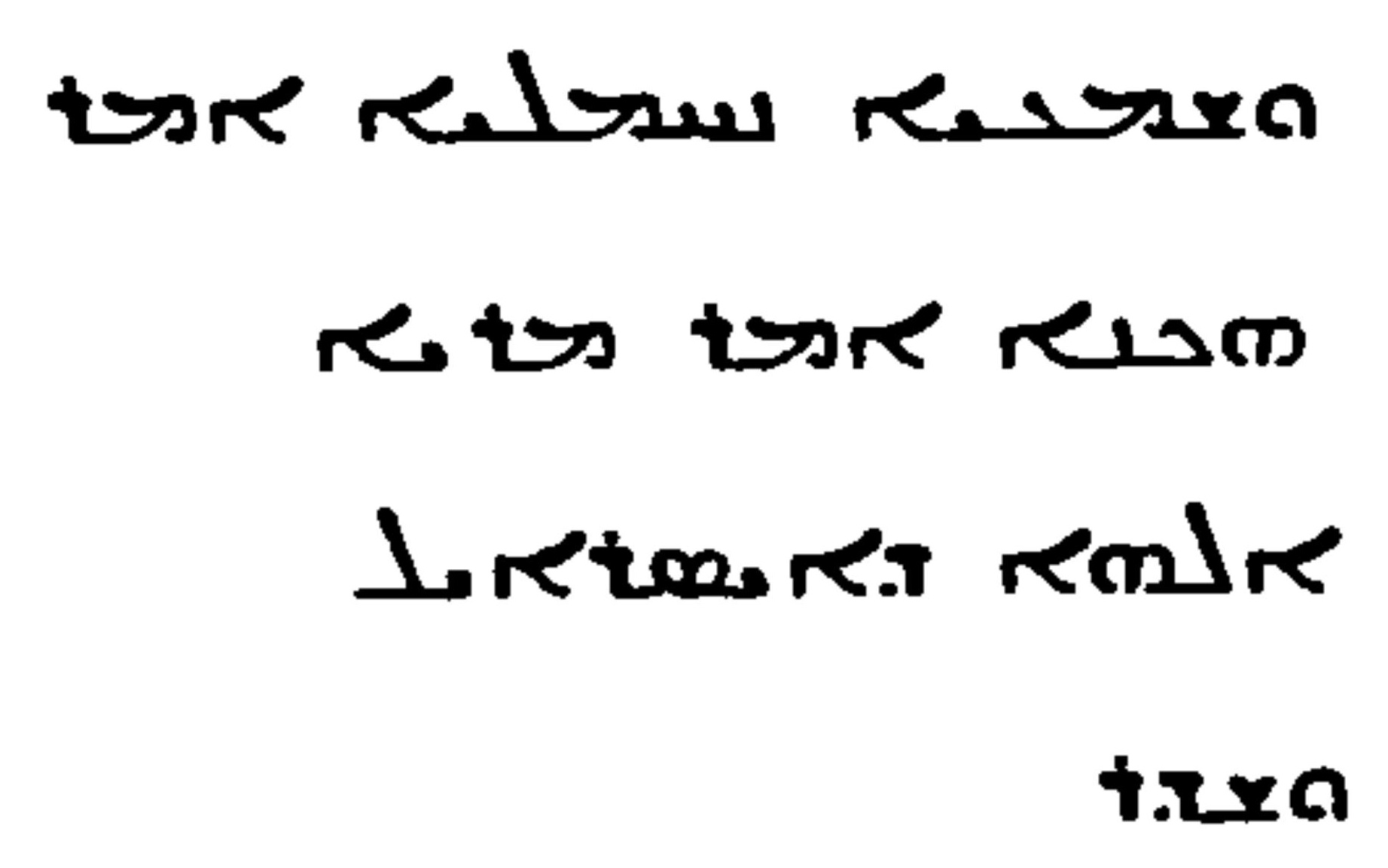

The consequence corresponding to יען אשר is lacking from the MT in this passage: McKane, 1996, pp.731-733 points out that it is postponed to למ in v. 32. The minus at this point in the Peshitta could therefore be attributed to the drive for grammatical cohesion. 
Chapter 4 Minuses

בשמכה is difficult: McKane argues for its deletion on the grounds that the supposition of oracular form is mistaken and that שלח here refers to the simple sending of a letter, not to the mission of a prophet. The corresponding term in the Peshitta, representing as it does בשמו does suggest that some idea of "in the name of..." was present in the Vorlage, for it would not have been necessary to add it to the passage to make sense: this is not conclusive evidence, however, as the term could have been an addition for the sake of clarity. The reason for the difference between the third person terms in the Peshitta and the second person terms in MT is unclear. McKane notes that the text following עי אשר is "an indication of the destination of a letter and an attempt to transform a third-person account into a prophetic oracle which was not carried through" and in the light of his understanding it is possible that the less intense third person of the Peshitta fits the original intention better.

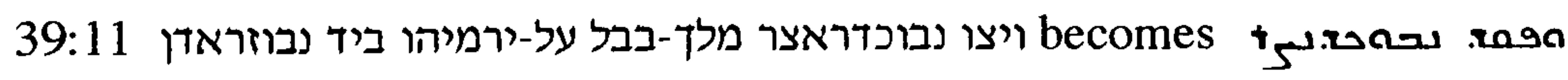
ביד, with no equivalent of possibly (see McKane, 1996, p.980) to make it clear that Nebuzaradan himself, rather than a subordinate, was to be responsible for the supervision of Jeremiah.

(iii) Minuses which throw light on the wording of the Vorlage

This group is itself divisible into three categories, according to the strength of the evidence:

Category A

In this category, the evidence is strongest:

textual criticism of MT identifies problems of a kind which may be particularly likely to occur during the development of a text, for instance possible secondary expansions, doublets, or dittography; these textual problems are absent from both LXX and the Peshitta. This amounts to strong suggestive evidence that the problems were absent from the Vorlagen and entered MT during the process of development of that 
document. These are "true" minuses with respect to MT, but "apparent" with respect to the Vorlagen; the Hebrew which seems to be lacking from the translations is in fact a post-Vorlage development.

\section{Category B}

The evidence is not so strong as for category $\mathrm{A}$ :

there is no convincing evidence of textual corruption in MT;

there are, however, a number of minuses where the Peshitta $=$ LXX against MT, in passages where there is no self-evident reason to suppose that the translation presented any difficulty which would have prompted the translators to move away from their Vorlagen.

\section{Category C}

Here too, the evidence is weaker than in category A:

there is convincing evidence of textual corruption in MT which is not represented in the Peshitta;

however, there is no support in LXX, not because the text which defines the minus in the Peshitta is present in LXX, but because the latter lacks the exactly corresponding passages.

\section{Category A}

Possible secondary textual expansions

5:becomes על-מן גדלו ויעשירו שמנו עשתו גם עברו דברי רע (28) 5:27,28

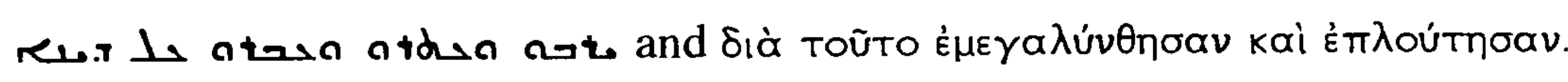

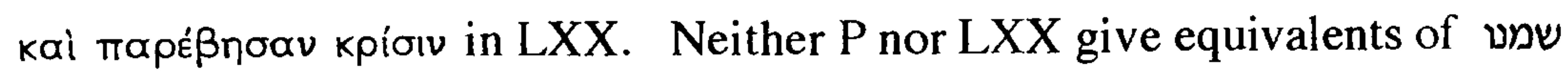
עשתו. This is a difficult phrase, but it seems unlikely that both translators found it too difficult even to attempt, and it seems possible that שמנו עשתו is a secondary 
elaboration $^{17}$ of גדלו ויעשירו.

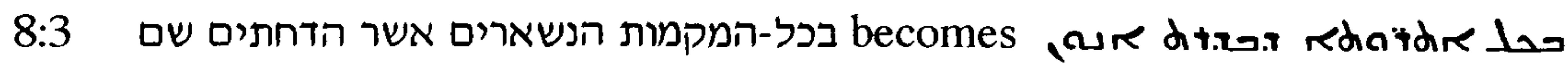

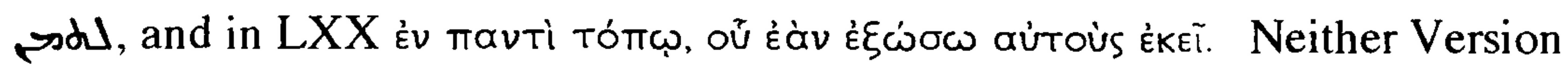
gives any equivalent of הנשארים at this point, its second occurrence in the verse. This repetition of הנשארים should probably be deleted: it breaks into a wordstring which, though with some variations, is well attested within Jeremiah $(16: 15 ; 23: 3,8 ; 24: 9 ; 29: 14,18 ; 32: 37 ; 40: 12 ; 43: 5 ; 46: 28)$.

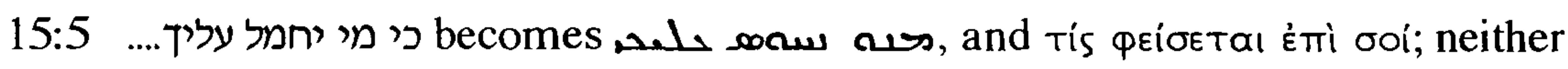
Version represents the opening $\supset$, which may well be a redactional link (see McKane, 1986, p.337).

ושב הגוי ההוא מרעתו אשר דברתי עליו ונחמתי על-הרעה אשר חשבתי לעשות לו

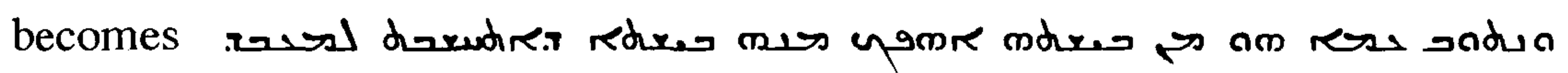

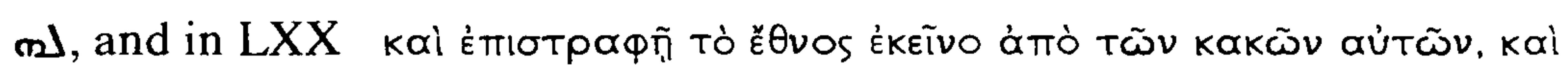

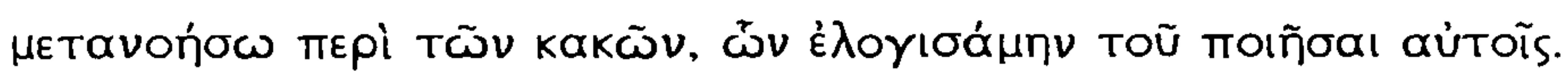

Neither version represents אשר דברתי עליו The MT text is awkward:"רעתו in must mean "its wrongdoing", but to make sense as the antecedent of אשר דברתי עליו in the meaning "doom" is required: God has not pronounced that wrongdoing, he has pronounced retribution. If אשר דברתי עליו is seen as a secondary and dubious expansion and considered no further, the verse reads perfectly clearly.

(MT is defensible if the solution adopted in NEB is accepted, taking "הגוי" rather than "אשר as the antecedent of if the nation which I have threatened turns back from its wicked ways, then I shall think better of the evil I had in mind to bring on it". This understanding depends on a complicated sequence of the phrases in MT.) (Ziegler, 1957, p.176). 


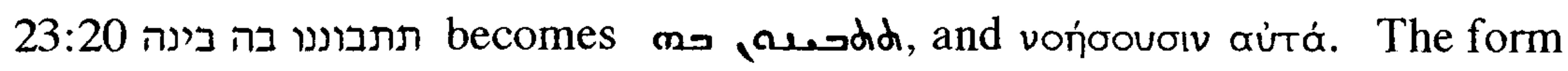
in this verse, with the repetition of the root, is not a standard idiom. Neither P nor LXX has an equivalent of בינה; and note that 30:24, the duplicate passage, has no equivalent term (see Chapter 3 ).

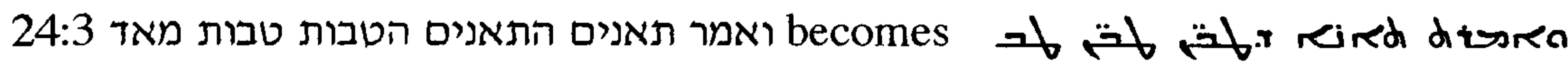

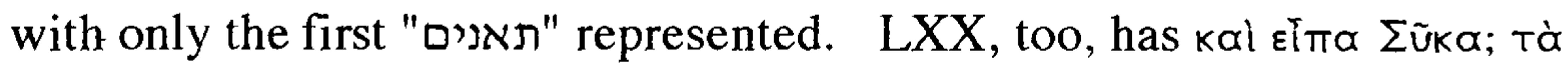
хрпота̀...... The second "תאנים" may be a secondary expansion, adding to the clarity and to the balance of the Hebrew ${ }^{18}$.

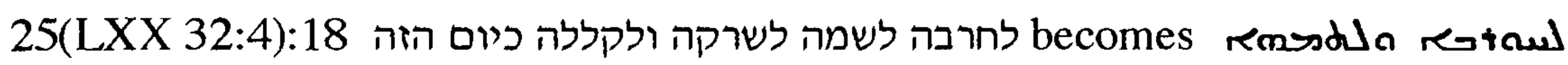

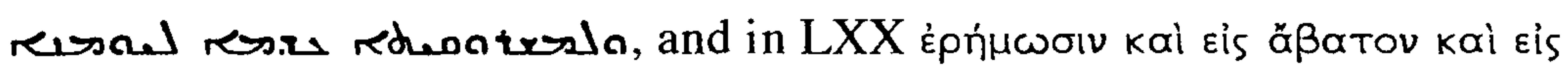
oupıruòv . ולקללה, represented neither in P nor in LXX, may well be a secondary supplementation on the model of, for instance, 44:22 לחרבה לשמה קללה ; ולקללה occurs in similar contexts in this and a number of other verses, though nowhere else in the exact sequence in MT 25:18.

29(LXX 36):12, 13, 14

וקראתם אתי והלכתם

והתפללתם אלי ושמעתי אליכם watodo

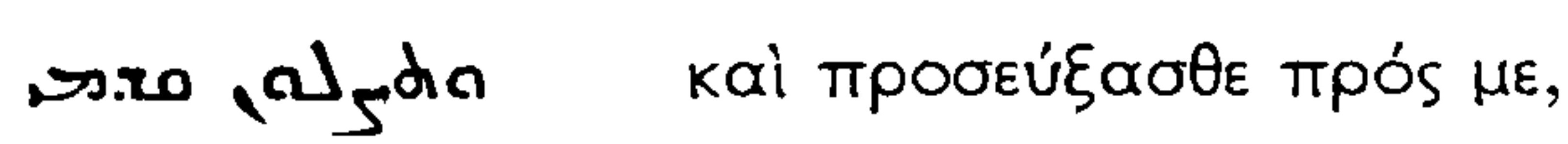

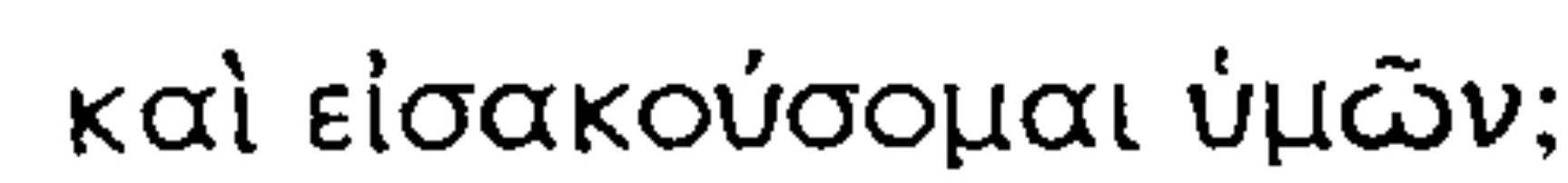

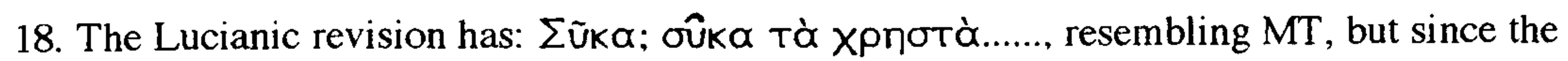
addition conforms to the style of that revision this is not conclusive evidence that the term was present in the Vorlagen of LXX and the Peshitta and was accidentally omitted from both. 
This is a particularly interesting verse, with minuses attributable to more than one cause:

, which is represented in neither Version, seems to obstruct the flow of the sense, and could well be a late gloss pre-supposing exile and dispersion, referring to making pilgrimage to Jerusalem.

The absence of any translation of ושמעתי עליכם from the Peshitta at first sight blurs the picture, since it cannot be explained in the same way: but there is a translation in 9a1 which evidently dropped from the text during later inner-Syriac corruption at this point.

: ובקשתם אתי ומצאתם : this minus could perhaps be deliberate, for the verse is repetitive; but this is by no means a standard approach to the translation of repetitive Hebrew. Haplography with ונמצאתי לכם נאם יהוה is just possible, but unlikely, and the reason for this minus remains unknown.

34(LXX 41):17 אתם לא-שמעתם אלי לקרא דרור איש לאחיו ואיש לרעהו becomes

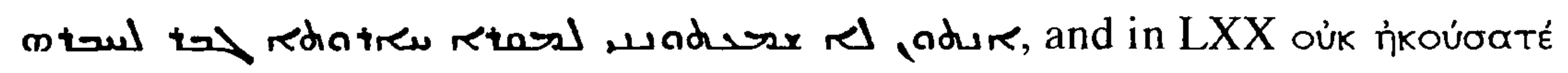

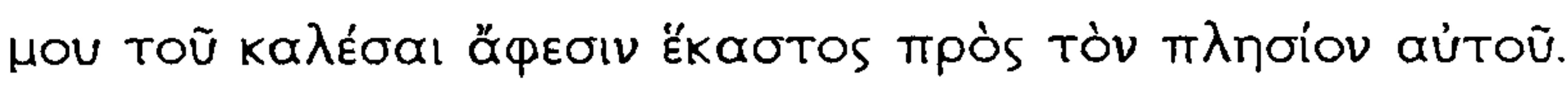

לאחיו is represented neither in $\mathrm{P}$ nor in LXX. Haplography, with a jump from is just possible but unlikely. It could only explain the omission from both the Syriac and the Greek if there were dependence of the first on the second, and the general picture of the translation technique makes this unlikely at this area of reasonably clear Hebrew. A secondary expansion seems the more likely explanation, and is supported by the resemblance between this verse without לאחיו and verse 15, לקרא דרר איש לרעהו.

35(LXX 42):17 לכן כה אמר יהוה אלהי צבאות אלהי ישראל הנני מביא אל יהודה

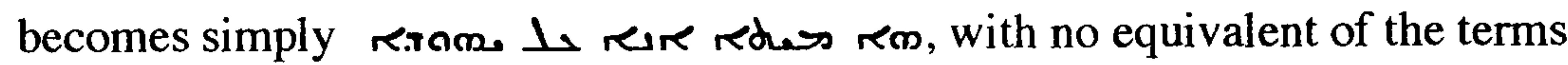

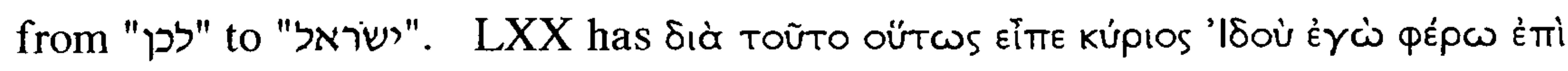

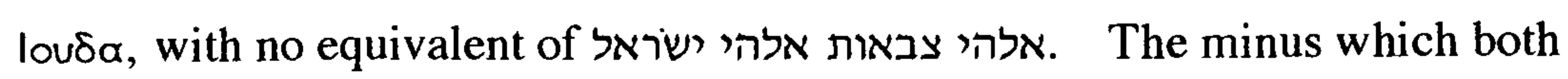
Versions have in common, אלהי צבאות אלהי ישראל, is probably a secondary expansion; כה אמר יהוה may be similarly explained, but is an expansion which entered the Vorlage used for LXX only, not that available to the Peshitta 
Chapter 4 Minuses

translators.

36(LXX 43):28

וכתב עליה

את כל-הדברים

הראשנים

אשר היו על-המגלה

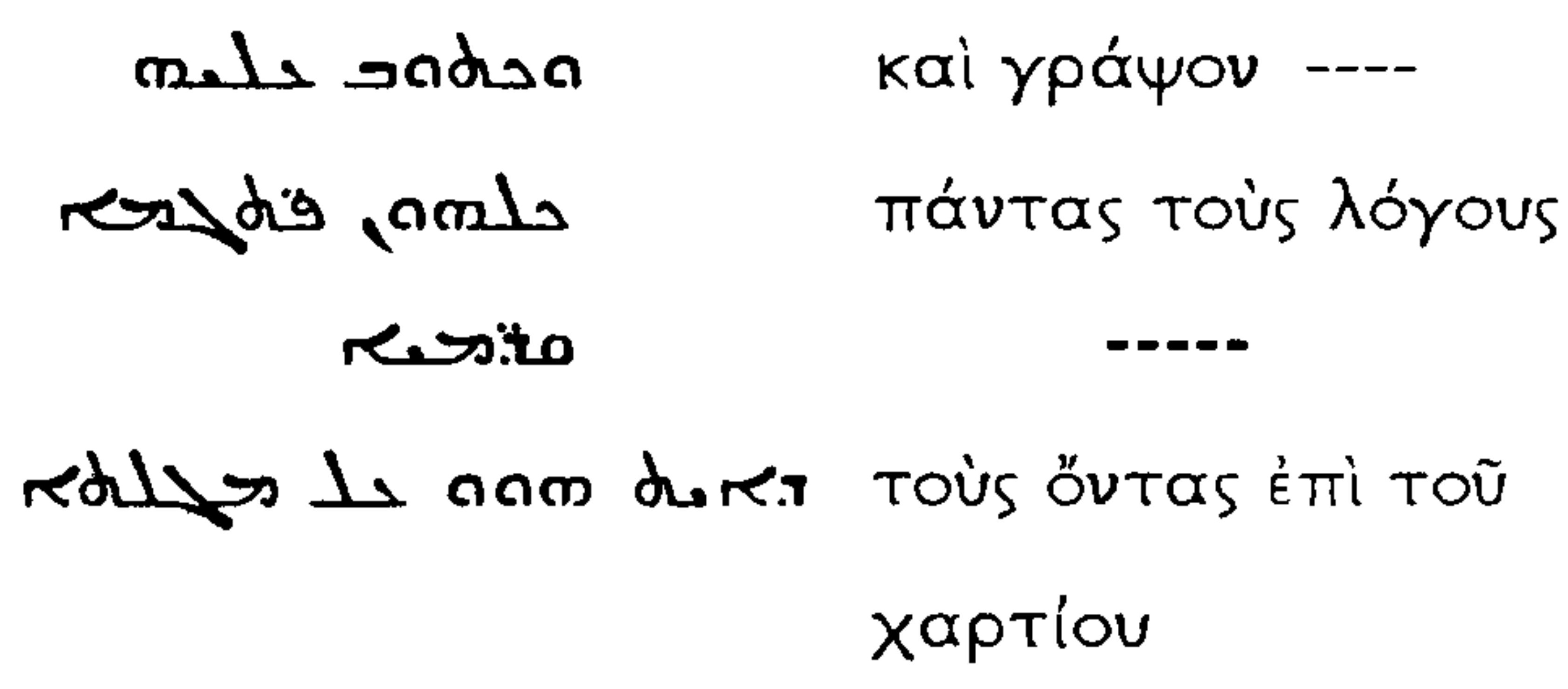

הראשנה

The pluses in MT in comparison with LXX may be secondary, הראשנים and עליה having entered the text in an attempt to improve clarity, after the translation into Greek, so that they were already present at the time of translation into Syriac. in contrast, was added to the Hebrew too late to get into either LXX or the Peshitta.

\section{3(LXX 50):5 אשר-שבו מכל-הגוים אשר נדחו-שם לגור בארץ יהודה}

becomes simply

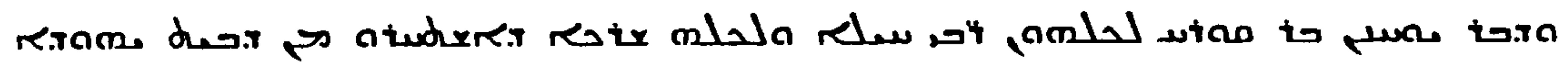
perhaps representing instead ויקח יוחנן בן-קרח וכל-שרי החילים את כל-שארית ....... אשר-שבו .....בארץ יהודה , and with

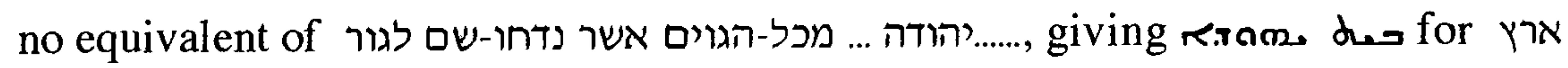
יהודה.

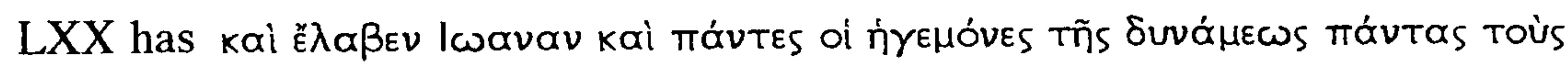

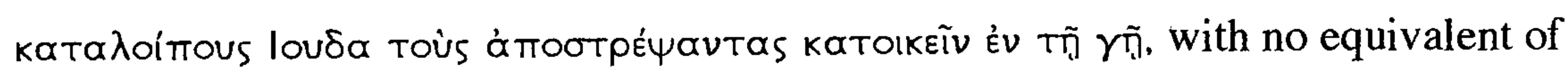
אשר-שבו (Note that is represented here, by tois

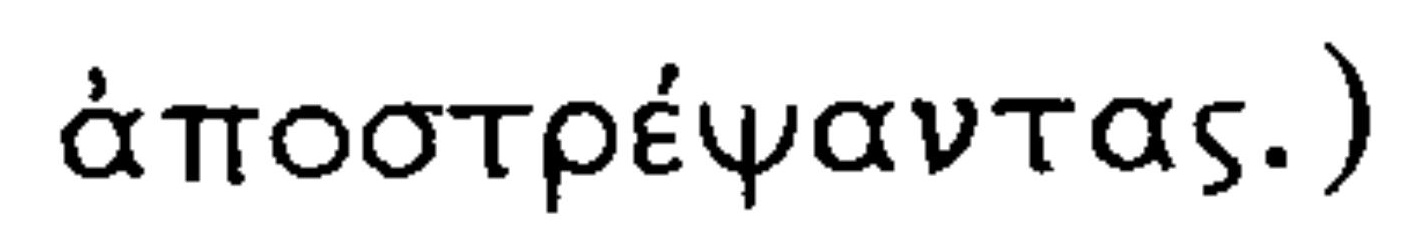

is the next problem, and there is no simple solution. LXX לגור בארץ לגור, which is confirmed in 4 QJer ${ }^{b}$, but not יהודה whesents is not, Judah": McKane (McKane, 1996, p. 1053) points out that it redefines that phrase. 
so the latter may be a late addition, too late for it to enter LXX, and the whole phrase may have entered the MT line of transmission too late to be seen by the Peshitta translator.

44(LXX 51):19 עשינו לה כונים להעצבה

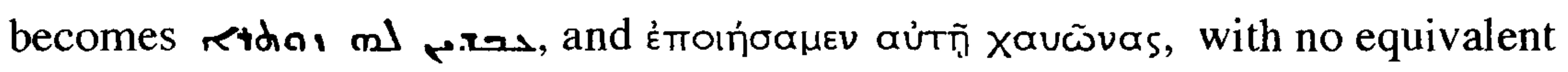
in either Version of להעצבה, perhaps a secondary elaboration in MT.

48(LXX 31):27

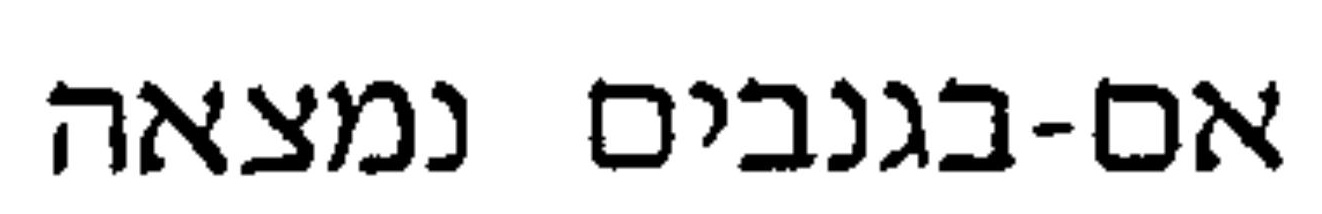

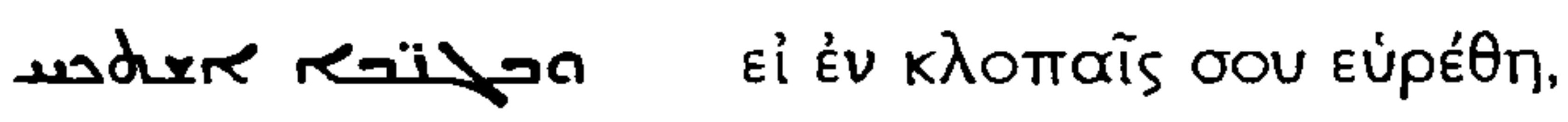

כי-מדי דבריך בו

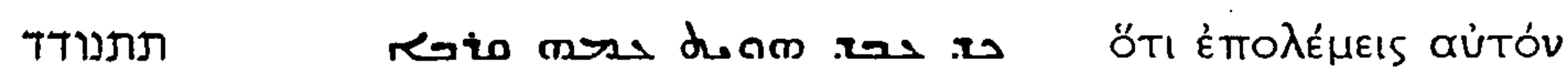

The verse, with the rhetorical question about ישראל, evokes 31:20 where a question is asked about אפרים ; possibly כי מדי דברי בו זכר אזכרנו עוד in the earlier verse prompted a secondary addition of כי-מדי דבריך בו the later context.

קדשו עליה גוים את מלכי מדי את פחותיה ואת כל סגניה 28):(LXX 28 ואת כל-ארץ ממשלתו

The MT phrase ואת כל-ארץ ממשלתו at the end of the verse is represented in neither the Syriac nor the Greek. It may be a secondary addition, from 1 K 9:19.

\section{1(LXX 28):33 בת בבל כגרן עת הדריכה עוד מעט ובאה עת הקציר לה}

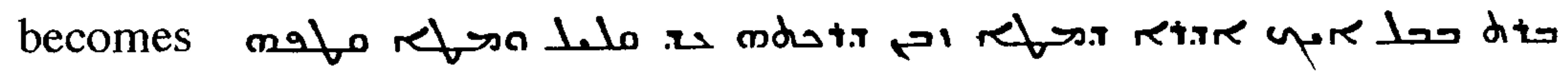

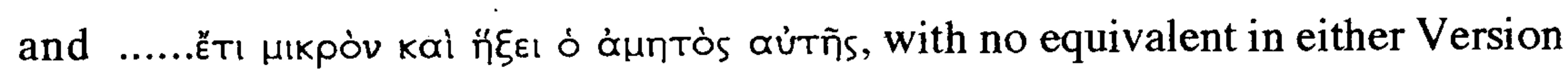
of the second עy which could be a secondary expansion of the text to harmonise with 50:16 ותפש מגל בעת קציר. The MT is difficult here; if is omitted the MT must be emended to ובא, ובאה מגר agreeing קציר, from with the masculine with the (usually) feminine עת. There are other problems with gender in this

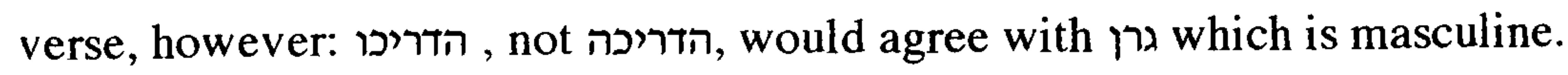
McKane (McKane, 1996, pp.1322, 1323) suggests that there is a confusion of genders between בבל and which may be continued with לה at the end of the verse, represented in both translations. 
Possible doublets

In the passages shown below, LXX represents one putative doublet, and the Peshitta the other, suggesting that the Vorlagen from which these two Versions were made were still distinct from one another at the time of writing of the Peshitta, though they were later merged to some extent.

\section{$7: 27,28$}

The whole of 7:28a is absent from P, whereas LXX has an omission from 7:27:

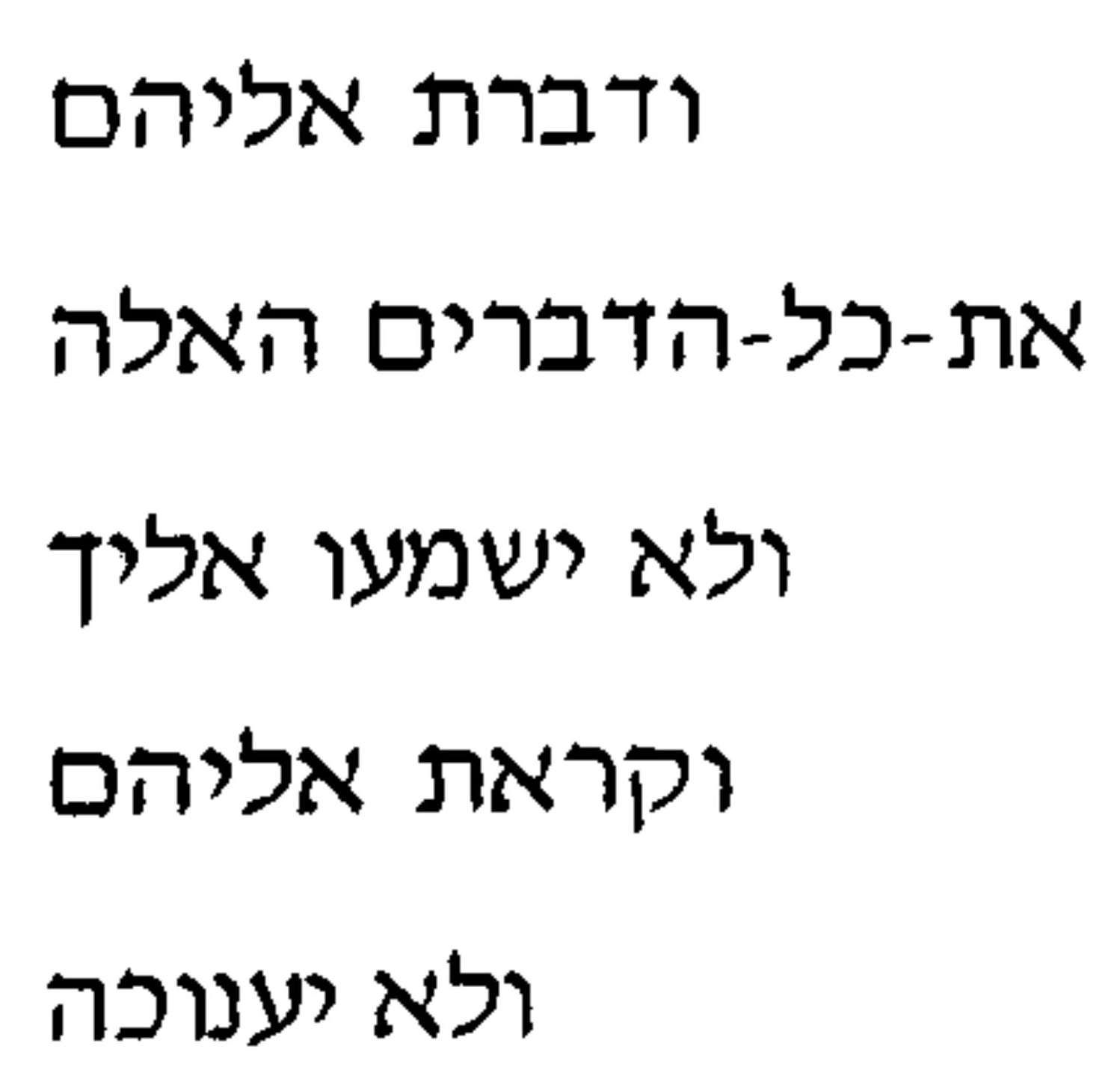

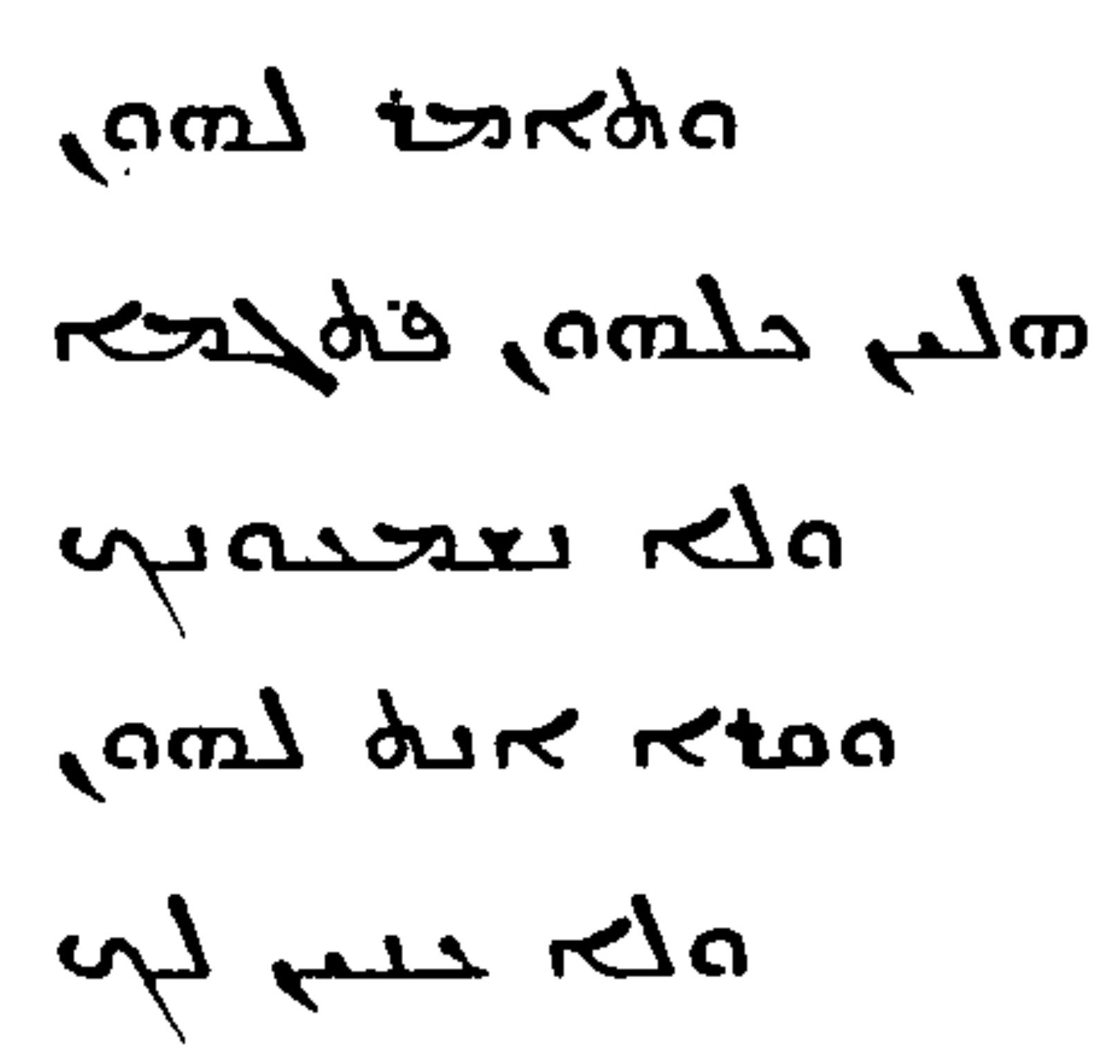
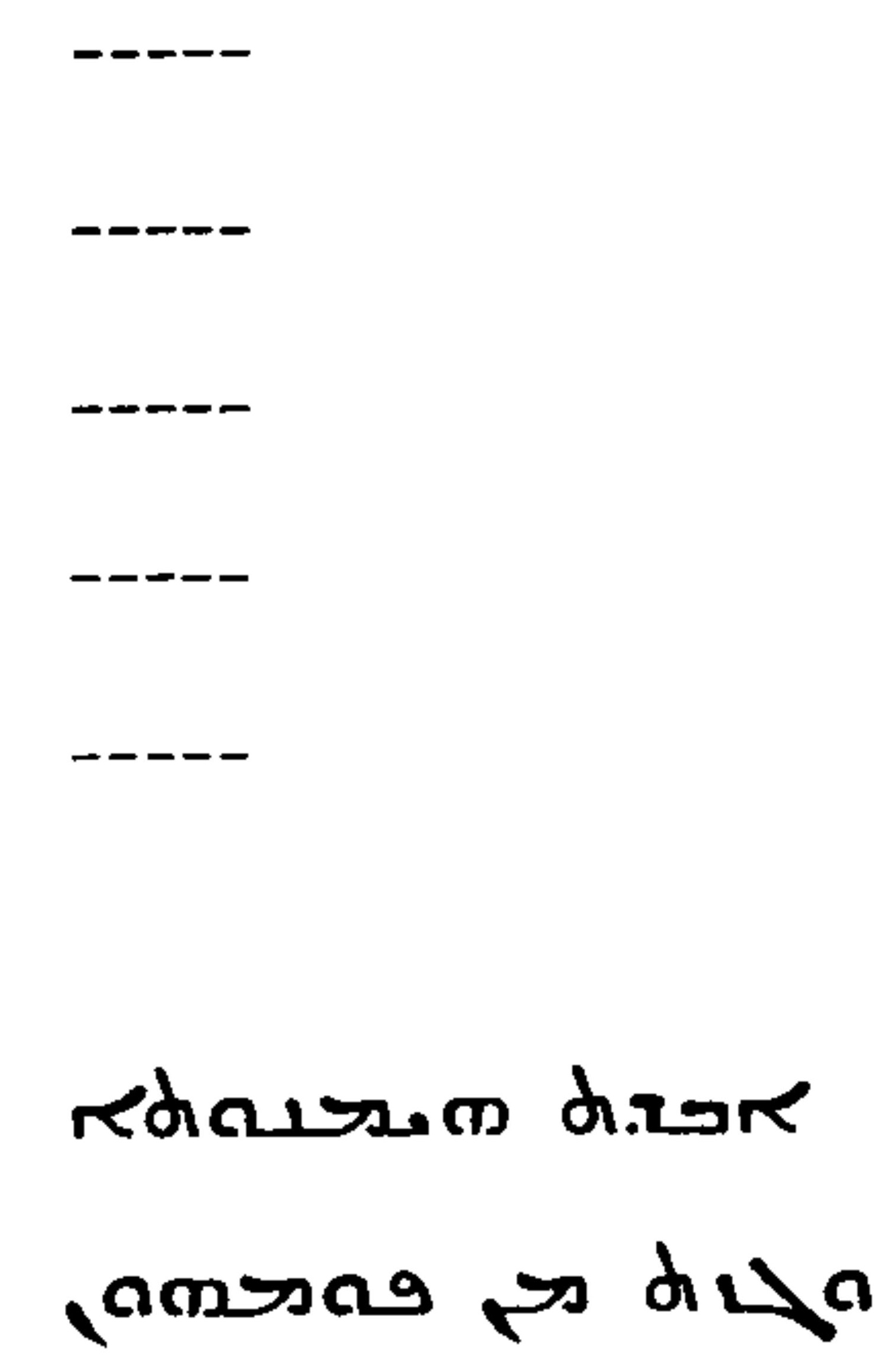

kaì Ėpeĩs aủToĩs

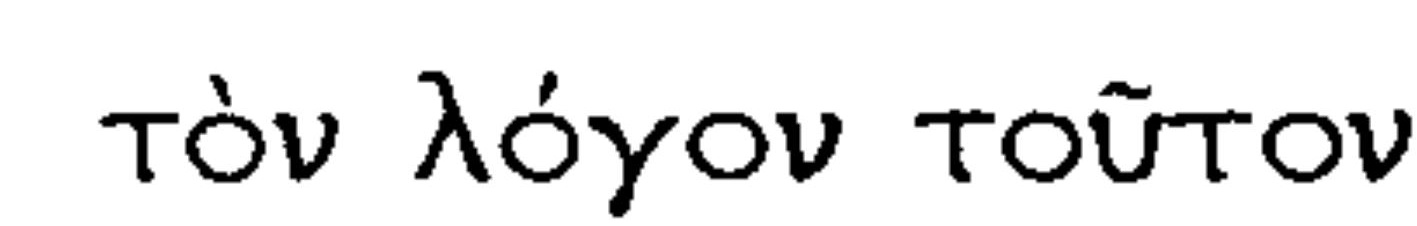
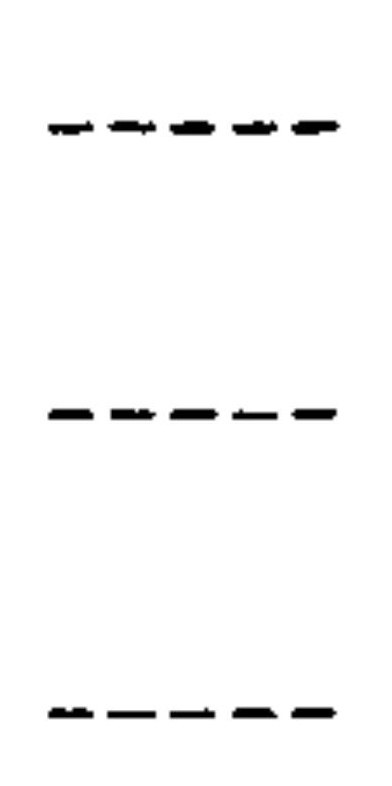

ToũTo Tò हैقvos,

ô oủk n̋kKovøe

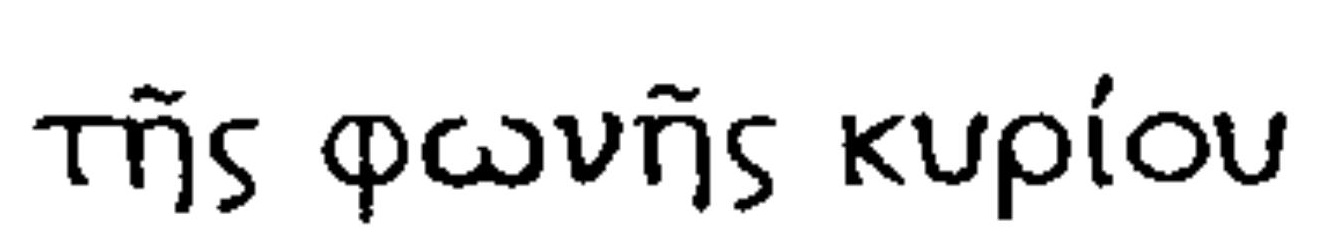

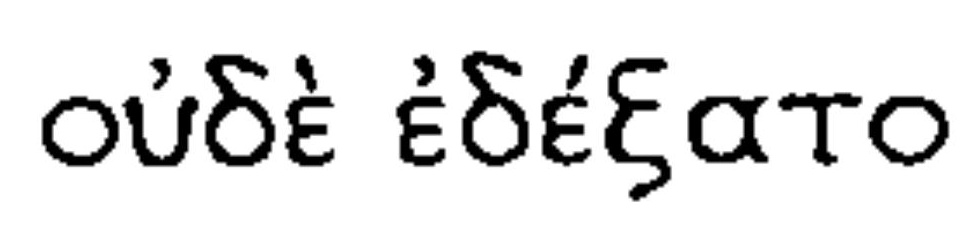
$\pi \alpha ı \delta \varepsilon i ́ \alpha \nu ;$

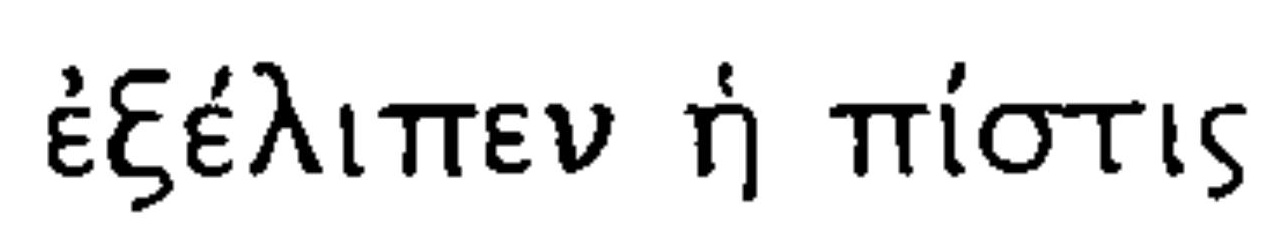
Ėk otónatos

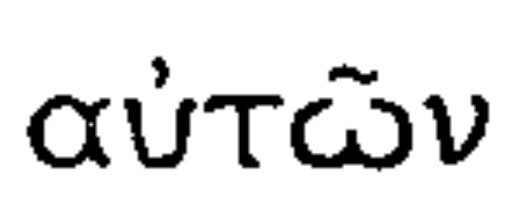

Vv. 27 and 28 (as far as מוסר) may therefore be variants, one preserved in the Peshitta and the other in LXX. 
Chapter 4 Minuses

$22: 30$

כתבו את-האיש הזה

ערירי

גבר

לא-יצלח בימיו

כי לא יצלח מזרען איש.....

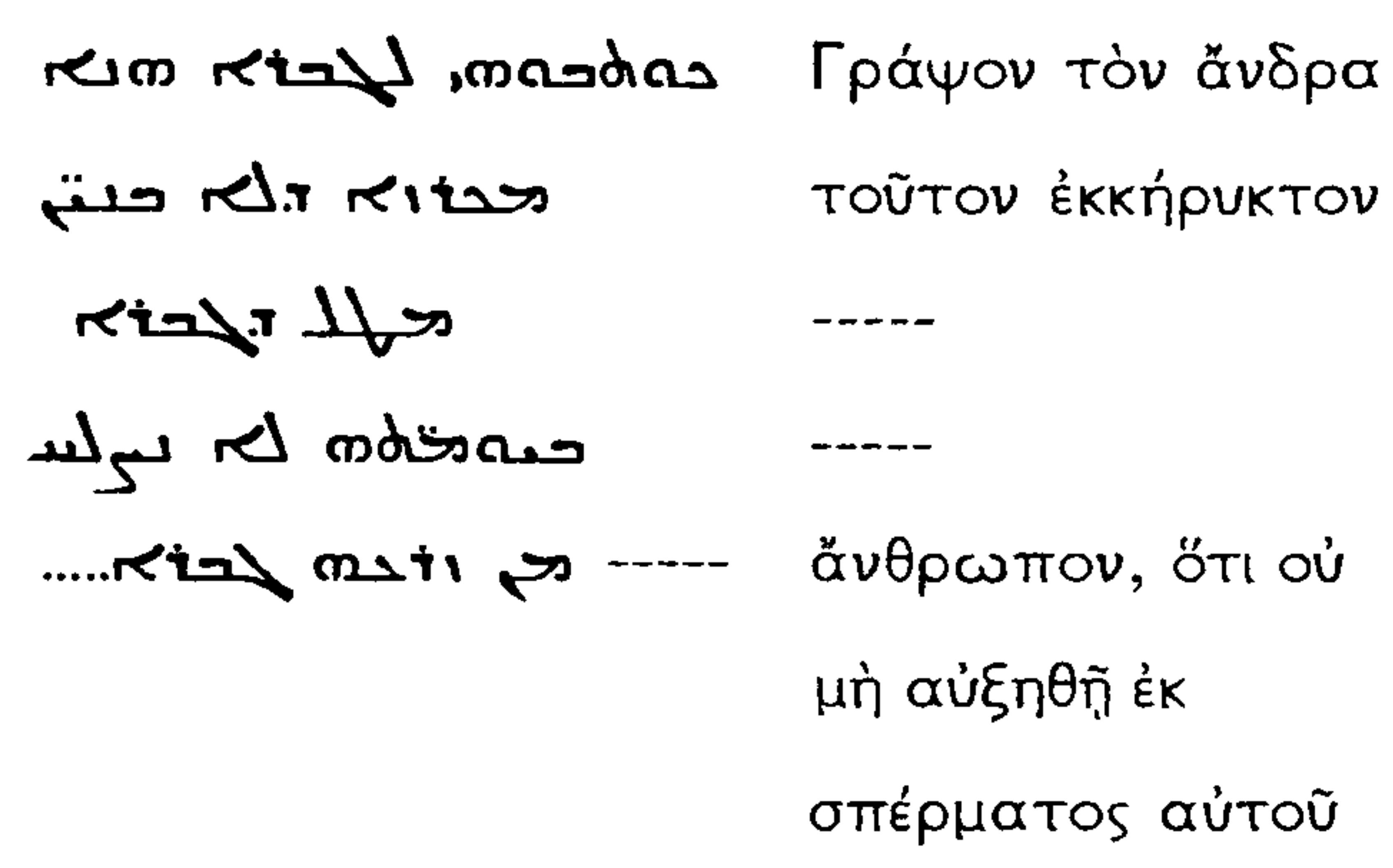

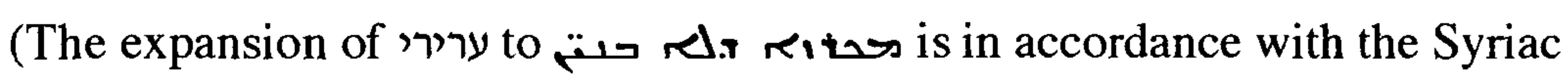
idiom.)

גבר לא- is not represented in the Peshitta. LXX has no equivalent of כי לא יצלח . יצלח בימיו

31(LXX 38):15 רחל מבכה על-בניה מאנה להנחם על-בניה כי איננו is in the Peshitta

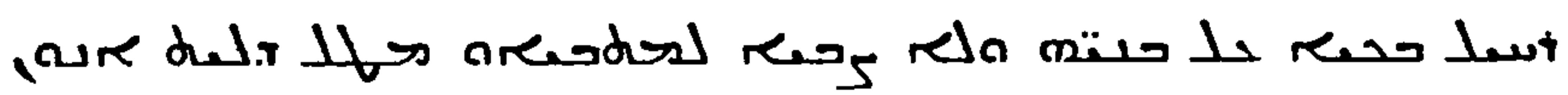

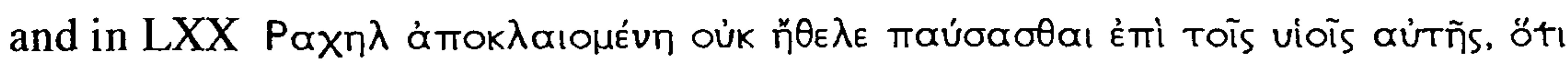
oǔk Eiolv. The first על בניה is a minus in LXX, and the second is a minus in P. One or other may have been a gloss.

41(LXX 48):14 ויסבו כל-העם אשר-שבה ישמעאל מן-המצפה וישבו וילכו becomes

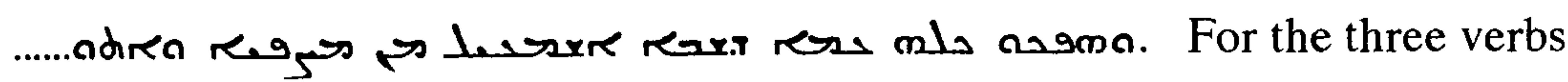
close in meaning, namely ויסבו, וילכו וישו, , וישו, the translation has only two,

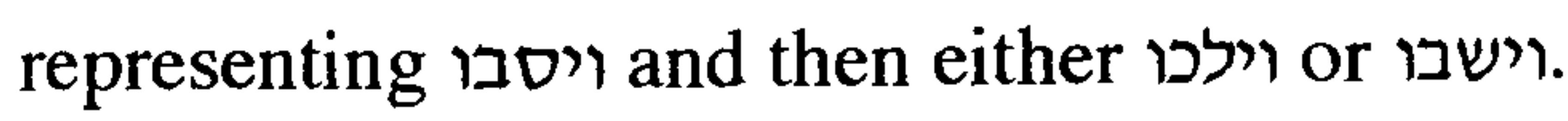

LXX has a much shorter text, giving only one term, ávéбтрєభаv. There may be initially adjacent doublets represented here in MT by יסבו and either וישבו or וילמו , these doublets having become separated by כל העם...המצפה which entered the text as an expansion specifying the subject of the verb rather than requiring the reader to refer back to the previous verse. 
Chapter 4 Minuses

44(LXX 51):3

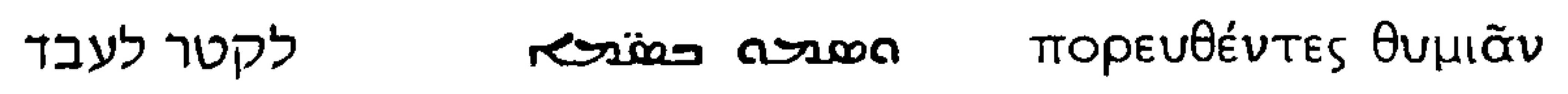

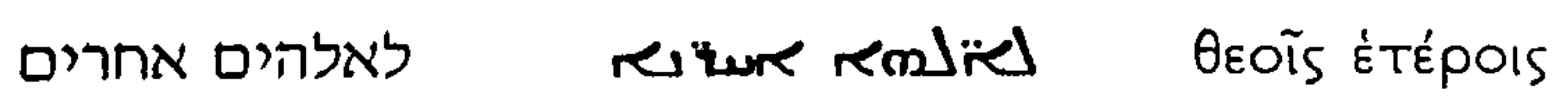

is represented neither in the Peshitta nor in LXX. It seems likely to be secondary in MT, though whether a doublet or a reinforcement of לקטר is uncertain.

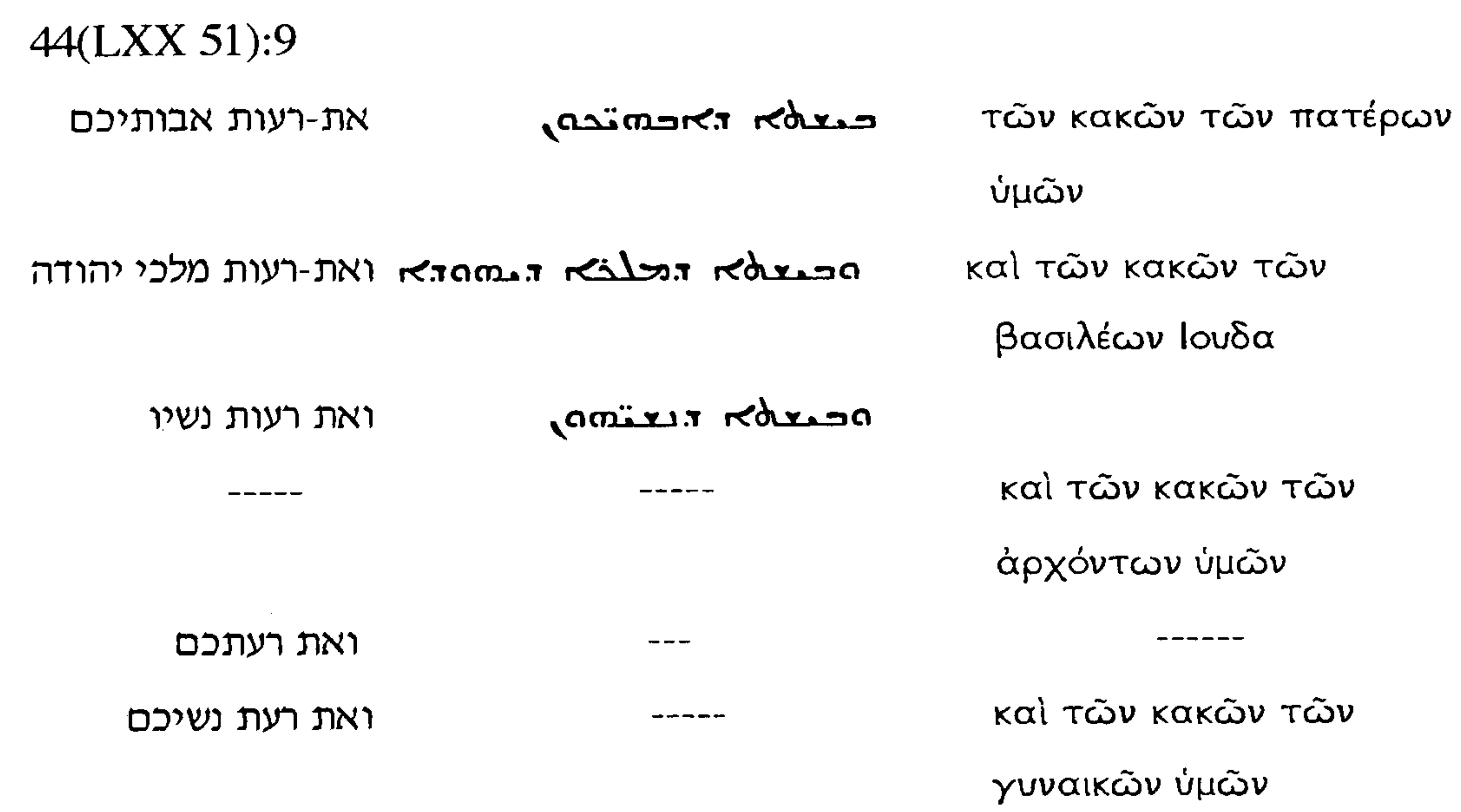

may be doublets, of which one entered the Peshitta and the other LXX. The picture is complicated by the omission from both the Peshitta and LXX of ואת רעתכם. This phrase has historical reference and does not comfortably fit the context, so the translators might have been motivated by the drive for clear sense to omit it. More probably, it could be a secondary expansion. The evidence is confusing, though, for ואת רעת נשיכם is equally inappropriate in the context and may have been deliberately left out of the Peshitta; its inclusion in LXX might be to act as an equivalent to נשיו, rendered in

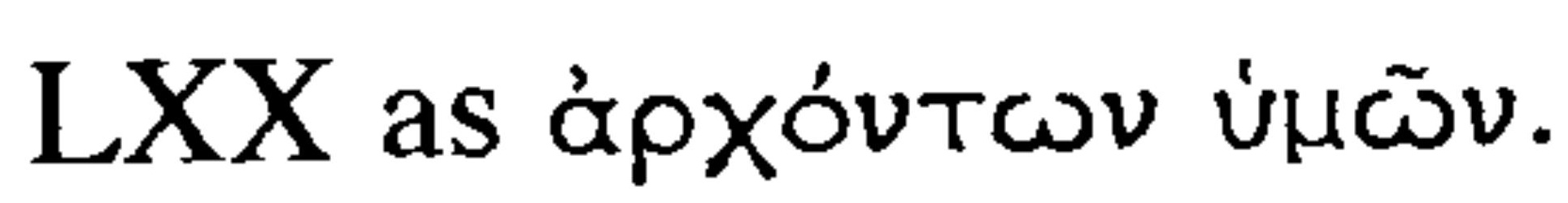

44(LXX 51): 12

ותמו כל בארץ מצרים

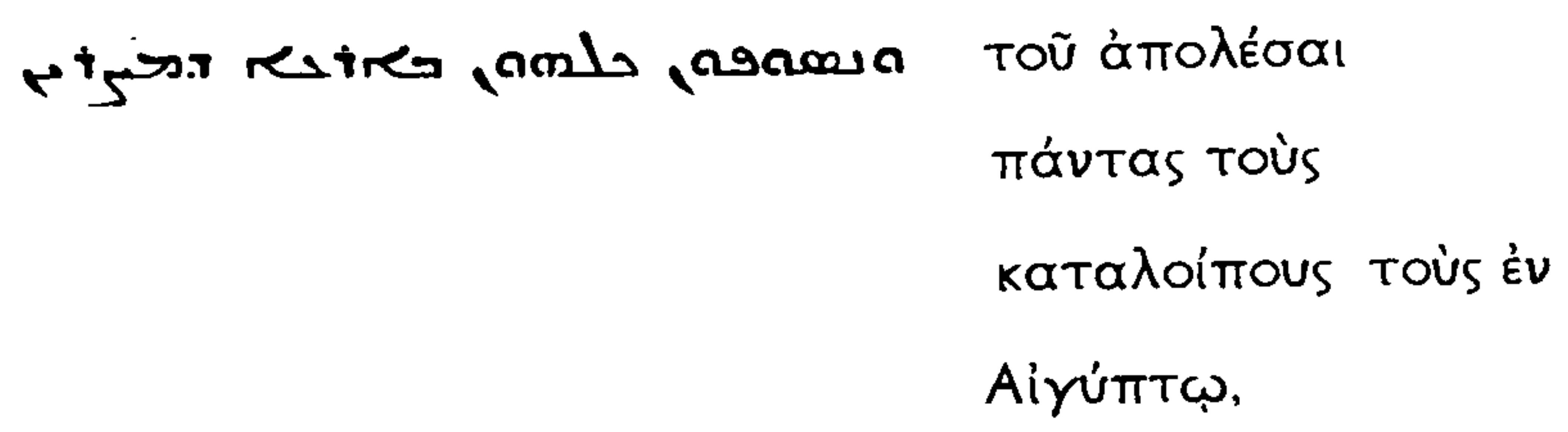


Chapter 4 Minuses

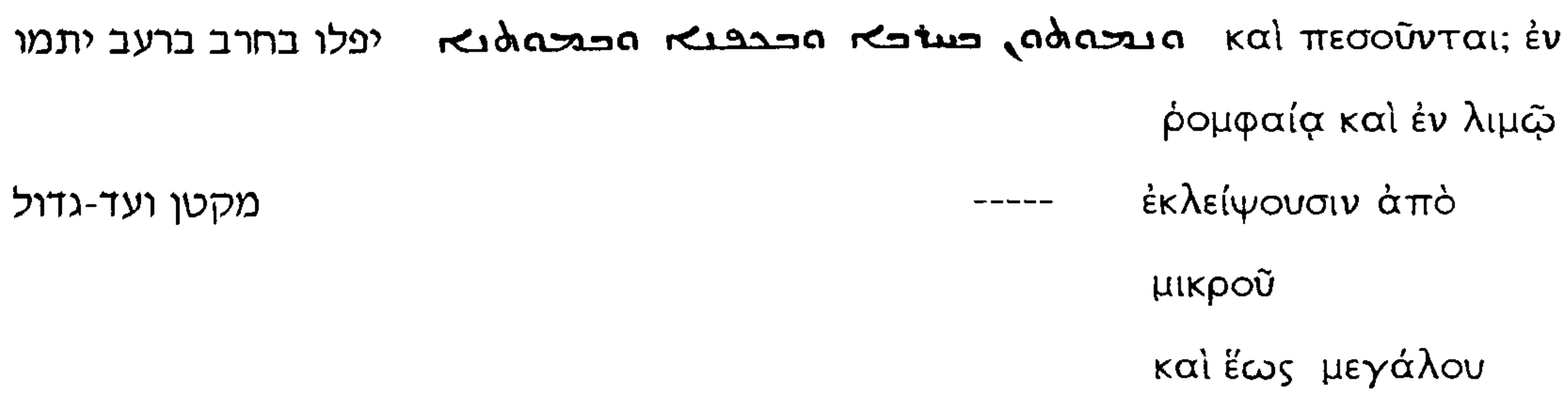

בחרב וברעב ימתו

As at 44:9 above, the picture is complicated. בחרב וברעב ימתו may well be a doublet of בחרב וברעב יתמו, but the omission from the Peshitta of any equivalent of מקטן ועד-גדול, which is represented in the Greek, cannot be explained in the same way. McKane says of this area of the text (McKane, 1996, p.1073) "There is little doubt that the text of MT at vv. 11-12 is grossly overloaded and that the verses have been laboriously and indiscriminately expanded": it may not be possible to disentangle the exact course of events which have produced the present MT form.

44(LXX 51):14 MT לשוב לשבת שם, to return to dwell there, becomes simply

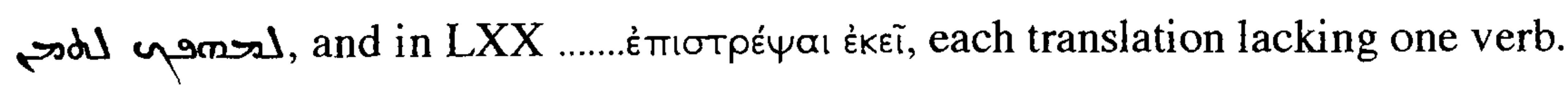
לשוב may be doublets, or לשבת may be a corrupt dittography of לשבת ma לשוב

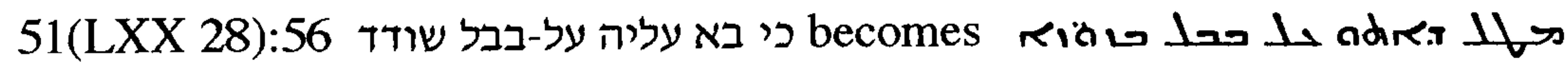

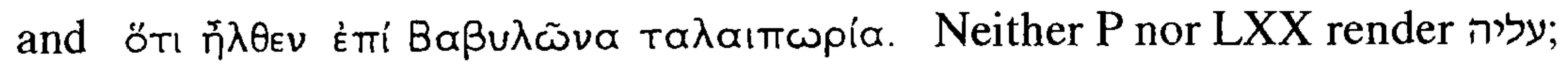
possibly, a conflate text, עליה a doublet of על-בבל.

$52: 34$

וארחתו

ארחת תמיד נתנה-לו....

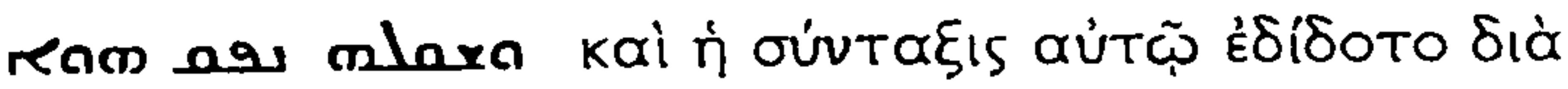
Tavtòs...

The MT may be a conflate text, the doublets being ארחת תמיד and וארחתו. 
Chapter 4 Minuses

Possible dittography

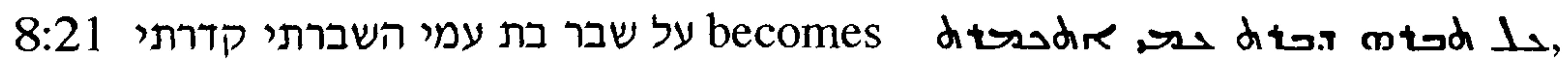

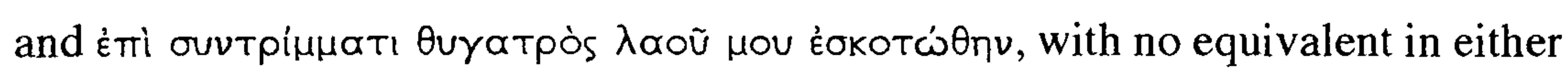
Version of השברת, probably an imperfect dittography of שבר בת עמי, or perhaps a secondary expansion of קדרתי.

38(LXX 45):28

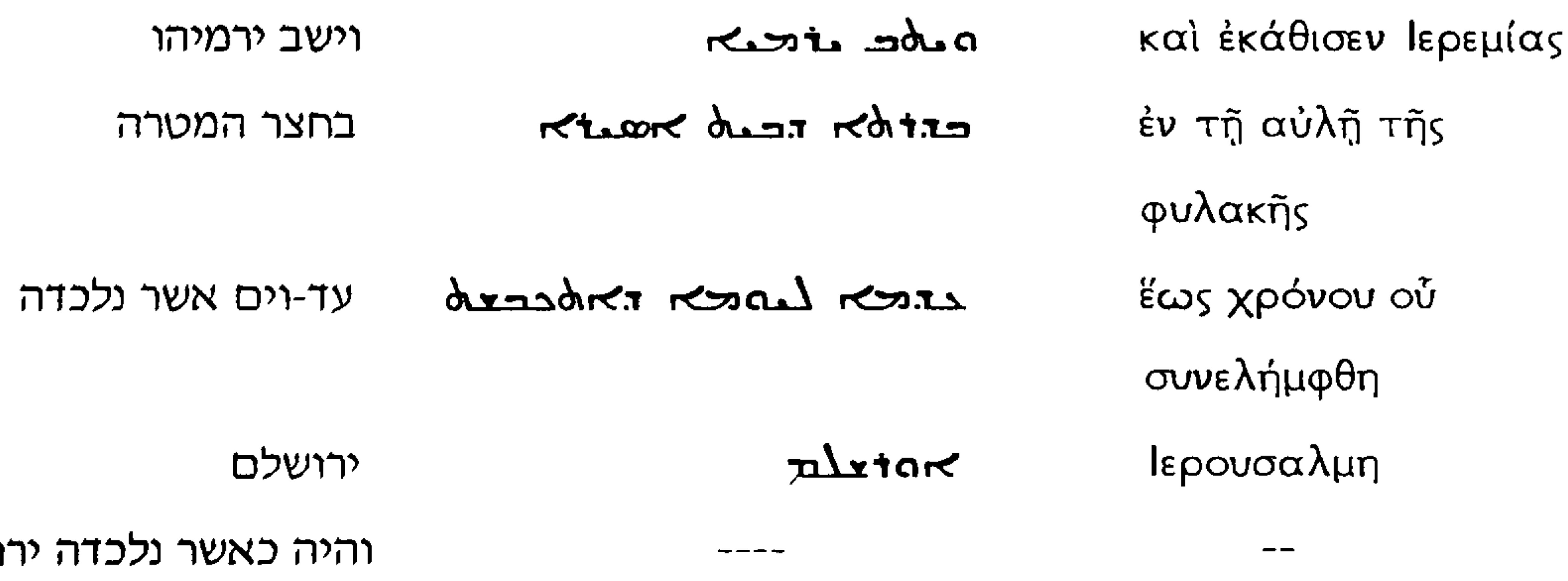

Dittography is a possible explanation of the repetition in MT. ( There is an alternative, that the repeated phrase was misplaced from a more appropriate site closer to 39:2.) (This example is also mentioned by Weitzman in a discussion of certain agreements between LXX and the Peshitta which imply that the two shared a Hebrew Vorlage different from MT (Weitzman, in press, Chapter 3, p.83).)

41(LXX 48):7 ויהי כבואם אל תוך העיר וישחטם ישמעאל בן נתניה אל תוך הבור

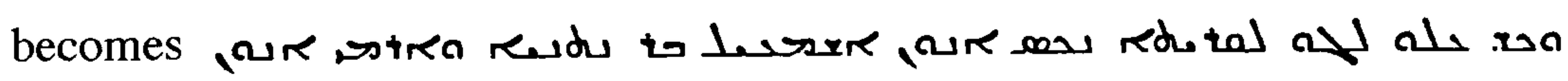
"תוך", which seems unnecessary, and is also a minus in LXX. Perhaps the second תוך entered the text after LXX and $\mathrm{P}$ were made, by dittography of the first.

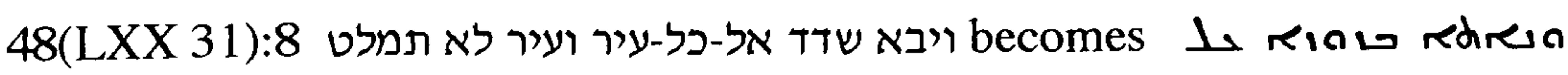

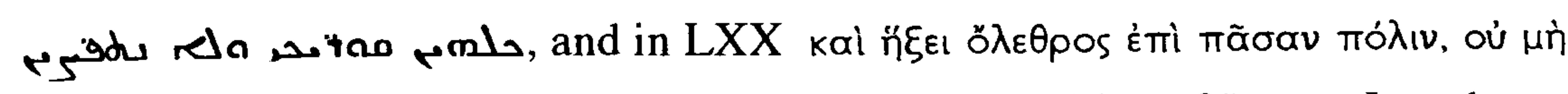
$\sigma \omega \theta \tilde{n}$. Both Versions have texts which omit the repetition of "עיר". Loss by haplography seems unlikely, since for this to explain the absence from both 
Syriac and Greek dependence of the Syriac on the Greek would need to be postulated in the translation of a text which presents no particular difficulty, an unlikely position.

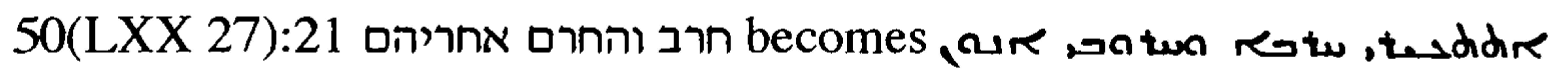

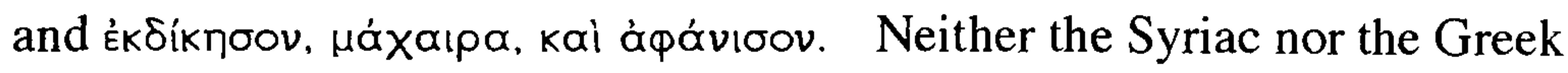
represent the difficult אחריהם, which may be a dittography either of והחרם, or of

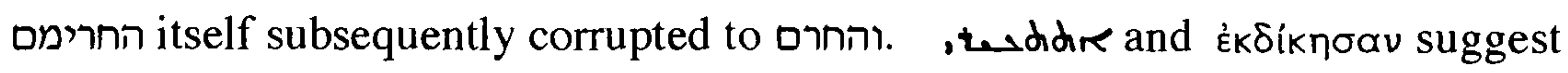
that a punctuation different from that in MT was understood by both translators: the previous phrase עלהעליה ואל ישבי פקוד has been taken to end not at פקוד but at

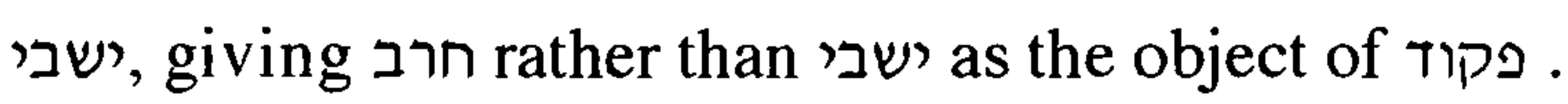

\section{Category B}

Here, there is no convincing evidence of textual corruption in MT; there are, however, a number of minuses where the Peshitta agrees with LXX against MT, in passages where there is no reason to suppose that the translation presented any difficulty which would have prompted the translators to move away from their Vorlagen.

Possible secondary expansions

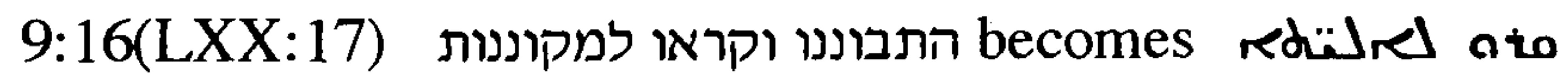

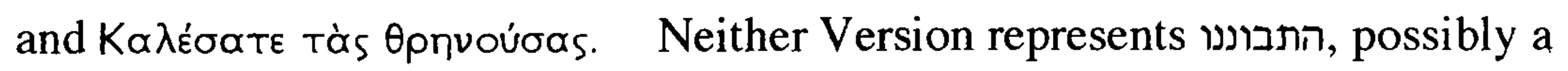
secondary expansion to harmonise with 2:10 שלחו והתבוננו.

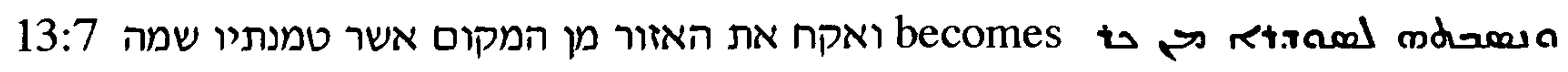

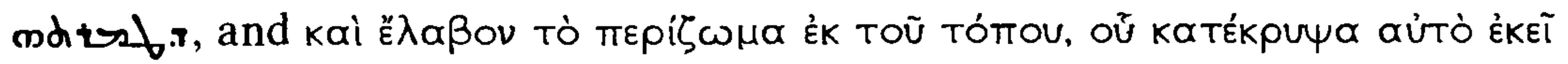
with no representation of ${ }^{2}$ in either Version. The minus seems unlikely to be deliberate, for it achieves nothing: although the sense is perfectly clear without ש , the term is not unclear or confusing. 
22:11 For MT שלם בן-יאשיהו מלך יהודה המלך תחת יאשיהו אביו, neither the Syriac nor the Greek render מלך יהודה. There is some uncertainty as to whether Shallum was Jehoahaz, Josiah's immediate successor, or one of Josiah's other sons who became king in due course, but there is no uncertainty in describing Josiah as מלך יהודה, and therefore no evident reason for not translating the phrase. Possibly, this phrase is a secondary expansion.

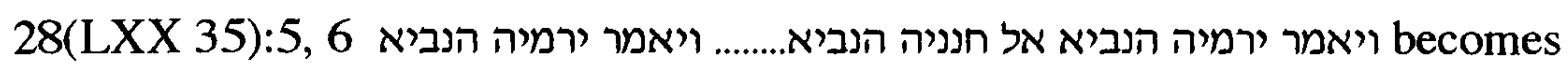

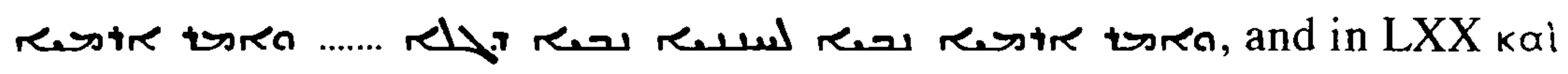
EآTEv lepenías mpòs Avavíav

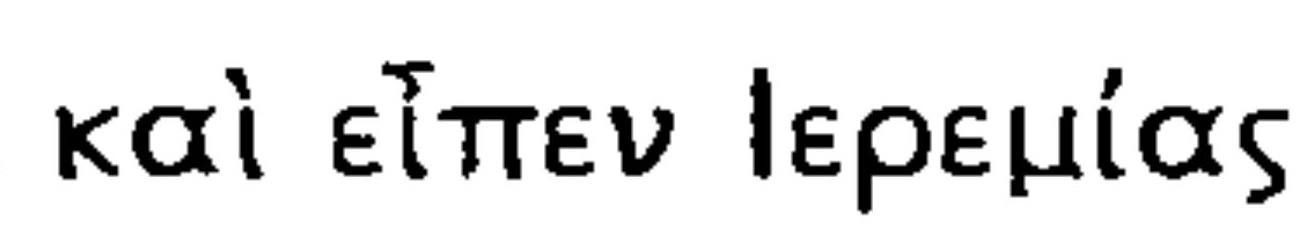

Possibly, the epithets entered MT in stages; none were present in the Vorlage of LXX, but the first two were present in the Vorlage of the Peshitta. (The addition of $\mathrm{r}$ is in keeping with the translation technique described in Chapter 2.)

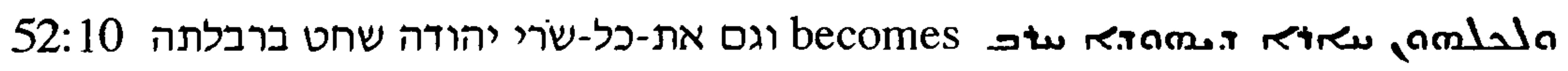

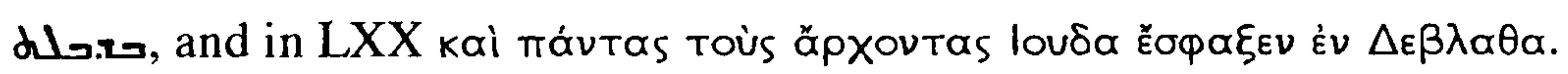

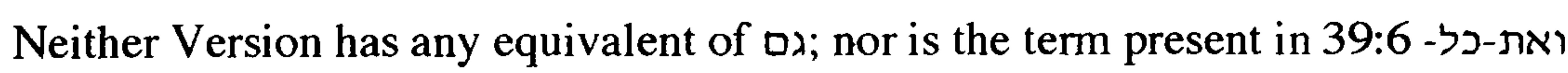
חרי יהודה שחט מלך בבל suggesting the possibility that it was a late addition to the text of MT.

\section{Category $\mathrm{C}$}

Here, there is convincing evidence of textual corruption in MT which is not represented in $\mathrm{P}$; however, there is no support in LXX, which lacks exactly matching passages at these points.

Possible secondary expansions כי היו בני ישואל ובני יהודה אך עשים הרע .... כי בני ישראל אך מכעסים אתי becomes

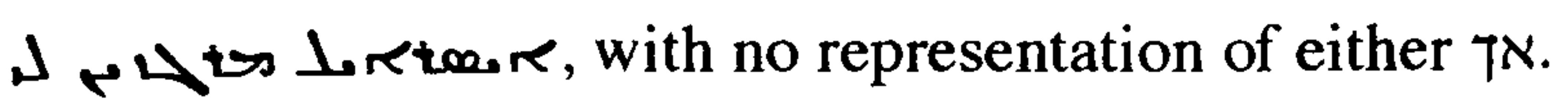


Chapter 4 Minuses

Possible doublet

$30: 13$

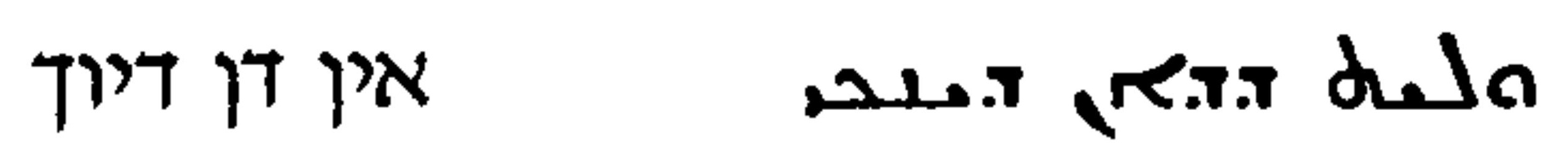

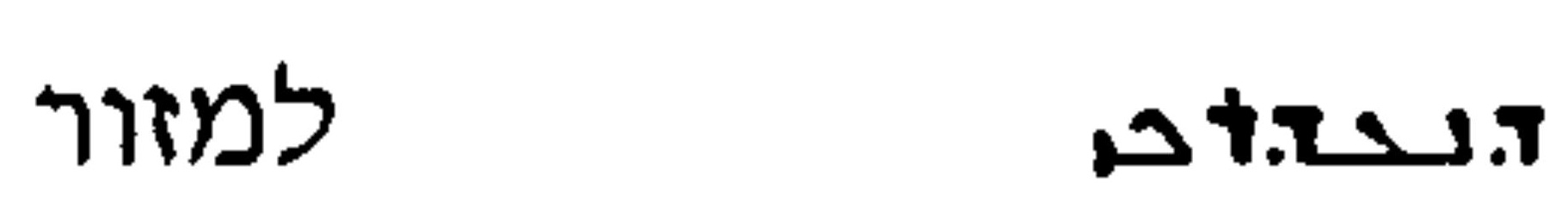

, רפאות

תעלה אין לך

There is no equivalent in the Peshitta of תעלה אין לך. At the closely similar 46:11, where the identical Hebrew phrase appears, the translator resorts to

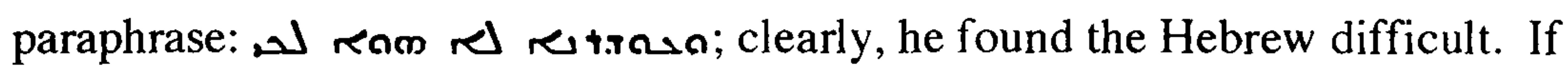
paraphrase was possible at 46:11, it could also have been used, as a last resort, at $30: 13$, so there may be some other reason for the omission. Textual criticism suggests that the terms may be doublets, or that רפאות glosses the more obscure תעלה; the translator may have given both 30:13 and 46:11 as they were in his Vorlage, 30:13 still in its pre-corruption form and 46:11 already incorporating the additional wording. 


\section{Translation policy maintained as editorial policy}

The evidence that translations from one part of the Peshitta may influence another part discussed in Chapters 2 and 3, though sparse, may suggest that the translators worked to some extent as colleagues rather than as separate individuals, feeling that they were members of a "Peshitta School". The ease with which the translations of the duplicate passages fit into the different books supports this impression, suggesting that there was an overall translation policy to be observed by the members of that School ${ }^{1}$. Once the translating generations were history this feeling of membership of a group could have died out; but it seems more probable that those who worked on the Peshitta after that initial stage would have been conscious of the tradition and felt that they had a duty to perpetuate it: they would have felt responsible for the character of the text. If they came across passages where, for instance, the level of clarity or grammatical consistency fell below the required standard they would have been capable of emending the text to "improve" it, and may have felt that they had a duty to do so, even though realising that in this way they would take their text further away from the Vorlage: accessibility and intelligibility were more important than fidelity to the original Hebrew. Indeed, despite the long period of time between the translation of the Vorlage and the writing of $7 \mathrm{a} 1$, it is reasonable to suppose that the editors would still have felt themselves to be part of the Peshitta School tradition: there would surely have been a continuous consciousness in eastern religious circles that this text, rooted in Judaism and spanning the early centuries of Christianity, was of the greatest importance.

1. It is also possible that the consistency of style in the different books of the Peshitta is due not to a number of translators conforming to an overall "house style", but to there having been only one translator: this possibility will be discussed in Chapter 7. For the present, the discussion will be based on the acceptance of the majority view, that is that there were a number of translators. 
The editors of the Peshitta mss. can indeed be shown to have had aims similar to those of the translators: certain characteristics of translation technique, analysed and discussed in Chapter 2, are clearly evident in the work of the editors too. The policy which had originally determined "translation technique" thus came, in the hands of the editors, to determine "revision technique".

The variants which show these editorial aims will be discussed in this chapter. The decision to discuss variants as a whole rather than piecemeal during the analysis of individual verses in earlier chapters was made for two reasons: first, the overall picture of the work of the editors is clearer if the examples are presented in this way, and second, if the variants are presented individually, they disrupt the train of thought ${ }^{2}$.

In this discussion, 9a1 is taken as the representative of an earlier stage of transmission: its many unique agreements with MT, particularly in Kings and Jeremiah (Weitzman, 1988, p.226) have sometimes been ascribed to revision after MT itself, LXX, or the minor Greek versions, but Weitzman argues that "a MS can preserve the original text uniquely if fed by a source not available to the rest" (p.227) and shows that revision does not explain all these agreements, though he accepts that it may account for a small number. For instance, certain surprising lexical equivalents can be convincingly shown to represent the peculiarities of the original translator (pp.229-236); in some other passages, the majority reading can only be explained as a corruption of the reading of $9 \mathrm{a} 1$ (pp.237-238); and there are also some passages (pp.238, 239) where 9a1 shows "a unique agreement with MT and a stark disagreement with MT in such close proximity as virtually to exclude the possibility of revision".

The reasons for taking $7 \mathrm{a} 1$ as the representative of later mss. were discussed in Chapter 2. The present chapter is based on a comparison of these two mss., 9a1 and 7a1, with one another and with MT; it has been made possible by the generosity of Dr. Konrad Jenner and Dr. Donald Walter, who have allowed me to use Dr. Walter's collations of variants in the mss. of Jeremiah in advance of the publication of the Peshitta text of Jeremiah edited by the Peshitta Institute. 
There are of the order of 300 differences $^{3}$ between $9 \mathrm{a} 1$ and $7 \mathrm{a} 1$; as in earlier pages, the most interesting examples will be discussed in this chapter, but a small number which add nothing further to the discussion have had to be excluded because of constraints on space.

These differences fall into two principal groups:

(i) those which show features in common between the work of the editors and the work of the translators;

(ii) those which seem to represent developments in the Syriac language with the passage of time.

(i) Features in common between the work of the editors and the work of the translators

These may be classified under the following headings:

a. freedom in the selection of lexical equivalents;

b. harmonisation of one verse with another, either in the same book or in another book;

c. additions to increase clarity or precision, and the use of additional epithets;

d. correction of grammatical inconsistency or logical imprecision.

Some of these differences between mss. may of course have occurred as a result of corruption during transmission, but their sheer number and the readiness with which they can be classified into the categories of translation technique presented in Chapter 2 suggest strongly that they are not simply the result of error of some kind but represent deliberate editorial emendment of the text: since, however, these editors had no personal contact with the Hebrew Vorlage the emendments cannot be described as manifestations of "translation technique", but should be seen as the work of the editors concerned to preserve and indeed strengthen the "presentational style" of the material.

3. There are many more which are trivial, for instance the presence or absence of waw, or are likely to result from accident, such as the presence or absence of seyame. 
The presence of such features in the work of editors is well known: for instance, papers presented by Brock, Koster, and Dirksen to the Peshitta Symposium held in Leiden in 1985 and published in the series of Monographs of the Peshitta Institute show clearly their presence in the sequence of mss. of Isaiah, Exodus, and Judges.

Brock (Brock, 1988, p.54) shows that editorial additions sometimes increase the precision of the text:

Isa 48:14 dor ] om 5ph1 6h5 8a1*9a1(fam) $=\mathrm{H}$ (Brock uses the term "Hreading" to refer to variants which are closer to the Hebrew). Thus MT מי בהם דבי , is, in the reading which is almost certain to be the original

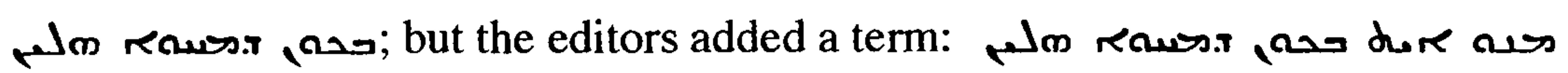

Similarly, Isa 65:12 יען קראתי ולא עניתם 5ph1 (vid ) 7a1 = H: here, MT was originally translated ad.e. the revised form: adees ra pado to. 1

Some add emphasis, as at Isa $65: 4$ in the new reading summing up the wrongdoing of the people:

rist... retrs] ] om 5ph1 6h5 9d2 913 10d1 11d1 12a1 12d2>=H; the

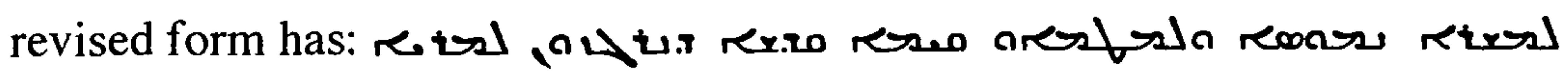

The evidence presented by Koster (Koster, 1988, pp.122, 110-111) also suggests a movement from the earlier "fairly literal" type of text to the gradually expanding text, diverging more and more from the Hebrew original, of the later mss. Koster cites, for instance,

Exod 14:12 הלא זה הדבר אשר דברנו אליך במצרים

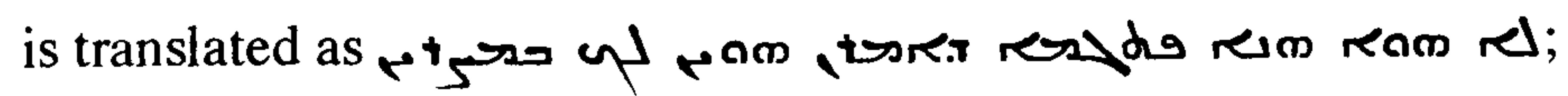

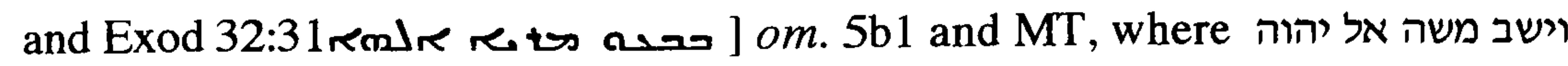

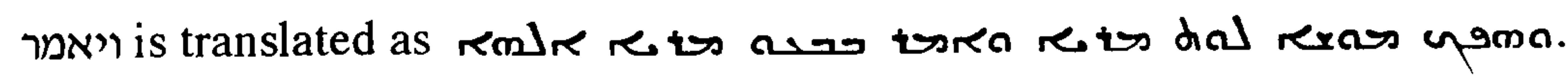

Dirksen (Dirksen, 1988, pp.132-138, 144) cites a number of readings which occur in at least two of the ancient mss. of the Peshitta to Judges which show a 
והנה tendency to increasing precision: for instance, Judges 3:25 where MT reads

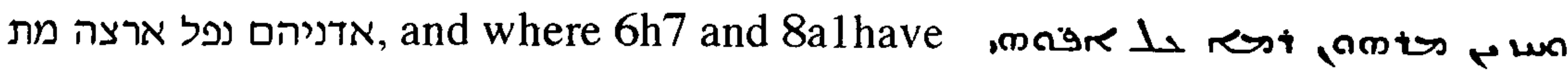
desa reitr.

As a final example from the many which these authors give, there is evidence of harmonisation in for instance Judges 11:3 where MT reads אנשים ריקים and 6h7 and 8al have <

Similar editorial work is clearly evident in Jeremiah; examples to be given below show that both 7a1 and 9a1 include some such features, and that although some are common to both others are unique to one or the other. The date of entry of those which are common to both remains unknown: such passages could be the work of the original translator, or of editors working at any time before the division of the two lines of transmission represented by 7a1 and 9a1. Those which are exclusive to one ms. or the other show that these features of translation technique were seen by later editors as of such value that they continued to be added: the presentational style of the Peshitta, its "house style", was so important that it justified the emendation of the text away from the original Hebrew, for these later editors must have realised that this would be the effect of their work; on the whole, though, the work of the editors was restrained, a point shown particularly well in the restricted introduction of harmonisation: this aspect of translation technique could of course be used to such an extent that it would become tedious, but has not. Barnes (Barnes, 1901, p.197) discussing the influence of LXX on the Peshitta, points out that whereas the translators must have known that their Hebrew understanding was good, the transcribers were ignorant of Hebrew and therefore susceptible to influence from the Greek; their consciousness of the difference between their skills and those of predecessors, as well as the less intense concentration on the words or phrases of the work immediately in hand required of a scribe in contrast to that required of a translator, may have made harmonisation a more frequent component of the work of the revisers than of the translators. 
The presence in each of these two mss. of differences from MT which are unique to one or the other confirms the suggestion that the two mss. belonged to different lines of transmission, a process explained by Weitzman (Weitzman, 1988, pp.244-245) and discussed by Brock in a comparison with the history of the Septuagint (Brock, 1988, p.79). 7a1 is not a revised edition of 9a1; rather, both mss. represent revised editions of the original translation. Brock compares the textual character of 9a1 (and of 5ph1) with that of the "Lucianic" mss. in the LXX tradition, arguing that separation from the mainstream was probably early, about 100 C.E. in the case of the latter, and that although 9a1 preserves many early or original readings; it is not free of secondary features. Analysis of the variants shows the truth of this in 9a1-Jeremiah too, although as the examples below suggest there are many more passages in which $9 \mathrm{a} 1$ agrees with MT against $7 \mathrm{a} 1$ than there are where $7 \mathrm{a} 1$ agrees with MT against $9 \mathrm{a} 1^{4}$.

\section{a. Freedom in the selection of lexical equivalents}

In some contexts, even without access to the Hebrew, it is possible to see that the original choice of lexical equivalent is not the only possible choice; an editor who valued his own opinion as to the best choice of lexical equivalent sufficiently highly to risk diverging further from the Hebrew of the Vorlage, and was therefore prepared to overrule his predecessor's choice, could and evidently did make changes in this respect. Some examples follow.

4. It is appreciated that it is unfortunately impossible for the reader to check that this statement is accurate until the publication of the Peshitta text of Jeremiah and its related critical apparatus, which is not expected (personal communication from Dr. K. Jenner) before 2000/2001. The only way to provide full information for the reader at this stage would be to reproduce all the collations so kindly provided by Dr. Walter and Dr. Jenner, clearly impossible before their publication. 
Editorial policy seems sometimes to have been intended to impose consistency with the choice of lexical equivalent elsewhere. For instance, in 3:2 שיאי עיניך על

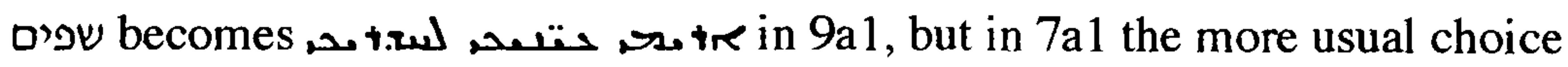
appears: Rresting variant: elsewhere in Jeremiah שפים) (שפיים occurs in $3: 21 ; 4: 11 ; 7: 29 ; 12: 12 ; 14: 6$. It is consistently translated with 2 , both in $9 \mathrm{a} 1$ and in 7a1, with the single exception of this passage. The translator may have judged from the context that

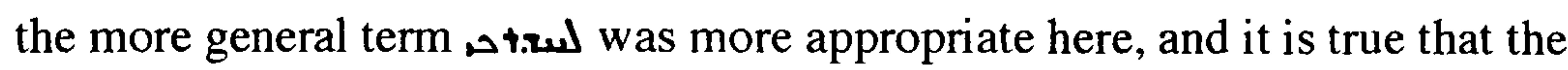
nuance of the Hebrew שפים is not the same here as in its other occurrences in Jeremiah $^{5}$. Perhaps it was the translation of על דרכים ישבת להם, later in the same verse, with 1 am wald have been suitable here, and which influenced the editors to make this change, clearly implying a parallel between שפים and דרכים.

In 5:14 נתן דברי בפיך, but in 7althe

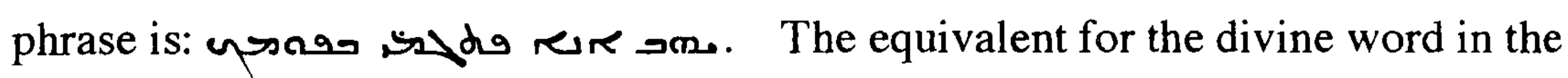
Peshitta is unstable, but the choice in 7a1 is the more usual (Weitzman, 1996, p.590).

\section{5. \\ 4:11 רוח צח שפיים במדבר \\ 7:29 שיאי על שפים קינה \\ 12:12 \\ 14:6 ופראים עמדו על שפים}

Gelston, 1971, here pp. 518-521, notes the idea of "height" which has been associated with in Isaiah 41:18 where LXX has ópéwv, and with Jer 3:2 probably because of the association with שאי עיניך, argues that this has no philological justification, that philologically "sand-dune" or "track" are equally acceptable, and that the evidence of the Versions and the contexts tip the balance in favour of "track" as the best understanding of שפים. 
In 8:3 is translated in 9a1 as קשר הדחתים שם but but in 7al as Sd) expel" and Jeremiah (see Chapter 2, n.25), and the equivalent used in $7 \mathrm{a} 1$ is the usual choice; root $\mathrm{R} \times \mathbf{x}$ is used nowhere else in this context in P-Jeremiah.

As a final example of the possible imposition of consistency in editorial policy, in

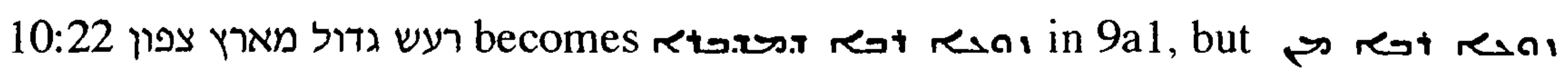
r.at. Tre in 7a1. Trouble usually comes from the north in Jeremiah ${ }^{6}$, and the reviser has substituted the more usual lexical equivalent.There is a similar example in 20:5 where עיר is translated with redus in 9a1 but with red o in 7a1. The editor's choice in $7 \mathrm{a} 1$ brings the verse into line with almost all the other translations of עיר In Jeremiah. With only two exceptions, in 19:15 ${ }^{7}$ and 51:31, the choice is red to: the preference in Jeremiah for the more conservative term is discussed by Weitzman (Weitzman, 1996, p.609). It is just possible

6. Childs, 1959 , p. 190 discusses the dating of "enemy from the North" passages in the Hebrew Bible, and the authorship of these passages in Jeremiah. Childs suggests, on the basis of the vocabulary, that $4: 24 ; 8: 16 ; 10: 22$ are distinct from other pre-exilic "enemy from the North" passages in Jeremiah, but the translation in the Peshitta does not indicate that any different nuance was evident to the translator or known in any tradition of which he was aware, for it is only in 10:22 that the less usual term is used in the Peshitta.

7. In 19:15, the choice of redw.s is doubtless a response to the context, with its implied comparison of the major and the minor settlements: הנני מבי אל העיר הזאת ועל כל עריה. The reason is less clear in $51: 31$, though it may be that the translator judged that the description of the city "נלכדב ... מקצה" implied a considerable size which he felt should be acknowledged. 
that the $7 \mathrm{a} 1$ choice may be the original, deliberately changed by the editor in the 9a1 line to express the might of the city, the ress dreto reders of Lamentations 1:1; though Weitzman points out that even in Lamentations, as in Jeremiah, אל מיר (Weitzman, in press, pp.181-182). In other passages, the revised choice seems to have been motivated by the desire for precision; for example, in 18:3 ארד בית היוצר is translated in 9a1 as rwe deal dson, but as rwe d.al didwa in 7a1; root dw is appropriate in the context.

In 11:7 השכם והעד מש. becomes in 9a1 העד העדתי d.rmo o.rmoss d.rmon, but in 7al dit.ren dss....... d.rmoo a.rmoss. Both equivalents have appropriate meanings, .rmo "to witness" and trx here "to send to say". Elsewhere in Jeremiah, root עוד "to bear witness" is at 6:10;29:23; 32:10, 12 , 25,$44 ; 42: 5,19 ; 44: 23$. In these passages, the sense "to witness" is clear, and

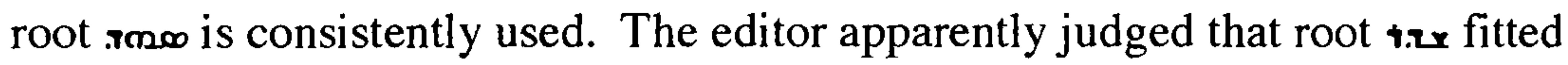
the context better at 11:7.

Similarly, in 11:8 ואביא עליהם את כל דברי הברית הזאת אשר צויתי לעשות ולא עשו the

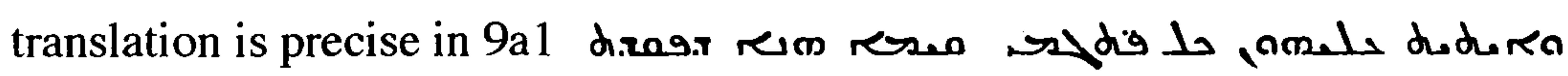

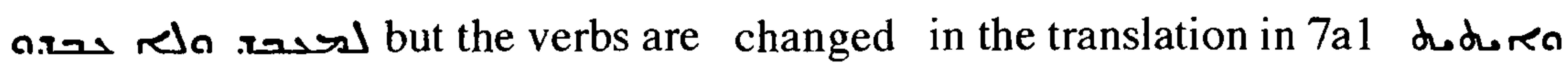

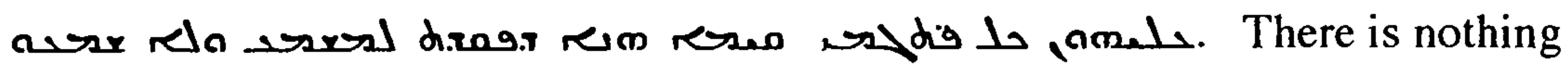
to choose between the two variants for precision; they seem simply to represent different opinions.

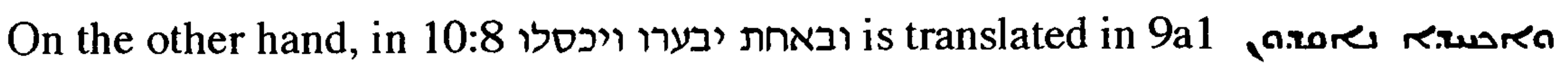
בער are (B.D.B., 1951, pp.128, 129) "to burn, consume" and "to be brutish"; both variants are closer to the first meaning. The revised choice is imprecise, perhaps because the editor felt that the sense was poor but hesitated to make a more sweeping change ${ }^{8}$.

8. There is also a possibility that corruption explains the difference, an original a.rore in 9al and 7al being mistakenly copied as ,n.tore (Weitzman, 1988, p.238). 
In 13:22 there is a particularly interesting example in the translation of ערב

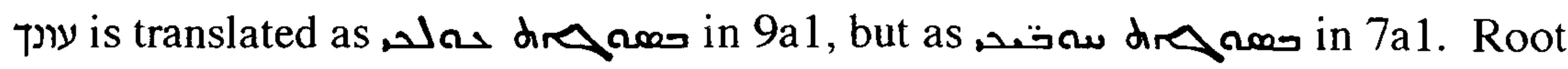
עון occurs frequently in Jeremiah, and the lexical equivalents used to translate it were discussed in Chapter 2: No is not an unusual choice, and there are no other passages in which the editor has changed this equivalent; there is no explanation apparent in the context (for instance, the equivalent selected is not dictated by the frequent parallelism with purely dictated by free choice.

The final examples show a freedom in the choice of lexical equivalent which tends towards another feature of translation technique discussed in Chapter 2, the characteristic approach to figurative language. Sometimes, the decoded imagery in the more precise phrase reduces the impact of the text: in 23:26 בלב הנבאים נבאי

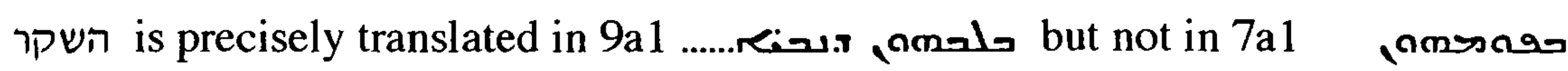

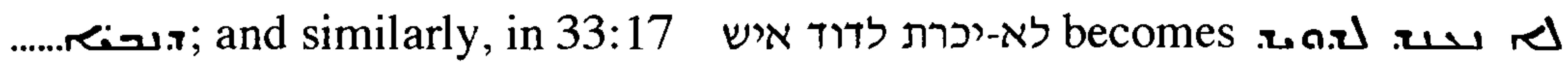

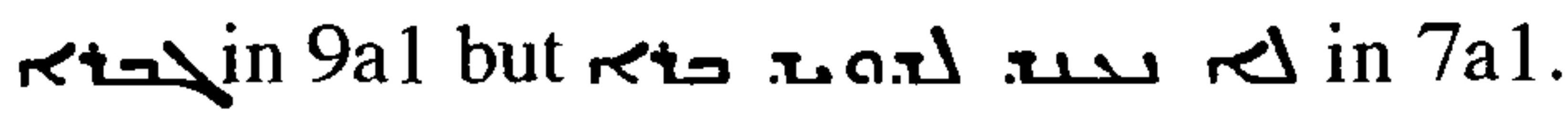

\section{b. Harmonisation of one verse with another}

First, examples where 9a1 agrees with MT against 7a1:

within Jeremiah, 18:7 לנתוש לנתוץ ולהאביד is translated toshosta

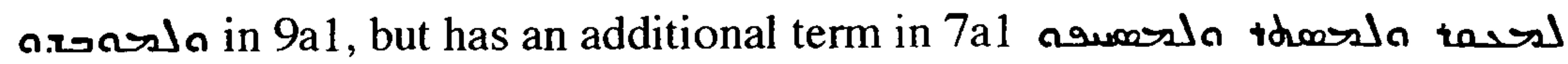
a.s Harmonisation in 7a1with other verses which include some or all of the series of infinitives which first appears in 1:10 לנתוש ולנתוץ ולהאביד ולהרוס is a possible explanation.

חרב ..... רעב " There are similar examples which involve terms from the recurring דבר......" : MT in 21:7 has all three terms, though not in the standard order: it has the sequence דבר...חרב...רעב. In 9a1 the translation is precise, ra.... ridos...rerar... 
In 44:27 the MT has an incomplete form of the sequence, חרב.... חרעב; here too 9a1 gives a precise translation, حar.... third term: reshas...reras.....Rat.

In 34:17 there is a particularly interesting position: MT gives the components of the sequence in a non-standard order, חרב....רבר.....רעב, but both 9a1 and 7a1 give the terms in the usual order, rdas...resa.... The This raises the possibility that the change was introduced into the Urtext, antedating the division in the line of transmission which separated $9 \mathrm{a} 1$ from $7 \mathrm{a} 1$; it is also of course possible that the $9 \mathrm{a} 1$ editors and the $7 \mathrm{a} 1$ editors both, independently, introduced this modification.

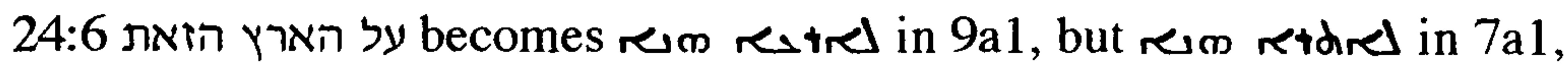
possibly to harmonise with MT מן המקום הזה in the preceding verse, which is translated rem rethre p.

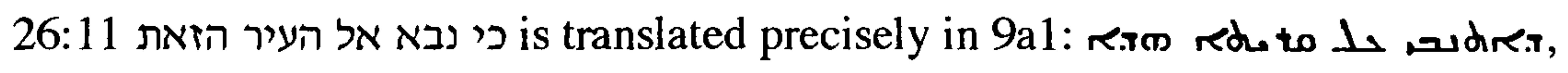

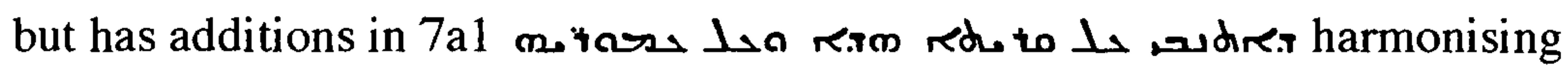
with e.g. איש יהודה וישבי ירושלם

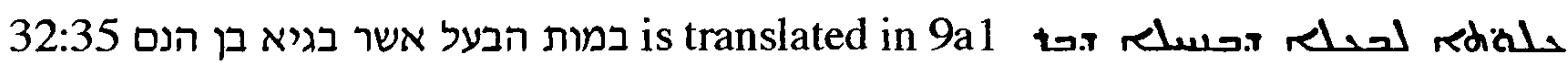

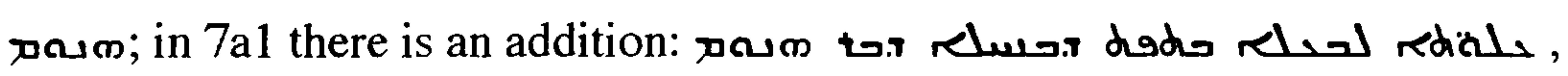
harmonising with e.g. 7:31 התפת אשר בגיא בן הנם

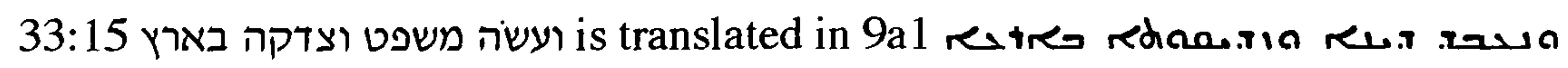

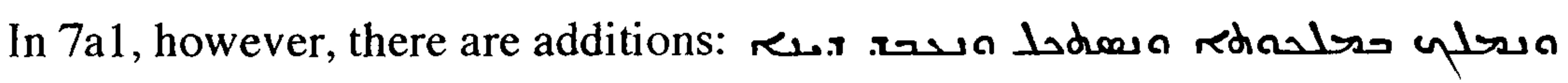
ומלך מלך והשכיל ועשה משפט וצדקה 23:5, harmonising with בארץ 
Chapter 5 The Work of the Editors

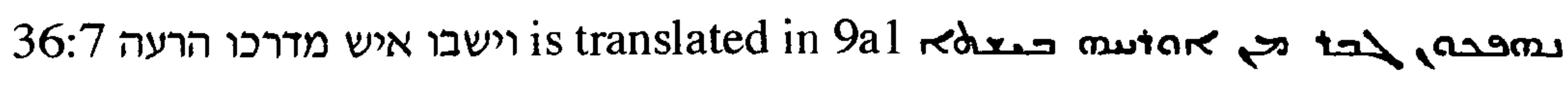

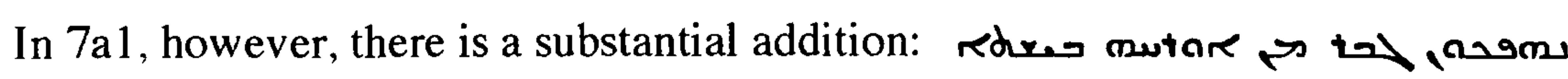

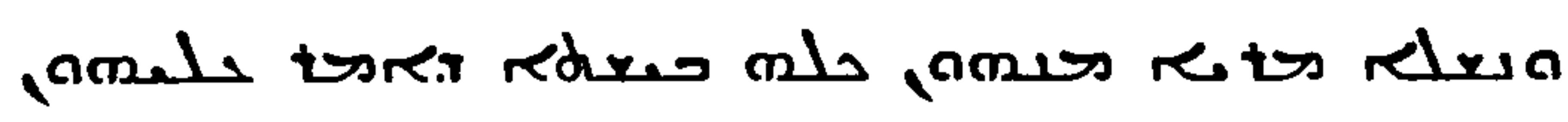

harmonising with 26:13 וינחם יהוה אל הרעה אשר דבר עליכם, translated as:

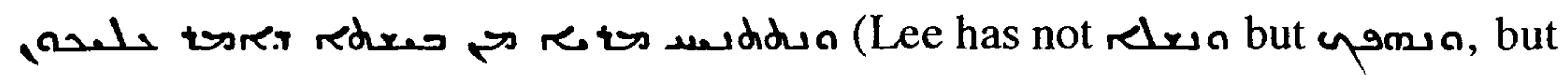
$7 \mathrm{a} 1$ has rela).

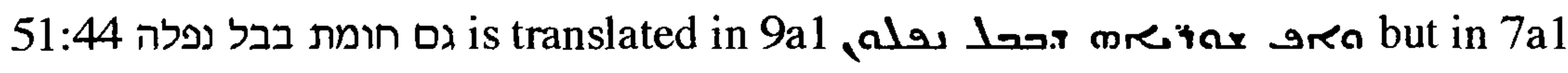
as חמות בבל הרחבה 51:58, harmonising with the process of harmonisation to a later verse is discussed in Chapter 2 with reference to the two verses 7:6 and 22:3, in which also the former seems to have been harmonised to the latter.

There is one example of harmonisation with a text from outside Jeremiah (noted in Weitzman, 1988 , p. 242):

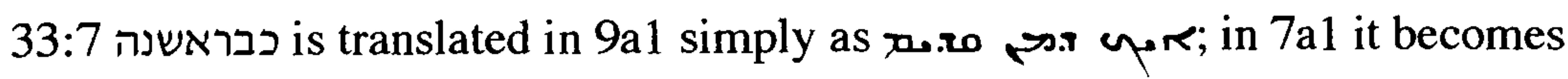

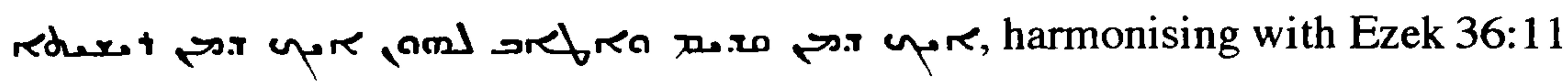

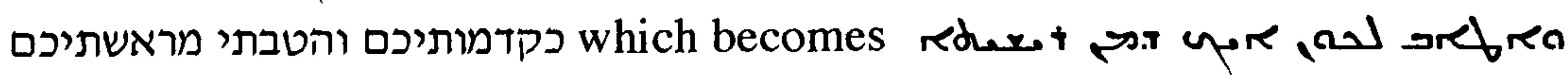

Examples where 7a1 agrees with MT against 9a1 are few, and there is only one which is fairly convincing, in 50:28 where היכלו is translated exactly in 7a1 but in 9a1 has an additional term: r.ro a r.m , perhaps intended to harmonise with, for example, Psalm 5:8 אשתחוה אל היכל קדשך

\section{c. Additions to increase clarity or precision}

First, examples where $9 \mathrm{a} 1$ agrees with MT against $7 \mathrm{a} 1$ :

15:4 is translated as בגלל מנשה in 9a1, but has an additional term in

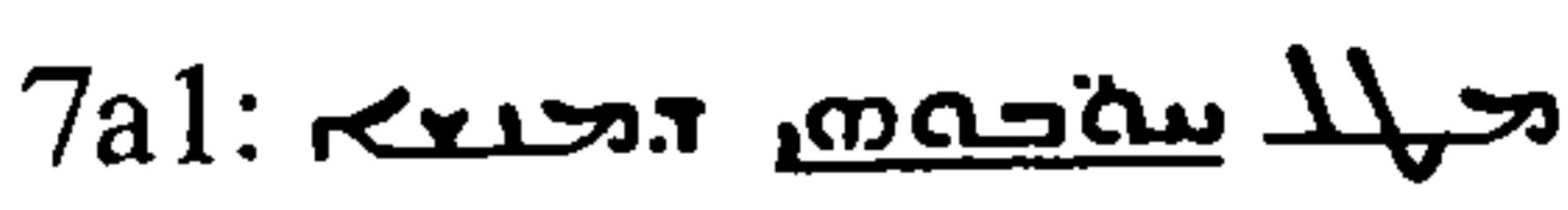




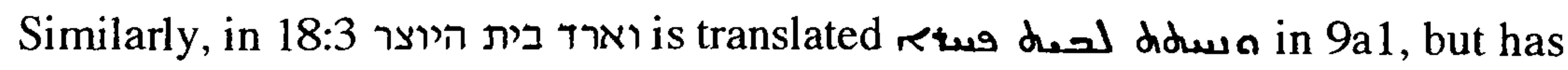

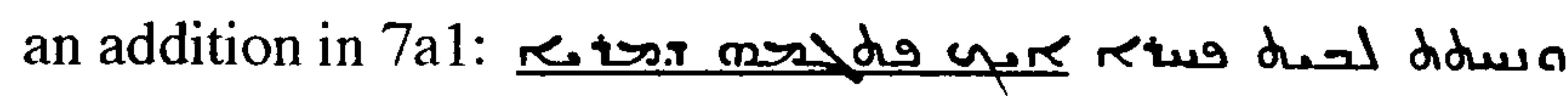

23:10 מנאפים מלאה הארץ is translated precisely in 9al restre delsdre rel

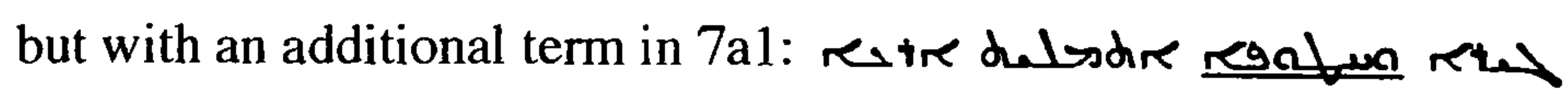

25:33 similarly is translated precisely in 9a1 as atcodu.... aredu.... n.cot, but has two additional terms in 7a1:

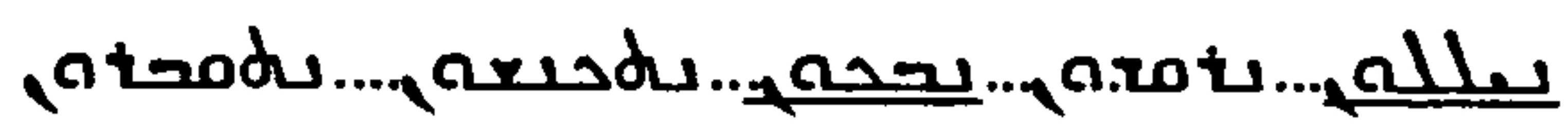

29:21 is translated והכם Ifo in 9a1, but has an additional term in 7a1: مere

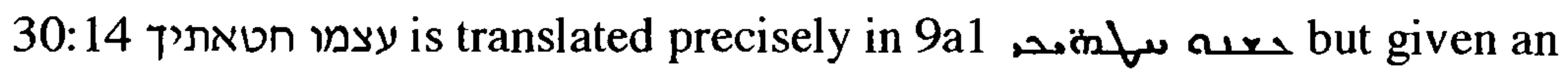

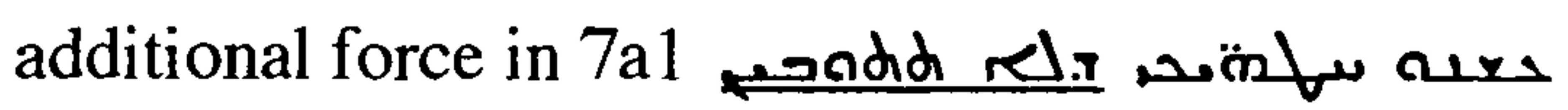

32:5 is translated precisely in 9a1 m עד פקדי אתו , but is

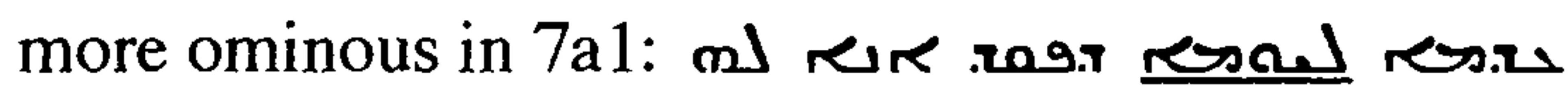

32:7 בענתות in 9a1, but information is added in 7a1:

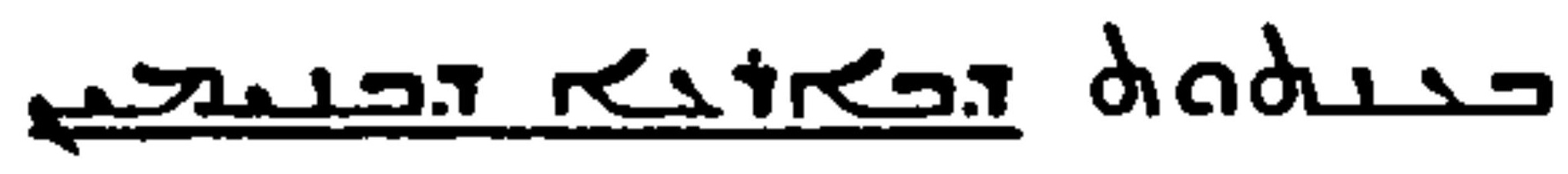

36:5 ברוך in translated 9 a1, but has an additional term giving ancestry in 7a1: rets to nato

36:25 is translated לבלתי שרף את המגלה in 9a1, but in 7a1

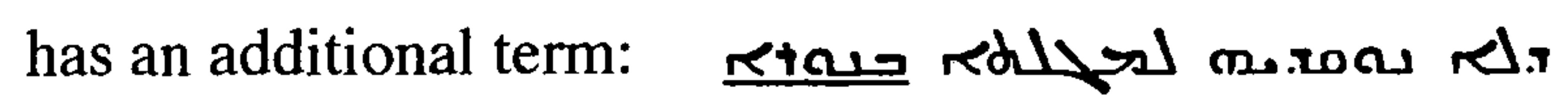

36:31 ולא שמעו is translated 9a1, but in 7a1 has an additional term:

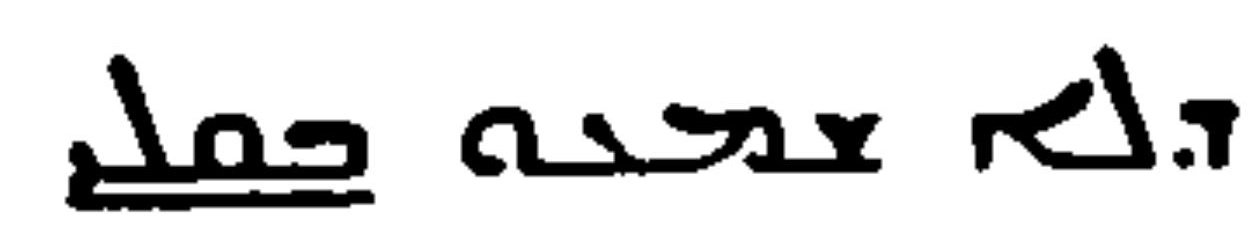


Chapter 5 The Work of the Editors

39:5 בومد is 9a1, but in 7a1 has an

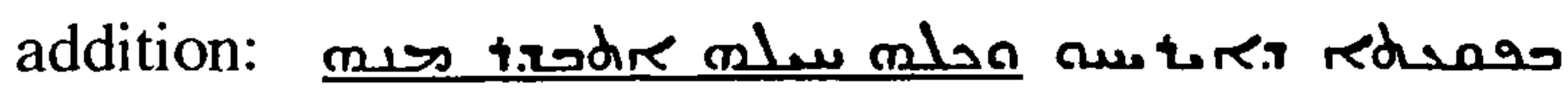

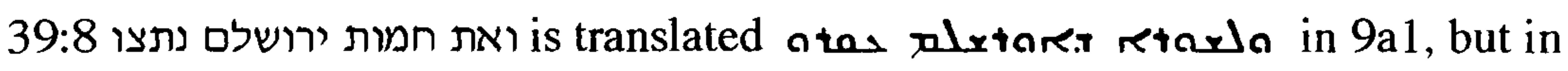

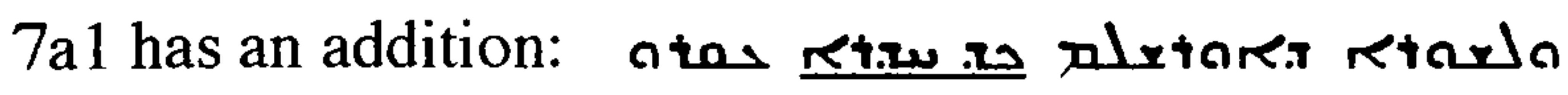

Second, examples where 7a1 agrees with MT against 9a1: once again, these are few.

13:2 האזור is qualified in 9a1 resdar rtrao but not in 7a1 rtrao.

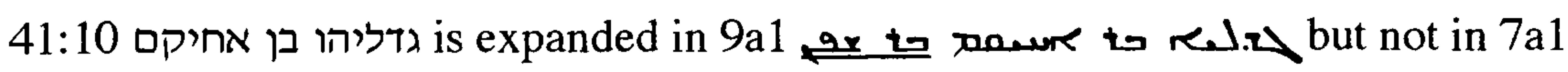
pawe to reld

In Chapter 2, additions to the text of the Peshitta against MT which increased clarity of precision were classified into subgroups: those which specify the subject or object, those which make explicit the identity of the speaker or addressee, and additional verbs. The same groupings are given here, for ease of comparison with Chapter 2.

The additional term specifies the subject or the object:

First, 9a1 agrees with MT against 7a1

31:18 יסרתני ואוסר is translated d.ridirea shor in 9a1 but expanded in 7a1:

d.Tidiren 스 storit

41:16 is similar, הכה את גדליה in 9a1 but with the subject specified

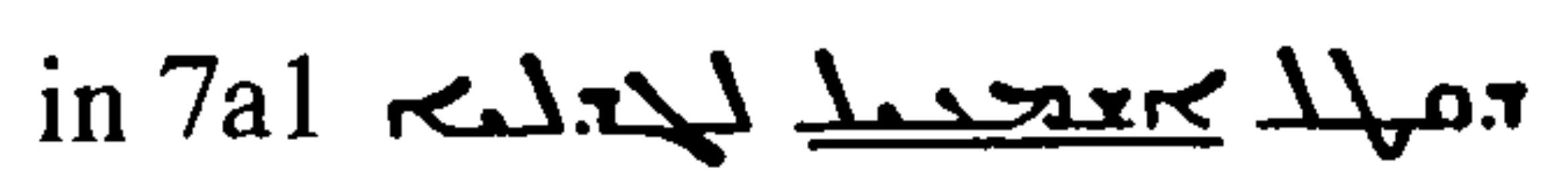

Second, $7 \mathrm{a} 1$ agrees with MT against $9 \mathrm{a} 1$

38:13 is expanded in 9a1 ויעלו אתו maseres, but not in 7a1, manooren. 
Chapter 5 The Work of the Editors

The additions make explicit the identity of the speaker or the addressee:

9a1 agrees with MT against 7a1

26:1 becomes היה הדבר הזה rom in 9a1, but 7a1 specifies the addressee: restre ل1 rem restdo ram

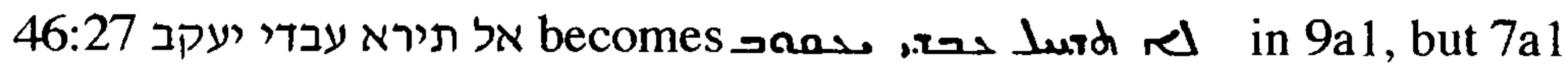

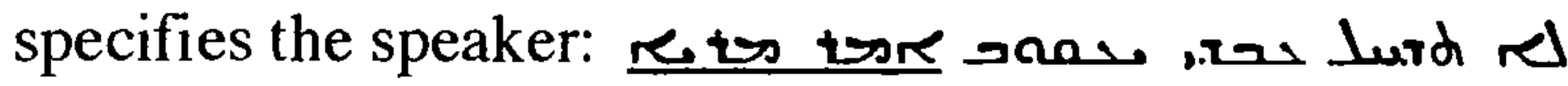

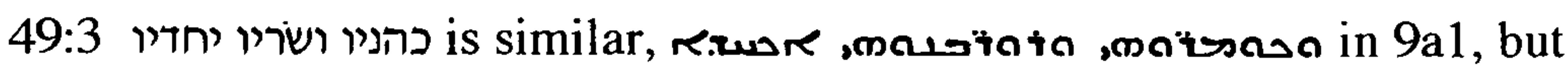

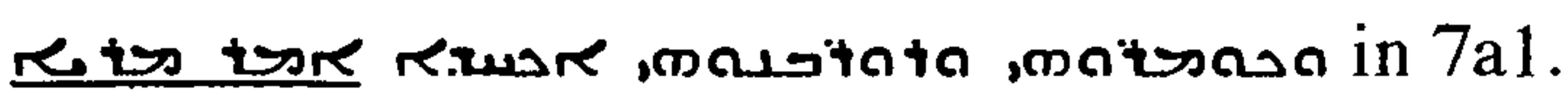

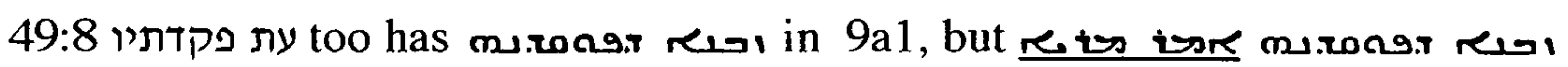
in $7 \mathrm{a} 1$.

7a1 agrees with MT against 9a1

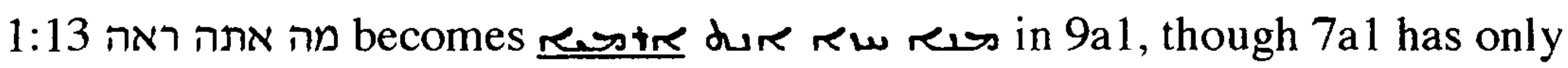
dur rers

The addition is in the form of a verb:

9a1 agrees with MT against 7a1

1:15 is exactly translated in 9a1 הנני קרא אזr, but has an additional verb in 7al ruk rton rer targ.

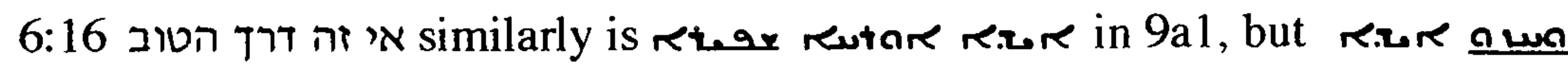
rtuar Rutare in $7 \mathrm{a} 1$.

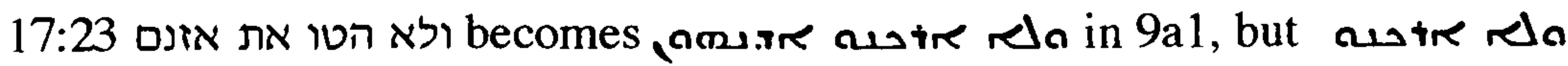
vars amir in $7 \mathrm{a} 1$.

18:11 שובו נא becomes and in 9a1, but ب9dro and in 7a1 ${ }^{9}$.

9. sood, however, is unusual, and redren may represent a gloss. 


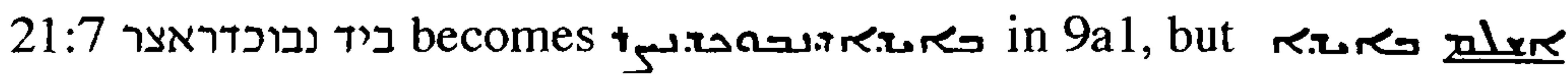
I.

27:6 becomes נבוכדנאצר מלך בבל עבדי in 9a1, but ألسمح.s in 7a1.

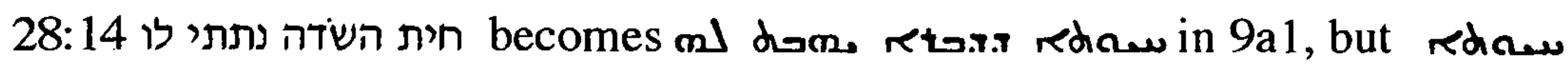
malas on in 7a1.

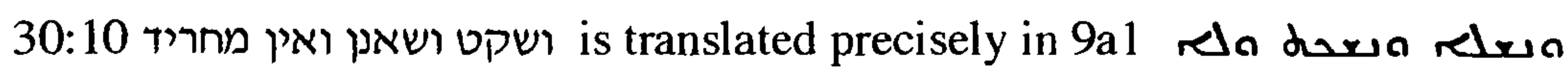
a

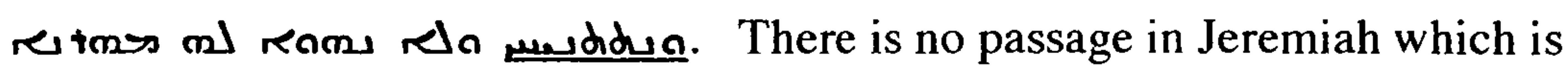
close to the expanded form. There is, though, a duplicate at $46: 27$, where the editor does not add the extra term: some inconsistency would however be expected in such a long work as this.

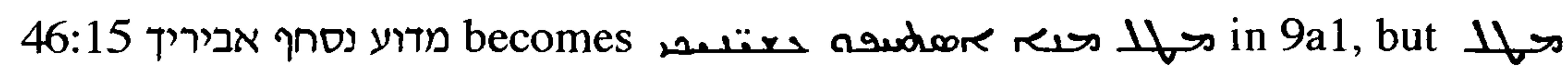
alasa a.rer autore ress in $7 \mathrm{a} 1$.

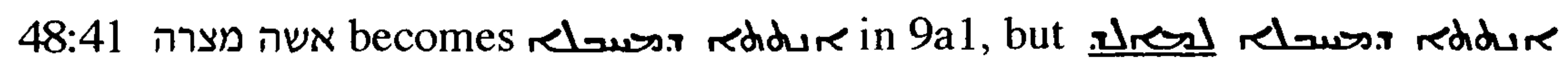
in $7 \mathrm{a} 1$.

7a1 agrees with MT against 9a1

5:9, 29 בגוי אשר כזה is expanded in 9a1 to but in 7a1 is simply rems rasa.

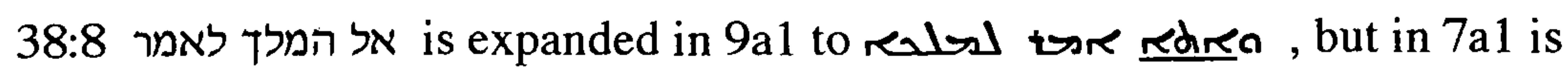
simply rabl torra.

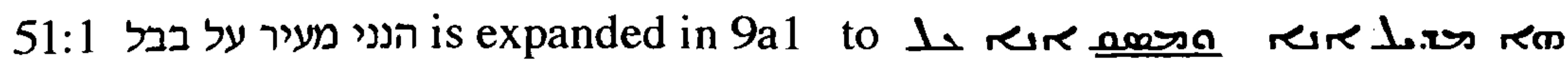
בת, but in 7al is simply 
Chapter 5 The Work of the Editors

The addition may be in the form of an epithet

First, 9a1 agrees with MT against 7a 1

A number of examples involve the divine title:

MT

9a1

$7 \mathrm{a} 1$

$11: 3 ; 13: 12 ; 25: 15 ; 45: 2$

יהוה אלהי ישראל

1.rtanks rmb reis

rmb redllw reis

1. retorkit

יהוה

lotonks rolk rets

remerdlu res

In rtankis

13:9 13וה

rets rolkerdlurets

1.rimorer

$25: 28,32$

יהוה צבאות

Rdlw wot

rabredlew ris

Irrion rer

$32: 18$

האל הגדול הגבור

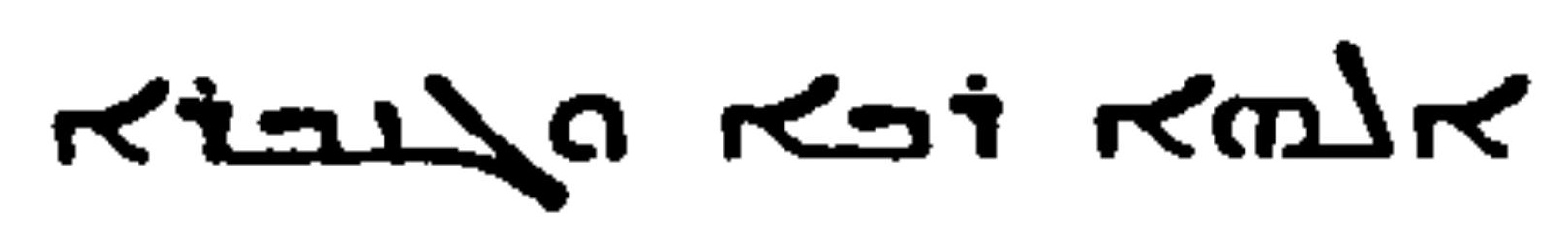

rot $r m b$

n

32:28

ros

Rmbrets

33:11 יהוה

ros

rdlures

34:17

ros

remle rets

I. Rtanks

$51: 1$

יהוה

rets rollew remtrets

Sometimes, other phrases are involved:

21:3

re.

$26: 7^{10} ; 33: 1 ; 37: 21$

ירמיהו

Restik

אריא Rastre

$46: 17$

פרעה

$a+9$

Rtols wato

10. Lee omits 
Chapter 5 The Work of the Editors

Second, 7a1 agrees with MT against 9a1:

28:5 20ימיה הנביא
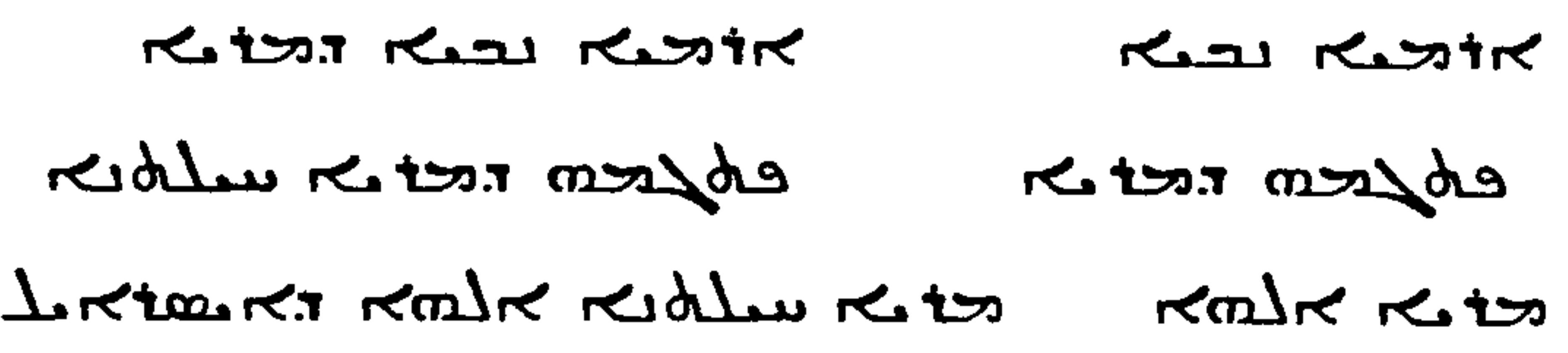

30:2 יהוה אלהי ישראל

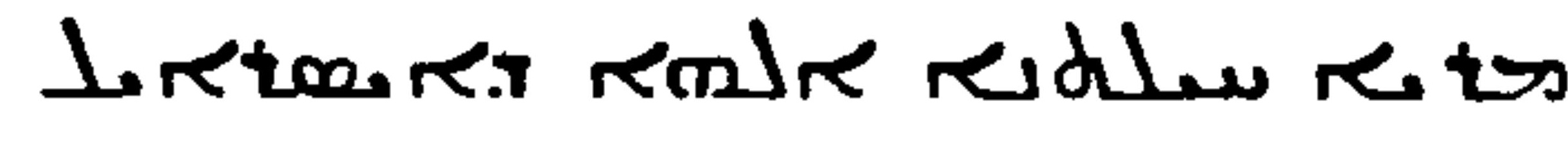

rentrers

Lrion rex

$37: 14$

ירמיהו

Kastir

restik

\section{d. Grammatical inconsistency or logical imprecision}

Translator and editors alike must have felt the urge to write good Syriac and to correct such elements in their texts, but needed to balance this desire against the desire for fidelity; in translation and editing, unlike free composition, a policy is needed in this respect.

9a1 agrees with $\mathrm{MT}$ against 7a1

MT

$9 \mathrm{a} 1$

$7 \mathrm{a} 1$

ילדתבנ........ והושיעע

enontso ........ sh.d.

م مdizl.

In MT, there is a grammatical inconsistency between the plural subjects and ילדתני המה מלכיהם שריהם וכהניהם ונביאיהם

אמרים לעץ אבי אתה ולאבן את ילדתני כי פנו אלי ערף ולא פנים

$$
\text { ובעת רעתם יאמרו קומה והושיענו }
$$

though of course with sensitive reading there is perfectly good sense in the Hebrew as it stands. $7 \mathrm{a} 1 \mathrm{ed.l}$. is in line with the reading tradition, for the Qere at ילדתננו: it may therefore represent a modification according to that tradition, though the uncertainty of the attitude of the translator to the Qere forms was discussed above. The singular suffix in $9 \mathrm{a} 1$ sd.zl tallies with the Ktib, and the singular suffix in 9a1 weontan may represent a deliberate modification to make the two terms consistent with one another, the action of an editor who did not know, or chose not to follow, the Qere custom. 


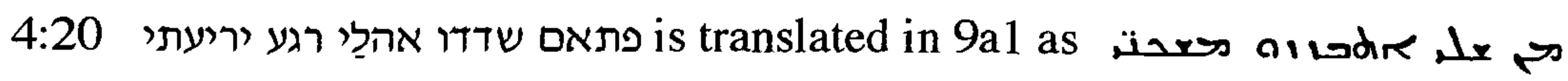

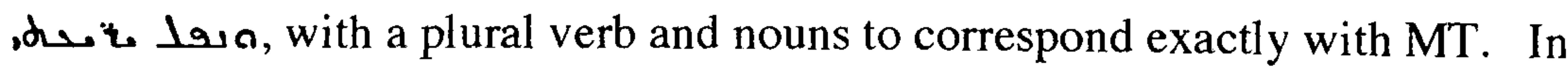
7a1, however, the form is , the with a more

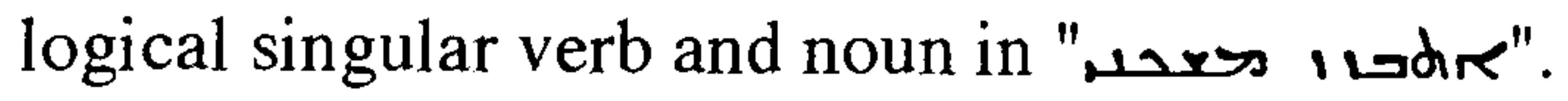

8:1 MT עצמות מלכי יהודה ואת עצמות שריו ואת עצמות הכהנים ואת עצמות הנביאים ואת raises a number of points of interest. First, there is the discrepancy between "שריו", "his princes", and the preceding plural "מלכי יהודה"; second, the further change from the possessive form in "שריו" to the plain plurals in "הכביאים" and "הנבים"; and third, the translation of the Hebrew construct "יושבי ירושלם".

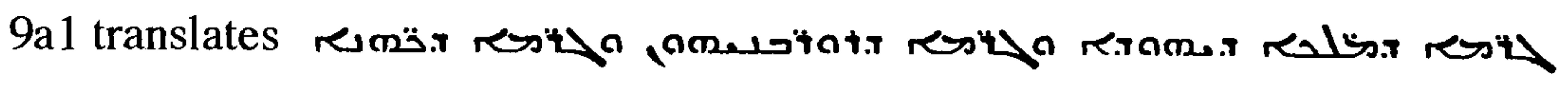

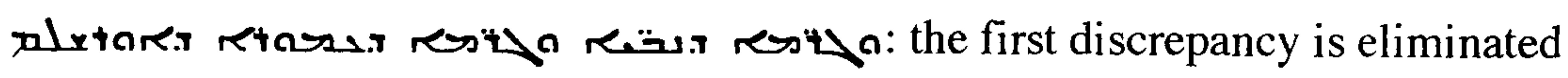

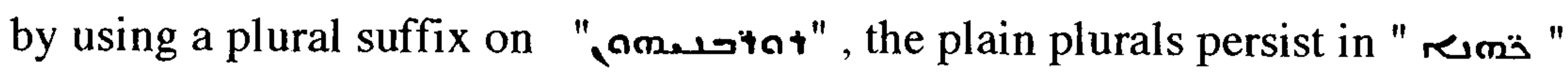
and "دتعك"; and the construct is translated with the emphatic form of the noun.

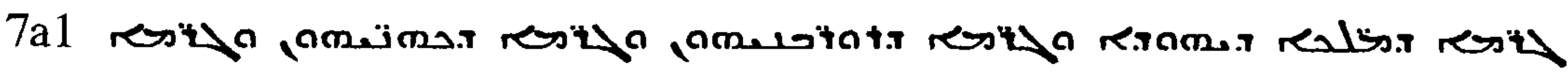
also eliminates the discrepancy between

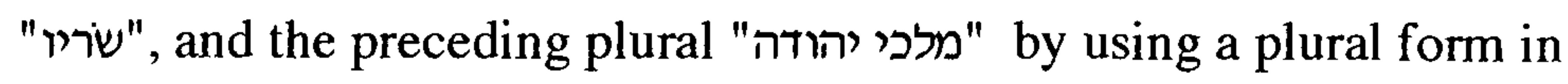

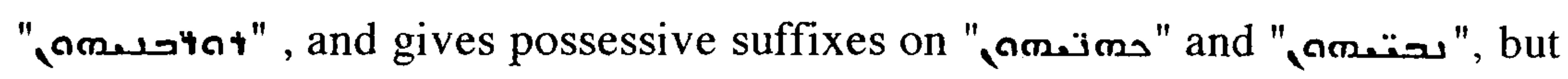
translates the construct by using an anticipatory suffix (translation of the construct will be discussed below).

16:12 MT has ואתם הרעתם לעשות מאבותיכם.....הלכים איש אחרי שררות לבו, with an apparent mismatch of the second person plural addressee with the third person singular possessive suffix in לבו. The mismatch is tolerated in 9a1, but not in

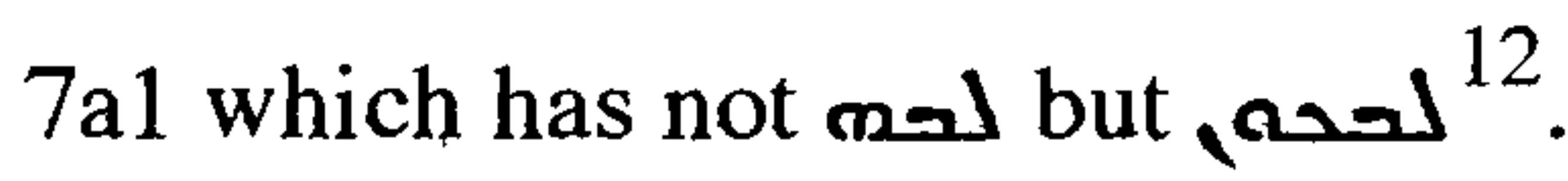

12. Lee has mal. 
27:1 בt is translated בראשית ממלכת יהויקם in 9a1, but in 7alhas been corrected: ك.0. The editor of 7a1 has corrected the mistake which had been transferred from the Vorlage to his Syriac text ${ }^{13}$.

31:9 $9^{14} \mathrm{MT}$, perfectly acceptably, has a singular term in parallel with a plural,

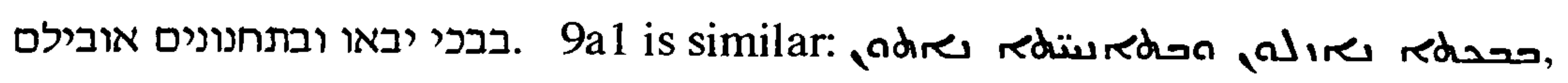
with a singular followed by a plural; 7a1, however, gives a singular form, and a different root, for the second term, rowuedro.

13. The chronology in MT is confused in the opening verses of chapter 27, for the episodes recounted in this chapter and the next evidently took place after Jersualem surrendered to Nebuchadrezzar in 597B.C.E.: in 27:6 God says ועתה אנכי נתתי את כל הארצות האלה ביד נבוכדנאצר מלך בבל עבדי; and in Chapter 28, at a date introduced in 28:1 as the same year, "בשנה ההיא", the king's name is given as Zedekiah, and Hananiah promises that God will ensure the prompt return of the booty taken from the temple on the occasion of that surrender. In 27:3 there is additional evidence that the time is that of Zedekiah's reign rather than of Jehoiakim's: the participants in the conference of 594/3 (Bright, 1980, p.329) are listed.

14. 7al agrees with LXX at this example, but polygenesis is possible. 
(ii) Features which seem to represent developments in the Syriac language with the passage of time

Some differences between 9a1 and 7a1 may represent not the work of editors wishing to strengthen the presentational style but rather their response to the development of Syriac itself with the passage of time.

\section{a. Transposition:}

First, examples where 9a1 agrees with MT against 7a1

In for instance $1: 4,11 ; 16: 1 ; 25: 3$ דבר יהוה אלי is translated exactly in 9a1:

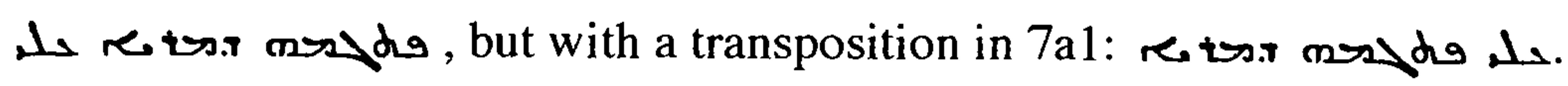

25:11 כמא is but with a transposition in 7almb resm ratr.

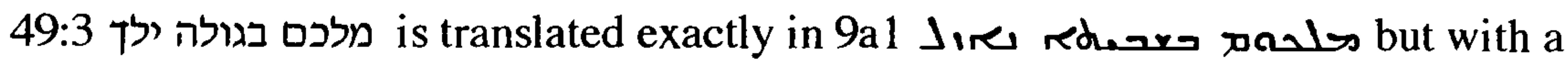

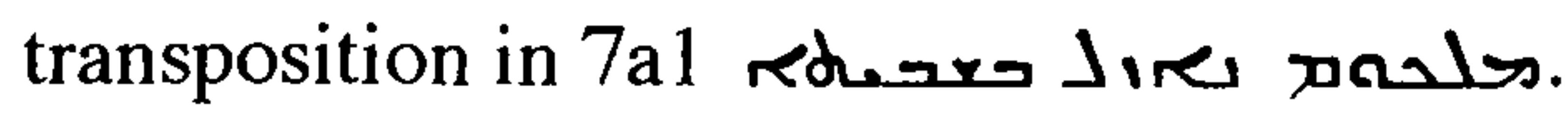

Second, 7a1 agrees with MT against 9a1

50:23 כבע but in a transposition in 9a1 rasecisely translated in $7 \mathrm{a} 1$ rasdl

There are a number of transpositions involving changing the order of roots; given the prevalence of "crossed equivalents" discussed in Chapter 2, it is not often possible to decide whether such transpositions are accidental, the result of corruption, or deliberate. Examples include:

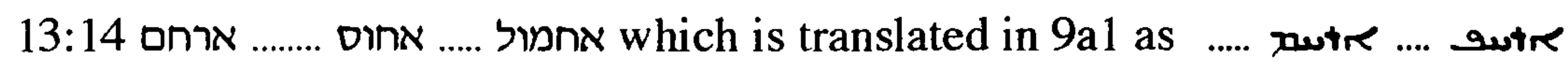
conure, with transposition of the second and third terms; in 7a1 the order is different but still transposed:sone ...... .

In both mss. the position of the cognate of root from that in MT. 
There are similar examples in 18:14 where מים זרים קרים is translated in 9a1 as

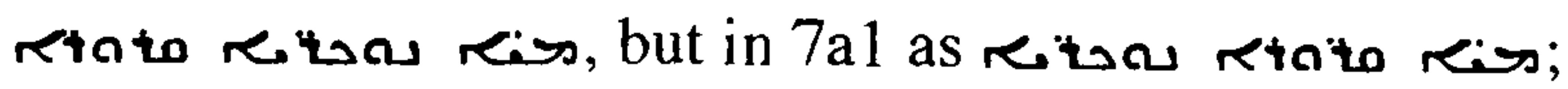

in 22:17 where the pair of terms מרוצה.....p is translated in 9a1 as roors....resalf, but in 7a1 as resalf ...... roors;

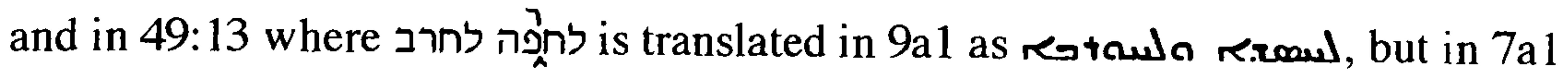
asriconda ratal

\section{b. Translation of the Hebrew construct}

The findings below result from an analysis of the methods by which the Hebrew construct is translated in P-Jeremiah. The sample used for analysis was made up of the first five constructs in each chapter, together with a further five from verse 10 onwards: this ensured that the sample was not dominated by the accounts of names and ancestry which are so often included in the early verses of a chapter. This would have given a total of 520, but the deficit of terms for analysis (not counting נאם-יהוה) in the short chapter 45 reduced the total to 515.

The translation is, on the whole, as expected (Nöldeke, 1904, pp.161- 168, particularly pp.161-163; Muraoka, 1987, pp.16-17, 41, 49-51) ${ }^{15}$.

15. Of the three methods of expression, i.e. (i) the construct, (ii) the emphatic state plus daladh, and (iii) the use of an anticipatory suffix plus daladh, the most common is (ii), used to render $299(58 \%)$ of the Hebrew constructs in this text. The remaining $42 \%$ are divided about equally, half translated by a construct, and half with an anticipatory possessive suffix. There is the expected difference between the translational approach to pure genitives and to other terms in the Hebrew construct: there are 113 pure genitives in the sample, of which $55(49 \%)$ are translated with an anticipatory possessive suffix; where this approach is not used, most are translated with the construct state; of terms which are not pure genitives, however, approximately $70 \%$ are put into the emphatic state. This large sample also showed an 
The point which is relevant here is that there seems to have been a development from the use of the emphatic state followed by dalath to the use of an anticipatory possessive suffix during the period between the idiom appropriate at the time of the ancestor of $9 \mathrm{a} 1$, and that of $7 \mathrm{a} 1:$ where the construct is represented differently in $9 \mathrm{a} 1$ and $7 \mathrm{a} 1$ the usual position is that $9 \mathrm{a} 1$ has the emphatic state but $7 \mathrm{a} 1$ has an anticipatory possessive suffix. Examples include, for instance:

MT

6:14 6בר עמי 6

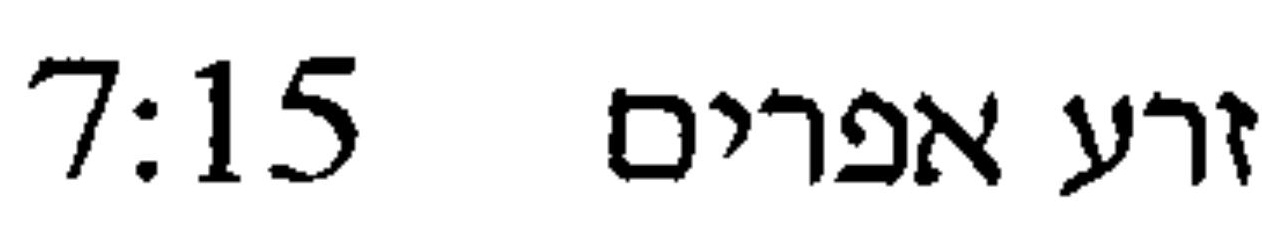

8:11 שבר בת עמי

שבר בת עמי 8:21

ארכת בת עמי 8:22

דבר יהוה 13:8

יתר העם 39:9

חומת בבל 51:44 9a1

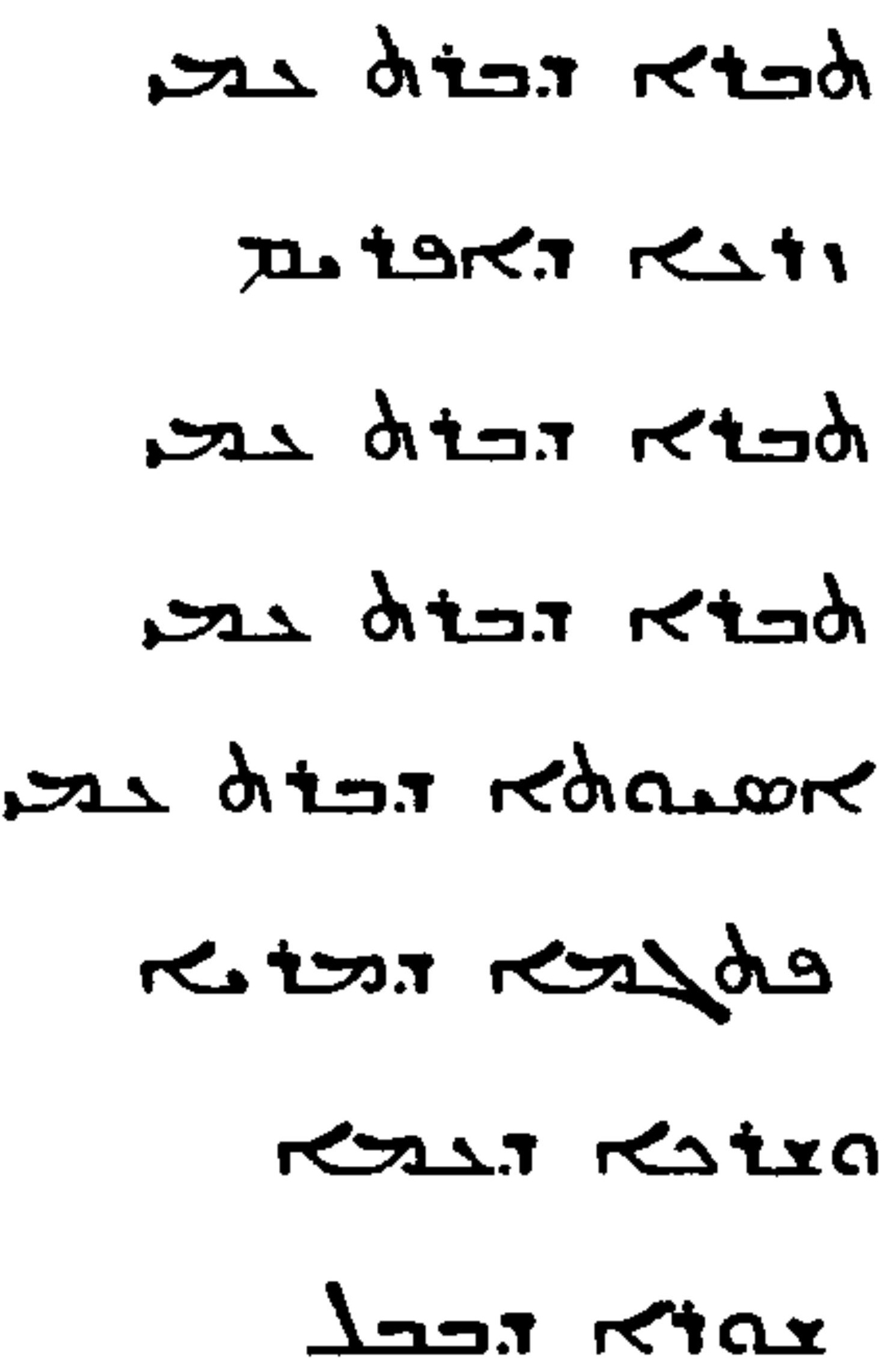

$7 \mathrm{a} 1$

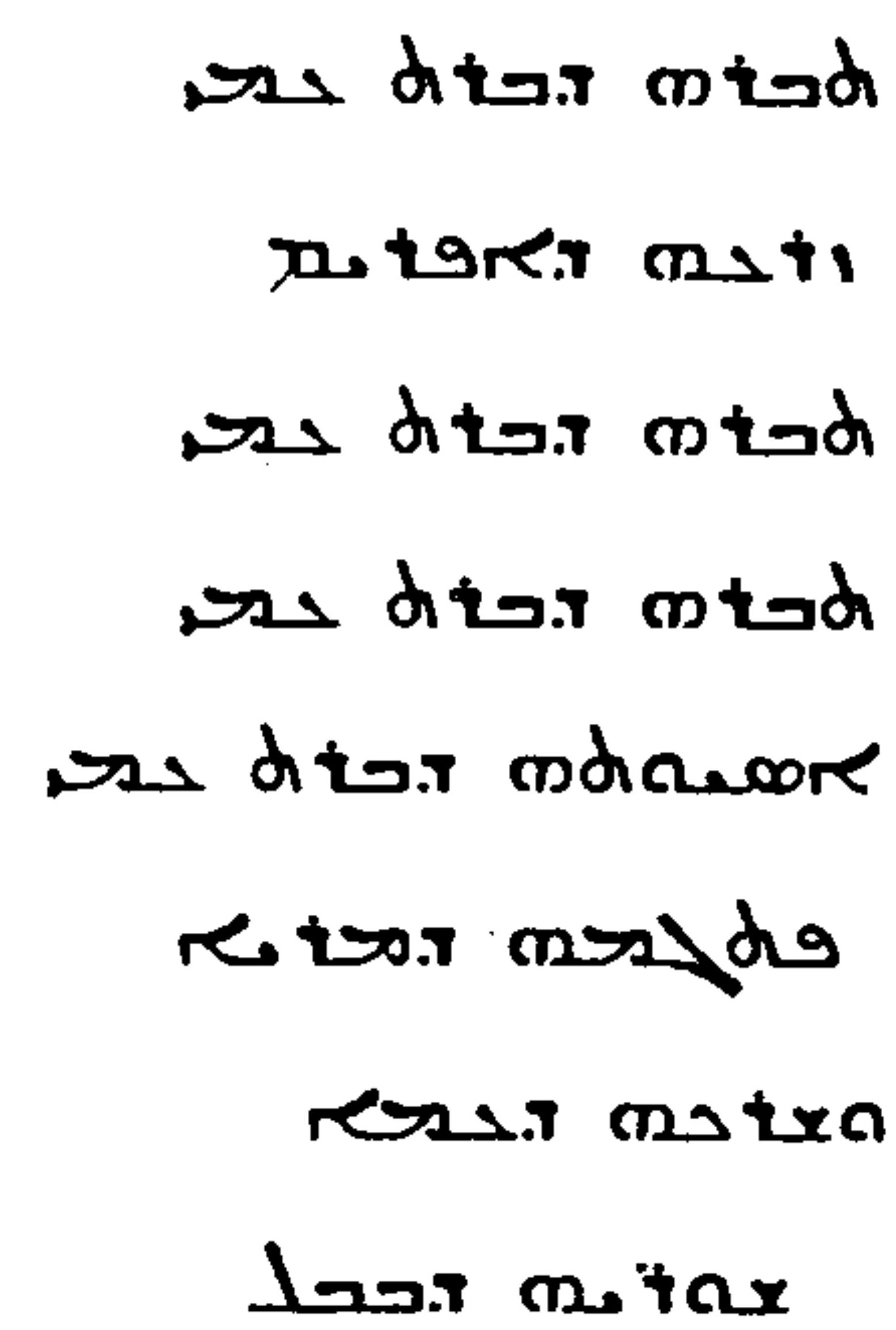

: איש יהודה וישבי ירושלם : this phrase, and small variations of it, occurs frequently in Jeremiah; relevant examples are in $4: 3,4 ; 11: 2,6,9,12 ; 17: 25 ; 18: 11 ; 19: 3$; $32: 32 ; 35: 13,17 ; 36: 31 ; 44: 6,9,17,21$.

Footnote from previous page contd.

unanticipated difference: whether a pure genitive is translated with an anticipatory possessive suffix or as a construct is not random. "Son of..." constructions, or similar constructions involving house, children, or daughter, which make up $31 \%$ of all pure genitives in this sample, are translated using the construct; constructions including "...of the Lord" which make up $28 \%$ of the pure genitives in this sample, are translated using an anticipatory possessive suffix. 
The usual translation in 7a1 is oletarer motasso risom. rety using the two standard Syriac constructions, the emphatic state followed by dalath, and the anticipatory possessive suffix followed by dalath, in turn. In the examples shown below, however, 9a1 has riasela: the emphatic state followed by dalath is used in both parts of the phrase:

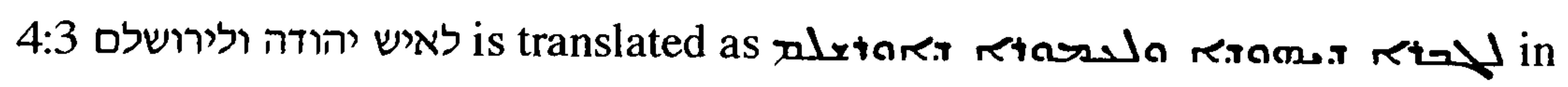

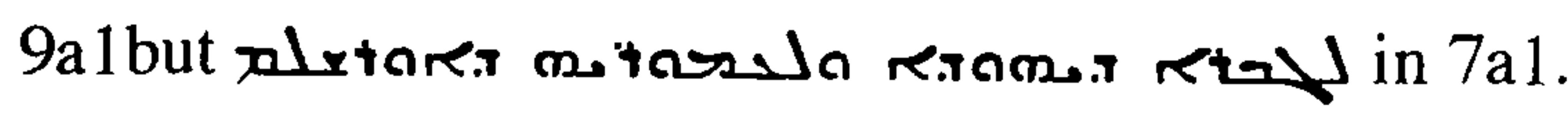

The following examples are all handled similarly:

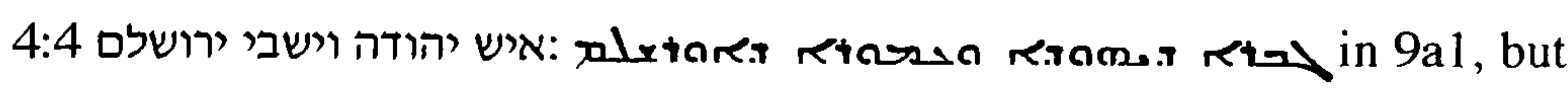

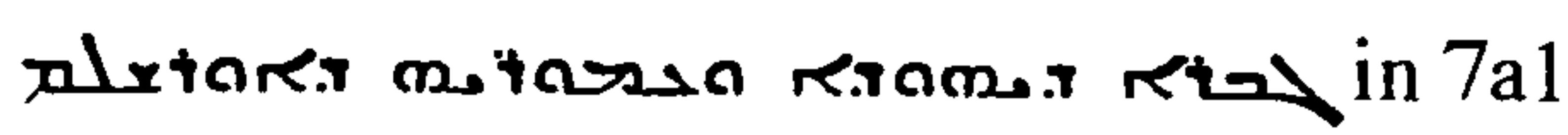

11:9 in 9a1, but

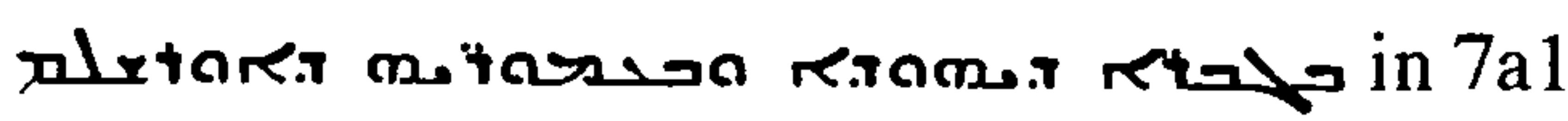

35:13 in 9a1but

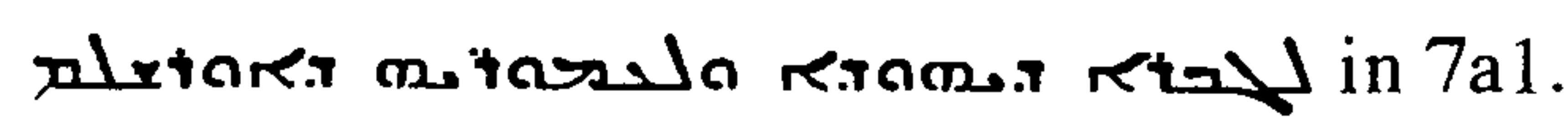

35:17 in

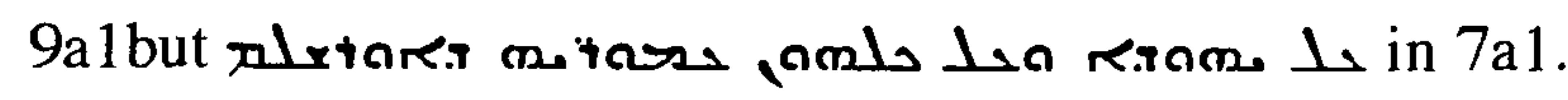

36:31 in 9albut riams resk lan pletares mitase in 7a1.

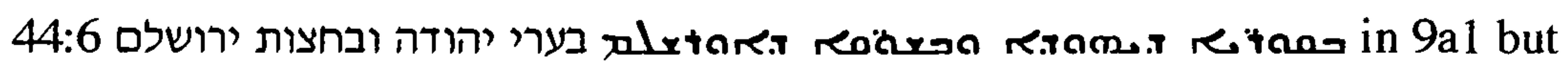

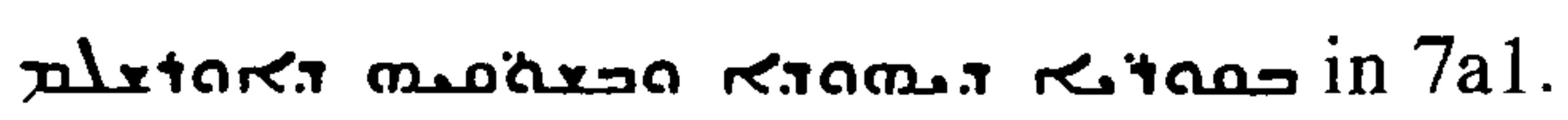

There is some inconsistency, to be expected in a work of this length, in which the opposite pattern is seen, with an anticipatory possessive suffix in 9a1 but the emphatic state in 7a1: for example,

ביד נבוכדראצר 29:21

35:18 מצות יהונדב

חמות ירושלם 39:8

$$
\begin{aligned}
& \text { באים }
\end{aligned}
$$

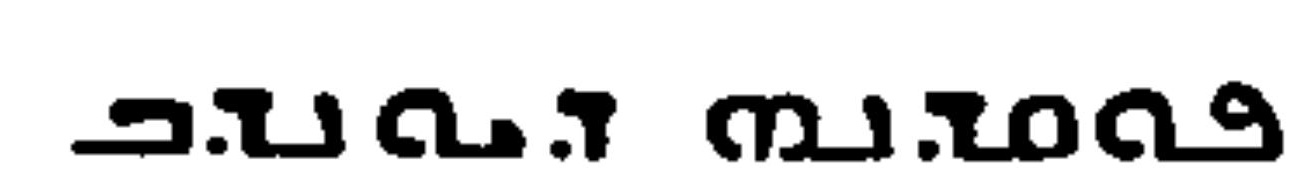

$$
\begin{aligned}
& \text { plutarex mtarl }
\end{aligned}
$$

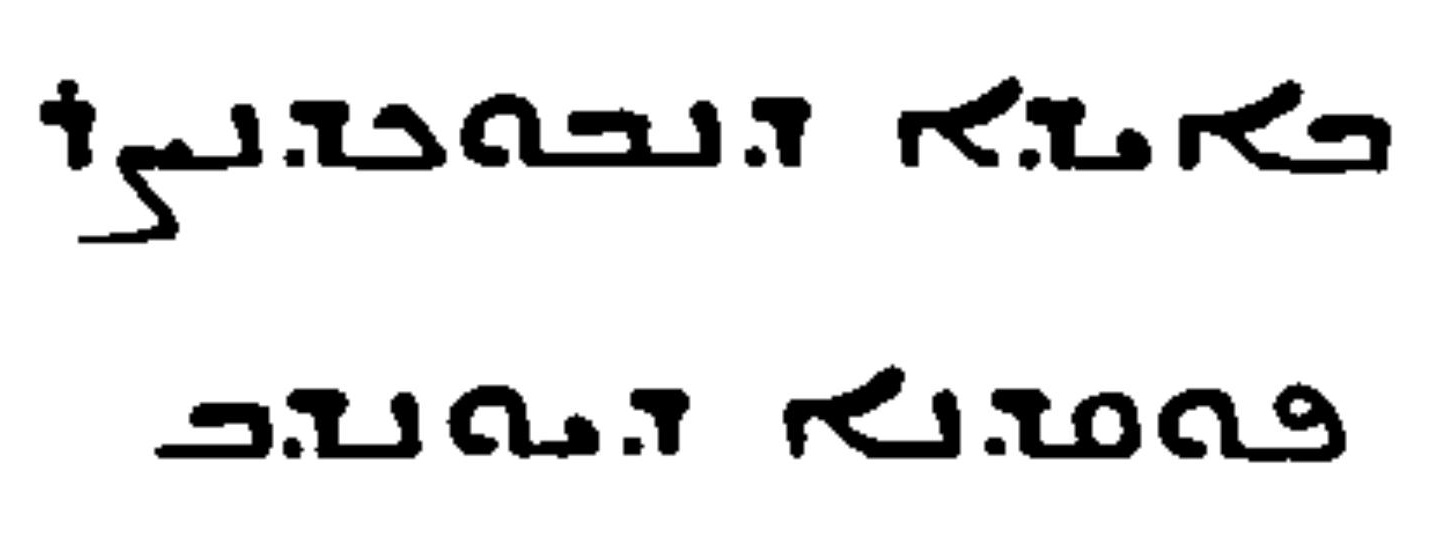

pletaris retarl 
Translation technique at passages which the translator failed to understand

The analysis of translation technique at passages of relatively clear Hebrew which was presented in Chapter 2 showed that the sense of MT is almost always literally rendered. Despite the care taken in this respect, there are some passages at which the meaning of the Peshitta differs from that of the Hebrew. Some of these, in which the difference was introduced deliberately, in a conscious effort to change the emphasis of a passage, were discussed in Chapter 2. Others, in which the difference was not deliberately introduced but which seems to have entered the text at points where the translator was working to the best of his ability, with no lack of concentration, but still failed to translate correctly because the Hebrew was obscure ${ }^{1}$, will be discussed in the present chapter. There is a subjective element in the classification, but this is inevitable; the decision as to which process has led to a change in sense in the course of translation at any individual example can only be made on the balance of probabilities.

The structured sample contains four examples of changes in sense occurring during the translation of difficult Hebrew; if this prevalence is truly representative of the whole book, the figure indicates that there would be approximately one hundred examples in the full text of Jeremiah. This suggests that the total of 106 examples presented below should be adequate to give a comprehensive overall view, though here as in earlier chapters the constraints of space have precluded any attempt to include every single example.

The evidence presented in this chapter will show that, even when confronted by a passage of obscure Hebrew, the presentation of the meaning of that Hebrew was the translator's primary aim, giving strong support to the findings discussed in

1. As noted in the discussion of "maximalist" or "minimalist" approaches to translation technique in Chapter 1, differences between the MT and the Peshitta which result from error, or from corruption during transmission of either the Hebrew or the Syriac, are not relevant in a discussion of translation technique and will not be included here. 
Chapter 2. Since the translator was unable to give an accurate translation of the meaning of the Hebrew at these difficult areas, he had perforce to give some substitute, but at most of these areas he restricted any freedom in his approach to the precise area of the problem, rendering the immediate context with his customary care to replicate the sense of MT, and not taking the difficulty of the Hebrew as a justification for veering any further than was inevitable from his source document: the approach is well documented in the published work, for instance Albrektson (Albrektson, 1963, p.211) who noted that at a difficult passage the translator "endeavours ... to produce a clear and plausible meaning", loyal as far as possible to the original but giving precedence to "clarity and coherence". Gelston (Gelston, 1987, p.158) discussing an example of Hebrew which the translator found difficult, writes that the translator tried to be as faithful as possible "while making certain modifications in order to secure a rendering which was intelligible".

These passages of obscure Hebrew would have given an excellent opportunity for the translator to impose on his work any agenda he wished to pursue, introducing nuance or even frank change in meaning of the kind discussed by Drijvers (Drijvers, 1994, pp.140-141) but he took this opportunity only rarely. In the pursuit of his main aim, to represent the sense of the Hebrew, he resisted any temptation he may have felt to use the text for his own ends; in this respect there is an interesting comparison with the work of the translator of Chronicles, who as Weitzman describes may have taken the opportunity provided by the poor state of the Vorlage (Weitzman, in press, p.208) to improvise or to guess at the Hebrew along lines which may reveal his own attitudes (see footnote (2), Chapter 2.

The presentational style too is evident here as in the translation of the clearer passages: for instance, certain emendations seem to have been governed by the pursuit of precision, internal consistency, or the desire to tighten internal logic; at a small number of passages, this may lead to an extension of a change in sense beyond the precise area of difficulty into the immediate context, but even at such points these associated changes are limited in scope. 
The approaches which are adopted in the translation of these passages of obscure Hebrew are of five principal kinds. In the 106 passages, the approaches are: (i) possible influence from LXX: the Peshitta and LXX agree against MT, or in selecting a particular meaning when other sense would be possible, in a total of 43 (41\%); of these 46, influence from LXX is probable or possible in 29 , but polygenesis is at least equally probable in 14;

(ii) guesswork, based usually on etymology, accounts for 43 (41\%);

(iii) guidance from other passages of the Hebrew Bible is probable in $9(8 \%)$;

(iv) mimicking the sound of the Hebrew occurs in six (5\%);

(v) in five $(5 \%)$ the translation is atomistic, perhaps to be considered as examples of the translator abandoning his function.

In this classification, as in deciding which passages should be discussed in this chapter, there is an element of subjectivity: there is a small number of cases where there is conclusive evidence in favour of one approach or another, but in many the same result could have been reached by more than one route.

These translations of areas of difficult text raise some points of general interest. First, the translator allowed his own judgment a good deal of play: he would often, apparently, adopt one approach to one term in a difficult phrase, and another at other problem areas within the same immediate context. This may not have been deliberate, of course, for in a text of this length total consistency throughout would be extremely difficult to achieve; it is inevitable that the translator would change his approach from time to time during the course of his work.

Second, there is evidence in the translations of these passages which, as in the examples of harmonisation of one verse with another discussed in Chapter 2 , shows that not only could the translation of a passage from earlier in Jeremiah, or from a book earlier in the (Hebrew) canon and therefore probably translated earlier (Beckwith, 1985, p.309), influence the translation of a later verse, but vice versa: the translation of a later passage within Jeremiah or the canon could influence the translation of an earlier one. As in the section on harmonisation, the former group is larger than the latter. Influence of an earlier translation on a 
Chapter 6 Difficult Hebrew

problem encountered later is easy to explain, the translator remembering his own solution and using it again. Influence of a later translation on a difficult passage earlier in the book may have two explanations, either that the translator returned to earlier passages in the light of subsequent reading and reworded them, or that he had such an excellent knowledge of the Hebrew Bible as a whole, as well as of the book which was his personal responsibility, before he began his work, that he could readily call to mind relevant passages. The first explanation seems unlikely to be true: in section (ii) below "unsupported guesswork" some evidence is presented suggesting that the translator of Jeremiah was unwilling to return to make corrections; Weitzman gives other examples which show that going back to impose consistency was not seen as essential (Weitzman, 1996, p.610).

The second explanation, that the translator had an excellent knowledge of the Hebrew Bible as a whole, as well as of the whole of Jeremiah, seems more probable: the particular importance of this book has been discussed in earlier chapters, and its translation would have been entrusted only to an expert. A term or phrase met early in the text would readily evoke similar passages to come later, and he would have had a thorough knowledge not only of the earlier books but also of those which were later in the canon. It is also possible that all those engaged in the work at any one time would meet to discuss their problems and progress, whether formally or informally: so a scholar would have been able to draw on his colleagues' knowledge as well as on his own.

The problems in the Hebrew text themselves fall into two groups: first, there are those where the problem is in a single term or terms, for instance the identification of an unfamiliar root, or the meaning of a root in an unfamiliar context, or the identification of the root where more than one would be possible in an unpointed text. This group is by far the larger, accounting for about four fifths of the total. Second, there are those where although each individual term can be accurately translated, the grammar or syntax of the Hebrew is such that the sense of the complete phrase is obscure. In translating problems in the Hebrew of the first kind, restricted to a single term or terms, any of the first four approaches is employed, and the difference between the Hebrew and the Syriac is almost always confined to the precise area of difficulty. 
The approach to problems in the Hebrew in the second group is different.

Confronted by problems of this kind, to which sometimes no convincing solution is available even today, the translator sometimes resorted to a freer approach. At some, where a difficult phrase evoked another simpler passage of the Hebrew Bible, the latter is used in the solution of the problem; others are translated atomistically: these examples account for all five passages translated in this way.

(i) taking guidance from $L X X$ :

There are numerous passages of difficult Hebrew at which the Peshitta and LXX agree against MT, or agree in selecting one of a number of possible meanings of MT; this alone, however, does not prove dependence of the one translation on the other. Weitzman (Weitzman, 1994, pp.52-55) discusses the various possible explanations, other than dependence, for parallels of two Versions against MT: the most frequent is polygenesis, the two translators working independently of one another and reaching the same decision as to the rendering of choice; other parallels may indicate that the Vorlagen differed from the MT; and in other cases, the two Versions may independently reflect common exegetical tradition. Weitzman (Weitzman, 1994, pp.55-57) then sets out the two types of critical passage in which influence from LXX on the Peshitta seems certain: in one, the Syriac seems to have been the result of consulting but misunderstanding LXX; in the other, the Syriac can only be explained by supposing that the translator amalgamated elements from both LXX and the Hebrew.

Examples are given below in three groups:

a. those at which there is strong evidence of influence of LXX on the translation in the Peshitta;

b. those at which either such influence, or polygenesis, may have operated to give the agreement of LXX and the Peshitta against MT;

c. those at which polygenesis is so plausible an explanation that there is no good reason to invoke influence of the one translation on the other. 


\section{Chapter 6 Difficult Hebrew}

Many of these passages form good examples of the difficulty of identifying the route by which the agreement between these two Versions was reached, for it is usually impossible to be sure whether influence or polygenesis operated in any given case.

a. passages at which there is strong evidence of influence of LXX on the translation in the Peshitta

There are some points at which influence from LXX on the Peshitta is clearly evident, though incontrovertible evidence of such influence is rare (Weitzman, 1994, pp. 55-60) within Jeremiah. Even where this influence is manifest, it is, as some of the following examples will show, sporadic. Within the Peshitta as a whole, Barnes characterises the LXX influence as "sporadic", affecting occasional words only, and not a general influence introducing a characteristic except in Psalms (Barnes, 1901, p.197). Weitzman takes the argument further, suggesting that even on one point in the Psalms, namely the introduction of a dread of anthropomorphism, Barnes may have exaggerated the influence of LXX: Weitzman argues that "it seems rather that the biblical text contains certain anthropomorphic expressions to which all the translators were equally sensitive, and that these expressions happen to be especially frequent in the Psalter (Weitzman, 1992, p.59). Mulder (Mulder, 1985, p.46) suggests that LXX perhaps "served as a critical commentary, only such interpretations being accepted as, in the judgment of the Syriac translators, best expressed the meaning of the original". 
This small group is illustrated here by four passages, given below in canonical order: 5:26; 48(LXX 31):34; 49(LXX 30:13):19; and 50(LXX 27):7.

5:26 is an example of LXX influence which belongs in Weitzman's second group in which the translator amalgamated elements from both LXX and the Hebrew.

כי-נמצאו בעמי רשעים

ישור כשך יקושים הציבו משחית אנשים ילכדו כניות

is translated:

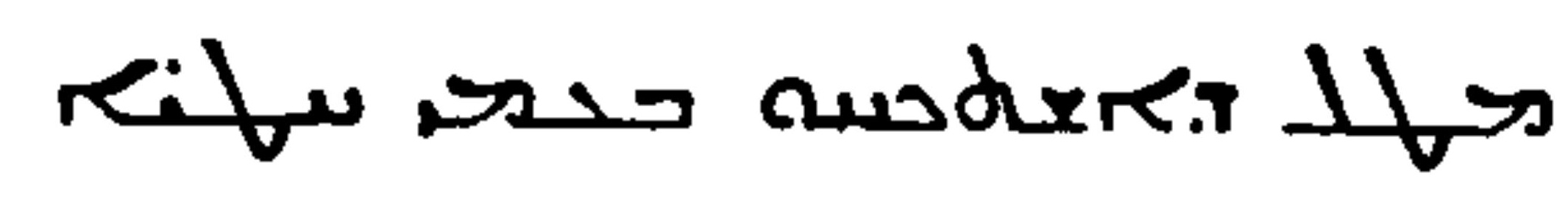

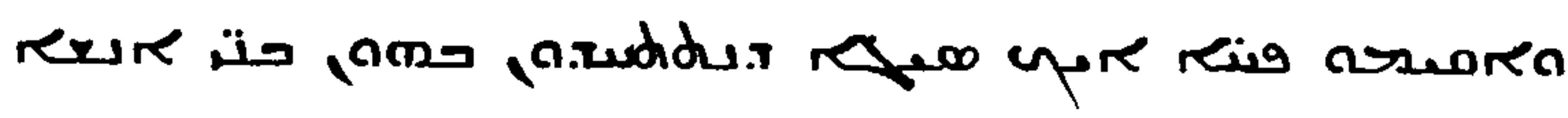

The rendering of this difficult Hebrew is based partly on influence from LXX and partly on pursuit of the standard presentational style, achieving clarity by omitting difficult terms.

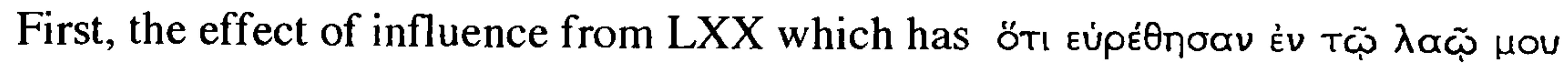

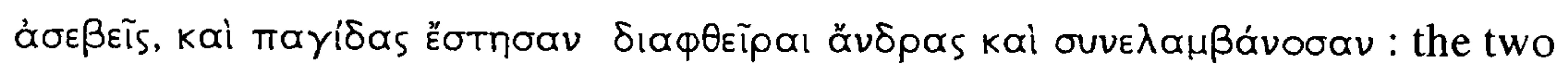
factors in common with the Peshitta which strongly suggest influence are:

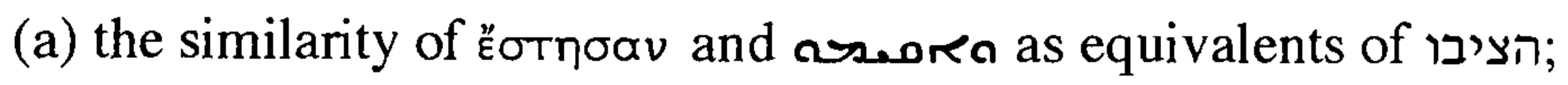

(b) the lack of an equivalent of ישור ישור, in a singular form, is difficult to account for if its subject is the רשעים, particularly in view of the plural verbs which follow. Both translators omitted it.

The drive towards clarity is probably responsible for the remaining emendations: P-Jeremiah omits משחי as if derived not from root anderstands ששך

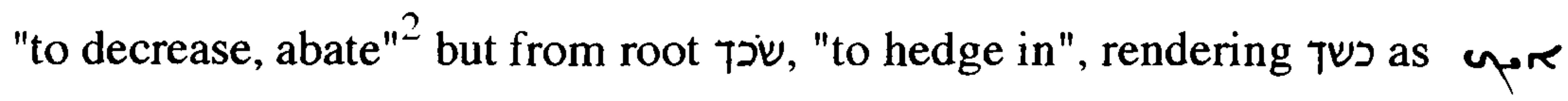
T.o. The word order has been changed, bringing aseora to the beginning of the phrase, preceding פטنץ, whereas in the MT the order is יקושים הציבו. The combination of approaches, partly taking guidance from LXX and partly pursuing the standard presentational style, is not rare and will be seen in a number of examples. As in his work on passages of relatively clear Hebrew discussed in earlier chapters, it is evident that the translator felt free to use his own initiative at times: as at 5:26, he would, within one verse or even within one

2. root שכ is not attested as meaning "crouch", a sense reached only by extrapolation from the attested meanings "decrease, abate" (B.D.B. p.1013b). 
Chapter 6 Difficult Hebrew

phrase, accept guidance from LXX on one point but not on another. This seems to be deliberate selectivity: the translator is confident in his own judgment and prepared to act independently. This sporadic use of LXX, alongside a Hebrew text as the main soure, is credible: it is discussed by Weitzman (Weitzman, in press, p.79) who gives as an analogy the Vulgate.

48(LXX 31):34 belongs in Weitzman's first group: the LXX has been consulted but not understood. מצער עד חרנים עגלת שלשיה is translated as

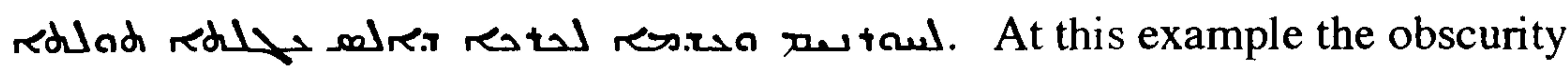
has not been clarified by the use of LXX. The problem is at עגלת שלשיה: the transmission process underlying this translation is discussed in detail by Weitzman (Weitzman, in press, p.75): an early transliteration of

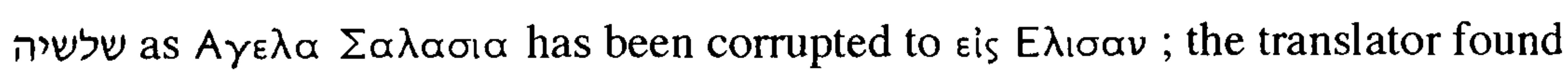

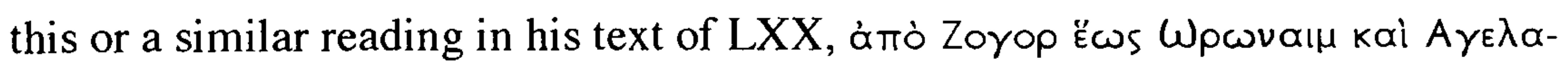
$\Sigma \alpha \lambda \alpha \sigma \mid \alpha$, and took it as a city. Welding of the Greek and the Hebrew is evident, but has not helped the translator who might have arrived at a closer rendering if he had ignored LXX (see also the discussion of this verse in Chapter 3).

49(LXX 29:20):19 נוה איתן becomes, עrer; MT and translation at 50(LXX 27):44 are similar.

The point of difficulty is at איתן, whose significance here is obscure.

The interest lies in the comparison with 5:15 where גוי איתן is translated as res am; root is a drudge-word in Jeremiah, discussed in Chapter 2, and is the usual rendering of איתן in the Hebrew Bible. The translation in chapters 49 and 50 seems to have been influenced by LXX tótrov Aı $\theta$ av: a good example of sporadic influence.

50(LXX 27):7 לא נאשם תחת אשר חטאו ליהוה becomes

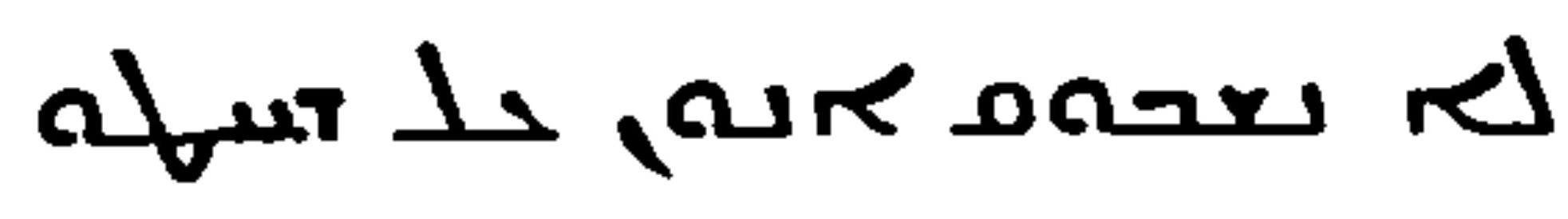

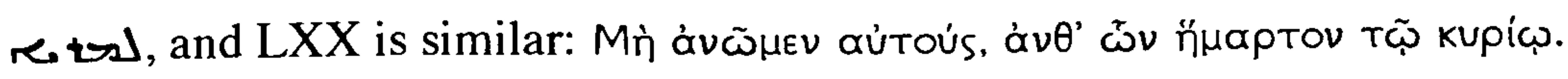
The particular interest here is that the similarity between $P$ and LXX against MT seems to have been based on error: it is so unlikely that both translators made the identical error that there is virtually certain influence of LXX on the Peshitta. 
Chapter 6 Difficult Hebrew

Both translations are based on a perception of root נשיא "to forgive" (B.D.B.p.671a) in נאשם, rather than root אשם to be guilty". Either understanding makes reasonable sense in the difficult context, following shortly נאשם after כל-מוצאיהם אכלום וצריהם אמרו : there is no reason to suppose that MT represents a corruption of an original form based on root נשיא which was present in both Vorlagen. The originality of MT is further supported by the probable

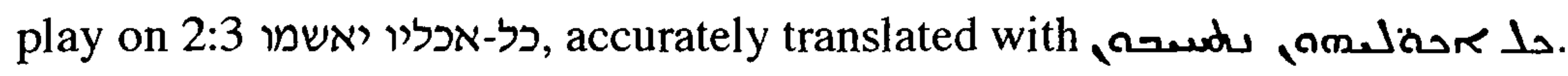
Root כי ארצם מלאה אשם also occurs in 51(LXX 28):5 in wach is reasonably rendered with the error in 50(LXX 27):7 results from the influence of a misreading in LXX.

b. passages at which either influence from LXX on the Peshitta, or polygenesis, may have operated to give the agreement of $L X X$ and the Peshitta against $M T$

Far more often there is no proof by which to distinguish between the effect of influence and the result of polygenesis, so that the decision whether to attribute agreement of these two Versions with one another to influence or to polygenesis must be made on the balance of probabilities. There are two principal factors which weigh in favour of influence rather than polygenesis: first, the quantity of possible examples of influence amounts to peripheral evidence against viewing all these instances as independent responses to the Hebrew: see for instance Frankl (Frankl, 1872, pp.444-456, 497-509), Gelston (Gelston, 1987, pp.162-171), and Weitzman (Weitzman, in press, p.70).

Second, the occasional evidence from the translations of passages of clear Hebrew that the translator may have referred to a Greek ms. rather frequently, even when not needing help in solving a problem, selecting solutions which he particularly liked and psychologically ready to be influenced. There is an example of this ready acceptance of guidance from LXX in, for instance, 51(LXX 28):43 where ארץ לא-ישב בהן כל-איש ולא-יעבר בהן בן-אדם is translated similarly in both Versions:

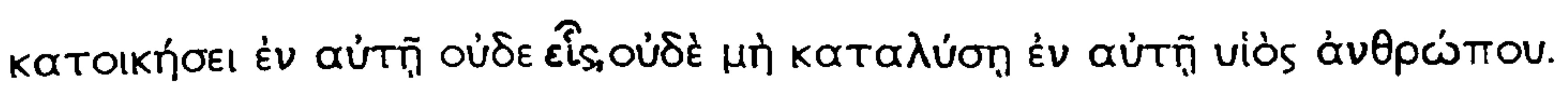


Chapter 6 Difficult Hebrew

Both the Syriac and LXX introduce a synonym into the parallelism, rendering both roots, עבר ישב, with terms for dwelling. Both lose the Hebrew בארץ לא-עבר בה איש ולא-ישב אדם 2:6 standard parallelism, seen for instance at Jer Q and rendered precisely into both the Syriac and the Greek:

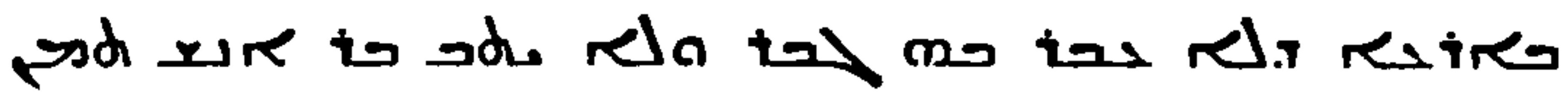

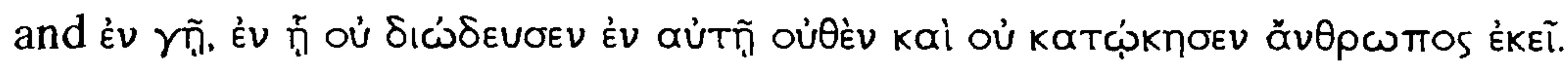

There is no apparent reason other than influence from LXX on the Peshitta to explain this agreement against MT, and this readiness on the part of the translator of the Peshitta to be guided by LXX is an important background consideration in the decision between this effect and polygenesis.

Nonetheless, the evidence that influence from LXX was apparently resisted at some passages is sufficient to show that such influence must never be assumed to have operated: each passage must be taken on its merits. There is a particularly interesting example of sporadic independence of LXX at the duplicate passages 6:23 and 50(LXX 27):42, where in translating ערוך כאיש למלחמה 6:23 the Peshitta gives Stal Here, the choice of the term rthearly a careful translation, giving a more precise sense than that of

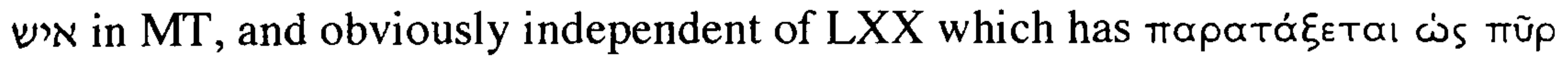

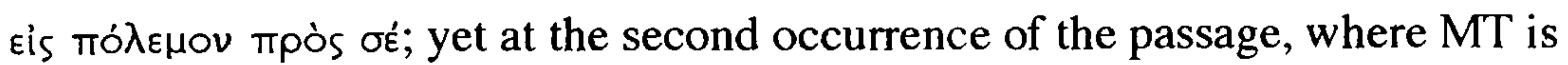
identical, the Peshitta has staresponding to LXX

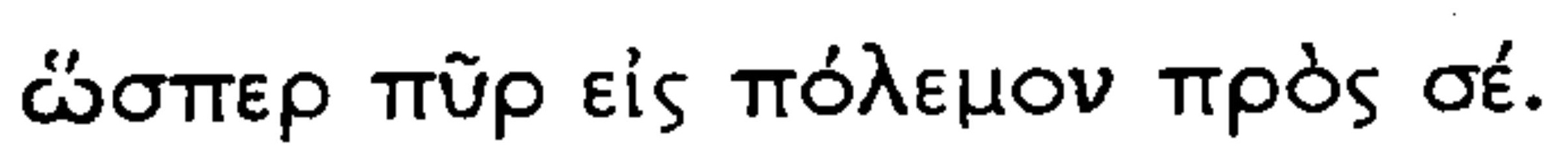

The Hebrew at ערוך כאיש למלחמה is discussed by Emerton (Emerton, 1972, p.110) who suggests that the agreement of the Peshitta with LXX at 50(LXX 27):42 probably represents an assimilation to the text of the Syro-Hexaplar, though this is perhaps not an entirely satisfactory explanation because, as Emerton points out, the Syro-Hexaplar has r+m qre at both passages. Certainly כאש למלחמה is surprising, but it is difficult to explain LXX unless this really was the wording in the Vorlage and was accurately rendered in both chapters by LXX, was rejected by the translator of the Peshitta at the first encounter where the translator judged that כאיש למלחמה was more probable, despite the term having been accepted in LXX, but who at the second encounter decided to render the Vorlage and agreed with LXX. 
This much larger second group, at which influence from LXX could well be argued, but polygenesis may alternatively have been responsible, is illustrated here by the following passages:

$2: 23,25,31,34 ; 3: 22 ; 4: 11 ; 5: 10,28 ; 6: 29 ; 9: 9(10)$;

$10: 18 ; 17: 9 ; 18: 12 ; 19: 4$;

30(LXX 37):13, 21; 31(LXX 38): 12; 32(LXX 39)21; 38 (LXX 45):19;

48(LXX 31):2, 27;

50(LXX 27):26, 27, 42.

51(LXX 28):43

2:23 בכרה קלה משרכת דרכיה becomes redwitare the points of interest are the understanding of בכרה and where the interpretation of the second has influenced the first.

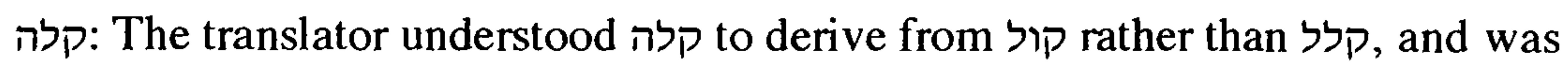
then forced to make a further guess, without etymological basis, at בכרה, simply to fit that context. These guesses are reasonable in the context; there are other passages, for instance Isa 60:6 בכרי מדין, where root בכר is correctly translated:

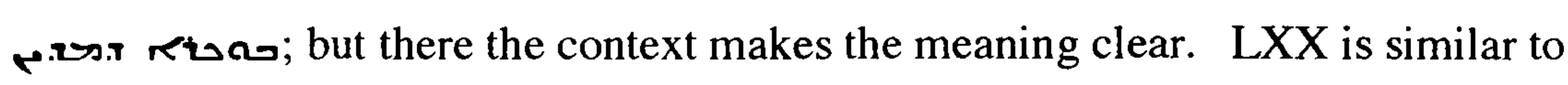

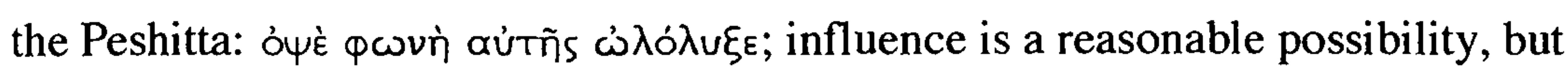
in favour of polygenesis is the lack of agreement in person: the 3rd fem. sing. form of בכרה is reproduced in LXX but not in the Peshitta which has a 2nd fem. sing. form ${ }^{3}$.

3. McKane (McKane, 1972, p.76) says in his discussion of possible dependence of the Peshitta on LXX in this passage: "Pesh. has less right to be regarded as a translation of the Hebrew than LXX": this assessment might lead the reader to a rather too ready assumption of dependence in general, and McKane says later (p.80) that the Peshitta to chapters 1-14 is faithful to MT, and accurate. He suggests that the resort to other versions by the Peshitta in this passage is a consequence of the difficulty which the Syriac translator experienced with parts of the Hebrew text. Of משזכת, McKane (McKane, 1972, p.77) says "Neither version has dealt faithfully with משרכת, and the renderings are more concerned with a moralising application of the simile than with the elucidation of the simile itself (hence "ways" as "behaviour" rather than "tracks")." 
2:25 ואמרו נואש כי-אחרי מחשבותינו נלך 18:12 ותמרי נואש לוא כי-אהבתי זרים the point of difficulty at both is the derivation of נואש. At both verses the Syriac translator has understood root איש "to be strong" rather than יאש "to despair",

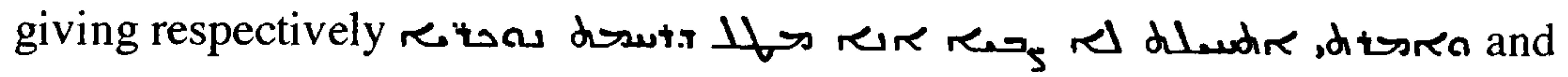

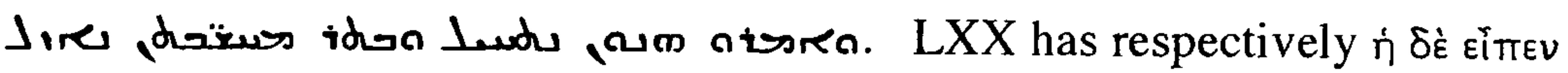

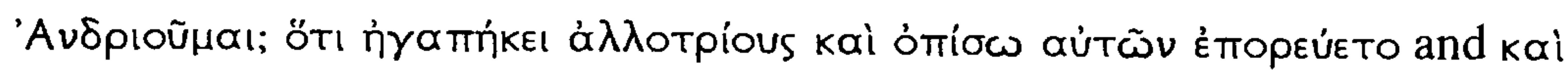

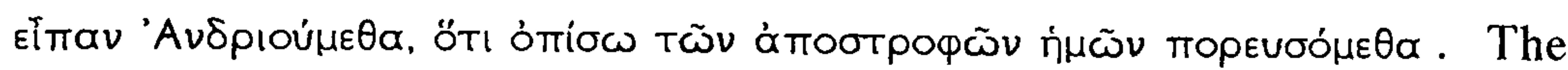

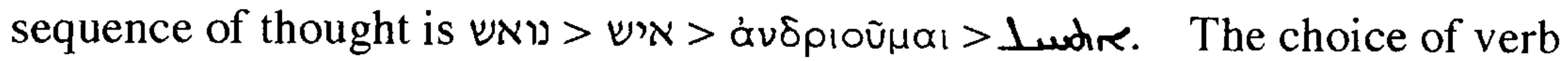
alone would suggest but not prove the possibility of influence; the likelihood of influence having operated is strengthened by the agreement in tense, and in person too in 18:12; McKane sees influence from LXX here (McKane, 1972, pp.79-80).

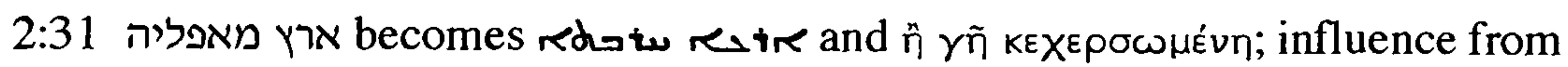
LXX seems more likely than polygenesis, though there are other possibilities here: $\uparrow$ and $\neg$ might have been transposed by a translator working under pressure, or tired, who intended to write 2 , deep darkness; equally, the transposition might have been the responsibility of a scribe working at a stage early enough for the transposition to enter all extant mss.

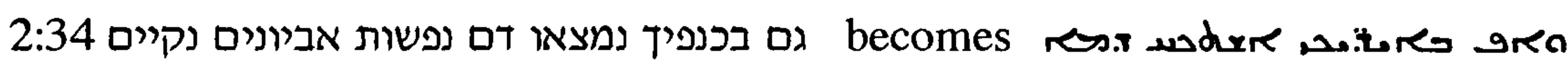

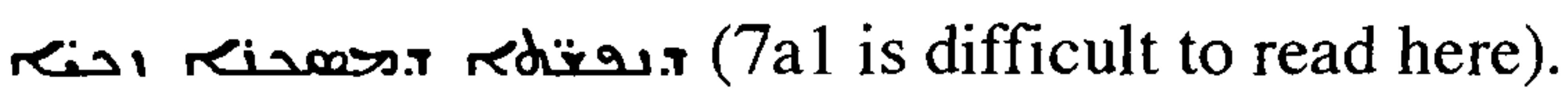

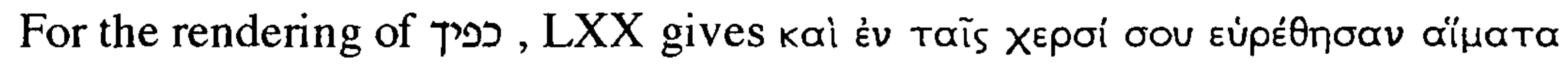
$\psi v \times \tilde{\omega} v \dot{\alpha} \theta \dot{\omega} \omega v$, so both translations represent בכפיך; rather than בכנפיך; however, the symbolism of "blood on your hands" is so much more obvious than the metaphor in MT that polygenesis is possible and influence cannot be assumed. LXX also indicates a Vorlage without אביונים; the term is rendered in the Peshitta, but this difference between these Versions would not argue against influence of the one on the other at בכנפיך. 


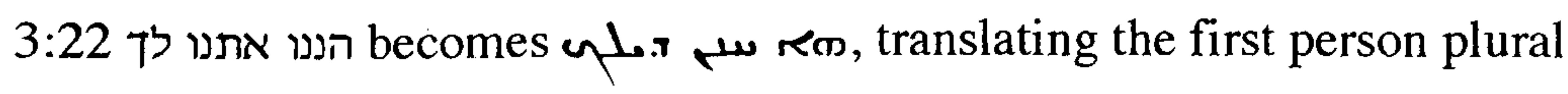

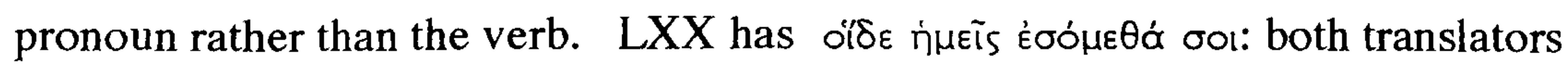
found here the plain אתא presents no difficulty at other passages, so there is a strong possibility that the understanding in the Peshitta is influenced by that in LXX.

4:11 This passage shows well the sporadic influence of LXX which was discussed above; although this influence apparently operates at one point, at another within the verse the translator confidently rejected such guidance, using his own judgment to maintain his standard presentational style which attached importance to internal consistency and usually preferred simplicity in figurative

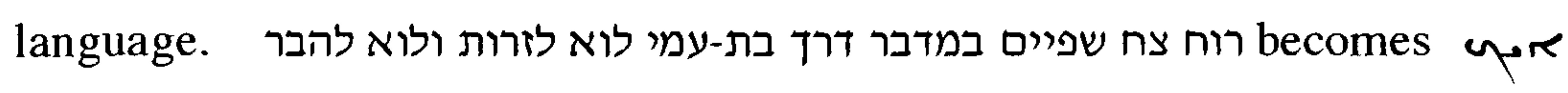

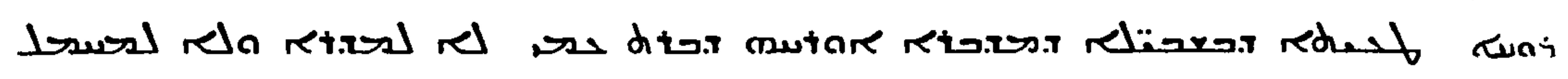

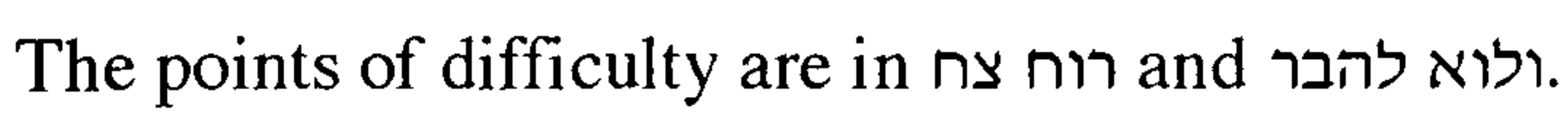

(i) :רוח צ' at this point, influence from LXX seems probable, for elements from both Hebrew and LXX seem to have been welded together inextricably. The MT imagery is complex: from root nחצ, to be dazzling, the association is with heat as for instance at Isa 18:4 צחיחה 68:7 so that the Hebrew in Jeremiah seems to mean "a scorching wind". The Peshitta, however, has

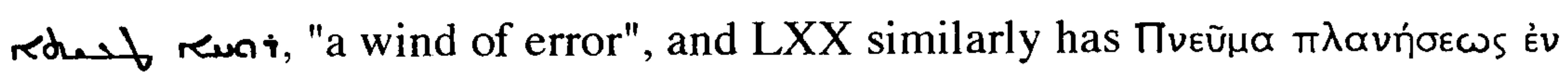

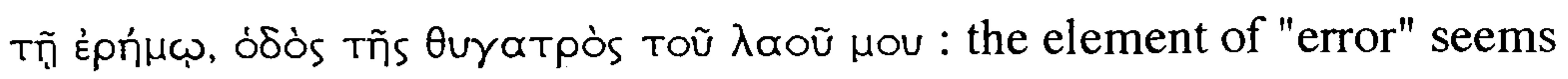
probably to come from the Greek ${ }^{4}$.

There is an additional factor in support of the suggestion that influence from

4. Holladay (Holladay, 1976, pp.29, 33) suggests that the concept of the wind in the desert is relatively unconventional, though that of "the way of the daughter of my people" is frequently found, and suggests the following structure and vocalisation:

רוח צח שפים

במדבר דָרךך בת עמי

with zaqeph qaton moved from במדבר where it is placed in MT. 
LXX decided the choice of rd. 6 . Although there are other passages at which root nnצ occurs where the sense in the translations is unchanged from that of MT (for instance at Isa 18:4 כחם צח עלי-אור כעב טל בחם קציר where the context makes the meaning clear, so the agreement on rews $\mu \varepsilon \sigma n \mu \beta$ pias is not remarkable) there are two others where the Peshitta and LXX agree strikingly against the sense of MT. The first is at Psalm 68(LXX 67)7 (6) אך סוררים שכנו צחיחה

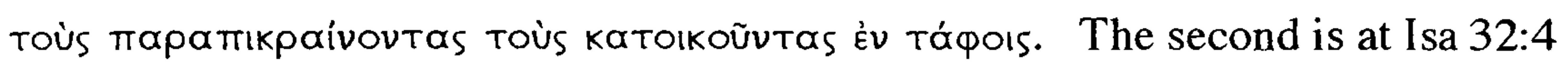

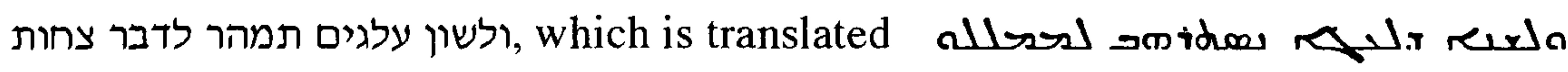

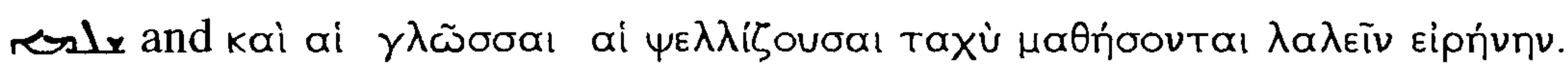

The immediate inference is that the Syriac translators turned to $\mathrm{LXX}$ for guidance at Jer 4:11, Psalm 68:7 (67:6), and Isa 32:4, for whereas agreement at any one of the three might have been independent of influence, though it is hard to see that that could have been so at Isa 32:4, it seems unlikely that all three cases can be explained by polygenesis.

There are two other possible factors which might have operated to give the same rendering in the Syriac as in the Greek: first, the concept of a "wind of error" could well have been idiomatic both in Syriac and in Greek, and both translators independently arrived at equivalent expressions. Second, it is just possible that the "wind of error" entered the text to create a nuance of deception referring back to v. אדני יהוה אכן השא השאת לעם הזה. This rather than influence from LXX might explain the choice of rode $\downarrow$, both translators independently having made the same decision 5 .

In the next word, however, the translation is independent of LXX: "عحتع is a

5. In his (unpublished) Ph.D. thesis, Weitzman (1974, p.C.21) shows how by a process known by logicians as the Fallacy of the Ambiguous Middle, 23:27 החשבים להשכיח את-עמי שמי "Will they (continue to) think to cause my people to forget my name..." becomes instead , لsho "who seek to mislead my people in my name". Underlying the process is the difference in the range of meanings of the two roots שכח and both can mean "to forget", but only the Syriac root can mean "to go astray". Thus השכיח "cause to forget" > , $<$ "cause to forget" > $>$ o $r$ "mislead". 
Chapter 6 Difficult Hebrew

frequent rendering in the Peshitta of "שפיים": see footnote 3, Chapter 5.

(ii) ולוא להבר: at this point, the predominant factor is the presentational style, manifest in a move towards internal consistency. לוא לזרות ולוא להבר , not to winnow and not to cleanse", is rendered נost, "not to winnow and not to gather in".

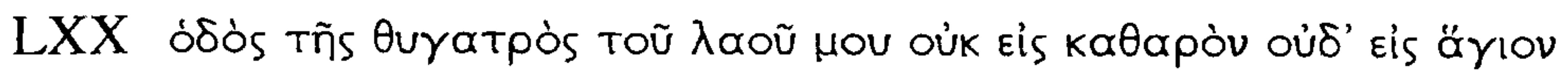

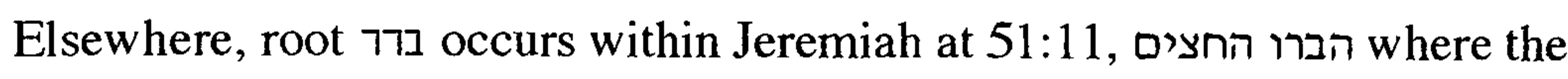
context is confused and it is not precisely rendered into Syriac. Outside Jeremiah it is found at, for instance, Isa 49:2, 52:11, and at 2 Sam 22:27, and at each it is translated appropriately with root "to choose, select". These different translations of a root in different books of the Bible does not necessarily show that the translators were unaware of one another's work, and the present example gives a good illustration of the complexity of the problem: the decision

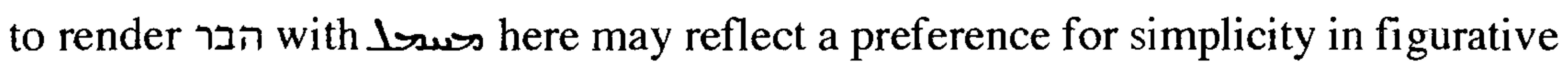
language: rather than being unaware of a colleague's choice, the translator here had a different primary motivation. In the parallel component of the phrase, the translator had selected the cognate זרה to translate root having made this decision, he may have preferred consistency of imagery, perhaps also influenced by the occasional Hebrew use of for corn, as at Jer 23:28, to accurate

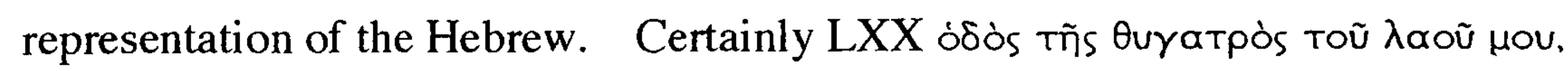

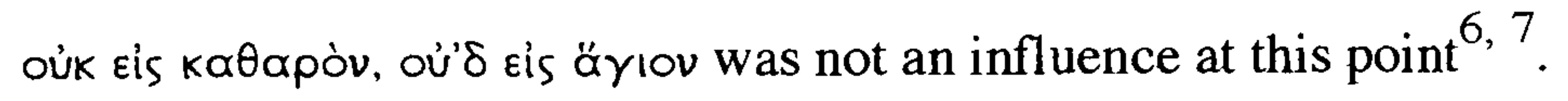

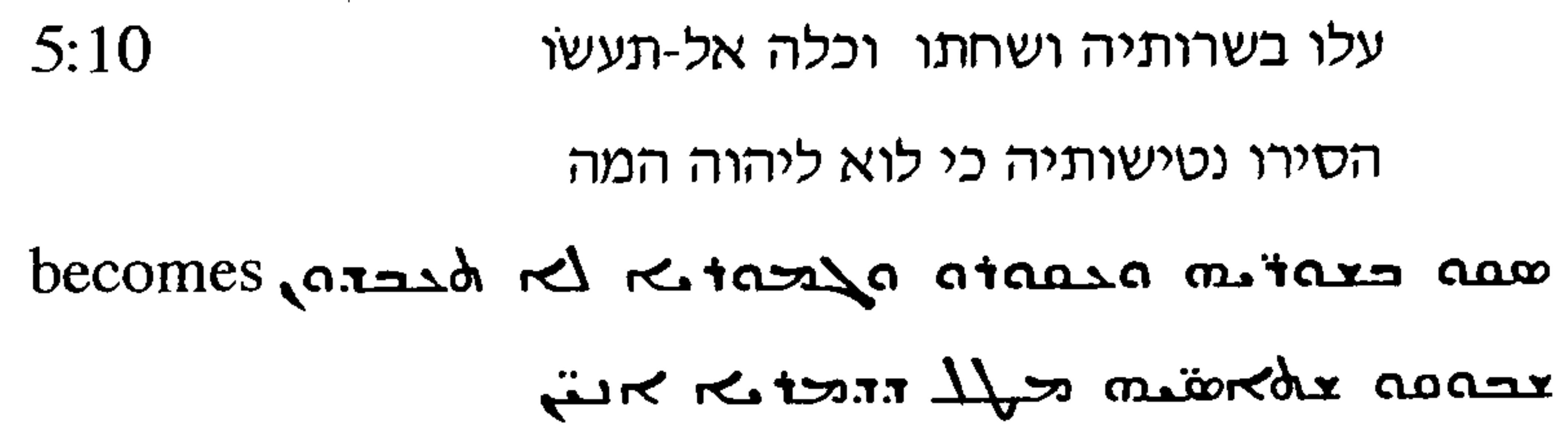

6. The combination of elements from the Hebrew and the Greek in this verse is reminiscent of the examples given by Joosten $(1995$, pp.64, 65) from the Peshitta to Proverbs, examples which Joosten describes as "a versional patchwork".

7. Weitzman notes the "intertwining" of elements from Hebrew and Greek in this verse (Weitzman, in press, p.73). 
The points of difficulty are the understanding of לוא, of שישותיה, and of שרותיה. (i) הסירו נטישותיה כי לוא ליהוה המה: the mood change in the MT from וכלה אל-תעשו to הסירו נטישותיה is eliminated by the change from "remove" in the Hebrew to "spare" in the Syriac, and the negative לוא is not translated. Although this is not an uncommon spelling of the negative in Jeremiah, it seems possible that the translator understood it as lamedh plus an objective suffix, "his". This interpretation required him to reverse the meaning of הסירו, and he did so economically. The similarity to the solution in LXX áváßnтє émi Toùs

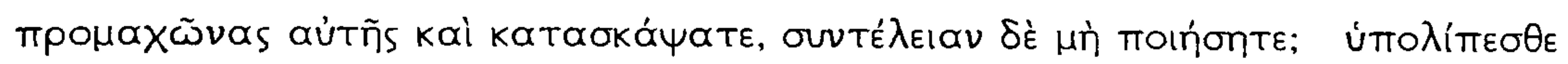

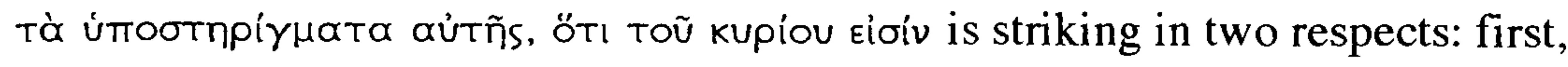
there is the understanding of נטישותיה, and second, the absence of the negative. (ii) שרותיה: there are, though, a number of points to consider before assuming that this similarity proves influence of LXX on the Peshitta. The first is the translation of בשרותיה, for which B.D.B. p. 1004 gives "probably a row of olives or vines"; the link with שור, "wall" is clear, and this is the sense taken in the Peshitta. This fits well with another feature of translation technique in the Peshitta, the tendency to clarify figurative language: given a choice between "vine rows" and "walls", when the subject is the destruction of Jerusalem, it is predictable that the translator would select the second. Having made this choice, another aspect of translation technique may have operated to determine the translation of the next part of the verse: the translator liked consistency of imagery, and having selected building rather than agriculture he would be likely to maintain that theme; so it is not surprising to find that נטישותיה is translated as meorrax, "foundations". God's city is to be preserved, but the Israelites are not to be saved. This understanding is also compatible with the absence of the negative: the idea that the foundations are to be spared fits better with than would "tendrils".

That this is a deliberate change in meaning, rather than the result of failure to understand the term, is shown by the accurate translation of נטישתיך 48:32 as is also accurately rendered,

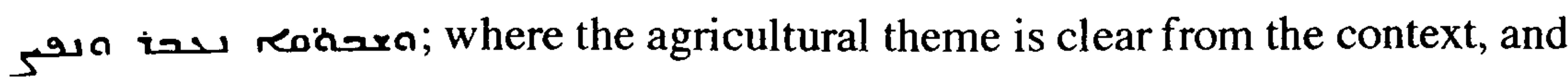
compatible with the translation technique, the term is precisely represented. The 
interest lies particularly in comparison of the Syriac with LXX, for it is apparent that just as these differences between MT and the Peshitta can be attributed to the standard translation technique, they can also be explained as due to the influence

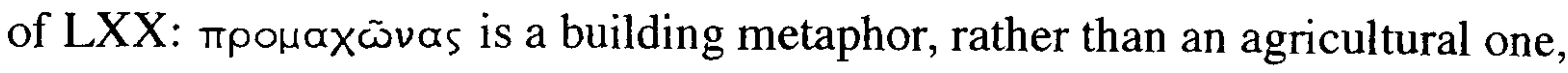
even though its sense is not exactly the same as max; similarly, úmootnpíyuata is close to mëredr though not the same; and at 48 (LXX 31):32 and at Isaiah 18:5 LXX has $k \lambda \eta_{\mu} \mu \tau^{\alpha} \alpha$ and $k \lambda \eta \mu \alpha \tau i ́ \delta \alpha s$ respectively.

The number of points of agreement between the Peshitta and LXX in this verse do suggest influence, but do not amount to proof.

גם עברו דברי-רע דין לא-דנו

דין יתום ויצליחו

ומשפט אביונים לא שפטו

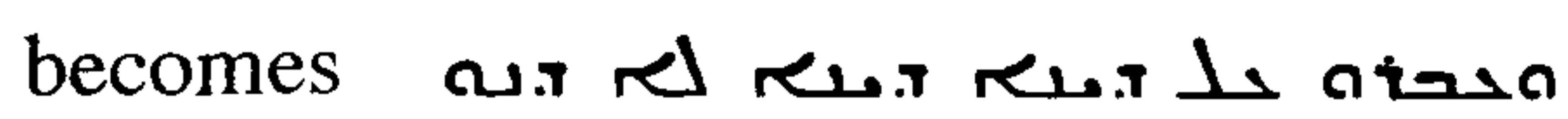

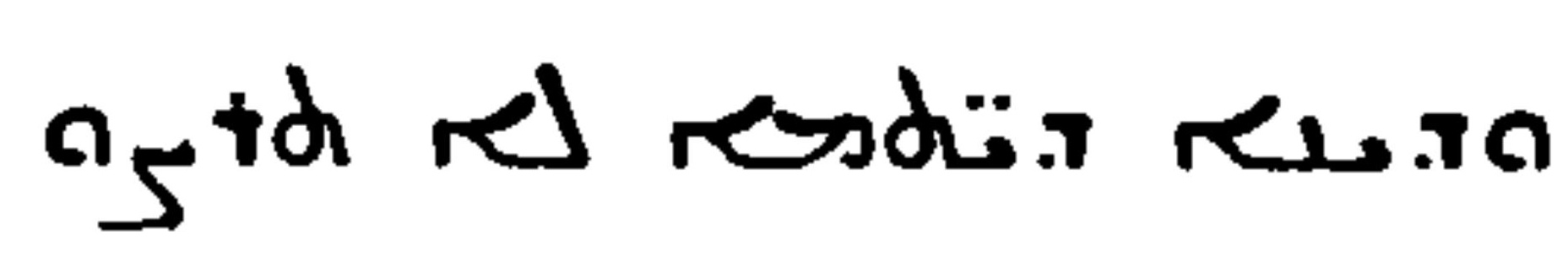

ه.

The difficulty is at עברו דברי-רע. Neither the Peshitta nor LXX kai mapéßnoav

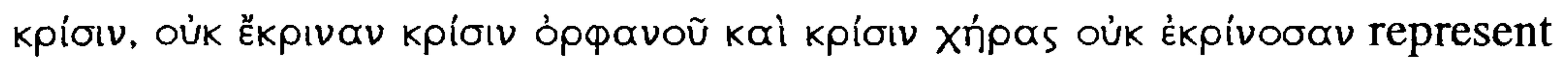

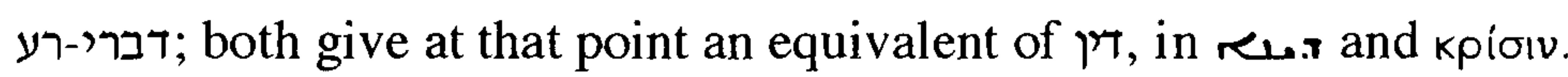

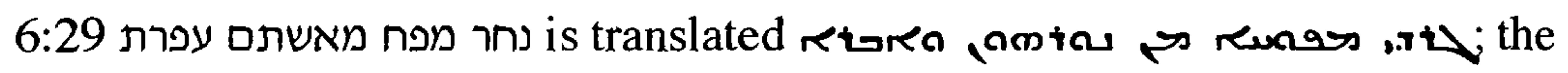
points of interest are the derivation of נחר מחר and the difference between the Ktib מאשתם and the Qere מאש תם.

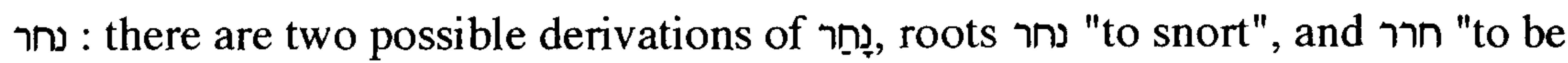

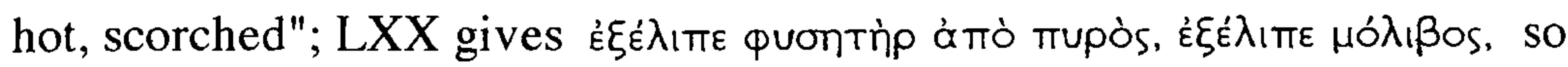
both translators have understood the second, perhaps the less obvious: both translations imply that the bellows have been rendered useless by the fire. In other respects, though, the two translations differ: in the Ktib which the Peshitta follows there is one verb only with two objects, i.e. root $\mathbf{x}$ "to strip" applying to both the bellows and the lead. LXX represents the Qere, מאש תם; this inconsistency, between the similar understanding of נחר and the different 
Chapter 6 Difficult Hebrew

representation of מאשתם does not constitute evidence against influence at the former.

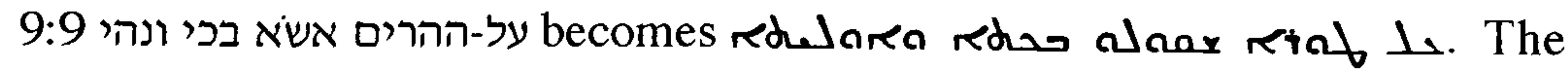
problem lies in the identity of the speaker at this opening phrase of the verse. Vv. 6, 8, and 10 must be, and v. 7 is probably, spoken by God; v. 9, however, could be an isolated exhortation spoken by Jeremiah himself. Indeed, if MT is original, Jeremiah must be speaking. LXX, though, has given an imperative, words which could be those of either God or Jeremiah: 'ETi tà őpn $\lambda$ áßєTE котєтòv; the Syriac is similar.

The simplest explanation is that the change was made to achieve precision, and the similarity to LXX is attributable to polygenesis. Direct influence from LXX, however, cannot be ruled out.

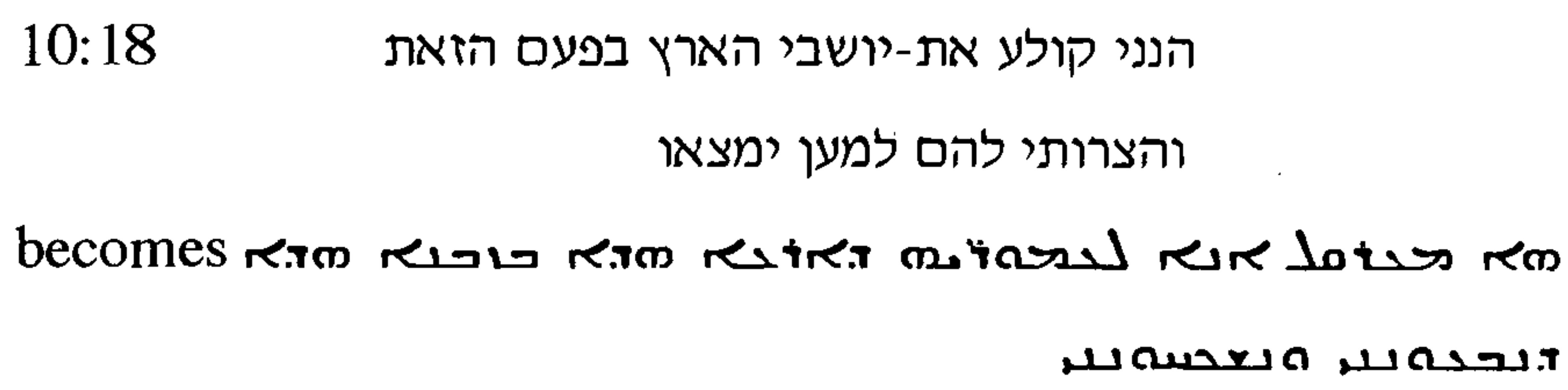

In this example one difference in sense introduced towards the end of the difficult passage has apparently involved the translator in other changes to preserve the internal consistency which characterises the presentational style. In the sequence of verbal roots in MT are קלע "to sling, hurl forth"; צרר "to bind", here in the Hiphil "to cause distress to"; מצה מצא מצה , מצח "to drain out, to squeeze". In the Syriac, the sequence is sar, here in the Parel "to entangle, confuse"; حـe, "to seek"; and " $x \omega "$ ", to find. It seems that the translator read root מצא rather than מצה, a reasonable understanding in view of the spelling, and then, in pursuit of consistency, made a radical decision to translate the earlier two verbs so as to

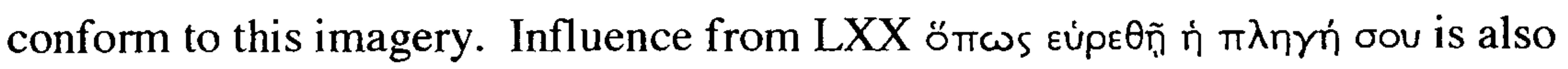
possible, initiating the train of thought. 
Chapter 6 Difficult Hebrew

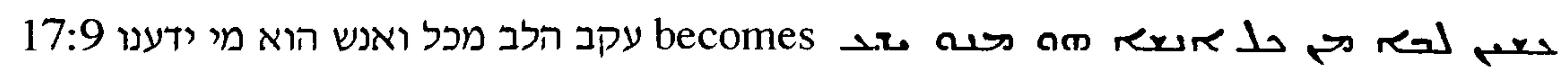

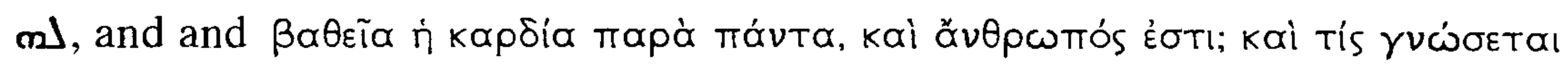
aùTóv

The points of difficulty are at the understanding of אנש מקב; the Syriac

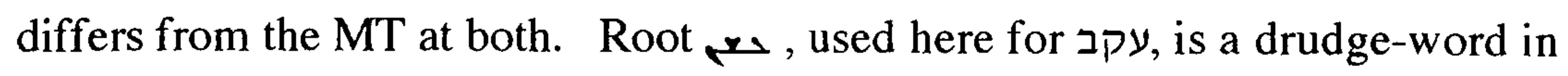
Jeremiah (Chapter 2). It seems unsatisfactory here: there is no etymological justification for understanding it to mean "deceit"; its use gives only poor parallelism with the next phrase, מי ידענו, to which the translator gives the plain meaning, and it fits poorly into the context of the next verse, אני יהוה חקר לב בחן

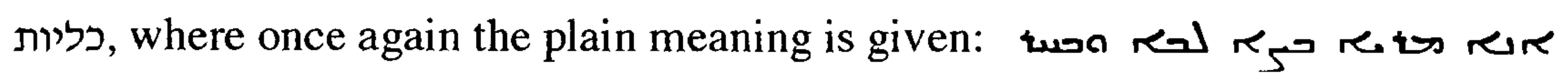
in its

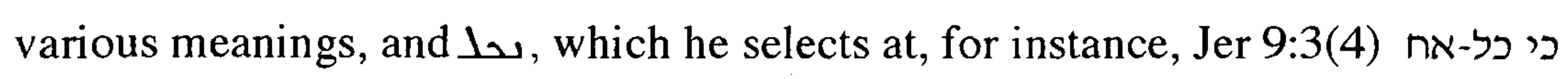

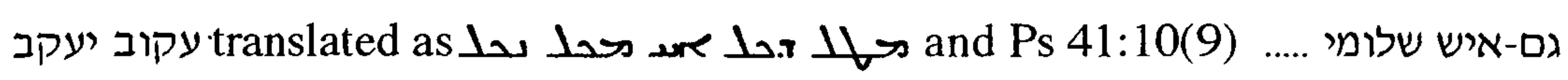
translated as הגדיל עלי עקב would have been appropriate here too.

Nor has he given the same sense as that in LXX, where $\beta \alpha \theta \varepsilon i \tilde{\alpha} \dot{\eta} k \alpha \rho \delta i \alpha$ is apparently exegetical, and this is another example of sporadic influence from LXX, for in the next phrase his policy again changes and the two Versions are similar: both translators have understood not "sickly", that is in this context

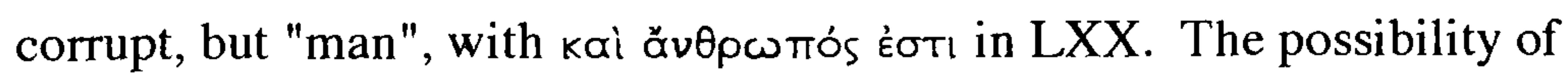
influence from LXX here is supported by other passages in which LXX and the Peshitta have similar understanding: elsewhere, the form אנוש occurs in Jeremiah in 15:18 and 17:16 (and in 30:12 which is similar to 15:18 but unhelpful in the present discussion because LXX differs too much from MT in that verse). In 15: 18 the context makes the general sense clear, but does not require the particular understanding shown in both LXX and the Peshitta:

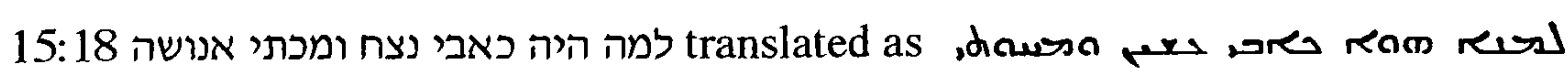

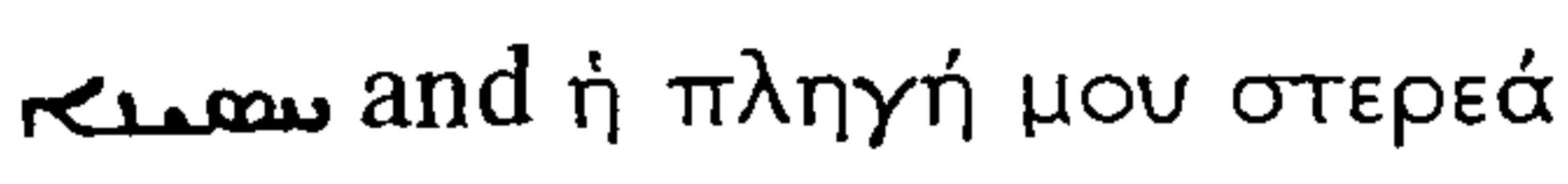

In 17:16 the context gives less guidance: ויום אנוש לא התאויתי is translated as

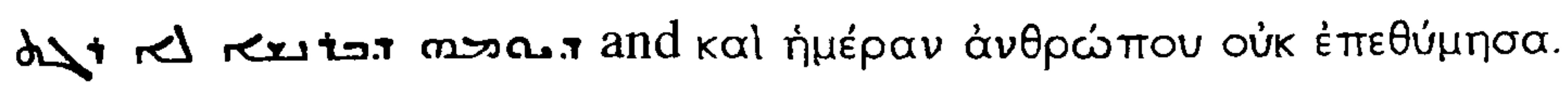




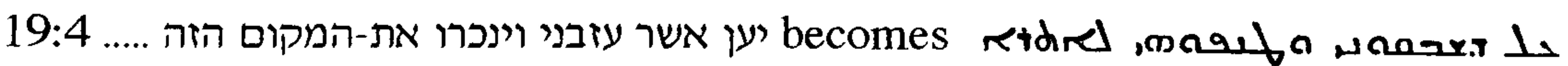

..... rum. The point of interest here is the lexical equivalent selected to translate root נכר . The sense is slightly different here from that at other occurrences, for instance Jeremiah 2:21, 5:19, and 8:19, in each of which it is translated with the cognate in the Peshitta and with a standard lexical equivalent in LXX:

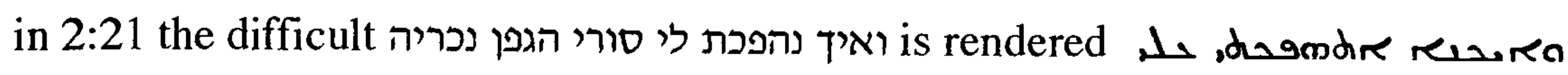

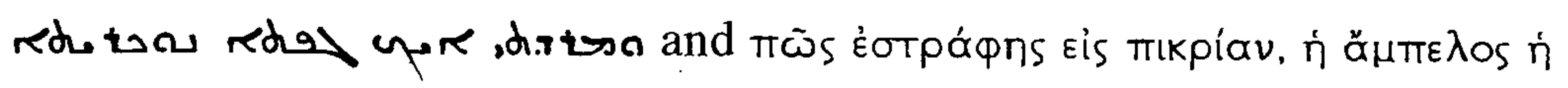

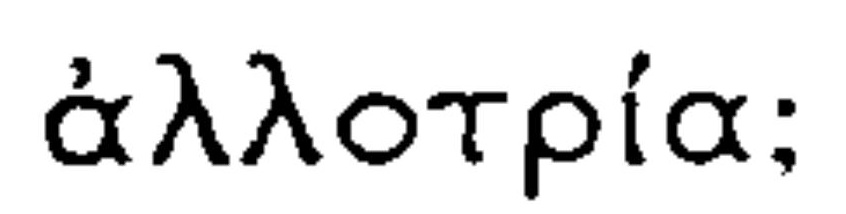

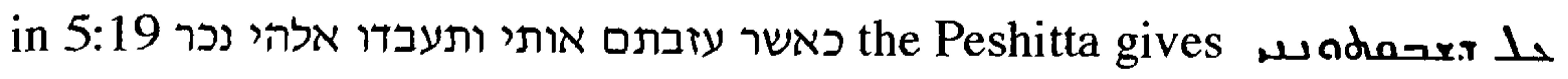

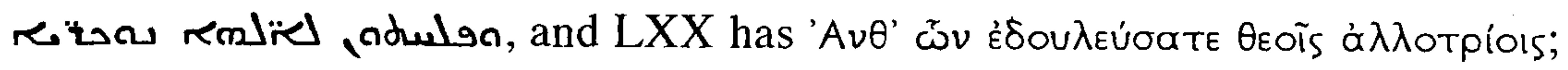

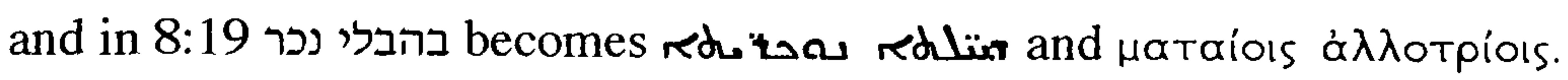
Both translators had a regular equivalent of root נכר בה: though neither used these in

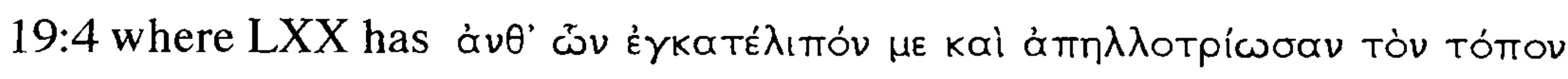
ToũTov: both may have reacted similarly to the nuance of the context, independently deciding not to use their regular lexical equivalent; alternatively, the translator may have been prompted by the nuance to seek guidance from LXX.

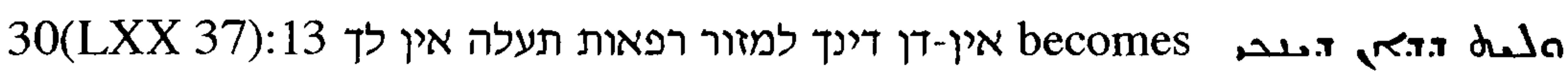
רפא root reore must be intended as the equivalent of root, despite its different place in the word order, and this is confirmed by the similar translation at 46:11 at which לשוא הרביתי רפאות תעלה אין לך becomes

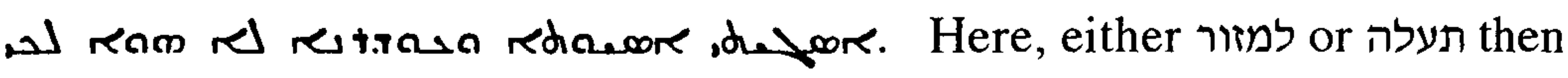
seems to have no equivalent; comparison with 46:11 suggests that תעלה is

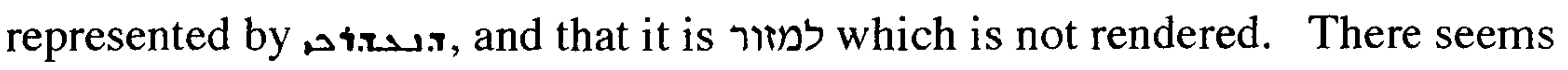

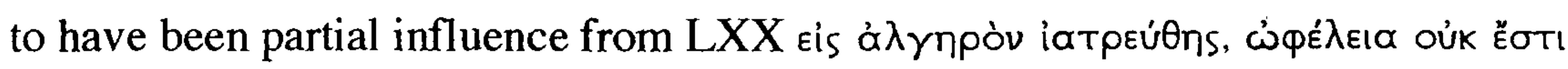

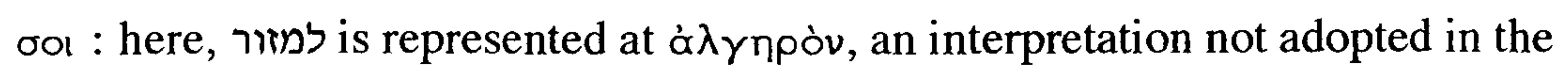

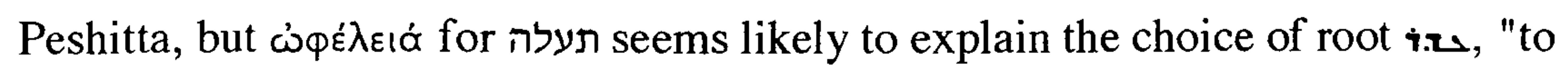
help". 
Chapter 6 Difficult Hebrew

30(LXX 37):21 In והיה אדירו ממנו .... והקרבתיו ונגש אלי

כי מי הוא-זה ערב את-לבו לגשת אלי נאם-יהוה,

is understood similarly by both translators:

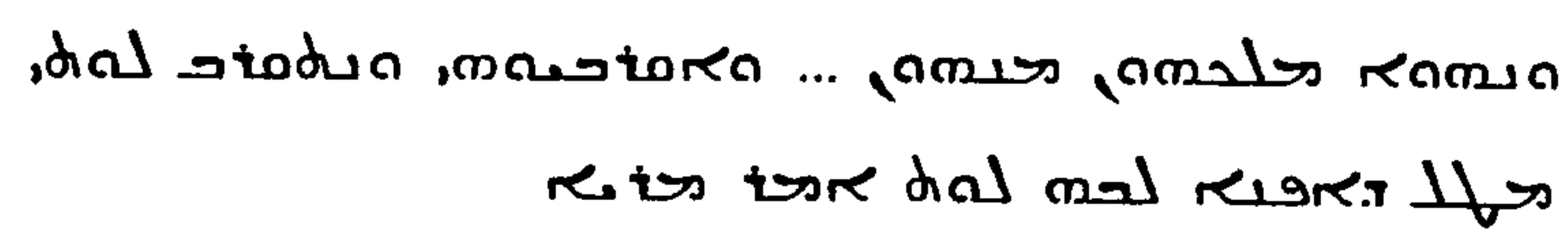

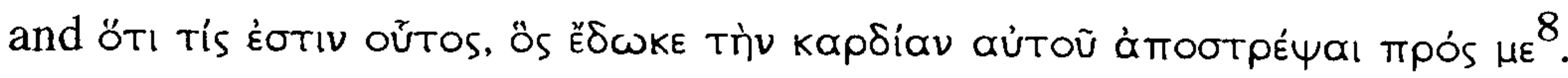

The understanding of ערב in the Peshitta and in LXX is close, and is not an

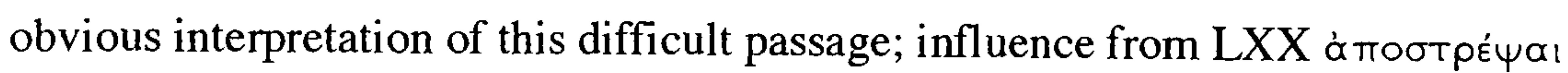
is a strong possibility.

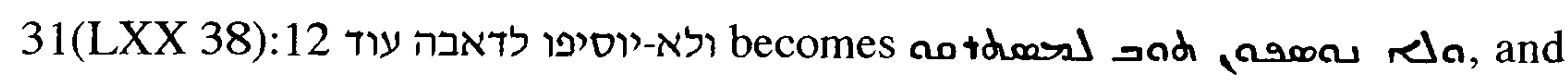

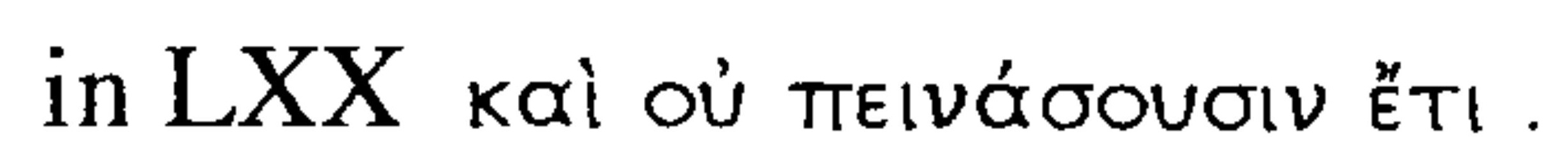

Root דאב appears in the Hebrew Bible only in Lev 26:16; Deut 28:65; Jer 31:11 and 31:25; Ps 88:10 (9); Job 41:14, and at all passages except that in Job ${ }^{9}$ is rendered similarly in LXX and the Peshitta, with two principal interpretations.

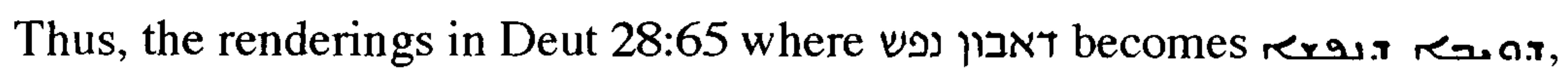

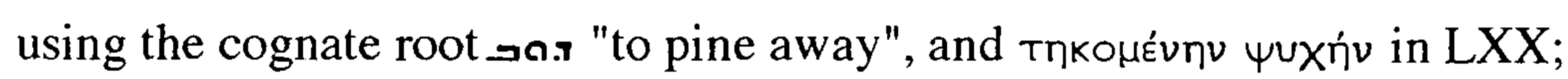

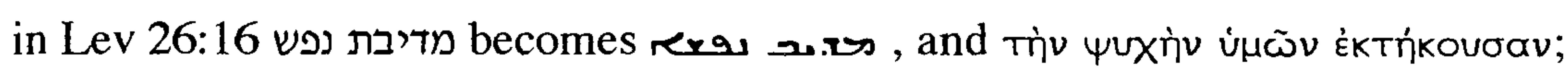

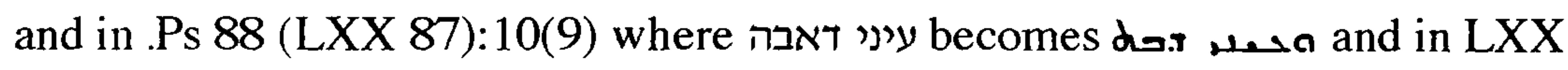

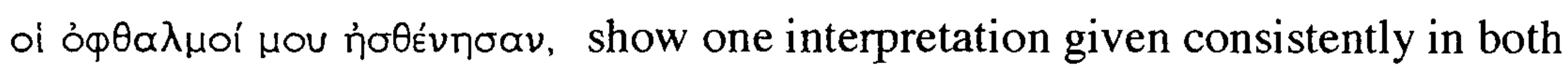
the translations.

The translators of Jeremiah seem to have perceived a different nuance: in using root oto at 31(LXX 38:12):11, "to be lacking" the Syriac is close to LXX kai ou דו הרויתי נפש עיפה וכל-נפש דאבה

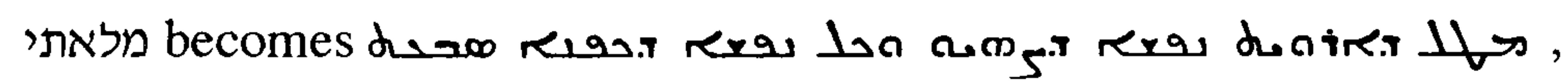

8. dal, rather than , dal, is the form in 7a1.

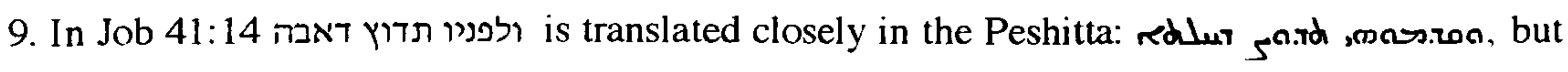

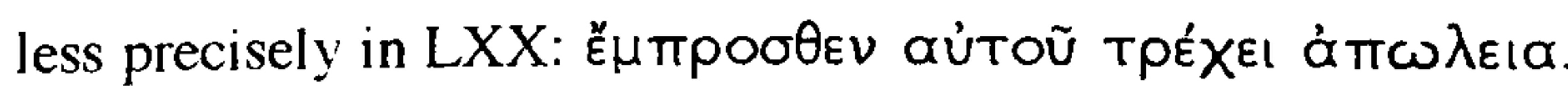


introducing a rather more pedestrian imagery with the parallel of thirst and hunger which resembles LXX ö

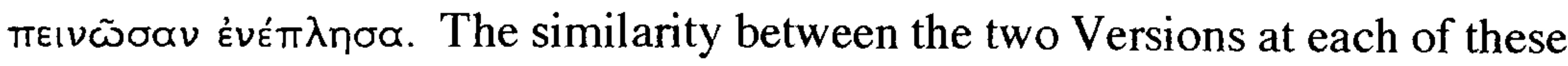
points suggests that the translation may have been consistently influenced by LXX.

32(LXX 39:21-22):21 ותצא את-עמך את-ישראל מארץ מצרים באתות ובמופתים וביד חזקה ובאזרוע נטויה ובמורא גדול becomes

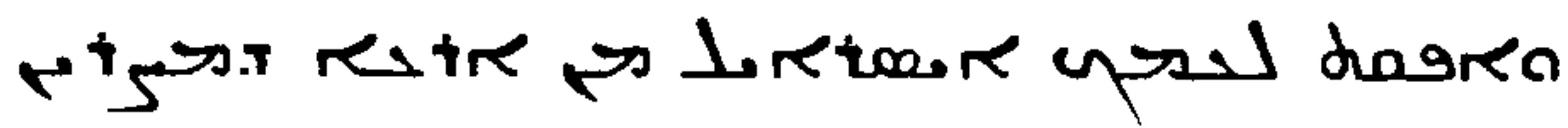

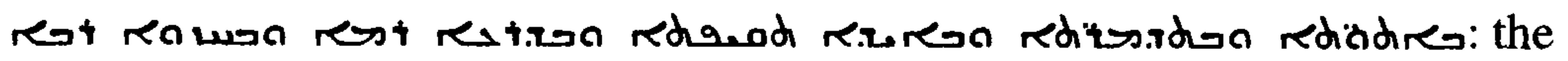
point of difficulty was the derivation of מורא.

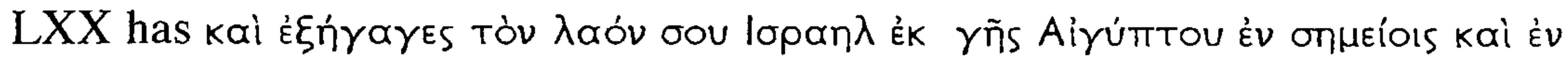

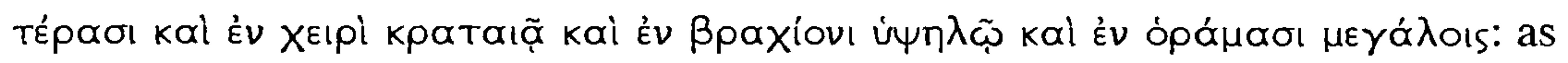
in the Peshitta, the passage has been translated as if the Hebrew were מִרֶָה, a vision, derived from root ראה, rather than מוֹרָא, fear, derived from root ירא. This agreement might well be due to polygenesis, were it not that a similar agreement is found in the translations of the similar passages of Deuteronomy. In Dt 4:34 במסת באתת במופתים ובמלחמה וביד חזקה ובזרוע נטויה ובמוראים גדלים despite the indication given by the Hebrew which parallels מוראים with מלחמה, suggesting "fear" rather than "vision" as an underlying theme, the Syriac has

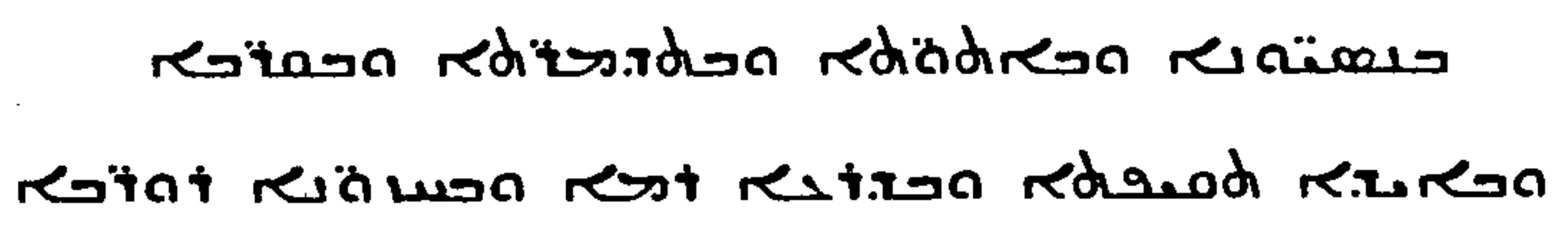

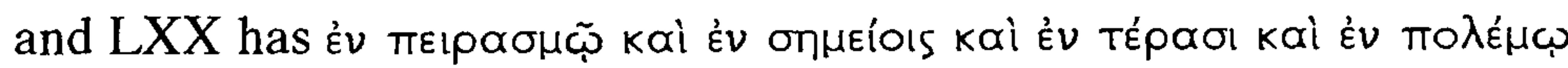

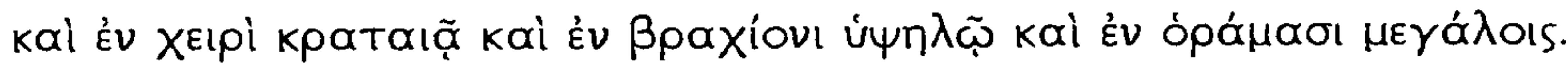
In Dt 11:25 the Hebrew text similarly gives a clue to the derivation, with a parallel of מוראכם and פחדכם and פחדכם ומוראכם יתן יהוה אלהיכם על-פני כל-הארץ. Here the translators both follow that lead: res Jdu raduna

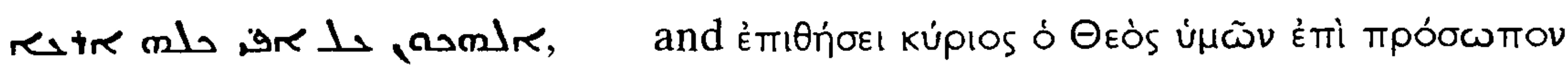

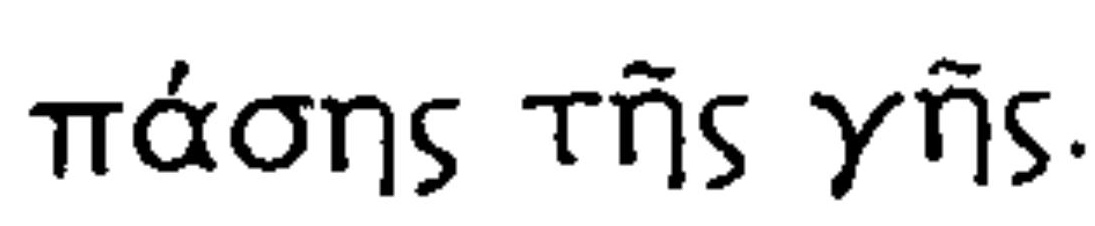

At Dt 26:8, which is particularly close to Jer $32: 21$, with no precise parallelism for ביד חזקה ובזרוע נטויה ובמרא גדל ובאתות ובמופתים : מרא גדל, the translations are 


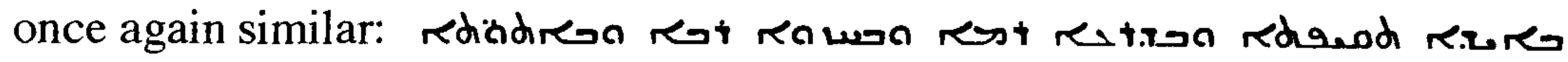

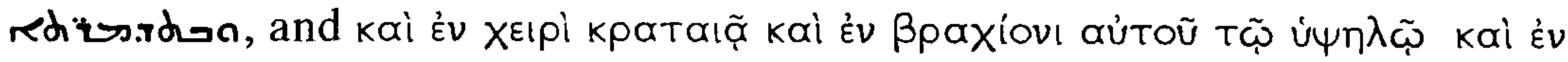

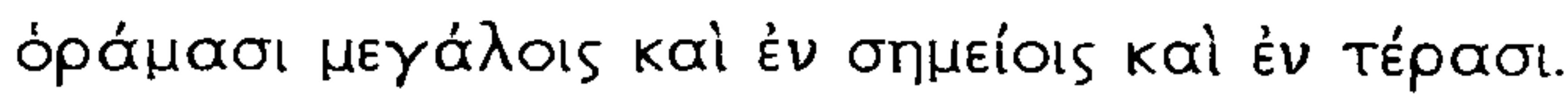

(At Dt 34:12 there is too much difference between the Hebrew and the Greek for the comparison to be useful.)

These additional agreements suggest influence in Deuteronomy rather than polygenesis, and support that explanation in Jeremiah too. There is, however, an additional possibility: since these passages from Deuteronomy precede Jeremiah in the canon, and had therefore probably already been translated (Beckwith, 1985, p.309) the translator of Jeremiah was probably familiar with them in the Peshitta text too, and it may have been the latter which influenced his decision in his work on Jeremiah.

This example shows well the need to be certain, if postulating influence of one translation on another, that there is no possibility that the influence is from the source text itself, rather than from the translation.

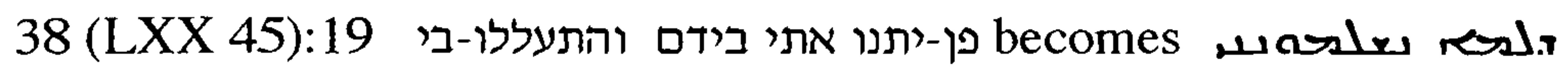

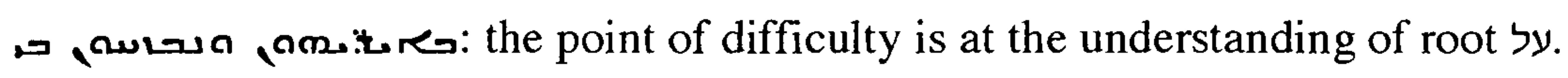

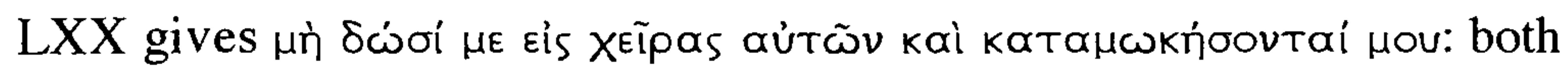
translators have selected the nuance of "mock", not the most obvious interpretation of root על על in this context. Polygenesis is possible, but influence of LXX on the translator is a real possibility: the treatment of the defeated was such that the king might be expected to fear a fate far more cruel than mockery. Elsewhere, root 2 is used in some other passages ( $\mathrm{Nu} 22: 29 ; 1$ Sam 6:6, 31:4); but so are roots 9t (Ex 10:2; Ps 141(140):4, Lam. 2:20); and (Judges 19:25), so this was by no means an automatic choice.

48(LXX 31):2 גם-מדמן תדמי becomes מדמן :Red is obscure;

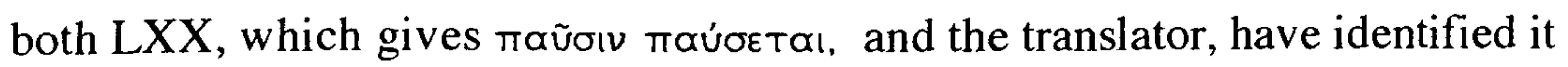
not as a place-name but as an auxiliary of תדמי. Both have taken root דמם in the sense "to be silent" rather than "to be destroyed". 


\section{Chapter 6 Difficult Hebrew}

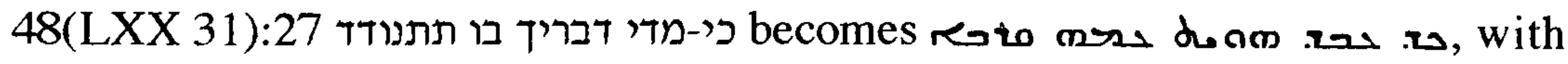
no rendering of כי-מדי דבריך, and reading root גדר rather than In both respects

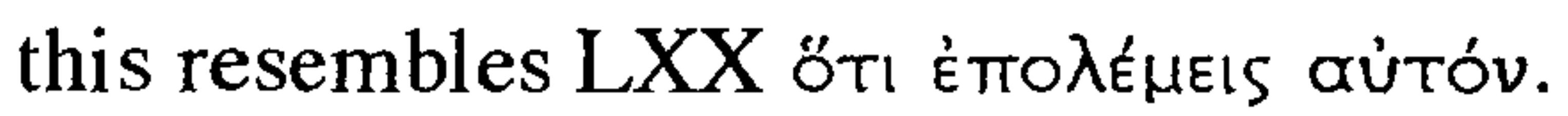

The significance of "to wag the head" is uncertain; the context, with ואם לוא at the opening of the verse, suggests that the sense may be יפטירו בשפה anilar to that at Ps 22:8, where ילעו ראו לי is paralleled with and is translated amery a.wer using the cognate of root TJ. At Jer 18:16

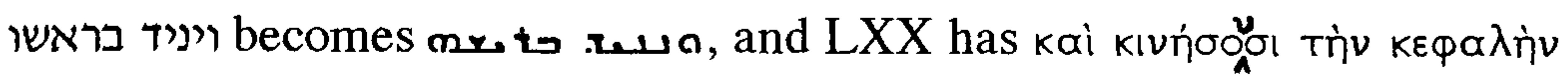

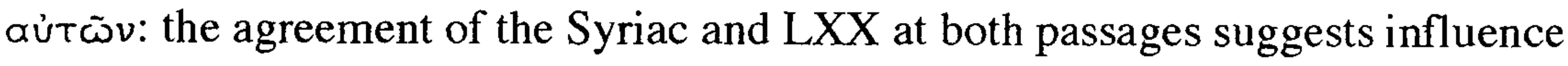
from the latter.

The similarity of LXX and the Peshitta in the minus at כי-מדי דבריך suggests that the phrase may have been absent from the Vorlage: not all minuses have this significance, but this has the characteristics of one which may (Chapter 4).

50(LXX 27):26 סלוה כמו-ערמים becomes red.lf the paints of difficulty are at סלמים and עלוה

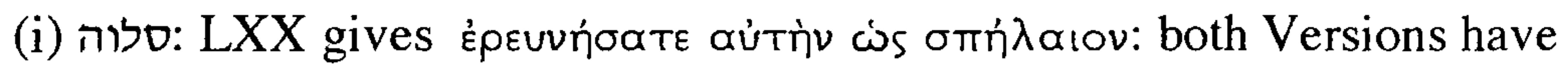
understood סלוה as "search it", by no means the obvious interpretation of root סל, usually "to lift or cast up". The train of thought is probably from tossing a heap of grain into the air in the process of searching for hidden valuables, but the expression of this as simply "to search" in both seems unlikely to be due to polygenesis.

(ii) כמו-ערמים: in on the other hand, the two translations differ, the

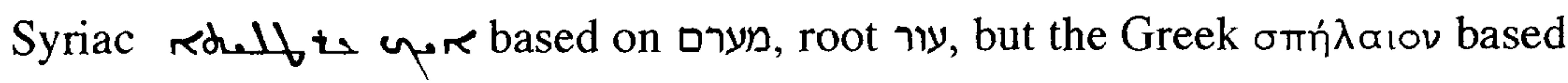
on מערר root. Nonetheless, although the understanding differs, both suggest כמעy in the Vorlage. The point of interest is that although neither translation is attractive, the Syriac "search it like a thing which has been stripped" making rather poor sense and the Greek "search it as a cave" an unconvincing simile, the two differ from one another: what seems to have happened is that the Syriac translator was defeated by סלוה in this context and took guidance from LXX; having done so, he then felt that he could do better than LXX in the translation of כמו-ערמים (or the form in the Vorlage). 


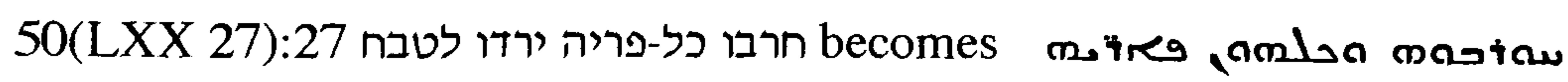

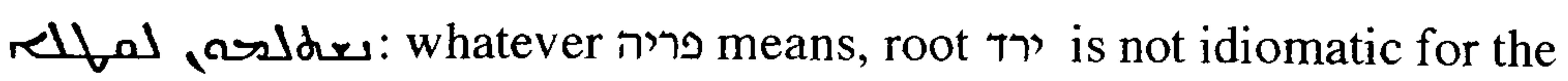
preparation for slaughter; if the term is a figure for "the great", "the mighty" root ירד would be appropriate for humiliation. This suggests that the understanding

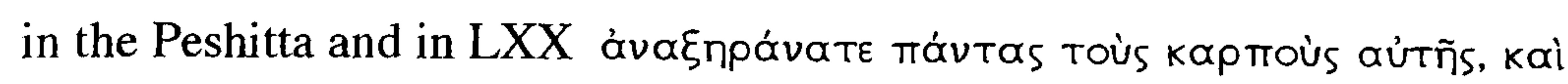

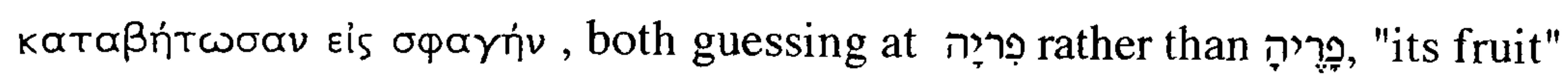
rather than "its bulls" is wrong; it is possible that a mistaken understanding in LXX influenced the Peshitta.

c. passages at which polygenesis is so plausible an explanation that there is no good reason to invoke influence of the one translation on the other

In the third group there are those passages at which the agreement of LXX and the Peshitta against MT can so plausibly be attributed to polygenesis that there is no strong reason to consider influence. It is difficult to decide where best to discuss these passages, for agreements due to polygenesis should not be given in the same section as those due to influence: they should be included in other sections of the discussion, for instance "unsupported guesswork". If that is done, however, it is necessary to note the similarity to LXX in the discussion of each example, even if only to say that despite this similarity there is no reason to ascribe the agreement of the two Versions against MT to influence of the one on the other. This would be repetitive, and it seems better to give the examples at this point in the chapter, but to note at each the factor which most probably led to the translators' decision: if polygenesis seems to have operated, it may follow from a variety of causes. For instance, the two translators may have made the same guess; their translation techniques, independently of one another, may have involved a common approach to the Hebrew; they may both have detected a particular nuance; and they may have had in common a traditional understanding of a difficult phrase. 
This is also a large group, illustrated here by the following examples:

$3: 23 ; 4: 16$

$11: 12$ and 14,$16 ; 13: 16 ; 14: 4 ; 15: 18 ; 17: 11,13$;

$20: 9 ; 22: 20 ; 23: 10$;

49(LXX 30:13):19; 50(LXX 27):29.

Divided into groups to show the factors which may have prompted the approach taken:

the two translators may have made the same guess:

$3: 23 ; 4: 16 ; 11: 16 ; 23: 10 ; 49(\operatorname{LXX} 30: 13): 19 ;$ 50(LXX 27):29;

their translation techniques, independently of one another, may have involved a common approach: $3: 23 ; 11: 12$ and $14 ; 14: 4 ; 17: 11,13 ; 20: 9 ; 22: 20$;

the two translators may both have detected a particular nuance: 15:18;

the two translators may have had in common a traditional understanding: 13:16.

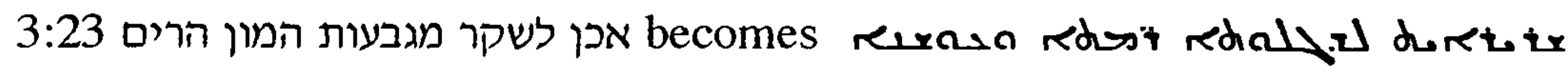

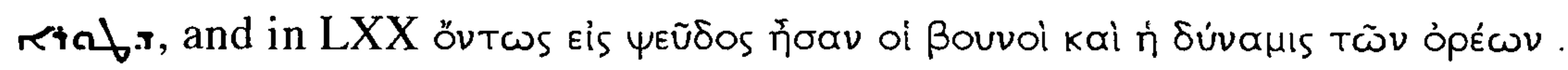

The points of difficulty are the sense of the initial mem in מגבעות and the understanding of המה root, המון

(i) מגבעות: neither translation represents the difficult mem in מגבעות. This might well have been a deliberate omission; as a solution to the obscurity of this phrase it is restrained and economical. Polygenesis, both translators independently seeking a clear rendering, is possible.

(ii) המון the the thather the the absolute המון, an interpretation which is compatible with the unvocalised text; LXX is similar, based on the construct rather than the absolute. Working from an unpointed text, polygenesis is clearly possible, both translators independently making the same, probably wrong, guess.

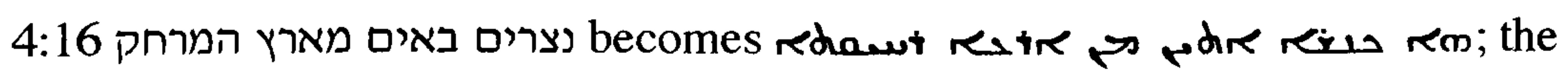
problem is the derivation of נצרים: נצר roots, to watch or 


\section{Chapter 6 Difficult Hebrew}

guard, are both possible, and the context gives no help in choosing between them.

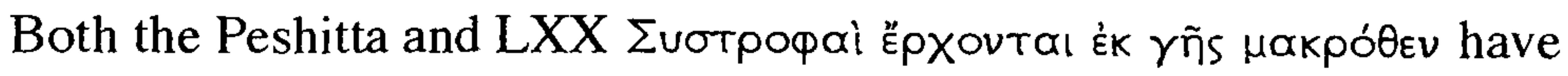
understood the sense of " crowds", which could have been reached from either root. Either influence, or polygenesis following the same guess made by both translators, are possible ${ }^{10}$.

\section{$11: 12,14$}

At v. 12 MT has והושע לא-יושיעו להם בעת רעתם, and at v.14 כי אינני שמע בעת קראם

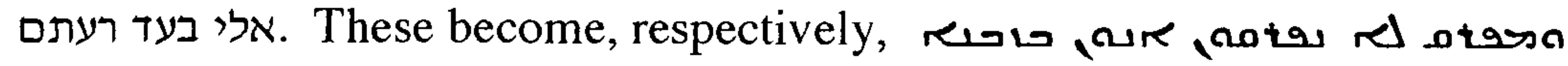

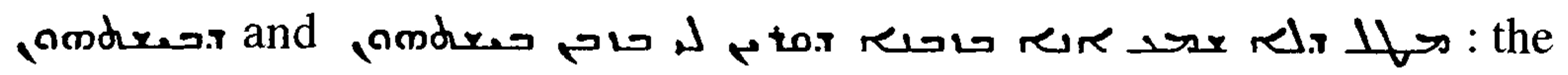

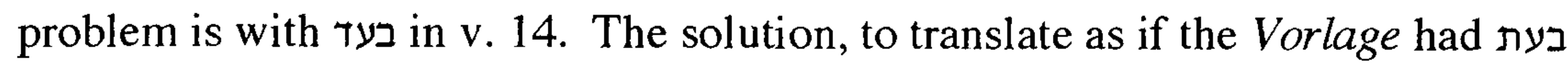

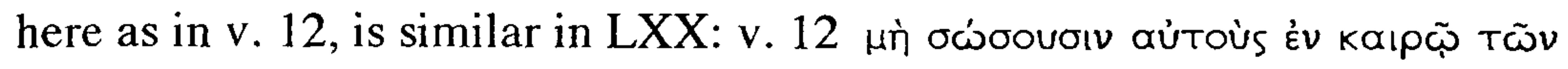

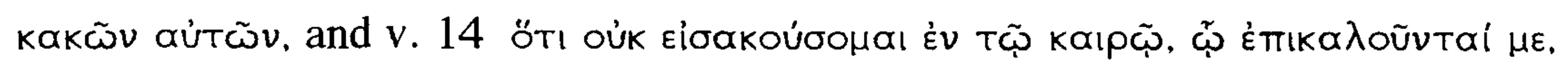

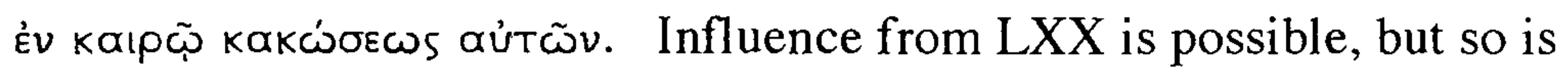
polygenesis, both translators pursuing greater clarity. Inner-Hebrew corruption is also possible, from an original בעת קראם אלי בעת רעתם to the form in MT: (Kennicott, 1776, p.107).

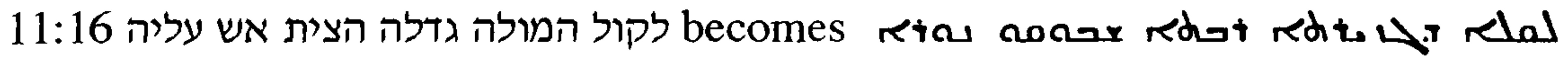

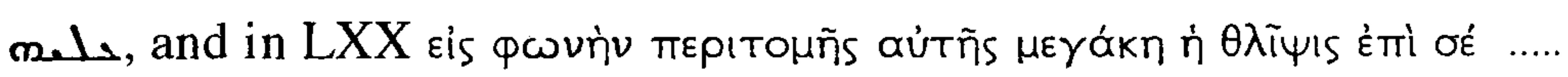

10. Rabin (Rabin, 1966, pp.45-46) has suggested that both the translators understood a derivation from a root $n s ̦ r$, "to chirp, murmur, mumble, grunt, sing, praise", describing the noise of the approaching crowd, which has a Syriac cognate كو but is not found in biblical Hebrew; both translators then moved from the noise of the crowd to the crowd itself. In support of this suggestion, the understanding would fit well into the context of the next phrase . ויתנו על-ערי יהודה קולם. Against it, however, is the complex thought process implied, and that if the Syriac translator believed that he recognised a Hebrew term with a Syriac cognate he might well have opted for that cognate in his translation. 
The problem is the derivation of מלמול : מלל possible roots are speak" and "to circumcise". The solution resembles that in LXX, so influence from the Greek is possible but so is polygenesis, both translators having made the same guess.

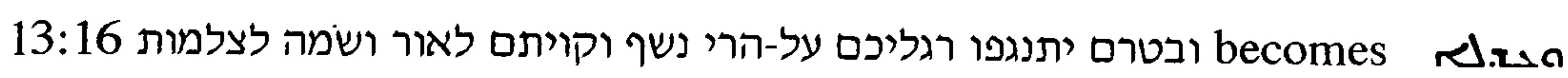
(t)dids rdas Itfa, and in LXX, with the same etymological understanding of צמות,

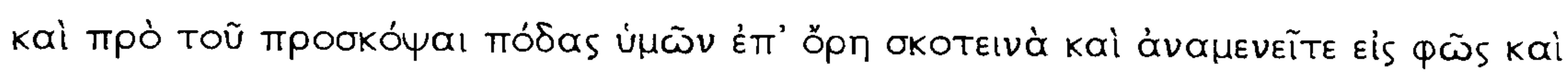

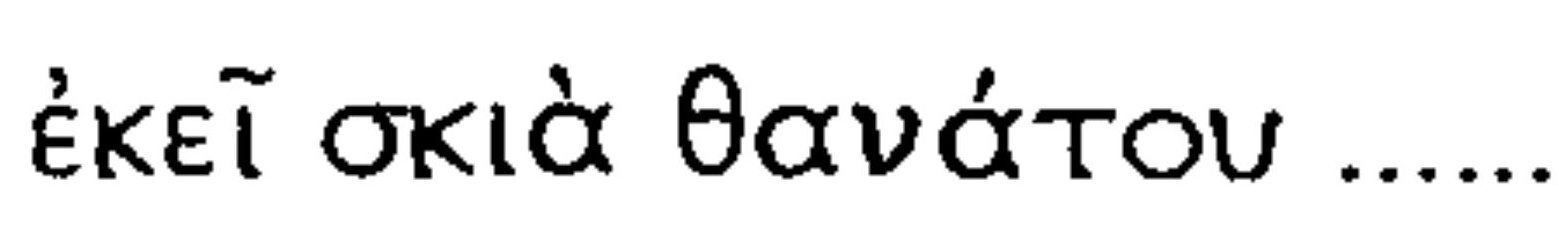

The passage is discussed by Barr (Barr, 1979, p. 302) who notes how widespread could be the segmentation of a Hebrew form into two Hebrew words taken as if they were compounded. (The term צלמות also occurs within Jeremiah at 2:6, but the phrase in which it appears is a minus in LXX.)

The similarity of LXX and the Peshitta could result from influence of the former on the latter, but a traditional understanding held in common by the two translators is possible.

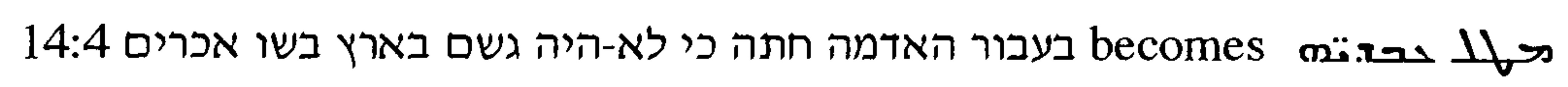
rtar adms rety ram restrex. The problem is the derivation of the translator has apparently understood root עבד, though because the distinction between "on your account" and "because of your actions" is easy to blur, it is

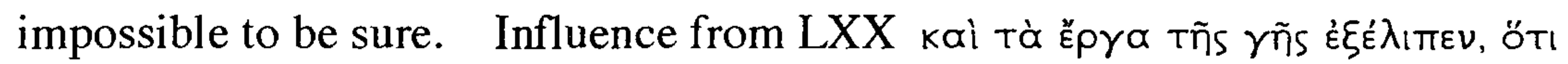

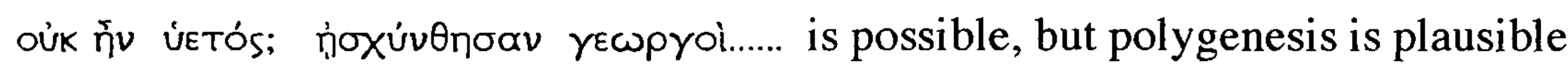
too, both translators taking the same simplifying approach.

There are further differences: neither בארץ have equivalents in the translation, an example of a minus common to both Versions which may shed light on the wording of the Vorlage.

In 15:18 for the Hebrew "unceasing", in למה היה כאבי נצח, the Peshitta has

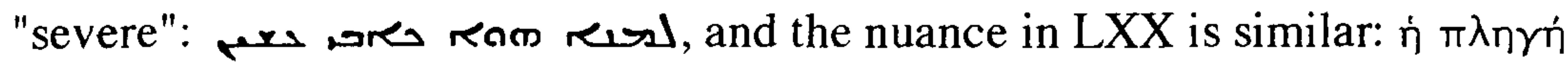

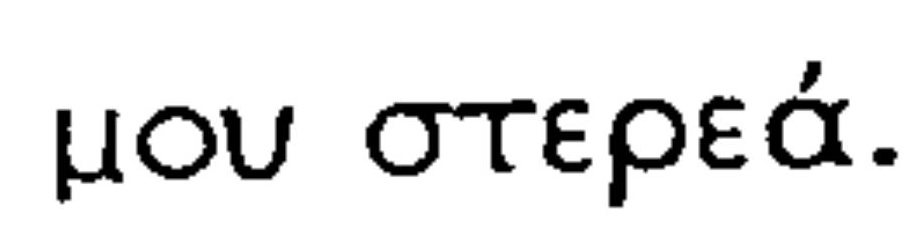

The two translators could have responded independently to the nuance of 


\section{Chapter 6 Difficult Hebrew}

"overpowering" in the underlying Aramaic sense of root נצח "to be pre-eminent". Influence of LXX on the Peshitta is also possible. There is a third possibility, the use of 2 as a drudge-word.

17:11 is difífult; the metaphor of the partridge gathering the chicks which she has not hatched is explained in the translation with a preliminary oper, and rem to link the two clauses:

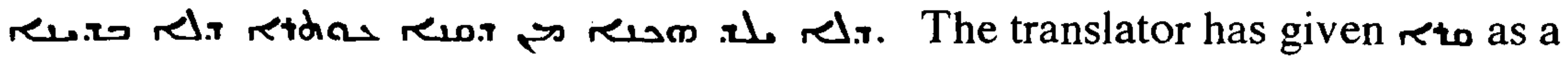
rather free rendering of דגר "to gather together as a brood", and wער as the equivalent of קרא, taking the latter not as a participle but as a noun. LXX too renders קרא as a noun, but differs from the Peshitta in giving a double rendering

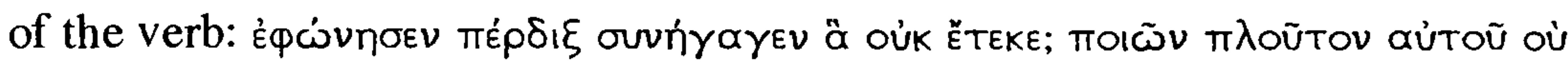

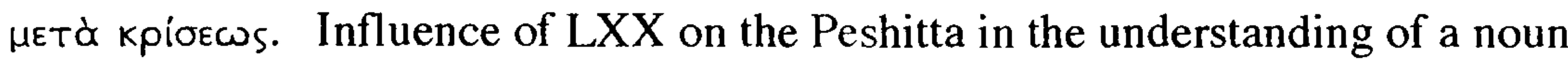
in קרא is possible ${ }^{11}$, but polygenesis is equally likely, the two translators independently pursuing clarity.

17:13 יסורי בארץ יכתבו, which becomes, andadu ratrea Rinteso, is obscure: the problem centres on the first person suffix at יסורי, which makes sense only if God is the speaker, fitting ill in the context of the opening of the verse מקוה ישראל וסור כל-עזביך יבשו in which God must be the addressee. The Qere is perhaps equivalent to וסורים (McKane, 1986, p.407) and this is the understanding in the Peshitta "and the rebellious ones will be written in the earth (presumably $=$ dust)", reading root סור rather than LXX is similar:

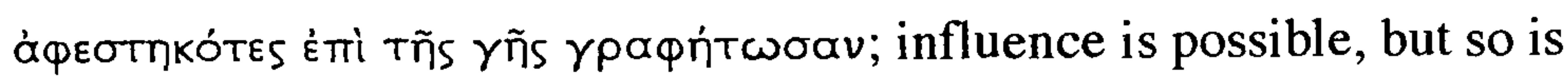

11. The translation of the verb in LXX has given rise to discussion: McKane (McKane, 1986, p.399) refers to the double rendering (which he comments is also found in the Peshitta, but this seems uncertain) and says that the text makes poor sense; he notes that Ziegler (Ziegler, 1957, p.235) deletes $\dot{\varepsilon} \phi \omega ́ \nu \eta \sigma \varepsilon \nu$. The manuscript tradition indicated by Ziegler is complex. 
Chapter 6 Difficult Hebrew

polygenesis, both translators having independently made the same decision to achieve better sense.

In 20:9 עצר בעצמתי , והיה בלבי כאש בערת עצר בעצמתי probably describes the restraint of containment of דבר-יהוה, referring back to v.8, within the unyielding substance of the bones, as a parallel to the fire in the heart but not as a synonymous parallel; in the translation, however, we have qre ramo

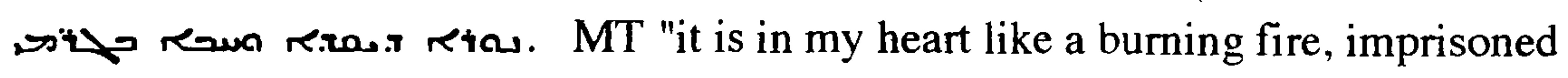
in my bones" in which "it" is "דבר-יהוה" and this rather than the fire is referred to in עצר בעצמתי becomes in translation "it is in my heart like a burning fire kindling in my bones". There is no exact equivalent of עצר which has been loosely translated with root wב "to be kindled, set on fire, burn fiercely"; the translator has apparently understood עצר, despite its masculine form, to be connected with אש, although the latter is usually feminine, rather than taking it to refer back to the masculine דבר-יהוה. This may be correct, for where two adjectives follow a feminine noun the first may be feminine (here בערת) and the second masculine (Gesenius, 1903, p.350). LXX is similar to the Syriac, reading kaì Éyéveto ćs

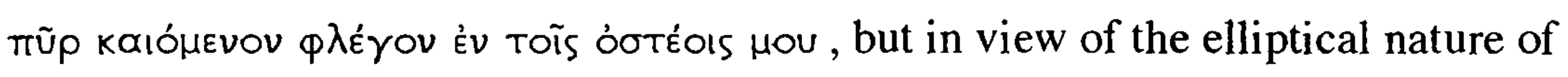
MT polygenesis is possible, both translators aiming independently at clarity, and both having independently made the same assumption concerning the term qualified by עצר.

22:20 מעבר ים has been translated as if it read ובבשן תני קולך וצעקי מעברים:

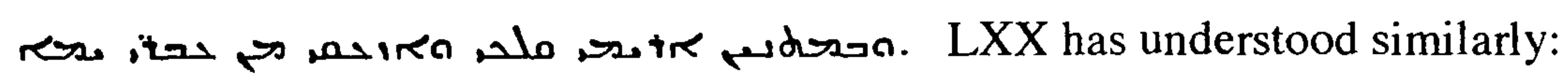

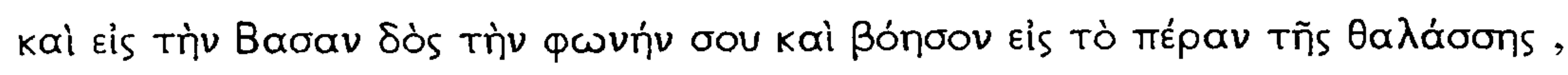
but here too polygenesis is possible, both translators independently trying to clarify the text.

23:10 מפני אלה אבלה הארץ is read as "these" it may be taken to refer to the מנאפים of the previous phrase, כי מנאפים מלאה הארץ; this makes sense, taking adultery as a metaphor for apostasy. But it

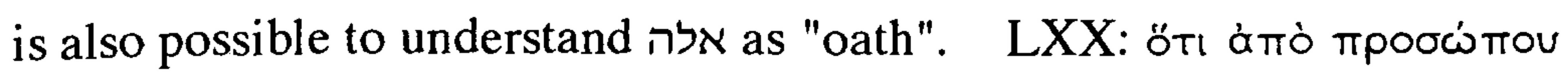

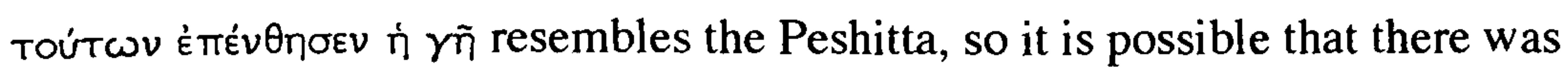


Chapter 6 Difficult Hebrew

Greek influence on the Syriac; however, אָלָה a אָלָה are indistinguishable in an unpointed text, so both translators independently may have made the same guess.

49(LXX 29:20):19 ומי בחור אליה אפקד becomes ralara, the translator evidently having taken the sense "young man" rather than "to choose";

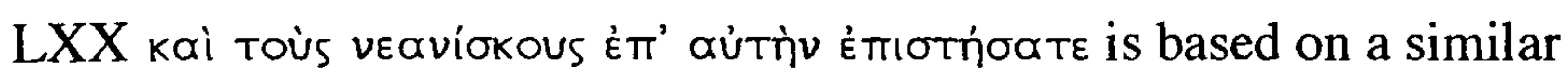
understanding which is reasonable in the context: both translators could well have independently made the same reasonable guess.

50(LXX 27):29 השמיעו אל-בבל רבים כל-דרכי קשת becomes

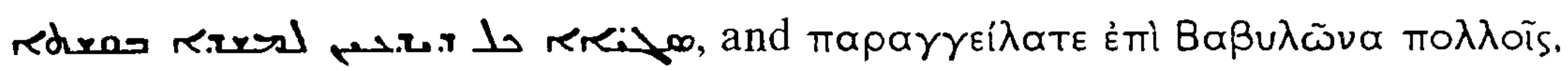

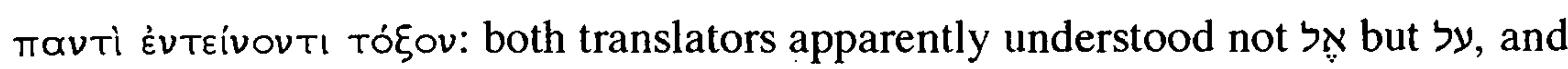

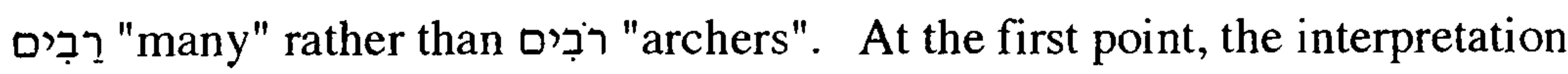
seems only sensible in the context, and there is no need to consider influence of LXX on the Peshitta; at the second, either is acceptable, כל-דרכי קשת being either a parallel or an explication depending on which has been understood, and both translators could well have independently made the same reasonable guess.

(ii) guesswork, based usually on etymology, occasionally on the context, and in one example apparently unsupported: this is a large group, represented here by forty-three examples.

$2: 19,21 ; 3: 6,8,11,12,14,22 ; 5: 6 ; 6: 6,28 ; 8: 5,6$ $10: 5,8 ; 11: 15 ; 12: 6,14 ; 13: 14,27 ; 14: 7,9 ; 15: 11-12 ; 17: 16$; $20: 3,10 ; 23: 14$

31:21(22); 33(LXX 40):6; 37(LXX 44):12; 39:10; 40(LXX 47):5; 47(LXX 29):5; 48(LXX 31):1, 18, 28; 49(LXX 30):4; 50:(LXX 27)17; 51(LXX 28):1, 3, 20, 27, 35 


\section{2:19}

This verse leads into the discussion of root שוב. Here, the results of study suggest that the Hebrew root had developed a meaning which may not have been embodied by the Syriac cognate. There is an interesting comparison in 20:3, discussed below, where root סבב illustrates the reverse position, having evidently developed in Syriac a meaning not found in the Hebrew cognate: in both these pairs, there is a "core" meaning common to both, and a further development of meaning has occurred in one language only; a related position in roots שכח and was noted above in the discussion of 4:11.

\section{שוב Root}

The translation of the derived forms of this root illustrates an important problem, the impossibility of being sure that the modern reader correctly understands terms which the translator uses, a point discussed in Chapter 1.

Translation of root שוב is usually straightforward, but where some of the derived forms are concerned there may have been some difficulty. These forms are those which have a negative meaning: some are translated with root $\neg$ od, but others are not, and there is sufficient variation in the translations to cause doubt as to whether the translator understood this negative sense.

Root שוב is used, within Jeremiah, both to mean to turn back to God, as for instance at 3:7 אחרי עשותה את-כל-אלה אלי תשוב ולא-שבה, or to turn away from God, as for instance at 8:4 which plays on the ambiguity in אם-ישוב ולא ישוב. 
The derived terms listed below, with the terms used in translation also shown, consistently have a negative sense in MT:

MT

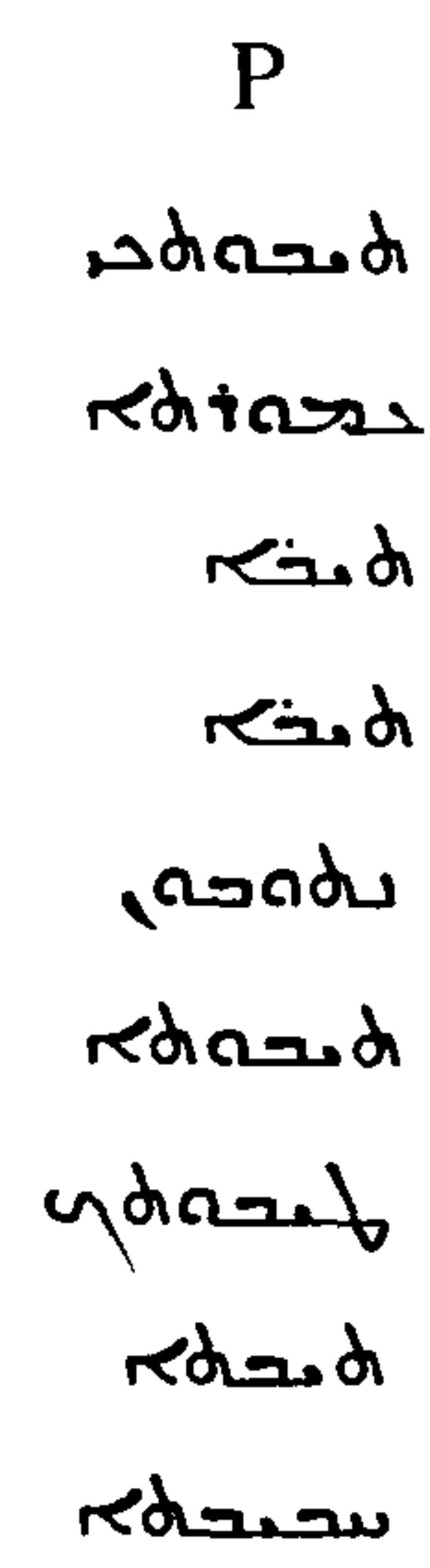

In books other than Jeremiah:

Hosea 14:5 משובתם

amdared

Mic 2:4 שובב

Isaiah 57:17 שובב

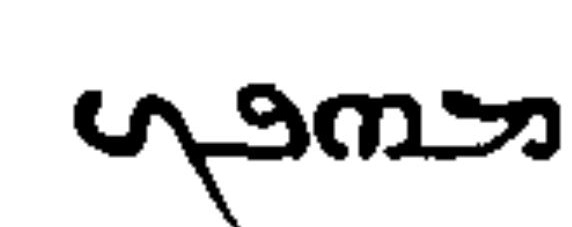

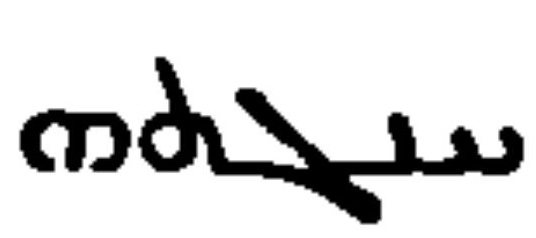

Ezekiel 37:23

מושבתיהם

Sprey (Sprey, 1957, pp. 408-410) argues, from Jeremiah 2:19, 3:22, and 8:5, and Hosea 14:5, that redared, which usually means return or repentance ${ }^{12,13}$,

12. Weitzman suggests that the translation of Ton by redandd may have been deliberate, in order to avoid confusion with the Syriac near-homonym (when pronounced with a hard " $d$ ") rizav "shame" (Weitzman, 1988, p.240), a point also noted by Koster (Koster, 1993, p.247).

13. Lane, discussing the translation of 7on in Lev 20:17, notes that "loving-kindness" would be inappropriate as a translation, and that the Peshitta has rirow: he suggests two possibilities, either that there is another Hebrew root 70 , or that the sense "shame" too is derivable from a basic meaning "liability" (Lane, 1994, pp.105-106). 
can also have the same meaning as the Hebrew, recantation or backsliding, because otherwise its use here would be inappropriate, and that the ambiguity reflects the basic meaning of the root, "to turn". Payne Smith (Payne Smith, 1879 , col.4401) who refers to $2: 19 ; 3: 14,22 ; 31: 22$ ) who gives "defectus" as the meaning of משבה in 2:19 and 3:22, and "apostatans" for שובב 3:14, 22 and 31:21(22) evidently had the same understanding.

However, the translation of the other occurrences of these derived terms, which are today understood to have only negative meanings, does suggest that the translator may have been uncertain of this point. His translations fall into four groups:

(i) paraphrase;

(ii) reading root שוב rather than root;

(iii) translation with root 2 od;

(iv) an etymological solution.

In Chapter 2 it was shown that this translator did not restrict himself to a one-toone system of lexical equivalents, so it possible that he would have taken this variable approach to these translations even had he been in no doubt as to the negative sense; the variation is however so wide, as will be shown in detail below, that it does seem possible that he felt a general uncertainty.

(i) Paraphrase: 5:6, 14:7

In 5:6 the negative sense of משבותיהם is clear, from the parallel with פשע; however, the translator does not commit himself to using root and and relying on the reader to understand this negative sense, but instead adds a negative of which the Hebrew has no equivalent so that he can use the root with a positive

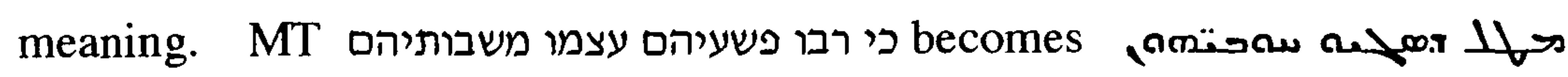
sandu R. Rersa

In 14:7 the change is even more marked, from root sad to root 20 , and from a first person plural suffix on משובתינו to a second person singular suffix on ndaref. (It is possible that ndaref results here from corruption of ydarad; if this is so, the change in person of the suffix would have been 
deliberate, to accommodate this error (as Sprey argues)).

אז, שלחה becomes אם-עונינו ענו בנו יהוה עשה למען שמך כי-רבו משובתינו לך חטאנו

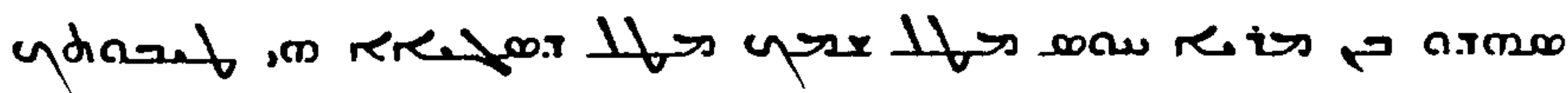

Paraphrase is unusual in P-Jeremiah, so its use in these two examples is striking.

(ii) Reading root ישב : 3:6,8,11, and 12

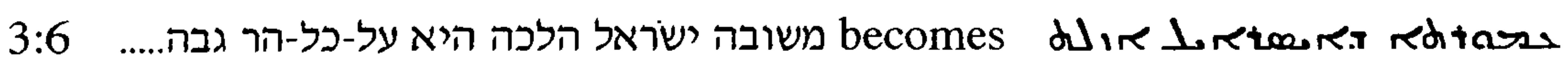

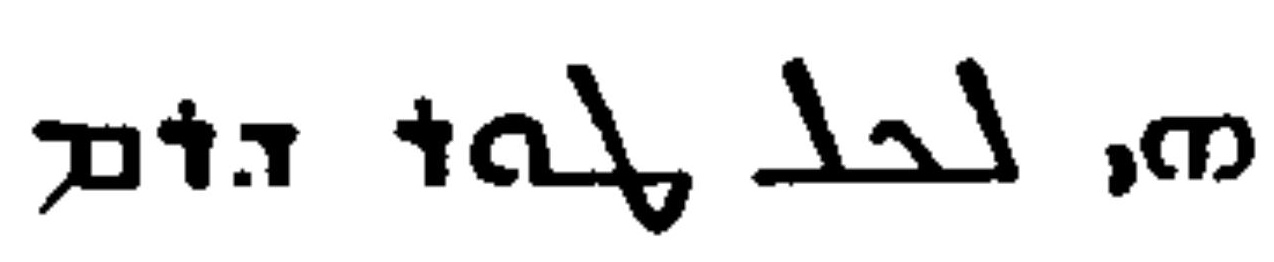

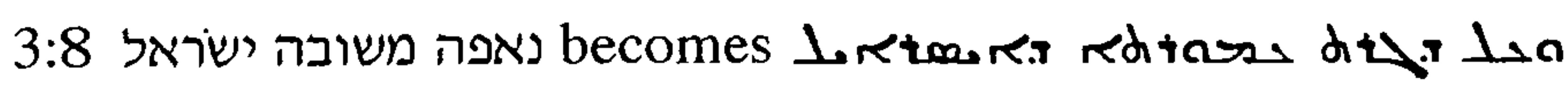

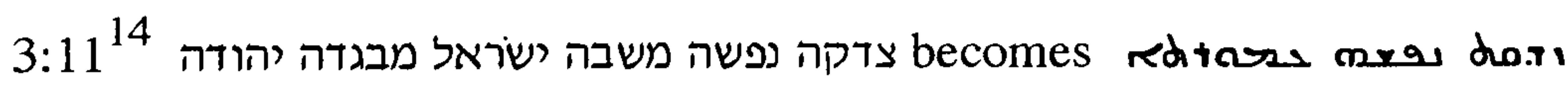

riane mdw redtax plortor ris

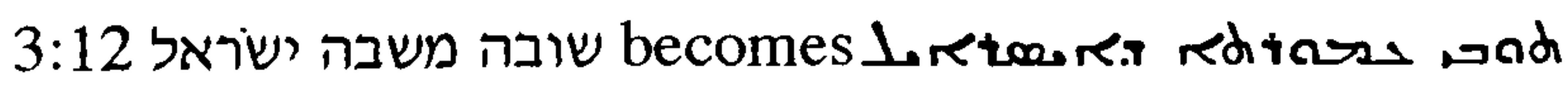

(iii) Translation with root 2 ad: $2: 19 ; 3: 14,22 ; 31: 21(22) ; 49: 4$

In each of these verses, the translation is to some extent ambiguous. In 2:19 there is a possibility, given too in the commentary ascribed to Ephrem (Sancti Ephraem Syri, Editio Romana 1740, p.101) ${ }^{15}$, that the ומשבותיך is a return to God, accompanied by painful feelings of guilt.

In תיסרך רעתך ומשבותיך תוכחך, the obvious interpretation is that Israel will be punished for both the parallel terms, משבותיך רעתד, her wickedness and her apostasy. However, whereas root יסר in the Piel means "to discipline, chasten, or chastise", root יכח, "to reprove" may put rather more emphasis on pointing out the error rather than of punishment for that error. The translation is

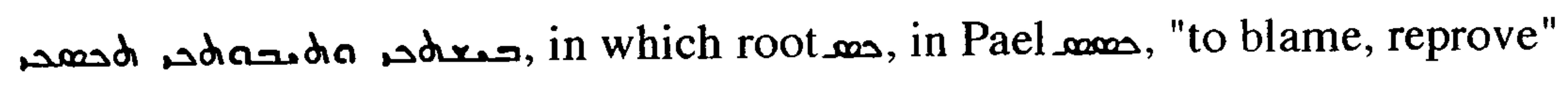
would fit this interpretation well.

14. In $3: 117 \mathrm{a} 1$ is difficult to read, and in $3: 12$ it is virtually illegible.

15. Burkitt strongly criticised this edition, describing it as "confusing and misleading" and noting that "the readings of the MSS are sometimes arbitrarily changed without any warning" (Burkitt, 1901, p.4). 
In 3:14, if שובו and a a a re read in a perfect sense, the verse could be saying that because the בנים שובבים have returned to God, he has already looked on them with favour; the sense of $כ$, though, is difficult if this is the understanding. מad כتש becomes שובו בנים שובבים .... כי אנכי בעלתי בכם .... והבאתי אתכם ציון

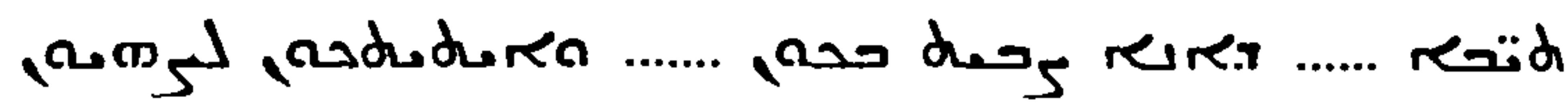

In 3:22, although only an undesirable quality would be the object of reore, it is possible that the intended sense of the Hebrew was "I will heal you in your repentant state", and that this is reproduced in the Syriac. שובו בנים שובבים ארפה

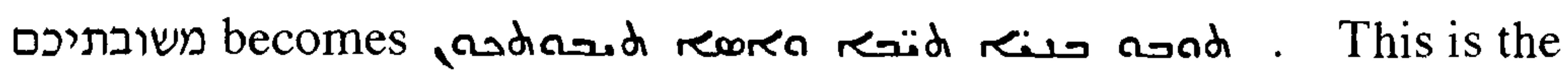
interpretation in the commentary ascribed to Ephrem on Hosea 14:5 (translated , ארפא משובתיכם (Sancti Ephraem Syri, Editio Romana 1740, p.248).

In 31(LXX 38):22 the translator may have been influenced by the preceding

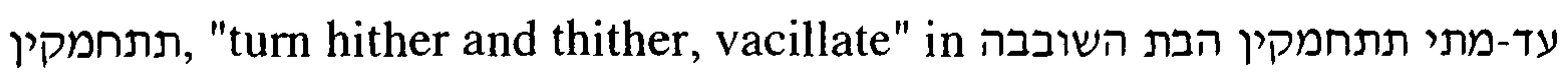

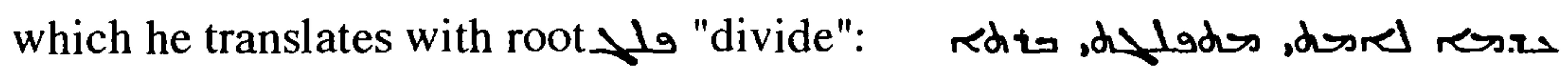

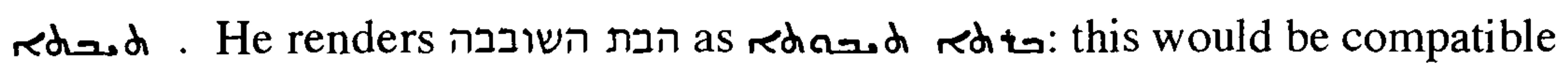
with an understanding of השובבה as a fickle repentance, rather than a settled backsliding, once again leaving open the intended meaning of root sad.

In 49(LXX 30:20):4 سבתרג may be a corruption of red ad, but there is no evidence in extant mss. to support this. There is the additional complication in this verse that הבת השובבה is here spoken of a heathen nation; the LXX

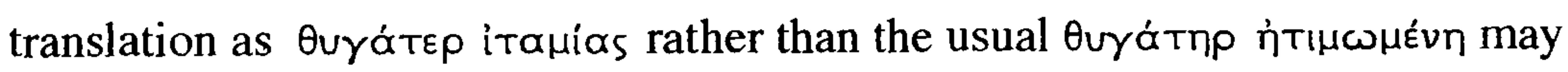

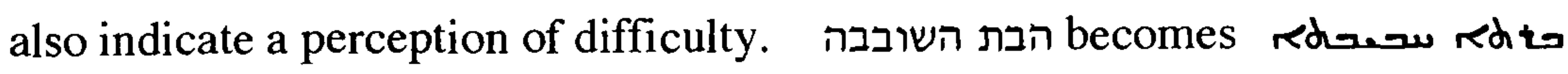

(iv) Resorting to an etymological rendering: 8:5.

In

מדוע שובבה העם הזה ירושלם

משבה נצח

החזיקו בתרמית מאנו לשוב נצח

the word-play emphasises the ambiguity of the Hebrew root. The translation has 
Chapter 6 Difficult Hebrew

internal contradictions: in the first phrases the people repent, but in the closing phrases they refuse to do so: rivtard rum ess sh res lo

$$
\begin{aligned}
& \text { rdag su rodond } \\
& \text { udas }
\end{aligned}
$$

The translator has reproduced the word-play, perhaps understanding it fully, but possibly opting for an etymological translation as a means of concealing his uncertainty, an approach rather similar to that in the small group of atomistic translations discussed below.

Passages outside Jeremiah provide no further evidence that redianod was understood to have a negative sense, and one:

Isaiah 57:17 וילך שובב בדרך לבו translated as awhich seems to be a guess based

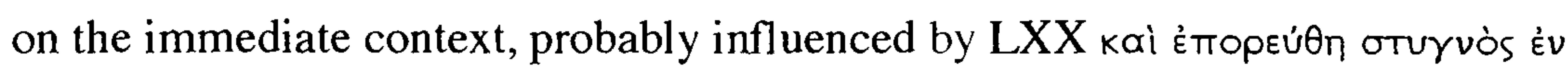
Taĩs óboĩs aưroũ, may well suggest that was seen as painful repentance rather than as perverseness.

Hosea 14:5 wרפא משובתם, which is translated הmdand Roor resembles Jer $3: 22$.

Ezekiel 37:23 והושעתי אתם מכל מושבתיהם is translated correctly: ametres dea mas

Other translations leave the translator's understanding in doubt:

Pr 1:32 כי משובת פתים תהרגם משובת משת Re, giving no clue as to the precise interpretation of

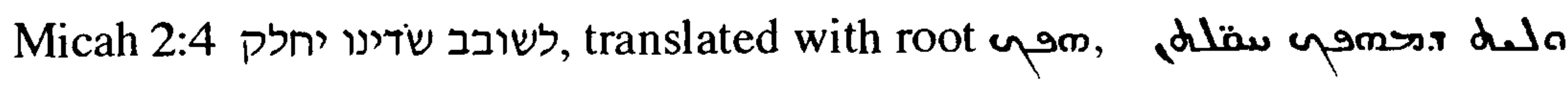
לשת , similarly gives no evidence that the "renegade" sense of לשובר was understood.

On balance, it is possible that the negative sense of these derived terms was perceived, but none of the translations is sufficiently precise to demonstrate this beyond doubt. The variation in the approach suggests, at the least, that the translator was sometimes uncertain of the sense. This is also the opinion of 
Chapter 6 Difficult Hebrew

Weitzman (Weitzman, 1974, pp.C:26-C:32) who argues that, because there are undoubtedly some passages of the Peshitta which do make rather poor sense, it must be accepted that this may be true of the verses which Sprey discusses (2:19; $3: 22 ; 8: 5$; Hosea 14:5), and that the negative meaning which would be inferred from these should not be added to lexica simply on this basis ${ }^{16}$.

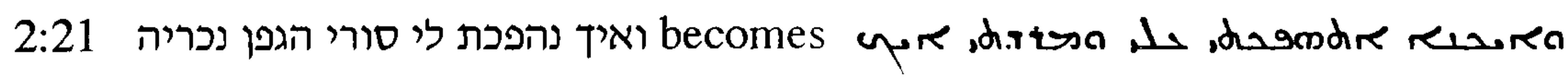
redou redal.

The problem lies in the syntax of MT: every word of the Hebrew can be accurately translated but the total sense remains obscure. The principal difficulties are at סורי לי לי

The translator has given a reasonable sense to לי, taking root הפך to mean "to turn against" and rendering סורי as, he has apparently

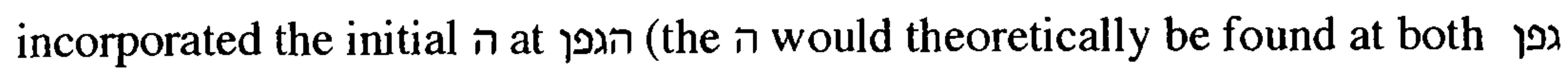
and at נכריה, or at neither, so this is not unreasonable) giving a hypothetical form סוריה, guessed at root be rebellious" which forms a good parallel with root in the sense he has ascribed to the latter, and translated appropriately with root st. He has then clarified the passage by adding an initial waw at dixtso, followed by yre which is so often a feature of the presentational style (Chapter 2), turning metaphor into simile. Given the considerable difficulty of the passage, he has arrived at a sense and structure as close to MT as possible, making only such changes as were needed to give clear Syriac.

6:6 שפכו על-ירושלם סללה : becomes :

is almost everywhere understood in the Peshitta (2 Sam 20:15; 2K 19:32= Isa $37: 33$; Ezek 4:2, 17:17, 26:8; Dan 11:15) to mean "ambush, to lie in wait" and translated using root حد. The reason may be prior familiarity with Jer סוללות 32:24 (Weitzman, 1996, p.605) which was understood to state that the

16. Holladay (Holladay, 1958, pp.48-50) discusses the translations in the Versions of nouns and adjectives derived from root שוב. He lists the interpretations but does not discuss the point discussed above. 
were about to enter the city: הנה הסללות באו העיר ללכדה. Given that this was the understanding, a precise translation of root שפך "to pour, pour out" would have been inappropriate, and the translator substituted root حק in as well as at (2000.

From this to the sense of "marauder" as at the single exception, Jer 33:4, is also plain; at that passage, the Peshitta gives rean.

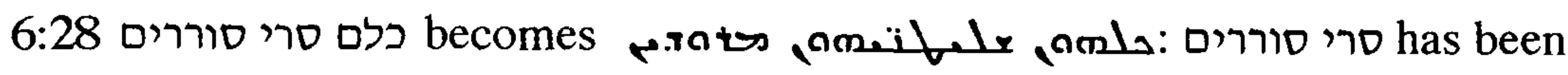
understood as if written שרי סוררים (Kennicott, 1776, p.99).

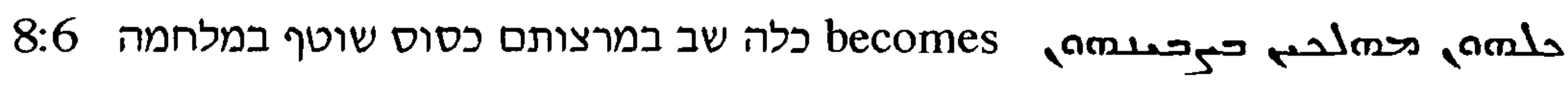
recono vere. The interest here is in the uncertainty as to the meaning of root שוב in this context ${ }^{18}$, and of the root of the term מרצותם.

(i) שוב root The translation of שב wath gives no clear sense of the change of direction which is implied by the wordplay in the Hebrew of the preceding passages: in v. אם-ישוב ולא-ישוב החזיקו בתרמת מאנו לשוב 5.

17. The rendering is similar to that of Targum כל רברביהון מרדין, but this does not amount to evidence either of influence from the latter or even of a common tradition, since the more usual

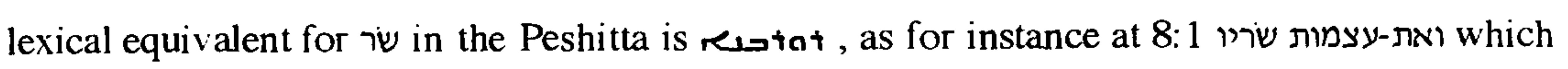
becomes amsertats restla. So restat, rather than fele, would have been closer to the Targum and therefore to be expected if either influence or a tradition in common had operated.

18. Driver, however, argues (Driver, 1937-8, p.105) שוב here is from a root distinct from

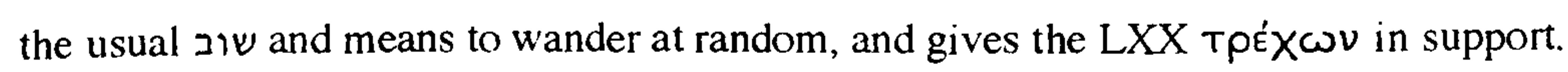


(ii) מרצותם:

Barr (Barr, 1968, p.243, n.1) suggests that the translator understood מרצותם as from root רצה "to be pleased with, accept" rather than the usually accepted derivation from רוץ "to run". There is so much overlap between the meanings of these two possible roots, in the present context, that it is difficult to be certain what the translator intended.

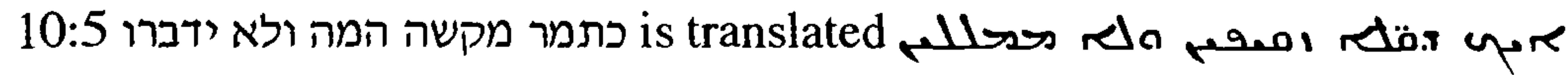

There are two principal problems here: the opening simile is itself obscure, and there is more than one possible understanding of the translation. תמקר , from a root meaning "to be erect, stiff", occurs only here and in Judg. 4:5 והיא יושבת חמש, תhere it is taken to mean "palm-tree" and is translated, תחת-תמר דבורה

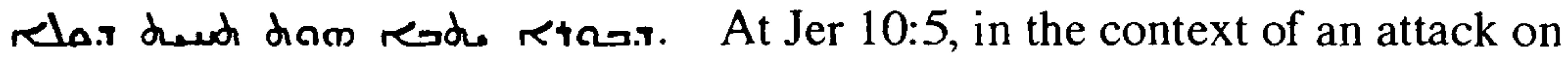
idolatry, "palm tree" seems unlikely, for this would imply a comparison of idols with living trees of obvious value. The most probable other meaning is "post"; P-Jeremiah, however, selected "palm-tree": Aox is used only to mean "palm trees", and is the standard lexical equivalent. This at least gives a reasonable sense in the context of the next phrase ולא ידברו; but fits poorly with מקשה .מקשה may be derived from root קשא, in which case it means "a cucumber field" as in Isa כמלונה במקשה 1:8 or from root קשה "to be hard" giving a possible meaning "hammered work". The translator seems to have understood the second derivation: at any rate, he has worked along lines different from those in the passage from Isaiah where the "cucumber field" sense is clear and the Peshitta has reforen "a lodge in a cucumber garden". The clue may be the understanding of the derivation of מקשה: if this was understood to be from root קשה, to be hard, giving a possible meaning "hammered work", the translator may have meant to portray an artificial palm tree, as much use as a post stuck into the ground, yielding little shade and no fruit, and with the connotation of metal work to link it with the image of expensively fashioned idols. 
10:8 ובאחת יבערו ויכסלו מוסר הבלים עץ הוא becomes, in 7a1

a.rorer riwro

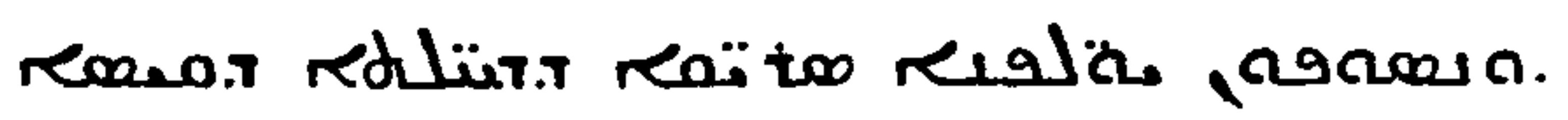

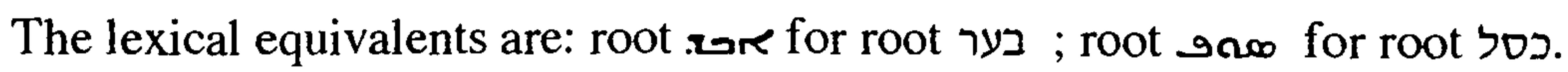
If associated with root כסל "to be or become stupid" as here, root בער must surely mean "to be brutish" rather than "to consume"; at Ps 49:11(10), for instance, יחד כסול ובער יאבדו

the same association is translated with using root tow "to be wanting". Possibly, the surprising choice at 10:8 results from the drive for clarity: מוסר הבלים אץ הוא is so difficult that the translator has allowed himself a limited paraphrase, making מוסר הבלים the grammatical subject of יבערו ויכסלו , and by association with the idea of wood, translating יבערו as "burn" rather than as "brutish"; the preference for consistency then in its turn dictated the choice of some similar meaning for ויכסלו .

\section{ובשר-קדש יעברו מעליך כי רעתכי אז תעלזי 11:15}

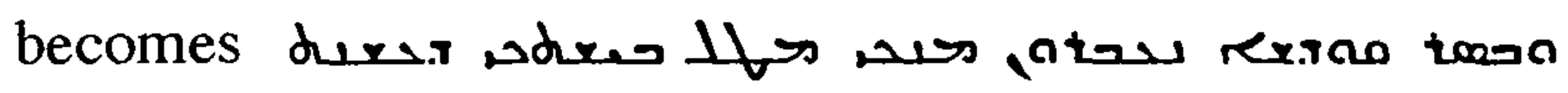

The translator has preserved the Hebrew as far as he could, translating precisely as far as רעתכי. He renders attempt at accuracy and clarity; at אז תעלזי, however, he resorts to a limited paraphrase. There may have been a subconscious association of the sound of "to exult", and that of root iry, "to be strong", which resulted in the use of root $\checkmark$, though this is a drudge-word in Jeremiah (Chapter 2, Table 8) and could therefore have been a deliberate rather than a subconscious choice. If this is the underlying process, אi is not rendered; alternatively, root represents and תעלזי has no equivalent in the translation.

\section{2:6 becomes קראו אחריך מלא}

Comparison with 4:5 is interesting: at the latter, קראו מלאו מלאו St, understanding root מלא in the sense, "to be full"; but at 12:6 "word" has been preferred. The difference is probably due to the contexts: at 12:6, the MT continues by pointing a contrast between קראו אחרידי מלא and the deceifful behaviour of the enemies: אל-תאמן בם כי-ידברו אליך טובות, which is translated so 
as to give a precise comparison, in accordance with the presentational style:

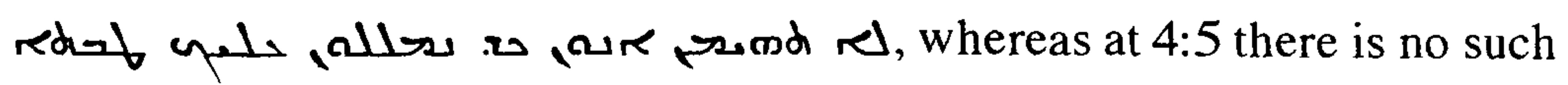
element in the context which relates purely to the giving of the warning.

12:14 with a reasonable guess at root רעה "to pasture", used figuratively of a ruler, rather than root רעע in רע "bad, evil".

\section{$13: 14,51: 20$}

These two verses form good illustrations of two general points, first that two or more possible motives for a given change in meaning may exist at many passages, and that any decision as to which of the possible motives operated has inevitably some subjective element. Doubtless, subconsciously, more than one could operate at once.

Second, these examples show the translator's reluctance to return to an earlier area of text and make a correction in the light of a later passage.

The problem centres on the same root, $ү$ j, in both examples.

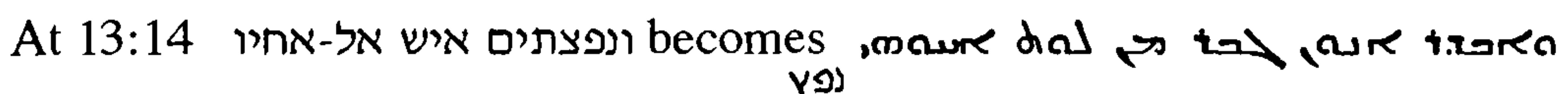

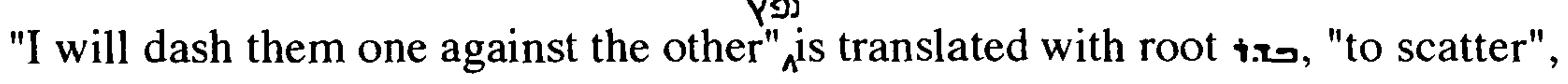
giving "I will scatter them, one away from the other". Since root נפץ may mean either "to shatter" or "to be scattered" this interpretation is possible in theory, but the preposition in אל-אחיו is only compatible with "to shatter", implying movement towards another body, rather than "to scatter", implying dispersion away from another body.

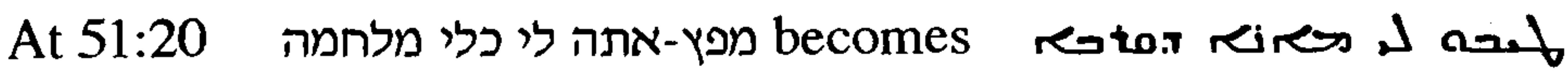

"You are my hammer and my weapon of war" (reading כְלִי מלחמה) is changed in translation to "Prepare for me weapons of war". This seems to be a guess at the meaning of מפץ; yet in the series of objects to be destroyed listed later in this verse and in vv. 21-23 the Piel perfect נפצתי occurs repeatedly and is translated with root 2 , to scatter, for instance in the translator understood either root נפץ "to shatter" or "to be scattered", or took this root as a variant of פוץ "to scatter"; in any case, he must surely have realised 
the relationship of נפצת and but he did not go back and revise his work, even when the correct translation became clear so soon.

The related term in Prov 25:18 מפיץ וחרב וחץ שנון is correctly understood in the

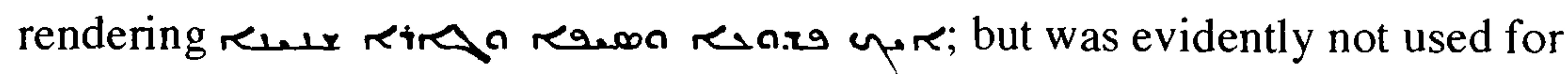
reference here.

(There is also a similar term at Ezek 9:2 ואיש כלי מפצו בידו which becomes mix a ming sïgs yro.)

There is another possible explanation of the translation at 13:14, namely influence

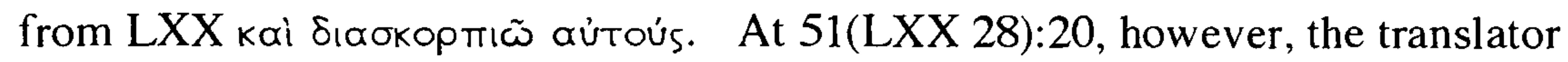

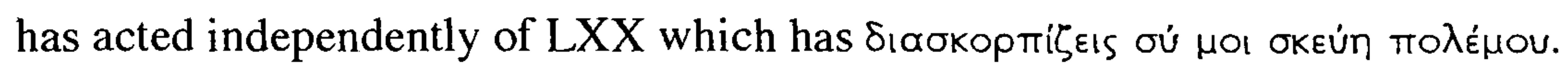
It is also possible that the understanding at 13:14 was motivated by the general preoccupation with exile in the Peshitta to Jeremiah which is discussed in Chapter 2 , pp. If this is so, and the translator took an opportunity to add a new meaning to the text, he did so subtly and economically, selecting from the Hebrew alternatives the sense he needed.

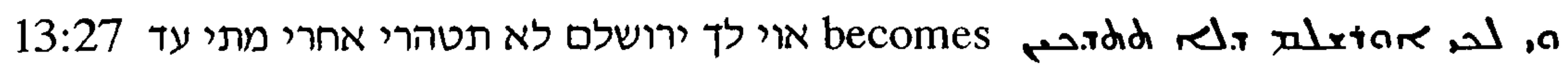
sad, אחים the translator has evidently interpreted עד מתי similarly to מתרי מתי at, for instance, 4:14 and 4:21 in

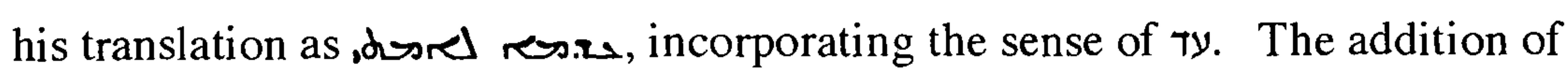
sond gives precision, making it clear that the return to God is equated with

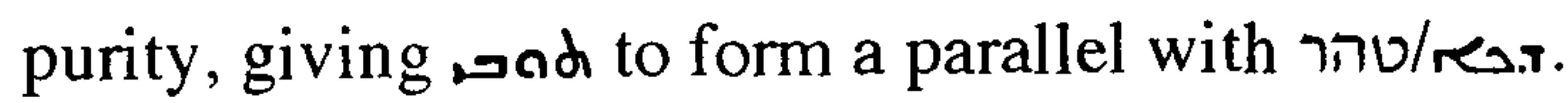

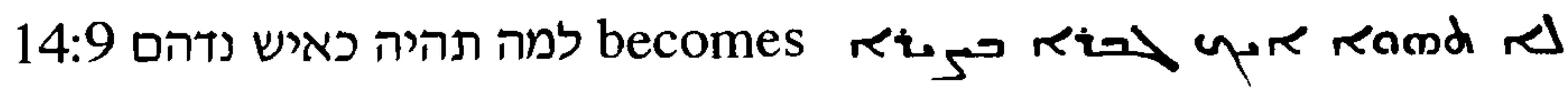

For root the astonish, astound" which occurs in the Hebrew Bible at this point only, the Syriac translator seems to have made a reasonable guess based only on the context. 
$15: 11,12$

The Hebrew and Syriac are aligned below to facilitate comparison:

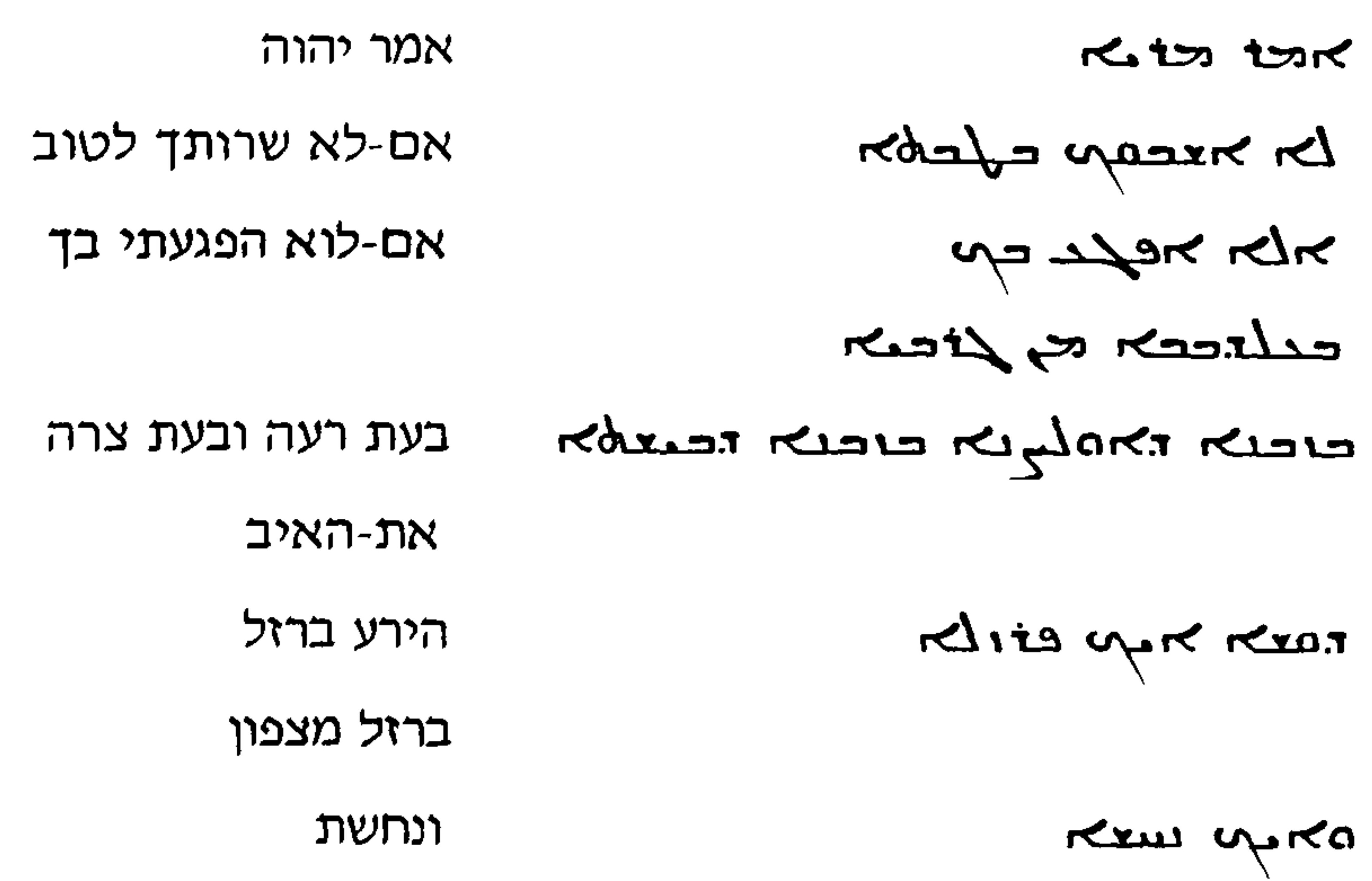

Here the translator has been forced by the pervading obscurity to introduce rather more diffuse change than is his wont.

is the first problem: there are a number of variants in different mss (Kennicott, 1776, p.112), including the Ktib שרותך, the Qere שרתץ, and also allowing the possibility (McKane, 1986, pp.347-348) of שאריתך. The translator has read the Qere, שריתך, and understood it as a Piel of root שרה "to set free", "to forgive"; he has then made sense of this understanding by reversing the sense of the first אם-לא by translating only the negative, losing the reassurance of the Hebrew. He has then achieved reasonable sense overall by treating the second as a contrast to the first, and translating it simply with אם-לא than read the verse as either God or Jeremiah recounting past events, he uses imperfects to enforce the threatening mood. He moves into paraphrase by bringing the reference to the north from v.12 into v. 11 (although the enemy customarily comes from the north in Jeremiah, as for instance at 6:22, 10:22, this is too marked a change to be classified simply as harmonisation of passages); verse 12 too is paraphrased, and treated as a description of the enemy threatened in verse 11 .

Although these emendments involve few terms, they produce marked changes in the sense of the passage, changes which exceed those which the translator usually introduced and which he doubtless felt were justified by the overall difficulty of the two verses. 
It is interesting that, even while making his way through this difficult passage, the translator has energy to spare to reverse the order of the equivalents of

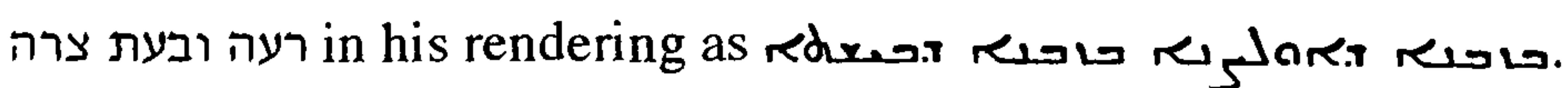

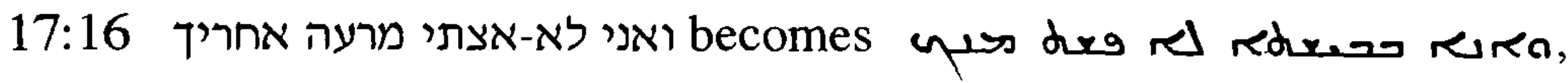
understanding root מרעה ather and rathering as if MT were

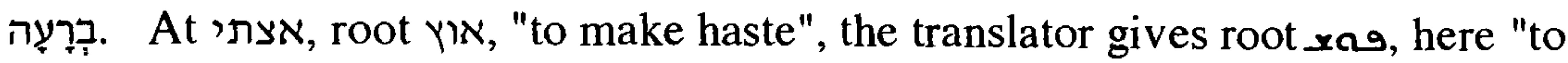
forsake", giving an overall sense "I did not forsake you in evil (times)", paraphrasing, a rarely used resort in P-Jeremiah, and changing the word order.

20:3 This is the second example (the first is at 2:19 above) of roots with imperfect correspondence of meaning in Hebrew and Syriac. In this case, as in root ref discussed above with reference to 4:11, the development is in the Syriac, not in the Hebrew. The root concerned here is סבב: the development in Syriac which did not occur in Hebrew is from root tow to rawa "one who wanders about, a beggar" (Weitzman, 1996, p.593).

At 20:3 is translated as לא פשחור קרא יהוה שמך כי אם-מגור מסביב

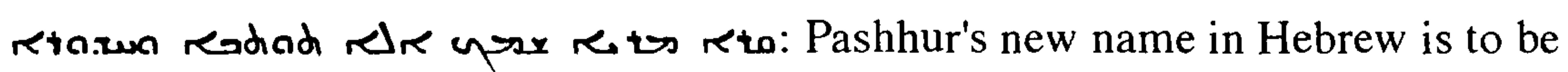
"terror on every side"; in the Peshitta, his new name is "a sojourner and a beggar", changing the sense, probably unintentionally, in two ways: the root of מגור was taken to be I גור (B.D.B.) "to sojourn" rather than III גור "to dread", and the Syriac development of the sense of root two is given.

The phrase מגור מסביב occurs also at 6:25, 20:10, 46:5, and 49:29, used not as Pashhur's name but in reference to current events; at these passages, it is differently translated, brought into the syntax of the context.

Translations are:

6:25, אל-תצאי השזה ובדרך אל-תלכי כי חרב לאיב מגור מסביב תمrad;

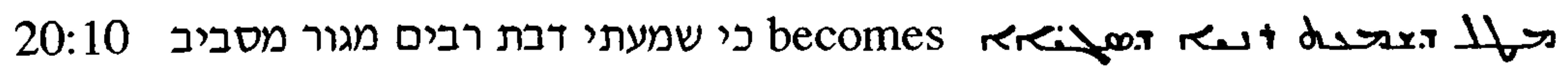
itis 
46:5 מדוע ראיתי המה חתים נסגים אחור וגבוריהם יכתו ומנוס נסו ולא הפנו מגור מסביב

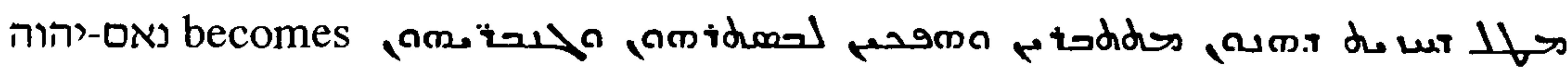

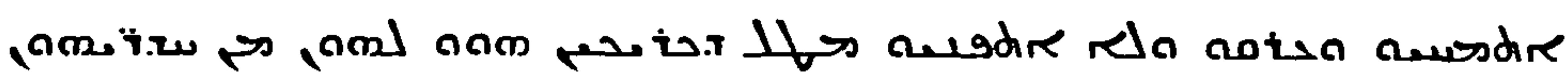

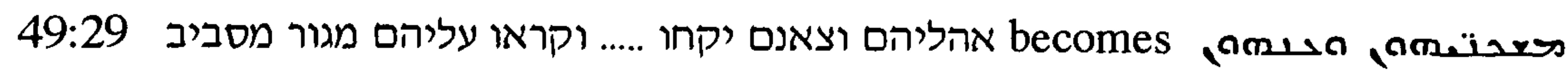

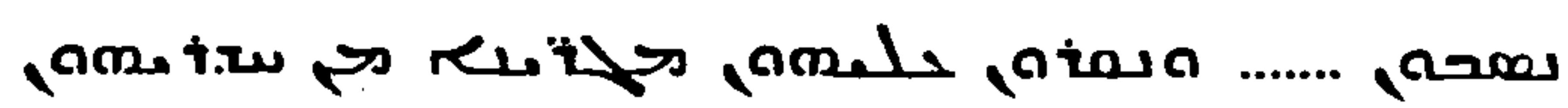

The remaining understanding of root has evidently been seen at these other passages, II גור "to stir up strife, to quarrel", giving the sense of assembling with hostile intent (McKane, 1986, p.461). The choice of lexical equivalent in the last passage is particularly interesting: having preferred roots $n$ t or until now, at this point the cognate is used in a form with a sense close to the Hebrew of II ר: גד, "a stirrer up of strife".

20:10

The two texts of this difficult verse are aligned here to facilitate comparison:

$$
\begin{aligned}
& \text { כי שמעתי דבת רבים } \\
& \text { מגור מסביב }
\end{aligned}
$$

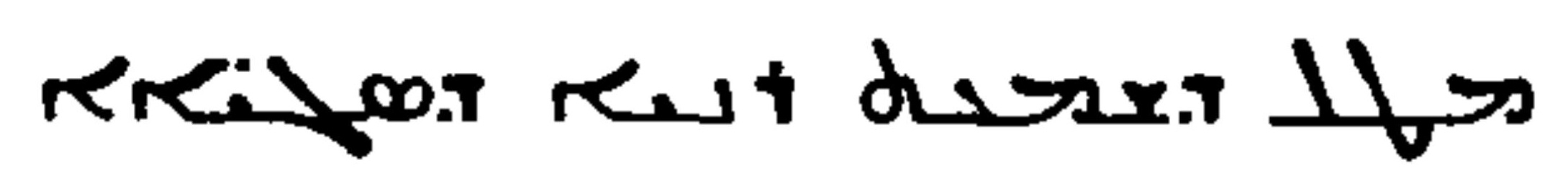

$$
\begin{aligned}
& \text { ד. } \\
& \text { nals perro }
\end{aligned}
$$

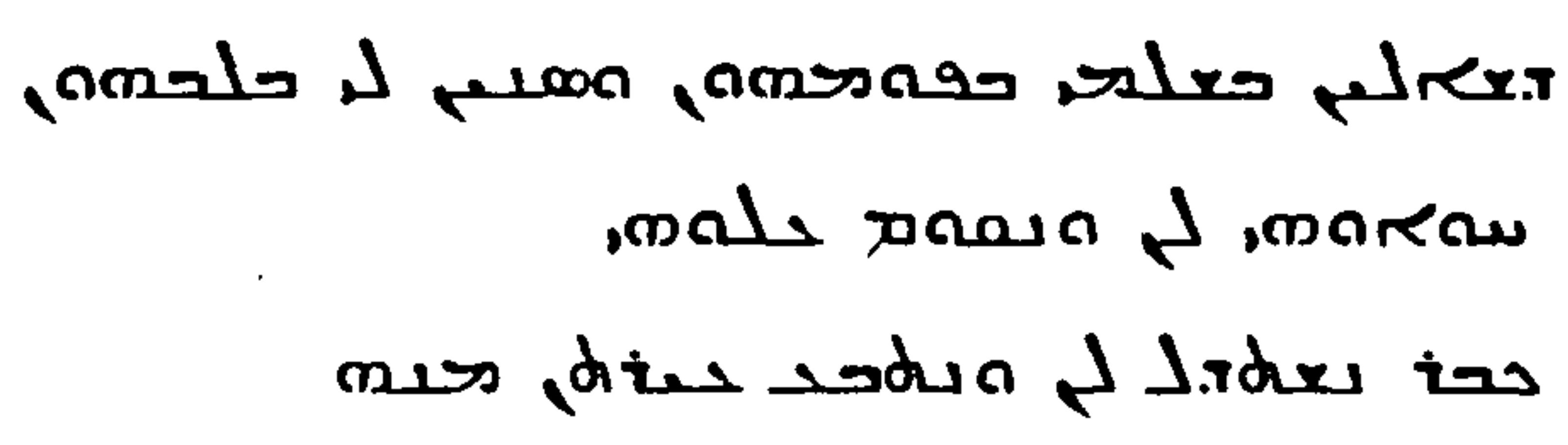

(מגור מסביב) was discussed above, at 20:3.)

There are changes in word order as well as in sense in this unusually complex rendering. . equivalent of הגידו ונגידנו: it is an addition in keeping with the presentational style, intended to increase the precision. The true equivalent of הגידו ונגידנו is

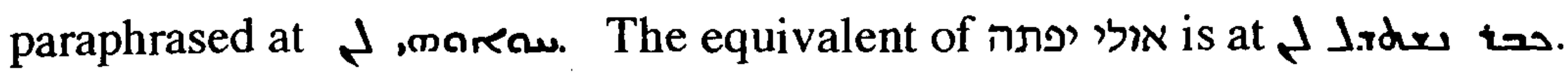

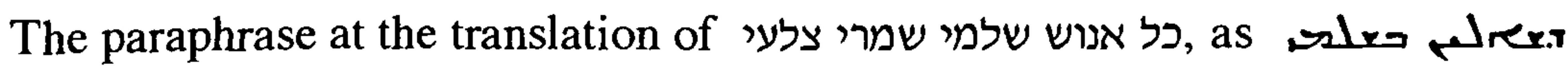
expressing in plain terms "yet hating me in their hearts" the hypocrisy of Jeremiah's associates who simulate friendship, involves 
a degree of deviation from the Hebrew which is most unusual in P-Jeremiah. Either the sense "to stumble" or "to limp" of root צלע may have been understood at prophet are in fact waiting for his downfall. Alternatively, the sense "side" may have been perceived: this understanding would imply that those who express good-will as they observe the prophet may in reality be spying on him, and hoping that he will encounter trouble. مس fits either understanding well.

These changes, more extensive than those which the translator usually introduced, were doubtless felt to be justified by the overall difficulty of the verse.

\section{3:14 is translated וחזקו ידי מרעים}

"they grasp the hands of their friends", as if מרעים were derived from root רעה in its meaning "to associate with", rather than from root

The form מרעים occurs in a closely similar phrase at Job 8:20 ולא-יחזיק ביד-מרעים,

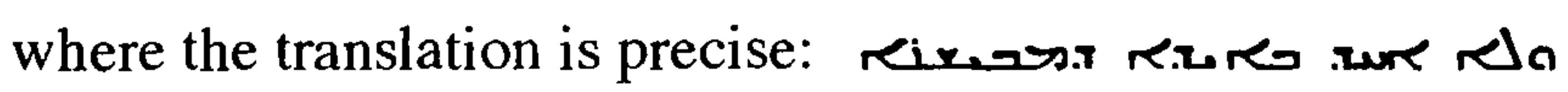
Within Jeremiah מרעים derived from root also occurs at 20:13, and elsewhere at Isa $1: 4 ; 14: 20 ; 31: 2 ;$ and at Ps $22: 17 ; 26: 5 ; 27: 2 ; 37: 9 ; 64: 3(2) ; 92: 12(11)$; 94:16; and 119(118):115. At each of these passages, the Syriac translator has correctly understood the root and rendered with some form derived from roots (though the rendering of Ps.92:11 is rather imprecise). מרעים or some similar form derived from root in meaning "to associate with" occur elsewhere in Jeremiah at 3:20 and 9:3(4), and outside Jeremiah at Gen 26:26, 31:49; Jud 14:11, 20, 15:2, 6; 2 Sam 3:8; Pr 12:26, 19:4, 7; Job 6:14; and Ecc 4:4. Some of the contexts, for instance Jer 3:20, dictate the sense, but even at those where this is not so the Syriac translator has correctly understood the root and rendered with some form derived from roots tרמ , ערמ x (as in e.g. Rarax), or rewr.

The failure in 23:14 to distinguish between these roots is, therefore isolated; it is not, however, without reasonable foundation in the context, and is compatible with the consonantal text. 
33(LXX 40):6 הנני מעלה-לה ארכה ומרפא becomes Kcore: the understanding of ארכה in the underlying sense of the root as the adjective אָּרָ "long" is surprising, particularly in view of the initial waw at ומרפא. The term occurs elsewhere in Jeremiah:

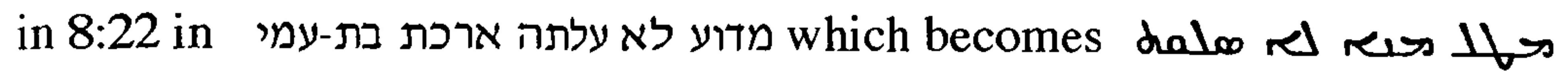
os dor mdacore, translating with root roor;

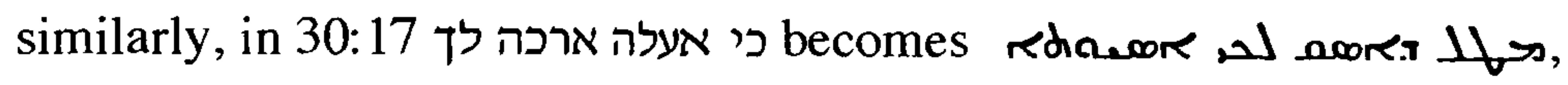
so the translation in 33:6, following two renderings based on אֶרוכָ "healing" is unexpected and difficult to explain; simple error seems unlikely. in the same sense occurs also in Isa 58:8, a difficult passage to translate in that the context gives no clue to the meaning of this term, and is translated with ydar. 1 ; neither of the other two occurrences in MT, in 2Ch 24:13 and Ne 4:1 is precisely represented in the Peshitta, so these are unhelpful here and the choice remains difficult to understand.

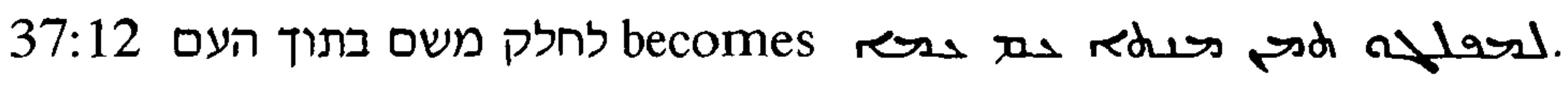

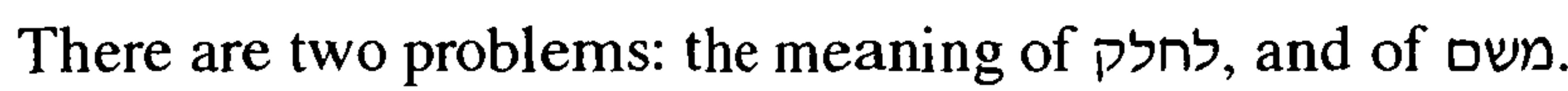

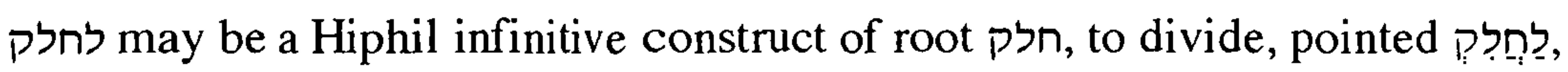
thus "to receive a portion", or perhaps a Qal infinitive construct of חלק, to be smooth, pointed לַחִלִל, giving "slipping away". The latter seems to make better sense in the combination with משם, but is an unusual use of the root; there is no other accepted use of this root, as an infinitive construct, in this sense. If the former is understood here, it requires the sense "to receive a portion there among the people". The translator seems to have taken this sense, supplied an object " משם to mean שם. This presents no problem: the wide range of meanings of $p$ in biblical Hebrew all express the idea of separation (B.D.B. p.577), but within this range there are usages where the essence of the idea is distinction rather than separation, with the emphasis on the locative rather than the ablative ${ }^{19}$. B.D.B. 
note, for instance, that מזה...מזה means "on this side...on that side; that for instance מקדם in Gen 13:11 ויסע לוט מקדם means that Lot journeyed towards, not from, the east; and that Isaiah 57:9 זתשלחי ציריך עד מרחק means "you sent יפל מצדך אלף ורבבה מימינך 91:7 messengers far away". Similarly, in Psalm the sense is not "from your side, ... from your right hand" but rather "at your side, ...on your right hand".

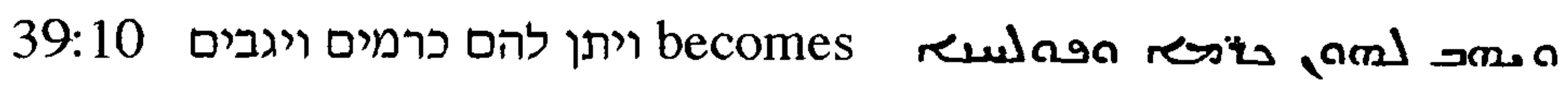
This translation is discussed in detail in Chapter 3.

$40: 5$

-.-- mb toska

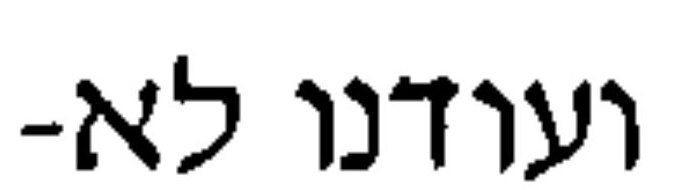

ישוב ושבה אל-גדליה בן-אחיקם בן-שפן

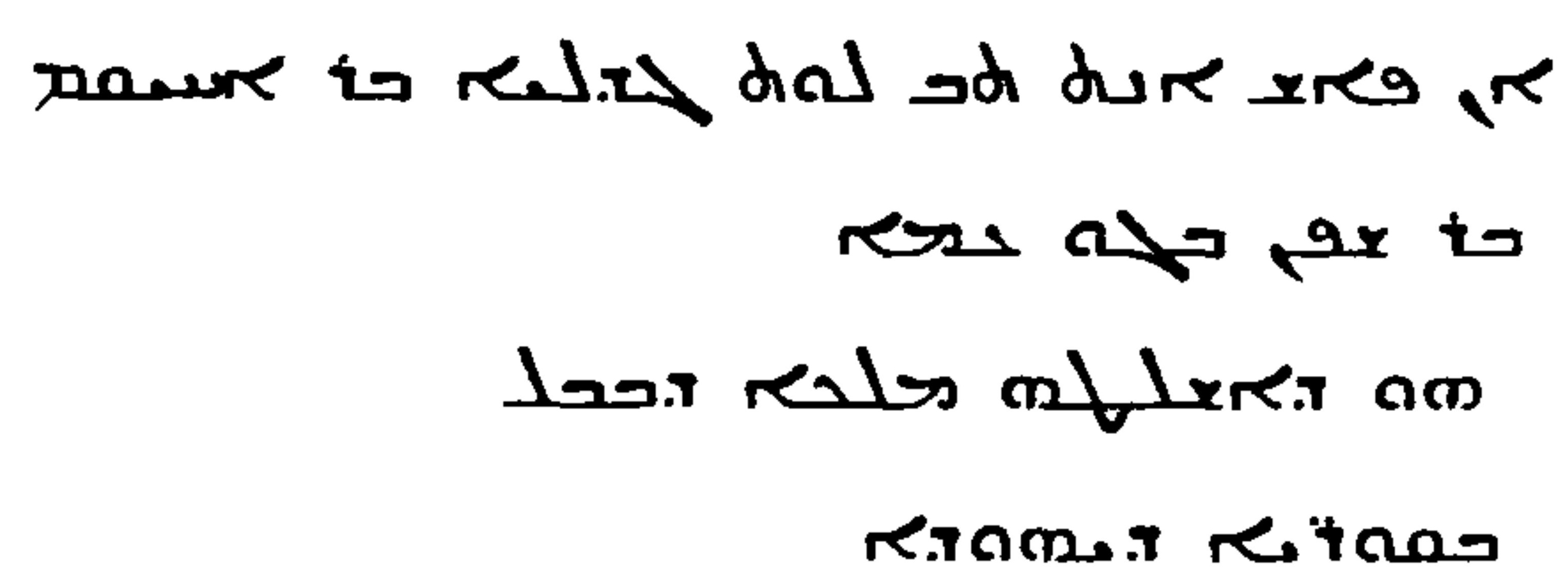

בערי יהודה

ושב אתו בתוך העם

The opening phrase is difficult. In the previous verse, Nebuzaradan is speaking, explaining to Jeremiah that he is free to choose whether or not to accompany him to Babylon. There is no indication in the MT that the identity of the speaker changes at ..... ושבה אל-גדליה. A reasonable understanding seems to be to assume that Nebuzaradan continues to speak, and to take root שוב in to mean "to give an answer", and in ושבה to mean "return". This would give "Then, before he had replied, (Nebuzaradan said) return to Gedalya ....and dwell with him..." The translation has: "If you stay (here), remain with Gedalya .... in the midst of the people ...." , ושבה ישב at reading root rendering the first with root פת "to stay" and the second with root מעודנו לא . "to dwell" seems to have defeated the translator, and been imprecisely rendered with $m$ isro, which fits well with the drive for clarity. The change in word order, putting earlier in the sentence than בתוך העם, serves the same purpose.

Considering the difficulty of the Hebrew, the approach is restrained. 
Chapter $6 \quad$ Difficult Hebrew

47(LXX 29):5

באה קרחה אל-עזה

נדמתה אשקלון שארית עמקם

עד-מתי התגדדי

becomes

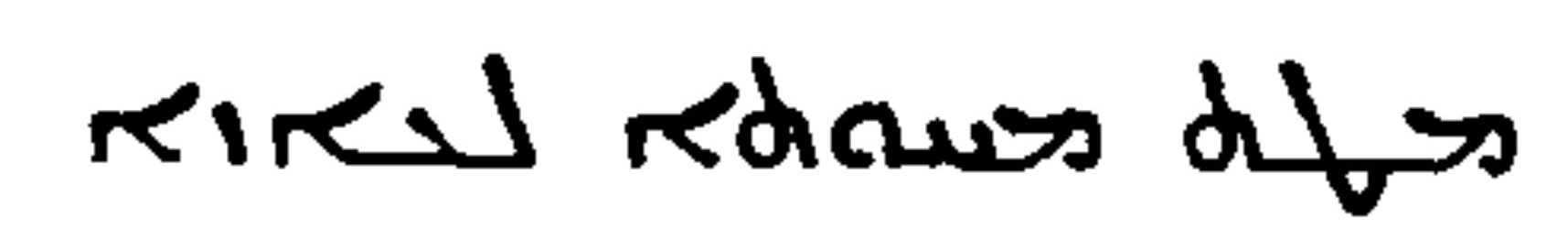

narode aivderex Jasa, alare dizddre

There are three principal points of interest in this rendering:

קרחה (i)

Rdow, "slaughter" rather than "baldness" is inaccurate, and surprising in view of the accurate translations given in similar contexts at 16:6 where ולא יקרח להם

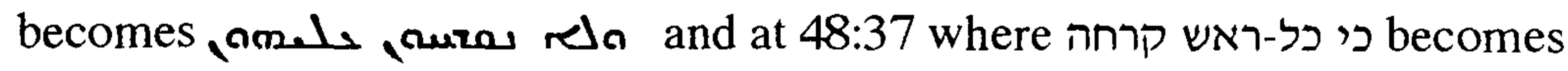
مroos in arext. There may be an attempt to give a closer parallel to root דמה (B.D.B. p.198b), here in the Niphal "to be cut off, destroyed, ruined". Targum too has a more general rendering of the term, giving פורענותא, possibly with the same aim.

(ii) שארית עמקם The sense of MT is uncertain, and the translator gives a paraphrase in amad.s sudrex 1 . The interest of this lies in its difference

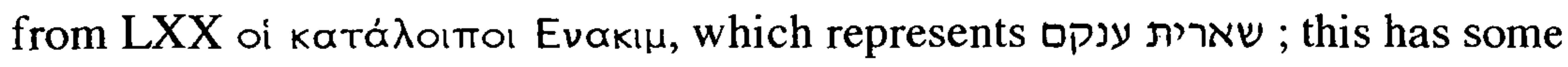
bearing on (iii) below:

עד-מתי התגדדי (iii)

Both LXX and the Peshitta lack this phrase. Their agreement against MT in this respect suggests either that LXX is based on (inaccurate) eye-skip, from עד-מתי in this verse to על ער in the next, and the Syriac was influenced by the LXX; or that the phrase was absent from the Vorlagen. This example would fit into the group "Minuses which throw light on the wording of the Vorlage" discussed in Chapter 4.

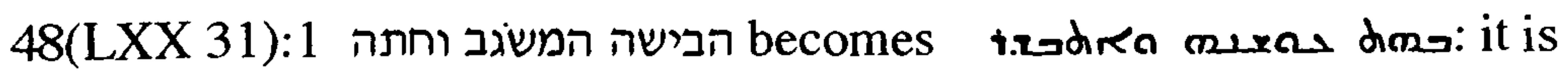
uncertain whether משגב is a place name; the translation takes it instead as a common noun, rendering with the drudge-word rea which in fact fits the 
context well, understanding root שגב as "to be (inaccessibly) high" and therefore a stronghold ${ }^{20}$.

48(LXX 31):18 ישבי בצמא becomes boto , giving "disgrace" rather than the Hebrew "thirst". The most probable explanation, not entirely satisfactory, seems to be that the translator mistakenly read בצאה "in filth", and rather than using the cognate gave $\mathrm{Rt}_{5}$ as a euphemism.

48(LXX 31):28 פי-פחת becomes בעברי פי-פחת bas is not represented. The translator has made a good guess at בעבֶר , reading the plural construct of here "side", and interpreting as "ledge"; he faltered at פי-פחת, and opted for clarity of expression. There is a metaphorical use of the term rear. in, for instance, (J.Payne Smith, 1990) equating ras. with worldly haughtiness which may have influenced the translation, fitting so well in the context of the next verse in particular:

שמענו גאון-מואב גאה מאד גבהו וגאונו וגאותו ורם לבו

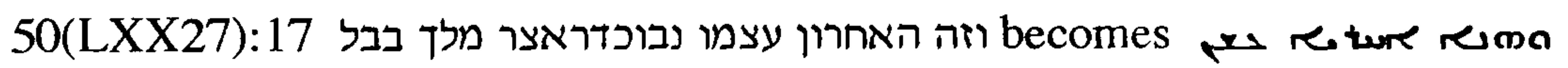
寉: the sense "strength" rather than "bone" has been taken at עצמו, and expanded in a paraphrase to give בת מצח

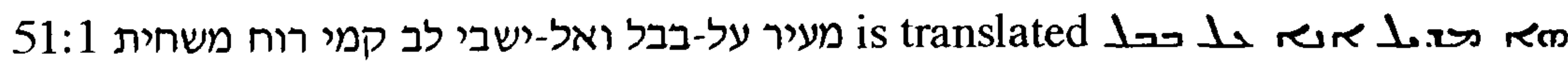

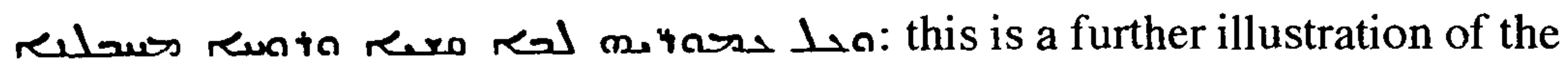
translator's reluctance to return to correct earlier renderings. The Athbash code for ואל-ישבי לב קמי in has been missed, and the term understood as a

20. Inner-Syriac comuption is possible, though there is no confirmatory evidence in extant mss: for the MT כתח, the translation has root trodre; root tod would however be a more probable equivalent of root תIn, so there may have been a corruption of todidre to t.sodre. 


\section{Chapter 6 Difficult Hebrew}

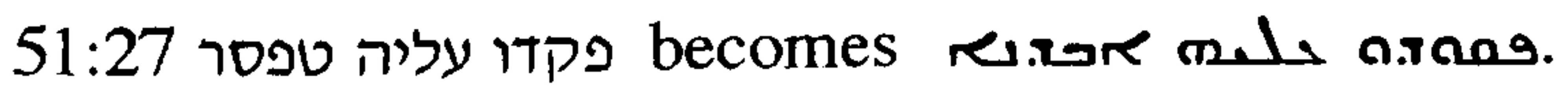

טפסר occurs in biblical Hebrew only here and at Nah 3:17(16). The term means a military official of high rank, but has been misunderstood and translated by an abstract term.

(At Nahum 3:17(16) root حهd حهتح, is used, in.)

\section{1:35 ממסי ושארי על-בבל 22 becomes}

This is an unusually loose translation, which includes some modification extending beyond שאר, the single difficult term. The second part of the verse, "my blood shall be upon the Chaldaeans", could have given a substantial clue to the meaning of the first, indicating the sense "blood-revenge, vendetta" for שאר in this context, and clarifying the grammar of חמסי. The clue seems not to have helped; the translation of root שאר with root has no etymological support, in turn led to the paraphrase of root nמith the drudge-word (for details of the use of this drudge-word in Jeremiah see Chapter 2, Table 9). Lastly, ع. ع ع "to lead away captive" has no equivalent in the Hebrew, and is an addition for clarity given to make sense of the translation.

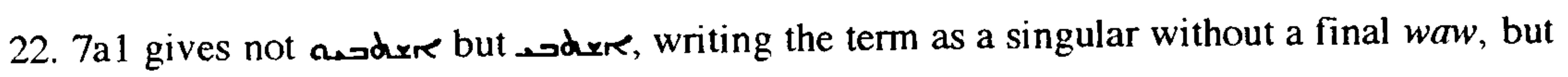
writing the yodh as an intermediate, rather than a final, form. 
Chapter 6 Difficult Hebrew

(iii) accepting influence from another part of the Hebrew Bible

In all but one of these examples the influence is from biblical books other than Jeremiah. The passages discussed below are, in order:

$2: 24$ where the probable influence is from Jeremiah;

3:14 where the probable influence is from Isaiah;

5:16 where the probable influence is from Psalms;

5:24 where the probable influence is from Proverbs, and verses of Leviticus and Deuteronomy may also have been in the translator's mind;

7:24 where the probable influence is from Psalms;

8:18 where the probable influence is from Job;

17:6 where the probable influence is from Job, and a verse of Isaiah may also have been in the translator's mind;

48:9 where the probable influence is from Isaiah, and a verse of Ezekiel may also have been in the translator's mind;

$51: 13$ where the probable influence is from Isaiah.

This gives a total of nine. A further three verses, 4:3, 5:6, and 15:9, are discussed for interest: in these examples the Peshitta may seem at first sight to have been influenced by other passages of the Hebrew Bible, but on further study this seems to be unlikely.

The suspected influence is from another part of Jeremiah::

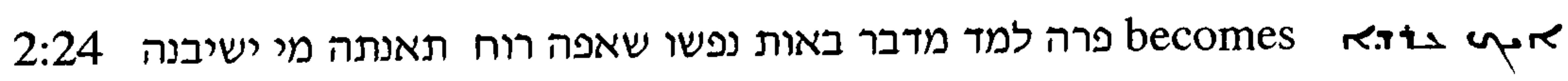

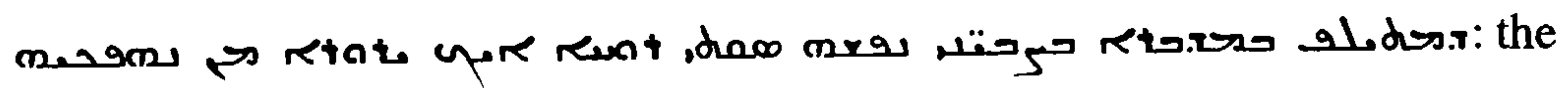
translator has apparently been influenced by 14:6 ופראים עמדו על-שפים שאפו רוח

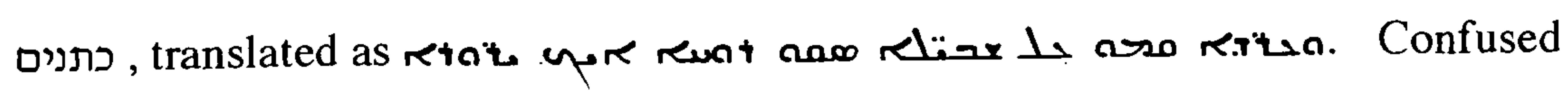
by the similarity of the two passages, the translator has failed to recognise the פרה למד in the first. He saw the two parts (אנה root) תאנתה hapax legomenon תאנתה מי ישיבנה and as if they were parallels, each with a different species of animal as the subject, as in the comparison of the wild asses and the jackals at $14: 6$, rather than understanding the second part of $2: 24 \mathrm{a}$ as an 
expansion of the first. Tאנתה, Taking the sense "jackal" forifies the figurative language by a standard approach, adding $u<$ to both parts of the phrase and so turning metaphor into simile.

The apparent direction of the influence, from a later verse to an earlier, is the point of particular interest and was discussed above.

The translator may also have been influenced by a tradition in common with that of the Targum, which derives תאנתה from תן, and gives ירורא 2:jackal" at 24: בערדא דמדורה במדברא מהלכא ברעות נפשה שתיא רוחא כירורא (McKane, 1972, pp.77-78; Weitzman, 1996, p.603).

Judges 14:4 might have given a clue to the correct understanding of תאנה: ואביו ואמו לא ידען כי מיהוה היא כי-תאנה הוא-מבקש מפלשתים

Here, the Hebrew is closely translated:

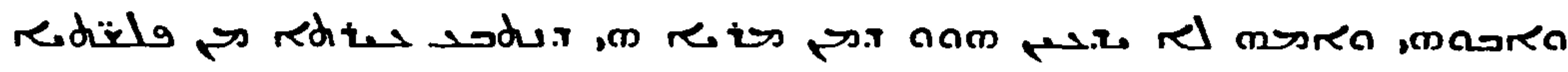
equating תאנה, here "opportunity, ground for quarrel" with "vengeance"; but the link of "opportunity" with "favourable time" was evidently obscure in the context of Jeremiah $2: 24$, and the close similarity to $14: 6$ prevailed in deciding the approach.

The suspected influence is from another book of the Hebrew Bible.

3:14 and 31(LXX 38):31(32) are an interesting pair, two closely similar Hebrew phrases rendered differently by a translator who evidently felt free to use his own judgment: at 3:14 the translation seems to have been influenced by a text from Isaiah, but at the similar 31(LXX 38):31(32) the influence is apparently from LXX.

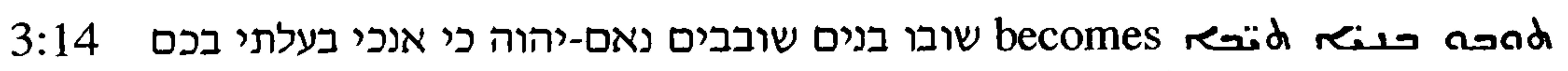

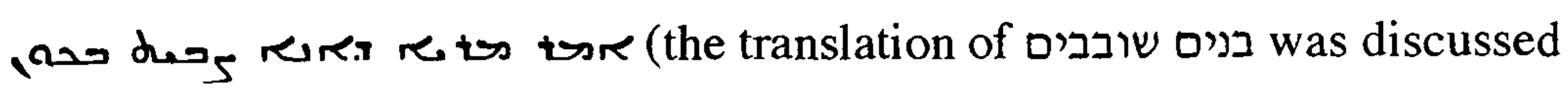
above).

The rendering of זיז differs strikingly between this verse and 31(LXX 38):31(32) אשר-המה הפרו את-בריתי ואנכי בעלתי בם, which is

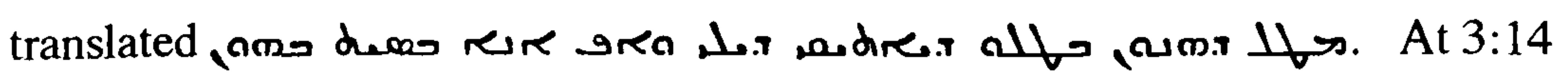


there is only one reasonable understanding of בעלתי ב: following the imperative at שובו , an instruction to the faithless Israelites to return to God, it must mean "I again take responsibility for you". At 31(LXX 38):31(32), however, בעלתי ב could be read in more than one way, depending on the sense of the waw in ואנכי; this could point a contrast, "they broke my covenant, yet nevertheless I care for them", "they broke my covenant, although I had taken care of them" or preface an expansion of the sense of the preceding phrase "they broke my covenant, and so I am now antagonistic to them". Since the general theme of this passage is not recrimination but forgiveness, God promising the new covenant to replace the old, broken, covenant, "they broke my covenant, yet nevertheless I care for them" seems to be the most appropriate interpretation.

The difference between the translations at these two verses is the point of interest. At 3:14, although the general sense must be an expression of God's forgiveness, translation of בעלתי ב with root ${ }_{5}$ "to delight in" is by no means the obvious first choice; the rendering probably reflects influence from Isa 62:4

$$
\begin{aligned}
& \text { לא-יאמר לך עוד עזובה ולארצך לא-יאמר עוד שממה } \\
& \text { כי לך יקרא חפצי-בה ולארצך בעולה } \\
& \text { כי-חפץ יהוה בך וארצך תבעל }
\end{aligned}
$$

which establishes a parallel between roots and and which is an appropriate comparison, with its emphasis on the change from God's displeasure

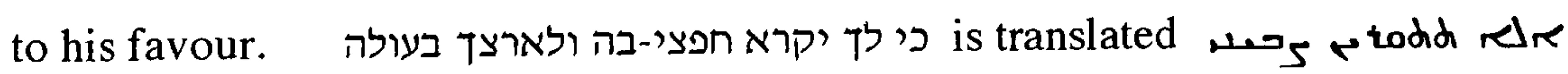
כגו corresponding to that in the Hebrew.

At 31(LXX 38):31(32) a different approach is evident, and this in itself is interesting, for the link with Isaiah seen at 3:14 could have been maintained here: at Isa 61:8 MT has וברית עולם אכרות להם, so the theme of covenant is nearby and would have been even more appropriate to chapter 31 with its theme of the new covenant. Had the translator wished, he could therefore have taken the sense "they broke my covenant, yet nevertheless I care for them". Instead he takes an

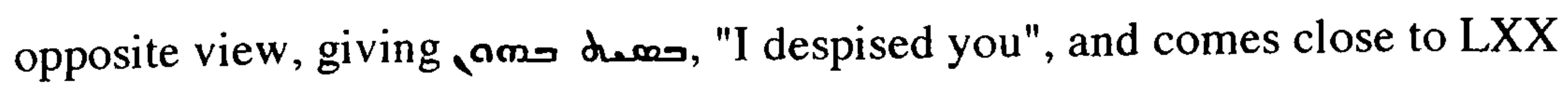

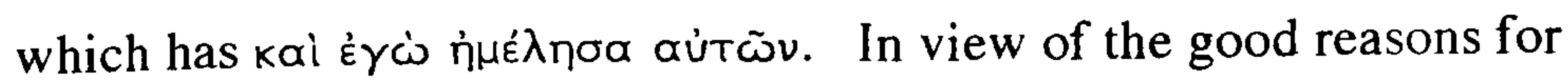


Chapter 6 Difficult Hebrew

interpreting rather as at $3: 14$, the similarity to LXX suggests influence rather than polygenesis.

5:16 אשפתו כקבר פתוח becomes ore motit: the reason for the change was not that the term אשפה was obscure: at for instance Isa 22:6 and 49:2 it is translated with reto "quiver"; and at La 3:13 בני אשפתו becomes, mair "arrows". The difficulty was presumably the complex nature of the image, which it would have been impossible to clarify without introducing considerable change to the passage, and recourse to Ps 5:10 קבר פתוח גרונם which is translated andity rewids rizo vero solved the problem. The psalms would of course have been familiar: there is evidence suggesting that they were recited daily (Kohler, 1897, p.196). The similarity between the sounds of redty and rita may also be relevant, perhaps leading to a subconscious link of "throat" and "arrow" in the translator's mind, and thus to his choice of the Psalm for help at this point.

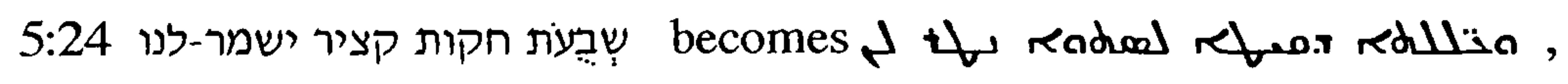

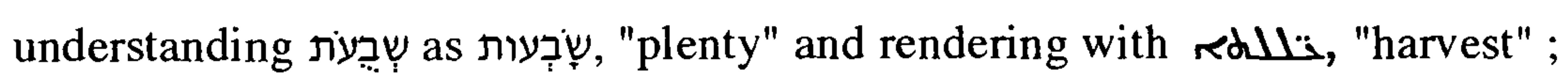
this reading is similar to that expressed in LXX, but there is no real reason to postulate influence from the Greek here, since the interpretation is so reasonable in the difficult context. To make a clear, though manufactured, meaning, is omitted ${ }^{23}$; the omission could have been justified on the grounds that the word

23. It is just possible that the translator omitted חקות because he perceived it to be a secondary element derived from the passages at Deut 16:9-12 שבעה שבעת תספר-לך ......... ושמרת ועשית את-החקים האלה (and perhaps Lev 23: 10-17 חקת עולם לדרתיכם שבע שבתות תמימת ..... עד ממחרת השבת השביעת though this is less close) where it is applied to the festal period of seven weeks; if this is so, however, it does not tally with the reading of root שבע rather than root and the addional term would be expected following rather than preceding קציר. 
order of MT שֶבֵעת חקות makes poor sense.

The addition of "winter", which has no equivalent in MT, may have been influenced by Proverbs 20:4 where winter and harvest are opposed ${ }^{24}$ : מחרף עצל לא-יחרש ישאל בקציר ואין

7:24 The text is complicated by the presence of a possible doublet, מעצות and וילכו במעצות בשררות לבם הרע in. Thרות, The syntax, as it stands, is difficult: the juxtaposition of בשררות and with the same preposition at both, makes poor sense. Janzen (Janzen, 1967, pp.435-436) explains the difficult syntax as due to conflation of the variants במעצות/בשררות. Both terms are represented in the

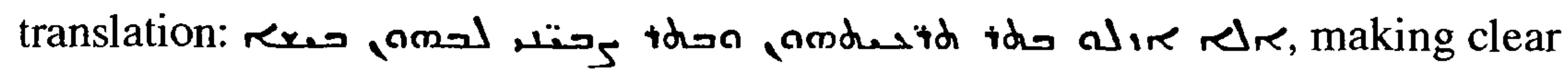
sense by a small change, introducing the second part with waw and repeating the preposition.

It is interesting, and emphasises the over-riding tendency towards an accurate translation, that the translator does not delete מעצות: had he been predominantly influenced by the tendency to harmonise passages with one another which is discussed in Chapter 2, pp.69: 75 he would perhaps have solved this problem by ולא-ילכו עוד אחרי שררות לבם הרע 3:17 forcluding this term from his rendering, for would have been fresh in his mind, and he would have known of, although he had not yet reached, the closely similar passages at $9: 13 ; 11: 8 ; 13: 10 ; 16: 12$; 18:12; and 23:17; he would also have been familiar with Deut 29:18 אלך.

The decision to retain the possible doublet may show influence from Ps 81:13 (12) and are appropriately translated in the Peshitta:

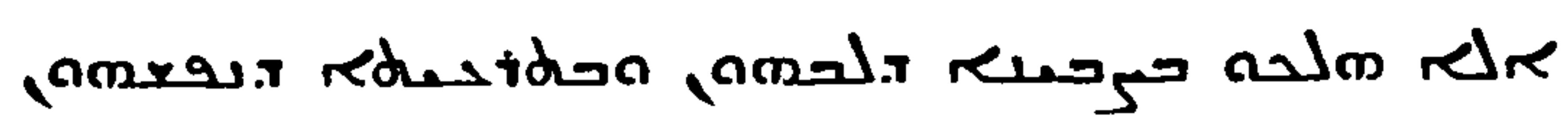

24. Frankl suggests that the translation was based on a corrupt text (Frankl, 1872, p.545).

25. 9a1 has a rendering which is closer to that of the Psalm, perhaps suggesting evolution in language between the time of the original translation and that of the editors: amderth ids is

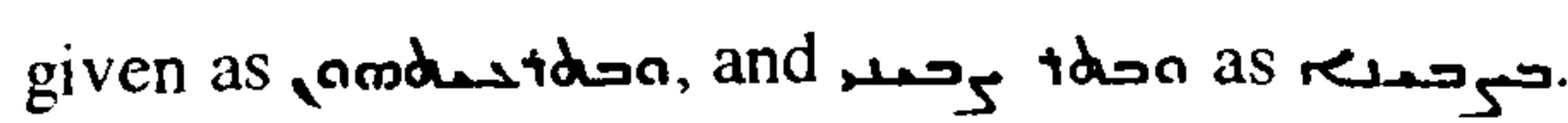




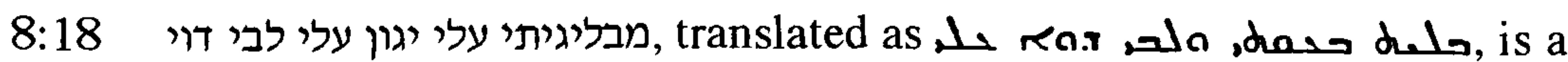
particularly difficult passage, discussed here because there is a possibility that the Peshitta results from influence from Job. מבליגיתי and the first עלי are the two principal problems.

מבליגיתי: if the sense "to gleam, smile", root בלג, is understood at מבליגיתי the meaning is obscure. The Syriac "I am worn out with my distress and my heart is sick within me" seems to be based on a paraphrase of מבליגיתי עלי יגון which may owe something to the Syriac translation of Job 9:27.

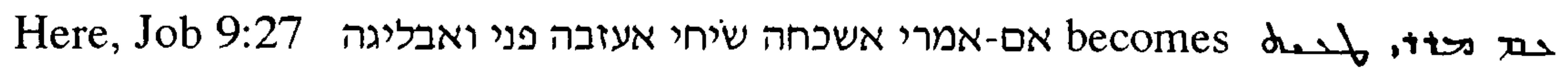
אעזבה פני , whith a translation of ואבליגה "I will leave off my complaint and look cheerful" based on root The translator of Job seems to have linked the sense of the final phrase of the verse with the sadness of the following verse, rather than with the immediately preceding phrase; this understanding has resulted in the presence in the translation of root, , and this is seen in Jer 8:18. The choice of root so to translate יגון, "sorrow", is appropriate, for it has the sense of "to be out of heart" (Payne Smith, 1901, col.2838) and of "sadness" (J.Payne Smith, 1990, p.406) as well as of the less specific "distress".

There is an alternative explanation, that the Peshitta is an imprecise rendering of the form מבלי גיתי which is seen in some Hebrew mss (Kennicott, 1776, p.102).

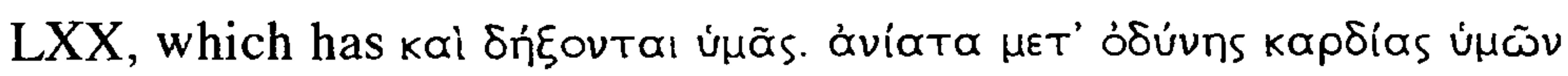
ámopoupévns, supports such a writing, with root בלה leading to ávíata, incurable. Root בלה, "to be worn out", has been understood, and translated with the cognate, which has the same meaning, root 1 . This explanation leaves the second term גיתי , גהה ,without cure", imprecisely translated, though the sense may be implicit in the paraphrase: if the heart is sick the affliction is deadly ${ }^{26}$.

26. The remaining three occurrences of root בלג, in Job 10:20 and the similar Ps 39:14, and Amos 5:9, are interesting in that at these passages too the Peshitta is based on paraphrase, indicating the difficulty of translation, but are of no direct relevance to Jer 8:18. 
Chapter 6 Difficult Hebrew

The understanding of the first על is uncertain; the Peshitta is compatible with Driver's suggestion (Driver, 1937-1938, p.105) that it should be read as עָערי derived from root עלה, rather than with the MT pointing given the imprecise translation, however, it is impossible to be sure.

17:6 is translated שכן חררים במדבר understanding is probably based on root חרו not in the sense "hot, parched" but "hole, ravine". There are comparable phrases in Isaiah 2:19 מחלות עפר and at

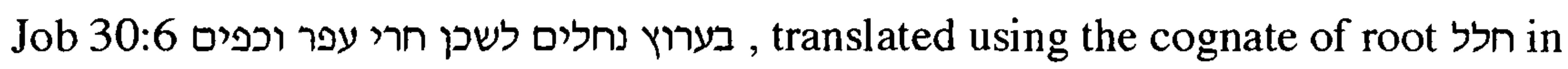
respectively; Job 30:6 is sufficiently close to Jer 17:6 for it to be reasonable to postulate that the translation in Job influenced that in Jeremiah.

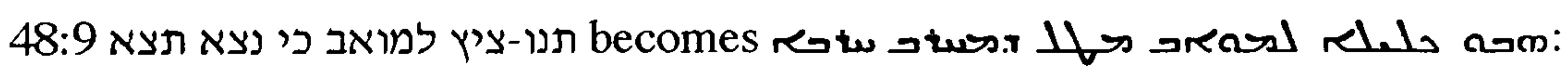
for the derivation of צy, the translator has understood not wing, which makes immediate sense in the context, but "crown, garland" which does not ${ }^{27}$. Possibly, he understood a sense of irony here, and perceived for instance an echo of Isa 28:1 הנה 7:10, or Ezekiel הוי עטרת גאות שכרי אפרים וציץ נבל צבי תפארתו צecomes

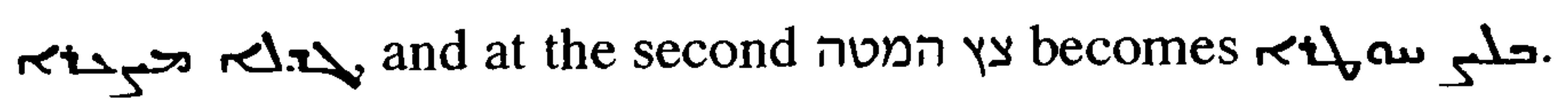

Footnote from previous page contd. In Am 5:9 המבליג שד על-עז too he resorts to paraphrase, giving rews L erlutess

In Ps 39:14(13) the tr. is based on Job 10:20: ושית ממני ואבליגב מעט, which becomes תמשי

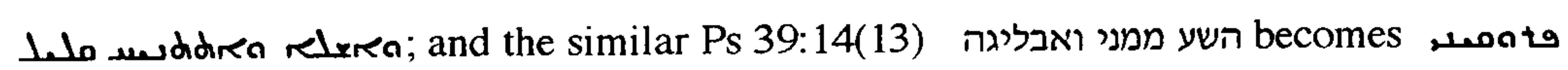
suddreo

27. McKane (McKane, 1996, pp.1163-1165) says of נצא תצא that both forms would be expected to be from the same root, though the MT does not support this: an emendation to would solve this problem, giving a possible sense "she will surely go out", that is, into exile. 
51:13 בא קצד אמת בצעך "Your end has come, the thread of your life is cut" is a difficult phrase which has been inaccurately translated in

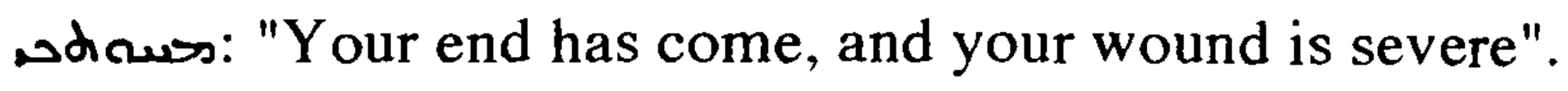

is a difficult phrase. The meaning seems to be "Your measure (i.e. the length of your life) is cut off"; the imagery is close to that of Isa 38:12 קפדתי כארג חיי מדלה יבצעני, but less clearly expressed; it

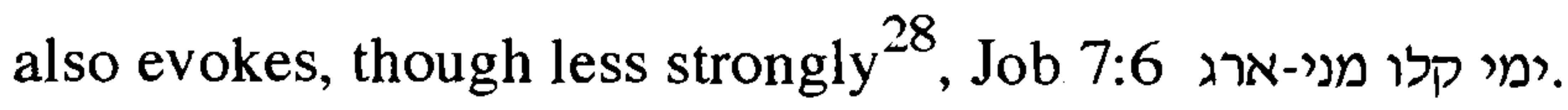

Root אמה is used nowhere else in the Hebrew Bible to mean "full measurement, limit"; the parallelism with קצד gives some help in interpretation, but the imagery is not clarified by the wider context, for the images of danger and destruction in this chapter are so varied, with no one metaphor used consistently. The Syriac translator seems to have (i) translated בצע7 first, taking the general sense of root "to cut off", and stretching this to mean "wound", not a usage found in the Hebrew Bible; (ii) then returned to deal with אמת, using the drudge-word rear (Chapter 2, Table 8). In this way he has reached "Your end has come, and your wound is severe....."

"Your end has come, the full measure of your unjust gain", would have been an alternative and would have fitted well in the context of the preceding phrase שכנתי על-מים רבים רבת אוצרות

but has not been chosen by the translator, strengthening the possibility of influence from the imagery of the other passages noted above.

Footnote from previous page contd. If, however, נצא תצא is associated with the sense of root

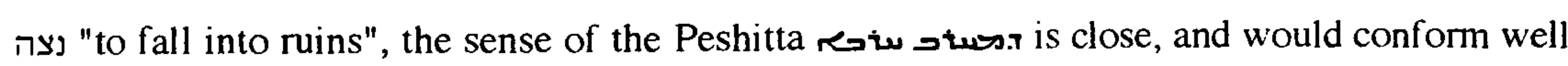
with McKane's argument that the understanding of the hapax legomenon "ציץ" as "wing" is unjustified, and that the suggestion that it represents "salt" (a philological explanation derived from the Akkadian) is preferable, implying that Moab's fate is to be a saline wilderness.

28. Weitzman (Weitzman, 1997, p.395) suggests that the translator of Job may have sought help here from the Peshitta of Isaiah. 


\section{Chapter 6 Difficult Hebrew}

For completeness, and to illustrate further the subjective nature of the classifications used here, some passages are given below which at first sight suggest the influence of other areas of the Hebrew Bible on the Peshitta of Jeremiah, but which on further consideration are not evidence of this effect. First, an example which suggests that the translators of Jeremiah and of the Twelve Prophets shared an idiom.

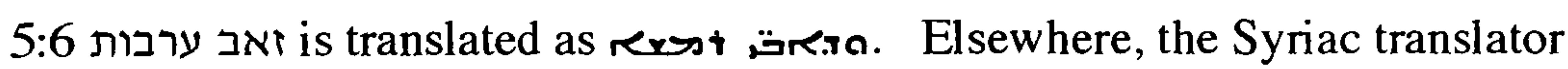
renders ערבה with appropriate roots (within Jeremiah, either wod 2:6, or פمد 17:6,39:4, and 52:7). At 5:6, however, he translates as if the root were ערב in the sense underlying "steppe", probably influenced by the closely similar passages at Hab 1:8 and Zeph 3:3, where the Peshitta has, as at 5:6, restrs 3:3, where בקר is paralleled with, but less so at Hab 1:8 where the context suggests wild country.

In the canonical order of the Peshitta, these two books precede Jeremiah, and were therefore likely to have been already translated and thus available for reference; but this is such a simple phrase that it seems unlikely that the translator would have looked elsewhere for guidance, and it is more probable, particularly in view of the reading at $\mathrm{Hab} 1: 8$, that the translation as rest ores indicates that both translators had a common idiom.

Second, two passages in which the similarity of understanding at Jeremiah and the Twelve Prophets and the Pentateuch respectively is probably due to shared error rather than to influence.

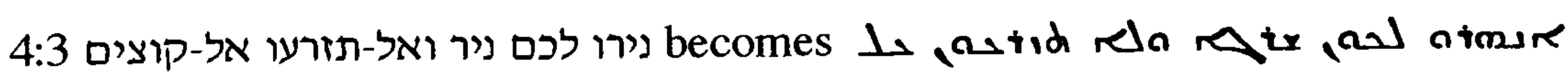
حمخא

Root ניר as a verb is nowhere recognised by the Syriac translators when it occurs in the Hebrew Bible:

(i) in Ho 10:12 נירו לכם ניר is translated in exactly the same way as in Jer 4:3.

(ii) in Prov 13:23 the difficult רב-אכל ניר ראשים ויש נספה בלא משפט is 
Chapter 6 Difficult Hebrew

inaccurately rendered aronk redrefor rescios

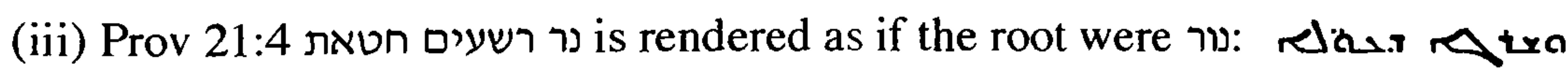
redefo

(iv) Num 21:30 ונירם אבד חשבון עד-דיבון is a corrupt passage (Gray, 1986, p.304) but is of interest here, for the rendering as (ע suggests that the root in this suffixed form was recognised.

In Jer 4:3 the translation with root "to give light" breaks the logical connection with the next phrase, ואל-תזרעו אל-קוצים. There are three possible explanations for this choice:

a. despite the evidence from Num 21:30 that root ניר was recognised at least once, the use of root נור here may be the result of simple error;

b. the changed meaning may have been a deliberate choice made so as to link this translation with 4:4b פן-תצא כאש חמתי, where sis a simile for God's anger.

The translator may have judged that this link was intended by the juxtaposition in MT;

c. influence from Hosea 10:12.

On balance, however, the rendering in Jer 4:3 seems more likely to have influenced that in Hosea than the other way round. The evidence is far from conclusive, but has two strands: first, the possible decision to evoke 4:4b is inapplicable to Hosea in which the "fire" simile does not appear; second, LXX

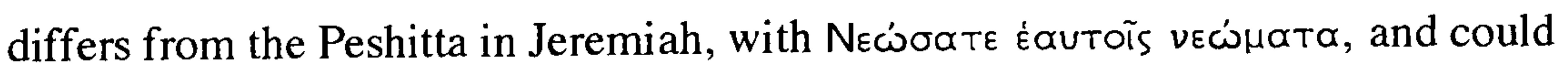
not therefore have been an influence, but is quite close to it in Hosea: $\phi \omega \tau i \sigma \alpha \tau \varepsilon$

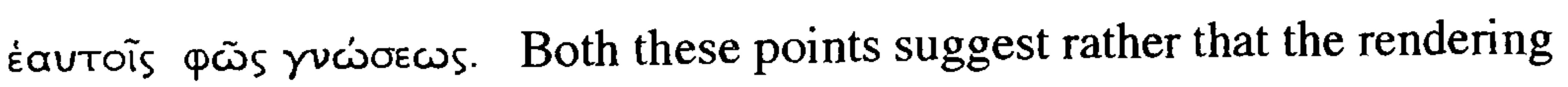
inJeremiah is independent, and that the direction of influence is more probably from Jeremiah to Hosea than the other way round.

Weitzman (Weitzman, in press, p.308) refers to this passage.

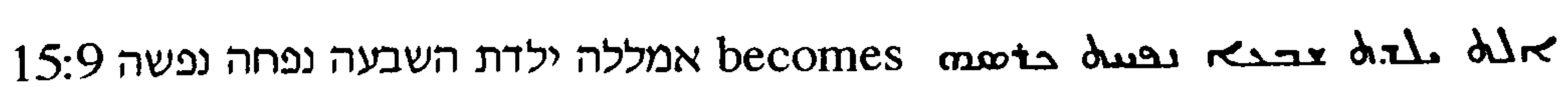

Evidently the Hebrew phrase evoked Numbers 5:27 where וצבתה בטנה is accurately rendered moot desa: the evocation must have been subconscious, triggered by a complex process: root נפח evoked the cognate root 
turn evoked the phrase in Numbers 5:27; next, in error, moot was given as an inappropriate equivalent of נפשה. This example is discussed by Weitzman (Weitzman, 1995, p. 243).

(iv) mimicking the sound of the Hebrew word in the Syriacterm selected There is a small number of particularly difficult passages at which the translator has resorted to paraphrase, and there are other passages at which he has given an atomistic rendering; in the latter perhaps feeling that where the sense of the Hebrew completely eluded him, the best of the range of unsatisfactory approaches available was to replicate the obscurity and hope that his readers would succeed in understanding the passage where he had failed.

This is a small group, illustrated here by six examples, $2: 6,12,20 ; 38: 11 ; 46: 18$; 47:2. Three examples in chapter 2 is a high proportion of the total, and may simply be due to chance, or may indicate that the translator's policy changed as he worked beyond the beginning of the book.

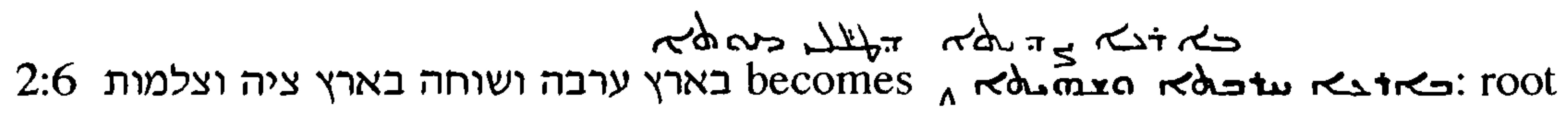
שוח, here "pitted", is translated with root Rex "to be void, waste" although its כי-כרו 18:22 כי-כרו שוחה לנפשי 18:20, and meaning was known and used in (at the latter, the Qere is שיחה ללכדני ( שוחה

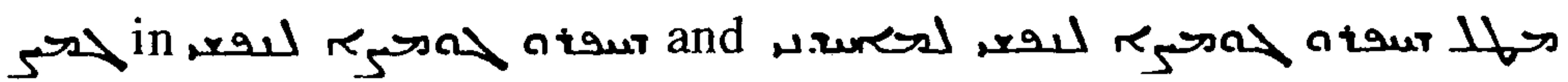
respectively. Its use here seems to be due to the similarity of the sounds of שוחה and reducos.

The use of root ציה "to be parched" here and in Jer 50:12 and 51:43 is surprising: the usual equivalent, seen in for instance Is 41:18, 53:2; Ez 19:13; Ho 2:5 (3); Joel 2:20; Ps 63:2, 78:17, 105:41 and 107:35 is $\mathrm{Rd}_{\mathrm{m}}$, root $\mathrm{Rm}_{5}$, "to thirst, to be dry", closer to the sense of the Hebrew. Possibly, this choice is a manifestation of the translation technique, the translator using two terms which are virtually synonyms of one another, giving close consistency of the second part of the problematic passage with the first. 
Chapter 6 Difficult Hebrew

\section{2:12 מושערו חרבו מאד}

שער here has the specific connotation of the hair standing up in horror. No precise Syriac equivalent was available, but the meaning is well conveyed by root $>0$, which may have been selected because it has the additional advantage of a similar sound (with a guttural ayin).

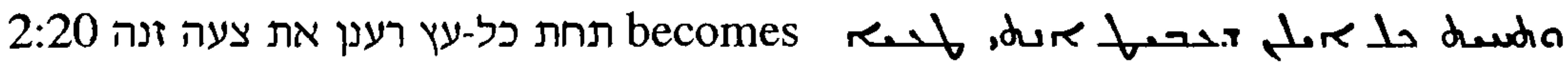
resso

The root concerned, צעה, is nowhere in the Hebrew Bible accurately translated into Syriac: it occurs elsewhere only in Jeremiah, in 48:12 ושלחתי-לו צעים וצעהו,

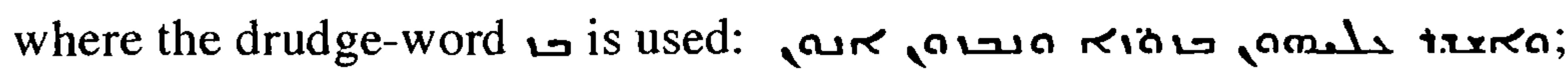

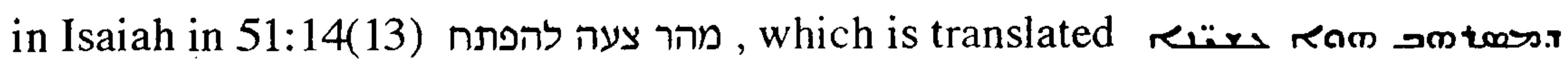
alausl;

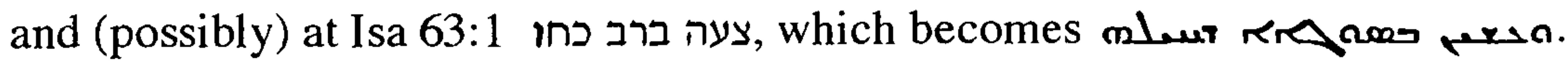
At 2:20 "under every green tree you sprawl in fornication (to fornicate)" becomes "under every green tree you wander and fornicate": uncertain of the true meaning, the translator may have been influenced subconsciously by the similar sounds of and rendered the latter. A conscious decision is also possible, had he been aware of the true etymological correspondence between the Hebrew $\checkmark$ and the Syriac $\downarrow$ of which there is an example at 46:14 where התיצב is rendered ר. fire (Weitzman, in press, p.37).

38:11 In ויקח עבד-מלך את-האנשים בידו ויבא בית-המלך אל-תחת האוצר ויקח משם בלוי הסחבות ובלוי מלחים

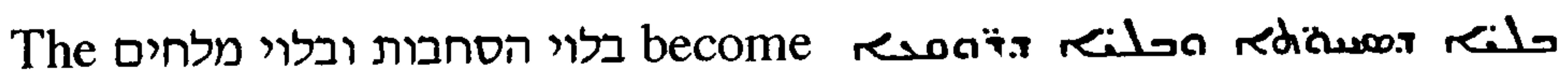
root portially echoing the sound of the Hebrew though giving poor sense.

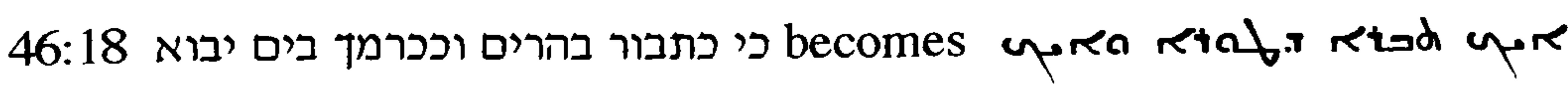
حكt, equating תבור with root tod. Frankl (Frankl, 1872, p.502) mentions this example. 
Chapter 6 Difficult Hebrew

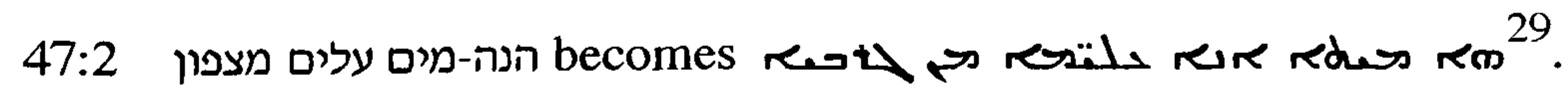
The change from "waters" to "young soldiers" was not made in response to an imagery which the translator found intrinsically unacceptable. The same metaphor is maintained, in the MT, into the following phrase: והיו לנחל שוטף

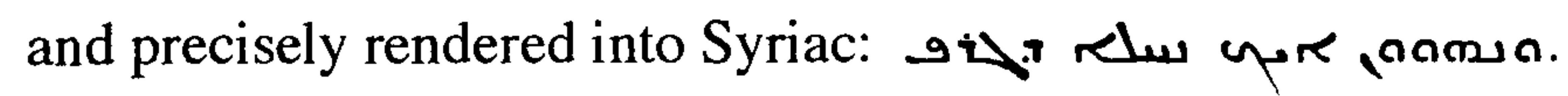

Similarly, it is used earlier in Jeremiah in 8:6 כסוס שוטף במלחמה, "like a horse plunging into battle", linking more directly the ideas of fighting and overflowing waters, translated where root שטף "to overflow" is used of Assyria; at these two passages too the translation is precise, with root 9 t.

There are three possible explanations of the difference between the MT and the Syriac at 47:2: first, the resemblance between the sounds of עלים is and is so close that it led to a process of Syromanie, and rere redes was added, to give precision in accordance with the presentational style; second, עֵלמע was seen as the sense of the perception is plausible and the term is used in 1 Sam 17:56 where שאל אתה בן-מי-זה העלם becomes dur אים

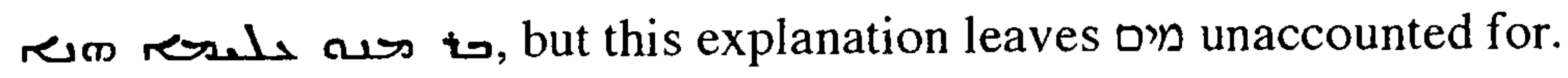

The third possibility is that the metaphor was originally present in the Syriac, in a precise translation of the MT, but was lost by a process of inner-Syriac corruption which changed an original sers, waters are coming, to r.ت. Frankl (Frankl, 1872, p.546) mentions this example.

(v) resorting to an atomistic translation

This approach, giving no clearer sense in the Syriac than that in the Hebrew, is a rare resort in P-Jeremiah: it is illustrated here by five examples, $3: 5 ; 6: 11 ; 21: 13$; $50: 5 ; 51: 9$.

29. The seyame on rin $7 \mathrm{a}$ is uncertain. 


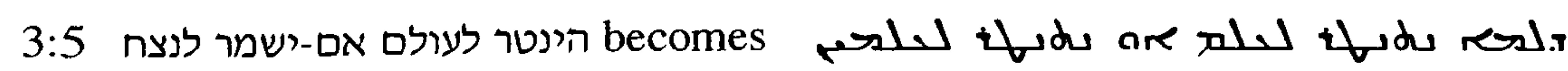
in an atomistic translation "Will it be kept for ever? or will it be kept for ever?". In MT, the variation in vocabulary makes sense of the repetition; in translation, the repetition seems meaningless. This repetition is not constrained by a poverty of vocabulary in the Syriac, for within Jeremiah root שמר is twice translated by

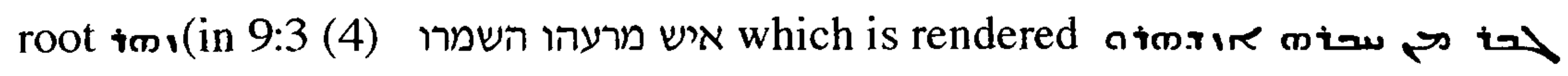

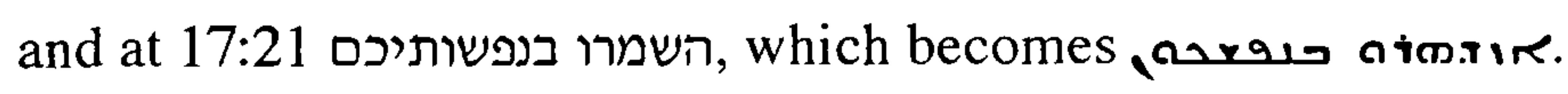

$$
\text { זפד זמא עמת יהוה מלאתי נלאיתי הכיל }
$$

There are several problems in this verse, due not to any obscurity in individual roots but to the difficult construction.

(i) the translator has read the opening term not as ואיוֹ but this is an acceptable understanding of the consonantal text, and would conform with the two verbal forms ending in yodh which follow if these are read as $2 \mathrm{nd}$ sing. fem. perfects and not as 1 st person ${ }^{30}$.

The translation is:

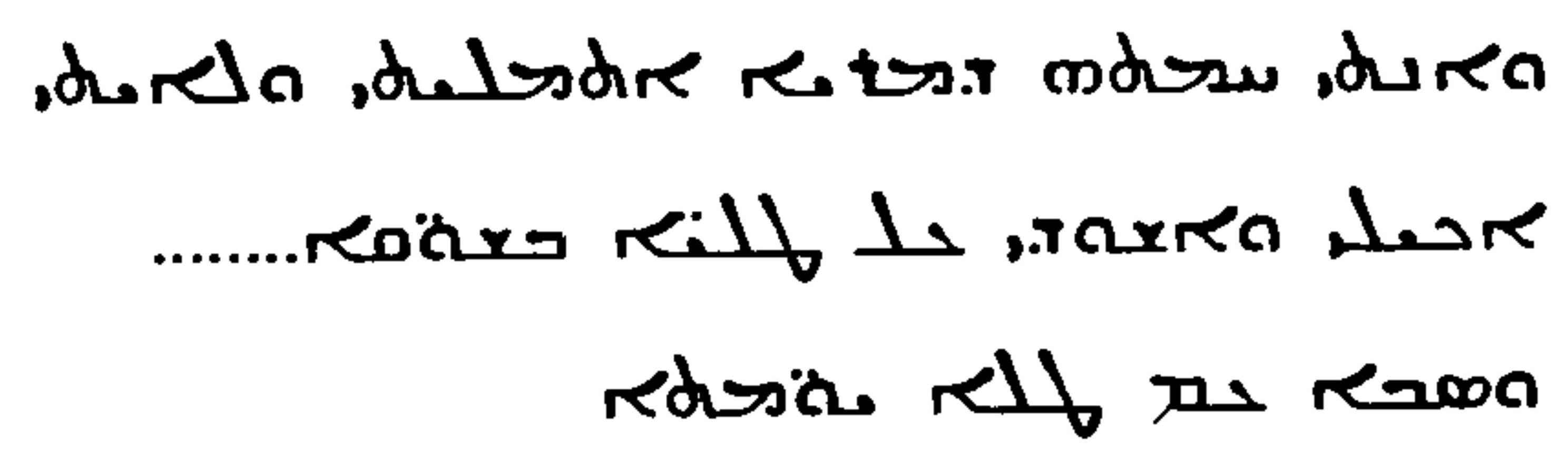

Possibly, the decision not to translate וארת was influenced by the previous verse, על-מי which Jeremiah complains that no-one will listen to him, opening with אדברה neat answer to that question.

30. Frankl (Frankl, 1872, p. 501, discusses this translation as an illustration of a point at which the translator has in his mind his own language, overpowering his target language: he suggests that it is because the translator was subconsciously thinking of the Syriac forms that he read second person feminine forms here. The suggestion is supported by the similarity of the forms, both the Hebrew construction here, and the Syriac feminine singular imperative ending in yodh ; Frankl does not, however, discuss the more fundamental interest of this translation, its atomistic nature. 


\section{Chapter 6 Difficult Hebrew}

(ii) The translator has understood punctuation different from that of MT, taking in the sense "to measure" rather than as "to contain", and linking it with the following term rather than the preceding in "measure and pour out" rather than "you are weary of containing". He arrives at a sequence of two imperatives, addressed to Jerusalem, the identity represented by ,du Ro, in an atomistic approach to שפך which results in poor sense.

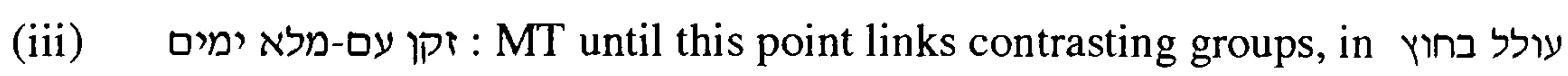

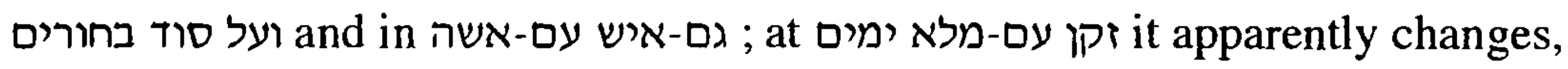
describing two similar gatherings. The MT is not represented by the Syriac which may represent the translator's judgment that the Hebrew was a corruption of לא מלא ימים, or may reflect the drive for precision maintaining the internal logic rather than interrupting it as in MT.

$21: 13$

becomes
ישבת העמק צור המישר

האמרים מי יחת עלינו

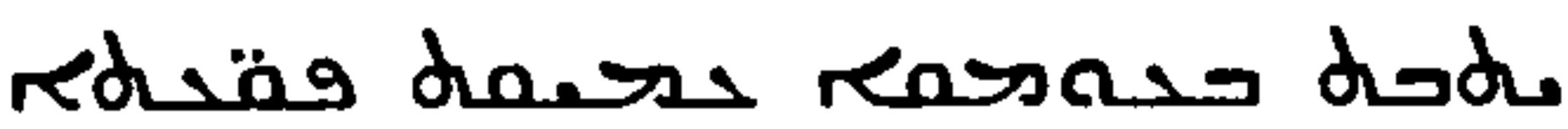

$$
\text { edres ros }
$$

is difficult to translate: the subject must surely be Jerusalem, but the sense of the phrase is unclear. Jerusalem owed some at least of its reputation for impregnability to its elevated position, recognised later in the verse in האמרים מי יחת עלינו, so the obvious meaning is inappropriate: as an epithet for Jerusalem "rock of the plain" is not immediately satisfactory, though the sense "rock in (surrounded by) the plain would be possible. The passage evokes for instance 48:8 ואבד העמק ונשמד המישר, but the clearer meaning at the latter gives no help in the translation of 21:13. Possibly, the sense "confine" in root was perceived, and stretched to give "hidden, deep" expressed in root , intended to give a picture of a city hemmed in by valleys; even so, the overall sense of

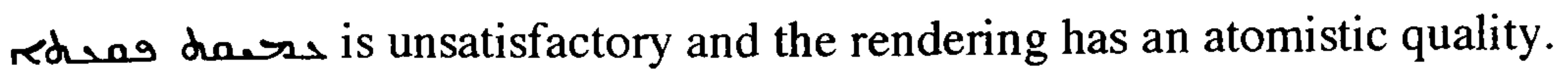
It is difficult to understand why, if that was the intended picture, root נח in the clear is rendered with root redrein האמרים מי יחת עלינו red lacking the specific reference to the height of the site of the city. Perhaps the city 
Chapter 6 Difficult Hebrew

hemmed in by valleys was not the sense intended and the change from "to come down" to "to come" was deliberate; it is impossible to be sure.

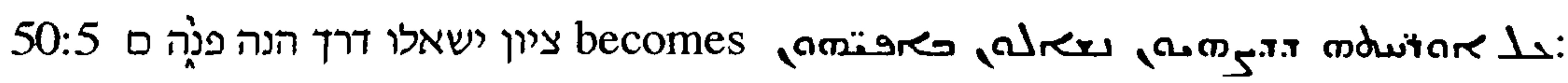
the opening words are given sense by means of a minimal paraphrase; but there is no attempt to make sense of פנj whose addition makes no real improvement.

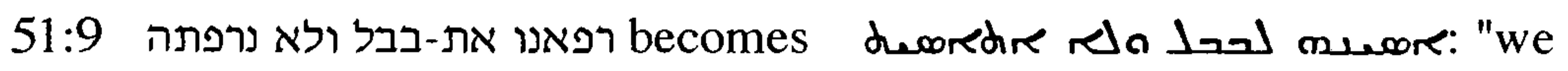
healed Babylon, and she was not healed" loses the conative force of the Piel in MT.

It seems surprising that this translator, whose aim was to make the biblical text intelligible to a Syriac audience, allowed such renderings to stand; but in a text of this length, some variation in standard is inevitable. 
Chapter 7 Conclusion

Great care has been taken in this analysis to ensure that all categories of text, the oracles against Israel, the oracles against the Nations, and the narrative sections, were given equal attention, although because of the constraints on space it was not possible to discuss each verse individually: the outstanding conclusion of this study is that the translation is homogeneous, despite the marked heterogeneity of the Hebrew Vorlage. There are of course some areas of inconsistency, with different approaches to translation within the same passage: but these are compatible with either a conscious desire to introduce some variety into this long text, or with simple human inconsistency.

This homogeneity suggests two particularly interesting trains of thought. First, the sheer length of this book is such that it would not have been surprising if more than one translator had been involved in the work. One might have been given the less demanding narrative chapters to work on, and another more experienced colleague entrusted with the more subtle, and more rewarding, oracular sections: there is however no evidence that this was so. Pursuing this question of the number of translators, the prevalence chapter by chapter of several characteristics of the translation technique was measured: it seemed initially that there might be different approaches in different parts of the book to three features, the choice of lexical equivalents, the preservation of the word order of the Hebrew, and the method of translation of the Hebrew infinitive. On further investigation, however, the evidence that this prevalence changes seems unconvincing, and does not support the suggestion that the work of more than one man is discernible.

Second, there is the question of the literary "style" of the Peshitta as a whole and of the translators who contributed to it. This train of thought is initiated by study of a particular feature of the book, the duplicate passages. Not only where both members of the pair occur within Jeremiah, but also where one member is found in another biblical book, the translation of both apparently reads acceptably in their contexts, with no feeling that either is discordant with its surrounding verses. This suggests that the style of the Peshitta to Jeremiah is readily compatible with that of these other books. By "style" here is meant that personal imprint which makes it possible for a reader to recognise the author of a sentence or phrase even when these are read out of context: this is an intuitive process, 
though susceptible to analysis by statistical techniques, leading to a recognition that one writer would have used a given construction, whereas another would not. It is a process quite different from, for instance, that of the analysis of the metre of classical poetry. There is no evident reason why such a personal imprint should not be detectable on study of a translation: yet in the work of Weitzman which covers all the books of the Peshitta it is nowhere mentioned. In his discussion of the number of translators, Weitzman shows that there are some books in which the translator was conservative, and others in which the features analysed suggest a more progressive approach: his argument is based largely on differences in the choice of lexical equivalents, and on the receptivity to influence from LXX; "style" is not mentioned. He also considered the difference in the degree of literalness between different books of the Peshitta, but emphasises that impressions that different translators took part must be treated with caution because, first, it is possible that "differences in technique are conditioned by the Hebrew text rather than a change of translator", and second, that "most books strike a balance between fidelity and intelligibity. Inevitably, some investigators will have been more impressed by the former tendency and others by the latter. Comparison of their perceptions would give an exaggerated impression of diversity within $P$, unless the primary sources are checked independently" (Weitzman, in press, p.165).

Weitzman had at the beginning of his career applied statistical techniques to the study of the Peshitta: the title of his (unpublished) Ph.D. thesis, accepted in 1974, was "A Statistical Approach to Textual Criticism, with special reference to the Peshitta Version of the Old Testament". In this thesis, his principal focus is on the application of statistical techniques in establishing the pattern of manuscript transmission, not precisely relevant to the definition of style discussed here; his later work, however, for instance measuring the value of a comparison of the range of vocabulary and text length as a style characteristic (Weitzman, 1971, pp.239-243) and of verb frequency in demonstrating whether or not a passage is composite (Weitzman, 1981, pp.451-471) is exactly that meant here and, in view of his interest, it seems most unlikely that, had his reading made him aware of differences in style in the different books of the 
Peshitta, he would not have commented on this.

This consistency in style could, theoretically, have been produced by the imposition of an overall "house style" to which all translators and editors had to conform. It is difficult, though, to imagine how this could have been so effective in practice. Even when working according to a set of simple rules, and translating a clear text, it is unlikely that two translators will arrive at stylistically indistinguishable renderings: both may follow the instructions, but some individuality will almost certainly be manifest. So it seems unlikely that consistency of this degree could have been achieved simply by issuing instructions concerning style. There is another theoretical possibility, that a senior member of the group of translators simply rewrote his colleagues' work, imposing his own style on the translation, phrase by phrase, as he did so; but experience in attempting an exercise of this sort shows that it is extremely difficult to arrive at a homogeneous text by such redrafting; and, of course, there is no manuscript evidence that this occurred.

Another possibility must be considered: perhaps the whole Peshitta is the work of one man: in this case, the characteristics which Weitzman showed distinguishing the conservative from the progressive translations would then represent not the difference between the work of different men, but developments in the work of one man with the passage of time. The translation would indeed have been an enormous undertaking: but time was presumably in adequate supply. Tyndale, for instance, translated a substantial portion of the Bible, so the task is not inconceivable.

There is one discrete puzzle to which Weitzman alludes briefly which might, on further study, throw light on this question. In his discussion of the range of approach, from the conservative to the progressive, he says "Isaiah and Psalms stand apart...the lack of a coherent policy towards innovations is itself a characteristic of these two books" (Weitzman, in press, p.177). These two books, both of great importance and of great beauty, would hardly have been entrusted to translators outside the mainstream of the work on the Peshitta. Possibly, they were the work not of different translators, but of one translator at a particular stage of development of his approach. A verse by verse analysis of 
Chapter 7 Conclusion

the translation technique in the Peshitta to Isaiah and Psalms, supported if appropriate by the application of statistical techniques, would go some way towards showing exactly how these books do and do not stand apart. This kind of approach, including quantitative as well as qualitative aspects, could elucidate the question of style and might then be applied to other books; it seems to be an obvious field for an extension of the present analysis. 
Bibliography

Biblical texts:

Biblia Hebraica Stuttgartensia, K.Elliger and W.Rudolph eds., Stuttgart:

Deutsche Bibelgesellschaft 1983

Kennicott B. ed., Vetus Testamentum Hebraicum cum Variis Lectionibus, Oxford: Clarendon Press: 1776-1780

The Hebrew Bible, ed.N.H.Snaith, London: The British and Foreign Bible Society, 1958

7a1, photolithographice edita, A.M.Ceriani, Translatio Syro Pescitto veteris Testamenti ex codice Ambrosiano sec. fere VI.,Mediolani 1876-1883

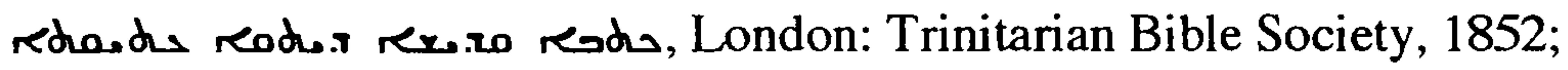

reprinted by The Whitefriars Press Ltd., 1954

The Old Testament in Syriac According to the Peshitta Version, Peshitta Institute Leiden eds., Part II, Fascicle 4, Kings, Leiden: E.J.Brill, 1974

The Old Testament in Syriac According to the Peshitta Version, Peshitta Institute Leiden eds., Part III, Fascicle 1, Isaiah, Leiden: E.J.Brill, 1987

Ziegler, J. ed., Ieremias, Baruch, Threni, Epistula Ieremias, Septuaginta Vetus

Testamentum Graecum Auctoritate Societatis Gottingensis editum 15, Gottingen:

Vandenhoeck and Ruprecht, 1957

The Holy Bible: Revised Standard Version, Edinburgh: Thomas Nelson and Sons Ltd., 1957

The New English Bible, Oxford: Oxford University Press, Cambridge University Press, 1970

\section{Dictionaries and lexicons:}

Brown, F., S.R.Driver, and C.A.Briggs, A Hebrew and English Lexicon of the Old Testament, Clarendon Press, Oxford, 1906

Costaz, L., Dictionnaire Syriaque-Francais, Béyrouth: Imprimerie Catholique, 1963

Jastrow, M., Dictionary of the Targumim, the Talmud Babli and Yerushalmi, and the Midrashic Literature, New York: Judaica Press, 1992 Koehler L., and W.Baumgartner, Lexicon in Veteris Testamenti Libros, ed. L.Koehler, Leiden: E.J.Brill, 1958 
Bibliography

Payne Smith J., ed. A Compendious Syriac Dictionary, Oxford: Clarendon Press, 1903, reprinted 1990

Payne Smith, R., Thesaurus Syriacus, Oxford: Clarendon Press, 1879

\section{Concordances:}

Mandelkern, S., Veteris Testamenti Concordantiae, Leipzig: Veit and Co., 1896

The Peshitta Institute Leiden, The Old Testament in Syriac, ed. Part V

Concordance, Volume I The Pentateuch, Leiden: E.J.Brill, 1997

Strothmann, W., Konkordanz zur Syrischen Bibel, Weisbaden: Otto

Harrasowitz, 1984-1995

\section{Grammars:}

Gesenius' Hebrew Grammar, Roediger ed., B.Davies tr., London: Asher and Co., 1903

Muraoka, T., Classical Syriac for Hebraists, Weisbaden: Otto Harrassowitz, 1987

Nöldeke, T., Kurzgefasste Syrische Grammatik, Leipzig: T.O.Weigel, 1880, First Edition

Nöldeke, T. , Compendious Syriac Grammar, J.A.Crichton tr., London:

Williams and Norgate, 1904, Second Edition

Reference books:

Aphrahat, Patrologica Syriaca, Pars Prima, ed. D.Ioannes Parisot, Firmin-Didot et Socii: Paris, 1894

Talmud Bavli, Vilna: Romm, 1862

Bright, J., A History of Israel, Third Edition, London: SCM Press, 1981

Dirksen, P.B., An Annotated Bibliography of the Peshitta of the Old Testament, Monographs of the Peshitta Institute 5, Leiden: E.J.Brill, 1989

Dirksen, P.B., Supplement to "An Annotated Bibliography of the Peshitta of the 
Bibliography

Old Testament", Monographs of the Peshitta Institute 8, The Peshitta as a Translation, P.B.Dirksen and A. van der Kooij eds., Leiden: E.J.Brill, 1995, pp.221-236

Ephrem, Sancti Ephraem Syri, Opera Omnia, II, ed. Romana, 1740; Ex Typographia Pontificia Vaticana, pp.98-163

Flavius Josephus, Jewish Antiquities, Books XII-XIV, tr. R.Marcus, Cambridge, Massachusetts: Harvard University Press, London: William Heinemann Ltd., 1976

Gray, G.B., A Critical and Exegetical Commentary on Numbers, International Critical Commentary, eds. S.R.Driver, A.Plummer, and C.A.Briggs,

Edinburgh: T. and T.Clark, 1986

Holladay, W.L., Jeremiah 1, ed. P.D.Hanson, Philadelphia: Fortress Press, 1986

Holladay, W.L., Jeremiah 2, ed. P.D.Hanson, Philadelphia: Fortress Press, 1989

McKane, W., A Critical and Exegetical Commentary on Jeremiah, Vol.I, International Critical Commentary, eds. J.A.Emerton and C.E.B.Cranfield, Edinburgh: T.\&T.Clark Ltd, 1986

McKane, W., A Critical and Exegetical Commentary on Jeremiah, Vol.II, International Critical Commentary, eds. J.A.Emerton, C.E.B.Cranfield, and G.N.Stanton, Edinburgh: T.\&T.Clark Ltd, 1996

Tov, E., Textual Criticism of the Hebrew Bible, Minneapolis: Fortress Press; Assen/Maastricht: Van Gorcum, 1992

Individual works consulted:

Aejmelaeus, A., "What Can We Know about the Hebrew Vorlage of the Septuagint", in Zeitschrift fur die Alttestamentliche Wissenschaft, 99, (1987), pp. 58-89

Albrektson, B., Studies in the Text and Theology of the Book of Lamentations, Lund: CWKGleerup, 1963 
Bibliography

B.Albrektson, "Reflections on the Emergence of a Standard Text of the Hebrew Bible", Vetus Testamentum Supplement Series, 29, (1978), pp.49-65

Avinery, I., "The Position of the Demonstrative Pronoun in Syriac", Journal of Near Eastern Studies, 34, (1975), pp.123-127

Avinery, I., "On the Nominal Clause in the Peshitta", Journal of Semitic Studies, 22, (1977), pp. 48-49

Avinery, I., "An Example of the Influence of Hebrew on the Peshitta Translation

- The Status Constructus", Textus, 9, (1981), 36-38

Baillet, M., J.T.Milik, and R. de Vaux, "Les 'Petites Grottes' de Qumran", in Discoveries in the Judaean Desert of Jordan III, Oxford: Clarendon Press, 1962

Barnes, W.E., "On the Influence of the Septuagint on the Peshitta", Journal of Theological Studies, 2, (1901), pp.186-197.

Barr, J., "Vocalisation and the Analysis of Hebrew among the Ancient Translators", Vetus Testamentum Supplement Series, 16, (1967), pp.1-11

Barr, J., "The Typology of Literalism in Ancient Biblical Translations", Mitteilungen des Septuaginta-Unternehmens XV, (1979), pp. 279-325

Barr, J., Comparative Philology and the Text of the Old Testament, London: SCM Press, 1983; Oxford: Clarendon Press, 1968

Barthélemy, D., Les Devanciers d'Aquila, Vetus Testamentum Supplement Series, X, Leiden: Brill, 1963

Beckwith, R., The Old Testament Canon of the New Testament Church, London: SPCK, 1985

de Boer, P.A.H. , "Towards an Edition of the Syriac Version of the Old Testament", Peshitta Institute Communication XVI, Vetus Testamentum 31, (1981), pp.346-357

Bogaert, P.-M., "Le Livre de Jérémie en Perspective: Les Deux Redactions Antique selon les Travaux en Cours", Revue Biblique, 101, (1994), pp.363-406 Brock, S.P., "Syriac Perspectives on Late Antiquity", III Aspects of Translation Technique in Antiquity, London: Variorum Reprints, 1984, pp.69-87 
S.P.Brock, "Text History and Text Division in Peshitta Isaiah", in The Peshitta: Its Early Text and History, Papers read at the Peshitta Symposium 1985, Monographs of the Peshitta Institute Vol IV, eds. P.B.Dirksen and M.J.Mulder, Leiden: EJ Brill, 1988, pp.49-80

Brock, S.P., "Towards a History of Syriac Translation Technique", in: Studies in Syriac Christianity: History, Literature, and Theology, X, Aldershot, Great Britain, Vermont, U.S.A: Variorum Press, 1992, pp.1-14

Burkitt, F.C., S. Ephraim's Quotations from the Gospel, Cambridge: Cambridge University Press, 1901

Burkitt, F.C., Early Eastern Christianity, London: John Murray, 1904

Carroll, R.P., Jeremiah: A Commentary, London: SCM Press, 1986

Chiesa, B., "Textual History and Textual Criticism of the Hebrew Old Testament", in Proceedings of the International Congress on the Dead Sea Scrolls, Vol. I, Madrid 18-21 March 1991, J.T.Barrera and L.V.Montaner (eds.), E.J.Brill, Leiden, 1992, pp.257-272.

Childs, B.S., "The Enemy from the North and the Chaos Tradition" Journal of Biblical Literature, 78, (1959), pp.187-198.

Cross, F.M., "The History of the Biblical Text in the Light of Discoveries in the Judaean Desert", in Qumran and the History of the Biblical Text, F.M.Cross and S.Talmon, eds., Cambridge, Mass.,: Harvard University Press, 1975 (i), pp.177-195

Cross, F.M., "The Oldest Manuscripts from Qumran", in Qumran and the History of the Biblical Texts, F.M.Cross and S.Talmon, eds., Cambridge, Mass.,: Harvard University Press, 1975 (ii), pp.147-176

Cross, F.M., "The Evolution of a Theory of Local Texts", in Qumran and the History of the Biblical Texts, F.M.Cross and S.Talmon, eds., Cambridge, Mass.,: Harvard University Press, 1975 (iii), pp.306-320

Dirksen, P.B., "The Ancient P-MSS. of Judges", in The Peshitta: Its Early Text and History, Papers read at the Peshitta Symposium 1985, Monographs of the Peshitta Institute Vol IV, eds. P.B.Dirksen and M.J.Mulder, Leiden: EJ Brill, 1988, pp.127-146 
Dirksen, P.B., "The Old Testament Peshitta", Mikra: Text, Translation, Reading and Interpretation of the Hebrew Bible in Ancient Judaism and Early Christianity, M.J.Mulder ed., Assen/Maastricht: Van Gorcum, and Philadelphia: Fortress, 1988, pp.254-297

Dirksen, P.B., "The Peshitta and Textual Criticism of the Old Testament", Peshitta Institute Communication 22, Vetus Testamentum 42, (1992), pp.376390

Dirksen, P.B., "Some Aspects of the Translation Technique in P-Chronicles" in The Peshitta as a Translation, P.B.Dirksen and A. van der Kooij eds., Monographs of the Peshitta Institute Leiden 8, Leiden: E.J.Brill, 1995, pp.17-23 Drijvers, H. , "Syrian Christianity and Judaism", in The Jews among Pagans and Christians, J.Lieu, J.North, and T.Rajak eds., London and New York:

Routledge, 1992, pp.124-146

Drijvers, H. , "Jews and Christians at Edessa", in History and Religion in Late Antique Syria, Variorum: Aldershot, Great Britain and Vermont, U.S.A., 1994, pp.88-102

Driver, G.R., Notes on the Hebrew Text and the Topography of the Books of Samuel, Oxford: Clarendon Press, 1913

Driver, G.R., "Linguistic and Textual Problems: Jeremiah", in Jewish Quarterly Review, NS 28, (1937/8), pp.97-129.

Driver, G.R., "Hebrew Notes", Vetus Testamentum 1, (1951), pp.241-250.

Emerton, J.A., "A Problem in the Hebrew Text of Jeremiah 6:23 and 50:42", Journal of Theological Studies, New Series 23, (1972), pp.106-113 Englert, D.M.C., The Peshitto of Second Samuel, Journal of Biblical Literature Monograph Series 3, Pennsylvania: Society for Biblical Literature and Exegesis, 1949

Frankl, P.F., "Studien über die Septuaginta und Peschito zu Jeremia," Monatschrift fur Gesch. und Wissenschaft des Judenthums, 21, (1872), pp.444456, 497-509, 545-557

Gelston, A., "Some Notes on Second Isaiah", Vetus Testamentum, 21, (1971), pp. $517-527$ 
Bibliography

Gelston, A., The Peshitta of the Twelve Prophets, Oxford: Clarendon Press, 1987

Gelston, A., "Some Readings in the Peshitta of the Dodekapropheton", Monographs of the Peshitta Institute, Vol. 4, Leiden: E.J.Brill, 1988, pp.81-98 Goldenberg, G., "Bible Translations and Syriac Idiom", in The Peshitta as a Translation, P.B.Dirksen and A. van der Kooij eds., Monographs of the Peshitta Institute, Vol. 8, Leiden: E.J.Brill, 1995, pp.25-39

Gordis, R., The Biblical Text in the Making, Pennsylvania: Jewish Publication Society, 1937

Goshen-Gottstein, M.H., "Review of A.Vööbus: Peschitta und Targumim des Pentateuchs", Journal of Semitic Studies, 6, (1961), pp.266-270

Goshen-Gottstein, M.H., "Theory and Practice of Textual Criticism - The TextCritical Use of the Septuagint", Textus 3, (1963), pp.130-158

Goshen-Gottstein, M.H., "Hebrew Biblical Manuscripts", in Qumran and the History of the Biblical Texts, F.M.Cross and S.Talmon, eds., Harvard: Harvard University Press, 1975, pp.42-89

Goshen-Gottstein, M.H., "The Development of the Hebrew Text of the Bible", Vetus Testamentum, 42, (1992), pp.204-213

Graf, K.H., Der Prophet Jeremia, Leipzig: T.O.Weigel, 1862

Holladay, W.H., The Root subh in the Old Testament, Leiden: E.J.Brill, 1958 Holladay, W.L., "Structure, Syntax and Meaning in Jeremiah 4:11-12a", Vetus Testamentum 26, (1976), pp.28-37.

Janzen, J.G., "Double Readings in the Text of Jeremiah", Harvard Theological Review 60, (1967), pp.433-447

Janzen, J.G., "Studies in the Text of Jeremiah", Harvard Semitic Monographs 6, Massachusetts : Harvard University Press, 1973

Joosten, J., "The Use of Some Particles in the Old Testament Peshitta", Textus, 14, (1988), 175-183

Joosten, J., "Doublet Translations in Peshitta Proverbs", in The Peshitta as a Translation, Papers read at the Second Peshitta Symposium 1993, Monographs of the Peshitta Institute Vol 8, eds. P.B.Dirksen and A.van der Kooij, Leiden: EJ Brill, 1995, pp.63-72. 
Kohler, K., "The Psalms in the Liturgy", Publications of the Gratz College, 1, (1897), pp.169-204

van der Kooij, A., "On the significance of Ms. $5 \mathrm{~b} 1$ for Peshitta Genesis", in The Peshitta: Its Early Text and History, Papers read at the Peshitta Symposium 1985, Monographs of the Peshitta Institute Leiden, Vol 4, eds. P.B.Dirksen and M.J.Mulder, Leiden: EJ Brill, 1988, pp.183-199

Koster, M.D., "Which Came First: The Chicken or the Egg", in The Peshitta: Its Early Text and History, Papers read at the Peshitta Symposium 1985, Monographs of the Peshitta Institute Leiden, Vol 4, eds. P.B.Dirksen and M.J.Mulder, Leiden: EJ Brill, 1988, pp.99-126

Koster, M.D., "The Peshitta Revisited, A Reassessment of its Value as a Version", Journal of Semitic Studies 38, (1993), pp.235-268

Kraft R.A., and A-E. Purintun, Paraleipomena Jeremiou, R.A.Kraft and AE.Purintun eds. and trs., Texts and Translations 1, Pseudepigrapha Series 1, Montana: Society of Biblical Literature, 1972.

Kutscher, E.Y., The Language and Linguistic Background of the Isaiah Scroll (1QIsa), [=Studies on the Texts of the Desert of Judah VI] Leiden: E.J.Brill, 1974

Lane, D.J., "'Lilies that Fester': The Peshitta Text of Qoheleth", Peshitta Institute Communication 15, Vetus Testamentum 29, (1979), 481-490

Lane, D.J., "'The Best Words in the Best Order': Some Comments on the 'Syriacing' of Leviticus", Peshitta Institute Communication 21, Vetus Testamentum 39, (1989), 468-479

Lane, D.J., The Peshitta of Leviticus, Monographs of the Peshitta Institute, Volume 6, Leiden: E.J.Brill, 1994

Loewe,R.J., "Jerome's Treatment of an Anthropopathism", Vetus

Testamentum, 2, (1952) 261-272

McKane, W., "Jeremiah II 23-25: Observations on the Versions and History of Exegesis", Oudtestamantische Studien, 17, (1972), pp.73-88

Marquis, G., "The Text-Critical Relevance of the Three in the Book of Jeremiah", in Origen's Hexapla and Fragments, Papers presented at the Rich Seminar on the Hexapla, A. Salvesen ed., Mohr Siebeck, 1998, pp. 255-273 
Bibliography

Mansoor, M., "The Massoretic Text in the Light of Qumran", Vetus

Testamentum Supplement Series 9, (1962), pp.305-321

May, H.G., "Towards an Objective Approach to the Book of Jeremiah: the

Biographer", Journal of Biblical Literature, 61, (1942) 103-155

Millar, F., "The Jews of the Graeco-Roman Diaspora between Paganism and Christianity, A.D.312-438" in The Jews among Pagans and Christians in the Roman Empire, eds.J.Lieu, J.North, and T.Rajak, London and New York: Routledge, 1992, pp.97-123

Mulder, M.J., "The Use of the Peshitta in Textual Criticism", La Septuaginta en la investigacion contemporanea, V Congreso de la IOSCS, N.F.Marcos ed.; Madrid: Instituto Arias Montano, 1985, pp.37-53

Muraoka, T., "On the Nominal Clause in the Old Syriac Gospels", Journal of Semitic Studies, 20, (1975), pp.28-37

Muraoka, T., "Response to G.Goldenberg "Bible Translations and Syriac Idiom"", in The Peshitta as a Translation, P.B.Dirksen and A. van der Kooij eds., Monographs of the Peshitta Institute Leiden 8, Leiden: E.J.Brill, 1995, pp.25-39

Murray, R., Symbols of Church and Kingdom, London and New York:

Cambridge University Press, 1975

Nicholson, E.W., Preaching to the Exiles: A Study of the Prose Tradition in the Book of Jeremiah, Oxford: Basil Blackwell, 1970

Owens, R.J., "Aphrahat as a Witness to the Early Syriac Text of Leviticus", in Monographs of the Peshitta Institute, Vol. 4, Leiden: E.J.Brill, 1988, pp.1-48

Rabin, C., "Noṣerim", Textus 5, (1966), pp.4452

Soderlund, S., The Greek Text of Jeremiah, A Revised Hypothesis, Journal for the Study of the Old Testament Supplement Series, 47, Sheffield: University of Sheffield Press, 1985

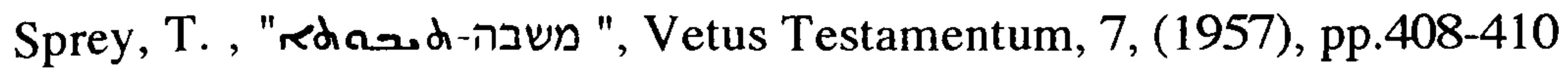

Talmon, S., "Aspects of the Textual Transmission of the Bible in the Light of Qumran Manuscripts", Textus, IV (1964), pp.95-132 
Bibliography

Talmon, S., "The Old Testament Text", in Qumran and the History of the Biblical Text, F.M.Cross and S.Talmon, eds., Harvard, Harvard University Press, 1975, pp.1-41

Taylor, R.A., The Peshitta of Daniel, Monographs of the Peshitta Institute, Leiden, Volume 7, Leiden: E.J.Brill, 1994

Tov, E., "Some Aspects of the Textual and Literary History of the Book of Jeremiah" in Pierre-Maurice Bogaert, Le Livre de Jeremie, Le Prophete et son Milieu, Les Oracles et Leur Transmission, Bibliotheca Ephemeridum Theologicarum Lovaniensium, LIV,Leuven: Leuven University Press,1981, pp.145-167

Tov, E., "The Literary History of the Book of Jeremiah in the Light of its Textual History", in Empirical Models for Biblical Criticism, ed. J.H.Tigay, University of Pennsylvania Press, Philadelphia, 1985 (i), pp. 211-237.

Tov, E., "The Nature and Background of Harmonisations in Biblical Manuscripts", Journal for the Study of the Old Testament, 31, (1985) (ii), pp.329

Tov, E., "The Nature and Study of the Translation Technique of the LXX in the Past and Present", VI Congress of the International Organisation for Septuagint and Cognate Studies, Jerusalem, 1986 (ed. C.E.Cox); Atlanta: Scholars Press, 1987, pp. 337-359

Tov, E., "The Jeremiah Scrolls from Qumran", Revue de Qumran, 14, (1989), pp.189-206

Ulrich, E., F.M.Cross, R.E.Fuller, J.E.Sanderson, P.W.Skehan, E.Tov, "Qumran Cave 4, X, The Prophets", Discoveries in the Judaean Desert 15, Oxford: Clarendon Press, 1997 Walter, D.M., "The Use of Sources in the Peshitta of Kings", in The Peshitta as a Translation, Monographs of the Peshitta Institute Vol.8, P.B.Dirksen and A. van der Kooij eds., Brill: Leiden, 1995, pp. 187-204

Weitzman, M.P., "How Useful is the Logarithmic Type/Token Ratio?", Journal of Linguistics, (1971), pp.237-243 
Weitzman, M.P. A Statistical Approach to Textual Criticism, with Special

Reference to the Peshitta of the Old Testament, 1974 (unpublished Ph.D.Thesis, University of London)

Weitzman, M.P., "Verb Frequency and Source Criticism", Vetus Testamentum 31 , (1981), pp.451-471

Weitzman, M.P., "The Origin of the Peshitta Psalter", in Interpreting the Hebrew Bible: essays in honour of E.I.J.Rosenthal, J.A.Emerton and S.C.Reif eds., Cambridge: Cambridge University Press, 1982, pp.277-298

Weitzman, M.P., The Originality of Unique Readings in Peshitta MS 9a1, in:

The Peshitta: Its Early Text and History, Papers read at the Peshitta Symposium 1985, Monographs of the Peshitta Institute Vol IV, eds. P.B.Dirksen and M.J.Mulder, Leiden: E.J.Brill, 1988, pp. 225-258

Weitzman, M.P., "Peshitta, Septuagint and Targum", VI Symposium Syriacum, R.Lavenant ed., Orientalia Christiana Analecta, 1994, pp.51-84

Weitzman, M.P., " Lexical Clues to the Composition of the Old Testament Peshitta", in Studia Aramaica, Journal of Semitic Studies Supplement 4, OUP, 1995, eds. M.J.Geller, J.C.Greenfield and M.P.Weitzman, pp. 217-246 Weitzman, M.P., "The Interpretative Character of the Syriac Old Testament", in Hebrew Bible/Old Testament, ed. Magne Saeb $\phi$, Vandenhoeck and Ruprecht, Gottingen, 1996, pp.587-611

Weitzman, M.P."Hebrew and Syriac Texts of the Book of Job", Vetus

Testamentum, 47, (1997), pp.381-399

Weitzman, M.P., The Syriac Version of the Old Testament, An Introduction, Cambridge: Cambridge University Press, in press 